Universidad de Salamanca

Departamento de Derecho Público General

TESIS DOCTORAL

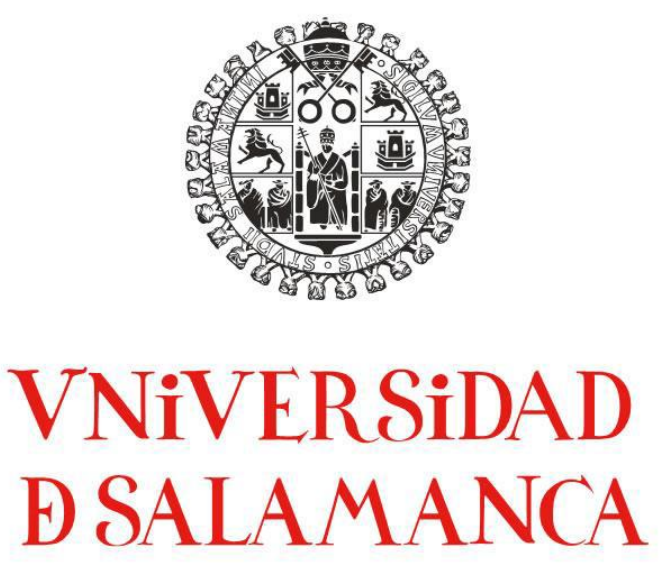

\title{
EL ANÁLISIS CONSTITUCIONAL DEL
} SISTEMA DE FINANCIACIÓN PÚBLICA DE PARTIDOS POLIÍTICOS EN ESPAÑA

Autora: Ana Claudia Santano Director: Augusto Martín de la Vega 
INDICE

INTRODUCCIÓN

\section{LOS PARTIDOS POLÍTICOS EN LA CONSTITUCIÓN ESPAÑOLA DE 1978}

\section{- EL DERECHO DE PARTIDOS} 11

1) La constitucionalización de los partidos políticos .............................................. 12

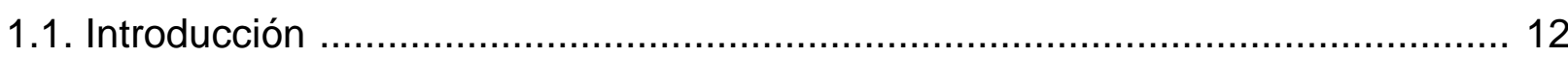

1.2. La constitucionalización de los partidos en España ......................................... 18

1.2.1. El artículo 6o de la Constitución Española y su proceso de elaboración ......... 23

2) La evolución de la definición de la naturaleza jurídica de los partidos ..................... 32

3) Las funciones de los partidos políticos prevista en el art. 6o de la Constitución Española y sus posibles crisis en el actual "momento" democrático

3.1. La idea de pluralismo político y su expresión a través de los partidos políticos

3.2. Los partidos políticos como actores importantes para la concurrencia, formación y manifestación de la voluntad popular: ¿Existe una crisis de representatividad?

3.3. Los partidos políticos como canales fundamentales de participación política y su relación con el actual sistema electoral ¿Existen condiciones para

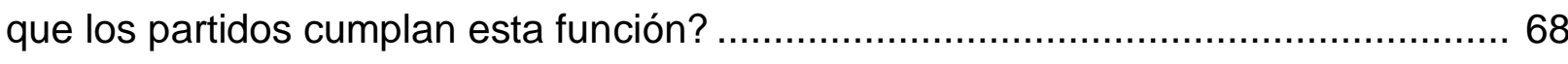

3.3.1. Breves notas sobre el sistema electoral vigente ......................................... 72

II. EL SISTEMA DE FINANCIACIÓN DE PARTIDOS POLÍTICOS ........................... 86

1) El debate sobre las medidas de financiación privada .......................................... 94

1.1. Las fuentes de financiación privada y su problemática ..................................... 98

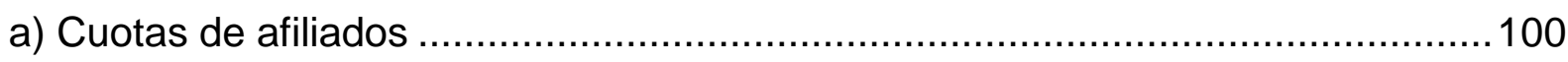




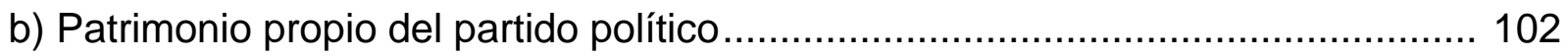

c) Publicaciones y otras actividades desarrolladas por el partido .......................... 103

d) Aportaciones de cargos y candidatos ……..................................................... 104

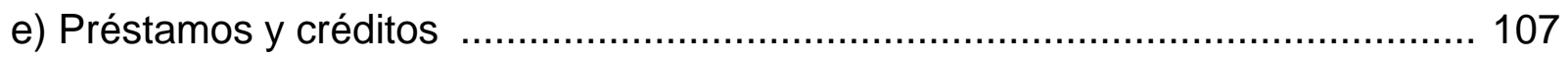

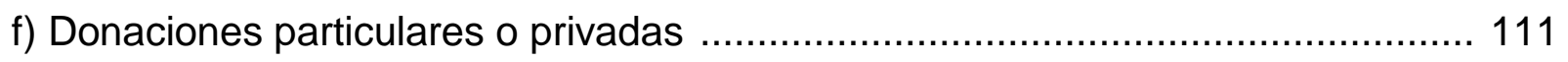

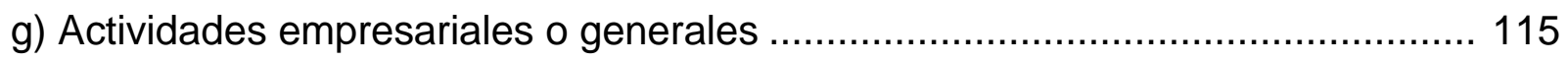

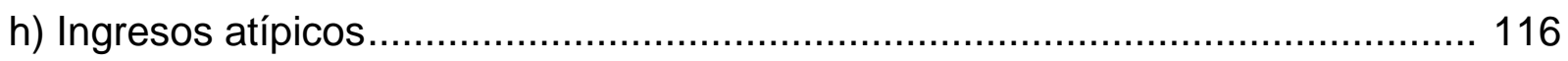

2) La adopción de medidas de financiación pública de los partidos y su adecuación a las actuales condiciones de los sistemas democráticos ........................ 117

2.1. La igualdad de oportunidades dentro del contexto de la financiación pública - El problema de la elección de los criterios de acceso y reparto de las subvenciones públicas

2.2. Diferentes aplicaciones de la financiación pública de los partidos políticos y algunas de sus consecuencias

2.3. La validez de la fundamentación de la financiación pública de los partidos políticos

3) La difícil decisión de fijar el punto de equilibrio - La financiación mixta como tendencia

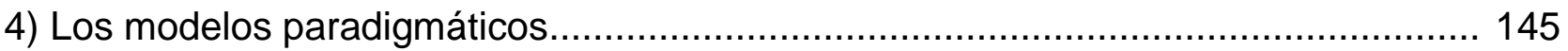

4.1. Estados Unidos de América .................................................................... 145

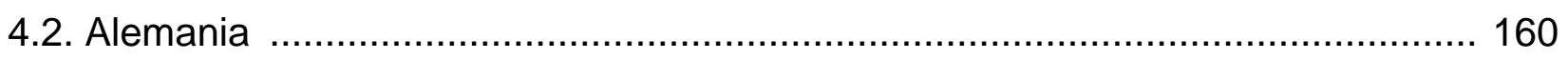

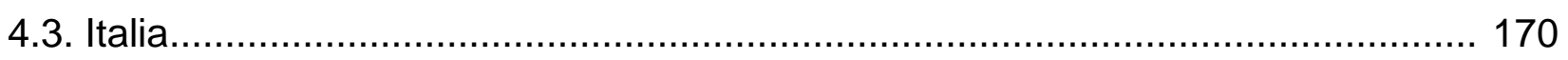

5) El desequilibrio entre la financiación pública y la privada y sus consecuencias

5.1. La financiación de los partidos y la corrupción

5.1.1. El problema del concepto de corrupción política 
5.1.2. Los incentivos de los partidos para la práctica de actos de corrupción a partir del sistema de financiación

5.2. Predominio de la financiación pública y cambios en la dinámica partidista - ¿partidos cartel? 200

\section{EL SISTEMA DE FINANCIACIÓN DE PARTIDOS POLÍTICOS EN}

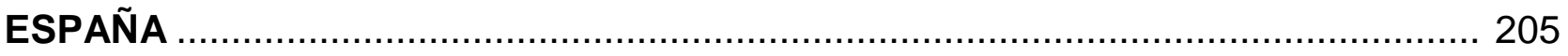

1) El desarrollo histórico del modelo español y las razones de su adopción ............... 208

2) La fragmentaria ubicación normativa de la regulación sobre financiación y su evolución histórica

2.1. La normativa sobre la financiación de las campañas electorales........................ 215

2.1.1. La ley de asociaciones $21 / 1976$, de 14 de junio.......................................... 219

2.1.2. El decreto-ley 20/1977 de 18 de marzo ………........................................ 221

2.1.3. La LOREG - ley orgánica $5 / 1985$ de 19 de junio ....................................... 230

a) La aprobación de la normativa, su estructura y reformas ................................ 231

b) El administrador electoral y la organización de la contabilidad de la

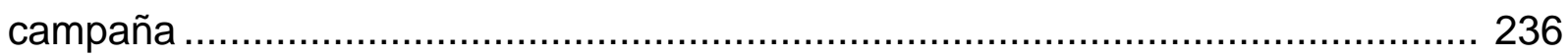

c) La financiación privada de la campaña electoral ........................................... 238

d) La financiación pública de la campaña electoral ............................................ 240

e) Procedimientos para la concesión de adelantos de las subvenciones

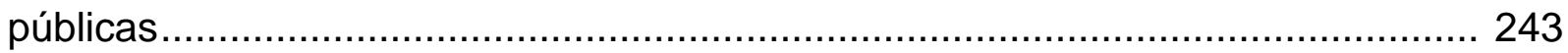

f) La prohibición a ciertos entes de realizar donaciones ..................................... 244

g) Las limitaciones a la financiación privada .......................................................... 246

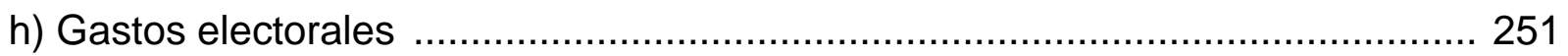

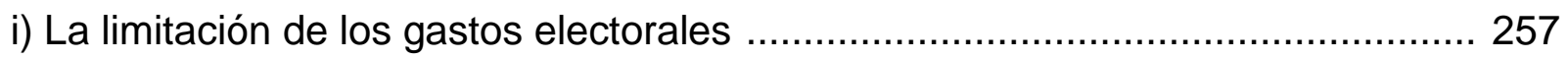

j) Control y fiscalización de la financiación electoral ............................................ 260 
2.2. La regulación de la financiación de las actividades ordinarias de los partidos políticos

2.2.1. Ley orgánica $54 / 1978$ de 4 de diciembre .................................................. 264

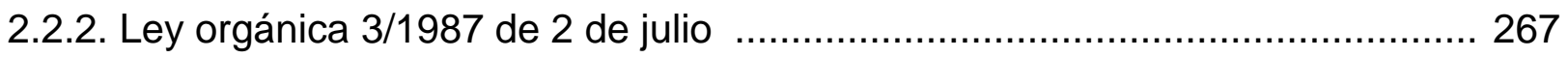

a) Fuentes de financiación ordinaria de los partidos políticos ............................... 271

b) Criterios de acceso y distribución de las subvenciones .................................... 273

b.1) El problema de la configuración del senado y su efecto en la financiación ordinaria de partidos ............................................................. 274

c) Otras características de la financiación pública ordinaria ................................ 277

d) La financiación ordinaria privada y el debate sobre la posibilidad de

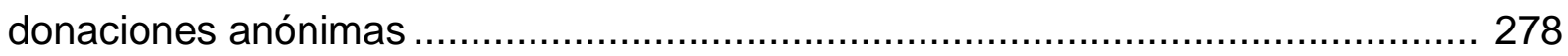

e) Prohibición de algunas fuentes de financiación ............................................. 280

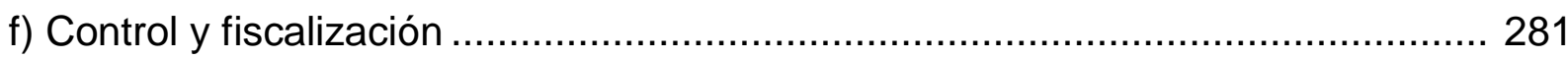

2.2.3. La ley orgánica $8 / 2007$, de 4 de julio sobre financiación de los partidos políticos. 283

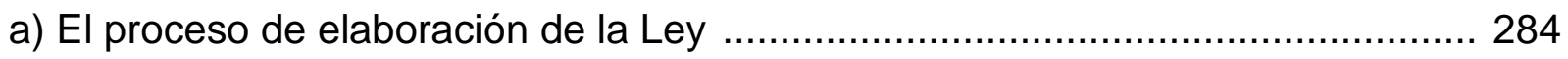

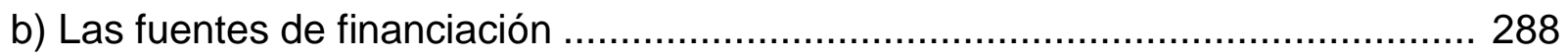

c) La financiación pública - criterios de acceso y reparto …..................................... 290

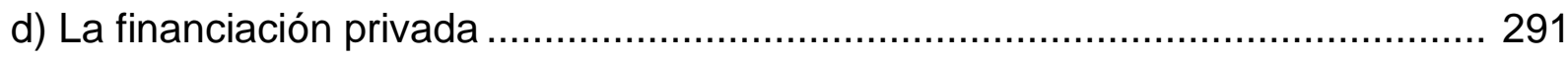

e) Régimen tributario de los partidos y beneficios fiscales..................................... 294

f) Obligaciones contables y control externo …………..................................... 297

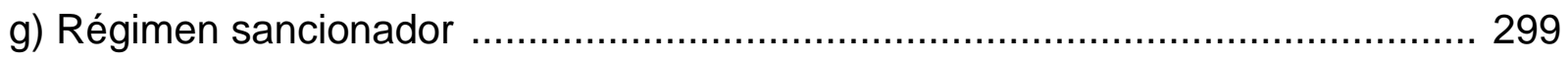

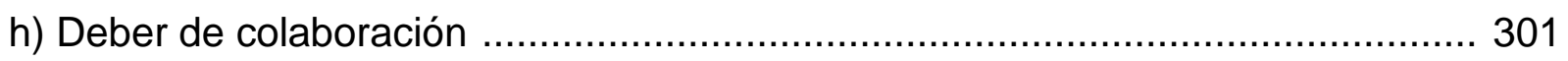

i) Asociaciones y fundaciones vinculadas a los partidos políticos........................... 302

j) Posibilidad de renegociación de deudas y actualización de valores..................... 304 
3) ¿Es posible separar la financiación de las actividades extraordinarias de las ordinarias de los partidos políticos? El problema de su diferenciación

4) El impacto de la financiación de partidos en determinados aspectos del Derecho de Partidos

4.1. La influencia de la financiación de partidos sobre la democracia interna de las organizaciones partidistas

4.2. Los efectos económicos de la disolución de los partidos 321

5) La financiación indirecta a nivel estatal de los partidos políticos.

6) Las bases para la adopción del modelo actual de campaña electoral y algunas cuestiones conflictivas sobre su financiación

6.1. El mailing (art. 175.3 de la LOREG) y la práctica electoral partidista 345

6.2. La precampaña y la campaña 351

6.2.1. El concepto de campaña electoral y el problema de la diferenciación con la precampaña

6.2.2. El problema de la definición de gastos electorales - el problema de la propaganda política y la propaganda electoral

7) La financiación electoral a nivel autonómico. 366

7.1. Breves apuntes sobre el sistema electoral autonómico 366

7.2. Una ojeada a la legislación autonómica 371

8) La financiación de las actividades ordinaras de partidos políticos 392

9) La financiación de los grupos parlamentarios 394

10) Breves notas sobre la financiación de partidos políticos y de las elecciones en el ámbito de la Unión Europea 403

\section{EL CONTROL DE LA FINANCIACIÓN DE LOS PARTIDOS POLÍTICOS Y SUS DISFUNCIONALIDADES}


1) Consideraciones generales sobre la función de fiscalización de los partidos políticos

1.1. Aspectos generales de la fiscalización - la "accountability" 418

1.2. La discusión sobre la competencia del Tribunal de Cuentas y su comparación con la ley orgánica 8/2007

1.3. Análisis de los datos constantes en los informes emitidos por el Tribunal de Cuentas

1.3.1. Informes sobre la financiación electoral 428

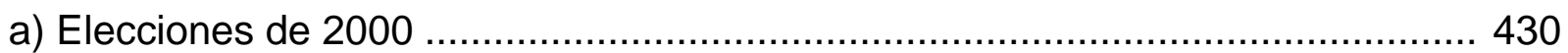

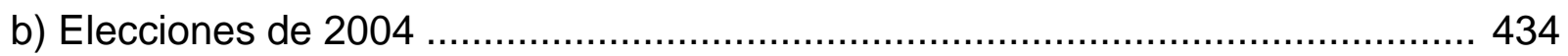

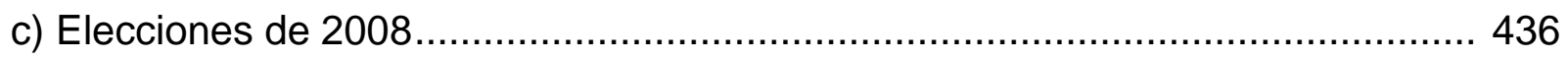

d) Conclusiones del Tribunal de Cuentas ....................................................... 439

1.3.2. Informes de la financiación ordinaria........................................................ 443

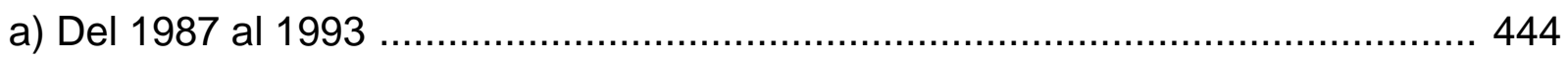

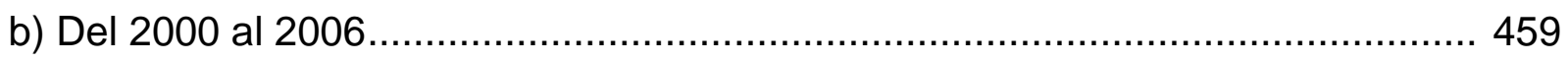

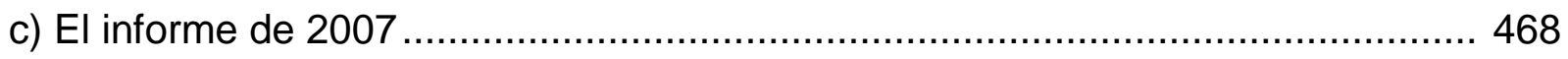

c.1) Las fundaciones vinculadas a los partidos fiscalizadas por el Tribunal

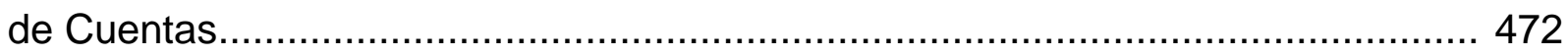

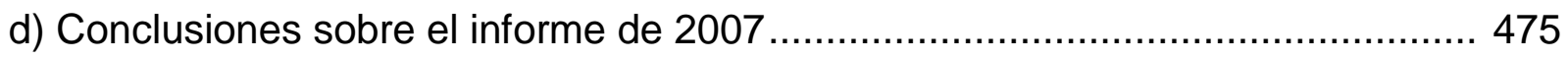

1.4. Conclusiones generales sobre el análisis de los informes del Tribunal de Cuentas - ¿la constatación de un control fallido?

2) Las consecuencias para el sistema democrático de la aplicación del actual modelo de financiación de partidos: desafección, apatía y deslegitimación.

\section{EL NUEVO PROYECTO DE LEY SOBRE LA FINANCIACIÓN ORDINARIA DE PARTIDOS POLÍTICOS}

1) Las enmiendas presentadas - La negociación previa 486 
2) El proyecto de ley tras su aprobación por el Congreso de los Diputados 490

CONCLUSIONES 495

BIBLIOGRAFIA 512 RESUMO PORTUGUÊS i CONCLUSAO PORTUGUÊS a 


\section{INTRODUCCIÓN}

Es un hecho que los partidos políticos generan una dualidad de percepciones. Si hay política, hay partidos, pues su existencia es necesaria para cualquier régimen democrático. Sin embargo, también están directamente vinculados al lado más "nebuloso" de las instituciones públicas, ostentando quizás la posición más "incomoda" dentro de la esfera pública.

La evolución de los partidos se ha acompasado al propio desarrollo de las sociedades democráticas occidentales. Desde el siglo XIX los partidos políticos fueron incorporándose paulatinamente a la escena pública, sirviendo de cauce de ciertas demandas sociales, o de igual forma reivindicando derechos del ciudadano antes inexistentes. En los orígenes del moderno Estado Constitucional tan solo existían, como es sabido, lo que se ha denominado de partidos de cuadros. Lo que pasó en las etapas posteriores no fue más que la consecuencia directa de la transformación de las estructuras sociales a partir de la gradual extensión del sufragio y de la agudización de las luchas sociales. Ante dichos eventos, fue una cuestión de tiempo que se originaran movilizaciones organizadas a través de los partidos de masas, con un perfil más popular, una mayor capacidad de agregar voluntades, y también de crear nuevas maneras de recaudar recursos económicos, y así poder competir con la élite, antes ocupante hegemónica del Estado.

No es necesario exponer cuál fue la función del dinero en esta dinámica. Dichas organizaciones elaboraron nuevas estrategias para hacer propaganda electoral y centraron su actividad política y su existencia económica a la militancia y en el pago de las cuotas, permitiendo que los nuevos partidos estuvieran en condiciones de mantener una estructura fija a partir de sus sedes, la confección de sus propios periódicos, y otros muchos mecanismos partidistas. Aunque los recursos económicos no eran abundantes, como solía ocurrir, por otra parte, con los partidos de cuadros, tenían la ventaja del apoyo popular, traducido en una participación política efectiva de los militantes.

Pero poco a poco un mundo en evolución fue provocando nuevos cambios, y, en último término, la aparición de un nuevo modelo de Estado, el Estado de Bienestar que a la vez provocó fuertes impactos en la vida política a 
la dinámica de lo que terminó denominándose de Estado de Partidos. El sufragio universal ya consolidado, motivaría la creación de nuevas tecnologías que pretendían llegar a la mayor cantidad posible de electores a través de una campaña centrada en los instrumentos audiovisuales. Esta nueva forma de propaganda electoral ha sustituido a las estrategias anteriormente usadas por los partidos de masas, afectando directamente a la militancia y sustituyendo esta movilización por el impacto mediático. Junto a ello, el apoyo económico que el Estado empezó a conceder a los partidos pasó a ser fundamental para su propia vida política, y si para el mantenimiento de esta ayuda eran necesarios electores, la lógica obligaba a hacer política a partir de una determinada ideología, pero flexibilizando dichos ideales, facilitando el convencimiento y la captación de votantes. Acabó por crearse así, junto con otros motivos, otro tipo dominante de partido político, que en la conocida denominación de KIRCHHEIMER serían los partidos "catch all".

Los partidos catch all serían los protagonistas de una profunda transformación en la forma de hacer política. Se trataba de organizaciones costosas, a partir de los gastos crecientes generados por el uso de los mass media y la profesionalización de la política, en un panorama de desvalorización de la militancia y debilitamiento de las ideologías en aras del éxito electoral. Dado que los recursos públicos son indispensables para el sostenimiento de este modelo, y siendo el principal requisito para su obtención el logro de representación electoral, no es difícil constatar que el tema de financiación de la política en este punto se vuelva crucial y complicado.

Uno de los efectos más visibles de este modelo de partidos se percibe en el ámbito de la participación partidaria, que se vuelve simbólica, privilegiando la impermeabilidad y la inmovilidad de la élite dentro de la organización. El propio militante "tipo" con fuerte identificación ideológica, termina desapreciado en la estructura real de poder, que, en virtud de la "transversalidad" que garantiza el éxito, termina reduciendo la vida política partidaria a la estricta relación entre la élite del partido y los electores. La financiación de dichas organizaciones también se ve alterada, ya que estas élites tienen a su favor el control real de los numerosos recursos públicos, disminuyendo así la importancia de la afiliación - junto con su base social - y 
de la contribución por medio de las cuotas. De manera paralela, las fuentes disponibles de recaudación de fondos económicos también se reducen, haciendo que surjan otras opciones que dudosamente atienden a los principios democráticos, como puede ser la financiación irregular, la influencia de grupos de presión, o incluso el aumento considerable de la financiación pública sin considerar el eventual rechazo de la opinión pública.

También es cierto que la profesionalización de la política trajo consigo una competencia más fuerte entre los partidos, demandando más recursos para este fin. Mucho más si se considera que, con la flexibilización de ideologías, el propio electorado acabó por volverse más volátil y cada vez más influenciable por las técnicas de marketing que empezaron a ser empleadas en las campañas electorales profesionales. No parece polémico que muy pronto estas circunstancias terminaron provocando importantes desequilibrios en el principio de igualdad de oportunidades entre los competidores electorales, pilar básico en cualquier sistema democrático. A partir de entonces la preocupación por la mejora en los sistemas de financiación de los partidos aumentó considerablemente al menos en la literatura jurídica sobre el tema, ya que tanto la igualdad como muchos otros principios - como el pluralismo político parecieron necesitar de una mayor garantía para ser preservados en medio de lo que se puede considerar un verdadero cambio de paradigma.

En el sistema de financiación de partidos existen por lo menos tres elementos claves objeto de regulación. El primero es la "renta" de los partidos, las fuentes de sus recursos, básicos para el mantenimiento de su organización y para su actividad electoral y partidista. Ninguno de los modelos de obtención de recursos parece, sin embargo, carecer de inconvenientes. El segundo aspecto es el de los "gastos" de los partidos. Y el tercero afecta a la propia regulación de las finanzas de los partidos, pues el Estado democrático actual debe asumir un papel fundamental en el mantenimiento de la dinámica abierta del sistema democrático, y por tanto deberá forzosamente intervenir en las cuestiones que distorsionen este proceso. No creo que esté claro que en la doctrina si es el sistema de financiación de los partidos el que influye de manera fundamental en el funcionamiento del sistema democrático o si ocurre al contrario, pero en este trabajo, asumiendo una cierta relación dialéctica, pero 
también autopoiética, entre ambos sistemas, se partirá no obstante del presupuesto de que la primera hipótesis es básicamente la preponderante, lo que nos permitirá subrayar hasta qué punto las normas de financiación de partidos en España tienen un impacto sobre el actual modelo de partidos y sobre el propio funcionamiento y calidad del sistema democrático.

En las últimas décadas, la financiación de los partidos políticos ocupó un lugar central en las discusiones públicas, ante todo por la creciente incidencia de escándalos políticos relacionados con sus recursos económicos y con la financiación de las campañas electorales. No parece sin embargo, que se haya conseguido ningún consenso doctrinal sobre el tema que posibilite reformas en profundidad de los diversos sistemas de financiación que, a su vez, permitieran recuperar un cierto "consenso social", base de cualquier "relegitimación" efectiva de este aspecto del Estado de Partidos.

Es cierto, sin embargo que se plantearon, en una dinámica cíclica, muchas posibles reformas, fruto de la identificación de puntos problemáticos aunque comunes - entre las diferentes legislaciones a este respeto. La falta de apertura y transparencia en la financiación; la ineficacia del ordenamiento jurídico para la regulación de este aspecto del Derecho de Partidos o la perniciosa "proximidad" entre los grandes donantes y los dirigentes de los partidos, son tópicos idénticos en cualquier país que se analice, y que parecen sortear permanentemente las proclamadas intenciones de un legislador que no deja de ser fiel reflejo de la estructura de partidos.

En el caso español, el debate sobre la adopción de un sistema de financiación de los partidos estuvo ya presente en el debate constituyente sobre el art. 6 de la Constitución Española, pero adquirió verdadera trascendencia pública desde la polémica sobre el denominado "caso Flick", en 1984, que motivó la creación de la primera Comisión de Investigación sobre la financiación de los partidos, la cual desgraciadamente no tuvo mucho éxito en sus conclusiones por la prematura disolución de las Cámaras Generales y la consecuente convocatoria de elecciones generales. En todo caso, sería el punto de inicio de un largo debate político y doctrinal todavía no cerrado.

La financiación de los partidos implica dos respuestas ante todo a tres problemas de significativa importancia: la suficiencia de fondos; la adecuada 
distribución de los recursos tanto entre los partidos como también entre los candidatos; y la transparencia del propio sistema. La sociedad no puede mantenerse al margen porque la financiación de partidos afecta a derechos directos de los propios ciudadanos, como la libertad de expresión, la igualdad de posibilidades electorales, la calidad y la legitimación democrática, o el control del uso de los recursos públicos. Es aquí donde creo que encuentra su justificación un trabajo de investigación como el que se presenta. En definitiva, las finanzas de los partidos desde siempre han resultado especialmente resistentes tanto a su normativización por el Derecho de Partidos, como a su enjuiciamiento crítico desde las categorías centrales del Derecho Constitucional.

En este trabajo, en todo caso, no se afirma que todas las soluciones estén en la regulación jurídica del fenómeno, y el derecho, y más en este campo, debe de ser consciente de sus limitaciones en su eficacia. Sin embargo, los cambios en el sistema deben probablemente empezar por una reformulación normativa. Es en este punto en donde se asienta el debate , porque si los partidos poco a poco fueron introduciendo normativas para consolidar su financiación a través de subsidios públicos, utilizando el Estado en beneficio propio, sin que el principio del check and balances les controlara, esta situación también ha abierto espacio para el surgimiento de lo que se denominan "partidos cartel", como una etapa sucesiva al desarrollo de la tipología de partidos después del partido catch all, y produciendo desequilibrios importantes en el propio sistema democrático.

El objeto principal de este trabajo es justamente el análisis del sistema de financiación de partidos en España bajo los nuevos paradigmas que han sido identificados. Por tanto, en el Capítulo I se juzgó conveniente que se expusieran algunas nociones sobre el Derecho de Partidos, partiendo de la constitucionalización de los partidos políticos hasta la regulación de estos, conectando el análisis con las funciones que les fueron asignadas por la Constitución Española y su relación con elementos básicos del sistema de legitimación democrática, como son el pluralismo político, la representación y la participación popular. Por otra parte se remarca la obvia relación entre el 
sistema de financiación y el sistema electoral, analizando también la jurisprudencia constitucional sobre este punto.

En el Capítulo II, el análisis se centra en la financiación de los partidos propiamente dicha, exponiendo los aspectos más relevantes tanto de la financiación privada, como de la pública. Se han tratado de sistematizar las principales controversias suscitadas en los distintos modelos, entendiendo que el establecimiento de un modelo mixto de financiación puede considerarse la tendencia dominante, aun cuando se carezca de criterios consolidados sobre el equilibrio más efectivo entre las medidas de financiación privada y pública. A continuación, se exponen tres modelos de sistemas de financiación, optando por Estados Unidos, Alemania e Italia como paradigmas de los modelos aplicados. La elección de los Estados Unidos se justifica por tener una legislación mucho más centrada en el control de los recursos utilizados - como es sabido, primordialmente de carácter privado - y por las constantes relativizaciones de dichos controles en favor de la libertad de expresión. Por su parte, la elección de Alemania se debe al hecho de que, a partir de un sistema de financiación pública de partidos bien estructurado, creo que es un ejemplo de los exitosos intentos en la preservación del pluralismo político y de la igualdad de oportunidades, con la colaboración directa del Tribunal Constitucional en la mejora de la legislación. Italia, por su parte, aunque haya partido del mismo punto que Alemania para la elaboración de su legislación sobre el tema, acabó por tomar otra dirección debido al fuerte rechazo popular que suscitó en un momento dado la financiación pública de los partidos, lo que se explica a partir de la peculiar trayectoria política de este país. Para finalizar dicho capítulo, se han analizados algunos desequilibrios identificados como más comunes entre la financiación privada y pública, prestando especial atención tanto el problema de la corrupción (a partir de su conceptualización, origen y motivación), como también a la polémica sobre la existencia de los llamados "partidos cartel".

El Capítulo III se centra en el ordenamiento español, exponiendo la financiación de los partidos desde el momento constituyente hasta la actualidad. Dicha evolución histórica es esencial para entender el panorama actual, condicionado por las últimas reformas del sistema de los partidos, como 
es el caso de la Ley Orgánica 8/2007 sobre la financiación ordinaria de los partidos, y la reforma recién aprobada en 2011 de la LOREG. Posteriormente se analiza las cuestiones especialmente problemáticas dentro del sistema, confrontando las reivindicaciones anteriores de la doctrina con los cambios efectivamente producidos en aspectos como la propaganda de campaña y precampaña, los gastos de publicidad, el mailing, y algunos otros. Hemos intentado también relacionar algunos de los efectos producidos por el modelo vigente con otros problemas del Derecho de Partidos, entre ellos su efecto distorsionante de la ya escasa democracia interna en los partidos, la polémica disolución patrimonial de los partidos ilegalizados o la ineficacia del actual modelo de campaña electoral. Posteriormente, el análisis se centra en el nivel autonómico, y en el incipiente ámbito europeo, abordando por último la financiación de los grupos parlamentarios, lo que complementa las conclusiones que poco a poco se va delineando.

Finalmente, en el Capítulo IV se estudia, desde la perspectiva del control y con un cierto detalle, los informes del Tribunal de Cuentas sobre la financiación de los partidos, tanto electoral como ordinaria, demostrando el carácter recurrente de los problemas antes abordados y comprobando de manera empírica los efectos de la aplicación de la legislación actualmente en vigor. Durante la corrección final de este trabajo, el Tribunal de Cuentas acabó por aprobar el primer informe a partir de la aplicación de la Ley Orgánica 8/2007, confirmando las deficiencias indicadas a lo largo de la exposición. Además, por tratarse de un periodo de transición, se percibe todavía la necesidad de introducir nuevas medidas en la fiscalización de los partidos. Como cierre de esta investigación, se exponen algunas conclusiones basadas en los informes del Tribunal de Cuentas, como también algunas expectativas con relación a la aplicación de la nueva normativa, para confrontarlas con las consecuencias generadas por este control en el sistema democrático.

En la fase final de la elaboración de este trabajo, se entendió necesario añadir el Capítulo $\mathrm{V}$, sobre el nuevo proyecto de ley de financiación de partidos políticos, en sustitución a la Ley Orgánica 8/2007. El nuevo proyecto, por más que tuviera en su origen la pretensión de eliminar algunas deficiencias constantes en la normativa, nuevamente no parece haber logrado avances 
sustantivos en la materia, aunque sí ha atendido a su principal objetivo, que era disminuir el montante económico de las subvenciones concedidas a los partidos, debido a la actual situación de crisis que vive España.

En definitiva, este trabajo no tiene obviamente la pretensión de agotar el tema objeto de estudio, pero sí pretende aportar elementos para el debate, y llamar la atención sobre las consecuencias que el modelo de financiación de partidos implica para el funcionamiento del sistema democrático español, cuando esta democracia ya se encuentra consolidada en España. Pero del mismo modo que los partidos y el funcionamiento democrático han ido evolucionando, la sociedad española también ha sufrido un enorme proceso de cambio que probablemente, alterado las condiciones de entonces, demanda ahora un replanteamiento, entre otras cosas, del vigente modelo de financiación de los partidos políticos.

Cualquier trabajo de este tipo sería, sin duda, imposible sin el apoyo moral o intelectual de muchas personas. Por ello, quiero expresar mi gratitud ante todo a mi director de tesis, el prof. Augusto Martín de la Vega, siempre enormemente paciente con mis inquietudes y que apoyó mis ideas y me amparó en los momentos de confusión académica. Gracias a su apoyo, pude lograr mi mayor objetivo profesional, que ciertamente no tendría el mismo resultado sin él.

Además, quiero mostrar mi agradecimiento al prof. José Luis Cascajo Castro, maestro de toda una generación de constitucionalistas. Sus palabras de incentivo me dieron el ánimo que muchas veces falta a los doctorandos, y me han motivado permanentemente por continuar este trabajo.

No podría tampoco dejar de mostrar mi agradecimiento a la prof. Mercedes Iglesias Báez, por su constante y tan benéfico apoyo durante la dura trayectoria de un doctorado; al Dr. Rafael Bustos Gisbert, por haberme aceptado y auxiliado para entrar en este programa de posgrado desde mi país de origen, y también por haber tenido tantas veces la paciencia necesaria con alumnos extranjeros como yo; y al Dr. Mario Hernández por ser solidario en dividir no sólo conmigo, sino con todos los que componen el Seminario de Derecho Constitucional su experiencia como doctorando, dándonos fuerza y motivación en diversos momentos de duda. 
A todos mis colegas componentes del mencionado seminario, que no sólo participaban en los largos momentos de concentración frente al ordenador, sino que también han dividido las angustias tan comunes cuando se está cursando un doctorado: muchas gracias por haber compartido este momento tan único en nuestras vidas.

Durante este camino también tuve el placer de visitar algunas instituciones de renombre que fueron fundamentales para elevar la calidad de la investigación realizada, como la Universidad Pompeu Fabra en Barcelona; la Universidad Complutense de Madrid, la Universidad Carlos III en Madrid; la Universitat de Valencia; la Biblioteca del Congreso de los Diputados; la Biblioteca del Centro de Estudios Constitucionales; la University of Oslo en Noruega; la Universidade de Coimbra en Portugal y la inolvidable Università di Bologna en Italia. Aquí, no puedo dejar de agradecer al prof. Dr. Lucio Pegoraro su generosa acogida, dándome todo el soporte necesario para la realización de una estancia especialmente rica para esta tesis doctoral.

Tampoco puedo olvidarme de la Universidad de Salamanca, institución que me ha acogido durante cuatro años y que me ha abierto generosamente las puertas de su academia.

Finalmente, es imposible no mencionar a mi padre, que junto conmigo ha sido directamente "afectado" por mi decisión de estudiar tan lejos de mi país, que me ha soportado en los buenos y malos momentos, siempre animándome a proseguir, por muy grandes que fueran los obstáculos en el camino..

Y como era de esperar, también a mis amigos que están por todo el globo, sea en Brasil, con la fe de algún día verme con el título de doctora, o aquellos que estuvieron conmigo en Salamanca, dado que algunos siguen y otros ya han concluido esta fase. No es posible nombrar a todos, porque el listado sobrepasa con mucho el espacio disponible, pero durante estos cuatro años ellos me han enseñado que el doctorado no era solamente una evolución intelectual, sino también personal, y han hecho todo lo que estaba a su alcance para hacerme seguir adelante en momentos difíciles. A mis amigos, faltan palabras para narrar toda la gratitud que siento. Aquí también menciono a mi ex profesora y ahora estimada amiga Eneida Desirée Salgado, que me ha 
inspirado a elegir el doctorado como objetivo profesional, y que me animó a estudiar en un país extranjero. 


\section{CAPÍTULO I}

\section{LOS PARTIDOS POLÍTICOS EN LA CONSTITUCIÓN ESPAÑOLA DE 1978 - EL DERECHO DE PARTIDOS}

El Derecho de Partidos se ubica en el núcleo del sistema democrático, ya que conecta elementos vitales como el pluralismo, el sistema de partidos, la representatividad y la gobernabilidad. Ante esto, se podría afirmar que el Derecho de Partidos es una variable dependiente del principio democrático, porque atañe a la democracia poniendo a los partidos entre la esfera jurídica y la realidad. ${ }^{1}$

Lo cierto es que dicho Derecho de Partidos se ve afectado por las disfuncionalidades que produce el hecho de ser en el fondo, como es sabido, una autorregulación, lo que puede siempre producir una cierta "ilusión del jurista", donde las demandas doctrinales de normativización se vean de hecho acompañadas por una débil efectividad jurídica que permite a los partidos mantenerse siempre en un "claroscuro" jurídico, siendo como son los directamente beneficiados por las insuficiencias de dichas normas. ${ }^{2}$ Así, y aunque no se trate pormenorizadamente, puede resultar conveniente resaltar algunos de los principios estructurales de esta gama del Derecho Constitucional más directamente relacionados con la problemática de la financiación de los partidos.

Como es sabido, la democracia debe ser entendida como algo plural, que se ampara en los sujetos políticos del mundo actual y que, sin ellos, no sería posible. Pero, debido a las distorsiones hoy existentes, se verifica que la relación entre la democracia, el pluralismo, y los propios partidos políticos es

\footnotetext{
${ }^{1}$ GRIMM, D. "Los Partidos Políticos". In: BENDA, E.; et al: Manual de Derecho Constitucional. Ed. Marcial Pons, Madrid, 1996. Pp. 391.

${ }^{2}$ MARTín DE LA VEGA, A. "Los Partidos Políticos y la Constitución de 1978. Libertad de Creación y Organización de los Partidos en la Ley Orgánica 6/2002". In: Revista Jurídica de Castilla y León, no extraordinario, enero, 2004. Pp. 207. Dentro del tema, PRESNO LINERA entiende que las distorsiones del papel de los partidos políticos empiezan cuando estos se sitúan en el centro de la comunicación de la sociedad con el Estado (algo que el autor denomina de autorreferencialidad política, considerando los sistemas sociales). Sin embargo, dichas distorsiones que antes se producían solamente en la práctica (es decir, en el mundo de los hechos), ahora está siendo cada vez más juridificadas (o la ausencia de ellas), agravando la situación. (In: PRESNO LINERA, M. Á.: Los Partidos y las Distorsiones Jurídicas de la Democracia. Ed. Ariel, Barcelona, 2000. Pp. 22-23).
} 
mucho más compleja de lo que aparenta ser. ${ }^{3}$ En todo caso, no es únicamente el Derecho de Partidos el que se ve afectado por dichas peculiaridades. Las discusiones acerca de los partidos dentro del Derecho Constitucional son un tema recurrente del mismo. Desde el origen de las primeras organizaciones hasta hoy, los debates sobre los factores relacionados con la organización de los partidos son multiformes, ya sea en el medio académico, o en el social. La aceptación de los partidos políticos en la literatura jurídica tampoco siguió un camino distinto. Solo a partir de un proceso lento aunque tardío, los partidos fueran aceptados como elementos vitales en la democracia moderna. ${ }^{4}$ Hay que admitir que los primeros análisis acerca de los partidos mostraron una desconfianza hacia su articulación jurídica y un difícil encaje en la teoría constitucional, que hoy, aunque superada, no deja de plasmarse en algunas de las críticas más generales del fenómeno. ${ }^{5}$

\section{1) La constitucionalización de los partidos políticos}

\subsection{Introducción}

El proceso de constitucionalización de los partidos políticos fue el resultado de la evolución de la situación que dichas organizaciones experimentaron a través de los años. Es un hecho que mucho antes de dicha constitucionalización los partidos ya existían en la sociedad, y un ejemplo de esto son los whigs y tories alrededor de 1680 , que posteriormente constituirían los grupos políticos de conservadores y liberales ingleses. La idea de una

\footnotetext{
${ }^{3}$ En este sentido, véase, por todos, MICHELS, R.: Los Partidos Políticos 1 - Un Estudio Sociológico de las Tendencias Oligárquicas de la Democracia Moderna. Ed. Amorrortu, 5o reimp. Buenos Aires, 1996; SARTORI, G.: Teoria Democrática. [s.l]:Fundo de Cultura Brasil/Portugal, 1962. Pp. 136 y GOMES CANOTILHO, J. J.: Direito Constitucional e Teoria da Constituição. $3^{\circ}$ ed. reimp. Almedina, Coimbra, 1999. Pp. 308.

${ }^{4}$ En este sentido, cfr. LINZ, J. J. "Conclusiones: Los Partidos Políticos en la política democrática, problemas y paradojas". In: MONTERO, J. R.; GUNTHER, R.; LINZ, Juan J.: Partidos Políticos: Viejos Conceptos y Nuevos Retos. Madrid: Trotta, 2007, Pp. 282; y LA PALOMBARA, J. "Reflections on Political Parties and Political Development, Four Decades Later". In: Party Politics. v. 13. no 2. Sage, London, 2007. Pp. 143.

${ }^{5}$ WARE afirma que, aunque política y gobierno siempre estuvieron muy conectados con los partidos, esto no los ha hecho instituciones reverenciadas por la sociedad. De hecho, muy lejos de ello, los partidos siempre sufrieron un sentimiento de rechazo y desconfianza por gran parte de la opinión pública. (In: WARE, A.: Political Parties and Party Systems. Great Britain: Oxford University Press, 1996. Pp. 1).
} 
organización con connotación política y partidista se consolidó mucho antes que su debida - y natural - integración en los textos constitucionales. ${ }^{6}$

En todo caso, y como es sabido, el reconocimiento jurídico de los partidos políticos solamente se produjo después de que el mundo viviera un período de colapsos de los sistemas políticos liberales, a partir del surgimiento de regímenes totalitaristas que prohibieron su existencia. Estos eventos dejaron claro que los partidos ejercían una función básica en el establecimiento de un sistema democrático, haciendo de su integración en el ordenamiento jurídico algo previsible y natural. Hubo algunos factores que contribuyeron a ello, como puede ser el retraso inherente con que el Derecho regula fenómenos de la vida social que todavía no se haya comprobado que tiene una cierta perdurabilidad en el tiempo o la resistencia de los propios partidos en ser regulados. Pero la causa principal fue, sin duda, la concepción liberal del Estado que, considerando a los partidos como asociaciones privadas, mantenía a la vez una rígida separación entre gobierno (Estado) y sociedad, dejándolos fuera de la esfera de regulación estatal. ${ }^{7}$

\footnotetext{
${ }^{6}$ MORODO entiende que el reconocimiento constitucional de los partidos políticos y también el reconocimiento de su importancia para el régimen pluralista piden su afianzamiento por parte del Estado y su desarrollo en la vida política. (In: MORODO, R. "Partidos y Democracia: Los Partidos Políticos en la Constitución Española". In: MORODO, R.; et al: Los Partidos Políticos en España. Labor Politeia, Barcelona, 1979. Pp. 14). También en este sentido, cfr. JIMENEZ CAMPO, J. "Sobre el Régimen Jurídico-Constitucional de los Partidos Políticos". In: AA.VV.: Jornadas de Estudios sobre el Título Preliminar de la Constitución. vol. III. Secretaria General Técnica - Ministerio de Justicia, Madrid, 1988. Pp. 1631. En opinión contraria a dichos autores, véase NAVARRO MENDEZ, J. I.: Partidos Políticos y "Democracia Interna". CEPC, Madrid, 1999. Pp. 165.

${ }^{7}$ MORODO afirma que el origen y el desarrollo de los partidos está bastante vinculado con el origen y desarrollo de la democracia parlamentaria liberal. En la revolución liberal, la idea de democracia representativa también conducía a la idea de partidos como 'adulteradores' de la voluntad popular, o también como 'limitadores' del mandato libre de los representantes. Por ello eran también considerados como facciones que perturbaban la sociedad política. Sin embargo, las críticas a los partidos políticos no se limitaron al original liberalismo e irán más allá de su consolidación y caída. En la consolidación del liberalismo, la crítica alcanzará la organización interna y funcionamiento de los partidos políticos (como es el caso de OSTROGORSKI y de MICHELS). La consagración del pluralismo político tras la caída de los regímenes totalitarios derrotados, lo que cambió la imagen de los partidos en dichas sociedades pluralistas. Ante esto, el autor vincula la democracia representativa liberal con la democracia de los partidos, ya que no hay una democracia pluralista sin ellos. (In: MORODO, Raúl. "Partidos y Democracia. Op. Cit." Pp. 8). Tratando también del tema, BISCARETTI DI RUFFIA afirma que la constitucionalización de los partidos siempre fue acompañada por algún tipo de control, considerando que estos generaban desconfianza en cuanto a su inserción en la dinámica estatal. Así, el autor clasifica en tres tipos de controles segundo su paulatina aparición, siendo el primero meramente exterior (o también negativo); el siguiente ideológico programático; y el último estructural y de funcionamiento interno. Se verifica que cada tipo de control de los partidos se identifica también con el modelo del Estado en un momento. Es decir, en el Estado
} 
Por todo ello se ha remarcado que, desde un punto de vista teórico, la función mediadora de los partidos entre la sociedad y el Estado dificulta su definición y caracterización jurídica, principalmente en constituciones que en ciertos aspectos mantienen la tradicional división entre Estado y sociedad. ${ }^{8}$ Por ello, hablar de la constitucionalización de los partidos políticos es también en cierta manera abordar el proceso histórico que culminó en lo que se conoce por Estado de partidos, es decir, es analizar, tanto en el contexto comparado como en el español, el desarrollo de los hechos que resultaron en la plena incorporación de dichas organizaciones en los ordenamientos jurídicos mundiales.

El surgimiento de los partidos políticos ante el Estado puede ser analizado a partir de las clásicas cuatro etapas descritas por Heirich TRIEPEL. ${ }^{9}$ En un primero momento hubo una lucha en contra de los partidos; en un segundo, la ignorancia de su existencia, como una actitud indiferente ante ellos; en una tercera etapa, el reconocimiento de los partidos políticos y su legalización y; como cuarta etapa, se produjo la incorporación constitucional de dichas organizaciones. ${ }^{10}$ Se puede ubicar la época del rechazo a los partidos en el siglo XIX, cuando dichas organizaciones eran consideradas como facciones que supuestamente iban en contra del sistema, siendo perjudiciales para el Estado y para la estabilidad del Gobierno. ${ }^{11} \mathrm{~A}$ la vez, este rechazo a los partidos se articuló en tres fases, empezando con la ignorancia hacia los partidos, su negación, y el rechazo explícito a través de asociaciones antipartidos. La fase de ignorancia puede ser ubicada en los mismos inicios del constitucionalismo, fase que rápidamente conduciría hacia una actitud hostil

liberal, predominará el control externo, ya que los partidos eran asociaciones privadas; ya en el Estado totalitarista, en época de guerra es relevante el control ideológico; y en el Estado democrático, se juzgo necesario regular las actividades internas de los partidos, ubicándose aquí la regulación sobre su financiación, por ejemplo. (In: BISCARETTI DI RUFFIA, P.: Derecho Constitucional. $3^{\circ}$ ed., Ed. Tecnos, Madrid, 1987. Pp. 781-782).

${ }^{8}$ MARTín DE LA VEGA, A. Los Partidos Políticos. y la Constitución de 1978... Pp. 206.

${ }^{9}$ Cfr. GARCíA COTARELO, R.: Los Partidos Políticos. ed. Sistema, Madrid, 1985. Pp. 51-53 y FERNÁNDEZ-MIRANDA CAMPOAMOR, C.; FERNÁNDEZ-MIRANDA CAMPOAMOR, A. F.: Sistema Electoral, Partidos Políticos y Parlamento. Ed. Colex, Madrid, 2003. Pp. 38-42.

${ }^{10}$ TRIEPEL, H. "Derecho Constitucional y Realidad Constitucional". In: LENK, K.; NEUMANN, F. (eds.): Teoría y Sociología Críticas de los Partidos Políticos. Ed. Anagrama, Barcelona, 1980. Pp. 187-188.

${ }^{11}$ GARCÍA GIRÁLDEZ resalta que los ataques a los partidos políticos venían más de los liberales que por parte de los conservadores, porque aquellos se consideraban los portavoces de los intereses de la sociedad. (GARCíA GIRÁLDEZ, T. "Los Partidos Políticos y el Derecho". In: VV.AA.: Curso de Partidos Políticos. Ed. Akal, Madrid, 2003 (¿). Pp. 146). 
hacia ellos, común al liberalismo y el conservadurismo de la época. ${ }^{12} \mathrm{~A}$ su vez, el rechazo explícito se produjo ya fuera del marco constitucional ocurrió a través de la creación del sistema de partido único con filosofía antipartidista. ${ }^{13}$ El escenario descrito cambiará en España a partir de la construcción de un sistema democrático con formas de gobierno predominantemente parlamentarias. Los fenómenos políticos de la época (la ampliación del sufragio, la movilización de las masas y la redemocratización de varios países victimas de regímenes totalitarios) acabaron convirtiendo a los partidos, como es sabido, en elementos imprescindibles, incluyendo la organización de elecciones con un cuerpo electoral amplio resultado del sufragio universal. ${ }^{14}$ Así, se pude afirmar que este proceso evolutivo fue fruto de la soberanía nacional pensada como algo difuso dentro de la sociedad, y que pasaría a ser ejercida a través de representantes del pueblo, justamente en el contexto de democracia representativa basada en la extensión del sufragio, la prohibición del mandato imperativo y el cambio del sistema electoral para sistemas proporcionales (en Francia e Italia), antes basados en sistemas mayoritarios. ${ }^{15}$ Para este nuevo

${ }^{12}$ FERNÁNDEZ SARASOLA, I. "Idea de Partido y Sistema de Partidos en el Constitucionalismo Histórico Español". In: Teoría y Realidad Constitucional, no 7, 1ํsemestre, UNED, Madrid, 2001. Pp. 218-224. En esta época, el autor narra que la negación liberal era basada en el difícil encaje de los partidos en la estructura del Estado, y también porque se desconocía el derecho de asociación. En este sentido, cfr. BASTIDA FREIJEDO, F. J. "La Relevancia Constitucional de los Partidos Políticos y sus Diferentes Significados. La Falsa Cuestión de la Naturaleza Jurídica de los Partidos". In: GONZÁLEZ ENCINAR, J. J. (coord.): Derecho de Partidos. Espasa-Calpe, Madrid, 1992. Pp. 71, con la diferencia que el autor entiende que la teoría liberal no rechaza a los partidos cuando estos no se presentan portadores de intereses sociales.

${ }^{13}$ Sobre ello, por todos: PÉREZ ROYO, J.: Curso de Derecho Constitucional. 10ํํ․ ed. rev. Marcial Pons, Madrid, 2005. Pp. 630-631), y ÁLVAREZ CONDE, E.: El Derecho de Partidos. Colex, Madrid, 2005. Pp. 98-99, para una clasificación de las fases de evolución de los partidos basada en la relación de estos con el Estado, fundamentando incluso que regímenes autoritarios fueron, de una manera, posibilitadas por la constitucionalización del partido único.

${ }^{14}$ MARTíNEZ SOSPEDRA, M.: Introducción a los Partidos Políticos. Ariel, Barcelona, 1996. Pp. 17.

${ }^{15}$ Cfr. LÓPEZ GUERRA, Luis. El Carácter Instrumental de las Organizaciones Partidistas de Masa. In: VEGA, Pedro de (ed.): Teoría y Práctica de los Partidos Políticos. Edicusa Cuadernos para el Diálogo, Madrid, 1977. Pp. 104. El autor complementa su explicación afirmando que existen tres razones para justificar la instrumentalidad de los partidos de masas, siendo la primera la extensión de la propaganda electoral, ya que el patronaje, la corrupción y etc. hacían que el partido de notables (de cuadros) fuera obsoleto, y el partido de masas conseguía mano de obra política; además, era también una fuente de financiación electoral, ya que los partidos socialistas (generalmente en el modelo de masas) no tenían grandes fuentes para su mantenimiento y; a la vez, permitía mantener la ideología del partido, a través de los intereses de clases. (LOPEZ GUERRA, Luis. El Carácter Instrumental de las Organizaciones Partidistas de Masa. In: VEGA, Pedro de (ed.): Teoría y Práctica de los Partidos Políticos. Edicusa - Cuadernos para el Diálogo, Madrid, 1977. Pp. 104-105). 
escenario, se exigían partidos fuertemente organizados. ${ }^{16} \mathrm{La}$ admisión de los partidos y el consecuente reconocimiento de su necesidad ha atravesado principalmente dos fases, siempre diversas en función de los países, siendo la primera la que encuadraba a los partidos políticos en un sistema fundamentalmente bipartidista, y la segunda la que los encajaba en un contexto predominantemente pluripartidista. La primera etapa corresponde mayoritariamente a la visión liberal clásica y la segunda gira en torno al concepto de la democracia pluralista. ${ }^{17}$

Con este espacio abierto a una nueva concepción de los partidos políticos, se produjeron oportunidades para cambios más significativos. Con todo, aunque hubiera acabado la situación generada por la ignorancia de estas organizaciones, dicho reconocimiento también ha contado con algunas contradicciones con el pensamiento liberal predominante en aquel momento, siendo corregidas solamente cuando la democracia pluralista ${ }^{18}$ se enfrentaba al ascenso del totalitarismo en el período de entreguerras ${ }^{19}$, lo que provocó a su vez un replanteamiento de la noción de partido en las sociedades

${ }^{16}$ Cfr. CRUZ VILLALÓN, P. "Teoría e Ideología del Partido Político". In: VEGA, P. de (ed.): Teoría y Práctica de los Partidos Políticos. Edicusa - Cuadernos para el Diálogo, Madrid, 1977. Pp. 34-35 y; GARCIA GUERRERO, J. L. "Algunas Cuestiones sobre la Constitucionalización de los Partidos Políticos". In: Revista de Estudios Políticos (nueva época), no 70, oct/dic, 1990. Pp. 143-144.

${ }^{17}$ FERNÁNDEZ SARASOLA, I. "Idea de Partido..." Pp. 225-230. Así, en el siglo XIX el reconocimiento de los partidos se plasmó en un bipartidismo predominante y por la idea de que eran organizaciones intraparlamentarias, y no organizaciones sociales, siendo considerados como elementos del sistema parlamentario que del sistema democrático propiamente dicho. Ya con la consolidación de la idea de grupo parlamentario, se produjo la diferenciación entre facción y partido, produciéndose también el cambio en la idea de oposición política, convertida ahora en una alternativa de Gobierno.

${ }^{18}$ LUCAS VERDÚ entiende que solamente cuando el Estado de Derecho empieza a sentirse amenazado por los partidos políticos de masa de izquierda y de derechas, se comienza una progresiva constitucionalización de ellos. Antes de esto, eran negados o simplemente ignorados. (In: LUCAS VERDÚ, P.: Curso de Derecho Constitucional. Vol. IV, Constitución Española de 1978 y Transformación Político-Social Española. Ed. Tecnos, Madrid, 1984. Pp. 560). Ya Sarasola entiende que el cambio de la idea de partidos no como organizaciones parlamentarias, pero si como organizaciones sociales abrió espacio para la apertura hacia el pluripartidismo, y por ello nacerían como consecuencia del ejercicio del derecho de asociación, reflejando en las instituciones representativas el pluralismo existente en la sociedad. (In: FERNÁNDEZ SARASOLA, I. "Idea de Partido..." Pp. 232).

${ }^{19}$ GARCÍA COTARELO afirma que el verdadero desarrollo de los partidos ocurrió después o en el período de entreguerras por el cambió que esto supuso. Con eso, surgieron la necesidad en adaptarse a los cambios del entorno, haciendo de los partidos políticos canales apropiados para formular propuestas de transformación social, económica y política (In: GARCíA COTARELO, R.: Los Partidos Políticos. Op. Cit. Pp. 55-56). 
occidentales. ${ }^{20}$ Así, se destaca el cambio subyacente de una noción negativa de los partidos a una valoración positiva, dentro del marco de las sociedades pluralistas, ${ }^{21}$ Dicho cambio de fondo se hizo más evidente después de la Segunda Guerra Mundial con la redemocratización de los sistemas políticos, lo que culminó en la percepción de la importancia de los partidos para la democracia y el refuerzo de la idea de Estado Democrático. ${ }^{22}$ Es conocido que la constitucionalización de los partidos políticos en Europa se inició en países con sistemas políticos destruidos, con viejos partidos sobrevivientes de la lucha en la clandestinidad y también de nuevas formaciones, en cierta forma improvisadas. Lo que permitió reconstruir políticamente dichos Estados fueron los partidos que patrimonializaron pronto la lucha antifascista y encarnaron las aspiraciones del nuevo Estado democrático. ${ }^{23}$ Por ello, la constitucionalización de los partidos políticos en Europa empezó ${ }^{24}$ en países como en Italia (art. 49) ${ }^{25}$, Alemania (art. 21) ${ }^{26}$ y Francia (art. 4). ${ }^{27}$ Uno de los últimos países de Europa a adherir a dicha tendencia fue lógicamente España en la que, debido

\footnotetext{
${ }^{20}$ Ante dichos cambios, BASTIDA FREIJEDO subraya que los partidos políticos de izquierda pretendieron convertir sus ideas en la nueva base jurídica del Estado, atacando justo la separación Estado/sociedad propia de los liberalistas. Con todo, para que los partidos políticos conquistaran legalmente el Estado, necesitaban pasar por la competición electoral, y por ello se obligaron a cambiar de actitud, montando estrategias y cambiando la propia definición de esas organizaciones. (In: BASTIDA FREIJEDO, F. J. "La Relevancia Constitucional..." Pp. 72.

${ }^{21}$ MORODO LEONCIO, R. "Artículo 6". In: ALZAGA VILLAAMIL, O. (dir.). Comentarios a las Leyes Políticas - Constitución Española de 1978. Tomo I, preámbulo y artículos 1 a 9. ed. Edersa, Madrid, 1983. Pp. 236. El autor afirma que, aunque el desarrollo legal de los partidos haya empezado a través de la vía interna de las Cámaras - como ya dicho anteriormente -, los grupos parlamentarios expresaban, directa o indirectamente, a los partidos políticos. pero su desarrollo legal llegó al tope solamente después de 1945, y en esa época, tampoco se discutía el relevante papel de los partidos políticos en el pluralismo político. (In: MORODO, R. "Partidos y Democracia. Op. Cit." Pp. 8-9).

${ }_{22}$ Cfr. MORODO, R.; MURILLO DE LA CUEVA, P. L.: El Ordenamiento Constitucional de los Partidos Políticos. $1^{\circ}$ ed. UNAM - Instituto de Investigaciones Jurídicas, Derechos Fundamentales, 2001. Pp. 27.

${ }^{23}$ GARCÍA-PELAYO, M.: El Estado de Partidos. Ed. Alianza, Madrid, 1986. Pp. 47-51. El autor también afirma que desde una visión jurídico-política el reconocimiento de los partidos también sede a su relevancia para el sistema, y que estos deberían tener garantías institucionales, ya que no eran solo un tipo diferenciado de asociación.

${ }^{24}$ Merece destacarse que la Constitución de Weimar recogió una cierta mención a los partidos, pero que únicamente después que la idea de constitucionalización de dichas organizaciones ha ganado fuerza. (In: STERN, K.: Derecho del Estado de la República Federal Alemana. ed. Centro de Estudios Constitucionales, Madrid, 1987. Pp. 751).

${ }^{25}$ Cfr. por todos MORTATI, C. "Note Introduttive a uno Studio sui Partiti Polítici nell'Ordinamento Italiano". In: AA.VV.: Scritti Giuridici in Memoria di V.E. Orlando. Tomo 2, ed. Cedam, Padova, 1957. Pp. 141 y ss.

${ }^{26}$ Véase por todos STERN, K. Op. Cit. Pp. 751 y ss.

${ }^{27}$ MORODO LEONCIO, R. "Artículo 6º Op. Cit." Pp. 238 y; LUCAS VERDÚ, P. Op. Cit. Pp. 561
} 
al largo período dictatorial vivido, solamente se pudo constitucionalizar a los partidos políticos a partir de la Constitución Española de 1978.

\subsection{La constitucionalización de los partidos en España}

El proceso de constitucionalización de los partidos políticos en España representa pues, desde una perspectiva de Derecho Comparado, un proceso tardío. ${ }^{28}$ Sin embargo, este hecho no evitó que España siguiera a los demás países europeos en lo que se refiere a su postura ante las organizaciones partidistas, ya que en 1977 - año que marcó la transición política - el fenómeno de los partidos políticos era algo innegable. De esta forma, la Constitución Española de 1978 fue la primera en reconocer expresamente la realidad de los partidos políticos en el ordenamiento jurídico español. ${ }^{29}$

En todo caso, en la historia constitucional española, una de las primeras normas que se puede citar que tenga algún tipo de mención a una especie de partidos políticos es el Decreto de 20 de octubre de 1820, que se refiere a las sociedades patrióticas ${ }^{30}$, que en una cierta forma serian el embrión de los partidos. ${ }^{31}$ Hubo también algunas normas que aunque no hacían mención expresa a los partidos, contemplaban organizaciones en defensa de intereses generales, como puede considerarse el estatuto real de $1834 .^{32}$ Ya con relación

${ }^{28}$ Cfr. GARCÍA GIRÁLDEZ, T. Op. Cit. Pp. 161-162, en que la autora expone algunas razones que no permitieron la constitucionalización de los partidos políticos antes de la Constitución Española de 1978.

${ }^{29}$ De manera expresa, no hay mención a los partidos políticos en las Constituciones anteriores a la de 1978, tampoco en las leyes orgánicas que las completan o en textos legales. Es un ejemplo de la ignorancia de una realidad política que venía existiendo desde la ampliación del sufragio, pero que dicha postura acabó por fomentar la formación de partidos de manera no regulada. (In: ARTOLA, M.: Partidos y Programas Políticos, 1808-1936. Tomo I, ed. Alianza Editorial, Madrid, 1991. Pp. 178).

${ }^{30}$ Sobre dichas sociedades, vid. por todos: GIL NOVALES, A.: Las Sociedades Patrióticas (1820-1823). 2 vol. ed. Tecnos, 1975. Cap. I-V y SOLÉ TURRA, J.; AJA, E.: Constituciones y Períodos Constituyentes en España (1808-1936). 17º ed. ed. Siglo XXI, Madrid, 1997. Pp. 24.

${ }^{31}$ La discusión sobre el derecho de asociación política a partir de estas sociedades patrióticas tuvo lugar en la sesión de Cortes de 28 de julio de 1820, con el señor Álvarez Guerra. El resultado de este debate solo se ha visto en el Decreto 20 de octubre de 1820, lo cual versaba sobre reuniones de individuos para asuntos políticos. (In: SEVILLA ANDRES, D.: Constituciones y otras Leyes y Proyectos Políticos de España. Tomo I, ed. Nacional, Madrid, 1969. Pp. 238-239).

${ }^{32}$ Aquí se intentó la creación de las asociaciones electorales, lo que TOMÁS VILLARROYA considera que fue una de las primeras intenciones de estructurar a lo que sería futuramente un partido en España. (In: TOMÁS VILLARROYA, J.: Breve Historia del Constitucionalismo Español. ed. Centro de Estudios Constitucionales, Madrid, 1981. Pp. 42-45). En este mismo 
a los proyectos de Constitución, el de la Monarquía Española de 20 de julio de 1836 tiene una brevísima mención, reflejando ante todo la idea de "tolerancia" hacia los partidos, y también el proyecto de Constitución Federal de 1873, inspirada por los cambios políticos que le acompañaron. ${ }^{33}$

Las fases de reconocimiento jurídico de los partidos también se encuentran presentes en la historia. En la Constitución de Cádiz no se reconoce el derecho de asociación como tal, y existía la típica postura de enfrentamiento y oposición a las asociaciones políticas, característica de los primeros años del Estado liberal. ${ }^{34}$ De esta forma, y también como un claro reflejo del Estado liberal, se privilegió a los derechos individuales, marginando el derecho de asociación que no era considerado como un derecho individual, ya que se entendía que quien se dirigía a las Cortes y al Rey eran los individuos, y no los grupos. ${ }^{35}$ Ya en la etapa de la indiferencia - o de la tolerancia - que siguió, las Constitución de $1837^{36}$, 1845 y el proyecto de Constitución de 1856 tampoco trajeron ninguna mención a las asociaciones. Por consiguiente, en la fase de legalización de los partidos - la cual tuvo inicio en 1868, a partir de los acontecimientos revolucionarios de la época (como la reivindicación del sufragio universal y del derecho de reunión y asociación pacífica, insertado en el decreto de 20 de noviembre de 1868), la Constitución Española de 1869 acabó por reconocer dicho derecho (que versa sobre el derecho de asociarse para todos los fines de la vida humana que no sean

sentido, cfr. SANCHEZ AGESTA, L.: Historia del Constitucionalismo Español (1808-1936). 4ํㅜㄴ ed. ed. CEPC, Madrid, 1984. Pp. 173 y ss.

${ }^{33}$ CORTÉS BURETA, P. "Los Recursos Económicos de los Partidos Políticos: Una Perspectiva Histórica de su Regulación". In: Revista Aragonesa de Administración Pública. no 22, junio, 2003. Pp. 108. Es de resaltar que, aunque la Constitución de 1876 reconocía el derecho de asociación, este no fue regulado hasta 1887 , no habiendo una base jurídica para constituir un partido, sino más bien había un ambiente tolerante hacia la asociación para fines políticos. (In: SANCHEZ AGESTA, L.: Historia del... Pp. 332).

${ }^{34}$ Vid. por todos: FERNANDÉZ SEGADO, F.: Las Constituciones Históricas Españolas (Un Análisis Histórico-Jurídico). 4ํe ed. ed. Civitas, Madrid, 1986. Pp. 68). En este mismo sentido, cfr. SANCHEZ AGESTA, L.: Historia del... Pp. 171 y ss., en que se destaca el perfil secreto de las asociaciones de hombres para fines políticos hasta 1834; FERNÁNDEZ SARASOLA, I.: Proyectos Constitucionales en España (1786-1824). ed. CEPC, Madrid, 2004. Pp. XXXII-XXXIII; y SUANZES-CARPEGNA, J. V.: Política y Constitución en España (1808-1978). ed. CEPC, Madrid, 2007. Pp. 78 y ss.

${ }_{35}$ En este sentido, cfr. CAVERO LATAILLADE, I.; ZAMORA RODRIGUEZ, T.: Constitucionalismo Histórico de España. ed. Universitas, Madrid, 1995. Pp. 70-71.

${ }^{36}$ Vid. TOMÁS VILLARROYA, J.: El Sistema Político del Estatuto Real, 1834-1836. Ed. Instituto de Estudios Políticos, Madrid, 1968. Pp. 578; SUANZES-CARPEGNA, J. V.: Op. Cit. Pp. 301303 y PRO RUIZ, J.: III - El Estatuto Real y la Constitución de 1837. ed. lustel, Madrid, 2010. Pp. 64 y ss. 
contrarios a la moral pública), pasando este mismo derecho a la Constitución de $1876 .{ }^{37}$

La revolución de septiembre de 1868 y el proceso que se desencadenó durante la restauración (30 de diciembre de 1874 hasta 13 de septiembre de 1923) no puede ser entendidos, en este aspecto, aisladamente del contexto político europeo de la época, pues con la ampliación del sufragio, hubo un enorme aumento en el censo electoral ${ }^{38}$, del cual buena parte se presentaría agrupado, en partidos clasistas, de notables y asociaciones y sindicatos principalmente de perfil laboral. ${ }^{39}$ También en este período, el bipartidismo y el turno ordenado de partidos desempeñaban un papel fundamental, con clara inspiración en el modelo británico. ${ }^{40}$

La crisis de la restauración fue provocada por un conjunto de factores, entre los principales podrían ser mencionados la creciente presencia de corrupción del sistema electoral a través del caciquismo ${ }^{41}$, o también el propio falseamiento del resultado de las urnas. Dichos hechos provocaron la desafección hacia el sistema, culminando en la quiebra del sistema bipartidista

${ }^{37}$ PORTERO MOLINA, J. A. "La Constitucionalización de los Partidos Políticos en la Historia Constitucional Española". In: Revista Española de Investigaciones Sociológicas - REIS, no 1, CIS, Madrid, 1978. Pp. 252-263. El trabajo del referido autor también recopila los textos integrales de las disposiciones acerca del tema. Además, esta Constitución permitió la promulgación de leyes que desarrollaban el derecho de reunión y asociación, siendo las principales la ley de 15 de junio de 1880 y de 30 de junio de 1887, respectivamente. (In: GARCÍA CANALES, M. "Los Intentos de Reforma de la Constitución de 1876". In: Revista de Derecho Político. no 8. UNED, Madrid, 1981. Pp. 114). Aún sobre el punto, SÁNCHEZ AGESTA atribuye a dos hechos al nacimiento de los partidos en España en los finales del siglo XIX, fueron las elecciones periódicas, que a la vez determinaron los comités electorales; y la llamada cuestión de gabinete, que definía el partido como grupo parlamentario. (cfr. SANCHEZ AGESTA, L.: Historia del... Pp. 168 y ss.).

${ }^{38}$ Según datos de MARTíNEZ CUADRADO, el censo electoral pasó de 800.000 electores a 4.800.000, siendo que alrededor de 68 por 100 de ellos pertenecían a zonas agrarias, y un 18 por 100 a zonas industriales. (In: MARTINEZ CUADRADO, M.: Elecciones y Partidos Políticos en España. ed. Taurus, Madrid, 1969. Pp. 529).

${ }^{39}$ Cfr. SANCHEZ AGESTA, L.: La Constitución de 1876 y el Estado de la Restauración. ed. Fundación Santa María, Madrid, 1985. Pp. 33 y ss. De hecho, el problema del caciquismo, con respecto a los partidos y su estructura, vid. por todos: VARELA ORTEGA, J.: Los Amigos Políticos. Partidos, Elecciones y Caciquismo en la Restauración (1875-1900). ed. Alianza, Madrid, 1977. Pp. 242-247).

${ }^{40}$ Cfr. SANCHEZ AGESTA, L.: Historia del... Pp. 265 y ss., donde el autor afirma que el sistema bipartidista entre los partidos constitucionalista y radical trataba de reproducir, de alguna manera, el sistema inglés; y FERNANDÉZ SEGADO, F.: Las Constituciones Históricas... Pp. 360-369.

${ }^{41}$ El malestar debido al caciquismo acabó 'por involucrar incluso a la prensa conservadora de la época (como el periódico ABC). (Cfr. SANCHEZ AGESTA, L.: La Constitución de 1876... Pp. 40). 
antes existente y la proliferación de líderes menores, dividiendo internamente a los partidos entonces existentes. ${ }^{42}$

Ya en la segunda república, se puede verificar una casi constitucionalización de los partidos políticos, con el nacimiento de nuevas formaciones políticas y una situación de excesiva fragmentación del sistema de partidos, que se prolongó hasta los últimos años de la República. ${ }^{43}$ La Constitución Española de 1931 no hará tampoco referencia directa a los partidos, pero seguirá implícitamente enmarcándolos. ${ }^{44}$ En el régimen franquista, como en todos los regímenes de este tipo, los partidos fueron ilegalizados ${ }^{45}$, y se construyó un sistema de partido único ${ }^{46}$, al que fue atribuida la condición de status de persona jurídica con relieve "constitucional", amparado a la vez con la prohibición de las demás opciones políticas. ${ }^{47}$

${ }^{42}$ Vid. SANCHEZ AGESTA, L.: Historia del... Pp. 340 y ss. Aun, sobre la frágil estructura partidista española, GARCÍA COTARELO cita que bastó un 'seudo-golpe' del general Primo de Rivera, para que los partidos 'dinásticos' desaparecieran, imposibilitando incluso su resurgimiento en la transición. (In: GARCíA COTARELO, R.: Los Partidos Políticos. Op. Cit. Pp. $65)$.

${ }^{43}$ Cfr. RAMíREZ JIMENEZ, M. "Los Partidos Políticos Durante la II República (Un Acercamiento al Sistema Republicano de Partidos)". In: TUÑON DE LARA, M.; et al: La Crisis del Estado Español 1898-1936. Ed. Cuadernos para el diálogo, Madrid, 1978. Pp. 428.

${ }^{44}$ Este período entreguerras refleja bien el surgimiento de las masas y la asunción por parte de los partidos de sus posturas políticas. Es decir, aquí los partidos están estructurados y presentes en la realidad política, pero sin que haya un respaldo constitucional para ello. Sin embargo, cabe destacar que, aunque sea una señal de la progresiva constitucionalización de los partidos, dicho evento ya tenía sus precedentes en el derecho comparado, como puede ser la Checoslovaquía e Irlanda. (In: FERNANDÉZ SEGADO, F.: Las Constituciones Históricas... Pp. 563-592). El derecho de asociación estaba previsto en el art. 39 de referida Carta Magna.

${ }^{45}$ Cfr. LINDE PANIAGUA, E. "EI Régimen Jurídico de los Partidos Políticos en España (193678)" In: MORODO, R.; et al: Los Partidos Políticos en España. Labor Politeia, Barcelona, 1979. Pp. 76-154 y; MORODO LEONCIO, R. "Artículo 6º. Op. Cit." Pp. 239-240.

${ }^{46}$ MORODO afirma que el fascismo de España, institucionalmente hablando, se vuelve como un Estado total, eliminación de todo el pluralismo político-social con la creación de un partido único que declara que los demás están fuera de la ley. Es como una concentración de poderes en un órgano unipersonal, o sea, un 'jefe total'. Ya bajo en enfoque social el fascismo es antidemocrático y contra-revolucionario, pero nunca anti-capitalista, además de los discursos socialistas, apoyando otras instituciones, como a Iglesia y las fuerzas armadas. Por ello, el autor entiende que el Franquismo es una versión del fascismo en España. (In: MORODO, R.: La Transición Política. 1ำ ed. reimp. Tecnos, Madrid, 1985. Pp. 37-46). Contrariando la idea de partido único existente en el franquismo, RODRíGUEZ DÍAZ entiende que había un cierto pluralismo dentro del régimen franquista, que teóricamente lo sostenía. Dentro del 'movimiento', aunque se institucionalizó el partido único, este nunca se concretizó, pues la clase política del régimen procedía de diversos grupos que actuaban en el reclutamiento de personal político, como Falange, Opus, Ejército, Iglesia y ACNP (Asociación Católica Nacional de Propagandistas), permitiendo así cierto pluralismo dentro del sistema. Se trataba de un pluralismo limitado que necesitaba de un líder, Franco. Ante las previsiones sucesorias, el pluralismo se percibió disfuncional para la perpetuación del régimen. (In: RODRIGUEZ DIAZ, Á.: Transición Política y Consolidación Constitucional de los Partidos Políticos. Centro de Estudios Constitucionales, Madrid, 1989. Pp. 65-67).

${ }^{47}$ PORTERO MOLINA, J. A. “La Constitucionalización..." Pp. 272. 
Sin embargo, en la transición política del régimen franquista a la democracia ${ }^{48}$ los partidos tomarían la posición de protagonistas en dicho proceso ${ }^{49}$, surgiendo como hecho inédito su constitucionalización. ${ }^{50}$ Este hecho parte de cambios en la legislación franquista que tenderán a eliminar la ilicitud de los partidos. ${ }^{51}$ Dicha eliminación fue progresiva, atendiendo también a la dinámica y naturaleza misma de la transición, a las exigencias de la oposición y también a la estrategia política seguida desde el Gobierno.$^{52} \mathrm{~A}$ partir de ese momento, la legislación destinada a legitimar a los partidos ante el ordenamiento jurídico se inició con la Ley de Asociaciones Políticas, de 14 de junio de $1976^{53}$, seguidas por el Real Decreto-ley de 08 de febrero de $1977^{54}$, del Real Decreto-ley 20 de 18 de marzo de 1977, de los reglamentos del

${ }^{48}$ Cfr. MORODO, R.: La Transición Política. 1ำed. reimp. Tecnos, Madrid, 1985, MIRANDALOZANA, C. F. "Bibliografía sobre la Transición Política Española". In: Revista de Derecho Político. no 42. UNED, Madrid, 1996. Pp. 213-223; y SUANZES-CARPEGNA, J. V.: Op. Cit. Pp. 609 y ss.

${ }^{49}$ Vid. por todos: BLANCO VALDÉS, R. L. "Veinte Años de Partidos: de la Constitucionalización a la Contestación". In: TRUJILLO, G.; et al (dir.): La Experiencia Constitucional (1978-2000). Ed. CEPC, Madrid, 2000. Pp. 98-99.

${ }^{50}$ RODRÍGUEZ DÍAZ entiende que la legalización de los partidos políticos puede ocurrir en un escenario de transición de un régimen autoritario a uno democrático por dos vías, siendo uno la liberalización del derecho de asociación restringido por el régimen; y otra el considerar a los partidos fundamentales para el derecho de asociación, como piezas claves del nuevo Estado democrático que se creaba. De esa manera, el proceso de legalización y de incorporación de los partidos se relaciona íntimamente con el derecho de asociación, de participación, de libertad de expresión, pero también implica un cierto control jurídico que se contrapese por el hecho de que los partidos integran ahora el nuevo Estado de partidos. (In: RODRIGUEZ DIAZ, A.: Transición Política... Pp. 112-113).

${ }^{51}$ HOPKIN entiende que, partiendo de la clasificación de Liphart (de democracia pluripartidista y democracia mayoritaria), el consenso alcanzado en la transición en España se produce en la dirección de la democracia pluripartidista, pero al final se ha reconvertido hacia la democracia mayoritaria, en un modelo "gobierno-oposición". (In: HOPKIN, J. "From Consensus to Competition - The Changing Nature of Democracy in the Spanish Transition". In: BALFOUR, S. (ed.): The Politics of Contemporary Spain. Ed. Routledge, London, 2005. Pp. 7-8).

${ }^{52}$ RODRIGUEZ DIAZ, Á: Transición Política... Pp. 120. Sobre la utilización de las leyes del régimen franquista para la transición, HERRERO DE MIÑON afirma que la transición democrática en España fue hecha en frase muy conocida 'de ley para ley', es decir, sin quiebra de ninguna legalidad formal, lo que permite decir que "la legalidad democrática surgió de la legalidad autoritaria". (In: HERRERO DE MIÑON, M.: El Valor de la Constitución. ed. Critica, Barcelona, 2003. Pp. 4).

${ }^{53}$ Dicha norma establecía que todos los españoles mayores de edad y en pleno uso de sus derechos civiles y políticos podrían constituir asociaciones de carácter político, siguiendo a los fines de dichas organizaciones, algunas reglas referentes a procedimientos internos entre los miembros, sobre su financiación y fiscalización. Cabe resaltar que dicha ley fue derogada por la Ley Orgánica 06/2002, actual ley de partidos. Sin la antigua norma, todavía dejaba traslucir un cierto recelo que se plasmaba en la propia terminología utilizada en la presentación del texto de ley.

${ }^{54}$ En dicha norma, no hay reglas sobre financiación de partidos, limitándose la regular el derecho de asociación política y a estructurar el mecanismo de la construcción de dichas asociaciones conforme el principio de libertad. 
Congreso y del Senado (responsables de institucionalizar a los partidos), y del anteproyecto constitucional. ${ }^{55} \mathrm{El}$ protagonismo de los partidos tanto en el proceso de transición como también en la constituyente fue determinante para la plena incorporación constitucional de dichas organizaciones ${ }^{56}$, concretizada en el artículo 6º, del título preliminar de la Carta Magna.

\subsubsection{El artículo 6o de la Constitución Española y su proceso de elaboración}

Como es sabido, el protagonismo de los partidos en el proceso constituyente se acentuó ante una cierta situación de apatía de la opinión pública en torno a la elaboración del texto constitucional. ${ }^{57}$ En todo caso, lo cierto es que regular constitucionalmente a los partidos políticos no fue una tarea tan fácil de concretizar, justamente por la versatilidad de su naturaleza, su actuación y dinámica, lo que supone la necesidad de su sutil encaje dentro de un contexto jurídico de libertad. ${ }^{58} \mathrm{Y}$ aunque España fue uno de los últimos

${ }^{55}$ PORTERO MOLINA, J. A. “La Constitucionalización...” Pp. 276-279.

${ }^{56}$ Esta condición es bien abordada por RUBIO LLORENTE in: RUBIO LLORENTE, F.: La Forma del Poder: (Estudios sobre la Constitución). ed. CEPC, Madrid, 1993. Pp. 49 y ss., donde el autor narra la organización de las fuerzas políticas previamente al proceso constituyente; y también cfr. ALÁEZ CORRAL, B. "La CE de 1978: ¿Ruptura o Reforma Constitucional?" In: Anuario de Derecho Constitucional y Parlamentario. no 9. Asamblea Regional de Murcia - Universidad de Murcia, Murcia, 1997. Pp. 161-188.

57 En ese sentido, la reclamación de la redacción del proyecto constituyente destacó fuertemente su protagonismo en este proceso, incluso porque los partidos aislaron de la sociedad el debate público sobre el tema. Por dicha razón algún autor no entiende que hubiera un sentimiento constituyente por parte de la sociedad. (In: RODRIGUEZ DIAZ, A.: Transición Política... Pp. 147-149). A la vez, DEL CASTILLO afirma que había un sentimiento de decepción hacia el gobierno de UCD de la época (elecciones de 1977), y que también la Constitución Española no logró suscitar la atención de la opinión pública por su largo tiempo de elaboración. (In: DEL CASTILLO, P. "La Campaña del Referéndum Constitucional”. In: Revista de Estudios Políticos. № 6. Ed. Centro de Estudios Constitucionales, 1978. Pp. 159). Como evidencia del débil envolvimiento social con la Constituyente, LUCAS VERDÚ afirma que ello pasó por haber ocurrido juntamente con eventos de otras naturalezas más cercanas de los ciudadanos, como la grave crisis económica, alarmas de terrorismo, etc. Sin embargo, la apatía del pueblo español con relación a la Constitución pudiera haber sido consecuencia de las reuniones de la Ponencia Constitucional, las cuales fueron confidenciales y que acabaron por alejar el debate público, aunque haya colaborado para facilitar el consenso. (LUCAS VERDÚ, P.: Op. Cit. Pp. 26-32). MORODO también apunta para algunos fallos del proceso constituyente que, en su opinión, comprometieron de una cierta manera el desarrollo de esta tarea: *confidencialidad de la Ponencia y su larga y demasiada discusión; *no representación de todas las fuerzas políticas existentes, como la minoría vasca, por ejemplo; *la no existencia de actas de la Ponencia sobre los debates hechos. (In: MORODO, R.: La Transición...Pp. 172174).

${ }^{58}$ MORODO, R.; MURILLO DE LA CUEVA, P. L.: El Ordenamiento Constitucional... Pp. 32. 
países de Europa en introducir la constitucionalización de los partidos políticos, no se caracterizó por su grado de innovación normativa ${ }^{59}$, obviando incluso algunas de las soluciones ya disponibles en el Derecho Comparado. En todo caso, no deja de sorprender la escasa atención dedicada al tema por parte de la ponencia y la comisión. ${ }^{60} \mathrm{El}$ debate girará inicialmente en torno a si los partidos deberían ser regulados por un artículo específico o bien resultaba suficiente su genérico reconocimiento a través del Derecho de Asociación. Dicho debate se reflejará en la presentación de las enmiendas al artículo $4^{\circ}$ del anteproyecto de la Constitución que versaba sobre los partidos. ${ }^{61} \mathrm{Al}$ final, prevaleció la corriente que abogaba por consagrar un artículo propio para los partidos, marcando su especificidad respecto del derecho de asociación en general. Se trata del recurrente debate en torno al vínculo entre el derecho de asociación y los partidos políticos, que como es sabido, resulta condicionado por la naturaleza jurídica que se atribuya a las organizaciones políticas.

El artículo 6o fue uno de los textos constitucionales comprendidos dentro del consenso que se produjo entre las principales fuerzas políticas constituyentes, a fin de acelerar el debate constitucional. Aún así, el referido artículo fue objeto de algunas significativas enmiendas. ${ }^{62}$ Fueron propuestas 7

${ }^{59}$ Según FERNÁNDEZ-MIRANDA CAMPOAMOR, la Constitución Española confiere, además del reconocimiento de los partidos, también sus condiciones de existencia. Así, a partir del momento que el artículo 6을 dispone que los partidos expresan el pluralismo político, concurren a la formación de la voluntad popular y son instrumento fundamental para la participación política, también les está dando un status público, que ultrapasa el simple derecho de asociación. (In: FERNÁNDEZ-MIRANDA CAMPOAMOR, C.; FERNÁNDEZ-MIRANDA CAMPOAMOR, A. F.: Sistema Electoral... Pp. 43).

${ }^{60}$ MORODO, R., MURILLO DE LA CUEVA, P. L. "Artículo $6^{\circ}$ Los Partidos Políticos". In: AA.VV.: Comentarios a la Constitución Española de 1978. Tomo I, ed. Edesa, Madrid, 1996. Pp. 321. MORODO, R.; MURILLO DE LA CUEVA, P. L.: El Ordenamiento Constitucional... Pp. 49. En uno de sus trabajos anteriores, MORODO ya defendía que debería haber existido una mayor modernización técnica, con nuevas garantías y controles favoreciendo siempre el pluralismo político. (In: MORODO LEONCIO, R. "Artículo 6. Op. Cit." Pp. 240). JIMÉNEZ CAMPO también se pronuncia así, entendiendo que el art. $6^{\circ}$ no da cuenta de todo lo que los partidos representan en el funcionamiento y organización del Estado. (In: JIMENEZ CAMPO, J. "Partidos Políticos". In: ARAGÓN REYES, M. (coord.): Temas Básicos de Derecho Constitucional - Tomo I. Derecho Constitucional y Fuentes de Derecho. Civitas, Madrid, 2001. Pp. 136-137).

${ }^{61}$ La redacción de dicho artículo era: "Los partidos políticos expresan el pluralismo democrático, concurren a la formación y manifestación de la voluntad popular y son instrumento fundamental para la participación política. Se forman y ejercen su actividad libremente dentro del respeto a la Constitución y a la ley". (In: Constitución Española. Trabajos Parlamentarios. Tomo I. Cortes Generales, Madrid, 1980. Pp. 8).

${ }^{62}$ BLANCO VALDÉS, R. L: Los Partidos Políticos. Tecnos, Madrid, 1990. Pp. 124. 
enmiendas al artículo $4^{\circ}$ del anteproyecto ${ }^{63}$, siendo la más conocida la ํㅡ 457 firmada por Raúl Morodo (Partido Socialista Popular - PSP), perteneciente al grupo parlamentario mixto, y que intentó añadir al texto algunos elementos que se juzgaban esenciales en la regulación de los partidos. El texto integral de dicha enmienda era:

“1. @ Los partidos políticos expresan el pluralismo democrático y concurren a la formación y a la manifestación de la voluntad popular. Se forman y ejercen su actividad libremente, dentro del respecto a la Constitución y a la Ley. Su estructura interna y funcionamiento deberán ser democráticos.

2. ㄴ Los partidos, en cuanto a medios de participación política de los ciudadanos, serán financiados con cargo a los presupuestos del Estado.

3. Corresponde al Tribunal Constitucional el control de lo dispuesto en este artículo."64

Dicha enmienda intentó pues agregar al texto elaborado por la Ponencia del Congreso tres elementos importantes para el desarrollo legal de los partidos políticos: democracia interna, financiación pública y el órgano judicial responsable del control de estas organizaciones. El autor de la enmienda justificaba su propuesta a través de su idea de que se tenía el derecho de fiscalizar a los partidos políticos internamente, en lo que se refiere a su democracia interna, y que ello debería acompañarse con la financiación estatal constitucionalizada, manteniendo así una financiación adecuada y neutral, frente a presiones externas y como garantía del pluralismo político. ${ }^{65} \mathrm{Sin}$ embargo, y a pesar de gozar de cierto predicamento ${ }^{66}$, acabó por prevalecer,

\footnotetext{
${ }^{63}$ Las enmiendas fueron no 2 del Sr. Carro Martínez; no 35, del Sr. Fuente de la Fuente; no 63 del Sr. Fernández de la Mora; oㅡ 328 del grupo socialista del congreso; ํo 457 del grupo mixto; no 736 del Sr. Ortí Bordás; y no 779, del grupo de la Unión de Centro Democrático. (In: Constitución Española. Trabajos Parlamentarios. Tomo I. Cortes Generales, Madrid, 1980. Pp. $67)$.

${ }_{64}^{64}$ MOROdO LeONCIO, R. "Artículo 6. Op. Cit." Pp. 240-241.

${ }^{65}$ Véase MORODO LEONCIO, R. "Artículo 6․ Op. Cit." Pp. 242; y MORODO, R.; MURILLO DE LA CUEVA, P. L. "Artículo 6. Op. Cit." Pp. 322-323.

${ }^{66}$ Se puede citar como ejemplo AJA, que entendía que la financiación pública, tanto la directa como la indirecta, también podría favorecer a la publicidad de los datos financieros de los partidos, además de colaborar al equilibrio de las desigualdades existentes entre las organizaciones existentes. En este sentido, cfr. AJA, E. "Propuesta para la Constitucionalización de los Partidos Políticos". In: VEGA, P. de (ed.): Teoría y Práctica de los Partidos Políticos. Edicusa - Cuadernos para el Diálogo, Madrid, 1977. Pp. 280-283.
} 
como es notorio, el texto sugerido por la Ponencia con algunas modificaciones de estilo y la mención a la democracia interna de los partidos. ${ }^{67}$

Puede subrayarse el carácter heterogéneo de las propuestas realizadas, y que aún así no motivaron mayores reacciones por parte de la Ponencia. Aunque parecían centrarse en meras modificaciones lingüísticas (como la enmienda $n^{\circ} 2$, que añadía la expresión "participación del pueblo en la política"), muchas de ellas conectaban los partidos al artículo 22 propuesto en el anteproyecto, como el caso de la enmienda ํo 63 de autoría del Sr. Fernández de la Mora (que proponía la supresión total del artículo de los partidos para su integración al art. 22), de la misma manera que la enmienda oํ 736 del Sr. Ortí Bordás; y la enmienda oㅜ 328 , del grupo socialista, que proponía la expresa vinculación entre los dos artículos. Un perfil más diferenciado tuvo la enmienda no 35 del Sr. Fuente de la Fuente, que por entender que los partidos no eran los únicos medios de expresión del pluralismo político, sugería el cambio en la redacción, aclarando esta condición. ${ }^{68}$ Dichas enmiendas fueron básicamente reiteradas en la discusión en Comisión, con la excepción de la defensa del prof. Tierno Galván que enfatizará principalmente la importancia de la obligación de una estructura interna democrática para los partidos. ${ }^{69}$

La conclusión de la Ponencia fue que aspectos que pretendía introducir la enmienda del PSP eran materia propia de la ley, y que no deberían estar en la Constitución. ${ }^{70}$ Sin embargo, mi opinión, quizás la Ponencia haya perdido

\footnotetext{
${ }^{67}$ Esto demuestra el amplio consenso existente entre los partidos sobre el tema. (In: RAMíREZ JIMÉNEZ, M. "Partidos Políticos en España: Práctica Política y Crisis Actual". In: AA. VV.: Régimen Jurídico de los Partidos Políticos y Constitución. Cuadernos y Debates, no 51, Centro de Estudios Constitucionales, Madrid, 1994. Pp. 17. La votación fue de un total de 320 votos, 317 a favor, 0 en contra, 3 abstenciones. (In: Constitución Española. Trabajos Parlamentarios. Tomo II. Cortes Generales, Madrid, 1980. Pp. 1967-1968).

${ }^{68}$ Constitución Española. Trabajos Parlamentarios. Tomo I. Cortes Generales, Madrid, 1980. Pp. 122; 146; 162; 272-273; 316 y 451.

${ }^{69}$ Constitución Española. Trabajos Parlamentarios. Tomo I. Cortes Generales, Madrid, 1980. Pp. 910. Combatiendo dicha argumentación, el Sr. Solé Tura ha subrayado que la expresión no tiene sentido si se yuxtapone a la afirmación de que la creación de partidos y su actividad son libres. Esto por si solo bastaría para determinar que los partidos deberían ser democráticos. Detrás de estas razones, existía también el temor a facilitar una más intensa intervención estatal en los partidos. (In: Constitución Española. Trabajos Parlamentarios. Tomo I. Cortes Generales, Madrid, 1980. Pp. 911-912).

${ }^{70}$ Constitución Española. Trabajos Parlamentarios. Tomo I. Cortes Generales, Madrid, 1980. Pp. 507.
} 
una gran oportunidad de analizar mejor la cuestión, porque muchos problemas que hasta hoy carecen de una solución firme podrían haber sido evitados. ${ }^{71}$

En el Senado el proceso constituyente no tuvo tampoco en la materia rasgos propios. Solamente se presentaron dos enmiendas, ambas de la Agrupación Independiente (de no 133 y 655), afectando la primera solamente a la redacción, y la segunda proponiendo el cambio de "pluralismo democrático" por el "pluralismo político" (por razones técnicas), y la previsión del control de los partidos como prerrogativa del Tribunal Constitucional, considerando que debería existir un control de constitucionalidad de dichas organizaciones. ${ }^{72} \mathrm{La}$ primera parte de la enmienda fue aprobada sin ninguna objeción, lo que no ocurrió con la segunda, por entender que sería una grave limitación al derecho de asociación política. ${ }^{73}$ Con ello, el Senado mantuvo la redacción original del Congreso, con el cambio de términos anteriormente descrito. ${ }^{74}$

En cuanto a su ubicación sistemática, gran parte de la doctrina ha subrayado la inclusión de los partidos políticos, vía art. 6, en el Título Preliminar de la Constitución. Se trataría de una cuestión importante porque además de encuadrarse junto a elementos esenciales de la CF, expresa el protagonismo de los partidos en el diseño constitucional, siendo estos también contemplados indirectamente en los artículos 22.1 y 23.1 de la Constitución Española. ${ }^{75}$ Hay autores que consideran que el art. $6^{\circ}$ está ubicado en el título que están contenidas las "decisiones políticas fundamentales", esto es, que más allá de la protección que confiere a dicho Título Preliminar el mecanismo de reforma aprobado $^{76}$, es evidente que el constituyente ha considerado a los partidos

\footnotetext{
${ }^{71}$ Uno de estos problemas que pueden es con relación a la interpretación del artículo 6o o leyes conectadas, como bien destacó Santamaría Pastor. (In: SANTAMARIA PASTOR, J. A. "Artículo 6". In: GARRIDO FALLA, F. (coord.): Comentarios a La Constitución. ed. Civitas, Madrid, 1980. Pp. 73-74).

${ }_{72}$ Constitución Española. Trabajos Parlamentarios. Tomo III. Cortes Generales, Madrid, 1980. Pp. 2719 y $2943-2944$.

${ }^{73}$ Constitución Española. Trabajos Parlamentarios. Tomo III. Cortes Generales, Madrid, 1980. Pp. 3096-3099.

${ }^{74}$ Constitución Española. Trabajos Parlamentarios. Tomo IV. Cortes Generales, Madrid, 1980. Pp. 4374.

${ }_{75}^{75}$ LUCAS VERDÚ, P.: Op. Cit. Pp. 578-579.

${ }^{76}$ Dicha protección es resaltada por Navarro Méndez, que entiende que además de tratarse de una garantía formal (ya que el procedimiento de reforma es más rígido), también se trata de una garantía a favor de los partidos de naturaleza constitucional y institucional, llegando a constituirse como una garantía al propio orden democrático de partidos. (In: NAVARRO MENDEZ, J. I.: Op. Cit. Pp. 202-204). A su vez, FLORES GIMÉNEZ también entiende que la ubicación del artículo 6ำ en el título preliminar de la Constitución Española significa que dicho
} 
como elemento esencial del orden constitucional, y que reformar aspectos relacionados con los mismos implicaría también reformar el modelo del $78 .^{77}$ De esta manera, no habría dudas sobre cuál fue la verdadera intención del constituyente: garantizar un nivel de reconocimiento específico a los partidos frente al resto de organizaciones asociativas.

Partiendo ya del texto definitivo del artículo $6^{\circ}$ de la Constitución Española, la doctrina suele dividir su contenido en dos partes: la primera se entiende referida a las funciones que se atribuyen a los partidos políticos y a las garantías especiales de las que gozan, y la segunda parte corresponde a los deberes que dichas organizaciones tienen que cumplir. Esto quiere decir que en la primera parte se recogen las funciones de los partidos, y en la segunda las limitaciones a su actividad en el ejercicio de dichas funciones. Existiría pues un principio de constitucionalización de los partidos y en segundo término un principio de constitucionalidad de los mismos. ${ }^{78}$ Dentro de la doctrina también se entiende que el art. 6ํaㅁ alberga no sólo las funciones que están asignadas a los partidos, sino también el régimen jurídico a que se encuentran sometidos en su proceso de constitucionalización. ${ }^{79}$

La literatura jurídica ha entendido de manera matizada y diversa la estructura del artículo 6․ González Encinar afirma que, en realidad, el artículo $6^{\circ}$ no establece las funciones de los partidos, sino sus fines. ${ }^{80} \mathrm{~A}$ la vez, Flores

apartado "contiene las bases ideológicas y estructurales del régimen político" y que también demuestra que el legislador procuró resaltar el papel constitucional de los partidos políticos frente al resto de las asociaciones. (In: FLORES GIMÉNEZ, F.: La Democracia Interna de los Partidos Políticos. ed. Congreso de los Diputados, Madrid, 1998. Pp. 60-61).

77 PÉREZ ROYO, J.: Curso de... Pp. 638.

${ }^{78}$ RODRIGUEZ DIAZ, A.: Transición Política... Pp. 154. Está de acuerdo con esta posición ANTONIO MONTILLA (ANTONIO MONTILLA, J. "Algunos Cambios en la Concepción de los Partidos. Comentarios a la STC 48/2003, sobre la Ley Orgánica 6/2002, de Partidos Políticos". In: Teoría y Realidad Constitucional, № 12-13, $1^{\circ}$ semestre 2003, 1ํs semestre 2004, ed. UNED, 2004. Pp. 563) y TAJADURA TEJADA (TAJADURA TEJADA, J.: Partidos Políticos y Constitución: Un Estudio de la LO 6/2002 de 27 de junio, de Partidos Políticos, y de la STC 48/2003, de 12 de marzo. Ed. Civitas, Madrid, 2004. Pp. 37 y ss.).

${ }^{79}$ BLANCO VALDÉS, R. L: Los Partidos Políticos. Op. Cit. Pp. 131-139.

80 GONZÁLEZ ENCINAR, J. J. "Democracia de Partidos "versus" Estado de Partidos". In: GONZÁLEZ ENCINAR, J. J. (coord.): Derecho de Partidos. Espasa-Calpe, Madrid, 1992. Pp. 25-29. El autor se posiciona así porque entiende que la 'parte' de los intereses de la sociedad que un partido representa sería un interés general, y por ello las funciones de los partidos deberán ser buscadas en la realidad, no en el texto del artículo 6ㅇ. Para fundamentarlo, el autor expone que la Constitución Española establece normas de organización del Estado y normas fundamentales entre Estado y sociedad (que es donde se encajan los partidos políticos). Así, los partidos nacen en la sociedad y tienen el Estado como objetivo, algo que está implícito en la Constitución. Sin embargo, hay que conceptuar 'Estado', pues la Constitución Española utiliza 
Giménez entiende que la primera parte del artículo $6^{\circ}$ es la que garantiza los partidos políticos, y la segunda parte es la que establece los principios constitucionales que los rigen, además de sus funciones también sus deberes, como el respeto a la Constitución, y que tengan un funcionamiento democrático. ${ }^{81}$ Es decir, el art. $6^{\circ}$ posee una faceta positiva, garantista, y otra negativa, que condiciona la garantía dada a los partidos. Así, se garantiza el pluralismo político, volviendo inconstitucional toda acción del legislador o de los poderes públicos que obstaculice o que niegue dicho pluralismo, a la vez que también impone a las asociaciones que desean ser consideradas como partidos el cumplimiento de algunas funciones contempladas en el artículo. ${ }^{82}$

El Derecho de Partidos ha gozado tradicionalmente de cierta autonomía conceptual dentro del estudio científico del Derecho Constitucional. No resulta por otra parte novedoso resaltar las evidentes particularidades, desde el punto de vista de su autoría y su eficacia normativa de este sector del ordenamiento jurídico. En pocos casos como en este resultan más evidentes las limitaciones del derecho a la hora de regular las realidades sociales conectadas con el poder político. ${ }^{83}$

Quizás por todo ello, no resulta pacífico en la doctrina la misma posibilidad de articular un control realmente efectivo en términos jurídicos, control y límites que, por otra parte, no deja de estar prescritos en la mayoría de los ordenamientos contemporáneos. ${ }^{84}$ En suma, la decisión de regular o no

tres conceptos: 1) como 'órgano central' (artículos 149 y 150); 2) como 'Estado-aparato' en organización de su poder, que se contrapone a la sociedad en ese sentido; 3) como 'autoorganización de la sociedad' (artículo 1.1). De esa manera, la idea de partido político como mediador entre Estado y Sociedad debe adoptarse la idea de Estado como 'aparato', en la interrelación entre la sociedad y la organización estatal que caracteriza el carácter democrático del Estado. Y, si la Constitución Española otorga al pueblo el poder del Estado, pero no su ejercicio, es justo aquí dada actuarán los partidos políticos, que es su fin constitucional, su razón de ser, y no su función, que para el autor, ni siquiera está constitucionalizada.

${ }^{81}$ FLORES GIMÉNEZ, F.: Op. Cit. Pp. 61.

${ }^{82}$ NAVARRO MENDEZ, J. I.: Op. Cit. Pp. 204-205.

${ }^{83}$ Vid. por todos: LANCHESTER, F. "II Problema del Partito Político: Regolare gli Sregolati". In: Quaderni Constituzionali. Anno VIII. no 3, Diciembre. Ed. II Mulino, Bologna, 1988. Pp. 439; GRIMM, D. Op. Cit. Pp. 442; SANCHEZ DE VEGA, A. "Notas para un Estudio del Derecho de Partidos". In: ASENSI SABATER, J. (coord.): Ciudadanos e Instituciones en el Constitucionalismo Actual. Ed. Tirant Lo Blanch, Valencia, 1997. Pp. 309 y ss.; y MORODO, R., MURILLO DE LA CUEVA, P. L. "Artículo 6. Op. Cit." Pp. 328-329.

${ }^{84}$ MORODO, R. "Partidos y Democracia. Op. Cit." Pp. 9. En ese sentido que MARTÍN DE LA VEGA entiende que las garantías que están en el artículo 6ํㅡ no tienen como objetivo final los partidos propiamente dichos, pero sí la apertura del sistema democrático a partir de los partidos plurales, es decir, del pluralismo político. (In: MARTíN DE LA VEGA, A. "Los Partidos Políticos 
a los partidos y qué intensidad deba tener dicha normativa es algo que todavía suscita un amplio debate doctrinal ${ }^{85}$, considerando que las líneas que separan la regulación y el intervencionismo son muy sensibles ${ }^{86}$, y más aún en países sin larga tradición de pluralismo político. ${ }^{87}$

Es cierto que, debido a la importancia de los partidos políticos en el proceso político moderno y a su mediación en la concretización de la democracia, su regulación jurídica resulta imprescindible para garantizar los derechos de los ciudadanos. Pero, a su vez, esta regulación debe orientarse también hacia la garantía de los derechos de los partidos frente al Estado, impidiendo que los órganos del poder público interfieran en la libre competencia partidista. Esta regulación también contempla un control ante una posible actuación ilícita por parte de los propios partidos. ${ }^{88}$ Así, de la misma manera que se produjo una gradual incorporación de los partidos en los ordenamientos jurídicos, se introdujeron los controles. ${ }^{89}$

La progresiva constitucionalización de estos controles es evidente que contribuye tanto a su interpretación junto a otros principios constitucionales, como a dotarlos de estabilidad y legitimidad democrática. Como es sabido, esta función de estabilidad debe ser compatible con una regulación que permita un cierto margen a la discrecionalidad del legislador, en cuanto, en esta materia, no deba olvidarse que el propio principio del pluralismo político es

y la Constitución de 1978. Libertad de Creación y Organización de los Partidos en la Ley Orgánica 6/2002". In: Revista Jurídica de Castilla y León, no extraordinario, enero, 2004. Pp. 202 y ss.).

${ }^{85}$ En este punto, cfr. GARCíA ROCA, F. J.; MURILLO DE LA CUEVA, P. L. "Democracia Interna y Control de los Partidos Políticos". In: Revista de Estudios Políticos (nueva época), no 42, nov/dic, 1984. Pp. 239-268. Aún, GARCÍA GIRÁLDEZ afirma el primero país a regular a los partidos políticos fueron los Estados Unidos, tanto a nivel estatal como también a nivel federal, 1866. (GARCÍA GIRÁLDEZ, T. Op. Cit. Pp. 148).

${ }^{86}$ MORODO, R., MURILLO DE LA CUEVA, P. L. "Artículo 6‥ Op. Cit. Pp. 3329.

87 FOGG, MOLUTSI y TJERNSTRÖM exponen los tipos de regulación, utilizando la clasificación elaborada por NASSMACHER: 1) la que privilegia la autonomía de los partidos y su autorregulación; 2) la que opta por la transparencia de las finanzas del partido; 3) la opción que todo sea conectado a una agencia regulatoria independiente; 4) la regulación diversificada que combina regulación precisa, con un tipo de negligencia benigna, incentivos públicos y sanciones ocasionales. Así, opinan que la falta de aplicación de la leyes probablemente más peligrosa que la falta de reglas, ya que generan desilusión y cinismo en la democracia. (In: FOGG, K.; MOLUTSI, P.; TJERNSTRÖM, M. "Conclusions". In: AUSTIN, R.; TJERNSTRÖM, M. (eds.): Funding of Political Parties and Election Campaigns. International IDEA, Stockholm, 2003. Pp. 169-172.

${ }^{88}$ SOLOZABAL ECHAVARRIA, J. J. "Sobre la Constitucionalización de los Partidos Políticos en el Derecho Constitucional y en el Ordenamiento Español". In: Revista de Estudios Políticos, no 45, may/jun, 1985. Pp. 157-158.

${ }^{89}$ MORODO, R. "Partidos y Democracia. Op. Cit." Pp. 10. 
salvaguardado por la regulación constitucional frente a eventuales mayorías partidistas. ${ }^{90}$ Normas constitucionales, desarrollo legal y estatutos de los partidos integran así el núcleo del Derecho de Partidos. ${ }^{91}$

Es cierto en todo caso que el nivel de intensidad de la regulación jurídica de los partidos resulta condicionada por la naturaleza jurídica por la propia calificación jurídica, que de los mismos se tenga. En el caso de España los partidos políticos son considerados mayoritariamente como asociaciones de naturaleza privada, con funciones constitucionales, o sea, como un ente privado aunque ejerza ciertas tareas de carácter público, lo que impide que el Estado elimine el amplio margen de la autonomía asociativa, aun cuando la extensión de la misma y el grado de intervención resulte también discutido en la literatura jurídica sobre el tema. ${ }^{92}$

En este punto, el Tribunal Constitucional es claro a la hora de subrayar la amplia libertad del legislador dentro del marco de la Constitución, y la necesidad de someter a un escrutinio intenso los límites establecidos al

${ }^{90}$ RODRIGUEZ DIAZ, Á.: Transición Política... Pp. 203 y MORODO, R.; MURILLO DE LA CUEVA, P. L.: El Ordenamiento Constitucional... Pp. 32-35.

${ }_{91}$ Cfr. MORODO, R., MURILLO DE LA CUEVA, P. L. "Artículo 6º. Op. Cit." Pp. 326. En este sentido, cfr. STC 56/1995, F.J. 3.

${ }^{92}$ Este debate ha variado profundamente en función del propio marco normativo vigente. La posición mayoritaria abogaba por la inexistencia de límites a los partidos que excedieran de los penales (los descritos en el art. 22). En este sentido, cfr. JIMENEZ CAMPO, J. "La Intervención Estatal del Pluralismo". In: Revista Española de Derecho Constitucional, no 1, vol. I, ene/abr, 1981. Pp. 177; SOLOZABAL ECHAVARRIA, J. J. "Sobre la Constitucionalización..." Pp. 163164; RODRIGUEZ DIAZ, A.: Transición Política... Pp. 231; y DE VEGA GARCÍA, A. S. "Constitución, Pluralismo Político y Partidos". In: Revista de las Cortes Generales, no 26, 2o cuatrimestre, Madrid, 1992. Pp. 93 y ss. Sin embargo, a partir de la vigencia de la Ley Orgánica 06/2002, esta doctrina, antes mayoritaria, se ha vuelto minoritaria, y la idea de aceptación de otros límites que no eran solamente los del art. 22, negando su condición de numerus clausus, acabó por ganar fuerza. En este sentido, cfr. por todos FERNÁNDEZ SEGADO, F. "Algunas Reflexiones sobre la Ley Orgánica 6/2002, de Partidos Políticos, al Hilo de su Interpretación por el Tribunal Constitucional". In: Revista de Estudios Políticos (nueva época), no 125, jul/sep, 2004; VÍRGALA FORURIA, E. "Los Límites Constitucionales a los Partidos Políticos en la LO 6/2002". In: MONTILLA MARTOS, J. A. (ed.): La Prohibición de Partidos Políticos. Ed. Universidad de Almería, Almería, 2004; ESPARZA OROZ, M.: La llegalización de Batasuna: El Nuevo Régimen Jurídico de los Partidos Políticos. Cuadernos Aranzadi del Tribunal Constitucional. Ed. Thomson/Aranzadi, Navarra, 2004. Por todos, vid. GARCíA-PELAYO, Manuel: El Estado de Partidos. Op. Cit. Pp. 52-61. El autor afirma también que dicha constitucionalización tiene como rasgos más comunes tratar de los status de los partidos: 1) status de libertad (derechos y deberes de los partidos); 2) status de libertad interna (derechos y deberes en el partido). Siguiendo esta línea, GARCÍA ROCA y MURILLO DE LA CUEVA entienden que cualquier disposición que contribuye a disminuir el grado de democracia interna de los partidos significa también disminuirla en las instituciones en que ellos operan. (In: GARCÍA ROCA, F. J.; MURILLO DE LA CUEVA, P. L. "Democracia Interna..." Pp. 252). Aún, PRESNO LINERA, M. A.: Los Partidos Políticos en el Sistema Constitucional Español Prontuario de Jurisprudencia Constitucional 1980-1999. Ed. Aranzadi, Navarra, 2000. Pp. 43. 
pluralismo político. ${ }^{93}$ La conexión del art. $6^{\circ}$ con el art 22 del texto constitucional continúa siendo clave en la jurisprudencia del Tribunal Constitucional. ${ }^{94}$ Ambos artículos se complementan, pues el garantizar la libertad de los partidos encuadrada en el art. 22 no es incompatible con una cierta lectura que se desarrolla en línea con la argumentación predominante desde la STC 48/2003, F.J. 6, y que me parece coherente. ${ }^{95}$

\section{2) La evolución de la definición de la naturaleza jurídica de los partidos}

Los partidos políticos son fruto, como es sabido, del ejercicio del derecho de asociación política. Este derecho se entiende tradicionalmente compuesto por tres libertades: la de creación e inscripción del partido; la de autoorganización y la de la libertad de actuación del partido ante el Estado. ${ }^{96} \mathrm{La}$ clasificación no creo que sea meramente académica, ya que influye en su nivel de regulación y en los principios constitucionales en juego.

En todo caso, la Constitución contempla el derecho de asociación de manera general en el art. 22, mientras que los partidos políticos, por su especial condición de instrumentos al servicio del derecho de asociación política, gozan de una regulación específica en el art. 6. Así, la distinción normativa entre sociedad y partidos desciende también al ámbito legislativo, como puede comprobarse. Es cierto que, dada su función mediadora entre Estado y sociedad, la clasificación jurídica de los partidos resulta compleja, por el hecho de que estos canalizan la voluntad popular en el Estado, y desde sus órganos la conforman. ${ }^{97}$ Un ejemplo de esta nebulosa relación es que tanto el art. 6o como el art. 22 de la Constitución Española poseen regulaciones aisladas entre sí, bastando con un breve análisis de las Leyes 06/2002 y

\footnotetext{
${ }^{93}$ Un ejemplo de esta posición del Tribunal Constitucional está en la STC 75/85, F.J. 4ํ․

${ }^{94}$ Cfr. STC 3/1981, F.J. 1; STC 10/1983, F.J. 3; STC 85/1986, F.J. 2 y STC 56/1995, F.J. 3.

${ }^{95}$ Aquí destacamos la posición de IGLESIAS BÁREZ, que entiende que en el art. 6을 caben algunos límites adicionales a los partidos que no sean previstos para las asociaciones en general, lo que da la clave del alcance de la ley de partidos. (In: IGLESIAS BARÉZ, M.: La Ilegalización de Partidos Políticos en el Ordenamiento Jurídico Español. Comares, Granada, 2008. Pp. 31).

${ }^{96}$ GRIMM, D. Op. Cit. Pp. 408-409; JIMENEZ CAMPO, J. "Partidos Políticos. Op. Cit.”. Pp. 136138; GARCÍA GIRÁLDEZ, T. Op. Cit. Pp. 164 y; IGLESIAS BARÉZ, M.: Op. Cit. Pp. 15.

${ }^{97}$ IGLESIAS BARÉZ, M.: Op. Cit. Pp. 5-6.
} 
01/2002 sobre los mismos, que aunque hayan sido editadas en el mismo año, no tienen en absoluto el mismo objeto. ${ }^{98}$

A la literatura jurídica sobre el tema se añadió pronto la jurisprudencia del Tribunal Constitucional, que ya a estos efectos se consolida en la STC 56/1985. En dicha sentencia los partidos políticos son considerados como una forma particular de asociación, pero encuadrándose en el régimen del art. 22 y sin subrayar en exceso de posibles implicaciones jurídicas de su específica regulación vía art. $6 .^{99}$

El debate doctrinal no se centró en este tema tras la toma de postura del máximo intérprete de la CF, y siguió girando en torno a la conexión "bipolar" entre el art. 6 y art. 22 del texto. Antes de la aprobación de la normativa actualmente en vigor, un sector doctrinal minoritario abogaba por la casi total identificación entre asociaciones en general y partidos. La consecuencia directa de ello, era la pretendida imposibilidad de imponer límites distintos a los partidos de los previstos en el art. 22. ${ }^{100}$ La estricta aplicación del régimen general de asociación a los partidos vendría justificada, en último término, por una interpretación "favor libertatis" de los principios constitucionales sobre la materia. $^{101}$

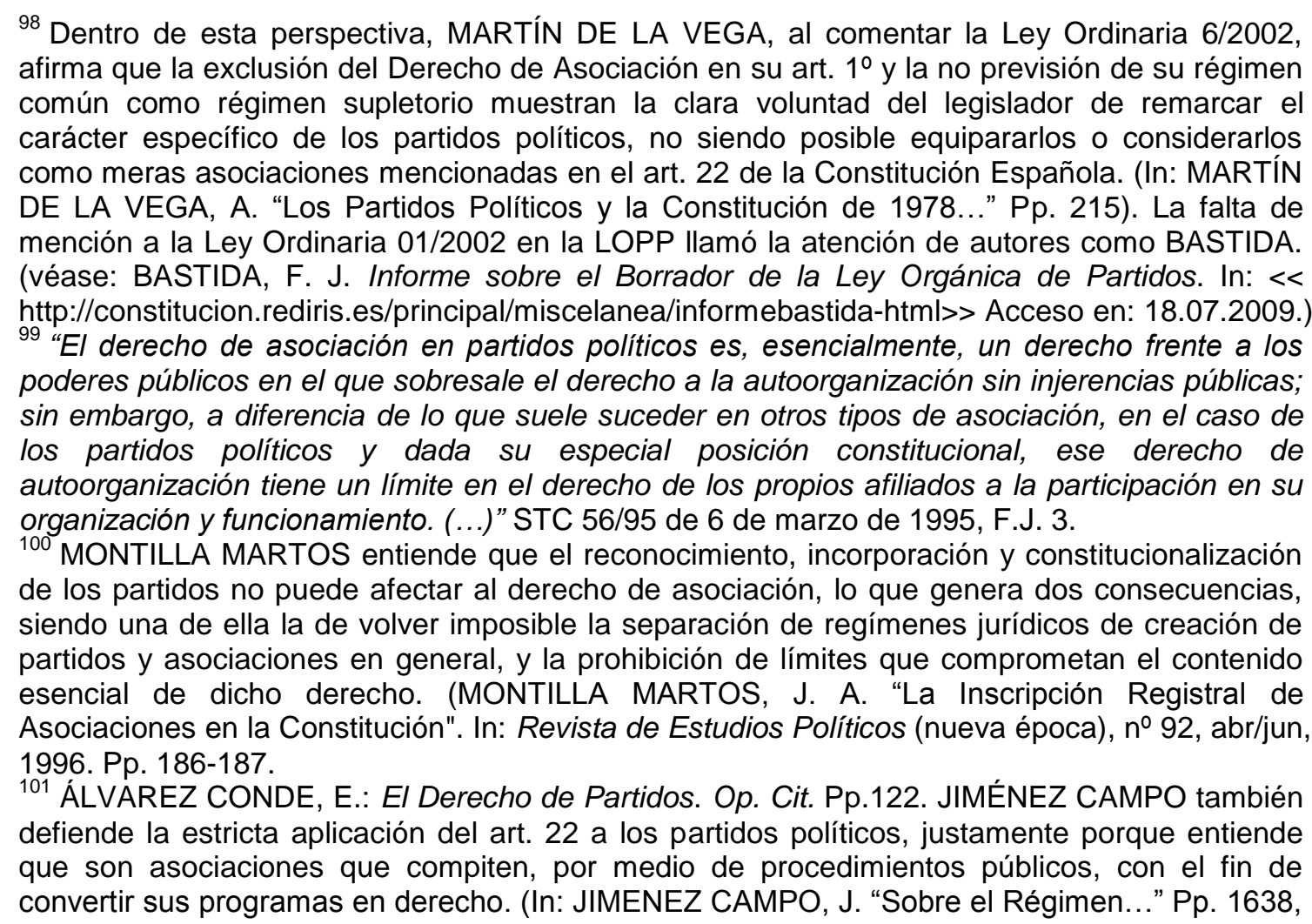


Las posturas que defienden un equilibrio entre régimen asociativo general y especificidad del régimen constitucional de los partidos, son muy plurales, y parten de reconocer en la creación de partidos el ejercicio del derecho de asociación. Sin embargo, los partidos son considerados como un tipo específico de asociaciones, con ciertas variaciones en la calificación del derecho fundamental. ${ }^{102}$ Este razonamiento conduce a la idea de que el art. 22 es una norma general y el art. 6 o la norma especial. ${ }^{103}$

A partir de esta idea, y en la evolución del debate doctrinal, es perceptible que la conexión de los arts. $6^{\circ}$ y 22 de la Constitución Española y la consecuente aplicación del régimen general de este último a los partidos queda circunscrita a la necesidad de considerar aplicables a los partidos las garantías constitucionales del Derecho Fundamental de asociación. ${ }^{104}$

y en otros de sus diversos trabajos, como "Los Partidos Políticos en la Jurisprudencia Constitucional". In: GONZÁLEZ ENCINAR, J. J. (coord.): Derecho de Partidos. Espasa-Calpe, Madrid, 1992. Pp. 207; y "Diez Tesis sobre la Posición de los Partidos Políticos en el Ordenamiento Español". In: AA. VV.: Régimen Jurídico de los Partidos Políticos y Constitución. Cuadernos y Debates, no 51, Centro de Estudios Constitucionales, Madrid, 1994. Pp. 37-38.

${ }^{102}$ Así se pronuncia el Tribunal Constitucional en referida sentencia: "Es cierto que en el art. 6 de la Constitución Española se han establecido unas condiciones específicas para los partidos políticos en relación al respeto al orden constitucional y a su estructuración interna de carácter democrático, pero tales exigencias se añaden y no sustituyen a las del art. 22, por situarse en un nivel diferente $y$, en cualquier caso, no repercuten propiamente en el área del derecho a constituirlos sino que, como ha venido señalando la doctrina científica, están en función de los cometidos que los partidos están llamados a desempeñar institucionalmente. (...) De la lectura conjunta del art. 6 de la Constitución Española en conexión con el art. 22 de la misma, resulta una protección reforzada de la libertad de partidos políticos que debe entenderse afecta no sólo a la actividad de los mismos, sino a su propia creación". (In: STC 85/86, F.J.2).

${ }^{103}$ Compartiendo esta opinión, desde la doctrina más clásica, SANTAMARIA PASTOR entiende que hay una imprecisión en el art. 22 de la Constitución Española, principalmente en lo que se refiere a su aplicación, ya que la propia Constitución mencionada también otros tipos de asociación, como es el caso de los partidos políticos. Sin embargo, el autor dice que las voluntades del constituyente era incluir en este artículo a los partidos. (In: SANTAMARIA PASTOR, J. A. "Artículo 22". In: GARRIDO FALLA, F. (coord.): Comentarios a La Constitución. ed. Civitas, Madrid, 1980. Pp. 281-282). También, cfr. FLORES GIMÉNEZ, F: Op. Cit. Pp. 6061; ESPARZA MARTíNEZ, Bernardino. "Estructura y Funcionamiento Democrático de los Partidos Políticos Españoles". In: Revista de las Cortes Generales, № 43, 10 cuatrimestre, Madrid, 1998. Pp. 102; NAVARRO MENDEZ, J. I.: Op. Cit. Pp. 228-229; CARRERAS SERRA, Francesc de. "Los Partidos en Nuestra Democracia de Partidos". In: Revista Española de Derecho Constitucional, año 24, № 70, ene/abr, 2004. Pp. 96-98.

${ }_{104}$ MORODO, R.; MURILLO DE LA CUEVA, P. L.: El Ordenamiento Constitucional... Pp. 65-71. Refleja exactamente el pensamiento expuesto en la STC 03/81 de 2 de febrero (F.J. 1), confirmado en la STC 56/95, como ya fue mencionado. En esta línea, ESPARZA OROZ, al tratar de la ilegalización de los partidos. Dicho autor afirma que no se puede debilitar la aplicación del art. 22 a los partidos políticos, porque su exclusión también significaría la imposibilidad de los partidos de utilizar el recurso de amparo para la defensa de sus Derechos Fundamentales, por el dispuesto en el art. 53.2 de la Constitución Española. Debido a ello, se debe vincular el art. 6 al art. 22, creando como un régimen propio para los partidos políticos pero privarles de las garantías iusfundamentales. (In: ESPARZA OROZ, M.: Op. Cit. Pp. 48). Desde el punto de vista de la democracia interna de los partidos, CARRERAS SERRA entiende 
Por otra parte, existió siempre un corriente doctrinal que subrayaba la diferenciación de regímenes jurídicos entre los arts. 6ำ y 22 del texto, atribuyendo a los partidos políticos un régimen especial que no se confunde con el régimen aplicado a las asociaciones en general. En último término, y desde el punto de vista teórico, se entendía que dicha diferencia era consecuencia de la opción constituyente, que no opta por un mero "reconocimiento" constitucional de los partidos, sino por una verdadera "incorporación" constitucional de los mismos. La diferencia entre una y otra concepción es determinante para el análisis de algunos de los temas centrales del Derecho de Partidos, como la creación y registro de dichas organizaciones (alterando la libertad de creación insertada en el derecho de asociación política) o la ilegalización de los mismos. ${ }^{105}$

La "incorporación" constitucional de los partidos fruto del artículo 6ํ de la Constitución Española, condiciona el concepto de partido político como una organización política que concurre para la formación de la voluntad popular, y que se mantiene como un instrumento de participación política. Los partidos pasan a ser entendidos así en relación a sus funciones constitucionales, esto es, solo cumpliéndolas gozarán del status especial que el ordenamiento constitucional otorga a los partidos. ${ }^{106}$ En caso contrario, se puede entender

que dicha obligación de haber democracia interna en los partidos sólo está prevista en el art. $6^{\circ}$ de la Constitución Española y no en el art. 22 por la posición privilegiada de los partidos en el sistema representativo. De aquí surge la necesidad de conectar los dos artículos. (In: CARRERAS SERRA, F. de. "Los Partidos en Nuestra Democracia..." Pp. 101 y ss.). También comparte dicha opinión SANCHEZ FERRO, in: SÁNCHEZ FERRO, S. "EI Complejo Régimen Jurídico Aplicable a los Partidos Políticos tras la aparición de la Ley Orgánica de Partidos Políticos de 27 de Junio de 2002". In: Revista Jurídica de la Universidad Autónoma de Madrid. oㅜ 12, 2005. Pp. 234 y; PÉREZ ROYO, J.: Curso de... Pp. 636 y ss.

${ }^{105}$ Cfr. BASTIDA FREIJEDO, F. J. "La Relevancia Constitucional de los Partidos Políticos y sus Diferentes Significados. La Falsa Cuestión de la Naturaleza Jurídica de los Partidos". In: GONZÁlEZ ENCINAR, J. J. (coord.): Derecho de Partidos. Espasa-Calpe, Madrid, 1992. Pp. 70. También en esta línea, cfr. ESPARZA OROZ, M.: Op. Cit. Pp. 44 y ss.

${ }^{106}$ Sería en esta línea que PAJARES MONTOLIO se posiciona, ya que entiende que hay una necesidad de que haya una conexión entre el real cumplimiento de las funciones asignadas a los partidos y el derecho de obtener las ventajas que el ordenamiento les brinda, posibilitando así que se juzgue a dichas ventajas con los dictámenes constitucionales, algo que también ocurre entre el Derecho de Partidos y el Derecho de Asociación, ya que el primero confiere un régimen especial a este tipo especifico de organización, que no se origina solamente del ejercicio de un derecho individual. (In: PAJARES MONTOLIO, E.: La Financiación de las Elecciones. Congreso de los Diputados, Madrid, 1998. Pp. 51-52). Cabe resaltar que el autor se basa en la STC 03/81 al posicionarse de esta manera. 
que esta asociación no es un partido. ${ }^{107}$ Se trata de atribuir a los partidos un régimen jurídico distinto de las asociaciones, debido a las funciones constitucionales y legales que les son especialmente conferidas.

Frente a la "incorporación", en el modelo de "reconocimiento" constitucional las funciones de los partidos provienen del ejercicio del derecho de asociación, sin ser, en cierto modo, "constitutivas" de su concepto constitucional. Primaría un enfoque menos institucional del partido y así, se subrayaría el hecho de que las funciones públicas realizadas por los partidos son fruto del ejercicio de un derecho con carácter subjetivo, lo que unido a una abstracción de los objetivos individualmente considerados, lleva a primar la consideración de los partidos políticos como una consecuencia social y política del derecho de asociación, pero no de sus funciones. El derecho de asociación ejercido justificaría su reconocimiento constitucional sin que las tareas fijadas por el texto constitucional pasen de lo meramente descriptivo. La concepción material del derecho de asociación contenida en la idea de "incorporación" constitucional de los partidos conllevaría en cambio unos elementos de naturaleza institucional y valorativa, implicando que el ejercicio del derecho debería encauzarse a través una institución garantizada. Hay pues un claro cambio de planteamientos, una teoría constitucional muy distinta. ${ }^{108}$

En definitiva, en la incorporación constitucional de los partidos, el status jurídico de estos está vinculado al cumplimiento de las funciones establecidas

\footnotetext{
107 JIMÉNEZ CAMPO, J. "Los Partidos Políticos en la..." Pp. 216. El autor destaca que no hay ningún pronunciamiento del Tribunal Constitucional en este sentido.

${ }_{108}$ En esta línea, BASTIDA FREIJEDO expone las fases que pasaron los partidos políticos en los ordenamientos jurídicos (haciendo clara alusión a las fases de TRIEPEL ya expuestas en el presente trabajo), como los niveles de rechazo por los legisladores (como forma de prohibición del derecho de asociación en agrupaciones con fines políticos), de ignorancia del legislador (siendo la asociación con fines políticos irrelevante jurídicamente), y de la legalización de los partidos (con amparo general a estos, no importando si tienen fines políticos o no), y que distinguiendo dicha legalización de la incorporación constitucional de los partidos políticos, no tratándose pues de una mera consecuencia o cambio de las normas reguladoras. La importancia de los partidos políticos en el funcionamiento del Estado los conduce al reconocimiento constitucional, y el establecimiento de sus funciones por la Constitución separa nítidamente el derecho de creación de partidos del derecho de asociación, aunque este tenga fines políticos. Por ello el autor defiende la creación de un régimen especial para los partidos separado claramente del derecho de asociación, justamente porque la libertad (como resultado del ejercicio de un derecho fundamental) de la creación de partidos puede atentar contra la propia democracia, y el surgimiento de la tesis de la democracia militante en Alemania son un ejemplo de las consecuencias de este régimen diferenciado, como también justifican la diferenciación entre el mero reconocimiento constitucional y su incorporación constitucional. (In: BASTIDA FREIJEDO, F. J. "La Relevancia Constitucional... Pp. 72-77.
} 
en la Constitución, dotándoles de los privilegios y garantías de asociaciones que tienen dicho status. ${ }^{109}$

En el caso de España, se entiende de manera mayoritaria por la doctrina, no obstante, que nos encontramos ante un mero reconocimiento constitucional de los partidos, ya que el art. $6^{\circ}$ se limitaría a describir las funciones que los partidos pueden desempeñar, sin que exista una imposición expresa de su cumplimiento. En otras palabras, la consideración de una organización como partido político no estaría condicionada a la verificación de la realización de las mencionadas funciones, algo que ocurriría en la incorporación constitucional. Esta puede entenderse que es la postura originaria de la jurisprudencia del Tribunal Constitucional ${ }^{110}$, aun con considerables matices. ${ }^{111}$ La tensión entre reconocimiento e incorporación se plasma en temas como, por ejemplo, el registro de partidos políticos. ${ }^{112}$ Otro ejemplo podría encontrarse en la STC $48 / 2003$, en la cual el Tribunal entiende como no contrario a los arts. 6o y 22 de la Constitución Española la atribución de regímenes distintos entre partidos y asociaciones en general, lo que apoyaría la hipótesis de la incorporación aun

109 PRESNO LINERA aclara que en la incorporación constitucional se considera que las funciones de los partidos ya se encuentran previstas en el ordenamiento jurídico y que en el caso de que los partidos no cumplan dichas funciones no deben ser considerados como tales. (In: PRESNo LineRA, M. Á.: Los Partidos Políticos en el Sistema... Pp. 26). A su vez, ESPARZA OROZ entiende que la idea de incorporación constitucional de los partidos remite a la idea de que las funciones fijadas en el artículo $6^{\circ}$ confieren a los partidos un régimen especial, es decir, solamente las asociaciones con el perfil constitucional previsto serán verdaderos partidos políticos, el resto, serán asociaciones con fines políticos, pero no partidos. (In: ESPARZA OROZ, M.: Op. Cit. Pp. 45).

${ }_{110}$ En este sentido, cfr. STC 3/1981 y 85/1986.

${ }^{111} \mathrm{La}$ existencia de dudas acerca de la real posición del Tribunal Constitucional, tiene reflejo en la STC 85/86, F.J. 2, por ejemplo, contraria el posicionamiento adoptado por el mismo tribunal en la STC 03/81, que era del reconocimiento constitucional de los partidos políticos. Hay diversos pronunciamientos del Tribunal Constitucional en los cuales se relaciona cada vez más estrechamente a los partidos con el desempeño de funciones institucionales o se entienden de forma institucional sus funciones, lo que contraria la idea de un mero reconocimiento de los mismos (vid. STC 75/85, F.J. 5) o en la STC 16/84 en la cual el Tribunal Constitucional atribuye a los partidos un lugar dentro de la dinámica institucional del Parlamento (cfr. F.J. 8).

112 BASTIDA FREIJEDO argumenta que en realidad hay muchos más partidos que los considerados como tales oficialmente, pero que no hay su reconocimiento porque no ejercen las funciones descritas en la Constitución y que los configuran como un partido. Sin embargo, las tareas que realizan siguen siendo funciones políticas. Una vez más, se cuestiona si en la Constitución Española hubo el reconocimiento o la incorporación constitucional de los partidos. (In: BASTIDA FREIJEDO, F. "Notas sobre la Naturaleza Jurídica de los Partidos Políticos y su Reconocimiento Constitucional". In: AA.VV.: Jornada de Estudios sobre el Título Preliminar de la Constitución. vol. III. Ministerio de Justicia - Secretaria General Técnica, Madrid, 1988. Pp. 1660-1661). 
cuando, en mi opinión, el Tribunal no ha logrado clarificar totalmente el razonamiento empleado para llegar a esta conclusión. ${ }^{113}$

Desde la perspectiva del reconocimiento constitucional, los partidos adquieren esta condición desde el momento del registro (de la atribución de personalidad jurídica). Desde la incorporación constitucional, esto determina que los partidos tienen que cumplir con determinadas funciones para que sean considerados como tal, a diferencia de las asociaciones comunes, que gozarán de su status jurídico sin la obligación de cumplimiento de funciones especiales o pre-determinadas. ${ }^{114}$ La óptica de la incorporación constitucional, implicaría su consagración como instrumentos necesarios para la articulación del Estado, más allá de su ámbito en la sociedad civil, garantizándoles ventajas y dotándoles de un régimen especial, encaminado a preservar el sistema democrático. Debido a eso, hay autores que entienden que la ley de partidos no puede ser vista como una mera norma integrada en el derecho de asociación, por tratarse de elementos distintos. ${ }^{115}$ Refuerza esta idea el hecho de que el art. 6 de la Constitución Española atribuya a los partidos un régimen especial, al igual que ocurre con la Ley Orgánica 01/2002 en su art. 1.3, situación esta explicitada por el Tribunal Constitucional ${ }^{116}$, aunque el mismo Tribunal haya resaltado que la Ley Orgánica 06/2002 impuso otro límite a los partidos, y ello va mucho más allá del dispuesto en el art. 22 de la Constitución. ${ }^{117} \mathrm{Y}$, justamente por ello se puede interpretar que existe una primacía del art. $6^{\circ}$ en cuanto norma especial sobre la norma general descrita en el art. 22. ${ }^{118}$

Así, previamente a la exposición sobre la naturaleza jurídica de los partidos, conviene afirmar que en este trabajo la separación de regímenes

\footnotetext{
${ }^{113}$ En este sentido, cfr. F.J. 5; 6 ; y 7.

114 BASTIDA FREIJEDO, F. J. "La Relevancia Constitucional..." Pp. 77-78.

115 LEONI, F. "Naturaleza Jurídica del Partido Político en Italia". In: Revista de Estudios Políticos (Nueva Época). n. 62. oct/dic, 1988. Pp. 140; GARCIA GUERRERO, J. L. "Algunas Cuestiones sobre la Constitucionalización de los Partidos Políticos". In: Revista de Estudios Políticos (nueva época), no 70 , oct/dic, 1990. Pp. 156. Compartiendo de esta misma opinión, véase FERNÁNDEZ-MIRANDA CAMPOAMOR, C.; FERNÁNDEZ-MIRANDA CAMPOAMOR, A. F.: Sistema Electoral... Pp. 48.

${ }^{116}$ El art. 1.3 de la LODA (Ley de Asociaciones) enumeran los destinatarios de la norma, fijando indirectamente un régimen para cada tipo de asociaciones identificable en la Constitución Española. Además, cfr. STC 48/2003, F.J. 6.

${ }_{117}$ ANTONIO MONTILLA, J. Op. Cit. Pp. 562-563.

${ }^{118}$ FERNÁNDEZ SEGADO, F. "Algunas Reflexiones..." Pp. 119.
} 
jurídicos entre asociaciones en general y los partidos se tiene como un dato, como un medio de reforzar las garantías concedidas a las organizaciones partidistas. El art. 22 reconoce a los partidos un status jurídico vital para su existencia, y el art. $6^{\circ}$ termina de perfilarlo, a partir de la atribución de funciones que deben ser cumplidas, para la concretización de la propia democracia. Gracias a las garantías propias del art. 22, las funciones reconocidas en el art. 60 se ven posibilitadas, favoreciendo no sólo la realización del pluralismo político del art. 1.2 de la Constitución Española, sino también atribuyendo a los partidos los beneficios que la legislación les confiere, como puede ser el caso de la financiación pública. Conforme el art. 4.3 de la LODA, las ayudas y subvenciones públicas pueden concederse a las asociaciones bajo la condición del cumplimiento de requisitos específicos en cada caso. ${ }^{119}$ En el caso de los partidos este criterio parece ser, casi únicamente, en la actual legislación el de la representación parlamentaria. Esto constituiría otro elemento reforzado en la STC 48/2003, que permite afirmar que en España hay un proceso de incorporación constitucional de los partidos ${ }^{120}$, no solamente de reconocimiento como afirma la doctrina precedente. Dicha conclusión influye directamente en el debate sobre la naturaleza jurídica de los partidos.

De la misma manera que parece existir un proceso de evolución en el análisis hasta ahora expuesto, también ha existido en la cuestión doctrinal de la naturaleza jurídica de los partidos un aspecto que, lógicamente, tiene íntima relación con la cuestión de la financiación de los partidos políticos y la definición de sus características, como también con la diferenciación entre partidos y asociaciones. Es importante en todo caso subrayar que los posicionamientos de la doctrina sobre el tema deben considerarse desde un punto de vista diacrónico. Se trata de posturas no estáticas que han ido acompañando al propio desarrollo del Derecho de Partidos.

El debate acerca de la naturaleza jurídica de los partidos políticos se divide, como es conocido, en tres corrientes: la primera les considera como

\footnotetext{
${ }^{119}$ Así dispone mencionado art.: "El otorgamiento de ayudas o subvenciones públicas y, en su caso, el reconocimiento de otros beneficios legal o reglamentariamente previstos, estará condicionado al cumplimiento de los requisitos establecidos en cada caso".

${ }^{120}$ En este sentido, cfr. IGLESIAS BARÉZ, M.: Op. Cit. Pp. 6, que cree que la STC 48/2003 es un reflejo de que el Tribunal Constitucional camina hacia el modelo de la "incorporación" constitucional de los partidos.
} 
asociaciones de derecho privado; una segunda posición los entiende como órganos públicos; y la tercera como asociaciones de derecho privado, pero dotados de cualidades con connotación pública, pudiendo ser entendidos como asociaciones especiales, con algunos privilegios y deberes que las asociaciones normales no tienen. ${ }^{121}$ Dichos posicionamientos doctrinales no dejan de encontrar apoyo en las múltiples modulaciones realizadas por una muy evolutiva doctrina del Tribunal Constitucional. ${ }^{122}$ Tampoco ayuda, lógicamente, a esta labor "clásicamente doctrinal", la evidente ausencia de una conceptualización legal de su naturaleza jurídica. ${ }^{123}$

Con arreglo a la primera corriente - predominante a la literatura jurídica inicial sobre el derecho de partidos - se entiende que los partidos políticos son tan sólo asociaciones de derecho privado surgidas como consecuencia del puro ejercicio del derecho iusfundamental de asociación ${ }^{124}$, valga aquí la

${ }^{121}$ GARCÍA DE MORA y TORRES DEL MORAL entienden que la discusión acerca de la naturaleza jurídica de los partidos políticos y su falta de consenso es generada por la 'bipolar condición' de que los partidos tengan características de género privado, como libertad de creación y de afiliación, y también por su aproximación a las entidades públicas, con su reconocimiento constitucional y sus funciones. (In: GARCIA DE MORA, Mํㅡㄴ. V. G.-A.; TORRES DEL MORAL, A.: Op. Cit. Pp. 125-126).

${ }_{122}$ GARCÍA-ESCUDERO MÁRQUEZ y PENDAS GARCÍA reflejan este entendimiento en su clasificación: *Partidos políticos como asociaciones privadas, incluso a veces sin personalidad jurídica; *asociaciones de naturaleza privada que cumplen 'fines públicos' o 'fines de interés general'; "partidos como fruto y producto del ejercicio directo del derecho de asociación descrito en el artículo 22 de la Constitución Española, no siendo órganos del Estado y tampoco poderes públicos, pero tienen relevancia constitucional; *sujetos o entes auxiliares del Estado que ocupan un lugar sistemático, que en un dado momento ejercen funciones públicas; *partidos como órganos constitucionales del Estado. Para facilitar la clasificación, los autores acaban por agrupar las teorías mencionadas en dos grandes bloques: 1) la teoría privatista 0 asociativa y 2) la teoría publicista u orgánica. (In: GARCÍA-ESCUDERO MÁRQUES, P.; PENDÁS GARCIA, B. "Consideraciones sobre la Naturaleza y Financiación de los Partidos Políticos". In: Revista de Administración Pública, no 115, ene/abr, 1988. Pp. 379-381). Otra clasificación posible es la expuesta GARCÍA GUERRERO, que entiende que hay cuatro posiciones en la doctrina: *partidos políticos como órganos del Estado, órgano constitucional; *partidos políticos como asociaciones de derecho privado; *posición intermedia que se aproxima del partido como órgano del Estado, o partidos como auxiliares del Estado y; *partidos políticos como auxiliares del pueblo, aproximando más de las asociaciones. (In: GARCIA GUERRERO, J. L. "Algunas Cuestiones..." Pp. 145-146).

${ }^{123}$ Esta es la opinión de MORODO y MURILLO DE LA CUEVA, que no tienen dudas de la naturaleza asociativa de los partidos políticos. (In: MORODO, R.; MURILLO DE LA CUEVA, P. L.: El Ordenamiento Constitucional... Pp. 63 y nota 80). También en el sentido de la ausencia de concepto para partidos políticos, véase GARCIA DE MORA, Mํa V. G.-A. TORRES DEL MORAL, A.: Op. Cit. Pp. 124.

${ }^{124}$ LEONI entiende que en Italia los partidos políticos son tenidos como asociaciones en su esencia, ya que surgen de la libre voluntad de los ciudadanos de unirse para concretizar fines comunes, porque también es duradera, y también es política porque defiende una ideología política a ser efectivada en el Estado. (In: LEONI, F. "Naturaleza Jurídica del Partido..." Pp. 131). Sin embargo, los partidos políticos en Italia siguen teniendo una naturaleza jurídica de asociaciones no reconocidas, por fuerza del tenor del artículo 49 de la Constitución. Ello hace 
postura clásica del prof. LUCAS VERDÚ, con su definición de los partidos como entidades que pertenecen al ámbito social cuya creación y funcionamiento se rigen por las reglas del derecho privado. ${ }^{125}$ En esta línea, el perfil asociativo tiene mucha más trascendencia que la dimensión de derecho público. Es decir, los razonamientos de carácter público tan solo se basan en la importancia de los partidos políticos para el funcionamiento de las democracias modernas, mientras que los de carácter asociativo adquieren un plus de carácter normativo constitucional. No se sabe claramente si las funciones que desempeñan los partidos son de carácter público (incluso cuando se usa como sinónimo los términos "estatal" y "público"), también porque hay otras organizaciones que hacen lo que hacen los partidos y que, a su vez, no son considerados entes públicos. Por ello, según este entendimiento, los partidos se basarían en un derecho fundamental ejercido por los ciudadanos, debiendo ser siempre más sociedad que Estado, sin que esto los limite a las funciones que les son constitucionalmente reconocidas. ${ }^{126}$ Dicha corriente doctrinal, muy influida en los inicios del modelo constitucional español por la doctrina italiana, no resulta hoy en absoluto predominante. Parece que, aun atendiendo a su naturaleza asociativa, no se puede ignorar el papel de los partidos ante el Estado, y su intermediación en la relación de éste con la sociedad.

La segunda posición en la literatura jurídica se ubicaría en el otro extremo. Una parte de la doctrina defiende que los partidos políticos tendrían en realidad una naturaleza "cuasi-estatal", una posición muy vinculada con la idea de incorporación constitucional de los partidos políticos de origen alemán. ${ }^{127} \mathrm{El}$ argumento de que los partidos son órganos estatales se basaría

que posiciones como la de LOMBARDI sigan siendo prolongadas en el tiempo, que considera a los partidos como reconocidos solamente en el parlamento, una porque mantienen débiles conexiones con la sociedad italiana, y otra porque en colegios uninominales, el papel intermediador de los partidos con la sociedad prácticamente no existe, dejando para el candidato individuo la titularidad de esta conexión. (In: LOMBARDI, G. "El Financiamiento de los Partidos Políticos y la Equidad en la Competencia Electoral”. In: AA.VV.: Administración y Financiamiento de las Elecciones en el Umbral del Siglo XXI - Memoria del III Congreso Internacional de Derecho Electoral. Tomo II, Instituto de Investigaciones Jurídicas, DF, México, 1999. Pp. 545).

125 LUCAS VERDÚ, P.: Op. Cit. Pp. 569

${ }^{126}$ GARCÍA-ESCUDERO MÁRQUES, P.; PENDÁS GARCIA, B. Op. Cit. Pp. 381-383. Pues a partir de aquí ya se verifica el cambio en el pensamiento doctrinal sobre el tema, acompañando la evolución sufrida por los partidos dentro del escenario político-social.

${ }_{127}$ Como ejemplo, cfr. MORLOK, M. "La Regulación Jurídica de los Partidos en Alemania". In: Teoría y Realidad Constitucional. № 6, o semestre, UNED, Madrid, 2000. Pp. 45. 
en la noción del electorado como poder público que ejerce una función estatal. Así sería por lo menos en aquellos partidos que poseen representación parlamentaria, ya que de hecho forman grupos parlamentarios y toman decisiones dentro del seno del Estado. Los partidos aparecen así mencionados y definidos en el texto constitucional, en su propio título preliminar, siendo vitales para la democracia y en último término responsables del ejercicio de la soberanía por parte del pueblo. Los intereses de los partidos quedan reflejados como intereses del Estado, siendo este su fin último. Por último, su financiación proviene de fondos públicos fiscalizados por el Tribunal de Cuentas como los de los órganos estatales. ${ }^{128}$

En realidad, esta acentuación del carácter público de los partidos políticos no llega en la literatura jurídica española a considerarlos plenamente órganos del Estado, en un trasunto excesivo de las consecuencias jurídico constitucionales del entendimiento del Estado constitucional moderno como un Estado de partidos. Más bien sugiere, en la literatura jurídica inicial sobre el derecho de partidos, una cierta "construcción artificial" para subrayar las críticas a los excesos de su visión predominantemente publicista. Actualmente parecería una manera de remarcar su falta de idoneidad como instrumento de la democracia participativa. En todo caso, la voluntad de los partidos no es, en términos jurídico-constitucionales la voluntad del Estado, y tampoco sus funciones son las de un órgano estatal. Además, el surgimiento de un partido no depende del Estado, sino de los ciudadanos. ${ }^{129}$

En este campo, predominan en realidad los posicionamientos más matizados que ubican a los partidos entre la sociedad y el Estado, insertando la

${ }^{128}$ LUCAS VERDÚ subrayó muy pronto que la "expresión" e "instrumento fundamental" del artículo $6^{\circ}$ no significa que el constituyente quisiera otorgar status de órgano constitucional a los partidos, y así siendo no pueden ser considerados órganos constitucionales de estructura del Estado. (In: LUCAS VERDÚ, P.: Op. Cit. Pp. 588). ESPARZA OROZ tampoco está de acuerdo con dicha posición, pues ello significaría la absorción de la sociedad civil por el Estado. Entre tanto, este autor no deja de considerar una posible naturaleza pública en sentido amplio de los partidos políticos, a partir del perfil administrativo de sus funciones, y para ello cita la STS 7/2000 de 14 de enero, en la cual el Tribunal Supremo supuestamente exagera en la consideración de los partidos como 'poderes públicos'. En este sentido, cfr. STS 7/2000, F.J. 2ㅜ. (In: ESPARZA OROZ, M.: Op. Cit. Pp. 47).

129 GARCIA GUERRERO, J. L. "Algunas Cuestiones..." Pp. 147-149. En este punto, RODRÍGUEZ DÍAZ cuestiona que, desde un punto de vista jurídico, puedan explicarse los partidos como órganos estatales, cuando se constituyen a la vez un resultado de la movilización y de la capacidad de los ciudadanos para participar en el Estado. (In: RODRIGUEZ DIAZ, A.: Transición Política... Pp. 207). También en este sentido, cfr. ÁLVAREZ CONDE, E.: El Derecho de Partidos. Op. Cit. Pp. 116. 
cuestión dentro de la dicotomía público/privada y reconduciendo la discusión a un cierto predominio del carácter público, pero no estatal, de los partidos. Los partidos políticos no formarían parte de la organización del Estado, pero sí formarían parte del Estado como organización (del Estado Comunidad, en la idea extraída de la STC 10/1983), localizándose en una posición intermedia entre el Estado y la sociedad. Al concurrir a la formación de la voluntad popular, estarían no solo insertos en la estructura política del Estado Constitucional, sino que también desempeñarían una tarea clave y esencial para el sistema democrático y para la propia Constitución. ${ }^{130}$

No es esta, sin embargo, la posición mayoritaria en la doctrina española, que parte del análisis del texto del art. 6ํㅜ de la Constitución Española al hilo de su interpretación en los pronunciamientos del Tribunal Constitucional que han acompañado el desarrollo de las normas del derecho de partidos. El entendimiento de los partidos políticos como asociaciones privadas que ejercen funciones públicas prima en la doctrina que parte del derecho de asociación, pero que lo relaciona con las funciones que les asigna la Constitución ${ }^{131}$, por entender que de su peculiar naturaleza se deriva un régimen constitucional diferenciado del meramente asociativo. ${ }^{132}$

${ }^{130}$ Idea defendida por GONZÁLEZ ENCINAR, que considera a los partidos como entes públicos justamente por su posición entre el Estado y la sociedad, entre la igualdad y a libertad. (In: GONZÁLEZ ENCINAR, J. J. "Democracia de Partidos..." Pp. 29-39).

${ }_{31}$ Según GARCÍA PELAYO, los partidos políticos no reúnen los requisitos para ser considerados como poder público, sin embargo, ejercen funciones públicas. (In: GARCíAPELAYO, M.: El Estado... Pp. 70). También en este sentido, aunque en el derecho portugués, CANOTILHO afirma que los partidos son considerados asociaciones privadas con funciones constitucionales, dado que su constitucionalización no presupone la estatalización de los mismos. (In: GOMES CANOTILHO, J. J.: Op. Cit. Pp. 307).

${ }_{132}$ El número de autores que se adhirieron a dicha posición es muy grande. Así, por todos, cfr. FERNANDEZ-MIRANDA CAMPOAMOR, A. "El Control Estructural-Funcional de los Partidos Políticos en la Jurisprudencia Contencioso-administrativa". In: Revista Española de Derecho Constitucional, año 2, no 4, vol. II, ene/abr, 1982. Pp. 125; LANCHESTER, F. II Problema del Partito..." Pp. 438-446; y TORRES DEL MORAL, A.: Principios de Derecho Constitucional Español 1. 3o ed. renov., ed. Servicio de Publicaciones de la Facultad de Derecho, Madrid, 1992. Pp. 478; PRESNO LINERA, M. Á.: Los Partidos Políticos en el Sistema.... Pp. 28; BLANCO VALDÉS, R. L: Los Partidos Políticos. Op. Cit. Pp. 148-155, sobre los votos disidentes habidos en la STC 10/1983. En este mismo sentido, CARRERAS SERRA atribuye a los partidos una naturaleza asociativa, que los mantiene en la esfera privada y que los asegura la aplicación del artículo 22 de la Constitución Española con intervención mínima e igualdad. Pero no son asociaciones privadas, ya que desempeñan funciones muy relevantes. (In: CARRERAS SERRA, F. de. "Los Partidos en Nuestra..." Pp. 96); CORTÉS BURETA, P.: Recursos Públicos y Partidos Políticos: Balances y Perspectivas de Reforma. Centro de Estudios Políticos y Constitucionales, Madrid, 2003. Pp. 34. En este mismo sentido de obligatoriedad del cumplimiento de las funciones constitucionales y de la atribución de un régimen especial, cfr. FERNÁNDEZ-MIRANDA CAMPOAMOR, C.; FERNÁNDEZ-MIRANDA 
En muchas definiciones de la doctrina que reflejan este entendimiento y que se basan en las sentencias del Tribunal Constitucional, los partidos aparecen como un tipo de asociación que ejerce funciones públicas, teniendo por ello un tratamiento privilegiado.

Este planteamiento evidentemente es deudor de la posición del Tribunal Constitucional. La jurisprudencia del Alto Tribunal evoluciona de manera paulatina, aunque lógicamente sin ofrecer nunca soluciones a un problema de carácter eminentemente doctrinal. En la primera sentencia en que abordó el problema (y que constituirá el marco inicial para el desarrollo de sus posiciones), la STC 3/1981, concedió el amparo a la denegación del registro del partido comunista. En esta decisión, el Tribunal considera a los partidos como una forma peculiar de asociación, (derecho este que no excluye la posibilidad que dicha asociación tenga perfil político - F.J. 1), con relevancia constitucional. ${ }^{133}$ Acompañan a esta decisión las sucesivas STC 10/1983 (F.J. 3); y 85/1986 (F.J. 2), dictadas cuando todavía estaba en vigor la Ley Orgánica 54/1978. La posición del Tribunal, sin embargo, empezó a perfilarse definitivamente en torno a la discusión sobre la constitucionalidad de la Ley Orgánica 06/2002 en la sentencia 48/2003. Acompañando al desarrollo legislativo que implicaba la nueva norma, el Tribunal intentó un cambio en el tono del discurso en dirección a un cierto nivel de incorporación constitucional, afirmando que los partidos no solamente se constituían como asociaciones con funciones especiales, sino que también el cumplimiento de estas funciones determina su naturaleza constitucional. Hay pues un aumento del status jurídico público de los partidos ante el ordenamiento, que se irá acentuando con el tiempo. ${ }^{134}$

CAMPOAMOR, A. F.: Sistema Electoral... Pp. 44-45; e IGLESIAS BARÉZ, M.: Op. Cit. Pp. 2930. Cfr. STC 3/1981, 19/1983 y 48/2003, como ejemplo de dicho posicionamiento por parte del Tribunal.

${ }^{133}$ En el F.J. 2 se observa una ligera "nota discordante" al afirmar que los partidos solamente podrán disfrutar de los beneficios que la legislación les confiere cuando cumplan a sus funciones constitucionales. Se trata de una cierta aproximación a la idea de incorporación constitucional de los partidos, aunque dicho Tribunal mantenga posteriormente que más bien la tesis de su "reconocimiento" en la STC 85/1986 (F.J. 2).

${ }^{134}$ En este sentido, cfr. STC 31/2009, F.J. 3; Vid. por todos, SOLOZABAL ECHAVARRIA, J. J. "Sobre la Constitucionalización..." Pp. 161. En su análisis, FLORES GIMÉNEZ afirma que el Tribunal Constitucional se fundamenta en dos principios para formar su posición sobre el tema, el de la libertad de organización, refiriéndose a la estructura y normas estatutarias dedicadas a cada partido que se crea, y el de autonomía, que limita la intervención estatal dentro de la 
De hecho, y sin mucha claridad, la evolución entre la postura de sentencias como la 10/83 y los pronunciamientos a partir de la STC 48/2003 resulta determinante. ${ }^{135}$

En todo caso, y saliendo del esquema de las tres posturas doctrinales antes mencionadas, hay autores que entienden que no se trata de atribuir una determinada naturaleza jurídica a los partidos propiamente dichos, sino de clasificar la naturaleza jurídica de las funciones que les son conferidas por la Constitución. Así, BASTIDA FREIJEDO entiende que lo realmente trascendente es considerar la naturaleza jurídica de las funciones de los partidos políticos, y su legitimidad constitucional, ya que son funciones públicas y no simplemente privadas. Será el tratamiento que el ordenamiento conceda a cada una de estas funciones el que determinará la naturaleza jurídica de los mismos. Algunas tareas de los partidos serán tenidas como muy relevantes jurídicamente, siendo de naturaleza jurídico-privada, y otras de extrema relevancia, siendo de naturaleza jurídico-pública, llegando incluso a tener nivel casi estatal.

Así, el status jurídico constitucional de los partidos políticos dentro de la idea de incorporación constitucional, y bajo el criterio institucional-funcional, determinará que solo sean un partido político cuando estuvieran inscritos como partidos y realicen las funciones constitucionales establecidas para ellos. Ello permite un concepto jurídico, en el que no se comprenden determinadas organizaciones políticas que, además de no concurrir en las elecciones, no

esfera partidista. (In: FLORES GIMÉNEZ, F.: Op. Cit. Pp. 64). Vid. también ÁLVAREZ CONDE, E.: El Derecho de Partidos. Op. Cit. Pp. 117-118. Uno de los autores que critica esta postura confusa del Tribunal Constitucional es ANTONIO MONTILLA, que afirma que, ante la indecisión del referido Tribunal en especificar si en la Constitución Española hubo incorporación o mera constitucionalización de los partidos políticos, temas complicados como la supuesta existencia de democracia militante en el sistema español también se quedan sin solución. (In: ANTONIO MONTILLA, J. Op. Cit. Pp. 564 y ss.). Así García Guerrero in: GARCIA GUERRERO, J. L. "Algunas Cuestiones... Pp. 147. También, cfr. STC 10/83, F.J. 7 y 8 del extracto y STC 18/84, F. J. 3, aunque en mi opinión, en este último, el Tribunal Constitucional omite un momento tratar el perfil eventualmente público de un partido político, y por ello no podemos concordar enteramente con la crítica de GARCíA GUERRERO, o por lo menos no con este ejemplo. Debido a ello que RODRíGUEZ LÓPEZ concluye que los partidos son entidades privadas no lucrativas de base asociativa, que desempeñan funciones públicas sociales e institucionales extremamente relevantes. (In: RODRIGUEZ LÓPEZ, Á.; MONROY ANTÓN, A. J. "Reflexiones acerca de la Naturaleza Jurídica de los Partidos Políticos" In: Actualidad Administrativa. tomo 1. no 4, quincena del 16/28 de febrero, Ed. La Ley, 2009. Pp. ${ }_{135}^{417) \text {. }}$ 
cumplen funciones de partido, y por ello no tienen este status. ${ }^{136}$ Así, no se trataría de "encajar" a los partidos en modelos ya existentes anteriormente, sino de intentar responder al problema a través de otra perspectiva, considerando otros elementos que son importantes: la estructura organizativa de los partidos y el conjunto de funciones a ser desarrollados por ellos en la sociedad. De esta manera, se clasifican las funciones, para después clasificar a los partidos, ubicándolos dentro de su naturaleza jurídica bidimensional. ${ }^{137}$

Considerando todo lo expuesto, pensamos que la posición más adecuada para esta cuestión es justamente esta última, la de clasificar antes las funciones de los partidos, para determinar su naturaleza posteriormente. Las significativas evidencias de la incorporación constitucional de los partidos, ahora aliada con la inclinación - aunque discreta por el momento - por parte del Tribunal Constitucional permiten adoptar esta postura, justamente para poder justificar el tratamiento legislativo de algunas de las materias del derecho de partidos. No se puede en definitiva aplicar únicamente esquemas privatistas cuando estas organizaciones están ejerciendo funciones nítidamente públicas, como tampoco se puede sostener la vigencia de un derecho público exhaustivo sobre actos que se constituyen con carácter privado. ${ }^{138}$

\footnotetext{
${ }^{136}$ BASTIDA FREIJEDO, F. J. "Derecho de Participación a través de Representantes y Función Constitucional de los Partidos Políticos". In: Revista Española de Derecho Constitucional, ano 7, no 21, sept/dic, 1987. Pp. 210. En otro de sus textos, el mismo autor constata que la evolución de los partidos también se ha visto acompañada por una evolución de la postura del Estado ante ellos, y consecuentemente de ellos ante el Estado, motivando que algunos de los ordenamientos jurídicos existentes hayan evolucionado desde las funciones de los partidos para originar un derecho de otro carácter, apartado del derecho de asociación, haciendo de ellos algo específico, obligados a cumplir con las tareas que les fueron confiadas. Por dichas variaciones, el autor concluye diciendo que no se puede afirmar una naturaleza jurídica única de los partidos, pero que se debe preguntar acerca de la naturaleza jurídica de sus funciones, pregunta esta que no puede tener solamente una respuesta. (BASTIDA FREIJEDO, F. J. "La Relevancia Constitucional... Pp. 91). También, cfr. BISCARETTI DI RUFFIA, P: Op. Cit. Pp. 784, que tiene el mismo posicionamiento, aunque ante el derecho italiano.

${ }^{137}$ NAVARRO MENDEZ, J. I.: Op. Cit. Pp. 224-225 y RODRIGUEZ LÓPEZ, A.; MONROY ANTÓN, A. J. Reflexiones acerca... Pp. 411.

${ }^{138}$ En este sentido, véase SOLER SÁNCHEZ, M.: Campañas Electorales y Democracia en España. Universitat Jaime, [s.I.], 2001. Pp.224-225, acompañando estas clasificaciones de las funciones de los partidos.
} 


\section{3) Las funciones de los partidos políticos prevista en el art. 6 de la Constitución Española y sus posibles crisis en el actual "momento" democrático}

La previsión del art. 6 CE sobre los partidos políticos adquiere así una centralidad clara en el derecho de partidos. ${ }^{139}$

Según el art. 6을 los partidos políticos expresan el pluralismo político, concurren a la formación y manifestación de la voluntad popular y son instrumento fundamental para la participación política. Dichas funciones ponen de relieve el papel de las organizaciones partidistas, que no se limita a constituir el principal vínculo en la relación entre el Estado-aparato y el Estadocomunidad, es decir, entre la 'sociedad política' y la 'sociedad civil', sino que también engloban la estructuración de la comunidad como un único sujeto políticamente actuante, teniendo en cuenta la complejidad siempre presente en las sociedades contemporáneas. ${ }^{140}$

Las funciones de los partidos consisten teóricamente en la movilización de los grupos sociales y en su integración en el proceso democrático, canalizando su participación y disminuyendo el desinterés por la política a límites que la democracia pueda tolerar. Además, también corresponde a los

\footnotetext{
${ }^{139}$ Así KATZ afirma que los partidos políticos tienen 2 (dos) clases de funciones, siendo una dentro del gobierno, que proveen una estructura para la organización de la cámara legislativa, para la construcción de coaliciones y para la coordinación entre las diferentes ramas del gobierno; y otra externamente, en que los partidos promueven el debate de ideas políticas y también conecta a los ciudadanos interesados en la política a participar de dicho proceso. (In: KATZ, R. S. "Party Organizations and Finance". In: LE DUC, L.; G. NIEMI, R.; NORRIS, P. (ed.): Comparing Democracies: Elections and Voting in Global Perspective. Ed. Sage, London, 1996. Pp. 108). Dentro de la perspectiva de la ciencia política, Alcántara Sáez trata de las funciones de los partidos desde un punto de vista distinto del jurídico, en que él enfatiza la oportunidad para que los ciudadanos puedan entrar para la política utilizando a los partidos políticos como medio para tal, siendo esto también un reflejo del pluralismo político que permite la competición entre los partidos. (In: ALCÁNTARA SÁEZ, M. "Las Tipologías y Funciones de los Partidos Políticos". In: VV.AA.: Curso de Partidos Políticos. Ed. Akal, Madrid, 2003 (i). Pp. 37-57). Véase también GARCÍA COTARELO, que utiliza la vinculación de los partidos políticos con la sociedad para definir sus funciones, teniendo dichas organizaciones un perfil institucional y otro social. Así, la clasificación de funciones sociales serían la socialización política; la organización y movilización de la opinión pública; la representación y articulación de intereses plurales; y la legitimación del sistema político. Las funciones institucionales serian el reclutamiento y selección de élites; la organización y realización de las elecciones; la organización y funcionamiento del Parlamento; la composición y funcionamiento del Gobierno. (In: GARCíA COTARELO, R.: Los Partidos Políticos. Op. Cit. Pp. 91).

${ }^{140}$ BLANCO VALDÉS, R. L. "Democracia de Partidos y Democracia en los Partidos". In: GONZÁlEZ ENCINAR, J. J. (coord.): Derecho de Partidos. Espasa-Calpe, Madrid, 1992. Pp. 43.
} 
partidos la traducción de las demandas sociales en programas de gobierno, con la expectativa de poder concretizarlos a través de los poderes públicos. ${ }^{141}$ Junto a esto, adquiere especial relevancia hoy en día la selección de una élite política destinada a ocupar los cargos representativos a través de las elecciones. Dentro de dichas funciones del art. 6ㅜㅡ, hay tareas que son mediatas e implícitas, como pueden ser la actividad electoral y parlamentaria, formación de la opinión pública, y otros. ${ }^{142}$ Sin embargo, nos detendremos a exponer la doctrina que trata específicamente de las funciones que están descritas en la Constitución dado que las mismas ya comprenden las funciones eventualmente vinculadas a los partidos de modo inmediato o mediato.

\subsection{La idea de pluralismo político y su expresión a través de los partidos políticos}

El pluralismo político es uno de los valores superiores ${ }^{143}$ de la Constitución Española, recogido en el artículo 1.1. ${ }^{144}$ La evolución histórica del

${ }^{141}$ GARCÍA-PELAYO, M.: El Estado... Pp. 75-80. El autor afirma que este papel también se extiende a generar políticas públicas que satisfagan al mayor número de ciudadanos, generando las demandas necesarias en el sector de la sociedad que se quiere satisfacer (political enterprises). Y por ello cree que la flexibilización ideológica de los partidos es necesaria, para la funcionalidad de los mismos en un sistema democrático.

${ }^{142}$ Cfr. SOLOZABAL ECHAVARRIA, J. J. "Sobre la Constitucionalización..." Pp. 157; y RODRIGUEZ DIAZ, A: Transición Política... Pp. 155. Sin embargo, hay autores que no comparten una visión optimista de los partidos, del cumplimiento de estas funciones por los partidos ya desde los años 50. En este sentido, en la década de 50, NEUMANN afirma que los partidos políticos son el instrumento principal para que el poder social se vuelva un poder político, ya que el partido permite la presentación de particulares - y muchas veces egoístas intereses como su fueran nacionales, y al mismo tiempo defiende que los intereses nacionales sean dominados por intereses particulares. Así, según el autor, la función de los partidos políticos en la democracia es ambigua. En cierta manera, cada grupo social presenta sus intereses particulares como universales. (In: NEUMANN, F.: The Democratic and the Authoritarian State. Approaches to the Study of Political Power. The Free Press, [s.I.], 1957. Pp. 12-13 - traducción libre). En una visión centrada en España, GARCÍA COTARELO afirma que, en la transición política de España, había una supuesta crisis de legitimidad en un contexto democrático. Con ello, la élite dominante lógicamente estaría interesada en una democracia de tamaño reducido a partir de una selección de gobernantes solamente englobando esta élite, a fin de seguir manteniendo inalterada la estructura económica del Estado de antaño. Así, el autor destacaba su visión capitalista de la cuestión, diciendo que los partidos desempeñan la tarea de legitimar un régimen económico dentro de la democracia. (In: GARCIA COTARELO, R. "Partidos Políticos y Crisis de Legitimidad del Capitalismo". In: VEGA, P. de (ed.): Teoría y Práctica de los Partidos Políticos. Edicusa - Cuadernos para el Diálogo, Madrid, 1977. Pp. 6063).

${ }^{143}$ No se abordará de la diferencia entre reglas, principios y valores superiores, que sin embargo es un tema de gran relevancia en la hermenéutica constitucional. Así, para un panorama general del debate, cfr.: ALEXY, R.: Teoría de los Derecho Fundamentales. Centro 
Estado Constitucional y el propio momento de elaboración del texto fundamental determinó la identificación prioritaria de los partidos con la expresión de dicho pluralismo, identificación que en todo caso no puede ser monopolizadora de una realidad mucho más rica. Por ello, la idea de pluralismo traduce la idea no solo de alternancia, sino de la diferencia de ideas. $Y$ es de esta riqueza ideológica de lo que está compuesta la propia democracia, a partir

de Estudios Constitucionales, Madrid, 1993. Pp. 138-157; GUASTINI, R.: Teoria e Dogmatica delle Fonti. ed. Giuffrè, Milano, 1998. Pp. 272-274; DÍAZ REVORIO, F. J.: Valores Superiores e Interpretación Constitucional. ed. CEPC, Madrid, 1997. Pp. 51. Este autor, desde el derecho comparado, resalta que la fórmula de valores superiores no es común, aunque se pueda encontrar enunciados valorativos a los textos constitucionales. En el caso español, FREIXES SANJUAN y REMOTTI CARBONELL entienden que los valores y reglas son derecho positivado, mientras los principios no, y a veces no están explícitos en el ordenamiento (In: FREIXES SANJUÁN, T.; REMOTTI CARBONELL, J C. "Los Valores y Principios en la Interpretación Constitucional". In: Revista Española de Derecho Constitucional. ano 12. ํo 35, may/ago, 1992. Pp. 99. En la misma línea SANTAMARÍA IBEAS, que destaca por la diferencia entre valores superiores y principios, como valores últimos y valores utilitarios, respectivamente, que la Constitución Española establece. En realidad, dicha distinción, aunque razonablemente argumentada por el autor, no lleva a consecuencias relevantes en su aplicación en la interpretación de normas. (Cfr. SANTAMARIA IBEAS, J. J.: Los Valores Superiores en la Jurisprudencia del Tribunal Constitucional: Libertad, Justicia, Igualdad y Pluralismo Político. ed. Dykinson, Madrid. 1997. Pp. 142-144). PAREJO ALFONSO afirma que los valores superiores determinan un orden de valores, pero que no agotan todos los valores que la Constitución Española posee, solamente indican aquellos que se sobresalen, estableciendo los fines últimos del Estado. (In: PAREJO ALFONSO, L. "Valores Superiores". In: ARAGÓN REYES, M. (coord.): Temas Básicos de Derecho Constitucional - Tomo I. Derecho Constitucional y Fuentes de Derecho. Civitas, Madrid, 2001. Pp. 31). A la vez, ZAGREBELSKY afirma que, dada la coexistencia de los principios y de los valores, no existe un sistema formal cerrado que impida su flexibilidad. En las constituciones pluralistas, no se puede permitir que estos valores tengan carácter absoluto, justamente para no caer en la retórica de la tiranía de los valores. (In: ZAGREBELSKY, G.: El Derecho Dúctil - Ley, Derechos, Justicia. $7^{\circ}$ ed. ed. Trotta. 2007. Pp. 124-125). En la doctrina española, en este mismo sentido, cfr. ARAGÓN REYES, M. "Principios Constitucionales". In: ARAGÓN REYES, Manuel (coord.): Temas Básicos de Derecho Constitucional - Tomo I. Derecho Constitucional y Fuentes de Derecho. Civitas, Madrid, 2001. Pp. 42.

${ }^{144}$ Dicho artículo fija los elementos que permiten identificar la organización política que se pretende expresar en la Carta Magna. Los valores serían, en este sentido, características esenciales del régimen político que se instituye a través de la Constitución, una norma básica que ampara a las demás normas del derecho positivo, lo que también es equivalente decir que depende de las demás normas para su concretización. Se trata de una cláusula abstracta útil como parámetro de ponderación para la función interpretativa. (In: MERINO MERCHAN, J. F. "Valores Superiores del Ordenamiento. Artículo 1.1 de la Constitución". In: AA.VV.: Jornadas de Estudios sobre el Título Preliminar de la Constitución. vol. V. Secretaria General Técnica Ministerio de Justicia, Madrid, 1988. Pp.3414-3418). La mención expresa a los valores superiores en la Constitución Española, según SÁNCHEZ DE VEGA GARCÍA, tiene un doble objetivo, siendo el primero el de declararlos y conectarlos al ordenamiento jurídico, limitando el libre decisionismo que el legislador pueda tener en la elaboración de normas. Además, se pretende limitar el campo de la interpretación. (In: DE VEGA GARCÍA, A. S. "Constitución, Pluralismo..." Pp. 72). 
de un debate libre y abierto entre la mayor cantidad de ciudadanos o participantes posibles. ${ }^{145}$

De todos los valores superiores recogidos en el art. 1.1 de la Constitución Española, el pluralismo político representa el perfil político de la base del Estado democrático español, porque involucra la relación de la sociedad con sus representantes, que componen las instituciones representativas, y determinan la actuación de estos dentro de la esfera pública. ${ }^{146} \mathrm{El}$ modelo democrático aplicado en España - que vincula estrechamente el art. 1.1 con el art. 6을 se caracteriza objetivamente por el pluralismo político, aunque haya autores que confieran una mayor trascendencia al resto de los valores constitucionales. ${ }^{147} \mathrm{El}$ hecho es que el pluralismo político se muestra como una cualidad insustituible dentro de la estructura pública democrática. ${ }^{148}$

El pluralismo político se conecta directamente con el principio democrático. ${ }^{149}$ Sin considerar el perfil filosófico del principio democrático, se

145 SÁNCHEZ FERRO, Susana. El Complejo Régimen Jurídico Aplicable a los Partidos Políticos tras la aparición de la Ley Orgánica de Partidos Políticos de 27 de Junio de 2002. In: Revista Jurídica de la Universidad Autónoma de Madrid, oㅜ 12, 2005. Pp. 233-234.

${ }^{146}$ En este sentido, véase MARTINEZ RUIZ, L F. "La Interdicción de la Arbitrariedad de los Poderes Públicos, Principio Garantizado por la Constitución". In: AA.VV.: Jornadas de Estudios sobre el Título Preliminar de la Constitución. vol. V. Secretaria General Técnica - Ministerio de Justicia, Madrid, 1988. Pp. 3390, en la cual el autor afirma que el pluralismo político, al contrario que los otros valores superiores, se refiere directamente a la estructura y dinámica de la "cosa pública", siendo los demás valores principios generales de derecho. Está claro que, en su obra, el autor no establece una diferenciación entre valores y principios.

${ }^{147}$ Se puede citar a TORRES DEL MORAL, que considera "curioso" que el constituyente haya elevado el pluralismo político a valor superior, ya que el término "libertad política" sería suficiente y por haber muchos otros tipos de pluralismo en la Constitución Española. (In: TORRES DEL MORAL, A.: Principios... Pp. 114). No estoy de acuerdo con el autor, porque, como entiende LUCAS VERDÚ, hace tiempo que el pluralismo político se ha convertido en un elemento axiológico en el pensamiento político actual. (In: LUCAS VERDÚ, P.: Op. Cit. Pp. 536). Por ello, aunque estén próximos, entiendo que libertad política no es lo mismo que pluralismo político. Como se verá, el pluralismo político no engloba solamente la permisión estatal de pertenecer a algún grupo de perfil político, sino también la necesidad de establecer posibilidad real de acceder a las instituciones representativas, diversificando la composición del Parlamento, en una clara demostración de la formación de la sociedad que dicho Parlamento representa.

${ }_{148}$ LOMBARDI, G. "Corrientes y Democracia Interna de los Partidos Políticos". In: Revista de Estudios Políticos (Nueva Época), no 27, may/jun, ed. Centro de Estudios Constitucionales, 1982. Pp. 13.

${ }^{149}$ Aunque no haga referencia expresa al pluralismo político, BORRELLO afirma que hay tres principios fundamentales en la racionalización del proceso político: el de la eficiencia, el de la transparencia y el de la equidad de tratamiento, haciendo una clara mención a la igualdad. Dichos principios serían condiciones de existencia de la democracia y están configurados de modo expreso o implícito en los textos de las constituciones de los estados de democracia pluralista. (In: BORRELLO, R. "Il Finanziamento Pubblico dei Partiti nella Dinamica dello Stato 
entiende que este representa un criterio que fundamenta la construcción teórica del Derecho Constitucional moderno. ${ }^{150}$ Dentro de este contexto, la democracia trae dentro de sí la idea de soberanía popular, de la libertad de elección de opción política, de competición igualitaria entre diferentes grupos políticos, de la periodicidad en el ejercicio de este poder $^{151}$, y su posibilidad de cambio. ${ }^{152}$ Es en este punto en el que surge la importancia del pluralismo político. ${ }^{153}$ Significa subrayar que la esencia de la democracia constitucional es la participación libre e ilimitada de los más diversos grupos en los procesos políticos y sociales. ${ }^{154}$

Preliminarmente al análisis del concepto de pluralismo político y su sentido en el art. 1.1, el análisis de su génesis histórica nos permite ilustrar mejor el peso de este valor en la Constitución Española, considerando que dicho artículo fija los elementos que se constituyen como características esenciales del régimen político que se instituye. ${ }^{155}$

di Democrazia Pluralista - Riflessione Generali e Caso Italiano". In: AA.VV.: Studi in Onore di Gianni Ferrara. vol. I, ed. G.Giappichelli, Torino, 2005. Pp. 369).

${ }^{150}$ ALVAREZ CONDE, E. "Los Principios del Derecho Electoral". In: Revista del Centro de Estudios Constitucionales, ํo 9, may/ago, 1991. Pp. 9.

${ }^{151}$ Cfr. LOWENSTEIN, K.: Teoría de la Constitución. $2^{\circ}$ ed., reimp. Ariel, Barcelona, 1979. Pp. 95.

${ }^{152}$ Cfr. KELSEN, que afirma que la idea de democracia se basa en cierta identidad de intereses entre dirigentes y dirigidos, siendo un gobierno del pueblo para el pueblo, haciendo una clara referencia al principio representativo. (In: KELSEN, H.: Esencia y Valor de la Democracia. $2^{\circ}$ ed. Ed. Guadarrama, Barcelona, 1977. Pp. 30). A la vez, RIDOLA afirma que, dentro de la democracia resulta incluido el pluralismo político, que acaba por ser una clave que garantiza que, aunque con factores de estabilidad del sistema político, se establezca la salvaguardia de la movilidad del propio sistema. (In: RIDOLA, P. "Le regole Costituzionali del Pluralismo Politico e le Prospettive del Diritto dei Partiti". In: Giurisprudenza Costituzionale. no 3. anno XXXVIII, mag/giu, ed. Giuffrè, Milano, 1993. Pp. 2968).

${ }_{153}$ Justamente por esto GIL CASTELLANO afirma que la política se basa en una lucha entre diversidad de grupos, siendo que su fin es el intento de supremacía de unos grupos sobre otros. Siendo así, el pluralismo político se vuelve un elemento intrínseco de una sociedad libre. (In: GIL CASTELLANO, José. "La Financiación de los Partidos Políticos: El Estado de la Cuestión". In: Cuadernos Constitucionales de la Cátedra Fadrique Furió Ceriol, oㅜ 36/37, Valencia, 2001. Pp. 250). Del mismo modo, BORIONI considera que el pluralismo político competitivo necesita de una organización permanente, sostenida con financiación, trabajo profesional y voluntariado. A partir de ello, la legislación sobre financiación debe ser la más sensible y lineal posible, individualizar limites de manera precisa, confiando en su cumplimiento no por la obligación, sino por incentivos, siendo la financiación pública un elemento central de incentivo, prevención y de sanción, en caso de violación de normas. (In: BORIONI, P.: Risorse per la Politica - II Finanziamento dei Partiti fra Tradizione e Innovazione. ed. Carocci, Roma, 2005. Pp. 18-25).

${ }^{154}$ LOWENSTEIN, K.: Op. Cit. Pp. 422-424. En este contexto, el autor considera el pluralismo de grupos como uno de los controles verticales entre detentadores de poder y destinatarios de poder, ya que influyen resistencia a los detentadores. Son barreras y frenos al gobierno y al Parlamento, en una analogía del check and balances.

${ }^{155}$ PECES-BARBA, G.: Los Valores Superiores. Tecnos, Madrid, 1986. Pp. 11. 
La primera redacción del art. 1.1 fue formulado por el grupo socialista, no existiendo referencia alguna al pluralismo político, pero sí a la soberanía popular. Las características más claras en esta primera redacción son la falta de mención al término "valores superiores", como también la plasmación de la justicia directamente en la libertad e igualdad. ${ }^{156}$ Será en los debates de la ponencia constitucional donde se añade tanto la expresión "valores superiores", como también la del pluralismo político, además de separar claramente todos los valores, aun manteniéndolos en un mismo nivel. ${ }^{157}$ En todo caso parece claro que la inclusión del pluralismo político es una clara consecuencia de las secuelas dejadas por el franquismo, y del papel de los partidos en la transición política. ${ }^{158}$ Lo que explica que junto con la elevación del pluralismo político a valor superior se produjera la inédita constitucionalización de los partidos políticos en el art. 6으, principal plasmación instrumental de dicho valor superior. ${ }^{159}$

La idea de pluralismo político ${ }^{160}$ se subrayó en la teoría democrática de la ciencia política de posguerra a partir del análisis de la influencia de los diversos grupos de interés sobre el proceso de toma de decisiones del Poder Ejecutivo. El proceso de gobierno estaría caracterizado por una amplia pluralidad de grupos de interés que compiten uno con el otro en el resultado de

\footnotetext{
${ }^{156}$ SANTAMARIA IBEAS, J. J.: Op. Cit. Pp. 34.

${ }^{157}$ Esta redacción - fruto de la propuesta del Sr. Fraga y de la minoría vasca - fue aceptado por unanimidad, con solamente una modificación, que fue a de poner en un mismo nivel a todos los valores del artículo, componiendo el texto actual. Las diversas enmiendas presentadas al artículo sobre el elemento que interesa para el análisis - el pluralismo político siguió en la redacción del artículo, no siendo influenciado por las sugerencias de cambios de texto habidas. Sin embargo, sobre el tema cfr. PECES-BARBA, G.: Op. Cit. Pp. 28 y ss.; y SANTAMARIA IBEAS, J. J.: Op. Cit. Pp.37 y ss.

${ }^{158}$ Así también pasó en Italia. El pluralismo político fue el primer valor a ser considerado por la constituyente de posguerra, como una condición esencial de una democracia con coexistencia, pero antagonismo de fuerzas políticas diferentes. (In: RIDOLA, P. "Partiti Politici". In: AA.VV.: Enciclopedia del Diritto. vol. XXXII, ed. Giuffrè, Milano, 1982. Pp. 82).

${ }^{159}$ También se debe resaltar que el pluralismo político fue el valor superior más discutido, pues había muchas voces que, sin destacar su importancia, no lo consideraban de relevancia y autonomía conceptual suficiente para fijar en el art. como "objetivo" del texto. Así, cfr. SANTAMARIA IBEAS, J. J.: Op. Cit. Pp. 349-350.

${ }^{160}$ Es sabido que existen muchos tipos de pluralismo, no centrándose solamente en el político. Sin embargo, debido a la amplitud de tipologías y al objeto principal del presente trabajo académico, no se profundizará en dichas clasificaciones. Así, se sugiere la lectura de LUCAS VERDÚ, P.: Op. Cit. Pp. 539 y ss.; DE VEGA GARCÍA, A. S. "Constitución, Pluralismo Político y Partidos". In: Revista de las Cortes Generales, № 26, 2ํㅡㄹ cuatrimestre, Madrid, 1992. Pp. 69-116; y GARCIA DE MORA, Mํㅡㄴ. V. G-A.; TORRES DEL MORAL, A.: Op. Cit. Pp. 114-117 para una breve exposición sobre la tipología del pluralismo dentro de la CE.
} 
las decisiones políticas. ${ }^{161}$ A partir de los años 60, el pluralismo partidista empezó a ser visto como la mejor defensa y legitimación del principio mayoritario limitado, es decir, del principio que sostiene que la mayoría debe respetar los derechos de la minoría, y que debe ejercitar su poder con moderación, hasta el límite impuesto para el respeto a este principio pluralista. ${ }^{162} \mathrm{El}$ proceso de decisión política sólo estará garantizado en los ordenamientos jurídicos democráticos por medio de la común aceptación de la diversidad de opiniones y del pluralismo de las formaciones sociales, lo que se traduce en la formación de la voluntad popular a través de un proceso dialéctico de compensación de fuerzas políticas operando en la sociedad. Por tanto, el respeto de las partes por las "reglas del juego" que aseguran la igualdad y la libertad en este proceso permite que a su vez exista la posibilidad de alternancia en el poder y la tutela del derecho de oposición. ${ }^{163}$

En la Constitución Española, el pluralismo político no puede ser entendido como una norma jurídica meramente descriptiva. Además de merecer protección jurídica, deber estar maximizado. ${ }^{164} \mathrm{El}$ pluralismo político

${ }^{161}$ WENMAN, M. "William E. Connolly: Pluralism without Transcendence". In: The British Journal of Politics \& International Relations. vol. 10, London, 2008. Pp. 157. A partir de esta época, la "regla" era ser plural, y dicho concepto incluso se trasladó al Estado, volviéndolo también pluralista. Así, GARCÍA-PELAYO conceptúa este Estado pluralista como uno que la política y la formación de la voluntad popular están conectadas - si no hechas - por la lucha y los acuerdos entre los poderes económicos y sociales fijados al margen del ámbito estatal, lo que demuestra de una cierta manera la evolución en la propia estructura del Estado. (In: GARCÍA-PELAYO, M.: Las transformaciones del Estado Contemporáneo. Ed. Alianza, Madrid, 1977. Pp. 204). Lógicamente que, sobre tales acuerdos, los partidos políticos son actores directos.

${ }^{162}$ SARTORI, G. "Pluralismo, Multiculturalismo e Estranei". In: Rivista Italiana di Scienza Politica, anno XXVII, no 3, dic., ed. II Mulino, Bologna, 1997. Pp. 482-485.

${ }^{163}$ RIDOLA, P. "Partiti Politici. Op. Cit." Pp. 110.

${ }^{164}$ Como dicho ejercicio de interpretación se relaciona directamente con la fuerza normativa de la Constitución, y también considerando que el principio democrático - que fundamenta toda la estructura del orden político vigente actualmente - está especialmente plasmado en el Derecho Electoral, se debe intentar alcanzar el mayor nivel de eficacia de las normas constitucionales, no haciendo de dichas cláusulas una expresión retórica de reglas. Lógicamente dicha eficacia es variable y exige ser ajustada por la interpretación constitucional y las matices de la discrecionalidad legislativa hacia la norma constitucional de cualquier contenido normativo, como suele pasar con el pluralismo político. En este sentido, cfr. GOMES CANOTILHO, J. J.: Op. Cit. Pp. 1077; ÁLVAREZ ÁLVAREZ, L. "Lealtad Constitucional y Partidos Políticos". In: LÓPEZ GUERRA, L.; ESPÍN TEMPLADO, E. (coord.): La Defensa del Estado. Actas del I Congreso de la Asociación de Constitucionalistas de España. Ed. Tirant lo Blanch, Valencia, 2004. Pp. 72; y FERNÁNDEZ SEGADO, F. "Algunas Reflexiones..." Pp. 118. Por el contrario VILAS NOGUEIRA afirma que la fórmula aplicada para los valores superiores en la Constitución Española intenta positivar la metapositividad, pero que al final, se frustra en este objetivo, ya que están los valores jurídicamente positivados, pero al mismo tiempo son irrelevantes, justamente por su metapositividad. (In: VILAS NOGUEIRA, J. "Los Valores 
exige que haya libertad de los grupos sociales para su articulación e iniciativas de carácter político, sin que haya intervención estatal. ${ }^{165}$ En este sentido, el pluralismo político no se limita sólo a tolerancia a otras opciones políticas, sino también a la clara defensa de dicha tolerancia, en una evidente oposición a quien no la adopte en esta dinámica. ${ }^{166}$ Por otra parte, el reconocimiento del pluralismo político a nivel constitucional hace que las instituciones representativas se abran a la complejidad de la sociedad que representan ${ }^{167}$, como también indica caminos para la participación política de los ciudadanos, siendo este punto la esencia de la propia democracia. ${ }^{168}$

Esta noción de pluralismo político, sin embargo, no lo vuelve autónomo en el contexto del art. 1.1. Parte de la doctrina entiende que el pluralismo político ya está insertado dentro del valor superior de la libertad o de la igualdad, no teniendo un relieve conceptual específico. ${ }^{169}$ En todo caso cuando se piensa en la relación entre los partidos existentes en las campañas electorales, por ejemplo, se debe también partir de una idea de igualdad inicial entre estos competidores, con reales posibilidades de alternancia en el poder.

Superiores del Ordenamiento Jurídico". In: Revista Española de Derecho Constitucional, ano 4, no 12, sep/dic, 1984. Pp. 93). Además, vid. CARRERAS SERRA, F. de. "Los Partidos en Nuestra..." Pp. 102.

${ }^{165}$ En este sentido, cfr. OTTO PARDO, I. de: Defensa de la Constitución y Partidos Políticos. Centro de Estudios Constitucionales, Madrid, 1985. Pp. 30 Y; DE VEGA GARCÍA, A. S. "Constitución, Pluralismo..." Pp. 71. En este punto, ambos autores entienden que la garantía jurídica que involucra el pluralismo político permite que cualquier proyecto realizable en principio, siendo la democracia la propia garantía de dicha posibilidad. Es aquí donde se ubican gran parte de las discusiones sobre la posibilidad de prohibición de partidos políticos y/o listas electorales, el exacto contenido del modelo de "democracia militante".

${ }^{166}$ ALVARÉZ CONDE, E. "Veinticinco Años de Derecho de Partidos". In: PEÑA GONZÁLEZ, J. (Coord.): Libro Homenaje a Iñigo Cavero Lataillade. ed. Tirant lo Blanch, Valencia, 2005. Pp. 75. ${ }^{167}$ PRESNO LINERA afirma que el pluralismo político tiene como premisa la aceptación de la variedad de formas de cómo entender la organización de la sociedad. La igualdad se refleja en este punto aporta la incertidumbre de saber cuál es la mejor alternativa, como todo y cualquier proceso de selección, dejando en el mismo nivel a todos los ciudadanos que participan de dicho proceso. A partir de ello, se tiene que todos están habilitados a declarar la opción que les parece la más adecuada, pronunciado a través de elecciones abiertas. (In: PRESNO LINERA, M. Á.: Los Partidos y las Distorsiones... Pp. 48-49)

${ }_{168}$ Cfr. en este sentido: JIMÉNEZ CAMPO, J. "Diez Tesis sobre..." Pp. 42-43; JIMENEZ CAMPO, J. "Pluralismo Político". In: ARAGÓN REYES, M. (coord.): Temas Básicos de Derecho Constitucional - Tomo I. Derecho Constitucional y Fuentes de Derecho. Civitas, Madrid, 2001. Pp. 122-123. Además, el reconocimiento del pluralismo político representa también la apertura para la participación ciudadana, sea a través del sufragio activo o del pasivo, sea a través de mecanismos de participación política directa. (In: ESTEBAN, J. de; LÓPEZ GUERRA, L.: Op. Cit. Pp. 73-74 y; OTTO, I. de: Derecho Constitucional... Pp. 40-41).

${ }^{169}$ Valga la conocida opinión de PECES-BARBA, que aunque confiera al pluralismo político su importancia, entiende que podría estar dentro del valor de la libertad. (In: PECES-BARBA, G.: Op. Cit. Pp. 117-118. 
Si no hay igualdad en el punto de partida debe existir una labor del Estado de garantía y promoción de dicha igualdad ${ }^{170}$, a fin de garantizar la efectividad del pluralismo político, manteniendo el orden político abierto y renovable. ${ }^{171}$ Dicho razonamiento hace que el pluralismo, en algunas interpretaciones, se encuentre velado en cierta medida, por el principio de igualdad. Sin embargo, se puede dotar al pluralismo político de un perfil autónomo dentro de los valores superiores, sin una relación estricta de dependencia con el valor de la igualdad o de libertad. La relación entre dichos valores es obvia, pues componen la base de la democracia, pero esto no permite vaciar de contenido propio al pluralismo político. ${ }^{172}$

Es cierto que la expresión del pluralismo a través de los partidos representa también el intento del consenso de ideas a través de la libre concurrencia de opiniones que objetivan llegar en el poder ${ }^{173}$, y ello genera algunas consecuencias. Dichas consecuencias pueden ser resumidas en tres, siendo la primera que el pluralismo supone concurrencia, esto es libertad de creación y actividad de los partidos; la segunda que el pluralismo debe estar presente en todos los ámbitos de actuación de los partidos, asegurando la presencia de las minorías, y que estas también tengan condiciones de ser mayoría algún día, lo que también puede ser entendido como tolerancia y respeto con otras opciones políticas; y la tercera que los poderes públicos deben facilitar las condiciones que permitan desarrollar este pluralismo. ${ }^{174}$

La conexión entre el pluralismo político y los partidos es pues "esencial". En realidad, se puede entender que la expresión del pluralismo político por los partidos es más que una función, es una constatación, porque cuando se habla

\footnotetext{
${ }^{170}$ Este concepto fue tratado primordialmente por DWORKIN, que afirma que las decisiones políticas fundamenta los objetivos colectivos, mientras que las decisiones justificadas por principios ya se refieren a un derecho individual. Debido a ello, el derecho no sería objetivos o metas, y los casos antidiscriminatorios, los cuales generalmente se basan en principios, las decisiones tomadas son políticas, considerando también que las medidas antidiscriminatorias son colectivas, con objetivos colectivos. De ahí el origen del el término reverse discrimination, traducido para el español como acciones positivas. (In: DWORKIN, R.: Taking Rights Seriously. ed. Duckworth, 60 ed., London, 1991. Pp. 82-83).

${ }^{171}$ Cfr. FERNÁNDEZ VIVAS, Y.: Igualdad y Partidos Políticos: Análisis Constitucional y Comparado de la Igualdad de Oportunidades de los Partidos Políticos. ed. Congreso de los Diputados, Madrid, 2007. Pp. 299-300.

${ }^{172}$ En este punto, estoy de acuerdo con GARCIA DE MORA, Mํㅡ. V. G-A.; TORRES DEL MORAL, A.: Op. Cit. Pp. 110.

173 SANTAMARIA PASTOR, J. A. "Artículo 6. Op. Cit." Pp. 74.

${ }^{174}$ NAVARRO MENDEZ, J. I.: Op. Cit. Pp. 232-233.
} 
de partidos, ya se está remitiendo una idea de pluralidad, pero lo que parece que el art. 6ำ quiso hacer fue justamente especificar qué tipo de pluralismo se deseaba: el pluralismo a través de los partidos. ${ }^{175}$ Basándose en ello, el pluralismo en los partidos puede manifestarse por medio de los partidos, por medio de la variedad de partidos, y también dentro de ellos. El pluralismo a través de los partidos se identifica con el artículo $6^{\circ}$ de la Constitución Española, para la formación y manifestación de la voluntad popular en el mundo fáctico. Ya en el pluralismo de partidos se puede considerar que un eventual control preventivo es el más grave atentado a este tipo de pluralismo, ubicándose en este punto la cuestión de la existencia de grupos minoritarios que pueden ser clasificados como antisistema. La libertad de los partidos, en este contexto, se identifica con la libertad de las minorías, y dentro de esta se encuentra la libertad de minorías que no se conforman con el sistema. ${ }^{176} \mathrm{Y}$ también engloba la idea de que el interior de los partidos puede estar formado por diversas minorías, que a veces no están de acuerdo entre sí, pero que no dejan de ser una expresión de pluralismo.

Por ello, se puede entender que el pluralismo político es un valor superior consagrado en la Constitución Española, responsable de la apertura de los límites ideológicos de la Constitución, es decir, es un amplio marco donde las ideas y posiciones políticas pueden ser defendidas. Sin embargo, en la práctica, las decisiones legislativas resultan esenciales. El hecho de que gran parte de estas fuerzas puedan a priori estar desprovistas de la posibilidad real de obtener representación política afecta la credibilidad de la existencia de un real pluralismo político, aunque sean de manera indirecta, y el actual sistema de financiación de partidos aplicado bajo los dictámenes del actual sistema electoral, es un ejemplo. ${ }^{177}$

\footnotetext{
175 SANCHEZ DE VEGA, A. "Notas para un...” Pp. 316.

176 DE VEGA GARCÍA, A. S. "Constitución, Pluralismo..." Pp. 84-88. Por ello opina el autor que el control del pluralismo político que se establezca tendrá como consecuencia el tipo de democracia que se pretende.

${ }^{177}$ Cfr. WARE, A. "Conclusions". In: BURNELL, P., WARE, A. (eds.): Funding Democratization, Manchester University Press, UK, 1998. Pp. 243. Se puede entender que las disposiciones constitucionales puedan fallar o ser incumplidas en sus objetivos por el tiempo, porque posee lagunas incluidas de propósito justamente para adaptarse en el tiempo, pero sin embargo, si no son actualizadas por las normas que dan forma a dichas disposiciones, a fin de poder ser aplicadas a nuevas situaciones, acaba por constituir mucho más en un reflejo de las relaciones de poder que existen en un determinado momento. (In: HESSE, C. "Constitución y Derecho
} 


\subsection{Los partidos políticos como actores importantes para la concurrencia, formación y manifestación de la voluntad popular: ¿Existe una crisis de representatividad?}

El artículo 6 CE deja claro que los partidos políticos son instrumentos relevantes en la función y manifestación de la voluntad popular, al seleccionar y permitir canales de comunicación entre la sociedad y el poder político. Dicha función es la que principalmente se ha asignado a los partidos, ya que deben agrupar la voluntad popular para intentar transformarla en la directriz del gobierno, del Estado, requiriendo para ello una voluntad permanente de concurrir a las elecciones y también adquiriendo los partidos una posición privilegiada en la contienda electoral. ${ }^{178}$

Ahora bien, obviamente los partidos no son los únicos responsables en la conformación de dicha voluntad popular. ${ }^{179}$, como tampoco el propio pluralismo político se limita únicamente a los partidos políticos, como se ha

Constitucional". In: BENDA, E.; et al: Manual de Derecho Constitucional. Ed. Marcial Pons, Madrid, 1996. Pp. 9).

${ }^{178}$ Esta es la opinión de GARCÍA GUERRERO, que añade que diciendo que esta es la única función de los partidos, y que las restantes no son en realidad funciones en sí, sino que solo vinculan a los partidos con otros valores y derechos fundamentales de la Constitución Española. Es decir, la remisión del artículo $6^{\circ}$ al pluralismo político no es una función, sino una remisión al artículo 1.1, que sitúa al pluralismo como un valor superior, y lo mismo ocurre con la mención a la participación política, que tampoco es una función para el autor, pero sí es una remisión al artículo 23.1, de la Constitución. (In: GARCIA GUERRERO, J. L. "Algunas Cuestiones..." Pp. 151-153).

${ }^{179}$ En este sentido, la doctrina destaca que los partidos no son los únicos a concurrir con la formación y manifestación de la voluntad popular, pero que, aunque no exclusivos, son los principales instrumentos existentes para dicha función constitucional. (In: RAMIREZ, M. "Los Partidos Políticos en la Constitución Española de 1978". In: Revista de Estudios Políticos (nueva época), no 13, ene/feb, 1980. Pp. 55). Con una visión negativa del tema, OFFE afirma que a partir del momento en que la voluntad popular es traducida a través de los partidos, esta deja de ser popular para ser una estructura formada para la concurrencia política. (In: OFFE, C. "Democracia de Competencia entre Partidos y el Estado de Bienestar Keynesiano: Factores de Estabilidad y de Desorganización". In: OFFE, C.: Partidos Políticos y Nuevos Movimientos Sociales. ed. Sistema, Madrid, 1988. Pp. 62). Asimismo, RODRíGUEZ DÍAZ entiende que la redacción del artículo $6^{\circ}$ de la Constitución Española, al optar por la palabra "concurren" a la formación de la voluntad popular, al mismo tiempo optó por un término de mercado económico liberal, equiparándolo como un mercado electoral. En este sentido, aunque haya una garantía de igualdad de oportunidades, es cierto también que la concurrencia no es perfecta y se evoluciona hacia la oligopolización del sistema. (In: RODRIGUEZ DIAZ, A.: Transición Política... Pp. 175). También, en este mismo sentido, cfr. PRESNO LINERA, Miguel Ángel: Los Partidos y las Distorsiones Jurídicas de la Democracia. Ed. Ariel, Barcelona, 2000. Pp. 46. También, GARCÍA DE MORA agrega que dicha voluntad popular se manifiesta por medio del sufragio y en el Parlamento a través de grupos parlamentarios de los partidos, sea para concretar su programa político, sea para responder a las demandas sociales, en línea con lo dicho por los autores arriba citados. (In: GARCIA DE MORA, Mํ V. G-A.; TORRES DEL MORAL, A.: Op. Cit. Pp. 129-131). 
concluido en el punto anterior. Lo que sí se puede afirmar es que la posición de los partidos políticos en la realización de esta función es privilegiada, es decir, que entre los actores existentes para ejercer dicha función de concurrencia, formación y manifestación de la voluntad popular, sin duda los partidos son los protagonistas. $^{180}$

De esta manera, al analizar el contenido del artículo 6ํㅡ, se constata que la expresión "ser instrumento" es una cualidad de los partidos políticos, y que "expresar el pluralismo" es una consecuencia de esta cualidad. Sin embargo, el mismo artículo no define qué es "voluntad popular" o "concurrencia a la formación y manifestación" de la misma, lo que conduce a muchas interpretaciones. Teniendo en mente que la expresión de la voluntad popular incluye a un amplio grupo de ciudadanos, se podría fijar un parámetro para su conceptualización que correspondería a las necesidades y exigencias que se originan en el seno de una sociedad, y que no pueden ser traducidas solamente a partir del voto. Por lo tanto, no sería erróneo entender que la voluntad popular no se expresa solamente en el momento del voto, es decir, que no se agota obviamente en el sufragio.

En este punto, GONZÁLEZ ENCINAR hace una interesante diferenciación entre los términos "pueblo" y "votantes", "democracia" y "elecciones", y "representación" y "democracia". En relación a la primera dicotomía, el autor afirma que el pueblo no tiene solo una voluntad, sino diversas voluntades, ya que se trata de un colectivo y forma parte de estos intereses los prejuicios, ignorancias y la apatía política, que afecta a estas "voluntades". Por ello no se puede decir que elecciones son expresión de la voluntad popular, porque dicha voluntad ni siquiera es apta para actuar políticamente. ${ }^{181}$ Posteriormente, la voluntad del Estado democrático es voluntad popular, porque pasadas las elecciones, los partidos elegidos

\footnotetext{
${ }^{180}$ GRIMM, D. Op. Cit. Pp. 389. Complementando la idea, ÁLVAREZ CONDE entiende que los partidos convierten la voluntad popular en voluntad estatal a través de las elecciones como "agencias de socialización política". (In: ÁLVAREZ CONDE, E.: El Derecho de Partidos. Op. Cit. Pp. 112).

${ }^{181}$ DE VEGA entiende que las críticas que los partidos sufren de que son organizaciones desintegradoras y que poseen solamente intenciones particularistas son, en realidad, críticas a la democracia, y no sólo a los partidos. Sería este el caso de la supuesta ignorancia de la voluntad popular por parte de los partidos pasadas las elecciones. (In: VEGA, P. de. "Presentación". In: VEGA, Pedro de (ed.): Teoría y Práctica de los Partidos Políticos. Edicusa Cuadernos para el Diálogo, Madrid, 1977. Pp. 14-15).
} 
conformarán el Estado para formar su "voluntad", y en estas instituciones del Estado hay voluntad popular porque de estas emanan las instituciones, es decir, los poderes del Estado vienen del pueblo y crean las leyes a partir de esta voluntad preexistente. ${ }^{182}$ Así, el Estado expresa su voluntad popular porque expresa la voluntad de manera democrática, de acuerdo con el procedimiento democrático. ${ }^{183}$ Debido a todo ello, el autor entiende que la formación de la voluntad popular es algo permanente en la sociedad y en el Estado, siendo las elecciones una manifestación de este proceso. No hay pueblo y Estado en este orden, sino un proceso que se traduce en una relación dialéctica entre ellos, y que, involucrado individuos y colectividad, permite a los partidos políticos destacar en la mediación en este proceso. ${ }^{184}$

Partiendo de este punto, los partidos serían un vehículo para la formación y comunicación de dicha voluntad popular y de la socialización política ya que, en la concurrencia existente, también organizan políticamente la sociedad, estableciendo conexiones entre la misma y el Estado. Además, también seleccionan una élite política responsable de conducir en las organizaciones representativas los programas electorales presentados para el electorado. También protagonizan el proceso electoral, y ejercen el papel de gobernantes o de oposición, dentro de la dinámica del Estado. Además, los partidos serían así los responsables tanto del control del propio gobierno, como también de la actualización de los programas políticos, adaptándolos a los cambios y a las nuevas demandas venidas de la sociedad. ${ }^{185}$

El problema de la voluntad popular surge de la gran complejidad de voluntades individuales de una sociedad. Siendo los partidos políticos

\footnotetext{
182 Junto a ello, GRIMM entiende que los partidos políticos no se limitan a la función de la formación de la voluntad popular, sino también la del Estado, a través de sus parlamentaros, que no solo representan a la sociedad, sino que también están vinculados a los propios partidos, y también dirigen el Estado. De este modo, la formación de la voluntad popular sería permanente, teniendo en las elecciones en su culminación. (In: GRIMM, D. Op. Cit. Pp. 396397).

${ }^{183}$ Maximizando esta afirmación, el autor entiende que todas las personas que ejercen cargos y oficios públicos representan la voluntad popular y no sólo los cargos elegidos directamente.

${ }^{184}$ GONZÁLEZ ENCINAR, J. J. "Democracia de Partidos..." Pp. 20-24. Dentro de esta perspectiva, de ESTEBAN y LÓPEZ GUERRA entienden que la función de los partidos de formación y manifestación de la voluntad popular solamente será ejercida efectivamente cuando los electores estén informados de los programas de los partidos y cuestiones políticas. Si así no fuera, dicha función no se realizaría y solamente se harán a los ciudadanos preguntas que ellos ignoran. (In: ESTEBAN, J. de; LÓPEZ GUERRA, L.: Op. Cit. Pp. 76-77.

${ }^{185}$ TORRES DEL MORAL, A.: Principios... Pp. 470.
} 
responsables principales, aunque no exclusivos, de la formación y manifestación de la voluntad popular, se convierten en un instrumento de reducción de dicha complejidad. ${ }^{186}$ Sin embargo, para que esta reducción esté en consonancia con el concepto de Estado democrático, los partidos deben saber cómo canalizar ese proceso y constituirse realmente en medios de expresión de toda esta pluralidad que pueda existir. ${ }^{187}$ Partiendo de estos presupuestos, NAVARRO MÉNDEZ entiende que esta es la principal función de los partidos, pero que únicamente se cumple cuando, en una sociedad compleja, los partidos logran seleccionar demandas $y$, a través de medios democráticos, hacer que dichas demandas sean escuchadas, sin eliminar las diferencias y el derecho de crítica. ${ }^{188}$

La voluntad popular, por ser amplia y global, se forma a partir de la competencia de los diversos partidos en la contienda electoral, y es aquí donde este asunto se conecta con el pluralismo político en las sentencias del Tribunal Constitucional, como la STC 101/1983, de 18 de noviembre y STC 69/1986, de 28 de mayo. En ambas sentencias, el Tribunal Constitucional remite la formación y expresión de la voluntad popular al hecho de la existencia de concurrencia de distintos partidos, los cuales representan cada parte que compone la sociedad como un todo. De ahí que el tema de la voluntad popular también sea la clave para muchos otros importantes pilares del derecho de partidos, como la regulación o no de los partidos, la imposición o no de límites a dichas organizaciones, y, también, la cuestión de la financiación de partidos.

Tangencialmente a la perspectiva descrita e interconectada con la complejidad de la sociedad y la capacidad de los partidos de filtrarla, y si la voluntad popular se hace escuchar a través del resultado del sufragio, dicha voluntad también reside en los órganos representativos elegidos. Partiendo de

\footnotetext{
${ }^{186}$ En este sentido, resulta obligada la cita de los trabajos de LUHMANN, N.: Legitimação pelo Procedimento. Brasília: UnB, 1980; LUHMANN, N.: Sociologia do Direito I. Rio de Janeiro: Tempo Brasileiro, 1983; LUHMANN, N.: Sociologia do Direito II. Rio de Janeiro: Tempo Brasileiro, 1985. Existe versiones en diversos idiomas.

${ }^{187}$ FERNÁNDEZ-MIRANDA CAMPOAMOR, C.; FERNÁNDEZ-MIRANDA CAMPOAMOR, A. F.: Sistema Electoral... Pp. 43-44. En este punto el autor complementa la idea con su opinión de que, aunque los partidos políticos no pueden ser considerados como órganos del Estado, se les reconoce un status constitucional que conlleva una protección especial, además de conferirles muchos beneficios, como tener acceso a las fuentes de financiación pública, que tienen como uno de sus objetivos justamente garantizar la igualdad de oportunidades en la participación política.

${ }^{188}$ NAVARRO MENDEZ, J. I.: Op. Cit. Pp. 233.
} 
este punto, los partidos que no concurren a la formación y expresión de la voluntad popular, y cuya actividad extraparlamentaria o cotidiana se limita a la de meras asociaciones políticas, suponen actividades no garantizadas o irrelevantes. ${ }^{189}$ Dentro de este panorama, lo cierto es que existe una discusión doctrinal sobre si el cumplimiento formal y material de estas funciones determina la condición de partido $\mathrm{y}$, consecuentemente, el disfrute de los beneficios y de la protección concedida por la ley. Hay autores como JIMÉNEZ CAMPO, que entienden que los partidos que no cumplen de manera formal y material la función de formación y manifestación de la voluntad popular no deben ser considerados partidos, sino meras asociaciones políticas. Siguiendo la legislación alemana sobre el tema, que tiene como requisito la participación de los partidos en elecciones anteriores en un período de seis años para que dichas organizaciones continúen siendo consideradas jurídicamente relevantes, y que sigan siendo beneficiados por su régimen ${ }^{190}$, en 2011 la Ley Orgánica del Régimen Electoral General sufrió una reforma significativa, agregando un apartado $3^{\circ}$ en el art. 169, que establece requisitos para la presentación de candidaturas tanto de partidos, federaciones o coaliciones que no lograron escaños en las elecciones anteriores, como para las agrupaciones de electores. La obligatoriedad del cumplimiento de dichos requisitos - basados en la presentación de firmas de por lo menos el $0,1 \%$ de electores listados en el censo electoral de la circunscripción donde se presenta la candidatura reafirmaría la posición de los autores que entienden que las elecciones son el momento de la verdadera expresión de la voluntad popular, y en consecuencia es el momento en que los partidos políticos cumplen con la función de formación y expresión de la voluntad popular. ${ }^{191}$ En algunas decisiones del Tribunal Constitucional también está implícita esta idea, aunque no de manera

189 JIMÉNEZ CAMPO, J. "Los Partidos Políticos en la..." Pp. 217.

190 Según dispone el artículo 2.2 de la Ley sobre los Partidos Políticos de Alemania: "Una asociación pierde su posición jurídica como partido si durante seis años no participa con sus propias propuestas electorales en unas elecciones para el Bundestag o para un Landtag". Traducción extraída del sitio web del Instituto Göethe <<http://www.goethe.de/in/d/presse/gesetzestexte/s/parteien-erster-s-f.html > Acceso en 29.09.2009.

${ }_{191}$ Cfr. NAVARRO MENDEZ, J. I.: Op. Cit. Pp. 236; y ESPARZA OROZ, M.: Op. Cit. Pp. 50, en la que el autor afirma que no es la mera existencia del partido lo que le confiere derechos, pero sí es necesaria su concurrencia a la manifestación de la voluntad popular, controlando la funcionalidad del gobierno y la eficacia de los poderes públicos, algo que también legitimaría la imposición de barreras electorales. 
directa. Por ejemplo, en la STC 3/1981 de 2 de febrero el Tribunal mantiene que "El régimen jurídico peculiar de los partidos políticos confiere a éstos ciertos derechos sólo en cuanto concurran a la manifestación de la voluntad popular tomando parte de las elecciones." ${ }^{192}$

Sin embargo, otros autores como LUCAS VERDÚ entienden que dejar de formar la voluntad popular no puede generar sanciones a los partidos políticos porque abarcar todas las demandas y aspectos sociales existentes es algo imposible. Así, el cumplimiento obligatorio y material escapa a la capacidad de los partidos políticos, y por lo tanto, estos no deben de perder parte de sus prerrogativas jurídicas. ${ }^{193}$ Además, si se considera como verdadera la idea inicialmente expuesta de que la voluntad popular no se forma o manifiesta solamente en el momento del sufragio, o que para ejercer esta función concedida por la Constitución sus titulares deberán cumplir requisitos previos, quizás cabe pensar si no se trata de una medida indebidamente impuesta a los partidos que acaba por obstaculizar el cumplimiento de dicha función, o si las medidas ahora exigidas en realidad reflejan en cierta forma una crisis en esta función de representatividad generada por el fallido ejercicio de las atribuciones partidistas.

Como breve comentario a la primera hipótesis, dado que la Constitución Española no ha conceptuado al partido político, y a partir del entendimiento mayoritario de que el registro del partido tiene naturaleza declaratoria ${ }^{194}$, sería más prudente entender que no se pueden deducir las cualidades jurídicas confirmadas con el registro de un partido solamente por el hecho de no participar de las elecciones, o de no haber logrado escaños. Teniendo en cuenta que la formación de la voluntad popular no está limitada a las

\footnotetext{
192 Cfr. extracto, 3 y F.J. 2. Posición también reiterada en la STC 75/1985, F.J. 5.

193 LUCAS VERDÚ, P.: Op. Cit. Pp. 585-587.

194 En este sentido, por todos cfr. OTTO PARDO, I. de: Defensa de la... Pp. 91-98; FERNANDEZ FARRERES, G. "El Registro de Partidos Políticos: Su Significación Jurídica Según la Jurisprudencia del Tribunal Constitucional". In: Revista Española de Derecho Administrativo, no 55, jul/sept, 1987. Pp. 439-446; y MORODO, R.; MURILLO DE LA CUEVA, P. L.: El Ordenamiento Constitucional... Pp. 92-97. En contra este posicionamiento, cfr. por todos MONTILLA MARTOS, J. A. Op. Cit. Pp. 188-191; ESPARZA OROZ, Miguel: La llegalización de Batasuna: El Nuevo Régimen Jurídico de los Partidos Políticos. Cuadernos Aranzadi del Tribunal Constitucional. Ed. Thomson/Aranzadi, Navarra, 2004. Pp. 89; TAJADURA TEJADA, J.: Op. Cit. Pp. 58-62; y SÁNCHEZ FERRO, S. Op. Cit. Pp. 242.
} 
elecciones $^{195}$, pero que prácticamente solo puede ser manifestada en este momento (aunque se cuente con mecanismos de democracia directa, como los referendos, momentos estos que también pueden ser considerados como expresión de la voluntad popular sin el filtro partidista), cualquier obstáculo en la concurrencia electoral debería superar un filtro de proporcionalidad. ${ }^{196}$

Con todo, todavía queda por considerar la segunda hipótesis: ¿Están los partidos sufriendo actualmente una crisis en esta función de representatividad generada por el fallido ejercicio de las atribuciones partidistas?

La representación política es uno de los principios de un Estado Democrático y se realiza a partir de la elección de los representantes por los ciudadanos - en una clara manifestación de la voluntad popular, dichos representantes expresarán las demandas sociales por las cuales fueron elegidos, aunque representarán a toda la sociedad. ${ }^{197}$ Así, la representación política ${ }^{198}$ puede ser entendida como un procedimiento en que una determinada clase política es elegida para conducir las demandas de la sociedad a los órganos e instituciones estatales, con el fin de involucrarlos en

${ }^{195}$ Con ello, me adhiero a la opinión de SOLOZÁBAL ECHAVARRÍA, que también entiende que la función de formación de la voluntad popular no se realiza sólo en las elecciones, sino mucho antes de ella, prolongándose después. (In: SOLOZABAL ECHAVARRIA, J. J. "Sobre la Constitucionalización..." Pp. 162).

${ }^{196}$ Sobre dicho principio, cfr. ALEXY, R.: Op. Cit. Pp. 523-546; BERNAL PULIDO, C.: El Principio de Proporcionalidad y los Derechos Fundamentales. 3ำ ed. CEPC, Madrid, 2007 y CARBONELL, M.; GRÁNDEZ CASTRO, P. P. (coord.): El Principio de Proporcionalidad en el Derecho Contemporáneo. ed. Palestra, Lima, 2010.

${ }_{197}$ Quiere decir que los representantes elegidos representan toda la colectividad, aunque exista el deseo por parte de la Constitución de que dicho representante dé efecto durante el mandato a las demandas expresadas por sus votantes. (In: BASTIDA FREIJEDO, F. J. "Derecho de Participación..." Pp. 212). También, cfr. BARBERA, A. "La Rappresentanza Politica: un Mito in Declinio?" In: Quaderni Costituzionali. Anno XXVIII. no 4, Diciembre. Ed. II Mulino, Bologna, 2008. Pp. 854.

${ }_{198}$ Por la amplitud del presente trabajo, no es posible tratar de todos los aspectos que involucran la representación política, principalmente si acaso considerar su origen y desarrollo filosófico. Así, cfr. para una exposición del perfil filosófico de la representación política, DUVERGER, M.: Instituciones Políticas y Derecho Constitucional. 5o ed, ed. Ariel, 1970. Pp. 116-120; LEIBHOLZ, G.: Problemas Fundamentales de la Democracia Moderna. Instituto de Estudios Políticos, Madrid, 1971. Pp. 13-49; FENICHEL PITKIN, H.: El Concepto de Representación. ed. CEPC, Madrid, 1985. Pp. 233-239; y UGO RESIGNO, G. "Alcune Note sulla Rappresentanza Politica". In: Politica del Diritto. no 4. Anno XXVI, marzo, ed. II Mulino, Bologna, 1995. Pp. 543-560, en que el autor compara este tipo de representación con la representación jurídica. Por fin, cfr. VEGA GARCÍA, P. de. "Democracia, Representación y Partidos Políticos (Consideraciones en torno al Problema de la Legitimidad)". In: ASENSI SABATER, J. (coord.): Ciudadanos e Instituciones en el Constitucionalismo Actual. Ed. Tirant Lo Blanch, Valencia, 1997. Pp. 19-39, trabajo en lo cual el autor trata del aumento del electorado, con la consecuente necesidad de aumento de la identificación de demandas sociales, ampliación del sufragio y la adopción de los partidos políticos como protagonistas en este proceso. 
el debate de las políticas públicas. ${ }^{199}$ Resultado del ejercicio del derecho de participación política ${ }^{200}$, se trata de una de las maneras en las cuales el art. $6^{\circ}$ concreta o vehicula la realización del pluralismo político. ${ }^{201}$ La idea clásica de representación política en los tiempos modernos se ve bastante distorsionada si se considera la natural complejidad de la sociedad y la ampliación de la base electoral, permitiendo el aumento significativo de esta complejidad y dificultando la relación representante-representado. ${ }^{202}$ En este punto, consideremos que los partidos identifican las demandas de la sociedad, y las representan ante las instituciones públicas, ya sea a través de su papel de gobierno o como oposición. Por más que se sepa que los partidos políticos no detentan el monopolio de la representación - como ya se ha dicho - no se puede negar que su papel ante el Estado y ante la sociedad es de extrema importancia, principalmente porque constituye una de las funciones recogidas por la Constitución Española. ${ }^{203}$

La expansión de la importancia de los partidos generó el tan connotado "Estado de partidos" 204 , en el que la voluntad de los partidos acaba por dirigir la voluntad de las instituciones representativas y estatales, y existe la posibilidad

\footnotetext{
${ }^{199}$ LUCAS VERDÚ, P.: Op. Cit. Pp. 531.

${ }^{200}$ Cfr. BASTIDA FREIJEDO, F. J. "Derecho de Participación...." Pp. 200 y ss. Como ejemplo jurisprudencial, también se puede citar la conocida posición de veta "clásica" del Tribunal Constitucional en la STC 10/1983, de 21 de febrero, F.J. 9, donde se entiende que los representantes elegidos no serán representantes solamente de los que le votaron, sino de todo el cuerpo electoral, ya que sus decisiones no afectarán solo a sus electores, sino que afectará a todos de manera general.

${ }^{201}$ Aún más si consideramos la posición de JIMÉNEZ CAMPO, que entiende que el art. 6ํtiene dos mandatos de representación del pluralismo político en las instituciones representativas, siendo el primero por sufragio, con los partidos políticos en una parte del procedimiento público que expresa este sufragio ( $\mathrm{y}$ por consecuencia es también la expresión del propio pluralismo político); y también a través del concepto de representación propiamente dicho, que significa reflejar con el mayor alcance la sociedad en dichas instituciones. (In: JIMENEZ CAMPO, J. "Sobre el Régimen..." Pp. 1635).

202 BARBERA, A. “La Rappresentanza...” Pp. 859.

${ }^{203}$ Es decir, que la representación política no se agota en los partidos, aunque sea esencialmente una representación a través de ellos. (In: GARCÍA ROCA, J.: Cargos Públicos Representativos - Un Estudio del Artículo 23.2 de la Constitución. ed. Aranzadi, Pamplona, 1999. Pp. 62-63).

${ }^{204}$ Dicha noción de Estado de Partidos se consagra en la literatura jurídica española a partir de las enseñanzas de GARCÍA PELAYO, autor este que afirma que el Estado de Partidos representa el Estado democrático en la actualidad, pues sin la mediación de los partidos, no sería posible la formación de la voluntad popular colectiva. (GARCÍA-PELAYO, M. El Estado... Pp. 35). Como excede de los límites del presente trabajo, no se profundizará en este concepto. También sobre el tema, cfr. GARCÍA ROCA, J.: Cargos Públicos..." Pp. 64 y ss., donde el autor comenta la evolución jurisprudencial sobre el lugar de los partidos políticos dentro de la representación.
} 
de que ellos confundan la voluntad popular con la suya. ${ }^{205}$ En realidad, el papel principal de los partidos es filtrar las demandas sociales, trayéndolas a la esfera pública y reduciendo la complejidad inherente a cualquier sociedad moderna. ${ }^{206}$ El monopolio actual de la representación por parte de los partidos genera sin embargo sentimientos antagónicos en la sociedad, como puede ser la desconfianza, por la que se pasa a dar cada vez menos crédito a dichas organizaciones en el sistema político. ${ }^{207}$ Entre tanto, desde el momento en que se tiene la impresión de que el Estado de partidos está sobreponiéndose a la democracia de partidos, hay una distorsión no prevista, y no parece un problema menor, ya que el modelo normativo de democracia a partir de dichas organizaciones, los vuelve obviamente indispensables. ${ }^{208} \mathrm{La}$ intervención por parte de los partidos en la relación Estado - sociedad y su consideración como elementos necesarios en esta dinámica les ha concedido un nivel de influencia quizás mayor de lo que las actuales sociedades consideran aceptable desde el punto de vista de la legitimación democrática. ${ }^{209}$

Aunque existan sistemas en los que no se da el monopolio de los partidos en la función de formación y manifestación de la voluntad popular (en sistemas que admiten otras alternativas, como iniciativas populares de ley, candidaturas independientes, y otros), no se pueda afirmar que las distorsiones que el comportamiento de los partidos y su "ubicación" en el Estado comporta

${ }^{205}$ Cfr. SANCHEZ DE VEGA, A. "Notas para un..." Pp. 311. De la misma manera, GARCíA GIRÁLDEZ aborda en su trabajo una breve aportación sobre los conflictos existentes en la relación entre Estado y partidos políticos, como es el caso del Parlamento, en el cual los partidos políticos discuten entre si las supuestas voluntades de la sociedad, es decir, el Parlamento no se considera como la última fase de la decisión política, ya que este está subordinado a los partidos, aunque sea un órgano estatal. (In: GARCÍA GIRÁLDEZ, T. Op. Cit. Pp. 157).

${ }^{206}$ Cfr. SARTORI, G.: Elementos de Teoria Política. ed. Alianza, Madrid, 1999. Pp. 274.

207 GONZÁLEZ ENCINAR, J. J. "Representación y Partidos Políticos". In: GARRORENA MORALES, A. (ed.): El Parlamento y sus Transformaciones Actuales - Jornadas Organizadas por la Asamblea Regional de Murcia (11-13 de abril de 1988), ed. Tecnos, Madrid, 1990. Pp. 75-79.

${ }^{208}$ GONZÁLEZ ENCINAR, J. J. "Democracia de Partidos...” Pp. 30-32 y GARCÍA, E.: El Estado Constitucional ante su 'Momento Maquiavélico'. ed. Civitas, Madrid, 2000. Pp. 55-59.

${ }^{209}$ Así que estoy totalmente de acuerdo con Carreras Serra, que tiene esta opinión. Cfr. CARRERAS SERRA, F. de. "Los Partidos en Nuestra..." Pp. 113-114. Siguiendo el autor, cfr. HOLGADO GONZÁLEZ, M. "Partidos y Representación Política". In: AA.VV.: Derecho Constitucional para el Siglo XXI - Actas del VIII Congreso Iberoamericano de Derecho Constitucional, Tomo II. Ed. Thompson - Aranzadi, Sevilla, 2006. Pp. 2697. 
no hayan alcanzado niveles muy altos. ${ }^{210}$ Sin negar que los partidos sigan siendo esta pieza esencial en la relación entre sociedad y Estado, la función de representación ejercida por dichas organizaciones va perdiendo calidad "representativa" lo que genera no pocas distorsiones para una correcta comprensión democrática de la soberanía popular con un valor actual, ${ }^{211}$ más allá de una democracia minimalista y "schumpeteriana", solo como procedimiento de elección entre élites capaces de gobernar. ${ }^{212}$

Por otra parte, si la representación es resultado del ejercicio del derecho de sufragio, y el responsable de instrumentalizar estos votos en escaños es el sistema electoral, es sabido que no hay sistemas electorales que no contemple correctores con los que obtener el resultado más adecuado a la realidad del país donde se aplique. Sin embargo, aunque justificadas, estas distorsiones pueden favorecer - como suele ocurrir - a los partidos mayoritarios. ${ }^{213}$ Así, el proceso de toma de decisiones a partir de las instituciones legislativas también sufrirá las influencias de este déficit representativo, haciendo que existan intereses sociales que queden marginalizados, o subrepresentados. ${ }^{214}$ Los efectos de la combinación de los sistemas que componen la estructura política de un Estado dependerán en mayor medida de cómo se maneje su interdependencia, es decir, del grado de conexión que un sistema tiene con el otro. Lo que cabe afirmar es que, de todos modos, esta compleja y "multinivel"

\footnotetext{
${ }^{210}$ No se trata de cuestionar teóricamente el ideal democrático, más bien es la identificación de un vacío entre la teoría y la praxis constitucional, que está llenándose por la "impostura", que hace que dicho vacío sea susceptible de convertirse en una "completa parodia de la realidad", en palabras de ELOI GARCÍA. Cfr. GARCÍA, E.: Op. Cit. Pp. 59.

${ }^{211}$ Aún más si se piensa que la crisis de los partidos ha hecho que la representación no sea más monopolio parlamentario, pero sí de diversos grupos de la sociedad, como los sindicatos y organizaciones de interés, entre otros. (In: BARBERA, A. "La Rappresentanza..." Pp. 885).

${ }^{212}$ SCHUMPETER afirma que la representación proporcional posibilita a todas las clases sociales tener una oportunidad en el gobierno, pero también tiene el poder de impedir que la democracia genere gobiernos eficientes, provocando tensión entre las fuerzas políticas. Así, para evitar este efecto, las atribuciones del Estado deberían ser transferidas a los individuos o equipos que dispongan de un apoyo electoral superior que los demás con que compiten. Todos serían libres de competir en un primer momento, pero esto podría ser peligroso para la eficacia del gobierno. (In: SCHUMPETER, J. A.: Capitalismo, Socialismo y Democracia. ed. Folio, Barcelona, 1984. Pp. 346-348). CANOTILHO denomina esta teoría como la teoría elitista de la democracia, en la cual la democracia no sería el poder del pueblo, sino el poder de las élites para que el pueblo solamente elija las élites. (In: GOMES CANOTILHO, J. J.: Direito Constitucional e Teoria da Constituição. 3oe ed. reimp. Almedina, Coimbra, 1999. Pp. 13171318).

${ }^{213}$ Muchas veces dichas distorsiones, aunque justificada por razones que quizás pudieran servir de soporte, acaban por favorecer a los partidos mayoritarios. Véase HOLGADO GONZÁLEZ, M. "Partidos y Representación..." Pp. 2692-2693.

${ }^{214}$ DEL CASTILLO, P. “La Campaña del Referéndum..." Pp. 153.
} 
relación entre sistemas no optimiza actualmente en muchos casos el principio representativo. ${ }^{215}$

Con la evolución de la denominada "partitocracia" dentro de las instituciones del Estado, parece común constatar un cierto bloqueo de la función de formación y manifestación de la voluntad popular ${ }^{216}$, afectando la credibilidad tanto de la democracia como también de los propios partidos. Su actuación conjunta acaba por formar una mayoría indirecta, lo que refleja en la idea de una sola clase política, aunque teóricamente no sea así. ${ }^{217}$ Dicha situación genera desconfianza ante los partidos, en vez de expresar el pluralismo existente, que terminan por tener un protagonismo "exclusivo y excluyente" ${ }^{218}$ en el Estado que debería ser democrático. ${ }^{219}$ En definitiva, lo que tan solo se quiso apuntar aquí es la obvia existencia de una cierta crisis de representatividad generada por el modelo de Estado de partidos, lo que quizás pida una nueva interpretación de las funciones de los partidos y de su relación con el Estado, para que un frecuente comportamiento con perfil corporativo no se prolongue en el tiempo.

\footnotetext{
${ }^{215} \mathrm{Y}$ esto se agrava aún más con el modelo de campañas electorales existente actualmente, basado en la propaganda fuerte y en la imagen, convirtiendo todo el proceso electoral en un mero procedimiento de plebiscito, más que en elecciones representativas. (In: ARAGÓN REYES, M. "Democracia y Representación: Dimensiones Subjetiva y Objetiva del Derecho de Sufragio". In: OROZCO HENRÍQUEZ, J. J. (coord.): Memoria del III Congreso Internacional de Derecho Electoral. vol. 1, [s.l.], 1999. Pp. 12).

${ }^{216}$ VEGA, P. de. "Presentación. Op. Cit." Pp. 19 y ss.

${ }^{217}$ REBOLlo DELGADO, L.: Partidos Políticos y Democracia. ed. Dykinson, Madrid, 2007. Pp.

${ }^{218}$ VEGA, P. de. "Presentación. Op. Cit." Pp. 20.

${ }^{219}$ HERRERO R. DE MIÑON, M. "Los Partidos como Estamentos Privilegiados: Ideas para su Reforma". In: La Democracia Constitucional. Estudios en Homenaje al Prof. Francisco Rubio Llorente. Ed. CEPC, Madrid, 2003. Pp. 201-202 y HERRERO DE MIÑON, M.: El Valor... Pp. 111 y ss. y 216. Suscribo la posición del autor, en el sentido de que era necesario simplificar la complejidad social en la transición política, reduciendo la presión y facilitando la instauración del sistema democrático. Sin embargo, los partidos ya están consolidados, como también la democracia, y por ello es el momento de abrirse al pluralismo político real.
} 


\subsection{Los partidos políticos como canales fundamentales de participación política y su relación con el actual sistema electoral ¿Existen condiciones para que los partidos cumplan esta función?}

La última función prevista en el art. 6º de la Constitución posee íntima correlación tanto con el pluralismo político ${ }^{220}$ como con la democracia representativa, ya que se trata de la participación política a través de representantes. Tampoco se puede ignorar la profunda conexión que dicha función tiene con el artículo 23.1 de la propia Constitución ${ }^{221}$, siendo una manifestación de dicho derecho fundamental. Es la posibilidad de participación en las elecciones a través de los partidos políticos lo que diferencia a los partidos políticos de las demás asociaciones políticas ${ }^{222}$, aunque ellos no sean, en realidad, los únicos canales disponibles de participación política de los ciudadanos, como se ha visto. ${ }^{223}$

Los partidos políticos no son los únicos representantes del pluralismo, ya que en un Estado social y democrático de Derecho también prima el protagonismo de otros entes de la sociedad. Es cierto que la participación a través de los partidos es sólo una vía, ya que en las sociedades modernas también hay un 'pluralismo organizacional'. ${ }^{224}$ Pero lo cierto es que en el actual modelo de Estado de partidos las decisiones jurídico-políticas pasan por ellos, a través del consenso que se forma entre sus componentes.

\footnotetext{
${ }^{220}$ DE ESTEBAN y LÓPEZ GUERRA entienden que los partidos políticos son considerados como canales de participación política por la imposibilidad de los ciudadanos de participar directamente en los asuntos políticos, y también por la imposibilidad de que haya tantas alternativas políticas como ciudadanos. Por ello, hay la representación y también los partidos. (In: ESTEBAN, J. de; LÓPEZ GUERRA, L.: Op. Cit. Pp. 77).

${ }^{221}$ Opinión de NAVARRO MÉNDEZ (In: NAVARRO MENDEZ, J. I.: Op. Cit. Pp. 236).

${ }^{222}$ GRIMM, D. Op. Cit. Pp. 409.

${ }^{223}$ ÁLVAREZ CONDE, E.: El Derecho de Partidos. Op. Cit. Pp. 112. El autor reafirma la opinión común, de que las funciones designadas por la Constitución a los partidos políticos no están cerradas y ni siquiera son exclusivas de los partidos, aunque sean ellos los protagonistas.

${ }^{224}$ RAMÍREZ JIMÉNEZ, M. "Partidos Políticos en España..." Pp. 26. Sin embargo, SORIANO DÍAZ opina que los partidos son el único medio de participación electoral, porque la legislación sobre el tema está totalmente volcadas en ellos. No hay una prohibición formal de presentación de candidaturas fuera de los partidos, pero es un hecho conocido que un candidato independiente no puede hacer mucho si no es a través de un partido, porque carece de apoyo material y técnico para su éxito electoral. (In: SORIANO DÍAZ, R. L. "EI Dominio de los Partidos Políticos: Partidos y Sociedad". In: Revista de Estudios Políticos (nueva época), no 105, jul/sep, 1999. Pp. 267).
} 
Esta función de expresión del pluralismo estaría imposibilitada si no se ofrecieran algunas garantías. Así, se puede decir que el derecho de sufragio universal activo (art. 23.1) permite que todo ciudadano tenga el derecho al voto, la oportunidad de expresar de manera formal su opción política, sin represión, de forma libre y secreta. Dichas condiciones son fundamentales para obtener una expresión genuina por parte de la sociedad, legitimando el resultado de las urnas y reflejando al máximo posible la voluntad del pueblo. Con todo, para que existan dichas condiciones de voto, es crucial respetar el principio de la igualdad, ya que todos los competidores deben encontrarse en condiciones sustanciales de igualdad, tanto ante el proceso democrático, como también en el acceso a los cargos electivos, haciendo a la vez referencia al derecho de sufragio pasivo. Además, es importante resaltar, en este punto, la igualdad debe actuar no solamente entre los aspirantes al cargo representativo, sino también respecto a los propios electores.

Hay también otro enfoque de esta función de los partidos políticos: representan una función activa en las decisiones políticas, por medio de la selección de representantes dentro de una democracia representativa y también a través de la formulación de alternativas de poder, sea componiendo el gobierno elegido por el electorado, sea como oposición para controlar al gobierno de turno. Esta función de ser instrumento de participación política, es pues, además de una función de los partidos, también una "descripción finalista" de los mismos, ya que dicha participación es el fin que los caracteriza (como también a las asociaciones con finalidad política), justificando el régimen jurídico diferenciado y otorgándoles beneficios públicos como son la financiación pública y el acceso a los medios de comunicación. ${ }^{225}$

Esta función de los partidos está relacionada con el derecho fundamental de participación política de los ciudadanos recogido en el artículo 23 de la Constitución Española. Este derecho tiene un significado muy importante no solo para la salud del sistema democrático, sino también como factor de armonía en las relaciones entre Estado y sociedad. ${ }^{226}$ Objeto de

${ }^{225}$ BAUTISTA PLAZA, D.: La Función Constitucional de los Partidos Políticos. Ed. Comares, Granada, 2006. Pp. 15.

${ }^{226}$ En este sentido, es de resaltar que, al tratarse de un derecho fundamental, posee una naturaleza dual, es condición objetiva de la propia democracia (al asegurar la protección de las 
muchas luchas, la participación política fue muchas veces suprimida como manera de bloquear cualquier demanda venida desde el pueblo que pretendiera cambiar el status quo vigente. Así, no fue raro que el derecho de sufragio - principal manifestación de este principio ${ }^{227}$ - tardara en ser introducido en los países occidentales, o que en muchas oportunidades fuera omitido justamente para el sostenimiento de algún régimen totalitario.

El derecho a la participación política en la Constitución se encuentra justamente en la parte de los Derechos Fundamentales, que debido a su importancia también cuenta con la protección especial del art. 168, a partir del procedimiento especial para eventuales reformas constitucionales. Dicha condición atestigua su relevancia para la vigencia de los pilares del Estado democrático. Sin embargo, el art. 23 no debe ser leído aisladamente, ya que el constituyente también eligió conectarlo con el art. 9.2, que trata de la obligatoriedad de los poderes públicos en promover condiciones iguales entre ciudadanos y grupos sociales, reflejando la idea de la igualdad material. El hecho es que el constituyente dejó claro que la vía principal de participación y de hacer efectivo el principio democrático es la participación representativa, no dejando mucho espacio en concreto para las vías de participación directa. Dentro de este principio de participación representativa se incluye el derecho de sufragio universal libre, directo y secreto en los diversos niveles del gobierno, de ahí que, lógicamente, los partidos asuman el protagonismo. ${ }^{228}$

La esencia de dicho derecho es justamente la participación política stricto sensu ${ }^{229}$, el derecho al voto, principal componente en el proceso electoral y portavoz de la voluntad popular. Según el Tribunal Constitucional, el

minorías y el respeto al pluralismo político), y a la vez tiene un perfil subjetivo, alcanzando directamente el sujeto tanto como elector como también como representante electo. (In: GARCÍA ROCA, J.: "Cargos Públicos..." Pp. 102 y ss.).

${ }^{227}$ Conforme declaración del Tribunal Constitucional en la STC 10/1983, de 21 de febrero.

${ }^{228}$ CARRERAS SERRA, F. de. "Derecho de Participación Política". In: ARAGÓN REYES, M. (coord.): Temas Básicos de Derecho Constitucional - Tomo II. Tribunal Constitucional y Derechos Fundamentales. Civitas, Madrid, 2001. Pp. 187-188. El autor alerta de que obviamente, en este artículo, no se da únicamente una interpretación de carácter político, y de que los partidos políticos no son los únicos legitimados para participar en este proceso.

${ }^{229}$ Como es el tema central del presente trabajo, se sugiere la lectura de HUARTE-MENDICOA, A. "Derecho de Sufragio". In: ARAGÓN REYES, M. (coord.): Temas Básicos de Derecho Constitucional - Tomo II. Tribunal Constitucional y Derechos Fundamentales. Civitas, Madrid, 2001. Pp. 190-194, para un panorama general sobre el derecho de sufragio, tanto activo como pasivo, englobando importantes discusiones, como puede ser el derecho de sufragio a extranjeros residentes. 
art. 23.1 trata del sufragio activo de manera exclusiva, que se agota con la elección de los componentes del órgano representativo. ${ }^{230} \mathrm{Sin}$ embargo, también se puede afirmar que dicho artículo es una de las expresiones del pluralismo, ya que es a través del voto como el elector declarará su preferencia electoral, en el intento de elegir a sus representantes, corroborando así las funciones de los partidos. ${ }^{231}$ Por tanto, el art. 23 traduce la obligatoriedad de que el Estado de partidos esté abierto a la recepción de toda y cualquier expresión política venida de la sociedad, estando prohibido su cierre efectivo, directa o indirectamente. ${ }^{232}$

Este derecho fundamental asegura no sólo la participación en los poderes públicos, sino también en las instituciones de interés público, a partir de procesos democráticos libres, transparentes y en igualdad en condiciones tanto entre los competidores políticos como entre para los electores. ${ }^{233}$ Así, la igualdad de condiciones en la competición electoral es la pieza clave para que los partidos puedan constituirse como canales fundamentales para la participación política. En este caso, la igualdad de oportunidades bajo la perspectiva del elector y sus implicaciones en el derecho de sufragio libre es determinante.

La igualdad de oportunidades tiene una natural influencia en el voto y se refiere ante todo al sufragio activo, al derecho de los ciudadanos a declarar cual es su opción política por el medio del voto libre en elecciones periódicas.

\footnotetext{
${ }^{230}$ Cfr. STC 51/1984, de 25 de abril, F.J. 2 y 212/1993, de 28 de junio, F.J. 4. Conforme entendimiento del Tribunal Constitucional en la STC 36/1990, de 1 de marzo. En este sentido, véase FERNÁNDEZ VIVAS, Y.: Op. Cit. Pp. 307 y ss., en que la autora aboga por la ampliación de este derecho. Además, se constituye como un derecho neutro, porque no se verá afectado en caso de cambios en las normas sobre el proceso electoral o el sistema electoral, entre otros, y con un carácter exclusivamente político, por dedicarse solamente a formar la voluntad popular. Por no tener intermediarios, también es un derecho de ejercicio directo, periódico y , más aún porque, debido a su proyección institucional y por constituirse como un elemento importante en el proceso electoral la periodicidad necesaria en la renovación de las instituciones representativas, pide la renovación de dicho derecho dentro de un determinado período de tiempo. En este sentido, cfr. GARCíA GUERRERO, J. L.: Escritos sobre Partidos Políticos (como mejorar la democracia). Ed. Tirant lo Blanch, Valencia, 2007. Pp. 197-198.

${ }^{231}$ Cfr. PRESNO LINERA, M. A.: Los Partidos y las Distorsiones... Pp. 27-28.

${ }^{232}$ Cfr. RODRIGUEZ DIAZ, A.: Transición Política... Pp. 234 y MORLOK, M. "La Regulación Jurídica..." Pp. 49.

${ }^{233}$ Cfr. AGUIAR DE LUQUE, L.; SANCHEZ MORÓN, M. "Artículo 23 - Derecho de Participación". In: ALZAGA VILLAAMIL, O. (Dir.): Comentarios a las Leyes Políticas Constitución Española de 1978. Tomo II, artículos 10 a 23. ed. Edesa, Madrid, 1983. Pp. 661663. Los autores añaden que, por ser un derecho fundamental, también es un parámetro en la interpretación de leyes.
} 
Debido a ello, factores como el sistema electoral y la barrera electoral pueden alterar directamente dichos elementos del sufragio activo, generando desigualdades y "tipos" de voto. ${ }^{234}$ Si hay una discriminación injustificada de los votos, y por consiguiente, de los ciudadanos con derecho al sufragio libre, no solo se vería afectado el derecho de participación política, sino que resultaría también perjudicada la condición obligatoria de igualdad en el resultado de las urnas. ${ }^{235}$ Por ello la elección de un sistema electoral u otro es pieza clave en esta dinámica.

\subsubsection{Breves notas sobre el sistema electoral vigente}

El sistema electoral, por sí solo, tiene un alcance limitado a los efectos de superar la crisis de legitimación política. ${ }^{236}$ En todo caso, como es sabido, es un factor determinante tanto del resultado electoral como del sistema de partidos. ${ }^{237} \mathrm{Y}$ justamente por ello, el sistema electoral es considerado por los partidos con capacidad de orientar la política legislativa como un elemento básico del status quo partidista. ${ }^{238}$ En resumen, hablar de sistema electoral es también hablar de cuestiones de poder, sin que resulten indiferentes elementos como los índices de real proporcionalidad del sistema. ${ }^{239}$

\footnotetext{
${ }^{234}$ FERNÁNDEZ VIVAS, Y.: Op. Cit. Pp. 57-59.

${ }^{235}$ En este sentido, cfr. STC 44/2010, de 26 de julio, F.J. 2.

${ }^{236}$ Cfr. en este sentido: NOHLEN, D. "Reforma del Sistema Electoral Español: Conveniencias, Fórmulas y Efectos Políticos". In: Revista de Estudios Políticos, № 34, jul/ago, ed. Centro de Estudios Constitucionales, 1983. Pp. 62 y; RAE, D.; RAMÍREZ, V.: 15 Años de Experiencia: El Sistema Electoral Español. ed. McGraw-Hill, Madrid, 1993. Pp. 5.

${ }^{237}$ En la definición de NOHLEN, un sistema electoral consiste en los "procedimientos mediante los cuales los electores pueden expresar su opción política en forma de votos, y se pueden transformar votos en escaños, o sea, en representación parlamentaria". (In: NOHLEN, D. "Sistemas Electorales y Tipos de Democracia Representativa". In: AA.VV.: Ley Electoral y Consecuencias Políticas. Ed. CITEP, Madrid, 1977. Pp. 43). Sin embargo, hay autores que consideran que, en un sentido amplio, hay un conjunto de reglas que disciplinan todo el proceso de las elecciones, antes, durante y después. Sin embargo, cuando se habla en sistema electoral, generalmente se refiere a su sentido estricto, o sea, a la fórmula electoral aplicada para convertir votos en escaños que, como es sabido, interactúa con la definición de la circunscripción, el tamaño del órgano y la forma de voto. (In: PEGORARO, L. et al: Diritto Pubblico Comparato. Ed. Giappichelli, Torino, 2004. Pp. 342-343). Como no se trata del objeto central de la presente investigación, expuesto solamente lo necesario para la comprensión del vínculo entre el sistema electoral y el sistema de financiación de partidos.

${ }^{238}$ HEYWOOD, P. "The Electoral and Party Systems". In: The Government and Politics of Spain. Ed. Macmillan Press, London, 1995. Pp. 165.
}

${ }^{239}$ NOHLEN, D. "Sistemas Electorales..."Pp. 46. 
El sistema electoral es utilizado frecuentemente para regular el nivel permitido de fragmentación en el sistema de partidos, aun cuando, como es sabido, la capacidad de los sistemas electorales para "orientar" el comportamiento del elector no deja de resultar el fruto de múltiples variables independientes. En el caso español, se puede entender que el sistema electoral para las Cortes Generales introducido en la transición política provocó cuatro efectos (que fueron en parte los pretendidos en el momento de la elaboración de la normativa inicial ${ }^{240}$ ). Por un lado, ha evitado un alto grado de fragmentación en el sistema de partidos, al tiempo que ha permitido el acceso a las Cortes de partidos de perfil nacionalista. Asimismo, ha favorecido a los dos grandes partidos, facilitando la formación de mayorías, a través de un sistema que favorece un bipartidismo imperfecto y coadyuva a la estabilidad gubernamental. Sin embargo, como es sabido, no ha dejado de producir algunas distorsiones importantes desde el punto de vista de la "representatividad" y el reflejo del pluralismo político, aun cuando, obviamente, no todos estos efectos guarden una relación univoca o directa con el sistema electoral. ${ }^{241}$

Es conocido que el sistema electoral español se caracteriza por su permanencia y continuismo desde la época de la transición política (ya que sus elementos básicos provienen del Decreto-ley 20/1977) ${ }^{242}$, alcanzando un punto

${ }^{240}$ En este sentido, cfr. FERNÁNDEZ-MIRANDA CAMPOAMOR, A. "El Sistema Electoral del Congreso de los Diputados". In: Revista de Derecho Político. oㅜ 52. UNED, Madrid, 2001. Pp. 35.

${ }^{241}$ NOHLEN, D. "Reforma del..." In: Revista de Estudios Políticos, no 34, jul/ago, ed. Centro de Estudios Constitucionales, 1983. Pp. 64-65. PALLARÉS PORTA, F. "Sistema Electoral y Sistema de Partidos". In: PAU I VALL, F. (coord.): Parlamento y Sistema Electoral - VI Jornadas de la Asociación Española de Letrados de Parlamentos. ed. Aranzadi, Pamplona, 1999. Pp. 63-65. El autor cita cuatro aspectos que deben ser considerados en un sistema electoral, que son la circunscripción electoral; el tipo de voto; la fórmula electoral; y la barrera mínima o umbral. A partir de ello, el autor considera que un análisis de los sistemas electorales debe de tener en cuenta ante todo por su tendencia, no solo sus efectos mecánicos, ya que en cada uno de estos elementos se pueden agregar incentivos y penalizaciones, que acaban por alterar los demás factores reforzando efectos o produciendo directamente un efecto contrario y limitando resultados antes automáticos para algunos de ellos.

${ }^{242}$ En la II República, la circunscripción electoral ya había sido fijada como provincial, salvo en el caso de grandes ciudades que formaban circunscripciones propias. Este es uno de los rasgos que han permanecido en el tiempo hasta los días de hoy. (In: OLIVER ARAUJO, J.: EI Sistema Político de la Constitución Española de 1931. ed. Universitat de les Isles Balears, Palma, 1991. Pp. 130-131). Además, como es sabido, la regla de la Reforma Política fue transferida al Decreto-Ley 20/1977. (In: FERNÁNDEZ-MIRANDA CAMPOAMOR, A. "EI Sistema Electoral..." Pp. 29). Lo que quizás resulte más cuestionable es su continuidad material hasta nuestros días. 
en que los rasgos principales de este modelo no fueron modificados en relación a las reglas generales, y cuyas características pasaron a su vez de forma lenta pero gradual a las leyes electorales autonómicas, produciendo una importante homogeneidad en los distintos niveles territoriales. ${ }^{243}$

Se puede decir que una de las funciones del sistema electoral es garantizar la igualdad del sufragio, para que todos los ciudadanos puedan influir en las decisiones políticas de manera igual. No obstante los "correctores" compuestos por la fórmula electoral afectan justamente a este punto, modulando fuertemente el resultado de las elecciones. ${ }^{244}$ En este punto está ubicada España.

En la época de la transición, existía una preocupación considerable en torno a la estabilidad gubernamental. ${ }^{245}$ Esto condicionó que se optara por un

${ }^{243}$ Cfr. GAVARA DE CARA, J. C. "La Distribución de Competencias en Materia Electoral en el Estado de las Autonomías". In: Cuadernos de Derecho Público. oㅡ 22-23. dic. Madrid, 2004. Pp. 18. Sobre los sistemas electorales autonómicos, véase Cap. III.

${ }^{244}$ SANCHEZ MUÑOZ, O. "Sistema Electoral y Principio de Igualdad del Sufragio". In: PAU I VALL, F. (coord.): Parlamento y Sistema Electoral - VI Jornadas de la Asociación Española de Letrados de Parlamentos. ed. Aranzadi, Pamplona, 1999. Pp. 491-496. El autor conceptúa igualdad de voto como "exigencia de igual eficacia potencial del sufragio de cada elector en orden a la designación de los titulares de los mandatos electivos". (In: SANCHEZ MUÑOZ, O. Sistema Electoral... Pp. 493). Con todo, FERNÁNDEZ-MIRANDA CAMPOAMOR afirma que el principio de proporcionalidad - que atiende al estricto reparto de escaños en la proporción del apoyo recibido por la sociedad - no puede ser, en ningún caso, aplicado en su formulación ideal. Primero, por el tamaño de la cámara, lo que por sí sola ya es un obstáculo al pluralismo, y también por la territorialización de los mecanismos de selección de los representantes. Este último incrementa per se los restos y la pérdida de votos. Por último, la proporcionalidad perfecta, según el autor, exigiría un colegio electoral único. (In: FERNÁNDEZ-MIRANDA CAMPOAMOR, A. "El Sistema Electoral..." Pp. 22).

${ }^{245}$ PALLARÉS PORTA narra que, durante las negociaciones en la transición, Suárez acepta el criterio proporcional, pero también introduce mecanismos de corrección para las inmediatas elecciones, con clara intención partidista - algo que realmente ocurrió - bajo el argumento de que había un interés colectivo en la reducción del número de fuerzas políticas, y por consiguiente, en la disminución de las posibilidades de fragmentación, que dificultaría la consolidación del sistema político recién instaurado. El mecanismo corrector clave de todo esto es la circunscripción provincial, que forzosamente tiene pocos escaños en muchas de ellas y, con ello, acaba por limitar los efectos proporcionales de la fórmula D'Hondt para la distribución de escaños, favoreciendo a las dos fuerzas mayoritarias especialmente a la ganadora a nivel de circunscripciones. Por ello, UCD, PSOE y los nacionalistas catalanes y vascos apoyaron la constitucionalización de este tipo de circunscripciones. (In: PALLARÉS PORTA, F. Op. Cit. Pp. 74). GARROTE DE MARCOS también narra la accidentada tramitación del art. 68 de la Constitución Española, ya que en el momento de su elaboración, más específicamente en el anteproyecto, no había referencia al sistema electoral, por considerar que era una materia de competencia del legislador. Sin embargo, la oposición acabó por forzar una confrontación abierta a fin de aplazar el debate hasta la aprobación del resto del texto constitucional. Cuando se retomaron los debates sobre dicho artículo, los grupos parlamentarios acabaron por formalizar un acuerdo donde se recogían básicamente los criterios establecidos en la ley para la Reforma Política, siendo esta redacción aprobada por amplio margen de votos. (In: GARROTE DE MARCOS, M. "El Informe del Consejo de Estado sobre Reforma del Sistema Electoral: Algunas Observaciones Acerca de las Posibilidades de Reforma del Sistema 
sistema electoral que privilegiara la estabilidad política en lugar de una posible futura fragmentación parlamentaria. De esta manera, se pensó en un sistema electoral para formar la composición del Congreso de los Diputados ${ }^{246}$ a partir de un modelo proporcional, con reparto de escaños a partir de la fórmula D’Hondt en circunscripciones electorales de pequeño tamaño ${ }^{247}$, indicado para dar estabilidad a nuevas democracias. ${ }^{248}$ Con la fórmula, también se adoptó un umbral del tres por ciento. ${ }^{249}$ Además de ello, para la forma de voto, se adoptaron listas cerradas y bloqueadas a fin de fortalecer a los incipientes partidos políticos, y la previsión de un mínimo de dos escaños por circunscripción. ${ }^{250}$ La designación de la provincia como circunscripción electoral fue muy criticada en un principio por la primacía de la representación territorial sobre el principio de proporcionalidad. Con todo, se observaban puntos positivos, como el aprovechamiento de la división administrativa y de la estructura burocrática en la organización electoral, así como el hecho de que emana un cierto perfil de neutralidad en el momento de determinar los distritos

Electoral del Congreso de los Diputados". In: Cuadernos de Derecho Público. ํㅜ 36. ene-abr. Madrid, 2009. Pp. 98-99). En realidad está claro que el debate comenzó con la tramitación de la Ley para la Reforma Política.

${ }^{246}$ No nos referimos aquí al sistema aplicado en el Senado por su escaso impacto en la financiación de los partidos políticos, y dado que dentro del propio sistema de financiación también hay discriminación con el Senado.

${ }^{247}$ Para la discusión sobre otras alternativas vid. Informaciones del Informe del Consejo de Estado para la Reforma de la LOREG. Disponible en: http://www.consejoestado.es/pdf/REGIMEN-ELECTORAL.pdf <<Acceso en 05/10/2011 >> Pp. 149.

${ }^{248}$ De hecho, la decisión sobre la circunscripción electoral fue una de las más complejas en el momento de redactar la Ley para la Reforma Política, que debería obedecer a alguna entidad administrativa a fin de prevenir su manipulación arbitraria, debiendo también ser plurinominal. (In: FERNÁNDEZ-MIRANDA CAMPOAMOR, A. "El Sistema Electoral..." del Congreso de los Diputados. In: Revista de Derecho Político. no 52. UNED, Madrid, 2001. Pp. 29-30).

${ }^{249}$ Aunque la cuestión fuera bastante debatida en su época, NOHLEN aportó algunas sugerencias a España antes de que ésta eligiera el sistema electoral que deseaba. Las sugerencias consistían en: 1 ) evitar que el sistema electoral se convirtiera en un instrumento para el ejercicio de poder (algo que en mi opinión tuvo un éxito relativo frente al status quo que surgió en las primeras elecciones); 2) el sistema debía basarse en el consenso de la mayoría de los grupos políticos (como efectivamente pasó); 3) debía reconocer estructuras sociales, técnicas, regionales, junto con los partidos; 4 ) debía ser un sistema sencillo y comprensible; 5) las circunscripciones y demás factores que influyen en el sistema no debían ser elaborados de forma artificial; 6) se sugería un Parlamento eficiente y operativo; 7) el sistema electoral debía facilitar la relación existente entre los partidos; 8) debería fomentar la participación política. (In: NOHLEN, D. "Sistemas Electorales..." Pp. 56-57). Como veremos, no todas las sugerencias fueron tenidas en cuenta.

${ }^{250}$ Cfr. art. 161 y ss. de la LOREG. 
electorales, alejando posibles sospechas en torno a la manipulación de límites, como podría ser el gerrymandering. ${ }^{251}$

Aparentemente, algunos factores fueron considerados de relativa importancia ${ }^{252}$ en la época, como pueden ser los efectos de la fórmula D’Hondt en circunscripciones pequeñas. ${ }^{253}$ A medida que se disminuye el tamaño de las circunscripciones, la ventaja de los grandes partidos aumenta de manera importante ${ }^{254}$, ya que los votos perdidos acaban por actuar en contra a los partidos más débiles en el sistema. ${ }^{255}$ Ello también desincentiva la creación de grupos disidentes autónomos, porque con este sistema, los partidos pequeños resultan claramente desfavorecidos. ${ }^{256}$ Se verifica, pues, como es sabido, que hay un sistema representativo de baja intensidad (o magnitud). ${ }^{257}$

${ }^{251}$ Cfr. JIMENEZ DE CISNEROS CID, F. J.: Ley Electoral. Imprenta Nacional, Madrid, 1983. Pp. 48. Un resumen de las causas de la elección del sistema electoral en los tiempos de la transición, junto con las disposiciones constitucionales de la época, cfr. HERRERO DE MIÑON, M.: El Valor... Pp. 1-12, en que el autor narra que se fijaron las circunscripciones electorales, sin borrador, y el sistema proporcional para el Congreso, "confusamente apuntado en el proyecto de Ley Básica por vía de disposición transitoria", y el sistema mayoritario para el Senado, permitiendo la elaboración de la normativa electoral. Vid. también en este punto BAR, A. "The Emerging Spanish Party System: Is there a Model?" In: BARTOLINI, S.; MAIR, P. (ed.): Party Politics in Contemporary Western Europe. Ed. Frank Cass, Great Britain, 1984. Pp. 138139.

${ }^{252}$ De hecho no se puede afirmar que realmente se desconociera el tema, toda vez que en la exposición de motivos del Decreto-Ley 20/1977 que "esta misma regla [a partir de la regla D'Hondt] ya supone un poderoso corrector del excesivo fraccionamiento de las representaciones parlamentarias".

${ }^{253}$ Aunque en la época de la aprobación de la LOREG se cuestiona la fórmula D'Hondt, las propuestas que existieron de sustituir dicho sistema de cocientes sucesivos por otro de restos mayores que se basaban en el cálculo de la cuota electoral (propuesta esta cuya autoría correspondía a los grupos parlamentarios menos representados) no prosperó debido al apoyo de los principales partidos a la regla D'Hondt. (Informaciones del Informe del Consejo de Estado para la Reforma de la LOREG. Disponible en: http://www.consejoestado.es/pdf/REGIMEN-ELECTORAL.pdf <<Acceso en 05/10/2011 >> Aún, en la página 155 y Ss. del informe, hay algunas de las propuestas para la reforma de dicho punto.

${ }^{254}$ En este sentido, cfr. FERNÁNDEZ-MIRANDA CAMPOAMOR, A. "El Sistema Electoral..." Pp. 25-26.

${ }^{255}$ RAE, D.; RAMÍREZ, V.: Op. Cit. Pp. 30. PRESNO LINERA también aborda este problema, afirmando que la desproporcionalidad entre votos emitidos en Madrid y Barcelona en comparación con Soria es bastante considerable, pues además de distorsionar la representatividad que hay entre Madrid (34 escaños) y Soria (3 escaños), hay un escaño en Madrid por cada 127.000 habitantes, y uno escaño en Soria por cada 26.500 habitantes, provocando un peso diferente de los votos, que deberían ser iguales. Y valga este ejemplo como una de las distorsiones que la combinación de las reglas del sistema electoral español causa en la práctica. (cfr. PRESNO LINERA, M. A. "Participación Política y Cuerpo Electoral". In: AA.VV.: Derecho Constitucional para el Siglo XXI - Actas del VIII Congreso Iberoamericano de Derecho Constitucional, Tomo II. Ed. Thompson - Aranzadi, Sevilla, 2006. Pp. 2707).

${ }^{256}$ RAE, D.; RAMíREZ, V.: Op. Cit. Pp. 35.

${ }^{257}$ RAE, D.; RAMÍREZ, V.: Op. Cit. Pp. 10. Esta evidencia también fue citada en el Informe del Consejo de Estado para la Reforma de la LOREG. Disponible en: http://www.consejoestado.es/pdf/REGIMEN-ELECTORAL.pdf. 
El sistema, que se integra básicamente en la LOREG, se prolongó en el tiempo y los efectos distorsionadores generaron algunos problemas que actualmente resultan más llamativos. ${ }^{258}$ Así, la combinación de la fórmula D'Hondt con otros elementos del sistema electoral, principalmente con el tamaño de la circunscripción electoral ${ }^{259}$, hace que éste produzca un resultado escasamente proporcional, habiendo una corrección demasiado fuerte en las circunscripciones menores y provocando un gran sesgo mayoritario. $Y$ no por casualidad, parte de la doctrina y la de opinión pública entienden que en España el pluralismo político no encuentra el reflejo en el sistema de partidos que sería deseable, considerando al sistema español como un sistema electoral proporcional de representación, con tendencia mayoritaria que penaliza a los partidos con base territorial difusa. ${ }^{260}$ De hecho, el propio Consejo de Estado, al elaborar el informe para el estudio de una posible reforma a la LOREG, entiende que el actual sistema "no atiende a los criterios de representación proporcional constitucionalmente previstos", siendo, por lo tanto, cuestionable. ${ }^{261}$

El escenario empeora al conectar el sistema de financiación de los partidos con el electoral (como se verá con mayor detalle), causando dificultades para la supervivencia de algunos partidos que, en realidad, no carecen de apoyo electoral, pero que se ven afectados por el sistema

\footnotetext{
${ }^{258}$ Cfr. FERNANDEZ-MIRANDA CAMPOAMOR, A "Sobre la Reforma Electoral". In: AA.VV.: EI Informe del Consejo de Estado sobre la Reforma Electoral. CEPC, Madrid, 2009. Pp. 703.

${ }^{259}$ En este sentido, cfr. FERNÁNDEZ-MIRANDA CAMPOAMOR, A. "El Sistema Electoral..." del Congreso de los Diputados. In: Revista de Derecho Político. oㅜ 52. UNED, Madrid, 2001. Pp. 39. ${ }^{260}$ Cfr. PALlaRÉS PORTA, F. Op. Cit. Pp. 67. Para entender las distorsiones entre la existencia de sobrerrepresentación de las áreas rurales y la infrarrepresentación de las ciudades más pobladas, traducidas en diferencia de sufragio, cfr. SANCHEZ MUÑOZ, O. "Sistema Electoral..." Pp. 523-524. Aún, cfr. HOPKIN, J. "From Consensus..." Pp. 8, en que el autor aborda sobre la clasificación dada supra al sistema electoral en España, justificando su punto de vista.

${ }^{261}$ Hay voces que abogan por la inconstitucionalidad de esta condición. Así, véase para un análisis general: http://www.consejo-estado.es/pdf/REGIMEN-ELECTORAL.pdf. Pp. 155; ya como crítica directa, cfr. SANTAOLALLA LÓPEZ, F. "Comentario a la Reforma Electoral Propuesta por el Consejo de Estado". In: Revista de las Cortes Generales, oㅡ 77, 2o cuatrimestre, Madrid, 2009. Pp. 78 y BASTIDA FREIJEDO, F. J. "Proporcionalidad Inversa en la Representación e Inconstitucionalidad de la Ley Orgánica del Régimen Electoral General. Propuesta para una Reforma". In: AA.VV.: El Informe del Consejo de Estado sobre la Reforma Electoral. CEPC, Madrid, 2009. Pp. 711-712. En contra de dicha tese, cfr. FERNANDEZMIRANDA CAMPOAMOR, A. "Sobre la Reforma..." Pp. 690-691.
} 
electoral. ${ }^{262}$ Con la concentración de escaños en los partidos mayoritarios, también se provoca una concentración en la financiación pública y, consecuentemente, se dificulta la permanencia de los partidos minoritarios de ámbito nacional. ${ }^{263}$ La fuerte reducción del pluralismo partidista viene pues así muy incentivada, aunque no solo como consecuencia de la combinación del sistema electoral con el sistema de financiación pública, ya que éste adopta el doble criterio de escaños y votos para el acceso a las subvenciones públicas. ${ }^{264}$

262 RAMÓN MONTERO, J. "El Debate sobre el Sistema Electoral: rendimientos, Criterios y Propuestas de Reforma". In: Revista de Estudios Políticos, oㅡ 87, ene/mar, ed. Centro de Estudios Constitucionales, 1995. Pp. 12. También como fuente de investigación, que trae un análisis detallado del sistema, véase: el informe para la reforma del sistema electoral elaborado por el Consejo de Estado en 2009 (In: http://www.consejo-estado.es/pdf/REGIMENELECTORAL.pdf), Pp. 143-211, donde hay un buen análisis general de los problemas causados por este sistema electoral, no solamente la vulneración de la igualdad de sufragio y la diferencia de representación en la distribución de escaños entre las circunscripciones, sino también el propio sistema de listas de candidatos, que impide la libre elección de los votantes.

${ }^{263}$ RODRIGUEZ DIAZ, A.: Transición Política... Pp. 131-132. Debido a ello, el autor juzga que el sistema detiene en la práctica un bipartidismo

${ }^{264}$ Esto fue lo que pasó en las primeras elecciones, ya que permitió que UCD hiciera un gobierno de partido, consolidando parte del modelo postransición. Sin embargo, aunque contribuyera a la estabilidad del sistema, también ayudó a extinguir muchos partidos pequeños, como fue el caso de FDC-EDC (Equipo de la Democracia Cristiana), que acabó por sucumbir después de las elecciones de 1977 sin lograr escaños; y el PSP (de Tierno Galván) que prefirió coligarse con el PSOE en el lugar de arriesgarse a la suerte de un partido minoritario y encima endeudado. (In: GUNTHER, R.; RAMÓN MONTERO, J.; BOTELLA, J.: Democracy in Modern Spain. Ed. Yale University Press, USA, 2004. Pp. 92). En todos estos años de aplicación del modelo de financiación, Izquierda Unida ha sido el partido más perjudicado, y esto se debe a dos factores: porque el partido actúa a nivel nacional, no teniendo características regionales (por lo tanto, siendo perjudicado por el sistema electoral); y segundo porque, a partir de su desplome electoral, automáticamente notó el impacto en sus finanzas, que tras cada proceso electoral disminuyen significativamente en comparación con los demás partidos, siendo un ejemplo las elecciones de 2008. Aunque cuente con una cantidad significativa de votos, Izquierda Unida logra cada vez menos escaños, y esta situación agravaba por el cambio en el comportamiento político de los electores, que en vez de mantener su voto para la opción política con la que más se identifican - como podría ser el caso de Izquierda Unida - acaban por votar a otro partido (generalmente el Partido Socialista Obrero Español), debido a un comportamiento de "voto útil". Considerando los datos de 2008, el impacto sobre la financiación a Izquierda Unida fue inmediato. Con la fuerte reducción de escaños en el Congreso, el partido no logró formar un grupo parlamentario en las elecciones de 2008, lo que le hizo también perder la financiación debida a título de mailing. Además, el partido contaba en la época con una deuda cerca de 12 millones de euros, los cuales se suponía que serían pagados a partir del reembolso electoral. En las declaraciones efectuadas en los debates sobre la nueva ley de financiación de partidos, la cúpula del partido dejó claro que, a su juicio, el problema del vínculo del acceso a los recursos públicos a partir del éxito electoral estaba comprometiendo la existencia misma de la organización. (Cfr. IU se aprieta el cinturón. El País. 28 de abril de 2008; y BOCG, no 114, de 27 de septiembre de 2005, pp. 5748-5479.). El proceso normal en que los partidos que no logran cubrir sus gastos electorales con las subvenciones a título de reembolso tienden a desaparecer de la competición, en este sentido, cfr. GAVARA DE CARA, J. C. "La Financiación Electoral en el Ámbito Autonómico". In: GÁLVEZ MUÑOZ, L. A. (Dir.): El Derecho Electoral de las Comunidades Autónomas. Revisión y Mejora. Cuadernos y Debates, Centro de Estudios Constitucionales, Madrid, 2009. Pp. 273. 
Por otra parte está comprobado que los partidos de perfil territorial delimitado tienen significativas ventajas en la combinación de la fórmula electoral con la circunscripción electoral del tamaño de las circunscripciones. Esto no solo perjudica a los partidos con electorado disperso ${ }^{265}$, sino que también ha producido en ocasiones, como es sabido, y frente a las iniciales previsiones, la estabilidad del gobierno dependa del comportamiento de los partidos nacionalistas, y la falta de cultura política basada en coaliciones hace que los acuerdos políticos hechos entre el gobierno y estos partidos no sean del todo transparentes, o que pueda acusárseles de ello. ${ }^{266}$ Hay autores que afirman que este efecto no deriva exactamente de que los partidos nacionalistas o regionalistas estén sobre-representados ${ }^{267}$, pero sí de que los partidos no mayoritarios de ámbito nacional estén infra-representados, porque una parte del apoyo electoral que los partidos nacionales pero con electorado difuso reciben resulta directamente "esterilizada" por la dinámica del sistema. ${ }^{268}$

Además, no se pueden ignorar los efectos del sistema electoral en el comportamiento político de los ciudadanos, la cuestión del llamado "voto útil". ${ }^{269}$ Tal y como está estructurado el sistema, se fomenta notablemente un

\footnotetext{
${ }^{265}$ Véase entendimiento de GAVARA DE CARA en: AA.VV. "Encuesta: Régimen Electoral". In: Teoría y Realidad Constitucional. oㅡ 22, 2osemestre. UNED, Madrid, 2008. Pp. 26-27.

${ }^{266}$ Esta es la opinión de DELGADO-IRIBARREN. Así, Cfr. AA.VV. "Encuesta: Régimen Electoral. Op. Cit." Pp. 18.

${ }^{267}$ En opinión de TORRES DEL MORAL, no hay sobrerrepresentación, pues estos partidos han logrado un apoyo electoral tan fuerte como los partidos a nivel nacional en sus respectivos ámbitos electorales. (In: TORRES DEL MORAL, A. "Sistemas Electorales y Sistemas de Partidos en las Comunidades Autónomas". In: GÁLVEZ MUÑOZ, L. A. (Dir.): El Derecho Electoral de las Comunidades Autónomas. Revisión y Mejora. Cuadernos y Debates, Centro de Estudios Constitucionales, Madrid, 2009. Pp. 219).

${ }^{268}$ En este sentido, véase MARTINEZ SOSPEDRA, M.; URIBE OTALORA, A. "La Reforma del Sistema Electoral Español: la Elección del Congreso de los Diputados a Examen. Diversas Soluciones para un Mismo Problema". In: Revista de las Cortes Generales, ํo 74, 2o cuatrimestre, Madrid, 2008. Pp. 55 y; RAMÍREZ GONZÁLEZ, V.; MÁRQUEZ GARCÍA, A. A. Un "Sistema Electoral Ecuánime para el Congreso de los Diputados". In: Revista Española de Ciencia Política. no 24, diciembre, 2010. Pp. 140.

${ }^{269}$ MANUEL ABELLÁN, A. "Problemas Representativos y Participación de los Ciudadanos: La Democratización de los Partidos Políticos y la Perspectiva Electoral". In: ASENSI SABATER, José (coord.): Ciudadanos e Instituciones en el Constitucionalismo Actual. Ed. Tirant Lo Blanch, Valencia, 1997. Pp. 302-303 y; GUNTHER, R.; RAMÓN MONTERO, J.; BOTELLA, J.: Op. Cit. Pp. 256-257. En este caso, el voto útil sería fruto de las percepciones e incentivos de los votantes frente a ese sistema, alterando el sistema de partidos. Hace incluso que los pequeños partidos se unan con los grandes y pidan el voto para éstos, mientras que los grandes utilizan el argumento de no desperdiciar el voto.
} 
comportamiento de esta naturaleza ${ }^{270}$, como ocurrió con Izquierda Unida y UPyD en las elecciones de 2008. Este comportamiento es adoptado por aquellos electores que no desean "desperdiciar" su voto en opciones políticas que consideran que no tienen verdaderas oportunidades de victoria en las urnas, por más que se identifiquen con ellas. ${ }^{271}$

Entre las elecciones de 1996 a 2008, Izquierda Unida, pasó de 2.640 .000 votantes (aproximadamente $11 \%$ de votos en sus candidaturas) y 21 escaños en el Congreso de los Diputados, a 970.000 votos y 2 escaños, lo que representa una pérdida de 2 de cada 3 votantes, y del $90 \%$ de sus diputados. ${ }^{272}$ En este caso, se puede suponer que el Partido Socialista Obrero Español heredó los votos de Izquierda Unida. La razón para esta posible migración de votos puede ser tanto las propias previsiones sobre la caída de sus resultados, o el rechazo al Partido Popular, o también la tendencia de los electores de Izquierda Unida a la abstención, lo que se explicaría por la falta de identificación partidista con los partidos existentes, por el sentimiento de impotencia en la posibilidad de introducir cambios a través del voto, ahora que los electores están más enterados del funcionamiento del sistema electoral, o por los errores de la propia IU, hipótesis que no puede ser ignorada. ${ }^{273}$

270 Cfr. VERGE, T. "Las Estrategias de los Partidos Políticos Españoles hacia las Organizaciones Sociales". In: Revista Internacional de Sociología. vol. LXL. № 48, sep/dic, 2007. Pp. 100 y ss.

${ }^{271}$ La ideología es utilizada por los electores como una manera de diferenciación entre varias opciones similares. Ellos consideran la ideología útil porque les ayuda a ver las diferencias entre los partidos, y también porque la ideología muchas veces condiciona el comportamiento de los partidos una vez han accedido al poder. Sin embargo, en un sistema donde las ideologías son cada vez más difusas en su sentido tradicional y la concentración de los partidos se da en el centro de la escala izquierda-derecha (como ocurre actualmente), los electores no logran ver las diferencias existentes entre ellos, lo que influye en el comportamiento electoral. Ahora bien, en la situación inversa, donde existe una cierta polarización entre los dos principales partidos, los electores sienten la obligación de votar por el hecho de que en caso de abstención, puede ser que el partido que no les gusta venza en las urnas. Así, hay una elección del mejor de los dos, o del "menos peor", siendo este un comportamiento estratégico. (In: DOWNS, A.: An Economic Theory of Democracy. ed. Harper \& Row, NY, 1957. Pp. 98-119). Desde el enfoque desde la economía política y la teoría del la rational choice, cfr. RIKER, W. H.; ORDESHOOK, P. C. A "Theory of the Calculus of Voting". In: American Political Science Review. no 1. vol. 62, mar/apr, ed. APSA, Washington, 1968. Pp. 2542. Sobre el voto útil, cfr. GARCIA VIÑUELA, E.; ARTÉS, J. "Una Estimación del Voto Estratégico de Izquierda Unida al Partido Socialista en las Elecciones Generales del Período 2000-2008". In: Revista Española de Investigaciones Sociológicas - REIS, № 128, oct/dic, CIS, Madrid, 2009. Pp. 37. También hay otra versión de este artículo en los anales del XVI encuentro de economía pública (5 y 6 de febrero), Palacio de Congresos de Granada, 2009.

${ }^{272}$ Fuente de datos: GARCIA VIÑUELA, E.; ARTÉS, J. "Una Estimación..." Pp. 37.

${ }^{273}$ GARCIA VIÑUELA, E.; ARTÉS, J. "Una Estimación..." Pp. 49-50. Sobre las razones para la abstención, véase NOHLEN, D. "Reforma del..." Pp. 66, donde el autor expone que no hay 
Ya en las elecciones de 2011, a partir del rechazo al gobierno del Partido Socialista Obrero Español, la victoria del Partido Popular en las urnas fue bastante significativa, y hubo un aumento en el número de votos tanto para Izquierda Unida como para UPyD, consiguiendo respectivamente $1.680 .810 \mathrm{y}$ 1.140.242 de votos y logrando 11 y 5 escaños. Sin embargo, tanto Izquierda Unida como UPyD han alcanzado un número superior de votos a los de Convergencia i Unió (con 1.014.263 de votos), y aún así, esta organización aún así ha logrado más escaños que aquéllas, un total de $16 .{ }^{274}$ No es extraño pues que se entienda la sensación de inmovilidad del sistema de partidos entre los electores. ${ }^{275}$

Como no podría ser de otra forma, la doctrina ha sido mayoritariamente crítica hacia el sistema electoral como un todo. Se destaca el efecto fuertemente mayoritario a partir de la fórmula D'Hondt en las circunscripciones pequeñas con su coste en términos de representatividad, aunque esto tienda a la consolidación de una gobernabilidad, ${ }^{276} \mathrm{y}$ que a veces tiene que construirse

manera de explicar a los electores que en el sistema electoral actualmente vigente en España la fuerza política más votada puede ser la primera derrotada.

${ }^{274}$ Se resalte que AMAIUR ha logrado solamente 333.628 votos, pero ha logrado 11 escaños, mucho por de arriba de UPyD, con el triple de votos. Se trata de una organización concentrada en el País Vasco y Navarra, y por ello se atribuye su éxito en las urnas. (fuente: http://elecciones.mir.es/resultadosgenerales2011/99CG/DCG99999TO_L1.htm).

${ }^{275}$ CARRERAS SERRA, Francesc de. Los Partidos en Nuestra Democracia de Partidos. In: Revista Española de Derecho Constitucional, año 24, oㅜ 70, ene/abr, 2004. Pp. 81. En línea con el autor, BLANCO VALDÉS comenta los resultados considerados sorprendentes de las elecciones de 3 de marzo de 1996, afirmando que tanto especialistas como también líderes políticos juzgan que la principal ventaja del sistema electoral utilizado para las elecciones en el Congreso de los Diputados es la funcionalidad que posee para la sólida formación de mayorías parlamentarias y consecuentemente el mantenimiento de gobiernos significativamente estables. Sin embargo, se apunta que ese mismo sistema tiene entre otras desventajas la intensidad de sus efectos desproporcionales, haciendo que en España exista uno de los sistemas más desproporcionales de Europa, llegando al punto de que, aunque se adopten características proporcionales para la representación, se aproxima bastante a los sistemas mayoritarios. Por ello se pide tanto la reforma de dicho sistema. (In: BLANCO VALDÉS, R. L. "¿Reformar el Sistema Electoral o Reformar a los Partidos?" In: RUIZ-RICO, G.; GAMBINO, S. (coord.): Formas de Gobierno y Sistemas Electorales (la Experiencia Italiana y Española). Ed. Tirant lo Blanch, Valencia, 1997. Pp. 231-233). Para otras críticas sobre el sistema electoral, cfr. SORIANO, R.; ALARCÓN, Carlos. "Las Elecciones en España: ¿Votos Iguales y Libres?" In: Revista de Estudios Políticos (nueva época), no 114, oct/dic, 2001. Pp. 119. Vid. también TORRES DEL MORAL, A. "El Estado Español de Partidos". In: Revista del Centro de Estudios Constitucionales, oํ 8, ene/abr, 1991. Pp. 101 y ss. Aún en este sentido, cfr. PRESNO LINERA, M. A. "Participación Política..." Pp. 2713.

${ }^{276}$ CARRERAS SERRA, F. de. "Los Partidos en Nuestra..." Pp. 114-117. Debido a ello, el autor entiende que, con las consecuencias actuales provocadas por el sistema, comportamientos políticos de la sociedad no permiten cambios bruscos a corto plazo, como sería el caso de la aplicación de listas abiertas. En relación a esto, SANTOLAYA MACHETTI entiende que el 
a través de partidos de perfil nacionalista, siendo estas organizaciones los socios más comunes del gobierno.

Con todo, aunque las críticas sean mayoritarias, el Tribunal Constitucional ha dejado claro que no hay sistema proporcionales puros, aunque admita la existencia de problemas provocados por la fórmula electoral D’Hondt. Además, considera que las ventajas obtenidas por los grandes partidos no son mayores que las concedidas por otras fórmulas. ${ }^{277}$ Sin embargo, se nota la ausencia de jurisprudencia constitucional sobre la adecuación del principio de la igualdad de sufragio en el reparto de escaños entre las circunscripciones en las elecciones para el Congreso de los Diputados. Existe sin embargo algunos pronunciamientos sobre el efecto proporcional y la representación en el ámbito del derecho electoral autonómico, que, aunque de manera indirecta, siguiera algunas líneas jurisprudenciales más o menos consolidadas. $^{278}$

En la STC 193/1989, de 16 de noviembre, fundamento jurídico 4, el Tribunal analiza si hubo realmente algún elemento discriminatorio en el reparto de escaños en la Asamblea Regional de Murcia, que acabó por dejar al Partido Cantonal sin ningún escaño, aunque hubiera obtenido más votos en una de las circunscripciones que los tres últimos Diputados del PSOE, que los tres últimos Diputados de AP y que el único Diputado del CDS. Y todo porque no obtuvo el mínimo para traspasar la barrera electoral de cinco por ciento de los votos válidos. No se discutirá aquí los detalles pormenorizados del caso, lo que se resaltará es que, lógicamente, el Tribunal Constitucional considera que, para que haya discriminación, para que exista una violación de la igualdad formal, la regla diferenciadora debe carecer de una razón objetiva y coherente, algo que

problema no está en la forma que se reparten los escaños, sino dónde se reparten, o sea, en la circunscripción. (In: AA.VV. "Encuesta: Régimen Electoral. Op. Cit." Pp. 28).

${ }^{277}$ FERNÁNDEZ VIVAS, Y.: Op. Cit. Pp. 460. Como ejemplo de la línea constante en esta materia del Tribunal Constitucional, cfr. STC 4/1992 de 13 de enero, decisión en que el Tribunal reafirma su jurisprudencia en el sentido de que "una proporcionalidad estricta es algo difícil de alcanzar en toda representación, y tanto más cuanto más reducido sea el número de representantes a elegir o el colegio a designar". (F.J. 2).

${ }^{278}$ Aquí cabe la observación de que a nivel autonómico, los criterios pueden ser diferenciados, dependiendo de la comunidad autónoma analizada. Así, los casos de las Islas Baleares, Murcia y Canarias son los que más despiertan el interés en el momento de evaluar un eventual fallo en la atención a la proporcionalidad, justamente por las peculiaridades de sus reglas electorales. 
se analiza caso a caso. ${ }^{279}$ En este caso específico, aunque el Tribunal afirme que "no puede negarse, como se dijo, que la Ley Electoral Murciana contenga un tratamiento desigual”, el Tribunal siguió fundamentación de la condición evidente de que la "desigualdad sólo podría considerarse discriminatoria, y por ello lesiva del art. 23.2 de la Constitución, si careciera de una justificación objetiva y razonable". 280 .

Como base de la argumentación, el Tribunal Constitucional utiliza la decisión STC 75/1985 de 21 de junio, fundamento jurídico 4, de que "La comparación es inviable, pues nos encontramos ante magnitudes cualitativamente diversas: En un caso el total de los votos conseguidos por unas ciertas candidaturas (las excluidas del reparto de escaños), en el otro caso, uno o varios cocientes, que no son, y aquí está la diferencia esencial, votos efectivamente obtenidos, sino más bien resultados convencionales deducidos, a efectos del reparto, del número total de votos de cada candidatura". Además, sobre la proporcionalidad, el Tribunal ha entendido que no comporta una correspondencia directa entre el número de votos obtenidos y el número de escaños (F.J. 5). Al final, el Tribunal entiende (para este y otros casos), que no hay discriminación porque la fórmula electoral fue aplicada por igual a todas las fuerzas políticas competidoras, no existiendo un trato diferenciado para las que obtuvieron escaños con menos votos. La STC 45/1992 de 2 de abril se enmarca en una cuestión genérica debido a la naturaleza de la demanda, la cual discute la constitucionalidad del sistema electoral autonómico de las Islas Baleares, atribuyendo 13 escaños para Menorca, 12 para lbiza y 1 para Formentera. Se argumentaba la violación del principio de proporcionalidad, ya que Menorca tenía menos habitantes que Ibiza, y que se estaba transformando el sistema proporcional en mayoritario, al atribuir solamente un escaño para Formentera. Además, el legislador autonómico no podría usar de su discrecionalidad para legislar sobre la materia, desfigurando el mandato constitucional del art. 152.1 CE. El Tribunal acabó por decidir que el criterio de proporcionalidad establecido en el Estatuto Autonómico sí fue atendido, dado que se trata de un criterio tendencial, o sea,

279 JIMENEZ CAMPO, J. "La Igualdad Jurídica como Limite Frente al Legislador". In: Revista Española de Derecho Constitucional, año 3, № 9, sep/dic, 1983. Pp. 94.

${ }^{280}$ Cfr. F.J. 4. 
que puede ser fuertemente modulado por el legislador a la hora de concretizarlo (F.J. 4). En cuanto al número de escaños asignados a cada territorio, pese que Ibiza cuenta con diferencias demográficas, esto no puede ser utilizado como criterio, y por más que lo admitiera, el legislador no habría incurrido en ninguna inconstitucionalidad (F.J. 3 y 5).

Amparándose en la jurisprudencia del Tribunal Constitucional, el informe del Consejo del Estado elaborado para debatir sobre la reforma de la LOREG concluyó, por su parte, que el art. 13 y 23.2 de la Constitución Española no imponen un sistema proporcional puro en relación con el art. 69. Además, la igualdad no obliga, según el informe, a una proporcionalidad máxima, permitiendo correcciones siempre que estas no fueran excesivas, o sea, que no sean "notablemente desventajosas", y que la desproporcionalidad carezca de criterios objetivos o razonamientos que la justifique. El informe, en todo caso, parte del hecho de que debe circunscribirse a las posibles modificaciones que no impliquen una reforma constitucional, y se limita a apuntar como criterios para lograr una mayor proporcionalidad la posible reducción del mínimo provincial de representación y la sustitución de la actual fórmula electoral. ${ }^{281}{ }^{282}$

Con todo, el sistema electoral no fue incluido en la amplia reforma de la LOREG efectuada en 2011, continuando con los mismos rasgos que anteriormente. ${ }^{283}$ En todo caso, no se pretende proponer ninguna medida de

\footnotetext{
${ }^{281}$ http://www.consejo-estado.es/pdf/REGIMEN-ELECTORAL.pdf. Pp. 184-190. En mi opinión cada una de las alternativas tiene desventajas importantes. El aumento de diputados puede ser una medida impopular por el aumento automático del gasto público, siendo hoy el rechazo quizás mayor por la actual crisis económica.

${ }^{282}$ En mi opinión cada una de las alternativas tiene desventajas importantes. El aumento de diputados puede ser una medida impopular por el aumento automático del gasto público, siendo el rechazo quizás mayor por la existencia de la actual crisis económica. La reducción de la representación mínima provoca nítidamente la disminución de la representación, que a la vez ya es acusada en gran parte del país. La opción sería alterar la fórmula electoral y su combinación con algún umbral o no. Pero como cada fórmula tiene una dinámica diferenciada, esto requeriría un análisis más profundo, lo que escapa a este trabajo.

${ }^{283}$ Vid. el comentario sobre las reformas de la LOREG sobre el sistema electoral de GAVARA DE CARA, que afirma que debido al hecho de que el modelo favorece a los partidos mayoritarios, las bases del sistema difícilmente serán modificadas, y esto solo ocurrirá en caso de reforma constitucional o alguna declaración de inconstitucionalidad del Tribunal Constitucional de preceptos de la LOREG. La reforma constitucional, por su procedimiento, será difícil que se plantee con excepción de la existencia de un consenso entre los grupos mayoritarios o debido a legislaturas de gobiernos minoritarios o mayoritarios compuestos por coalición o pactos de gobierno. Sin embargo, hasta hoy, las únicas coaliciones fueron con los partidos nacionalistas, también beneficiados por el sistema. Por otro lado, el Tribunal Constitucional se ha pronunciado en más de una ocasión, también a través de algunas declaraciones sobre normas de procedimiento electoral, sin reflejo en el sistema electoral
} 
reforma ${ }^{284}$, pero sí subrayar que el sistema electoral tiene un impacto directo sobre el sistema de financiación de los partidos, y que esta es una de las claves de los problemas que se observan en los criterios de acceso y reparto de la financiación pública, penalizando doblemente a los partidos pequeños y a los nacionales con electorado disperso.

propiamente dicho. (In: GAVARA DE CARA, J. C. "La Distribución... Pp. 55). Para un amplio análisis de las propuestas en el Informe del Consejo del Estado, véase GARROTE DE MARCOS, M. Op. Cit. Pp. 100 y ss., donde la autora no se muestra de acuerdo con algunas de ellas, por no contribuir a la mejora de la proporcionalidad, aunque se mejore la igualdad de voto. También, cfr. IRIBARREN GARCÍA CAMPERO, M. D. "La Reforma Electoral en Ciernes: A Propósito del Informe sobre la Reforma Electoral Aprobado por la Comisión Constitucional del Congreso de los Diputados el 30 de Junio de 2010". In: Corts - Anuario de Derecho Parlamentario. no 24, Valencia, 2011. Pp. 43-62, donde el autor resalta el hecho de que el sistema electoral haya quedado al margen de la reforma, aunque el informe se detuvo considerablemente.

${ }^{284}$ PRESNO LINERA, M. A. "Participación Política..." Pp. 2716. Sobre el tema de reformas, cfr. MARTINEZ-PUJALTE, A. L.: El Sistema Electoral Español: Contribución a un Debate. Ed. Fundación Ciudadanía y Valores, Madrid, 2008, utiliza datos recientes de la elecciones generales de 2008 para fundamentar sus propuestas de reforma, dando especial relieve a la caída de rendimiento electoral de IU - Izquierda Unida. 


\section{CAPÍTULO II}

\section{EL SISTEMA DE FINANCIACIÓN DE PARTIDOS POLÍTICOS}

La financiación de partidos políticos siempre ha sido una cuestión constitucional clásicamente sometida a debate doctrinal dada su propia complejidad. Los problemas surgen continuamente, y es un hecho que no se pueden resolver de manera definitiva, aún más si se considera la velocidad de cambios que sufre constantemente tanto los partidos como la sociedad en general. Las necesidades financieras de dichas formaciones políticas tienden a ser infinitas ${ }^{1} \mathrm{y}$, a partir del momento que los partidos se han vuelto "verdaderos sostenedores del Estado", los modelos de financiación se enfrentan a retos que superan claramente a los que habían abordado originalmente. ${ }^{3}$ Los nuevos tiempos traen al centro del debate la relación de los partidos con el dinero, principalmente porque por su complejidad los problemas de su aceptación social resultan más evidentes que en el pasado. ${ }^{4}$ Junto a ello, tanto en las elecciones como también dentro de los propios partidos no hay grandes incentivos para adoptar un comportamiento racional económico. El papel de los

\footnotetext{
1 PETER SCHNEIDER, H. "Los Partidos Políticos y el Dinero: Problemas Actuales de la Financiación de los Partidos". In: Revista de las Cortes Generales, № 36, 3o cuatrimestre, Madrid, 1995. Pp. 24. También en esta misma línea de raciocinio, MURILLO DE LA CUEVA y MORODO afirman que, debido a los problemas que plantea el tema, la legislación referente al asunto se sucede rápidamente, pudiendo incluso cambiar de paradigma, reformando el sistema por completo. (In: MORODO, R.; MURILLO DE LA CUEVA, P. L.: El Ordenamiento Constitucional de los Partidos Políticos. $1^{\circ}$ ed. UNAM - Instituto de Investigaciones Jurídicas, Derechos Fundamentales, 2001. Pp. 162).

${ }^{2}$ LEIBHOLZ, G.: Problemas Fundamentales de la Democracia Moderna. Instituto de Estudios Políticos, Madrid, 1971. Pp. 143-144. Lo que es cierto, es que, considerando todos los beneficios concedidos por el Estado a los partidos tanto de manera directa como también de manera indirecta, es prácticamente imposible saber cuánto se gasta en ellos. (Cfr. PIERRE, J.; et al. "State Subsidies to Political Parties: Confronting Rhetoric with Reality". In: West European Politics. vol. 23. oㅡ 3, jul, Frank Cass Press, London, 2000. Pp. 12).

${ }^{3}$ FISICHELLA afirma de manera filosófica que la democracia y el dinero poseen una relación que desde siempre es conocida. (In: FISICHELLA, D.: Denaro e Democracia: Dall'antica Grecia all'economia Globale. 2ㅇ. ed., ed. II Mulino, Bologna, 2005. Pp. 57 y ss.).

${ }^{4}$ La crítica a la situación actual es general. LUCAS VERDÚ, ya afirmaba que los partidos acabaron por traducir el mercado económico oligopólico dentro de la esfera política. Es decir, objetivan el mayor número de votos sin un real trasfondo ideológico. De hecho, la falta de este - y su enmascaramiento en la "moderación" del centro socio-político - los ayudan a ganar votos y a mantenerlos en el poder, sin que estos se esfuercen en lograr un apoyo social verdadero. (In: LUCAS VERDÚ, P.: Curso de Derecho Constitucional. Vol. IV, Constitución Española de 1978 y Transformación Político-Social Española. Ed. Tecnos, Madrid, 1984. Pp. 523).
} 
recursos económicos en la política es ambiguo y por esto las reformas de las leyes que se relacionan con el tema no pueden ser analizadas sin un diagnóstico de su impacto y de los posibles cambios que acarrean en el sistema democrático ${ }^{5}$

En este sentido la evolución histórica de los partidos políticos demuestra que el papel del dinero en las democracias modernas es más evidente que nunca. ${ }^{6}$ Desde luego no puede haber democracia sin partidos, y no puede haber partidos sin los recursos necesarios para mantenerlos. ${ }^{7}$ Además, los

\footnotetext{
${ }^{5}$ Cfr. MILYO, J. "The Political Economics of Campaign Finance". In: The Independent Review. v. III. no 4, [s.I.] 1999. Pp. 541-545.

${ }^{6}$ ALEXANDER afirma que el dinero tiene gran conexión con la política porque puede comprar bienes, conocimientos y servicios que pueden no ser apartados voluntariamente por un determinado partido. También cita los posibles privilegios que los particulares pueden obtener a través del dinero privado en la política, como es el caso de un contrato con la Administración Pública. (In: ALEXANDER, H. E. "Introduction". In: ALEXANDER, H. E.; SHIRATORI, R. (eds.): Comparative Political Finance Among the Democracies. Westview Press, USA, 1994. Pp. 1-2). En realidad, la transformación de los partidos de masa en catch-all acompañó al proceso que transformó la sociedad preindustrial, con una creciente disponibilidad de bienes de consumo, y los partidos políticos fueron sometidos a todas las inseguridades del acceso a dichos bienes no durables. Sin embargo, era necesario asegurar votos, y era a través de los votos como se alcanzaba la financiación. (In: BIANCO, A.: Il Finanziamento della Política in Italia. ed. Giuffrè, Milano, 2001. Pp. 1-3). Los estudios y datos empíricos no comprueban la real importancia que el dinero tiene en la política, ya que no se puede afirmar que realmente exista una relación directa y unidireccional. Si el mercado de la financiación política no funciona bien, la intervención estatal sólo debe ser adoptada realmente implica una mejora, porque una reforma en la regulación requiere costes, y cuanto más detallada sea la regulación, mayores serán estos costes. Dichas regulaciones acaban por generar problemas de equidad afectando principalmente a los partidos pequeños, y son siempre los partidos mayores los que se encuentren en condiciones de cumplir la ley. (In: GARCÍA VIÑUELA, E. "La Regulación del Dinero Público". In: Revista Española de Investigaciones Sociológicas - REIS, № 118, abr/jun, CIS, Madrid, 2007. Pp. 76-77). En la perspectiva latinoamericana, ZOVATTO afirma que la relación entre el dinero y la política es vital para la salud y la calidad de la democracia, porque es una herramienta importante de hacer política. Pero esta relación implica problemas, como el conflicto existente entre los principios de libertad de expresión y de iguales condiciones en la competición electoral (justicia en las elecciones). El problema aumenta ante el encarecimiento de campañas electorales, dejando a los partidos políticos aún más dependientes del dinero. Así, en América Latina el tema de la financiación de la política está muy relacionado con la desilusión que se tiene con la propia política, pues los escándalos de corrupción, tráfico de influencia, etc., están muy presentes ante la opinión pública, y tanto partidos como candidatos se acusan mutuamente de conseguir capital de origen dudoso o de utilizar el dinero de manera inapropiada. (In: ZOVATTO, D.; FREIDENBERG, F. "Democratización Interna y Financiamiento de los Partidos Políticos". In: PAYNE, M.; et al (eds.): La Política Importa: Democracia y Desarrollo en América Latina. BID e Instituto Internacional para la Democracia y la Asistencia Electoral, Washington D.C., 2006. Pp. 214-215).

${ }^{7}$ NASSMACHER apunta tres criterios para la competición entre los partidos, siendo el primero la organización; el segundo el trabajo voluntario; y el tercero el dinero. Todos están muy conectados, porque para tener una buena organización, es necesario haber un trabajo voluntario; y la cantidad de trabajo voluntario dependerá del nivel de integración del partido con la sociedad. Para aumentar y maximizar todo eso, hay que organizar meetings, eventos, etc., lo que requiere dinero. El dinero es obviamente indispensable en casi todas las actividades del partido, desde la selección de candidatos y las estructuras permanentes de sus sedes, como
} 
procesos electorales también tienen un coste, y los partidos tienen que estar preparados para estas frecuentes consultas populares. ${ }^{8}$ Ante esto, el primer problema que se plantea es la desigualdad económica, que se contrapone al principio de la igualdad de oportunidades y que puede a su vez amenazar la estabilidad del sistema (y sus bases de legitimidad). ${ }^{9}$ El segundo problema puede ser la dependencia económica de los partidos políticos y candidatos ante las fuentes de financiación más ventajosas, originada por el deterioro de los medios de autofinanciación (con la crisis de afiliación; desvalorización de la imagen de los militantes; o la desmovilización política y todo ello acompañado por el encarecimiento de las campañas electorales provocado por los nuevos métodos de propaganda de masas). ${ }^{10} \mathrm{Y}$ es que efectivamente el cambio en la manera de "hacer política" fue determinante para generar una crisis financiera de los partidos de todo el mundo ${ }^{11}$, tanto en las organizaciones norteamericanas (más frágiles, y muy basadas en la figura personal del candidato) como también en las europeas (formadas por una estructura partidista fuerte, imponiendo una lista al electorado). ${ }^{12}$

para la campaña electoral en sí, una vez que los gastos con los medios serán los mayores. (In: NASSMACHER, K.-H. "Introduction: Political Parties, Funding and Democracy". In: AUSTIN, R.; TJERNSTRÖM, M. (eds.): Funding of Political Parties and Election Campaigns. International IDEA, Stockholm, 2003. Pp. 4).

${ }^{8}$ CASTILLO VERA, P. del: La Financiación de Partidos y Candidatos en las Democracias Occidentales. CIS Siglo XXI, Madrid, 1985.Pp. 1.

${ }^{9}$ En este sentido, cfr. LANCHESTER, F. "Introduzione: Il Finanziamento della Política tra forma de Stato e Vincoli Sistemici". In: LANCHESTER, F. (a cura de): Finanziamento della Política e Corruzione. Giuffrè, Milano, 2000. Pp. 7-10.

${ }_{10}$ Sobre eso, cfr. BURNELL, que entiende que la cantidad de dinero utilizado para la financiación y su influencia en el resultado de las elecciones no puede ser sobreestimado, pues hay otros elementos que tienen una influencia decisiva. (In: BURNELL, P. "Introduction". In: BURNELL, P., WARE, A. (eds.): Funding Democratization, Manchester University Press, UK, 1998. Pp.6). La importancia del dinero para el éxito electoral es resaltada dentro de la doctrina específica por MORODO y MURILLO DE LA CUEVA, que afirman que el dinero no garantiza el triunfo, pero ayuda, algunas veces de manera decisiva, a alcanzarlo. (In: MORODO, R.; MURILLO DE LA CUEVA, P. L.: El Ordenamiento Constitucional... Pp. 160). Ya FISHER y EISENTADT afirman que el dinero distorsiona la equidad política y un gran financiador significa una gran influencia política, aunque todos los ciudadanos tengan igual derecho de participación política. La consecuencia de ello es que la falta de equidad generada por el dinero es la mayor que en cualquier otro recurso en la vida política. (In: FISHER, J.; EISENSTADT, T. A. "Introduction Comparative Party Finance. What is to be Done?" In: Party Politics. v. 10. № 6. Sage, London, 2004. Pp. 619).

${ }^{11}$ Cfr. MURAYAMA, C. "Dinero, Medios y Elecciones". In: Revista Nexos, no 331, julio, 2005. $<<h t t p: / / w w w . n e x o s . c o m . m x / a r t i c u l o s . p h p ? i d \_a r t i c l e=429 \& i d \_r u b r i q u e=150>>$ Acceso en: 23.05.09.

12 CASTILlo VeRA, P. del: La Financiación de Partidos y Candidatos... 2-3. Con un entendimiento similar, BALMELLI afirma que la colusión de los poderes políticos e ideológicos convierten la financiación de la política en un elemento inquietante, ya que está ligada 
Con esto se pretende subrayar que, a nuestro juicio, la regulación de la financiación de la política (considerada en este trabajo como la financiación de los partidos políticos, candidatos y grupos parlamentarios ${ }^{13}$ ) es uno de los mayores problemas de las democracias actuales, y un ámbito en que son los propios partidos los sujetos y los destinatarios de la regulación normativa. ${ }^{14}$ Además de lo que ello implica respecto a su legitimidad social, debe admitirse que las soluciones que a veces incorporan el ordenamiento pecan con frecuencia de una excesiva generalidad $^{15}$, y de una falta de coherencia

directamente al acceso y a la conservación del poder. El sistema democrático obliga a los candidatos $o$ a políticos a someterse a la opinión pública, y los electores no suelen votar a opciones políticas que no conocen, haciendo de la información y la propaganda las claves determinantes para el éxito. Y para ello, son necesarias grandes cantidades de dinero. (BALMELLI, T.: Le Financement des Partis Politiques et des Campagnes Électorales: Entre Exigences Démocratiques et Corruption. Universitaires Fribourg, Suisse, 2001. Pp. 20). También en este sentido en el ámbito de América Latina, véase: CASTILLO, P. del. "La Financiación de los Partidos Políticos en España". In: CASTILLO, P. del; ZOVATTO G., D. (eds.): La Financiación de la Política en Iberoamérica. 1ำed. IIDH/CAPEL, San José, 1998. Disponible en: <<http://www.iidh.ed.cr/comunidades/redelectoral/docs/red_publinea/indicefinanciacion.htm $>>$ Acceso en 17.06.2009. Pp. 2.

${ }^{13}$ NASSMACHER considera que el término 'financiación de la política' tiene diferentes connotaciones. Una que contraste la financiación privada con la pública tanto de partidos y elecciones, o que solamente se refiere a la financiación de partidos y campañas, sin referirse si es privado o público. (In: NASSMACHER, K-H "Comparing Party and Campaign Finance in Western Democracies". In: GUNLICKS, A. B. (ed.): Campaign and Party Finance in North America and Western Europe. Westview Press, USA, 1993. Pp. 238). En una visión más general, CASAS-ZAMORA entiende que un sistema de financiación de la política son disposiciones institucionales complejas que combina una diversidad de instrumentos, como regulación de fuentes de recaudación de candidatos y partidos políticos; regulación de gastos; regulación de transparencia de la actividad de candidatos y partidos políticos. (In: CASASZAMORA, K.: Paying for Democracy: Political Finance and State Funding for Parties. ECPR Press, UK, 2005. Pp. 17 - traducción libre). A su vez, GRUENBERG sugiere dos definiciones para financiación de la política, una restringida a los recursos recaudados por partidos y candidatos para sostener gastos electorales y sus actividades permanentes, y otra definición más amplia, que engloba todo y cualquier recurso usado en la política, como los lobbies. (In: GRUENBERG, C.: El Costo de la Democracia: Poder Económico y Partidos Políticos. Ed. Capital Intelectual, [s.I.], 2007. Pp. 17). Se tiene que la definición restringida es la adoptada para este trabajo.

${ }^{14}$ WEBER ya mantuvo que las finanzas de los partidos constituyen la parte menos clara de su historia, lo que se contrapone con el hecho de que también sea uno de los puntos de los más importantes. (In: WEBER, M.: Economía y Sociedad I: Teoría de la Organización Social. Ed. Fondo de Cultura Económica, Derechos Fundamentales, México, 1944. Pp. 303). Sobre la presencia inevitable del dinero en la dinámica política combinada con el sistema de partido, BURNELL afirma que el número de fuerzas políticas en un país está condicionado por clivajes ideológicos y sociales, y por la elección del sistema electoral, lo que ayudará a los partidos a "blindar" cuestiones como la financiación. (In: BURNELL, P. Op. Cit. Pp. 1).

${ }^{15}$ SCARROW, S. E. "Explaining Political Finance Reforms: Competition and Context". In: Party Politics. v. 10. oㅡ 6. Sage, London, 2004. Pp. 653-655. Complementando la idea, la autora afirma que el argumento de que la regulación de la financiación de la política y sus reformas reflejan los intereses de los partidos políticos que están en el poder es válido, pero no ayuda a solucionar la cuestión, ya que no hay consenso sobre qué es estar "en el poder" y por la falta de conocimientos de cómo los partidos definen sus intereses cuando se trata de financiación. 
sistemática ${ }^{16}$ fruto, en ocasiones, de múltiples intervenciones por parte del poder judicial. En este marco, los cambios legislativos son constantes ${ }^{17}$ y los partidos, bajo la solución del problema concreto tienden en mayor medida a aumentar sus fuentes de financiación que a fomentar la igualdad de oportunidades para el acceso a las funciones políticas, proteger la libre formación de opinión de los electores, evitando que grupos económicos poderosos ejerzan influencia en las políticas estatales, o a asegurar que los actores políticos sean independientes en su actuación. ${ }^{18}$

En cualquier caso, es importante destacar en este tema la importancia de la cultura política de cada país, porque la decisión por el predominio de un modelo $u$ otro de financiación dependerá en gran medida de este factor. Por su parte, una costumbre permisiva con la corrupción determina la ineficacia de las medidas simplemente prohibitivas, mientras que si, por ejemplo, existe la idea de que el Estado no debe colaborar en la financiación de los partidos, las subvenciones públicas encuentran tal resistencia ante la opinión pública que se volverán en la práctica una medida imposible. ${ }^{19}$

Considerando la evolución de la financiación de los partidos políticos, Rosa MULÉ (que se basa en el modelo de HEIDENHEIMER), establece una vinculación entre las fases de desarrollo de la financiación partidista y la

En un claro intento de definir los intereses de los partidos, considerándose que pueden ser infinitos, la autora busca identificar el comportamiento de dichas organizaciones como un producto de esta diversidad de intereses, para luego definir los intereses que serán priorizados o no y en qué circunstancias. Puede ser que los partidos políticos siempre consideren prioritarios aspectos que tienen el apoyo público, en el caso de reformas legislativas, pero que puede no ser exactamente favorables por su partido. En materia de financiación política, es frecuente que los partidos no apoyen la actitud de "cuanto más, mejor" (incluso porque antes de una reforma no está claro quién será el verdadero beneficiario), pero la tendencia será siempre la de apoyar el aumento de ingresos.

${ }^{16}$ FISHER, J.; EISENSTADT, T. A. Op. Cit. Pp. 623.

17 PAJARES MONTOLIO, E.: La Financiación de las Elecciones. Congreso de los Diputados, Madrid, 1998. Pp. 33.

${ }_{18}$ BALMELLI, T.: Op. Cit. Pp. 24-25.

${ }^{19}$ SANTAOLALLA afirma que hay dos tipos de mecanismos normativos que pretenden corregir las posibles desigualdades que el dinero introduce dentro de un sistema de partidos: 1) de tipo reglamentario, donde se ubican medidas de anticorrupción; limitaciones y prohibiciones de contribuciones públicas y privadas, etc.; 2) las que intentan, a través de concesión de privilegios, a disminuir las desigualdades, como es la financiación indirecta de acceso a los medios o la financiación pública. El problema de la primera es que es casi imposible de controlar, y acaba por ser letra muerta en la práctica; y por ello se confía más en la segunda medida. (In: SANTAOLALLA, F. "Regulación de Campañas Electorales y Financiación de Partidos Políticos". In: Documentación Administrativa. ํำ173, ene/mar, Madrid, 1977. Pp. 156157). 
evolución de los propios partidos. Así, la autora denomina de fase A, la que refleja un electorado limitado y campañas baratas, con un débil y no estructurado crecimiento de los partidos dado el voto censitario. La fase B, se caracteriza por la expansión de las técnicas de comunicación, que aumentan el coste de las campañas, junto con un modelo irregular de recaudación por parte de los partidos de cuadros, en contraste con el modelo adoptado por los sindicatos, por ejemplo. La fase $\mathrm{C}$, abarca campañas baratas por el cambio de militancia, que pasa a ser voluntaria o institucional con la difusión del modelo de partido de masas y sus nuevas técnicas de campaña, que llevó a los partidos de cuadros a invertir mucho dinero para combatirlos. Por último, la fase $D$, implicaría una considerable distancia entre los recursos materiales disponibles y el coste de la persuasión política y el servicio (o militancia) voluntaria, lo que aumentó mucho el coste de las campañas. También hay que tener aquí en cuenta la emergencia de los grupos de presión como la parte principal de los ingresos de los partidos políticos. ${ }^{20}$.

En definitiva, el factor del dinero dentro de la política actual tiene una posición se quiera o no, central en el juego democrático. La expresión de NASSMACHER de que el dinero en la política es como mother's milk of politics ${ }^{21}$ es más correcta que nunca. ${ }^{22}$ Los ciudadanos, cuando no tienen interés o talento para participar de la política parecen estar dispuestos a conceder su tiempo, haciendo que el dinero sea una opción frecuente de

\footnotetext{
${ }^{20}$ MULÉ, R. "Financial Uncertainties of Party Formation and Consolidation in Britain, Germany and Italy: The early years in Theoretical Perspective". In: BURNELL, P., WARE, A. (eds.): Funding Democratization, Manchester University Press, UK, 1998. Pp. 48-53. La autora complementa su punto de vista, diciendo que la expansión del Estado de Bienestar hizo que muchos individuos se sintieran seguros y no necesitaran más tener educación política o ser "protegidos" por los partidos como "hábitat socio-cultural. La estratificación social se ha vuelto menos rígida y los grupos de interés se han diversificado, haciendo que los propios líderes partidistas eligieran flexibilizar sus ideologías, para acceder a los diversos intereses de estos grupos. En línea con la autora cfr. MARTíNEZ SOSPEDRA, M. "La Financiación de los Partidos Políticos. Ensayo de Aproximación". In: Cuadernos Constitucionales de la Cátedra Fadrique Furió Ceriol, no 11/12, Valencia, 2o época, 1995. Pp. 13-14; y BOZÓKI, A. Political Parties and the Prospects for In: <<http://www.unc.edu/depts/europe/conferences/parties/papers/bozoki_cosntitution2.pdf >>. Acceso en 22.11.2009. Pp. 11-13.

${ }_{21}$ Cfr. NASSMACHER, K-H. "Comparative Political Finance in Established Democracies". In: NASSMACHER, K-H. (ed.): Foundations for Democracy - Approaches to Comparative Political Finance. ed. Nomos Verlagsgesellschaft, Baden-Baden, 2001. Pp. 9.

${ }^{22}$ ALEXANDER, H. E. "Introduction. Op. Cit." Pp. 1-2.
} 
sustitución, adaptando así una peculiar forma de participación social democrática. $^{23}$

En este escenario, la regulación de la financiación de la política adquiere importancia como forma de intentar mantener a los partidos protegidos de las presiones económicas y también de garantizar el principio de la igualdad de oportunidades dentro de la esfera electoral, ${ }^{24}$ haciendo que los sistemas de financiación tengan que decidir la medida del equilibrio entre la financiación pública y la privada. En caso de que se privilegie la primera, la desventaja es una eventual o posible dependencia respecto del Estado (abriendo un peligroso camino de "estatalización" de los partidos), la cual repercute en un alejamiento de los partidos respecto de la cambiante realidad social. Privilegiándose la financiación privada, puede producirse una desmesurada influencia de particulares sobre los partidos. Si bien, también debe tenerse en cuenta que el apoyo financiero de los ciudadanos, si este fuera difuso contribuiría al enraizamiento de los partidos en la sociedad. ${ }^{25}$

Por ello, el nivel ideal de financiación de los partidos políticos debería ser aquel que hiciera a los partidos capaces de establecer conexiones propias con todos los votantes, sin hacer que la recaudación de dinero sea su fin último o que su actuación resulte condicionada por sus financiadores. Lo ideal sería que los partidos políticos recaudaran fondos de amplias franjas de la sociedad, reflejando la plural estructura de intereses existente en ella. ${ }^{26}$ La articulación

23 ALEXANDER, H. E. "Money and Politics: Rethinking a Conceptual Framework". In: ALEXANDER, H. E. (ed.): Comparative Political Finance in the 1980's. Cambridge University Press, UK, 1989. Pp. 10. Justamente en esa línea, Williams afirma que el dinero compra acceso, favores, conocimientos, habilidades, mercancías y servicios que son esenciales para la actividad partidaria, es decir, el dinero compensa la falta de militantes o voluntarios y muchas veces permite la movilización de un individuo. Así, el dinero es la transferencia y conversión de recursos que ayudan a movilizar y a asegurar la influencia de los partidos políticos. (In: WILLIAMS, R. "Aspects of Party Finance and Political Corruption". In: WILLIAMS, R. (ed.): Party Finance and Political Corruption. McMillan Press, London, 2000. Pp. 1.

${ }^{24}$ GIL CASTELLANO, J. "La Financiación de los Partidos Políticos: El Estado de la Cuestión". In: Cuadernos Constitucionales de la Cátedra Fadrique Furió Ceriol, nํ 36/37, Valencia, 2001. Pp. 249.

${ }^{25}$ GONZÁleZ-VARAS, S.: La Financiación de los Partidos Políticos. Dykinson, Madrid, 1995. Pp. 22.

${ }^{26}$ WARE, A. "Conclusions". In: BURNELL, P., WARE, A. (eds.): Funding Democratization, Manchester University Press, UK, 1998. Pp. 230-232. El autor complementa su idea afirmando que el dinero es relativamente más importante como recurso $\mathrm{y}$, por eso, los partidos hacen mucho más esfuerzo para conseguirlo de manera directa. A la vez, NASSMACHER afirma que el Estado puede intervenir en la financiación de los partidos políticos de dos maneras: a través de la regulación (como de la corrupción, conducta de partidos, candidatos y donantes); y 
del sistema de financiación de partidos determina, pues, la relación de los partidos con el Estado y el desarrollo de la política en el sistema democrático. ${ }^{27}$

De este modo una adecuada exposición sobre la financiación de partidos políticos tendrá que recalar necesariamente en el concepto de financiación política, que a la vez implica una denominación muy amplia que engloba toda entrada y salida de recursos a través de los partidos, tanto para sus actividades electorales como su actividad permanente. ${ }^{28}$ Estamos ante la utilización de los recursos en la obtención de bienes que se destinan para fines políticos ${ }^{29}$ y aunque sea un concepto un tanto genérico, es el que mejor se acomoda a nuestro juicio a un estudio general de los modelos de financiación. ${ }^{30}$ En todo caso, los modelos de financiación atienden a la clásica división tripartida de financiación privada, pública, y mixta. Ocurre que cada una de ellas es objeto hoy de una amplia polémica, siempre constante, por lo que se abordaran en principio separadamente.

medidas de distribución de subsidios. Por consiguiente, la regulación puede ser tres: autonómica, la cual respeta el carácter de asociación voluntaria de los partidos; transparente, que informa al público el comportamiento financiero de los partidos; y a través de una agencia pública. Aún, la regulación puede variar de país para país, pero sea cual sea, hay cuatro elementos que son indispensables: *transparencia; *estímulo; * apoyo público; *supervisión. Sin embargo, la solución no será perfecta, aunque pueda alcanzar a ser óptima. (In: NASSMACHER, K-H. "Introduction: Political Parties, Funding and Democracy". In: AUSTIN, R.; TJERNSTRÖM, M. (eds.): Funding of Political Parties and Election Campaigns. International IDEA, Stockholm, 2003. Pp. 9-13). Ya ubicando la realidad de América Latina, ZOVATTO cita las variables que deben ser considerados en la financiación de la política: 1) el tipo de sistema; 2) los objetos que son financiados por el Estado; 3) criterios de asignación; 4) barreras legales al acceso a la financiación pública; 5) prohibiciones de contribuciones de origen privada particular; 6) limites de las contribuciones privadas; 7) calendario de desembolso; 8) acceso a los medios de comunicación; 9) régimen de regulaciones y sanciones. (In: ZOVATTO, D.; FREIDENBERG, F. "Democratización Interna..." Pp. 218).

${ }^{27}$ FERNANDEZ-LLEBREZ, F. "La Financiación de los Partidos Políticos: Evolución y Rasgos Principales". In: VV.AA.: Curso de Partidos Políticos. Ed. Akal, Madrid, 2003 (i). Pp. 171.

28 ZOVATTO, D. "Estudio Comparado de las Características Jurídicas y Prácticas del Financiamiento de los Partidos Políticos y las Campañas Electorales en América Latina". In: ALCÁNTARA, M.; BARAHONA, E. M.: Política, Dinero e Institucionalización Partidista en América Latina. ed. IFE, México DF, 2003. Pp. 39. En esta línea, véase: NAVAS, X. "La Financiación Electoral: Subvenciones y Gastos". In: NOHLEN, D.; PICADO, S.; ZOVATTO, D. (comp.): Tratado de Derecho Electoral Comparado de América Latina. Ed. Fondo de Cultura Económica, DF, México, 1998. Pp. 455.

${ }^{29}$ ESPARZA MARTíNEZ, B. "Estructura y Funcionamiento Democrático de los Partidos Políticos Españoles". In: Revista de las Cortes Generales, № 43, 1ํㅡㄴ cuatrimestre, Madrid, 1998. Pp. 97.

${ }^{30}$ Además, también es interesante observar la estructura elaborada por MELCHIONDA, en la cual contextualiza el modelo liberal de financiación de partidos, con donaciones normales; el social democrático, con contribuciones de inscritos; el plutocrático, compuesto por grandes donaciones; y el particrático, con las subvenciones públicas. Cfr. MELCHIONDA, E.: II Finanziamento della Politica. Ed. Riuniti, Roma, 1997. Pp. 43 y ss. 


\section{1) El debate sobre las medidas de financiación privada}

Atendiendo a los esquemas liberales burgueses, las medidas de financiación privada fueron las primeras en aparecer dentro del escenario económico partidista, por la lógica de la propia evolución de los partidos. Los partidos de cuadros o de notables estaban compuestos por individuos con una significativa capacidad económica, y por otra parte el voto censitario también seleccionaba a los ciudadanos en el momento de las elecciones, a partir de esta misma capacidad económica. Ante esto, no resulta sorprendente que los partidos de aquella época se mantuvieran con los recursos de sus propios miembros. ${ }^{31}$

En el inicio del siglo XX los partidos políticos burgueses - conocidos por su modelo de partido de notables, o de cuadros - no necesitaban de ningún recurso concedido por el Estado, pero no así los partidos socialistas (que atendían más a un modelo de partidos de masas) aunque en general estos tampoco eran estrictamente partidarios del dinero de naturaleza estatal, por entender que constituía un intento de corrupción. ${ }^{32} \mathrm{~A}$ partir de ello, se podía pensar en un modelo de autofinanciación de partidos, sin la presencia de recursos públicos. La financiación privada siempre tendrá un perfil de financiación directa, ya que la indirecta (si es que se puede pensar en una financiación privada indirecta) tendría un valor empresarial y, conectar la imagen de una empresa a un partido suele comprometer la reputación de esta ante la sociedad o ante el mercado. Así, las empresas prefieren la financiación privada directa, incluso porque tiene un carácter más discreto. ${ }^{33}$

La financiación privada de los partidos políticos consiste pues en que los propios partidos deben obtener sus ingresos a partir de diversas fuentes de

\footnotetext{
${ }^{31}$ Así lo manifestaba Andrés BORREGO, pionero en la materia en España, que defendía que la financiación de los partidos de la época (siglo XIX) debería hacerse a partir de los recursos de sus miembros, a cargo de una Comisión Central que estableciera las cuantías, de Comisiones Provinciales que las recaudaran. (In: BORREGO, A.: De La Organización de los Partidos en España. ed. Anselmo Santa Coloma, Madrid, 1855. Pp. 19, 29 y 33). Sin embargo, el autor intuía la evolución de los partidos de cuadros hacia los de masas, como realmente ha ocurrido posteriormente.

${ }^{32}$ VON BEYME, K. "Los Partidos Políticos en las Democracias Occidentales". CIS Siglo XXI, Madrid, 1986. Pg. 253.

${ }^{33}$ GARCía COTARELO, R.: Los Partidos Políticos. ed. Sistema, Madrid, 1985. Pp. 193-194.
} 
recursos privadas, sean estas propias o ajenas. ${ }^{34}$ La conveniencia de una mayor o menor presencia de financiación privada en un sistema ha sido siempre una cuestión polémica. Debido a la fuerte influencia que el dinero tiene en la política dado el alto coste de las campañas electorales modernas y del mantenimiento de los partidos en su formato "profesional", la apertura del sistema hacia la aceptación de recursos privados puede, con la misma facilidad, resolver problemas, o generar otros muchos. Aunque se abogue por reconocer la libertad de los partidos para la captación de recursos privados y por una disminución del valor de las campañas electorales, lo cierto es que existe una tendencia según la cual cuando los recursos son escasos y los gastos electorales no disminuyen, los partidos frecuentemente recurren a entes privados para afrontar sus compromisos. ${ }^{35}$ Se han defendido modelos de financiación privada aludiendo a la satisfacción de algunas actividades que no suelen ser abarcadas por la financiación pública, como puede ser la promoción de la cultura política o la investigación especializada. En este punto también que se abre espacio para otros tipos de participación ciudadana en la política, a través del apoyo económico. ${ }^{36}$ Sin embargo, la sociedad valora correctamente como prioritario que los mismos partidos sean independientes en su actuación, principalmente respecto de grupos que pretenden influir directamente en sus políticas. $^{37}$

\footnotetext{
${ }^{34}$ MARTínEZ SOSPEDRA, M. Introducción a los Partidos Políticos. Ariel, Barcelona, 1996. Pg. 64. Bajo la misma perspectiva, cfr. la clasificación de MELCHIONDA, que usa dos variables para determinar las fuentes de financiación existentes. Bajo su estructura, también están contenidos todos los tipos de financiación irregular. Cfr. MELCHIONDA, E.: Op. Cit. Pp. 37.

${ }^{35}$ ALBERTO CORDERO, L. "La Fiscalización del Financiamiento de los Partidos Políticos: un Asunto de Conciencia Crítica". In: AA.VV.: Administración y Financiamiento de las Elecciones en el Umbral del Siglo XXI - Memoria del III Congreso Internacional de Derecho Electoral. Tomo II, Instituto de Investigaciones Jurídicas, DF, México, 1999. Pp. 381-382. ARGANDOÑA también entiende que los problemas con la financiación privada son estos, pues dada la insuficiencia de los fondos recaudados (haciendo que los partidos políticos tengan que recurrir en ocasiones a la financiación ilegal), viene acompañada también con la expectativa de los miembros que pagan sus cuotas de algún tipo de contraprestación, y la utilización de medios ilegales como para crear una "obligación" para las empresas de contribuir con dichas organizaciones para tener sus derechos respetados y observados. (In: ARGANDOÑA, A. "La Financiación de los Partidos Políticos y la Corrupción en las Empresas". In: Papeles de Ética, Economía y Dirección. no 6, [s.l.], 2001. Pp. 8-10).

${ }^{36}$ TORRES FERNANDEZ, J. J. "El Control de las Subvenciones a los Partidos Políticos". In: XV Jornadas de Estudio: El Sistema Económico en la Constitución Española - Vol. II. Secretaria General Técnica - Centro de Publicaciones, Ministerio de Justicia, Madrid, 1994. Pp. 1861.

${ }^{37}$ ALBERTO CORDERO, L. Op. Cit. Pp. 396.
} 
Con todo, son conocidas las consecuencias de un modelo puramente privado, aunque no haya sido puesto en práctica totalmente. Se supone que sería muy perjudicial para la independencia de los partidos, cuya garantía sería muy difícil o imposible. El Estado estaría indirectamente vinculado por otra parte a esta dependencia de los partidos. ${ }^{38}$ La regulación de la financiación privada de los partidos políticos no resultaría probablemente "imparcial" (aunque no se puede considerar que esta sea actualmente hecha de manera neutral, porque no lo es), y no garantizaría la igualdad de oportunidades entre dichas organizaciones. Así, una regulación absolutamente permisiva del tema en puntos como las cuotas y las donaciones iba a favorecer a los sectores económicamente más fuertes de la sociedad, alterando la idea de igualdad de oportunidades entre los partidos. ${ }^{39}$ Pero esto no significa que no haya quien defienda un modelo de financiación puramente privado, y ello argumentando que, en realidad, las desigualdades causadas por dicho sistema se reproducen en los esquemas de financiación pública cuando esta está basada solamente en criterios aritméticos que favorecen a los grandes partidos ya consolidados. Además, se considera también que la financiación privada es más eficaz contra la corrupción, ya que obliga a los partidos políticos a cuidar de su credibilidad ante el electorado, y a que realicen una mejor gestión de los recursos. Por otra parte, se trata también de una forma de participación política, ya que al mismo tiempo fomenta la relación de confianza entre los partidos y los ciudadanos, estimula el trabajo de las organizaciones locales de los partidos, y acaba por fomentar la democracia interna. Finalmente, también se afirma que es el modelo de financiación que realmente se corresponde con la naturaleza

\footnotetext{
${ }^{38}$ ALBERTO CORDERO, L. Op. Cit. Pp. 396.

39 PETER SCHNEIDER, H. "Los Partidos Políticos..." Pp. 26. El autor incluso entiende que debido a razones socio-estructurales, no es posible garantizar a los partidos la igualdad en las oportunidades de manera absoluta, como tampoco a los ciudadanos la oportunidad de participar de igual forma en la política. FERREIRA RUBIO entiende también que la financiación privada puede generar una colonización de las estructuras estatales por parte de grupos privados y poderosos económicamente, afectando a la esencia de la democracia representativa. Sin embargo, la autora admite que ello posibilita la existencia de una cierta aproximación de los partidos con la sociedad, ya que se tiene la idea de que los partidos son asociaciones privadas y de participación voluntaria. (In: FERREIRA RUBIO, D. "Financiamento de Partidos e Campanhas: Fundos Públicos versus Fundos Privados". In: Novos Estudos, no 73, nov. ed. CEBRAP, 2005. Pp. 10-11).
} 
predominantemente jurídico-privada de dichas organizaciones en el ordenamiento español. ${ }^{40}$

Asumiendo que el voto es solamente una de las formas de ejercer la participación política, la transferencia de recursos económicos desde la sociedad a los partidos intenta defenderse desde postulados participativos, y no solamente en tiempos de campaña electoral. No es posible pensar que en la democracia actual puedan existir partidos ajenos a la actuación de los grupos de presión, ni tampoco que las donaciones privadas a favor de los partidos no constituyan instrumentos importantes y no desechables de participación política voluntaria. $^{41}$

La influencia a través de las donaciones dependerá en gran medida del modelo de financiación adoptado. Lógicamente, la intensidad de que dicha influencia dependerá mucho de los límites autorizados para las donaciones privadas. En todo caso, es incuestionable que la financiación privada acarrea inconvenientes. El dinero es siempre en el sistema un factor potencial de perdida de autonomía del sistema político como tal. También es evidentemente un instrumento de "dominación" política en su sentido clásico y puede distorsionar la política al punto de ser esencial para articular consensos. En definitiva, y como es sabido, la mayor demostración de la difícil relación entre el dinero y la política es que transforma la participación política y determina las acciones de los representantes del pueblo. ${ }^{42}$

En todo caso, parece necesario analizar cada fuente de financiación, que más allá de sus ventajas o inconvenientes teóricos, también se verá

\footnotetext{
${ }^{40}$ CASTILLO, P. del. "Objetivos para una Reforma de la Legislación sobre Financiación de los Partidos Políticos". In: La Financiación de los Partidos Políticos. Cuadernos y Debates, no 47, Centro de Estudios Constitucionales, Madrid, 1994. Pp. 61-63. La autora complementa su punto de vista sugiriendo que, para fomentar la financiación privada de los partidos políticos y disminuir la importancia de la financiación pública, se deben liberalizar las contribuciones privadas de personas físicas y personas jurídicas; desgravar donaciones, principalmente de pequeños donantes, como también las cuotas de afiliados; limitar el papel de los fondos públicos; y limitar el incremento de las subvenciones públicas al IPC, por ejemplo. Cabe subrayar que algunas de estas medidas fueron adoptadas por la Ley Orgánica 08/07 aprobada en España, aunque no englobe la financiación electoral. Con la misma posición, cfr. ARIÑO ORTIZ, G.: La Financiación de los Partidos Políticos. Documentos del Foro de la Sociedad Civil. no 1. Ed. Foro de la Sociedad Civil, Madrid, 2009. Pp. 28-29.

${ }^{41}$ Cfr. MOLINA VEJA, J. E.; SADEK, M. T. "Participación Política". In: AA.VV.: Diccionario Electoral. CAPEL-IIDH, Costa Rica, 1989. Pp. 513. Los autores también trazan un panorama general sobre el término participación política. LUCIANI, M. "Danaro, Política e Diritto". In: Rivista di Diritto Costituzionale. Ed. G.Giappichelli, Torino, 2006. Pp. 7.

${ }^{42}$ LUCIANI, M. Op. Cit. Pp. 12-20.
} 
fuertemente afectada en su funcionamiento práctico por distintos elementos de la cultura política dominante en cada país.

\subsection{Las fuentes de financiación privada y su problemática}

Existen múltiples fuentes posibles de financiación privada. NASSMACHER separa en tres grupos los orígenes de los recursos privados utilizados en la financiación de partidos (que el autor denomina "grass-roots" financing): la cuota de los miembros; las donaciones voluntarias de los miembros de los partidos que superan el valor de la cuota; y las contribuciones de simpatizantes, tanto individuos como empresas. ${ }^{43}$ Hay autores que incluyen la cuota de los cargos públicos elegidos o el fruto del patrimonio de los partidos, sus publicaciones y otras actividades en general. ${ }^{44} \mathrm{Ya}$ se adelanta que en este trabajo, la cuota pagada a los partidos por parte de los cargos públicos electos no será considerada como fuente de financiación privada, como tampoco los recursos concedidos a los grupos parlamentarios, por entender que estos no se confunden con las finanzas de las formaciones políticas.

Así, para la exposición de las fuentes de recursos privados existentes y su problemática, se utilizará la clasificación ${ }^{45}$ de MARTíNEZ SOSPEDRA. ${ }^{46} \mathrm{EI}$ análisis se basará en fuentes generales de financiación privada, pero siempre enfocado hacia el caso español. Dicha clasificación consiste en: a) Recursos propios: *Cuota de afiliados; *Patrimonio propio del partido; *Publicaciones y otras actividades desarrolladas por el partido; y *Aportaciones de cargos

\footnotetext{
${ }^{43}$ NASSMACHER, K-H. "The Funding of Political Parties in the Anglo-Saxon Orbit". In: AUSTIN, R.; TJERNSTRÖM, M. (eds.): Funding of Political Parties and Election Campaigns. International IDEA, Stockholm, 2003. Pp. 36.

${ }^{44}$ En este sentido, cfr. VON BEYME, K.: Political Parties in Western Democracies. Ed. Gower, Great Britain, 1985. Pp. 253-254. El autor resalta que los recursos de los afiliados fueron muy necesarios para la auto-sobrevivencia de los partidos de masas, mientras que los partidos burgueses disponían de fuentes exteriores.

${ }_{45}$ Hay otras clasificaciones más simples disponibles en la doctrina. Como ejemplo, véase FERNANDEZ-LLEBREZ, F. Op. Cit. Pp. 176, que describe cinco fuentes de la financiación privada: 1) cuotas de afiliados; 2) donativos; 3) préstamos y créditos; 4) gestión del patrimonio propio; 5) ingresos atípicos. Ya en un enfoque más vuelto a la ciencia política, cfr. la clasificación in: MELCHIONDA, E.: Op. Cit. Pp. 32-33.

${ }^{46}$ Dicha clasificación puede ser encontrada en: SOSPEDRA, Manuel Martínez: Introducción a los... Pp.64 y MARTíNEZ SOSPEDRA, M. “La Financiación...” Pp. 15.
} 
públicos y candidatos. b) Recursos de carácter privado: *Préstamos / créditos; *Donaciones; *Actividades empresariales; e *Ingresos atípicos.

En relación a los ingresos atípicos, muy relacionados con la corrupción propiamente dicha, su exposición se realizará en el marco de un planteamiento general de la corrupción política y su relación con la financiación de partidos. Aunque tengan una fuerte connotación penal, no pueden ser englobados solamente bajo este perfil (a la vez que no todos los ingresos atípicos están tipificados como delitos), y tampoco pueden ser ignorados en ningun análisis porque representan una parte importante de la economía de los partidos, aun cuando no existan datos oficiales sobre la cuestión.

Con todo, también se debe incluir en el listado de recursos de carácter privado los valores transferidos por las asociaciones y fundaciones afines a los partidos. Con el Orden de 7 de julio de $1997^{47}$, se establecieron las bases reguladoras para la concesión de subvenciones a fundaciones y asociaciones con dependencia orgánica de partidos políticos y para sus actividades de estudio, desarrollo del pensamiento político, social y cultural. Es conocido el hecho de que los partidos han creado asociaciones y fundaciones fuertemente vinculadas a los mismos, que incluso reciben también subvenciones por parte de algunas Asambleas Autonómicas, como ocurre en el País Vasco. ${ }^{48}$ Dichas subvenciones también están reservadas a asociaciones y fundaciones que están conectadas a partidos con representación parlamentaria y, con la Ley Orgánica $8 / 2007$, además de poder recibir donaciones privadas por un valor bastante superior al autorizado a los partidos, también deberán someterse a la fiscalización realizada por el Tribunal de Cuentas.

Está claro que los partidos son los beneficiarios últimos de dichos recursos, como poco indirectamente. Existen formas de integrar estos valores en las finanzas de los partidos (por lo menos antes de la Ley Orgánica 8/2007, cuando se autorizaban pequeñas donaciones anónimas), diluyendo el montante en pequeñas partes. Sin embargo, y es algo que será comentado

\footnotetext{
${ }^{47}$ Publicado en el BOE no 165, de 11 de Julio de 1997, Pp. 21462-21463. La resolución más reciente es de 15 de abril de 2011, publicado en el BOE № 110, de 9 de mayo. Pp. 4709847102.

${ }^{48}$ Publicado en el BOPV, № 176, de 15 de septiembre de2011. Orden de 7 de septiembre.
} 
más adelante ${ }^{49}$, lo cierto es que no están reguladas las actividades de las propias asociaciones y fundaciones a favor de los partidos, es decir, no solo es el hecho de que puedan recibir subvenciones públicas y donaciones privadas en mayor cantidad que las organizaciones partidistas, sino también la falta de previsión para valorar las actividades, por ejemplo en la campaña electoral, realizadas por estas fundaciones. Es solamente un ejemplo de un amplio abanico de imprevisiones legislativas que sin duda cuestionan la eficacia de la Ley Orgánica 8/2007, cuyo objetivo declarado era el intensificar el control sobre los partidos en estas materias.

\section{a) Cuotas de afiliados}

Se trata de uno de los mecanismos más tradicionales en la financiación privada de los partidos, pues desde su origen es el que permitió costear las actividades ordinarias del partido, de su estructura, y otros gastos que posibilitan su funcionamiento y continuidad. Además, representa el a veces débil hilo existente entre el miembro y la organización, y que, renovado periódicamente, transmite la intención del asociado de continuar formando parte de las estructuras partidistas. Así, tiene una doble función, que es financiar las actividades cotidianas de los partidos, y de confirmar la adhesión de sus miembros, diferenciándose en este punto de las donaciones, que no implican ningún vínculo entre donante y partido, por lo menos directamente. ${ }^{50}$ Con múltiples variantes, las cuotas pueden ser uniformes para todos los afiliados o relacionarse con el nivel de renta de cada miembro, un sistema este último casi nunca utilizado en la práctica. ${ }^{51}$

\footnotetext{
${ }^{49}$ Sobre el tema, véase Cap. III, punto 2.2.3 "i".

50 En este sentido, cfr. GARCíA COTARELO, R. Los Partidos Políticos. Op. Cit. Pp. 194; MARTÍNEZ SOSPEDRA, M.: Introducción a los... Pp. 65 y ss.; HOLGADO GONZÁLEZ, M.: La Financiación de los Partidos Políticos en España. Tirant lo Blanch, Valencia, 2003. Pp. 185. Reforzando la idea de vínculo entre los miembros del partido y su representación a través de la cuota, véase: MARTÍNEZ SOSPEDRA, M. “La Financiación...” Pp. 15.

${ }^{51}$ SOSPEDRA, M. M.: Introducción a los... Pp. 66. El autor considera que sería ideal que la cuota tuviera un pago fraccionado, mejor que el anual, ya que en su opinión, a cada pago que el afiliado hiciera, estuviera renovando su adhesión por la organización.
} 
Actualmente la importancia de esta fuente de financiación es claramente secundaria, y ciertamente varia notablemente en cada caso. ${ }^{52} \mathrm{El}$ reclutamiento masivo es una tarea compleja relacionada con el control de la organización por la cúpula directiva. Ello requiere una cierta identidad ideológica y limita la capacidad de maniobra por parte de la élite de la organización, aumentando a su vez la competencia por los puestos públicos que están al alcance de los miembros del partido. En la política moderna, a partir de partidos políticos fuertemente estructurados bajo una jerarquía interna, ni la élite del partido y ni los militantes tienen incentivos para afiliarse o ampliar esta afiliación, ya que ambos pueden tener interés en restringir la competencia, especialmente si hay otros medios de financiación - tanto pública como privada - para mantener la situación como está. Hay que tener en cuenta que los partidos de masas preveían sanciones razonables para los que no pagaban su cuota, lo que no encaja en el modelo catch all, que permite conjugar disposiciones estatutarias claves, con una amplia tolerancia en el impago de cuotas. ${ }^{53}$ Por otra parte, el gran volumen de financiación pública hace que los partidos que tienen acceso a ella no se vean compelidos a fomentar el aumento del número de afiliados, siendo esta una consecuencia importante causada por la desmedida financiación pública. ${ }^{54}$

Ante esto, los problemas que se perciben van desde la falta de seriedad - tanto por parte de los miembros en mantener este vínculo como también por el partido en ser más exigente en este mantenimiento - al exponencial

\footnotetext{
${ }^{52}$ En un análisis comparado, NASSMACHER comprueba a través de datos que hubo una fuerte reducción en el pago de las cuotas de afiliados para el mantenimiento del partido, no siendo ya relevante como fuente de recursos. (In: NASSMACHER, K-H. "Comparing Party..." Pp. 252). Ya FERNANDEZ-LLEBREZ afirma que, aunque tengan su origen en los partidos de masas y haber se extendido a los demás partidos, este proceso también fue acompañado por la "intrascendencia" que dichas cuotas acabaron por tener a ellos. Sin embargo, son relevantes porque se tratan de una forma importante de expresar el enlace que hay entre partidos y sus miembros, no solamente con connotaciones materiales, sino también psicológicas. (In: FERNANDEZ-LLEBREZ, F. Op. Cit. Pp. 176).

${ }^{53}$ COTARELO también resalta que los mecanismos de sanción de impagos no son muy utilizados por los partidos porque además de afiliados, los miembros también son votantes. Lo que los partidos quieren, en su opinión, es un gran grupo de votantes, ya que los votantes no generan competencia en la élite del partido, los miembros sí. (In: GARCÍA COTARELO, R.: Los Partidos Políticos. Op. Cit. Pp. 196-197). También en este sentido, cfr. FERNANDEZLLEBREZ, F. Op. Cit. Pp. 176-177.

${ }^{54}$ Cfr. BLANCO VALDÉS, R. L. "La Problemática de la Financiación de los Partidos Políticos en España: Regulación Jurídica y Propuestas de Reforma”. In: Revista de Estudios Políticos, oㅡ 87, ene/mar, ed. Centro de Estudios Constitucionales, 1995. Pp. 178.
} 
debilitamiento de esta fuente de financiación. Las cuotas no llegarán a desaparecer probablemente porque la propia naturaleza del partido político es la de una asociación. No obstante, el fomento normativo de esta fuente mejoraría sin duda la imagen de los propios partidos, que perderían connotaciones jerárquicas y ganarían en su imagen de expresiones políticas de la sociedad.

Con la Ley Orgánica 8/2007 hay un nuevo, aunque débil, incentivo para afiliarse a un partido, que es la desgravación fiscal sobre el pago de cuotas. El legislador privilegió la desgravación del pago de cuotas frente a las donaciones de pequeño valor, y por lo tanto ha elegido un límite bajo para autorizar el beneficio fiscal. Además, cabe recordar que no sólo el miembro tiene ventajas con la desgravación fiscal, sino también el propio partido al estar exentos por las cantidades obtenidas a título de cuota de afiliados. ${ }^{55}$ Queda por determinar si desgravaciones y exenciones fiscales como estas van a ser correctamente fiscalizadas.

\section{b) Patrimonio propio del partido político}

En los tiempos de los partidos de cuadros, el patrimonio propio de los partidos como fuente de financiación resultaba en cierto modo relevante. En todo caso, los eventuales recursos originados por el patrimonio propio de los partidos políticos no suelen ser considerados como una real fuente de financiación privada. La clave se encuentra hoy en día en el patrimonio inmobiliario utilizado como sedes del partido. Su revalorización en el mercado, que quizás podría generar algún recurso para el partido, suele no ser rentable políticamente cuando dichas sedes del partido posean algún sentido histórico y político fuerte. ${ }^{56}$ Por otra parte, no es fácil visualizar este patrimonio como una verdadera fuente de financiación, ya que difícilmente el partido elegirá deshacerse de sus posesiones a favor de la realización de alguna actividad electoral o partidista. Para ello existen opciones menos onerosas, como los préstamos o incluso cualquier otro tipo de financiación irregular.

\footnotetext{
${ }^{55}$ Cfr. art. 12.2, Ley Orgánica 8/2007.

${ }^{56}$ MARTÍNEZ SOSPEDRA, M. “La Financiación..." Pp. 17.
} 


\section{c) Publicaciones y otras actividades desarrolladas por el partido}

Aunque en el pasado con los partidos de masas, estas actividades constituyeron importantes fuentes de ingresos, actualmente ya no puede considerarse así, pues la prensa partidista perdió su sentido debido a múltiples factores: la evolución de los partidos hacia el modelo catch all, y su consecuente desideologización, la transformación del electorado, con un perfil más volátil y menos fiel, y los avances en los medios de comunicación de masas que también hicieron perder relevancia a esta forma de divulgación de los ideales del partido. ${ }^{57}$ Con todo, con la disminución del papel de las publicaciones, aumentó la relevancia de los eventos organizados por el partido, como fiestas y celebraciones, cenas, etc. MARTíNEZ SOSPEDRA cita la fiesta Alderdi Eguna, del PNV-EAJ, la Festa de Treball del PSUC y L'Humanité, del PCF, que poseen, o poseían, un sentido histórico, como un ritual, además de lograr mantener una capacidad significativa para recaudar recursos a favor de las organizaciones. ${ }^{58}$ También en otros países, como Brasil, son muy comunes las cenas organizadas al comienzo del período electoral, justamente para recaudar recursos para las candidaturas, y también para realizar algunas conexiones políticas entre los propios partidos, como posibles coaliciones, apoyos, etc. $^{59}$

Se podría argumentar sobre la posibilidad del uso del internet como manera de sustitución de estas publicaciones, pues además de ser una forma de movilización partidista, lo es de captación de algún recurso económico a través de anunciantes. Con todo, esta opción no es del todo factible, porque las empresas (potenciales anunciantes) suelen negarse a conectar sus servicios 0 su marca a alguna opción política. Con ello, esta fuente de financiación se reduce forzosamente a los eventos organizados por los partidos.

\footnotetext{
57 HOLGADO GONZÁLEZ, M.: La Financiación de los... Pp. 191.

58 MARTÍNEZ SOSPEDRA, M. La "Financiación..." Pp. 17-18. El autor argumenta que la prensa auxilió en la politización de los ciudadanos, siendo los periódicos y las revistas el canal de comunicación entre la sociedad y los partidos, prácticamente el único. Sin embargo, el autor apunta que, actualmente, las publicaciones pueden ser más una fuente de gastos que una fuente de recursos.

59 Diversos ejemplos de eventos de dicha naturaleza pueden ser encontrados en: www.pt.org.br, y en los varios sitios web de los partidos en general.
} 
Una de las iniciativas adoptadas por los partidos es la venta de bonos como manera de recaudar fondos para las campañas electorales. Desde la década pasada, la presencia de los bonos es creciente y es subrayada por el Tribunal de Cuentas. ${ }^{60} \mathrm{Ya}$ en las elecciones de 2011, Iniciativa per Catalunya y Unión, Progreso y Democracia (UPyD) emitieron bonos cuya inversión se comprometieron a devolver en el plazo de dos años, con intereses. Las motivaciones van desde la económica en tiempos de evidente crisis, a la falta de financiación alternativa, y al mismo tiempo el deseo de establecer otro tipo de vínculo con los simpatizantes, como ocurre con las cuotas. ${ }^{61}$ Con el aparente éxito de la medida, su tendencia puede ser creciente en las próximas elecciones.

\section{d) Aportaciones de cargos y candidatos}

Estas aportaciones tienen un perfil muy polémico, ya que se nutren tanto de los sueldos recibidos por los parlamentarios electos como de las ayudas que se conceden a los grupos parlamentarios para la contratación de personal, y son considerados como fuentes de recursos para la financiación de los partidos políticos. ${ }^{62}$ Por otro lado, también se nutre de parte de los sueldos de los cargos electos, porque constituye una cierta forma de retribución al partido que hizo posible su elección, y por ello se juzga que el electo debe pagar una "retribución" más permanente a la organización. ${ }^{63}$

${ }^{60}$ En Tribunal de Cuentas apuntó que en el ejercicio de 2001, Convergencia i Unió y CDC recaudó una gran cantidad de dinero a partir de la venta de bonos a bajo precio, y que los compradores quedaban en el anonimato.

Cfr. http://www.elpais.com/articulo/cataluna/Iniciativa/emitira/bonos/financiar/campana/electoral/elpe piespcat/20111028elpcat_7/Tes <<Acceso en 07/12/2011>>

62 El origen de dicha fuente, según MARTíNEZ SOSPEDRA, vino de los partidos de cuadros novecentistas, que tenían como dichas contribuciones como vitales para la financiación de las campañas electorales, motivada también por el sistema uninominal. Así, las actividades ordinarias de los partidos era financiada por los electos, con un perfil de 'honor'. Posteriormente, por la presión de tener recursos, fue adoptada por los demás modelos de partidos. (In: MARTíNEZ SOSPEDRA, M. "La Financiación..." Pp. 18).

${ }^{63}$ En realidad, la naturaleza jurídica de esta fuente de financiación, si fuera así considerada, sigue en discusión, ya que hay autores que defienden que se trata de financiación privada, como también otros que dicen que es financiación estatal. Ya sobre la aceptación de esta fuente de financiación, HOLGADO GONZÁLEZ utiliza el PSOE como ejemplo, y afirma que primero el partido recibe el sueldo de todos los diputados, deduce el valor de esa retribución, y sólo después entrega a los políticos electos la cantidad restante. Ella entiende que esto está 
Aunque sea ya algo normal en el funcionamiento de los partidos, quizás este "carácter de retribución" de los electos al partido eventualmente justifique dichas deducciones del "impuesto" partidista. El problema reside en la forma en que se realiza. Es claro que el cargo electo, al afiliarse al partido, acepta los términos del estatuto, pues además de tratarse de una afiliación voluntaria, se supone que él tiene conocimiento de las clausulas insertadas en el documento. Los estatutos de los partidos disponen en ocasiones la obligatoriedad del pago de una cuota por parte de estos futuros cargos públicos, que se diferencian en función del nivel en que se ubican, o sea, estatal, autonómico y municipal. ${ }^{64}$ También es cierto que, si el partido no deduce la "cuota" previamente al abono de la retribución pública, pueden producirse numerosos casos de incumplimiento. Aquí se refleja una relación que está más basada en la costumbre que en la confianza, y debido a ello, es aceptada y difícilmente cambiará.

Como fácilmente se puede constatar, dicha fuente de financiación de los partidos no está incluida en la LOREG o en la LOFPP, lo que debería impedir que los partidos determinaran una cuota de este perfil. Aunque se pueda entender que este "impuesto del partido" encuentra su justificación en el hecho de que sin el partido, el individuo no ocuparía realmente el cargo público al que accedió, hay que considerar que la voluntad popular expresada a través del voto guarda una relación directa con la titularidad "personal" del cargo, según la conocida jurisprudencia del Tribunal Constitucional, La importancia del elemento partidista, incluso materialmente es evidente, pero sí no hay monopolio para la presentación de candidaturas, no hay justificación para que el "impuesto" se mantenga. Se compromete también la propia naturaleza de su retribución, totalmente distinta de la naturaleza de la financiación de partidos.

permitido, por el hecho de que hay el consentimiento implícito de los parlamentares (HOLGADO GONZÁLEZ, M. La Financiación de los... Pp. 214-217).

${ }_{64}$ Como ejemplo se puede citar el estatuto del PSOE, que en el título III, que trata sobre la selección de candidatos y candidatas en los diferentes procesos electorales, en la disposición adicional primera, dispone claramente medidas sobre el tema; y en el estatuto del partido político, art. 54.2, que trata sobre el régimen patrimonial del partido. (In: www.psoe.es/download. . $\mathrm{e}$ ?id $=42990$ http://imagenes.publico.es/resources/archivos/2008/11/10/1226350131083ESTATUTOS\%20PP $\% 20 X V I \% 20 C O N G R E S O . p d f$. 
Así, debido a la falta de una previsión legal que permita incluir esta fuente en las finanzas del partido, se aboga aquí por la preferente exclusión de esta práctica por parte de los partidos, aunque se sepa que esto es bastante improbable.

Ya en lo que se refiere a las ayudas concedidas a los grupos parlamentarios para la contratación de personal, existen una cierta discusión doctrinal, pues algunos autores ${ }^{65}$ entienden que, además del hecho de que el grupo parlamentario no sea una extensión jurídicamente hablando del partido político y por ello no debería utilizar dichos recursos, se da también la cuestión de que, si no se contrata personal para uso del grupo parlamentario, la ayuda pierde su sentido, y por ello debe ser excluida como fuente de financiación. ${ }^{66}$ Junto a ello, existe también una clara discusión sobre la naturaleza pública o privada de esta fuente de financiación, a la vez que, aunque haya un intermediario (como el candidato electo o el grupo parlamentario) y su naturaleza sea privada, el hecho es que el recurso se paga por el Estado. ${ }^{67}$

Lo que parece claro es que las deducciones realizadas por el partido en los sueldos de los cargos electos y la existencia de subvenciones concedidas a los grupos parlamentarios es un hecho consumado, siendo así que en no pocas ocasiones el grupo parlamentario se queda con la mayor parte de los recursos transferidos por el Estado. Con ello, la práctica más común es que el grupo parlamentario gaste sus recursos para mantener a los funcionarios permanentes del partido y no proceda a la contratación de asesores especiales $\mathrm{u}$ otras necesidades del mismo. ${ }^{68}$ En realidad, también en este aspecto, el grupo parlamentario acaba por ser una extensión del partido político. ${ }^{69}$

Cabe recordar que, aunque constituya una práctica común, dichas aportaciones venidas directamente de candidatos y de los cargos electos no están previstas en la ley de manera directa, como tampoco fueron incluidas en

\footnotetext{
${ }^{65}$ En ese caso se puede citar PRESNO LINERA y ÁLVAREZ CONDE, y muchos otros por la doctrina.

${ }^{66}$ Utilizando nuevamente el PSOE como ejemplo, consta en su estatuto, título $\mathrm{V}$, de la administración y patrimonio del partido, artículo 61, que indica expresamente que las subvenciones recibidas por los grupos parlamentarios como parte de su patrimonio (www.psoe.es/download.do?id=42990, pg. 43).

${ }^{67}$ HOLGADO GONZÁLEZ, M.: La Financiación de los... Pp. 213-219.

68 MARTÍNEZ SOSPEDRA, M. "La Financiación..." Pp. 19 y RODRIGUEZ LÓPEZ, A.: Contabilidad y Financiación de los Partidos Políticos. ed. CISS, Madrid, 2011. Pp. 101-104.

${ }^{69}$ Sobre el tema, cfr. Cap. III, punto 9.
} 
las disposiciones de la Ley Ordinaria 8/2007, ley de financiación de partidos políticos vigente o en el nuevo proyecto de ley aprobado en 2012, lo que permite entender que, si el candidato quiera aportar fondos, deberá someterse al régimen de donaciones privadas de personas físicas, como todo ciudadano.

\section{e) Préstamos y créditos}

El tema de los créditos bancarios plantea cuestiones de difícil resolución. Dichos créditos ganaron fuerza como fuente de financiación a partir de la consolidación de la financiación pública en España, pues ésta supuso una garantía de los partidos para poder hacer frente a sus préstamos. ${ }^{70}$ Durante la vigencia de la Ley Orgánica $3 / 1987^{71}$, los partidos solo podían comprometer hasta el 25 por 100 de los ingresos provenientes de la financiación pública obtenida para el pago de los créditos e intereses, regla esta que tenía la pretensión de frenar el endeudamiento desmesurado de dichas organizaciones partidistas. Sin embargo, dicho límite no fue respetado por muchos de los partidos, como se constata el Tribunal de Cuentas en sus informes. Esto conduce a la conclusión de que la intención de la ley no se logró, y los partidos continuaron endeudándose para hacer frente a sus gastos. Los partidos políticos pueden, si así lo desean, financiar tanto sus actividades ordinarias como las extraordinarias a través de créditos bancarios, aunque son pocos los casos de préstamos para costear actividades interelectorales. El problema es que dicha postura puede no ser prudente para la salud económica del propio partido, y que considerando además que los préstamos para las campañas electorales, hasta muy recientemente constituía una verdadera "política bancaria", todo ello contribuye a que la situación de dependencia de los partidos ante la banca sea cada vez más complicada de resolver. ${ }^{72}$

Los problemas comienzan en el momento mismo de establecer los criterios de concesión de estos créditos por parte de las entidades bancarias. Como dichos requisitos no pueden ser normativizados - justamente por la dificultad que comporta - suelen ser aplicados de manera distinta para cada

\footnotetext{
${ }^{70}$ MARTÍNEZ SOSPEDRA, M.: Introducción a los... Pp. 72-73.

${ }^{71}$ Véase art. 9.

72 MARTÍNEZ SOSPEDRA, M. “La Financiación...” Pp. 19.
} 
partido, según la posición que el partido tenga en el Parlamento. ${ }^{73} \mathrm{Si}$ el partido tiene una buena posición electoral, tendrá cómo garantizar el pago del crédito, y así logrará obtener nuevos préstamos. Dicho procedimiento por parte de los bancos no suele ser acorde con el principio de igualdad de oportunidades que debe regir la competición electoral, provocando fuertes desequilibrios. Por otra parte, cabe al menos, respecto a la posibilidad de entrar en el "juego electoral" por parte de nuevos partidos, también cuestionar que, con el volumen actual de financiación pública, exista realmente la necesidad, o sea políticamente conveniente permitía, a través del silencio de la ley, la existencia de flujos económicos de financiación del montante de los actuales.

La objeción última para la realización de este tipo de operación es que puede resultar de hecho irregular. Uno de los problemas más graves se refiere al hecho de que en muchas ocasiones los préstamos son, en realidad, donaciones disfrazadas, constituyéndose en una deuda que el partido no pagará $^{74}$, con fraude a la normativa legal, lo que es aún más grave. Además, como generalmente los partidos políticos hacen uso de los créditos para las campañas electorales, siendo esta medida una de las fuentes de financiación principales de dichas campañas ${ }^{75}$, el creciente endeudamiento de las formaciones políticas con la banca despierta gran preocupación, porque se sabe - aunque sin datos todavía exactos - que los partidos asumen deudas bastante altas. Como se ha dicho, ni siquiera el art. 9 de la Ley Orgánica 3/1987 pudo contener el crecimiento de dicha deuda, pudiendo comprobarse

\footnotetext{
${ }^{73}$ Sobre el punto, GALLEGO CASTAÑERA afirma que los bancos poseen una variedad muy grande de criterios, pero que muchas veces prevalece la afinidad política. También se considera la capacidad del partido para afrontar su deuda (la autora cita el caso de PSOE y PCE, en que los primeros años de democracia consiguieron tener fama de buenos pagadores), y también de escaños de cada partido, verificando las posibilidades que la organización tiene de acceder a las subvenciones estatales. (In: GALLEGO CASTANERA, C.: Los Partidos Políticos en el Ordenamiento Constitucional Español: Constitución de 1978. ed. Universidad Complutense - Facultad de Derecho, Madrid, 1988. Pp. 42 ss). En este sentido, cfr. también: GARCía COTARELO, R.: Los Partidos Políticos. Op. Cit. Pp. 200-201; como también CASTILLO VERA, P. del. "Financiación de las Elecciones Generales de 1986". In: Revista de Derecho Político. no 25. UNED, Madrid, 1989. Pp. 135-138; y SOLER SÁNCHEZ, M.: Campañas Electorales y Democracia en España. Universitat Jaime, [s.l.], 2001. Pp., 249.

${ }^{74}$ Esto pasa incluso por fuerza del artículo 125.4 de la Ley Orgánica del Régimen Electoral General (a partir de ahora, LOREG), que facilita la ocurrencia de donaciones disfrazadas. (GARCÍA VIÑUELA, E. "La Regulación del..." Pp. 79).

${ }^{75}$ SOLER SÁNCHEZ, M.: Campañas Electorales... Pp. 248 y ss.
} 
que el límite formal a la concesión de créditos no obtiene los efectos pretendidos. $^{76}$

Un aspecto importante que debe subrayarse es que la Ley Orgánica 8/2007 no ha incluido en sus disposiciones ninguna limitación para este tipo de operaciones, a diferencia de la ley anterior. Lo cual significa que los partidos son libres de embarcarse hasta el nivel que estimen necesario en créditos bancarios. $Y$ junto a dicha ausencia de limitación, la disposición transitoria segunda de la Ley Orgánica 8/2007 conlleva también la legalización de la condonación de deudas con las entidades financieras. La existencia de dichas negociaciones aparece ya constatada por el Tribunal de Cuentas, que a la vez requería constantemente la regulación de la materia por parte del Legislativo. Sin embargo, además de permitir la concretización de donaciones disfrazadas (y quizás otros tipos de operaciones irregulares), la nueva normativa liberalizó su régimen. El texto legal remite a los usos y costumbres del tráfico mercantil los parámetros de la realización de dichas negociaciones, lo que deja la cuestión sujeta a no poco margen de inseguridad o incertidumbre dada la materia. Es decir, predomina la anomia tanto en la concesión del crédito, como en el de su resolución, muchas veces, sin la devolución del montante prestado. Ya en el nuevo proyecto de ley para la reforma de la Ley Orgánica 8/2007 existe la previsión de una limitación de valores referentes a las condonaciones de deudas negociadas, siendo el limite, de momento, de cien mil euros anuales. Dicha limitación queda pendiente de su aprobación por el Senado.

Creemos conveniente por ello la existencia de una regulación sobre los criterios tanto de concesión del crédito como de negociación de la deuda. Aunque sea una cuestión bastante complicada, considerando que las entidades financieras tienen una naturaleza mercantil y privada (no importando si el Estado tiene o no participación en ellas), a partir del momento en que ellos prestan una cantidad razonable a los partidos, que son destinatarios de

\footnotetext{
${ }^{76}$ LOPEZ GARRIDO, D. "La Financiación de los Partidos Políticos. Diez Propuestas de Reforma". In: La Financiación de los Partidos Políticos. Cuadernos y Debates, no 47, Centro de Estudios Constitucionales, Madrid, 1994. Pg. 69. No obstante, posiciones en la doctrina que no juzgan el endeudamiento de los partidos políticos de este modo. En ese sentido, véase: GONZÁLEZ-AURIOLES, J. A. "EI Problema Público de Regular Jurídicamente la Financiación Partidaria". In: Teoría y Realidad Constitucional. ํo 6, ㄴo semestre. UNED, Madrid, 2000. Pp. 213-223.
} 
funciones constitucionalmente establecidas y protegidas en pro de la defensa de la democracia, las entidades bancarias también deberían asumir algunas obligaciones, para que realmente se pueda garantizar igualdad y equidad en dichas operaciones bancarias, y por tanto, indirectamente, en un elemento clave de la competición electoral. ${ }^{77}$ Nos parecen correctas las sugerencias de Murillo de la Cueva, que considera que sería bueno limitar tantos los sujetos autorizados a prestar dinero a los partidos, como también limitar la cantidad de dichas operaciones. Además, el autor sugiere que los autorizados sean entidades financieras privadas que no tengan la participación estatal, considerando que el resto de la financiación de los partidos ya está a cargo del Estado, no siendo justo que las entidades públicas asumieran también esta tarea. ${ }^{78}$

Aunque se requieran también ciertas cautelas a la hora de regular el comportamiento de las entidades privadas en el momento de la concesión del crédito, lo que se debe en todo caso garantizar es que dicha operación funcione como cualquier otro préstamo contraído por los ciudadanos, o sea, que se trate de una deuda real, con garantías reales y criterios específicos y definidos. De esta manera, por lo menos, dicha dinámica sería más transparente. Con todo, creo que cabe subrayar que, analizando la actual situación de endeudamiento de los partidos, la condonación de las deudas podría ser una solución necesaria, aunque no la más deseada. Dichas negociaciones deben ser controladas estrictamente por el Tribunal de Cuentas, que a su vez debe de tener mecanismos por hacer valer el deber de colaboración contemplado en el art. 19 de la Ley Orgánica 8/2007. Es importante para la transparencia de las finanzas de los partidos y del propio sistema financiero, a fin de impedir no solo prácticas perjudiciales a la democracia sino deshonestas en general.

\footnotetext{
77 Del mismo modo que se impuso la apertura de una cuenta bancaria específica en las campañas electorales, ya que los bancos no pueden hacer distinción entre las diferentes opciones políticas.

${ }_{78}$ MURILLO DE LA CUEVA, L. "La Financiación de los Partidos y de las Elecciones". In: AA.VV.: Homenaje a Joaquín Tomás Villarroya. Tomo II, Ed. Fundación Valenciana de Estudios Avanzados, Valencia, 2000. Pp. 713.
} 


\section{f) Donaciones particulares o privadas}

Las donaciones de naturaleza privada constituyen, como ya se ha dicho, quizás la manera más común también discutida de financiación de los partidos. No es para menos. Valores concedidos por parte de personas físicas o por empresas y grupos de interés poseen muchas intenciones dependiendo del contexto a que se inserten, además de situarse en el centro del juego de intereses políticos.

Definiciones clásicas como la de GARCÍA COTARELO, que las clasifica como "dádivas voluntarias periódicas" que tienen origen privado son adecuadas para ilustrar lo que son. Las ventajas y desventajas que las donaciones proporcionan van desde la posibilidad de solución rápida de los problemas económicos de las organizaciones políticas constituyendo una forma de participación política por parte de los ciudadanos, hasta también el inconveniente de ser una arma para influir en la agenda política o una posible dependencia de los partidos frente a estos grandes donantes, viéndose "obligados" (dentro de la dinámica del cambio de favores) a concederles algún tipo de privilegio en los programas partidistas, o incluso en el gobierno, cuando el partido que recibió donaciones acceda a cuotas de poder. ${ }^{79}$ Justamente es la posible dependencia de los partidos, y la influencia desmedida de los donantes, la que vuelve esta fuente de financiación tan polémica, y la que la convierte en objeto de una regulación mayor, como son, por ejemplo, los límites máximos de donaciones, las prohibiciones de recursos de determinados donantes, y tantas otras restricciones.

Aunque las donaciones hayan perdido gran parte de su protagonismo en la financiación de los partidos políticos en muchos países - a diferencia de lo que ocurría a comienzos del siglo $X^{80}$ - su importancia dentro del sistema es innegable, considerando que la presencia de mecanismos de financiación privada pueda colaborar con la salud de todo el sistema de partidos. Existe una

\footnotetext{
${ }^{79}$ GaRcía COTARelo, R.: Los Partidos Políticos. Op. Cit. Pp. 198.

${ }^{80}$ MARTÍNEZ SOSPEDRA, M. "La Financiación..." Pp. 20. A la vez, FERNANDEZ -LLEBREZ argumenta que el origen de las donaciones privadas fue en los partidos conservadores, en los que había una relación entre determinados intereses privados y los candidatos, haciendo que hubiera individuos dispuestos a pagar por las campañas. (In: FERNANDEZ-LLEBREZ, F. Op. Cit. Pp. 177).
} 
verdadera "policromía" doctrinal sobre el tema, ya que la tarea de recaudar recursos permite una aproximación de los partidos a la sociedad, además de encuadrarse en sentido material en el derecho de los ciudadanos a participar de la vida política. ${ }^{81}$ Hay que evaluar igualmente que las donaciones no poseen carácter periódico, y que aunque puede existir el riesgo de comprometer la independencia de los partidos, al mismo tiempo permite mantener este vínculo entre donantes y formaciones políticas. ${ }^{82}$ Claro está que un sistema basado solamente en la financiación privada a partir de las contribuciones, acaba por distorsionar los buenos efectos que puedan tener, como la influencia determinante de ciertos sujetos, empresas o grupos de ellos - tanto lícita o ilícitamente - ante la "desesperación" de los partidos en conseguir recursos para costear sus gastos. Sin embargo, la nítida señal de enraizamiento del partido en la sociedad representada por un buen nivel de donaciones privadas podría ser bien manejada con límites máximos a las contribuciones individuales, y otras garantías presentes en las legislaciones sobre este punto. ${ }^{83}$

No es factible querer alejar a los partidos de los recursos privados ajenos. El dinero procedente de donaciones privadas siempre estará presente en las arcas de dichas organizaciones y cuanto más duras sean las normas prohibitivas, probablemente serán más ineficaces. Ejemplo de ello son las normas limitativas de los EE.UU. en la época del escándalo de Watergate (conforme será descrito a continuación), y en el propio sistema español (valga el caso Filesa), que aunque muy rígido en relación a las donaciones privadas, como no cuenta con una fiscalización fuerte, no se puede afirmar que sean reglas eficaces. Basta un breve análisis en los informes del Tribunal de Cuentas para tener la impresión de que la propia ley fue usada para el fraude de las reglas prohibitivas de las donaciones y lo normal sería que no se

\footnotetext{
${ }^{81}$ MURAYAMA, C. "Dinero, Medios y Elecciones". In: Revista Nexos, no 331, julio, 2005. <<http://www.nexos.com.mx/articulos.php?id_article=429\&id_rubrique=150 > Acceso en: 23.05.09. Pp. 4.

${ }^{82}$ FERNANDEZ-LLEBREZ, F. Op. Cit. Pp. 177.

83 ZOVATTO G., D. "La Financiación Política en Iberoamérica: Una Visión Preliminar Comparada". In: CASTILLO, P. del; ZOVATTO G., D. (eds.): La Financiación de la Política en Iberoamérica. $1^{\circ}$ ed. IIDH/CAPEL, San José, 1998. Disponible en: <<http://www.iidh.ed.cr/comunidades/redelectoral/docs/red_publinea/indice-financiacion.htm>> Acceso en 17.06.2009.
} 
produjeran cambios significativos, considerando las nuevas lagunas legales que la Ley Orgánica 8/2007 posee.

Cuando se habla de donantes no nos referimos prioritariamente a ciudadanos donando sus recursos económicos en favor de una opción política, sino a empresas, personas jurídicas que poseen un evidente potencial para colaborar con los partidos y en la realización de sus campañas. Aunque no se descarte que existan ciudadanos que realizan donaciones por altruismo, el hecho más común es encontrar a empresas importantes detrás de donaciones significativas, y aquí reside la mayor cantidad de casos de corrupción. Los grandes escándalos involucrando financiación de partidos y donaciones de empresas tienen un largo recorrido histórico y no alcanzan solamente a España, sino a todos los países democráticos. Incluso países donde se regula el lobbying, como es el caso de EE.UU., no están exentos de estos problemas. Debido a todo ello, hay una parte de la doctrina que aboga por la prohibición total de donaciones realizadas por empresas ${ }^{84}$, algo que, bajo mi punto de vista, no resulta oportuno ante todo por su posible ineficacia.

Existen muchas cuestiones problemáticas en torno las donaciones, y ello queda claro al analizar la legislación comparada. Hay rasgos comunes entre la regulación de la cuestión por muchos países, como la prohibición de recursos donados por determinados entes, los límites a los valores de las donaciones, etc., lo que se justifica porque las donaciones en realidad deberían tener un perfil más de ayuda. Sin embargo, la idea procedente de los partidos de cuadros de que las donaciones deberían ser significativas y constantes hace que se produzca una desigualdad considerable entre las formaciones como un todo. ${ }^{85}$ Es cierto que, dependiendo de la posición del partido dentro del espectro político, será más favorecido o no por las donaciones privadas, ya que la posición ideológica del partido no resulta una variable independiente del nivel socio-económico de sus potenciales electores, generando una desigualdad que puede afectar la igualdad de condiciones en la contienda electoral. $Y$ justamente por ello se justifica una regulación limitativa de esta fuente de

\footnotetext{
${ }^{84}$ En este sentido, cfr. SATRUSTEGUI GIL DELGADO, M. "La Reforma Legal de los Partidos Políticos". In: Revista Española de Derecho Constitucional. año 16, № 46, ene/abr, 1996. Pp. 101.

${ }^{85}$ MARTÍNEZ SOSPEDRA, M. “La Financiación...” Pp. 20-21.
} 
financiación privada, en un intento de al menos controlar un eventual desequilibrio en las posibilidades políticas de cada organización. ${ }^{86}$

Pero los problemas que conlleva la cuestión de las donaciones privadas van mucho más allá del flujo de recursos entre individuos o empresas y partidos. Aunque en España no se haya debatido con tanta profundidad el tema bajo este aspecto, el derecho a la libertad de expresión es invocado muchas veces en este punto, porque tanto los ciudadanos de manera individual como a través de una corporación, tienen el derecho de declarar su simpatía por una opción política, y a colaborar económicamente con ella. El conflicto existente entre la transparencia y el control de las finanzas partidistas y el derecho a libertad de expresión resurge muy frecuentemente en países como los EE.UU, en cada cambio en la legislación sobre la financiación de partidos. Y como en aquél país la libertad de expresión integra decisivamente el contenido de la First Amendment de la Constitución norteamericana, la cuestión suele decidirse por la Supreme Court de manera definitiva, por lo menos hasta la próxima discusión. ${ }^{87}$ Junto a dicho problema, existen otros aspectos de difícil tratamiento, como el control de las finanzas de los partidos y la publicidad de sus datos, lo que entra a la vez en conflicto con el secreto de voto o con el eventual derecho al anonimato. Todas esas vicisitudes dependerán en alto grado de la cultura política del país donde se las discute, pero independientemente de ello, ninguna solución será perfecta a largo plazo.

\footnotetext{
${ }^{86}$ Comparte esta posición ZOVATTO, que entiende que pueden haber dos tipos de donaciones: aquellas que el donante hace porque quiere realmente participar en la política y apoyar a su partido de preferencia, y aquellas en que el donante está interesado en adquirir influencia política o comprar acceso a cualquier de los privilegios que la política puede ofrecerle. (In: ZOVATTO, D.: Dinero y Política en América Latina: Una Visión Comparada. International IDEA, Lima, 2003. Pp. 43). Como caso empírico, el éxito de Barack Obama en las elecciones de 2008 para la presidencia de los Estados Unidos fue viabilizado también por el montante realmente considerable de recursos de pequeñas donaciones, pero en cantidades masivas. El presidente electo logró recaudar 747.8 millones de dólares, sin considerar lo que el partido demócrata ha logrado recaudar por sí solo. Del montante recaudado por Obama, el $91 \%$ lo fue a través de contribuciones individuales; y solamente $9 \%$ lo fue a través de PAC's y otras contribuciones. Debe tenerse en cuenta también que la utilización de medios como el internet colaboró con el resultado. (Fuente: <<http://www.fec.gov/DisclosureSearch/mapApp.do?cand_id=P80003338\&searchType=\&searc hSQLType=\&searchKeyword=>> Acceso en 16.07.10). También sobre el record de recaudación de 66 millones de dólares a favor de Obama, cfr. Obama bate en Agosto el Récord de Recaudación de la Campaña. El País. 15 de septiembre de 2008.

${ }^{87}$ El tema será tratado más pormenorizadamente en el punto 4.1 de este capítulo, al tratar del sistema de financiación estadounidense.
} 
Sin embargo, lo que no puede obviarse es que los grupos de interés siempre estarán presentes en la financiación de los partidos, y que las donaciones tanto para partidos "conservadores" como para los "progresistas" son muy importantes, incluso limitadas en su montante, ya que estas donaciones requieren un esfuerzo por parte del propio partido para captarlas. ${ }^{88}$ Por ello, los sistemas mixtos de financiación ganan fuerza, justamente porque equilibrando medidas de financiación pública con algunas privadas se puede llegar a un punto optimo de protección de los valores jurídicos que están en juego.

\section{g) Actividades empresariales o generales}

Las actividades generales de los partidos que también pueden ser fuente de ingresos suelen tener relación con actividades que involucran a su patrimonio, es decir, se trata de alguna actividad ejercida por el partido dentro de la esfera privada, en el mercado. Los dividendos obtenidos con dichas actividades pueden ser utilizados para el soporte ordinario de los partidos políticos $\mathrm{y}$, aunque dichas organizaciones sean asociaciones sin fines lucrativos, existe la posibilidad de que ejerzan alguna actividad que genere ganancias. ${ }^{89}$ Sin embargo, esto no es común, ya que generalmente cuando un partido intenta algún tipo de actividad mercantil, la experiencia muchas veces queda lastrada por la falta de experiencia en la dinámica de los mercados, o por la propia falta de cultura de competencia gerencial, además del hecho de que muchas actividades mercantiles no son en el fondo compatibles con el perfil de los partidos, y acaban por vincularse con actividades irregulares 0 ilícitas, o incurriendo en supuestos encubiertos de tráfico de influencias. ${ }^{90}$

\footnotetext{
${ }^{88}$ MARTÍNEZ SOSPEDRA, M.: Introducción a los... Pp. 76. Incluso el autor resalta que en los EE.UU. se respetan mucho las donaciones de bajo valor, como pasó en el caso de las elecciones de Barack Obama.

${ }^{89}$ Como pasó con el Partido Nacional Vasco (PNV) en 1997, cuando este invirtió en la bolsa de valores y obtuvo ganancias.

90 BOURSAULT, L. T. "La Financiación de los Partidos Políticos". In: AA.VV.: Jornadas de Estudios sobre el Título Preliminar de la Constitución. vol. III. Secretaria General Técnica Ministerio de Justicia, Madrid, 1988. Pp. 1939. MARTINEZ SOSPEDRA sostiene que fueron frecuentes los intentos de los partidos en recaudar recursos a partir de actividades empresariales, pues había la posibilidad de que fueran intentos exitosos. Sin embargo, la combinación entre la racionalidad económica con la política no es tan posible como se
} 
En España, antes de la Ley Orgánica 8/2007 algún partido obtenía beneficios con estas actividades, pero con la actual legislación, el ejercicio de cualquier actividad de carácter económico y mercantil queda prohibida en virtud del art. 6, y tan solo las actividades "propias" ejercidas por estas organizaciones y que estén relacionadas con el fin último de los partidos no están vetadas conforme el art. 2.2.

\section{h) Ingresos atípicos}

Algunos autores apuntan a los ingresos atípicos de los partidos políticos como fuente de financiación. ${ }^{91}$ Sin embargo, su análisis se complica debido a la falta de datos fiables sobre esta zona gris. De lo que no cabe duda es de que dichos ingresos están presentes en las finanzas de prácticamente todos los partidos, siendo muchas veces el resultado de prácticas corruptas o de actos irregulares, es decir, puede que no sean delito por la ausencia de su tipificación penal, pero como constituyen violaciones a las reglas de financiación de partidos, son irregulares. Como ejemplo se podría citar a las donaciones extrajeras, al tráfico de información privilegiada; el otorgamiento de contratos, concesiones administrativas y licencias; el cobro de comisiones; y también donaciones ocultas o la asignación de funcionarios y empleados públicos. ${ }^{92}$

Por el interés general, las cámaras legislan sobre la financiación de partidos y corrupción. Dichas reglas buscan la protección jurídica penal de la función pública, e inciden directamente en el sistema de financiación elegido porque los partidos tienen funciones constitucionales y por estar íntimamente conectados con la democracia. Así, la financiación irregular es resultado de una disfunción del sistema de partidos, ya que se produce una utilización de funciones públicas para satisfacer el interés privado de los partidos, sea para

pensaba. (In: MARTíNEZ SOSPEDRA, M. "La Financiación..." Pp. 21). Con todo, el autor cita áreas como export-import y comercio exterior, como también actividades editoriales, como siendo áreas "exitosas" para los partidos. (MARTíNEZ SOSPEDRA, M.: Introducción a los... Pp. 76-77). Algunas de estas actividades pueden ser encontradas en el punto 1.4.2 del Cap. IV, cuando se trata sobre los informes del Tribunal de Cuentas de sobre las actividades ordinarias de las formaciones políticas.

${ }^{91}$ En ese sentido, véase GARCíA COTARELO, R.: Los Partidos Políticos. Op. Cit. Pp. 201-202, y otros tantos.

${ }^{92}$ Cfr. MARTíNEZ SOSPEDRA, M. “La Financiación...”. Pp. 22-23; FERNANDEZ-LLEBREZ, F. Op. Cit. Pp. 179; y RODRIGUEZ LÓPEZ, A.: Contabilidad... Pp. 85 y ss. 
obtener ventajas, sea para lograr supervivencia económica. Debido a ello, tratar de esta fuente de financiación aisladamente del análisis de la corrupción propiamente dicha implicaría distorsionarlo, y por ello ambos puntos serán tratados conjuntamente al final de este capítulo.

\section{2) La adopción de medidas de financiación pública de los partidos y su adecuación a las actuales condiciones de los sistemas democráticos}

A partir de la constitucionalización de los partidos políticos, proceso acentuado después de la segunda guerra mundial, se empezaron a cuestionar algunos elementos de la regulación jurídica de los partidos. Uno de los puntos que se discutió abundantemente fue la manera en que los partidos políticos iban a hacer frente a sus gastos, ante el cambio que se produjo en la relación de dichas organizaciones y la sociedad considerando aspectos como la disminución de las afiliaciones, la profesionalización de la política, y la flexibilización de las ideologías en el seno de los mismos. ${ }^{93}$ Así se afianzó la primacía de la financiación pública ${ }^{94}$ de los partidos políticos. Utilizando el

${ }^{93}$ Vid por todos LÓPEZ GUERRA, L. "El Carácter Instrumental de las Organizaciones Partidistas de Masa". In: VEGA, P. de (ed.): Teoría y Práctica de los Partidos Políticos. Edicusa - Cuadernos para el Diálogo, Madrid, 1977. Pp. 107; OFFE, C. "Democracia de Competencia entre Partidos y el Estado de Bienestar Keynesiano: Factores de Estabilidad y de Desorganización". In: OFFE, C.: Partidos Políticos y Nuevos Movimientos Sociales. ed. Sistema, Madrid, 1988. Pp. 65; MAIR, P.: Party System Change: Approaches and Interpretations. Clarendon Press, Oxford, 1997. Pp. 101-102. Para un análisis de esta evolución en la tipología de partidos, hasta los partidos catch all, cfr. LOPEZ GUERRA, L. "Sobre la Evolución de las Campañas Electorales y la Decadencia de los Partidos de Masas". In: Revista Española de la Opinión Pública. № 45, jul/sept, Madrid, 1976. Pp. 92-98, donde el autor destaca incluso el fenómeno propagandístico que acompañó estos resultados. Además, es interesante destacar la comparación de de la teoría del partido burocrático de masas para el profesional electoral de Panebianco, y la de Kirchheimer. El autor expone en términos más claros que el modelo que sucede a los partidos de masas cuenta, básicamente, con la especialización de la elección de los nichos electorales, y de los aportes económicos para las campañas venidos desde el Estado. El autor, así, demuestra que Kirchheimer trataba de la ideología de los partidos y su relativización, mientras él se centra en la parte administrativa de dichas organizaciones. Así, cfr. PANEBIANCO, A.: Modelli di Partiti: Organizzazione e Potere nei Partiti Politici. Bologna, 1982. Pp. 480 y ss. A su vez, Martínez Sospedra cita como ejemplos de esta evolución hacia el partido catch all a los partidos SPD alemán (Sozialdemokratische Partei Deutschlands) y el PSF francés (Parti Social Français). (In: MARTíNEZ SOSPEDRA, M. "La Financiación de los Partidos Políticos. Ensayo de Aproximación". In: Cuadernos Constitucionales de la Cátedra Fadrique Furió Ceriol, № 11/12, Valencia, oe época, 1995. Pp. 56).

${ }^{4}$ BIANCO entiende que la financiación pública de la política aumentó la responsabilidad del Estado en el sentido de proveer de los recursos necesarios a los partidos y también de evitar las ilegalidades, combatiendo también que el dinero sea un factor decisivo para el éxito en las 
concepto de Blanco Valdés, podríamos definirla como "el sistema consistente en otorgar a los partidos subvenciones procedentes del erario del Estado destinados a cubrir los gastos realizados por ellos en el desarrollo de sus actividades". 95

El sistema de financiación fue adoptado primeramente en Uruguay (1928), Costa Rica $(1949)^{96}$, seguida de Argentina (1961) y Alemania Occidental $(1959)^{97}$, siendo esta la primera en modular dicha financiación en dos partes, una de ellas como contribuciones destinadas a instituciones partidarias con fines no directamente electorales (las fundaciones de los partidos políticos principalmente), y la otra como reembolso de los gastos de campaña. $^{98}$

En los comienzos de la legislación específica sobre financiación de los partidos políticos, existía una cierta preferencia por la limitación de gastos de las formaciones políticas y de los candidatos, como también por la imposición de restricciones sobre algunas contribuciones a fin de controlar las diferencias de oportunidades de los partidos. ${ }^{99}$ También se pretendía evitar que

urnas. (In: BIANCO, A.: // Finanziamento... Pp. 4-5). También, cfr. GIL CASTELLANO, J. Op. Cit. Pp. 249, como ejemplo de la doctrina que trata sobre las causas de la adopción de la financiación pública.

${ }^{95}$ BLANCO VALDÉS, R. L: Los Partidos Políticos. Tecnos, Madrid, 1990. Pp. 192. En el mismo sentido, cfr. NASSMACHER, K-H. "Structure and Impact of Public Subsidies to Political Parties in Europe: the Examples of Austria, Italy, Sweden and West Germany". In: ALEXANDER, H. E. (ed.): Comparative Political Finance in the 1980's. Cambridge University Press, UK, 1989. Pp. 238; y HOLGADO GONZÁLEZ, M.: La Financiación de los... Pp. 63. Sin embargo, cabe destacar el entendimiento de CRESPI, de que es necesaria una ley que destine recursos públicos a las fuerzas políticas para que sea financiación pública. Si no hay ninguna ley, se trata de financiación privada, aunque sean recursos del Estado, pero sin disposición legal en este sentido. (In: CRESPI, Roberto: Lo Stato deve Pagare i Partiti? II Problema del Finanziamento dei Partiti Politici in Italia. Ed. Sansoni, Firenze, 1971. Pp. 25-26).

${ }_{96}$ Un dato interesante es expuesto por ZOVATTO, que afirma que la financiación pública no fue priorizada en el comienzo de la transición política en América Latina, pero conforme la importancia del tema fue creciendo, también fue ocupando un lugar en la agenda política de los países de la región, hecho este que provocó importantes debates sobre las maneras de volver las elecciones más justas, con más transparencia en la rendición de cuentas acerca del origen y asignación de recursos públicos y privados, y de impedir el tráfico de influencias y la corrupción política, evitando también el ingreso de dinero por parte del crimen organizado. (In: ZOVATTO, D.; FREIDENBERG, F. "Democratización Interna..." Pp. 216).

97 NASSMACHER, K-H. "Structure and Impact..." Pp. 238. Según DEL CASTILLO, en las democracias occidentales la financiación pública es un rasgo común en las legislaciones. (In: CASTILLO VERA, P. del: La Financiación de Partidos y Candidatos... Pp. 64-65).

${ }^{98}$ NASSMACHER, K-H. "Structure and Impact..." Pp. 239.

99 Desde el punto de vista de MEZZETTI, las limitaciones al coste de las campañas electorales y las medidas de financiación privada interesaban evitar que la política pública se alterara en función de una donación excesiva. (In: MEZZETTI, L. "Finanziamento e Condizionamiento del Partito Político". In: AA.VV.: Anuario 2008: Partiti Politici e Società Civile a Sessant'anni 
dependieran de algún grupo con intereses particulares que no fueran compatibles con la naturaleza democrática de un gobierno representativo. ${ }^{100}$ Posteriormente, se constató que dichas medidas acabaron por ser puramente paliativas (como es el caso de las prohibiciones de algunos tipos de donaciones y la prohibición de algunos donantes, o la limitación en gastos o en donaciones), y se empezaron a adoptar medidas de financiación pública de los partidos. ${ }^{101}$ Ello significaba que el Estado debería contribuir a sostener las organizaciones políticas, permitiendo que estas cumplieran sus funciones, aunque hay autores que atribuyen el surgimiento de la financiación pública en los años ochenta a una respuesta a la dominación del dinero de origen privado en la política, su abuso, y las influencias privadas en las políticas nacionales. ${ }^{102}$

La idea de que el Estado debería contribuir a la financiación de los partidos tiene su origen en su consideración como elementos imprescindibles de los sistemas democráticos europeos de posguerra. La importancia conferida a los partidos en la democracia, aun acompañada de la idea de que los partidos no eran los únicos articuladores de la voluntad popular en el sistema, pero sí en todo caso los actores necesarios en este proceso, acabó por abrir los caminos a la financiación pública y para la regulación de su organización y actividad en la democracia moderna. ${ }^{103}$

El modelo de financiación pública fue más difundido en el contexto europeo, y las razones suelen coincidir en los distintos países. Son varias las motivaciones para el empleo de recursos públicos en el sostenimiento de los partidos, siendo la primera la que se relaciona principalmente con la idea de inversión en la democracia y la consecuente disminución de los recursos partidistas y en su renta causada por dicha inversión. Si las campañas y la

dall'entrata in Vigore della Costituzione - Atti del XXIII Convegno Annuale Alessandria, 17-18 Ottobre, 2008. ed. Jovene, Napoli, 2009. Pp. 121).

100 CASTILLO VERA, P. "La Financiación Pública de los Partidos en España". In: Revista de Derecho Político. oㅡ 22. UNED, Madrid, 1986. Pp. 149.

101 CASTILLO VERA, P. del: La Financiación de Partidos y Candidatos... Pp. 64 y ss y ALEXANDER, H. E. "Money and Politics..." Pp. 12-23.

${ }_{102}$ Cfr. ALEXANDER, H. E. "Money and Politics..." Pp. 19.

${ }^{103}$ Cfr. BLANCO VALDÉS, en sus diversos trabajos, como "La Problemática..." Pp. 164 y EI "Régimen Jurídico Regulador de la Financiación de los Partidos Políticos en España". In: Justicia Electoral - Revista del Tribunal Federal Electoral. n‥ 5. vol. IV, MX, 1995. Pp. 99. También, cfr. GARCÍA LAGUARDIA, J. M. "La Financiación Política en América Latina". In: AA.VV.: Derecho Constitucional para el Siglo XXI - Actas del VIII Congreso Iberoamericano de Derecho Constitucional, Tomo II. Ed. Thompson - Aranzadi, Sevilla, 2006. Pp. 2636-2637. 
política se han vuelto más caras por la profesionalización de los partidos, también debían recaudar más dinero. ${ }^{104} \mathrm{El}$ fuerte incremento que sufrieron los gastos electorales en los años 50 y 60 a partir de la necesaria utilización de los medios de comunicación de masas ${ }^{105}$, provocó el aumento de las necesidades de recursos procedentes de grupos de interés a cambio de ventajas ante el legislativo y el gobierno, culminando con el surgimiento de grandes escándalos de corrupción. ${ }^{106}$ Se trataba pues no solo de encontrar una solución al problema de la falta de fondos para afrontar económicamente las campañas, sino también de prevenir nuevas situaciones que contribuyeran a deslegitimar el proceso democrático.

Así, el combate a la financiación irregular y a la corrupción se constituyó como un fuerte estimulo para la adopción de medidas de financiación pública, aunque actualmente se sea consciente de que no fue exitoso respecto a este fin, no porque no fue condición suficiente, sino también por haberse producido una crisis correlativa de los sistemas tradicionales de financiación - como la disminución considerable del pago de la cuota de afiliados - incluyendo la propia crisis del modelo de partidos de masa y las necesidades de los partidos de formato "catch all" en tiempos contemporáneos. ${ }^{107}$ La paulatina disminución de la afiliación, generada por la pérdida de identificación entre ciudadanos y partidos $^{108}$ y falta de ideología por parte de las formaciones políticas ${ }^{109}$ afectó

${ }^{104}$ Es un fenómeno consecuencia de la transformación de la sociedad en una "sociedad de información", donde la mass media ejerce un poder cada vez más determinante. Cfr. BLANCO VALDES, R. L. "El Régimen Jurídico..." Pp. 99.

${ }^{105}$ El año de 1960 es especialmente citada por BLANCO VALDÉS, porque era el año de las elecciones presidenciales en los EE.UU., y fue la primera vez que se notó realmente la gran influencia que la mass media estaban empezando a ejercer en la política. (In: BLANCO VALDES, R. L. "EI Régimen Jurídico..." Pp. 100).

${ }^{106}$ El escándalo Watergate, de Nixon, en EE. UU. puede ser citado como ejemplo. Aunque no involucraba solamente a la financiación irregular de campañas, este fue un facto desencadenante.

${ }^{107}$ BLANCO VALDÉS, R. L.: Las Conexiones Políticas: Partidos, Estado, Sociedad. Alianza Editorial, Madrid, 2001. Pp. 63-64. Debido al fallo de la financiación pública en combatir la corrupción, hay autores que abogan incluso por la adopción de un modelo de financiación exclusivamente público y totalmente limitado. Cfr. ESPARZA MARTíNEZ, B. Op. Cit. Pp. 131132). En este trabajo no se está de acuerdo con ningún modelo puro, sea público o privado, ya que comparte la idea de que sistemas puros provocan mucho más distorsiones que sistemas mixtos.

${ }^{108}$ VAN BIEZEN afirma que, con la crisis de militancia, los partidos políticos perdieron muchas personas que antes trabajaban voluntariamente para la organización. Esto hizo que hubiera una sustitución de dichos voluntarios por profesionales pagados, y junto con la pérdida de dinero provocada por la falta de pago de las cuotas, los partidos políticos tuvieron que buscar otros medios de recaudación de recursos. A partir de esa lógica, la autora entiende que la 
también a sistemas políticos que han sido redemocratizados, pues la súbita legalización de estos partidos sin estructuras organizativas razonables para cumplir con sus funciones políticas (por su reciente creación, o porque pocos pudieron mantenerse estructurados durante largas épocas de represión política) hizo que se introdujera de manera muy rápida - y quizás poco reflexiva - modelos muy preponderantes de financiación pública en estos países (como en el sur de Europa $)^{110}$, lo que acabó por generar serias distorsiones. Los partidos necesitaban de soporte financiero para desempeñar su papel, siendo la financiación pública directa e indirecta una solución, quizás la única, viable. ${ }^{111}$

La segunda motivación importante está relacionada con la igualdad de oportunidades, con la justicia y el equilibrio en la competición electoral, alcanzando principalmente a los partidos que no disponen de las mismas oportunidades que los más grandes o tradicionales, o que no tienen programas partidistas que interesen a determinados sectores de la sociedad o intereses estabilizados por organizaciones sociales. ${ }^{112}$ La ineficacia de las medidas de limitación de gastos y contribuciones a la hora de resolver problemas de igualdad de oportunidades y de la dependencia de los partidos de los grupos de interés ${ }^{113}$, determinó la apuesta por las ayudas económicas estables para

intervención estatal fue necesaria para garantizar la existencia de los propios partidos. (VAN BIEZEN, I. "Political Parties as Public Utilities". In: Party Politics. v. 10. no 6. Sage, London, 2004. Pp. 706).

${ }^{109}$ Cfr. MARTíneZ SOSPEDRA, M. "La Financiación..." Pp. 24 y VAN BIEZEN, I. "Political Parties as Public..." Pp. 706.

${ }^{110}$ Argumentando que la financiación pública fue la solución para las dificultades económicas de los partidos en casi todas las democracias consolidadas, con excepción a Suiza, Nueva Zelandia y por cierto modo a Reino Unido, cfr. PIZZIMENTI, E.; IGNAZI, P. "Finanziamento Pubblico e Mutamenti Organizzativi Nei Partiti Italiani”. In: Rivista Italiana di Scienza Política. no 2, anno XLI, agosto, II Mulino, Bologna, 2011. Pp. 200.

${ }_{111}$ VAN BIEZEN, I. "Political Parties as Public..." Pp. 705-709. La autora sigue resaltando la igualdad de condiciones en la competición electoral como razón fundamental para la adopción de este sistema en las democracias jóvenes, ya que la participación de organizaciones comunistas contaban con su continuidad organizacional desde cierto tiempo, lo que les conferían ventajas sobre las nuevas fuerzas políticas.

${ }_{112}$ Cfr. BLANCO VALDÉS, R. L: Los Partidos Políticos. Op. Cit. Pp. 192, en que el autor entiende que la financiación pública es una medida positiva dentro de un conjunto de medidas de intervención negativas para alcanzar la concretización del principio de igualdad y del pluralismo político.

${ }_{113}$ MARTíNEZ SOSPEDRA afirma que un sistema de financiación pública nunca vendrá resulta aislado, es decir, siempre estará acompañado de mecanismos de control de partidos, como es la limitación de donaciones y gastos, medidas fiscales especiales, y otras. (In: MARTíNEZ SOSPEDRA, M. “La Financiación...” Pp. 25). 
democratizar la financiación. El reconocimiento constitucional de los partidos junto con el sistema de subvenciones públicas, garantizaría a la postre su propia función dentro del sistema democrático. ${ }^{114}$ Por otra parte, con la disminución de la influencia del dinero privado, se limitaría igualmente el poder de distorsión que este tiene sobre la democracia. ${ }^{115}$

También es interesante considerar contextos distintos al europeo cuando se analizan las motivaciones por las cuales se adoptó la financiación pública en los sistemas políticos de determinados países. En el caso de los Estados Unidos, se puede afirmar que los fondos públicos se reconocieron como forma de paliar la necesidad de recursos que los candidatos tenían para presentar sus ideas o a sí mismos ante el electorado. La ayuda pública también fue pensada para disminuir las necesidades de financiación a través de donantes adinerados, o de grupos de interés, minimizando su influencia excesiva en los partidos políticos. En relación a las primarias, la financiación pública tenía como intención volver dicho proceso más competitivo, así como para animar a los candidatos a ampliar sus bases de apoyo, buscando un mayor número de pequeños contribuyentes. Además, la financiación pública jugó un cierto papel en la fase de primarias en candidaturas de nombres no muy conocidos por la sociedad, existiendo casos como de Jimmy Carter y George Bush en que sin la financiación pública, no hubieran estado en condiciones de triunfar en sus respectivas nominaciones. ${ }^{116}$

En el caso de América Latina, con los partidos ubicándose en el centro de la política a partir de la redemocratización junto con el encarecimiento de las campañas electorales (la "mercadotecnia"), con asesores profesionales (algunas veces profesionales extranjeros), las encuestas y los "focus groups",

${ }^{114}$ CASTILLO VERA, P. del: La Financiación de Partidos y Candidatos... Pp. 65-66. Sin embargo, existen otras razones que no se corresponden exactamente con un discurso políticamente correcto, pero que igual tienen su lógica. Hay quien entiende que la financiación pública se justifica por el hecho de que el partido que triunfa en la democracia debe recibir su recompensa, ya que su trabajo es el resultado de muchos hombres que se dedican a la política. Además, también se puede considerar que la financiación pública fue elegida dado que no fue posible encontrar otro medio capaz de garantizar el cumplimiento de las funciones de los partidos políticos. (In: GALLEGO CASTAÑERA, C.: Op. Cit. Pp. 38). Se resalte que la visión de mercado expuesta por la autora no parece ser la más correcta en este contexto.

${ }_{115}$ VAN BIEZEN, I. "Political Parties as Public..." Pp. 707.

${ }^{116}$ ALEXANDER, H E. "American Presidential Elections Since Public Funding - 1976-1984". In: ALEXANDER, H. E. (ed.): Comparative Political Finance in the 1980's. Cambridge University Press, UK, 1989. Pp. 95-106. 
todo ello dio ocasión para el surgimiento de una importante financiación ilegal (ya que lo importante era conseguir recursos, sin importar mucho su origen). ${ }^{117}$ Debido a ello, casi todos los países cuentan con algún tipo de financiación pública, sean subvenciones directas (recursos o bonos) o indirectas (como servicios, beneficios tributarios, capacitación, etc). ${ }^{118} \mathrm{El}$ modo de distribución puede ser de dos maneras, o bien combinando una alícuota para todos los partidos políticos y otra según su fuerza política, o bien integrando la representación parlamentaria. También, en la mayoría de los países de la región hay un umbral para acceder a las subvenciones públicas, y los recursos pueden ser entregados en forma de reembolso de gastos, o en dos partes, una antes de las elecciones y otra después, o todo previamente. ${ }^{119}$ Dicho panorama deja claro que en la región el papel de la financiación pública también es considerable. $^{120}$

Ante esto, la igualdad de oportunidades entre los competidores está presente como finalidad en casi todos los aspectos que involucran a la financiación pública, y por ello nos detendremos brevemente en ella antes de profundizar en este modelo de financiación.

\footnotetext{
117 ZOVATTO, D.: Dinero y... Pp. 11-12. El autor cita como casos de financiación ilegal la narco-financiación, un problema desgraciadamente muy común en la región.

118 ZOVATTO entiende que la financiación pública directa puede ser de tres tipos: *la subvención de gastos electorales; *la de las operaciones permanentes del partido; "para investigación y fortalecimiento institucional de los partidos políticos. (In: ZOVATTO, D.: Dinero y... Pp. 34). Consideremos aquí solamente las subvenciones electorales y para las actividades ordinarias como financiación pública directa. Los recursos públicos destinados a otras actividades o entidades vinculadas a los partidos políticos serán entendidos como financiación indirecta.

119 ZOVATTO, D.: Dinero y... Pp. 19.

120 Esta comparación entre Europa, EE.UU. y América Latina se refleja en el pensamiento de VON BEYME, que entiende que hay dos tradiciones en la actitud de financiar a los partidos políticos con recursos públicos: 1) La anglosajona, que objetiva mantener la competencia en el mercado, estableciendo límites máximos de gastos para los partidos, pero que no están preparados para una ayuda directa; 2) la tradición continental, en la cual la financiación pública es más considerada una cuestión social que un asunto jurídico, para combatir la corrupción, y para ello se introduce el reembolso de los gastos para la campaña electoral. Sin embargo, en las dos formas el autor apunta una zona (que él denomina de gris) para las ayudas indirectas, que pueden tener muchas naturalezas. (In: VON BEYME, K.: Political Parties... Pp. 204-207).
} 


\subsection{La igualdad de oportunidades dentro del contexto de la financiación pública - El problema de la elección de los criterios de acceso y reparto de las subvenciones públicas}

La igualdad material traduce algo que se logra de manera progresiva dentro de un Estado democrático de Derecho. La dificultad de su aplicación reside justamente en determinar que criterios deben ser utilizados para concretizar dicha igualdad. La democracia es también influencia, y los partidos son el instrumento a través del cual los ciudadanos participan e influyen en la política. ${ }^{121}$ La existencia o ausencia de una regulación de la financiación de los partidos incide directamente en la igualdad de oportunidades justamente porque es un punto central en un correcto funcionamiento del sistema democrático. ${ }^{122}$

La idea de igualdad de oportunidades sugiere que, dada una situación de competencia en la que sus participantes sean distintos entre sí, sólo serán aceptadas ventajas procedentes de las características que les diferencian, sin considerar las ventajas que provengan del resto de sus características. En el campo electoral, quién debe decidir qué es relevante y que no como factor de diferencia es el legislador electoral, ya que hay que identificar lo que contribuye a la participación popular y lo que falsea dicha participación. Todo ello está conectadocon el deber de los poderes públicos de compensar las desigualdades diagnosticadas e identificadas empíricamente. ${ }^{123}$

A la vez, el principio de la concurrencia entre los partidos políticos presupone no sólo la garantía de la libre competencia, sino también una

\footnotetext{
${ }^{121}$ MORLOK, M. "La Regulación Jurídica de los Partidos en Alemania". In: Teoría y Realidad Constitucional. № 6, 2o semestre, UNED, Madrid, 2000. Pp. 46-47.

${ }_{122}$ LANCHESTER, F. "Finanziamento della Política e Uguaglianza delle Opportunitá". In: Quaderni Constituzionali. Anno XIX. № 1, Aprile. Ed. II Mulino, Bologna, 1999. Pp. 128. Como sugerencia de lectura, cfr. RIDOLA, P. "Finanziamento della Política ed Eguaglianza delle Chances". In: Nomos. fasc. 1, ed. Istituto Poligrafico e Zecca dello Stato, Roma, 1999. Pp. 7-19, con versión más actual en RIDOLA, P. "Finanziamento della Politica ed Uguaglianza delle "chances". In: LANCHESTER, F. (a cura de): Finanziamento della Política e Corruzione. Giuffrè, Milano, 2000. Pp. 23-43. Aunque el autor se centre más el sistema italiano, es interesante observar que la preocupación sobre el tema es creciente en todas las democracias consolidadas, y esto se comprueba aun más con la asociación constante de esta igualdad de oportunidades con los sistemas de financiación de partidos.

${ }^{123}$ Cfr. SÁNCHEZ MUÑOZ, O.: La lgualdad de Oportunidades en las Competiciones Electorales. CEPC, Madrid, 2007. Pp. 14-15.
} 
posición neutral del Estado frente a dicha competición. El Estado, de esta manera, debe distribuir las subvenciones públicas destinadas a su financiación de manera proporcional, basándose en las posibilidades existentes de cada fuerza política, es decir, considerando que pequeños y nuevos partidos tienen muchas más dificultades de llevar una campaña electoral frente a los de mayor proporción y, por lo tanto, más poderosos económicamente. ${ }^{124}$ Ante ello, si el Estado busca promover verdaderamente la igualdad de oportunidades, una de las maneras es elaborar una normativa de financiación pública englobando también estos partidos, utilizando criterios que equilibren las diferencias entre las opciones políticas, o que neutralicen en la medida de lo posible la desproporción existente entre ellos, en aras de mejorar la calidad democrática del sistema. $^{125}$

Hay dos perfiles en la igualdad de oportunidad. El primero se refiere al derecho de igualdad en el origen, o sea, el Estado debe garantizar un punto de partida igual para todos, de manera neutral e imparcial, sin una intervención directa por respeto al equilibrio de fuerzas; y el segundo perfil remite a la necesidad de que el Estado actúe positivamente en pro de la garantía real de la igualdad de oportunidades de todos los involucrados. ${ }^{126}$ Por otro lado, el principio de la igualdad de oportunidades también determina que no le está permitido al Estado operar de manera discriminatoria sobre las opiniones políticas, como tampoco sobre la dinámica de agregación de las fuerzas políticas. Por ello, el Estado tiene que ser neutral, estando vedado hacer diferenciaciones conforme su contenido, lo que impide una nivelación absoluta de todas las opciones políticas que compiten. ${ }^{127}$

\footnotetext{
${ }^{124}$ GRIMM, D. "Los Partidos Políticos". In: BENDA, E.; et al: Manual de Derecho Constitucional. Ed. Marcial Pons, Madrid, 1996. Pp. 417.

${ }_{125}$ En este sentido, cfr. GARCIA GUERRERO, J L. "Algunas Cuestiones sobre la Constitucionalización de los Partidos Políticos". In: Revista de Estudios Políticos (nueva época), o 70, oct/dic, 1990. Pp. 171.

${ }^{126}$ Cfr. SARTORI, G.: Elementos de Teoría Política. ed. Alianza, Madrid, 1999. Pp. 102-104 y FERNÁNDEZ VIVAS, Y.: Igualdad y Partidos Políticos: Análisis Constitucional y Comparado de la Igualdad de Oportunidades de los Partidos Políticos. ed. Congreso de los Diputados, Madrid, 2007. Pp. 291-298.

${ }_{127}$ Al tratar del tema, RIDOLA afirma que el Estado debe elegir entre dos tipos de igualdad en la competición política, siendo una la esquemática (en alemán skematische, en su traducción libre), en la que la igualdad significa un mero hecho en el cual se desarrolla la competición política; y la proporcional, que donde se da la garantía de la más completa movilidad de agregación política, con el consecuente rechazo a los mecanismos deformantes de la dinámica
} 
La libertad de partidos no es posible sin la igualdad de oportunidades, aunque es un hecho que los partidos son desiguales en su inserción política, implantación electoral, capacidad de movilización y de organización y en sus recursos materiales. Así, dicha igualdad puede ser traducida como una apertura del proceso político por la paridad de tratamiento, tolerancia, neutralidad de los poderes públicos y relatividad de los valores políticos, que evita la diferencia entre partidos grandes y pequeños, de gobierno y oposición, parlamentarios y extraparlamentarios. ${ }^{128}$

Teniendo ello en mente, está claro que la mayor incidencia de la igualdad de oportunidades se debe producir en la financiación pública, tanto en la directa como en la indirecta. La distribución de los bienes públicos entre las fuerzas política se vuelve una pieza clave para lograr un sistema de financiación más justo y más democrático. ${ }^{129}$ El sistema de financiación pública de las campañas electorales fue pensado justamente para neutralizar la capacidad de influencia del poder económico sobre el electorado, y esto deja claro que, sin acciones positivas por parte del Estado, solamente estará presente la igualdad formal, siendo imposible la igualdad de oportunidades reales para todas las fuerzas políticas. ${ }^{130}$ Solo a partir de elecciones realmente competitivas relacionadas con un cierto nivel en la igualdad de oportunidades se producirá una decisión democrática más legítima. ${ }^{131}$ Sin duda, si bien el proceso electoral solamente estará legitimado bajo los supuestos de igualdad

de partidos políticos. (In: RIDOLA, P. "Partiti Politici". In: AA.VV.: Enciclopedia del Diritto. vol. XXXII, ed. Giuffrè, Milano, 1982. Pp.84-85).

${ }_{128}$ GOMES CANOTILHO, J. J.: Direito Constitucional e Teoria da Constituição. $3^{\circ}$ ed. reimp. Almedina, Coimbra, 1999. Pp. 310.

${ }^{129}$ Cfr. RIDOLA, P. "Partiti Politici. Op. Cit." Pp. 85.

130 SÁNCHEZ MUÑOZ, O.: La lgualdad... Pp. 15.

${ }^{131}$ Pero no se limita a ello, la igualdad electoral está reflejada en las disposiciones sobre la campaña institucional (que no puede influir en el voto); en la celebración de actos públicos coordinado por las juntas electorales; los locales para propaganda electoral cedidos por los ayuntamientos; la prohibición de contratación de publicidad electoral en los medios de comunicación; la neutralidad informativa y el respeto al pluralismo político en dichos medios; la prohibición de que miembros de las fuerzas armadas, de seguridad, policías autonómicas y provinciales, jueces, magistrados y fiscales de las juntas electorales realicen campañas electorales, y finalmente las encuestas electorales, junto con la limitación de gastos. En este sentido, cfr. GARCÍA GUERRERO, J. L.: Escritos sobre Partidos Políticos (como mejorar la democracia). ed. Tirant lo Blanch, Valencia, 2007. Pp. 198-207. 
de oportunidades, el sistema de financiación puede alterar de manera profunda esta dinámica. ${ }^{132}$

Si es así, de la misma manera que la normativa sobre el tema puede dificultar la concretización de la igualdad y del pluralismo, existe también una obligación constitucional de que el Estado promueva dichos elementos vitales de la democracia por medio de acciones positivas, esto es, por medio de un sistema de financiación que realmente favorezca una mayor igualdad 0 equilibrio entre las fuerzas políticas, dotándolas de reales oportunidades de poder y, así, de concretización del verdadero pluralismo político.

Como los competidores electorales no son iguales en sus características, este factor influye directamente sobre sus posibilidades de triunfo en las urnas. Es decir, teniendo en cuenta que a través de la igualdad entre los partidos también se logra la igualdad de trato del derecho de los ciudadanos, también se debe modular dicha igualdad entre las organizaciones partidistas para garantizar la igualdad de derechos de los ciudadanos a participar en los asuntos públicos. Ante esto, la igualdad de oportunidades no puede significar una igualdad de trato absoluta, que no observe la representatividad de cada fuerza política. Tratar de manera desproporcionada a partidos con un bajo nivel de representatividad sería también privilegiarlos indebida e injustificadamente, y al mismo tiempo conceder más ventajas a los ciudadanos que han elegido participar de la política a través de un partido pequeño. ${ }^{133}$

No pueden entenderse como igualitarias las reglas que son exclusivamente paritarias, ya que así se trataría como iguales a los que no lo son. Aquí está la clave de los sistemas de financiación pública. ${ }^{134}$ En un Estado social de Derecho, los poderes públicos deben remover los obstáculos que impiden la igualdad real y efectiva, considerando las diferencias existentes en

\footnotetext{
132 SÁNCHEZ MUÑOZ, O.: La lgualdad... Pp. 17-23.

${ }^{133}$ SÁNCHEZ MUÑOZ, O.: La lgualdad... Pp. 28.

${ }^{134}$ DEL CASTILLO entiende que hay dos factores que afectan a la relación entre los partidos y el Parlamento, siendo el primero el papel (o la influencia) de las subvenciones públicas en la financiación global de los mismos y el grado de centralización que las normas de financiación establecen en el momento de fijar los niveles del partido que recibirán los fondos o que serán responsables por ellos. (In: CASTILLO, P. del. "La Financiación Pública de los Partidos Políticos y su Impacto en las Instituciones Representativas". In: GARRORENA MORALES, A. (ed.): El Parlamento y sus Transformaciones Actuales - Jornadas Organizadas por la Asamblea Regional de Murcia (11-13 de abril de 1988), ed. Tecnos, Madrid, 1990. Pp. 85-87).
} 
la práctica, y concediendo un tratamiento más adecuado a los portadores de dichas diferencias. ${ }^{135}$ El Estado debe disminuir el desnivel entre las posibilidades de todos los que desean competir en la esfera electoral, disminuyendo la influencia del dinero privado, así como intentando neutralizar algunos efectos que se relacionan con esta contienda, como pueden ser la utilización de los medios de comunicación. ${ }^{136}$

Dicho esto, uno de los mayores problemas que hay en la legislación de financiación pública de los partidos políticos es la decisión acerca de qué criterios aplicar para el acceso y reparto de las subvenciones, es decir, si se puede financiar a todos los partidos que estén formalmente inscritos como partidos (dentro de los requisitos legales) o se puede seleccionarlos a partir de criterios como la representatividad dentro del Parlamento, número de votos (traduciéndose en un umbral ${ }^{137}$ ), o combinando criterios, como el número de votos y de escaños. Se trata de una decisión clave que puede afectar a todo el sistema de partidos existente, a la vez que algunos criterios favorecen la permanencia del status quo de los partidos parlamentarios y el alejamiento de los extraparlamentarios, o favorecer al pluripartidismo dentro del Estado. ${ }^{138}$

Del mismo modo, se puede constatar que, con el criterio exclusivo del número de votos para el acceso y reparto de las subvenciones públicas, en cada voto que se emite a favor de un determinado partido, el elector también

\footnotetext{
${ }^{135}$ HOLGADO GONZÁLEZ, M. "Financiación de Partidos y Democracia Paritaria". In: Revista de Estudios Políticos. oํ 115. ene/mar. CEPC, Madrid, 2002. Pp. 139.

${ }_{136}$ PECES-BARBA considera que la igualdad de oportunidades es una de las facetas más alejadas de la igualdad material, porque no se refiere a la mencionada distribución de bienes, sino tan solo a que no existan obstáculos en el camino hasta dichos bienes, favoreciendo la competitividad. Así, la igualdad se queda solo en el punto de partida, y por ello es compatible con una sociedad desigual. (In: PECES-BARBA, G.: Los Valores Superiores. Tecnos, Madrid, 1986. Pp. 161). A la vez, GRIMM entiende que la igualdad de oportunidades brinda a los partidos solamente la igualdad formal, lo que muchas veces no significa la neutralidad del Estado, ya que las dificultades de esto emanan del hecho del Estado ser también compuesto por los partidos. (In: GRIMM, D. Op. Cit. Pp. 415).

${ }_{137}$ Sobre la cuestión del umbral, NASSMACHER afirma que, si el sistema de financiación contiene medidas de financiación pública, debe prestarse mucha atención a los pequeños y nuevos partidos. Así, el umbral puede ser utilizado como un buen medidor de la capacidad que estos partidos tienen de ser serios competitivos y llegar a ciertas franjas de la sociedad. (In: NASSMACHER, K-H. "Introduction..." Pp. 14).

${ }^{138}$ NAVAS entiende que el criterio que atiende a la fuerza electoral es lo más justo en teoría para ser adoptado en el reparto de las subvenciones que el criterio de la representación parlamentaria, ya que permite a un mayor número de partidos acceder a los recursos estatales. Sin embargo, reafirma la exigencia de un porcentaje mínimo de votos para la correcta aplicación de este criterio electoral, dejando aparte los partidos con votación irrelevante. (In: NAVAS, X. Op. Cit. Pp. 462).
} 
está declarando quien es su destinatario elegido para recibir las subvenciones, recursos estos que son fruto del pago de impuestos, y que integran los presupuestos generales del Estado. Todos los electores contribuyen a dichos presupuestos. Nada más justo que dejarlos también declarar hacia qué opción política desea que sean destinados los recursos. ${ }^{139}$ Dicha discusión también involucra un eventual favorecimiento de los partidos mayoritarios y minoritarios dentro del Parlamento (en el caso de haber una combinación de criterios de representación política, número de votos y un umbral muy alto, distorsionado incluso por la fórmula electoral que se utiliza). ${ }^{140}$ Hay países como EE.UU. que incluso establecen diferenciaciones entre los propios candidatos de los partidos mayoritarios y minoritarios. ${ }^{141}$ En fin, muchos países poseen diversos criterios para el acceso a los recursos públicos por parte de los partidos, ya que depende en gran medida del diseño institucional adoptado por cada uno de ellos. En todo caso, parece recomendable que se adopte un criterio doble para este reparto, combinando una parte fija a todos los participantes, y otra variable en función al número de votos. ${ }^{142}$

Como se tratará más adelante con mayor detalle, el sistema español de financiación de partidos que se constituye prácticamente con recursos públicos a partir del rendimiento electoral (criterio escaños/votos), es comúnmente sospechoso de desincentivar el pluralismo político. Muchos autores que tienen como foco de estudio la política en España consideran el sistema de partidos como un pluralismo político moderado ${ }^{143}$ o atenuado en la mejor de las hipótesis, en el cual existen formalmente muchos partidos, pero una escasa

\footnotetext{
${ }^{139}$ En este sentido, cfr. PALLARÉS PORTA, F. "Sistema Electoral y Sistema de Partidos". In: PAU I VALL, F. (coord.): Parlamento y Sistema Electoral - VI Jornadas de la Asociación Española de Letrados de Parlamentos. ed. Aranzadi, Pamplona, 1999. Pp. 75 y ss.

${ }^{140}$ En este sentido, véase SCARROW, S. E. "Party Subsidies and the Freezing of Party Competition: Do Cartel Mechanisms Works?". In: West European Politics. vol. 29. № 4, sept, Frank Cass Press, London, 2006. Pp. 624, donde la autora argumenta que un umbral alto favorece la permanencia de los mismos partidos en el poder, y un umbral bajo, y no distorsionado por la fórmula electoral, puede abrir caminos para los pequeños partidos, y también eliminar las organizaciones políticas que no se muestren serias en la competición electoral.

${ }_{141}$ CASTILLO VERA, P. del: La Financiación de Partidos y Candidatos... Pp. 69-71.

142 PANARA, C. "II Rapporto tra il Finanziamento Pubblico dei Partiti Politici ed il Principio di Eguaglianza delle Chances: I Casi Tedesco ed Italiano". In: Diritto Pubblico Comparato ed Europeo. vol. I. ed. G. Giappichelli, Torino, 2006. Pp. 199.

${ }^{143}$ Cfr. SARTORI, G.: Partidos y Sistema de Partidos. ed. Alianza, Madrid, 1990. Pp. 168, traduciéndose en una fragmentación sin polarización.
} 
proporción de ellos logran acceder al poder, ${ }^{144}$ componiendo los partidos mayoritarios un bipartidismo imperfecto ${ }^{145}$, en un sistema gobierno-oposición, sin permanente influencia determinante de las demás minorías. Como es sabido, la competición electoral a nivel nacional acaba por centralizarse en los dos mayores partidos, en una tendencia bipolar. ${ }^{146} \mathrm{Si}$ dicho escenario "distorsionado" fue determinado en parte por el sistema electoral adoptado desde los tiempos de la transición política, la situación se agrava seriamente conectando el sistema de financiación de partidos a los resultados de este sistema electoral.

La financiación pública de los partidos, aunque tenga sus inconvenientes, es vital y necesaria para el mantenimiento de la democracia actual. Sin embargo, cuando dicha financiación se basa en la representación proporcional, por sí solo ya no es razonable. ${ }^{147}$ En realidad, los criterios de acceso a la financiación pública no deberían ser menores que los criterios electorales para acceso a los escaños, pero tampoco tan altos que de facto perpetúen el sistema de partidos. ${ }^{148}$ Se debe pensar que además de los criterios de acceso a la financiación propiamente dichos, se suman los criterios electorales, justamente porque de una manera o de otra los resultados electorales serán relevantes para determinar las cantidades que se entregan a cada fuerza política. No se debe abrir el sistema de forma irresponsable, porque cada opción política debe ser tratada conforme a su relevancia en el espectro político. Sin embargo, si es el modelo de financiación pública ha

\footnotetext{
${ }^{144}$ Cfr. BAR, A. "The Emerging Spanish Party System: Is there a Model?" In: BARTOLINI, S.; MAIR, P. (ed.): Party Politics in Contemporary Western Europe. Ed. Frank Cass, Great Britain, 1984. Pp. 139 y; TORRES DEL MORAL, A: Principios de Derecho Constitucional Español 1. 3은 ed. renov., ed. Servicio de Publicaciones de la Facultad de Derecho, Madrid, 1992. Pp. 485.

${ }^{145}$ Cfr. VAN BIEZEN, I.: Political Parties in New Democracies: Party Organization in Southern and East Central Europe. Ed. Palgrave, MacMillan, Great Britain, 2003. Pp. 79.

${ }^{146}$ Cfr. HOPKIN, J. "From Consensus to Competition - The Changing Nature of Democracy in the Spanish Transition". In: BALFOUR, S. (ed.): The Politics of Contemporary Spain. Ed. Routledge, London, 2005. Pp. 13.

147 PASQUINO, G. "Contro il Finanziamento Pubblico di Questi Partiti". In: PASQUINO, G.: Degenerazione dei Partiti e Riforme Istituzionali. ed. Laterza, Roma-Bari, 1982. Pp. 59, aunque el autor enfoque los partidos italianos.

${ }^{148}$ Cfr. BORRELLO, R. "II Finanziamento Pubblico dei Partiti nella Dinamica dello Stato di Democrazia Pluralista - Riflessione Generali e Caso Italiano". In: AA.VV.: Studi in Onore di Gianni Ferrara. vol. I, ed. G.Giappichelli, Torino, 2005. Pp. 391; PANARA, C. Op. Cit. Pp. 198 y; PINELLI, C. "Le Spese Elettorali: Limiti, Controlli, Rimborsi, Sanzioni". In: D'ALIMONTE, R.; FUSARO, C. (a cura di): La Legislazione Elettorale Italiana. ed. II Mulino, Bologna, 2008. Pp. 256.
} 
elegido el criterio solo de los votos, o un doble criterio excesivamente simplificado de votos/escaños, siempre el sistema electoral acabará, en la práctica, siendo determinante absoluto del sistema de financiación, y sus efectos con ello siempre serán amplificados. Si los umbrales para el acceso a la financiación son mucho menores que los umbrales electorales: dicha situación conduciría a la creación artificial de partidos y, muy posiblemente, a una mayor incidencia de la corrupción y a otras distorsiones en el sistema, provocando a la vez, una mayor fragmentación política con baja o nula representatividad de la sociedad. A su vez, si los criterios de acceso a la financiación pública son mucho más altos que los criterios electorales, el efecto mediato será la cristalización del sistema de partidos, con la eliminación de otras opciones como alternativas reales de poder. Esto petrifica el sistema existente, generando en el electorado una sensación de impotencia frente a dicha estructura. Dicho sentimiento, una vez asumido como rutina electoral, provoca profundas alteraciones en el comportamiento político en los procesos electorales, como el crecimiento del "voto útil", la abstención, y posteriormente la desafección política, deslegitimando el sistema democrático desde sus bases. $^{149}$

No hay respuestas concretas para este problema. El doble criterio puede funcionar muy bien en otros contextos diferentes del español, o quizás en este propio, si se amortiguaran sus consecuencias a partir de medidas indirectas, como podría ser la reforma electoral. Con todo, estando conectado al sistema electoral, estos criterios no tienden a colaborar con la igualdad (o a neutralizar las diferencias) en la oportunidad de los competidores políticos. ${ }^{150}$

\footnotetext{
${ }^{149}$ Por ello, estoy de acuerdo con BORRELLO, que aunque trate de la realidad italiana, sus lecciones se aplican perfectamente a España. (In: BORRELLO, R. "Il Finanziamento Pubblico..." Pp. 392).

${ }^{150}$ Es esta la opinión de VILLORIA MENDIETA, la cual estoy de acuerdo. Cfr. VILLORIA MENDIETA, Manuel: La Corrupción Política. Ed. Sintesis, Madrid, 2006. Pp. 218.
} 


\subsection{Diferentes aplicaciones de la financiación pública de los partidos políticos y algunas de sus consecuencias}

Hay muchos factores que pueden ser tenidos en cuenta en la aplicación de medidas de financiación pública. En primer lugar, se puede indicar la procedencia de los fondos, ya que pueden involucrar a los presupuestos del Estado (como ocurre en la mayoría de los países que utilizan este tipo de financiación), o pueden venir de un fondo creado especialmente, como es el caso de los EE.UU y Brasil. En el caso de provenir directamente del presupuesto del Estado, cabe añadir aquí la necesidad de combinar este origen con un correspondiente criterio de actualización monetaria, para que se evite que los valores establecidos en ley se vuelvan obsoletos, y también para impedir el posible abuso por parte de los partidos del aumento de este montante, dada su posición dentro del Estado.

Otra cuestión determinante afecta a los niveles estatales que deben ser financiados por los recursos públicos, es decir, si las subvenciones deben ser concedidas a las sedes centrales de los partidos, o si también deben ser distribuidas a nivel autónomo (en el caso de España), provincial o municipal. Dicha decisión se vincula con el grado de centralización que tienen los partidos, ya que, optándose por distribuir las subvenciones a nivel estatal se producirá un grado de centralización mayor, conducente en mayor medida a una fuerte jerarquización partidista. ${ }^{151}$ Sin embargo, la decisión de distribuir la financiación

\footnotetext{
${ }^{151}$ Aunque se trate de una afirmación no absoluta - porque la dependencia de los recursos públicos vienen generalmente asociada con la de la centralización de los recursos en la sede central de los partidos, hay autores que piensan que la existencia de financiación pública es una condición, aunque no suficiente, para hablar de una verdadera centralización de recursos en el partido. En este sentido, cfr. PIZZIMENTI, E.; IGNAZI, P. Op. Cit. Pp. 215. CASTILLO VERA, P. del: La Financiación de Partidos y Candidatos... Pp. 73, también "La Financiación Pública..." Pp. 157. NASSMACHER entiende que la financiación pública puede contribuir a la disminución de la democracia interna en los partidos políticos, pero que la noción de oligarquía no es algo de las modernas democracias, es algo que vino desde mucho antes de la idea de la propia financiación pública. (In: NASSMACHER, K-H. "Structure and Impact..." Pp. 250). BLANCO VALDÉS opina que la organización interna de los partidos no fue considerada en la regulación de la financiación pública, y que, en el caso español, la distribución de las subvenciones solamente a nivel central de los partidos favorece sobremanera el proceso de oligarquización. (BLANCO VALDÉS, R. L. "La Problemática..." Pp. 168-169; BLANCO VALDÉS, R. L. Las Conexiones... Pp. 77). También, CARRERAS SERRA entiende que además del problema de la dependencia del dinero de la financiación entre los miembros del partido, también puede ser que alguien con un cargo directivo superior tenga influencia para conseguir un gran volumen de recursos, en su cargo orgánico que él quien administra los
} 
a nivel autonómico, provincial y municipal también puede generar una independencia exagerada de las subsedes, creando fuertes divisiones internas, inestabilidad partidista, etc. El problema se ha debatido con detenimiento en España, sin que se haya plasmado realmente un cambio normativo. De hecho, de la misma manera que la propia democracia interna no es pormenorizadamente tratada en la legislación, se teme que un cierto grado de autonomía de los niveles que no sean los centrales de los partidos acabe por tener consecuencias graves no solo en el sistema de financiación. Debido a ello, en España la distribución es centralizada, fortaleciendo la jerarquía interna de las organizaciones partidistas.

Así, creemos conveniente que se utilice un criterio razonable a fin de equilibrar la relación entre los distintos niveles territoriales de organización en los partidos, concediéndoles una cierta independencia, sin que esto tenga consecuencias indeseables para el sistema político. ${ }^{152}$

Otra cuestión es que generalmente los recursos pueden ser utilizados discrecionalmente, como también puede ser que haya determinados recursos finalistas, como es el caso de las subvenciones para fundaciones y asociaciones conectadas con los partidos políticos. Además, pueden articularse a través de reembolso o contribución a los gastos electorales, pudiendo ser el momento de la entrega de la parte correspondiente al partido anterior o posterior a las elecciones, como lo es en la mayoría de las legislaciones, ya que la distribución de los recursos depende muchas veces de los resultados de las urnas. Sin embargo, también existen adelantos de cantidades, basados en el resultado electoral anterior de cada partido. La opción por un momento u otro

ingresos dentro del partido sea más influyente que uno de cargo superior, generando un ejercicio indebido de función y de poder interno, que distorsione las reglas democráticas contenidas en el estatuto. (In: CARRERAS SERRA, F. de. "Los Partidos en nuestra Democracia de Partidos". In: Revista Española de Derecho Constitucional, año 24, no 70 , ene/abr, 2004. Pp. 106-107).

${ }^{152}$ Robert MICHELS, uno de los precursores de la literatura acerca de los partidos, ya había escrito en 1915 sobre la gran influencia del dinero dentro de las organizaciones partidistas. Aunque su idea principal era afirmar que los partidos se configuraban como organizaciones siempre tendientes a la oligarquización, el autor apuntó muchos aspectos que pudieran contribuir a ello, y uno de ellos era la centralización de los recursos partidistas, hecho este que aislaba a los dirigentes del partidos tanto de sus parlamentarios como también de los demás miembros, provocando una oligarquización traducida en la gran dependencia de muchos de los miembros a las pequeñas cúpulas partidarias de la sede central. En ese sentido, cfr. MICHELS, R. Los Partidos Políticos 1 - Un Estudio Sociológico de las Tendencias Oligárquicas de la Democracia Moderna. Ed. Amorrortu, 5o reimp. Buenos Aires, 1996. Pp. 155 y ss. 
en la entrega de las subvenciones debe tener en cuenta que, si la entrega de los recursos se produce después de los procesos electorales, perjudicará a los partidos de reciente creación, menos dotados económicamente en principio y con menor capacidad crediticia ante las entidades financieras. Por otro lado, la entrega posterior de los recursos, con naturaleza de reembolso, tiene efectos positivos sobre el control de los gastos de las formaciones políticas, a fin de que estas sean transparentes en sus contabilidades, constituyendo un incentivo para que los partidos mantengan contabilidades permanentes y detalladas de ingresos y gastos. ${ }^{153}$

Dependiendo del sistema donde se inserten, las medidas de financiación pública pueden alcanzar a los partidos o los candidatos, o a ambos, y esto se relaciona directamente con la dicotomía existente entre el modelo estadounidense y europeo. ${ }^{154} \mathrm{Si}$ se financia sólo a los partidos políticos, los candidatos serán dependientes de estos, y a la inversa. ${ }^{155}$ Junto a ello, otro problema consiste en decidir cuáles son las actividades de los partidos políticos que deben ser objeto de financiación estatal, es decir, si serán financiadas solo las actividades electorales (también denominadas por la doctrina "extraordinarias") 0 bien si también se financiarán las actividades interelectorales (conocidas por "ordinarias"). Dicha decisión se relaciona en gran medida con la concepción que se tenga de los partidos políticos y de su naturaleza jurídica. Esto es, si se decide financiar las actividades partidistas no electorales, esto significa también reconocer que los partidos poseen muchas más funciones que la electoral (que sería lo mismo que admitir que la función de formación de la voluntad popular es algo constante y no aislado en el

\footnotetext{
${ }^{153}$ ZOVATTO G., D. "La Financiación Política...” y ZOVATTO, D.: Dinero y... Pp.38-39.

${ }^{154}$ Se resalta normalmente que el sistema estadounidense difiere mucho del sistema europeo, pues, como subraya BLANCO VALDÉS, ambos sistemas siguieron distintas vías para garantizar a las formaciones políticas las fuentes financieras necesarias al cumplimiento de sus funciones. (In: BLANCO VALDÉS, R. L. "La Problemática..." Pp. 172).

${ }^{155}$ CASTILLO VERA, P. del: La Financiación de Partidos y Candidatos... Pp. 66-67. Como es conocido, en los EE.UU. el sistema es personalista, es decir, el protagonismo político es del candidato, y por ello la financiación pública de aquél país privilegia a los candidatos, algo que no ocurre en Europa. Considerando ambos sistemas, WILLIAMS afirma que bajo los estandartes alemanes, los de EE.UU., son huecos y débiles. Bajo los estandartes norteamericanos, los partidos alemanes son demasiado fuertes y "criaturas" del Estado. (In: WILLIAMS, R. "Conclusions: Problems and Prospects". In: WILLIAMS, R. (ed.): Party Finance and Political Corruption. McMillan Press, London, 2000. Pp. 205). Dicha afirmación deja clara las diferencias entre ambos sistemas.
} 
proceso electoral), y que el desequilibrio económico que existe entre los partidos tampoco se puede reducir a los períodos electorales, sino que es permanente. ${ }^{156}$ En este sentido, también se puede entender que la financiación de las actividades ordinarias permite a los partidos continuar con sus trabajos de manera permanente, no centrándose sólo en las elecciones. ${ }^{157}$ La decisión de financiar solamente las actividades electorales de los partidos políticos está relacionada por su parte con argumentos en torno a la posible dependencia de los partidos frente a la financiación estatal completa, la cual comprometería su libertad de acción en la sociedad, y también con la interferencia estatal dentro del marco de los partidos, algo que se ve con bastante recelo. ${ }^{158}$

Finalmente, hay también que optar por la combinación de la financiación pública con otras medidas, como la prohibición de los medios de financiación privada, limitaciones de gastos electorales o de las propias subvenciones estatales. $^{159}$ Se trata de una cuestión directamente relacionada con el encarecimiento de las campañas electorales y con el equilibrio entre la financiación pública y privada, intentando que la financiación pública sea sustitutiva de la privada irregular, aun cuando en realidad suela ser complementaria, ya que cuando los partidos se sientan necesitados de más recursos, probablemente no dudarán en recurrir a fuentes oscuras para completar su presupuesto. ${ }^{160}$

\footnotetext{
${ }^{156}$ CASTILLO VERA, P. del: La Financiación de Partidos y Candidatos... Pp. 68-69. Los países paradigmáticos para analizar dicha discusión son Alemania e Italia, aunque actualmente su legislación fue cambiando en una misma dirección.

${ }^{157}$ VON BEYME, K.: Los Partidos Políticos.... Pp. 272-273.

${ }^{158}$ CASTILLO VERA, P. del: La Financiación de Partidos y Candidatos... Pp. 69. Considerando esto, SANTAOLALLA entiende que los que se posicionan a favor de la financiación pública consideran a los partidos políticos como entidades híbridas, ya que estos serian asociaciones privadas, y en periodos electorales adoptarían un perfil como de órganos del Estado, lo que justificaría la financiación pública para costear sus gastos electorales.(In: SANTAOLALLA, F. "Regulación de Campañas..." Pp. 169). A su vez, VON BEYME apunta otras razones bastante convincentes para negarse a la total financiación pública de los partidos, o quizás a la financiación pública de actividades no electorales ejercidas por ellos: el retroceso del nivel de afiliaciones, consecuencia de la falta de esfuerzos por parte de los partidos en mantenerlos 0 conseguir nuevos militantes, ya que tienen la seguridad de sus ingresos; y el debilitamiento de la oposición dentro del Parlamento, a partir de la adopción de un comportamiento de "cartel" entre todas las organizaciones partidistas. (VON BEYME, K. Los Partidos Políticos.... Pp. 267270).

${ }^{159}$ CASTILLO VERA, P. del: La Financiación de Partidos y Candidatos... Pp. 74.

160 BLANCO VALDÉS subraya el falso dilema de los partidos políticos entre arriesgarse a la financiación ilegal y ser condenados públicamente por escándalos que pueden surgir o seguir la ley, aunque esto les obligue a reducir costes y adaptarse a una nueva situación ante la
} 
Las consecuencias de la aplicación de este modelo de financiación sobre el sistema de partidos son de considerable importancia ${ }^{161}$, y se destacan aquí cinco de ellas. ${ }^{162}$ Puede ser que haga que los partidos sean menos dependientes de las donaciones privadas o incluso de las propias cuotas de los afiliados y de los apoyos de los simpatizantes, o sea, afecta tanto a partidos de perfil más liberal y burgueses (librándolos de la dependencia de donaciones de empresas y organizaciones patronales y profesionales) como también a los partidos socialistas (independizándoles de las cuotas de afiliados y contribuciones de simpatizantes), aunque actualmente no es propiamente así por el bajo nivel de afiliación existente y por la propia ausencia de factores diferenciadores de su ideología. Acaba también por alejar a la cúpula del partido de su base de apoyo formada por los afiliados y puede ser que fomente la oligarquización del partido, disminuyendo el interés por captar nuevos miembros como también el peso de los afiliados dentro de las estructuras del partido. Pero en cambio se limita la influencia del dinero proveniente de los grandes poderes privados sobre los partidos y permite una mayor igualdad entre partidos relevantes en el sistema. Con todo, hay efectos de la financiación pública en el ordenamiento jurídico, considerando que estos son en parte de naturaleza jurídica privada. Dentro de una perspectiva liberal o

política (pudiendo incluso perder elecciones). (In: BLANCO VALDÉS, R. L. Las Conexiones... Pp. 56).

${ }^{161}$ ARGANDOÑA apunta tres posibles problemas en la aplicación de la financiación pública: que sea insuficiente, que según su punto de vista es lo menos probable, pero que puede perjudicar la libertad de expresión de los partidos; que sea excesiva, que sería la más probable, porque son los propios partidos políticos los que legislan, que, aunque excesiva, puede ser insuficiente tanto para partidos como para candidatos, justamente por el aumento de los gastos de los partidos políticos y campañas electorales en sus diferentes niveles, las estructuras permanentes, la falta de rendimiento de los recursos utilizados en las campañas, y también porque si un partido gasta " $x$ ", su concurrente tendrá que gastar " $x+y$ ", sin que ello se plasme en un beneficio real. (ARGANDOÑA, A. Op. Cit. Pp. 5-6).

${ }_{162}$ Aunque bajo otros supuestos científicos, NASSMACHER afirma que un análisis empírico del impacto de la financiación pública en los sistemas de partido están relacionados conceptos como participación legitimación, identificación, centralización y burocratización. También, el término "petrificación" del sistema para el autor se refiere a la ausencia de cambios en este. Sin embargo, está claro que la competición política entre partidos en relación a la financiación pública favorece más a los partidos mayores que a los menores. Con todo, hay dos dimensiones de dicha petrificación: la estabilidad de los partidos políticos existentes, los comparados uno con otro; la cristalización, que se traduce en la falta de oportunidades para los nuevos partidos políticos de entrar en el sistema. (In: NASSMACHER, K-H. "Structure and Impact..." Pp. 248). Como ejemplo de dicha afirmación, el autor cita el caso del partido verde en Alemania, que ha logrado superar el umbral de $0.5 \%$ de los votos para accede a los subsidies públicos, y que desde entonces, ha crecido significativamente en el espectro político alemán. 
individualista, la financiación pública acaba por alterar el estatuto de los partidos, ya que estos pierden en cierta forma su condición de asociaciones privadas, y pasan a ser en la práctica una institución pública con base asociativa, que ejerce funciones y tareas de perfil público. Debido a ello, desde posiciones neoliberales se han criticado con dureza las subvenciones públicas concedidas a los partidos. ${ }^{163}$

Con todo, queda la duda de si todavía cabe la inserción de medidas de financiación pública en las modernas democracias por las razones que antes las justificaban.

\subsection{La validez de la fundamentación de la financiación pública de los partidos políticos}

La adopción de la financiación pública siempre estará marcada por una fuerte polémica y divide las opiniones doctrinales. ${ }^{164}$ Los argumentos a favor se centran en la importancia de los partidos en la democracia y, por lo tanto, la financiación pública sería una garantía del cumplimiento de sus funciones

\footnotetext{
${ }^{163}$ MARTÍNEZ SOSPEDRA, M. "La Financiación..." Pp. 30-31. El autor sostiene que esta publificación de los partidos es un proceso sin retorno atrás, ya que acaba por reducir invariablemente la complejidad social que la propia política intenta conciliar en la sociedad. A su vez, Ramón Rollón entiende que la financiación pública de los partidos políticos es resultado de una evolución de los sistemas democráticos y también una consecuencia de la importancia de los partidos políticos en nuestros sistemas. Sin embargo, este sistema, aunque pretenda crear condiciones más equitativas en la competición electoral y una mayor transparencia en esa financiación, significa una estatalización de los partidos políticos y su dependencia hacia los recursos del Estado, provocando un alejamiento de la sociedad, crisis en la militancia partidista y una creciente deslegitimación de los partidos como instituciones políticas. Por ello el mayor dilema es cómo conciliar estos dos elementos, equidad versus independencia estatal. (In: RAMÓN ROLLÓN, M. L. "La Financiación de los Partidos Políticos en América Latina: Estado Actual y Propuestas de Reforma". In: Revista de Estudios Políticos (nueva época), no 102, oct/dic, ed. CEPC, Madrid, 1998. Pp. 327-329). VAN BIEZEN y KOPECKY a su vez ya diagnostican una dependencia cierta de los partidos políticos de las subvenciones del Estado, porque el aumento de la importancia de las subvenciones estatales es progresivamente más fuerte entre el Estado y los partidos. Sin embargo, los autores aclaran que, dado su punto de vista, ello no significa que otros tipos de recursos se hayan vuelto irrelevantes, aunque sea claro que las subvenciones estatales son más relevantes que otras. Con todo, en los años recientes, como resultado del aumento de la intervención del Estado, los partidos han sido agregados al dominio público, aumentando la intervención estatal sin precedentes en el Estado Liberal, ahora ha contribuido a volver a los partidos en un tipo especial de entidad de utilidad pública. (In: VAN BIEZEN, I.; KOPECKY, P. "The State and the Parties - Public Funding, Public Regulation and Rent-Seeking in Contemporary Democracies". In: Party Politics. v. 13. № 2. Sage, London, 2007. Pp. 238-239).

164 Para un panorama general cfr. VON BEYME, K.: Political Parties... Pp. 207-209 y NASSMACHER, K-H. "Introduction..." Pp. 8.
} 
dentro de la democracia, librando a los partidos de utilizar la financiación irregular o ilegal, sin afectar a su independencia. ${ }^{165}$ También se plantea la cuestión de la garantía de la igualdad o por lo menos de la disminución de las desigualdades existentes dentro de la competición electoral entre los partidos, facilitando incluso la actuación de un régimen de control más eficaz, ${ }^{166}$ pero que no facilite la dependencia del Estado, con medidas que excluyan el riesgo de influencias políticas, a partir de criterios claros. ${ }^{167}$

Los argumentos en contra de la financiación pública se centran ante todo en la crítica a la real fundamentación de la necesidad de financiación pública. ${ }^{168}$ Dichos argumentos insisten en el hecho de que dicho modelo solamente atiende a los intereses de los partidos, petrificando el sistema de partidos y dificultando el surgimiento de nuevas fuerzas políticas, lo que a la vez rompe con la igualdad de oportunidades. ${ }^{169}$ Tampoco se elimina la desigualdad

${ }^{165}$ En este sentido, cfr. CONTRERAS CASADO, M. "A la Sombra del Ogro Filantrópico. Algunas Consideraciones sobre el Estado, los Partidos y su Financiación". In: Sistema. no 118/119. Marzo. Ed. Fundación Sistema, Madrid, 1994. Pp. 79-84; PAJARES MONTOLIO, E.: La Financiación de las... Pp. 29-32; MORLOK, M. La Regulación Jurídica..." Pp. 47; FERREIRA RUBIO, D. Op. Cit. Pp. 8-10. Sin embargo, ARIÑO ORTIZ critica este argumento de la independencia de los partidos políticos, porque entiende que dicha independencia debe ser tomada con reservas, ya que no es saludable para la democracia que los partidos estén separados o apartados de sus fuerzas sociales. También, para el autor, no es coherente que los ciudadanos sean obligados a contribuir con los partidos de manera obligatoria con sus impuestos. Por ello, debería haber un sistema - en el caso español - como hay para la Iglesia, es decir, que el ciudadano pudiera decidir si desea o no donar recursos a los partidos. (In: ARIÑO ORTIZ, G.: Op. Cit. Pp. 21-22).

${ }^{166}$ MORODO, R.; MURILLO DE LA CUEVA, P. L.: El Ordenamiento Constitucional... Pp. 165166. También con estos argumentos, véase: GARCIA DE MORA, Mํㅡ. V. G-A.; TORRES DEL MORAL, A.: Sistema Electoral, Partidos Políticos y Parlamento. 1‥ ed. Colex, Madrid, 2003. Pp. 182. Ya BURNELL tiene otra postura, porque considera que la financiación pública puede ser un "caballo de Troya" que permita la directa intervención y el control estatal en los partidos políticos. (In: BURNELL, P. "Introduction". In: BURNELL, P., WARE, A. (eds.): Funding Democratization, Manchester University Press, UK, 1998. Pp. 8).

${ }^{167}$ MORLOK, M. "La Regulación Jurídica..." Pp. 50-51. En el mismo sentido, cfr. ZOVATTO G., Daniel. "La Financiación Política..." y ARGANDOÑA, A. Op. Cit. Pp. 4. Debido a ello que el autor cree que hay motivos reales para que la financiación de los partidos esté compuesta tanto de fondos públicos como privados.

${ }^{168}$ En este sentido, cfr. FERNANDEZ-LLEBREZ, F. Op. Cit. Pp. 191, que entiende que las razones que basaban a la financiación pública ya no son aplicables en los tiempos actuales.

${ }^{169}$ Cfr. GARCIA DE MORA, Mำ V G-A.; TORRES DEL MORAL, A.: Op. Cit. Pp. 182-183 y CARRERAS SERRA, F. de. "Los Partidos en Nuestra..." Pp. 106, que resalta el hecho de que el voto de los partidos mayoritarios es esencial para la aprobación de leyes de las que ellos mismos son beneficiarios. Sin embargo, NASSMACHER rebate los argumentos en contra la financiación pública en este sentido, porque, en su pensamiento, los subsidios estatales no significan necesariamente un impacto negativo sobre la afiliación masiva, incluso cuando es considerado como el principal ingreso de los partidos políticos. El autor también argumenta que dichos subsidios tampoco son la razón para la cristalización del sistema de partidos, porque todos los subsidios fomentan de alguna manera esa petrificación, además, los sistemas de 
existente entre los grandes y pequeños partidos, aunque todos sean beneficiarios de las subvenciones públicas, y también se perjudica a la democracia interna de los partidos, ya que el sistema tiende a cristalizar las estructuras de dirección. ${ }^{170}$

Por otra parte, los mecanismos de control resultan en gran medida ineficaces al atribuir en gran parte al Parlamento la capacidad de sancionar indirectamente eventuales violaciones de las leyes de financiación (como ocurre en el caso español, dada la ausencia de dicha potestad del Tribunal de Cuentas en su función de fiscalización). Sin embargo, la consecuencia más relevante es una eventual dependencia de los partidos de las subvenciones estatales $^{171}$, provocando un aumento de gastos que además contribuye a su indiferencia ante el escaso enraizamiento en la sociedad. No se logra tampoco eliminar la financiación irregular o ilegal $^{172}$, y colabora a generar un gasto desproporcionado y muchas veces poco responsable de recursos, ya que las subvenciones estarán garantizadas de todos modos. ${ }^{173}$

partidos europeos fueron considerados como consolidados mucho antes de la introducción de la financiación pública en el sistema, y esto no interfiere en la volatilidad del electorado. (In: NASSMACHER, K-H. "Party Funding in Continental Western Europe". In: AUSTIN, R.; TJERNSTRÖM, M. (eds.): Funding of Political Parties and Election Campaigns. International IDEA, Stockholm, 2003. Pp. 134). Bajo nuestro punto de vista, en cambio, cada situación en la cual se aplica la financiación pública debe ser analizada atendiendo a sus rasgos específicos, y no solamente por el hecho de que esté compuesta por recursos públicos transferidos a los partidos políticos. También como ejemplo de un análisis empírico de esta afirmación, aunque con datos de los años 90, véase PIERRE, J.; et al. Op. Cit. Pp.14-21, donde los autores concluyen que no hay evidencias de la dependencia de los partidos de las subvenciones públicas, o de que esto no implique la petrificación del sistema de partidos.

${ }_{170}$ En este sentido, y ubicando la cuestión en España, GARCíA VIÑUELA afirma que hay un impacto significativo de la financiación pública en la organización interna de los partidos, pues es cierto que ha contribuido de manera relevante para la burocratización de los mismos, pero que la centralización de los recursos puede haberse agudizado como consecuencia del aumento de la financiación autonómica, generando una descentralización de las fuentes de financiación pública y dejando a la financiación de las Cortes Generales con un peso relativo para los niveles inferiores al central del partido. (In: GARCÍA VIÑUELA, E. "Financiación Pública de los Partidos y Cartelización de la Oferta Política". In: Revista Española de Ciencia Política. o 20, abril, ed. Cyan, Madrid, 2009. Pp. 90).

${ }^{171}$ Un estudio atestiguando esta condición puede ser encontrado del caso italiano con PIZZIMENTI, E.; IGNAZI, P. Op. Cit. Pp. 218 y ss.

${ }^{172}$ Como ejemplo de contraposición de esta afirmación, cfr. KRISTíN BIRNIR, J. "Where Are the Disgruntled Voters? Voter-Party Relations under Cartelizing Conditions". In: Party Politics. v. 16. o 1 . Sage, London, 2010. Pp. 29-49, donde la autora afirma que la distancia habida entre partidos con financiación pública y votantes no es larga solamente por el hecho de haber subvenciones públicas, habiendo bienes que los partidos siguen proviniendo a sus electores. $\mathrm{Si}$ este vinculo se rompe, la autora entiende que los partidos no estarán en una fase post-cartel, pero sí regresaran a los partidos de cuadros.

173 En este sentido, cfr. AA. VV.: "Debates". In: La Financiación de los Partidos Políticos. Cuadernos y Debates, no 47, Centro de Estudios Constitucionales, Madrid, 1994. Pp. 89; 
En la última década se produjo una cierta hegemonía de este modelo en diversos países, pero muchos autores juzgan que, en realidad, era solamente un medio para preservar el status quo de los partidos. ${ }^{174}$

Ante todas estas críticas, hay quienes subrayan que dichos posicionamientos en el fondo parten de una concepción privatista de los partidos políticos, es decir, que ven a los mismos como asociaciones privadas que no tienen razones de interés general que justifiquen su mantenimiento por todos los contribuyentes, ya que los partidos tenderían a defender los fines más concretos de los grupos sociales que ellos representan. ${ }^{175}$ Por ello, la financiación pública sería ser la responsable del alejamiento entre los partidos y la sociedad, algo que únicamente se evitará si dichas organizaciones siguen dependiendo de los ciudadanos, o sea, se mantienen como canal de comunicación entre la sociedad y el Estado. La financiación pública no puede englobar la totalidad de la necesidad financiera de los mismos, deben esforzarse para conseguir otras fuentes de recursos. ${ }^{176}$

Centrándose en las democracias modernas, pensamos que el mayor riesgo que existe es la evolución de los partidos hacia al modelo "cartel". Las consecuencias para el sistema político en general de este comportamiento por parte de los partidos se reflejan no solo en la fragilidad de los propios partidos, sino también de la propia democracia como sistema político. Se trata de una cadena que parte de la financiación pública desmedida a favor de los partidos, y acaba en el Parlamento como sinónimo de actuación partidista, y no como

zovatTo G., D. "La Financiación Política..."; ALBERTO CORDERO, L. Op. Cit. Pp. 397, y MORODO, R.; MURILLO DE LA CUEVA, P. L.: El Ordenamiento Constitucional... Pp. 168-169. 174 También, cfr. CARRERAS SERRA, F. de. "Los Partidos en Nuestra..." Pp. 110. Sin embargo, vale recordar la opinión de NASSMACHER, que afirma que hasta los días actuales, ninguno partido de la democracia occidental logró combinar eficiencia con los recursos entregados a los partidos a título de financiación pública, ya que poseen una organización permanente; que acompañaron el proceso de aumento de costes generales debido a la inflación y la gran gama de actividades que los partidos actuales tienen que ejercer; que son independientes y son responsables por dichos costes; pero que también poseen inseguridad con relación a la recaudación de fondos, que podrá ser insuficiente. (In: NASSMACHER, K-H. "Structure and Impact..." Pp. 240). BALMELLI, T.: Op. Cit. Pp. 376-377. También en este sentido, véase: FISHER, J.; EISENSTADT, T. A. Op. Cit. Pp. 621. También, citando la crisis del Estado de Bienestar conjuntamente con la hipótesis de imposibilidad de evitar otros tipos alternativos de financiación, cfr. FERNANDEZ-LLEBREZ, F. Op. Cit. Pp. 191 y PIZZIMENTI, E.; IGNAZI, P. Op. Cit. Pp. 225-227.

175 SANTAOLALLA, F. “Regulación de Campañas...” Pp. 168.

${ }^{176}$ Cfr. ALBERTO CORDERO, L. Op. Cit. Pp. 382 y MORLOK, M. La Regulación Jurídica... Pp. 51-52. 
centro de decisiones políticas. En el fondo es la preocupación inversa a la de la estatalización de los partidos, ya que serían los partidos quienes monopolizarían al Estado. Aunque no existan sistemas puramente públicos de financiación, tanto de partidos como de candidatos (lo que no es ni siquiera factible), la financiación pública en grandes proporciones puede generar tantos o más daños a la democracia que el dinero privado en la política. ${ }^{177}$

Sin embargo, es importante tener en cuenta que, una vez que se adopten mecanismos de financiación pública a partir de los presupuestos del Estado, es prácticamente imposible suprimirlos. ${ }^{178}$

\section{3) La difícil decisión de fijar el punto de equilibrio - La financiación mixta como tendencia}

Elaborar la normativa de financiación más adecuada para un determinado sistema político no es tarea fácil. Siempre que se privilegia la solución a un problema que se cree que es determinante, se acaba por provocar otro, y las fórmulas importadas ipsis literis tienden a fallar. No se trata únicamente de combatir la corrupción, sino también de dar a las fuerzas políticas condiciones reales de existencia y competición. La ley debe obviamente responder al modelo de los preceptos constitucionales, a partir de la vinculación de las bases sociales con los partidos, sin que ellos se autonomicen y acaben por caer en una dependencia de los recursos públicos. Además, el proceso político debe mantenerse abierto al cambio, en una competición saludable en pro de la democracia. ${ }^{179}$

\footnotetext{
${ }^{177} \mathrm{Y}$ en ello se basa el punto de vista de SORAUF, que aun siendo de la década de los 90 , sirve para subrayar esta idea de que la financiación pública ya no es considerada positiva como anteriormente, incluso como perjudicial, porque mientras muchos la idealizan para conceder recursos a los partidos, se afianza la corriente que la une como una manera de mantener el status quo. En este sentido, cfr. SORAUF, F. J.: Inside Campaign Finance - Myths and Realities. Yale University Press, USA, 1992. Pp. 153 y ss.

${ }_{178}$ En este sentido, cfr. VON BEYME, K.: Los Partidos Políticos... Pp. 272; PAJARES MONTOLIO, E.: La Financiación de las... Pp. 33 y NASSMACHER, K-H. "The Funding of..." Pp. 33.

${ }^{179}$ GONZÁLEZ-AURIOLES, J. A. Op. Cit. Pp. 219-220.
} 
Así, el formato mixto de financiación de los partidos es sin duda el que mejor responde a las necesidades planteadas por la doctrina. ${ }^{180}$ No podría ser de otra manera, ya que en casi todos los contextos políticos existentes, el equilibrio entre la financiación privada y la pública es esencial en la actualidad, a la vez que la aplicación de modelos puros parece disfrutar de muy escasos defensores. ${ }^{181}$ Por todo ello, encontrar el delicado equilibrio entre cada tipo de financiación se convierte el principal reto de la financiación de los partidos, un punto ideal casi siempre muy difícil de encontrar ${ }^{182}$, según la realidad del sistema electoral y el sistema de partidos existentes, considerandos estos conjuntamente. ${ }^{183}$

La utilización del dinero como un recurso más de la política necesariamente acarrea una inequidad en su distribución. La combinación entre financiación pública y privada pretende atenuar esta situación amortiguando los respectivos inconvenientes de los dos modelos. ${ }^{184} \mathrm{La}$ proporción adecuada entre las dos fuentes de financiación es el origen real de los debates actuales sobre la financiación de los partidos políticos. ${ }^{185}$ Detrás de ello el perfil del sistema de partidos existente resulta determinante. ${ }^{186}$

180 PRESNO LINERA, M. A.: Los Partidos y las Distorsiones Jurídicas de la Democracia. Ed. Ariel, Barcelona, 2000. Pp. 92.

181 ZALBIDEGOITIA entiende que los partidos políticos que tengan solamente a la financiación pública o la privada no serán independientes, porque la independencia está en las ideas, valores, fuerza o de los grupos de presión o del propio Estado. (In: "Debates". In: La Financiación.... Pp. 86).

${ }_{182}$ En este sentido, estoy de acuerdo con BORRELLO, que entiende que no se trata de separar o alejar la democracia del dinero, sino de seleccionar el dinero "bueno", que es necesario para el funcionamiento de la democracia, del "malo" o mal intencionado, que busca alterar el equilibrio en la competición política o en la relación competición económica e interés colectivo. Además, la posibilidad de acceder y utilizar los recursos necesarios para competir son una de las formas de barrera idónea para seleccionar cuantitativamente y también cualitativamente a los competidores en la arena política, determinando, conforme la vía elegida, un cierto tipo de competición, condicionando del mismo modo la calidad de la democracia. (In: BORRELLO, R.: Finanziamento della Política e Diritto Pubblico: Profili di Teoria Generale e Caso Francese. ed. Giuffrè, Milano, 1997. Pp. 20-22

${ }_{183}$ LÓPEZ DE LERMA entiende que la financiación mixta es la más adecuada porque es la más indicada para garantizar el pluralismo político. Es claro también al afirmar que "cerrar el grifo" de la financiación pública es también iniciar el principio del fin de los partidos políticos tal y como entendemos actualmente. (In: "Debates". In: La Financiación... Pp. 83).

${ }_{184}$ Esto garantiza incluso la salud de la propia democracia, realizando verdaderas elecciones competitivas. En este sentido, cfr. NASSMACHER, K-H. "Introduction..." Pp. 6. y ZOVATTO, D.; FREIDENBERG, F. "Democratización Interna..." Pp. 216.

${ }^{185}$ NASSMACHER, K-H. "Introduction..." Pp. 7. Williams refuerza la idea afirmando que los partidos políticos siempre tendrán la necesidad de solicitar fondos de los intereses sociales y económicos de la sociedad. Incluso el modelo de financiación pública resultó fallido, según el 
Está claro que la autofinanciación de los partidos hoy en día es imposible, pero esto no impide que los mismos adecuen sus ingresos a sus gastos, cumpliendo sus funciones de interés general no sólo durante las elecciones, sino también de manera permanente. Por ello, la financiación pública parece justificable, aunque se pueda considerar que su adopción en exclusiva es improbable (o por lo menos no recomendable). Se debe facilitar la combinación de las medidas públicas y privadas dentro de un contexto mixto, conjugado con mecanismos de control. ${ }^{187}$ Aunque en el Estado Liberal, por sus características, no se acepte la financiación pública, y en el Estado Social esta se hace imponente, no es aconsejable negar la financiación privada. Es vital que se fomente la independencia de los partidos ante el Estado, a partir del desarrollo de las medidas de financiación privada ${ }^{188}$, no solo por parte de la sociedad, como también por parte de la militancia, de su base social. ${ }^{189}$

Teniendo esto en cuenta, un sistema mixto deberá atender a ciertos criterios, entre ellos destacadamente el principio de la igualdad, que no permite favorecer la mayoría a través de la exclusión de financiación que permita el cumplimiento de las funciones de interés general de los partidos políticos, junto a la prevalencia del principio de la transparencia y del control efectivo, tanto interno como externo, con sanciones eficaces en el caso de incumplimientos.

autor, y no permite ser aplicado en países en desarrollo o en transición, por motivos políticos y económicos, imposibilitando esta medida. (In: WILLIAMS, R. "Conclusions...” Pp. 209).

${ }^{186}$ Cfr. GONZALES-VARAS IBAÑEZ, S. "La Financiación de los Partidos Políticos en Alemania tras la Sentencia del Tribunal Constitucional de 9 de abril de 1992". In: Revista Española de Derecho Constitucional, año 12, no 36, sep/dic, 1992. Pp. 300 y ZOVATTO, D.: Dinero y... Pp. 31.

${ }_{187}$ ÁLVAREZ CONDE afirma que a partir del sistema de financiación pública, las prácticas corruptas aumentaron o se agravaron, haciendo que se replanteara la cuestión de la financiación privada, que se legitima aún más en tiempo de crisis económica. (In: ÁLVAREZ CONDE, E. "Algunas Propuestas sobre la Financiación de los Partidos Políticos." In: AA. VV.: La Financiación de los Partidos Políticos. Cuadernos y Debates, № 47, Centro de Estudios Constitucionales, Madrid, 1994. Pp. 14-15).

${ }^{188}$ Cfr. CASTILLO, P. del. "Problems in Spanish Party Financing". In: ALEXANDER, H. E.; SHIRATORI, R. (eds.): Comparative Political Finance Among the Democracies. Westview Press, USA, 1994. Pp. 103.

${ }^{189}$ Cfr. PRESNO LINERA, M A. "La Reforma del Sistema de Financiación de los Partidos Políticos". In: Revista Española de Derecho Constitucional. año 19, no 57, sep/dic, 1999. Pp. 209-210. Corroborando dichas conclusiones, VAN BIEZEN muestra evidencias de la evolución de la afiliación de simpatizantes a los partidos - y consecuente generación de renta a través del pago de las cuotas - cuando ellos trabajan para dicho fin. Incluso, en su obra, la autora muestra casos de partidos que han logrado doblar el número de afiliados, como pasó con el PCE entre 1975 a 1977, y con el PP en 2002. (In: VAN BIEZEN, I.: Political Parties in New... Pp. 83-85). 
Así se puede evitar que los recursos privados se conviertan en un medio de presión sin publicidad, o que una financiación pública genere un sistema de partidos débil. ${ }^{190}$ Se añade a dichos criterios la base de la distribución de las subvenciones a partir de los principios de igualdad y proporcionalidad, combinados con otros elementos que reflejen el enraizamiento del partido en la sociedad (como votos, recursos recaudados, etc.). ${ }^{191}$

Aunque se pueda afirmar que muchísimos países utilizan el sistema mixto, de una manera u otra cada país opta por privilegiar las medidas de financiación pública o las privada, como ocurre en el análisis comparado entre el modelo estadounidense y europeo de financiación, subrayando la diferencia de bases teóricas entre el Estado liberal y el Estado de bienestar intervencionista. ${ }^{192}$ De esta manera, a continuación se expondrán tres casos de aplicación en la práctica de sistemas mixtos, que cuentan cada uno con sus propios rasgos en la combinación de los modelos público y privado. Es importante resaltar que los sistemas también se difieren en su forma de gobierno y en sus sistemas electorales, y que dichos detalles poseen directa influencia en el modelo mixto aplicado en cada caso. Sin embargo, el sistema mixto continúa su tendencia creciente en las agendas para las reformas políticas del mundo entero.

\footnotetext{
190 ÁlVAREZ CONDE, E.: El Derecho de Partidos. Colex, Madrid, 2005. Pp. 381-382. Para el autor, la discusión sobre el carácter público privado de la financiación no es productiva, ya que ambos casos se producen distorsiones similares.

191 "Debates". In: La Financiación... Pp. 108, en las palabras de BLANCO VALDÉS; y FERREIRA RUBIO, D. Op. Cit. Pp. 11.

192 Para CASAS-ZAMORA, todas las democracias europeas occidentales proveen a los partidos de una financiación permanente, en América Latina se destaca la financiación electoral, como también en EE.UU. Esto refleja claramente las diferencias en el entendimiento de la naturaleza y las funciones de los partidos. En los EE.UU., por ejemplo, las normas sobre las subvenciones que los partidos son los actores principales en la competición electoral, pero que no tanto como los candidatos que ellos presentan, y en ellos se concentra en el periodo electoral. La orientación electoral de la organización de los partidos es también un rasgo presente en América Latina. Al revés, en los sistemas de Europa Occidental, se acentúa el carácter de organizaciones permanentes responsables de los gobiernos y que deben ser subvencionados de acuerdo con ello. Estas diferencias de percepción acompañan las diferencias entre los sistemas institucionales que cada uno tiene, a partir de los regímenes presidencialistas de EE.UU. y América Latina, y del régimen parlamentario europeo. (In: CASAS-ZAMORA, K.: Op. Cit. Pp. 33).
} 


\section{4) Los modelos paradigmáticos}

A partir del análisis empírico de modelos anteriormente mencionados es posible verificarse la diferencia de "tradiciones" que son aplicadas en distintos continentes. Las tradiciones anglosajona y continental quedan muy delimitadas, principalmente en su sistema electoral, como también en sus concepciones de democracia. ${ }^{193}$ En EE.UU. ${ }^{194}$ el sistema está centrado en las campañas electorales y sus candidatos, mientras que en Europa está mucho más inclinada hacia la visión institucional de los partidos políticos. No solo eso, hay una cierta constancia de que en países en donde prevalece el sistema mayoritario, hay una tendencia a la financiación privada, y que los países con sistemas proporcionales más acentuados, acaban por inclinarse a la financiación pública. ${ }^{195}$ Las legislaciones también son distintas, porque las motivaciones para la adopción de la financiación pública, por ejemplo, fueron diferentes, considerando que en EE.UU. la principal razón fue por el encarecimiento de las campañas causado por los nuevos medios de publicidad, entendidos como fundamentales para el triunfo en las elecciones, y en Europa fue el modelo de organización de los partidos políticos, entendidos como asociaciones permanentes, lo que dificulta mucho su autofinanciación. ${ }^{196}$

\subsection{Estados Unidos de América}

El modelo adoptado en EE.UU. se enfoca mucho más hacia la financiación de las campañas electorales que hacia la financiación de las demás actividades ejercidas por los partidos, justamente por la tradicional

\footnotetext{
193 MELCHIONDA afirma que la comparación Europa - América también puede ser denominado como el del modelo partitocrático vs. modelo plutocrático, haciendo clara mención a la tendencia europea a favor de las subvenciones estatales, y la norteamericana hacia la influencia de las élites capitalistas. (In: MELCHIONDA, E.: Op. Cit. Pp. XIV)

${ }^{194}$ El caso utilizado en el análisis. No pueden excluirse otros países de América, como Latinoamérica. Sin embargo, se nota en ellos una clara tendencia a las reformas políticas dirigidas a reforzar la financiación pública en ellos.

${ }_{195}$ PINTO-DUSCHINSKY, M. "Financing Politics: A Global View". In: Journal of Democracy. no 4, vol. 13, oct. ed. John Hopkins University Press, Washington, 2002. Pp. 75.

${ }^{196}$ NASSMACHER, K-H. "Comparing Party..." Pp. 238.
} 
desconfianza histórica que ha contribuido no poco a su debilitamiento ${ }^{197}$, obligando a los candidatos a financiar sus propias campañas, dado que los partidos reciben tan solo una pequeña cantidad de los recursos destinados a este fin. ${ }^{198}$ De mismo modo, se trata también de una señal de la concepción liberal que dicho país tiene de la política como un todo, pues aunque el modelo adoptado puede ser considerado como mixto, también debe de tenerse en cuenta que nos encontramos ante un país donde la libertad de expresión ocupa una posición central en este campo, según la consolidada jurisprudencia del Tribunal Supremo. ${ }^{199}$ Del mismo modo, la descentralización típica de la forma de gobierno estadounidense se traduce en partidos altamente descentralizados y en una autonomía relevante de sus candidatos que ha contribuido a elevar fuertemente los gastos de las campañas electorales, acentuando a su vez los casos de corrupción. ${ }^{200}$ La financiación privada es, pues, claramente

${ }^{197}$ El descrédito de los partidos políticos en los Estados Unidos viene ya del siglo XIX, justo porque reflejaban la idea de intereses parciales, y no de intereses colectivos. Este desprestigio era tan acentuado que la introducción de las primarias fue una manera de distanciar a los candidatos de los partidos, junto con las leyes de reforma del sistema, que acabó por fomentar el debilitamiento de los partidos en las elecciones y en el gobierno. La elección interna de candidatos, a s vez, motivó el desarrollo de campañas no amparadas en los recursos de los partidos políticos, debilitando una vez más las máquinas partidarias. Se empezó así a notar la fuerte presencia del capital privado en las elecciones (con tecnología, trabajo, etc.), evidenciando la influencia del dinero en la financiación política de aquél país. Con el debilitamiento de la máquina partidista, los partidos políticos se vieron en dificultades para sostenerse, ya que nunca tuvieron una afiliación significativa, y por ello nunca contaron con el valor de las cuotas de afiliados y siempre utilizaban recursos externos (de individuos y grupos). Por ello en los EE.UU. los partidos son especialmente dependiente de la financiación privada con connotaciones "lobbystas". (Véase: MONTERO GISBERT, José R. "La Financiación de los Partidos Políticos y de las Elecciones en los Estados Unidos". In: VEGA, P. de (ed.): Teoría y Práctica de los Partidos Políticos. Edicusa - Cuadernos para el Diálogo, Madrid, 1977. Pp. 391 392; y McSWEENEY, D. "Parties, Corruption and Campaign Finance in America". In: WILLIAMS, R. (ed.): Party Finance and Political Corruption. McMillan Press, London, 2000. Pp. 38-39). DI hecho el mayor gasto de los partidos son las campañas electorales, y no los gastos ordinarios. (In: KOOLE, R. "Political Finance in the United States". In: NASSMACHER, K-H. (ed.): Foundations for Democracy - Approaches to Comparative Political Finance. ed. Nomos Verlagsgesellschaft, Baden-Baden, 2001. Pp. 35).

${ }^{198}$ WILLIAMS, R. "Conclusions..." Pp. 206. Lo que sostiene realmente las campañas son los grupos de interés, como también son los que gastan más con eso. (Cfr. McSWEENEY, D. Op. Cit. Pp. 37).

199 NASSMACHER destaca que el modelo de federalismo de los EE.UU. tiene un impacto directo sobre la regulación legal de la financiación de los partidos políticos, ya que puede haber regulación en todos los niveles estatales. También, el autor resalta la importancia que la libertad de expresión tiene sobre la legislación en este tema, ya que la Supreme Court intervino en múltiples ocasiones con declaraciones de inconstitucionalidad, basadas en la first amendment, reconfirmando la regulación sobre financiación. (In: NASSMACHER, K-H. "The Funding of..." Pp. 49).

${ }^{200}$ WILLIAMS, Robert. "Aspects of Party Finance and Political Corruption". In: WILLIAMS, R. (ed.): Party Finance and Political Corruption. McMillan Press, London, 2000. Pp. 11. 
hegemónica a lo que coadyuvan las reglas que rigen cada una de ellas. ${ }^{201}$ Cabe resaltar también que en la Constitución norteamericana no existe ninguna previsión acerca de los partidos y del derecho de asociación ${ }^{202}$, siendo este reconocido por la primera vez en $1958^{203}$ por la Supreme Court, que consecuentemente llevó al reconocimiento del papel constitucional de los partidos políticos, como fruto de dicho derecho, en $1973 .^{204}$

Así, la inclinación de todo el sistema hacia la financiación privada es evidente. Aunque en las campañas electorales presidenciales la financiación pública es bastante solicitada desde su implantación en 1976, en las elecciones para el Congreso y Senado el escenario es otro. Sin embargo, ya se conocían los efectos nefastos de la financiación privada. Antes de la FECA (Federal Election Campaign Act), la corrupción "financiera" era extraordinariamente común en las campañas electorales. ${ }^{205}$ Además, también se debe considerar que, como no hay concesiones gratuitas en la televisión para los partidos y candidatos, los EE.UU. destacan de hecho entre los países con un muy alto nivel de gasto electoral. ${ }^{206}$

Más allá de las competencias legislativas concedidas a los estados federados $^{207}$, la presente exposición versará únicamente sobre el sistema

${ }^{201}$ En este sentido, cfr. ISSACHAROFF, S. "Party Funding and Campaign Finance Law in the United States". In: BIGLINO CAMPOS, P.; DELGADO DEL RINCÓN, L. E. (eds.): La Resolución de los Conflictos Electorales: Un Análisis Comparado. Cuadernos y Debates, Centro de Estudios Constitucionales, Madrid, 2010. Pp. 183. El autor atribuye este dato a la histórica desconfianza de la sociedad estadunidense hacia la financiación de los partidos, y también a las dificultades encontradas por el legislador al intentar controlar la financiación privada de las campañas electorales.

${ }_{202}$ SÁNCHEZ GONZÁLEZ, S. "La Financiación de los Partidos Políticos en los Estados Unidos". In: Teoría y Realidad Constitucional. no 6, ㄴo semestre, UNED, Madrid, 2000. Pp. 7172.

${ }^{203}$ En el caso N.A.A.CP vs. Alabama.

${ }^{204}$ En el caso Kusper vs. Pontikes.

205 Para un panorama general del escenario de corrupción en la financiación de campañas en aquél país, cfr. WARE, A. "The Funding of Political Parties in North America". In: BURNELL, P., WARE, A. (eds.): Funding Democratization, Manchester University Press, UK, 1998. Pp. 24 y SS.

${ }^{206}$ Cfr. SÁNCHEZ GONZÁLEZ, S. Op. Cit. Pp. 72 y PINTO-DUSCHINSKY, M. Op. Cit. Pp. 7475.

${ }^{207}$ Este constituye uno de los grandes retos de la reforma del sistema estadounidense, porque debido a su forma republicana, se debe proteger los gobiernos de los estados (término conocido por Guarantee Clause Mandate), lo que algunas veces impide que el Congreso actúe firmemente respecto a los problemas del sistema de financiación de las campañas electorales. Se trata de un mandato constitucional que no fue citado en la decisión Buckley v. Valeo, pero si invocado en el momento de la discusión de la Bipartisan Campaign Reform Act. Sobre el tema, cfr. ALEXANDER, M. C. "Campaign Finance Reform: Central Meaning and a New Approach". 
federal, que creemos clave en el análisis del sistema de financiación en aquél país. ${ }^{208}$ Sin embargo, cabe añadir que la financiación pública solo alcanza las elecciones presidenciales, no a las del Congreso. ${ }^{209}$

La legislación federal sobre de la financiación de los partidos políticos se inició a través de medidas negativas, es decir, a partir de prohibiciones o limitaciones. ${ }^{210}$ Se adoptó el sistema de limitación de gastos basándose en las medidas británicas (las cuales a la vez pretendían combatir la corrupción y más específicamente la compra de votos, práctica común en la época) alrededor de 1910. El fenómeno, sin embargo, permaneció notoriamente presente en la dinámica electoral. ${ }^{211}$ Las primeras disposiciones que posteriormente fueron anuladas, de hecho, fueron ya incumplidas durante todo el periodo de su vigencia, tanto por las facilidades que la propia ley ofrecía para burlar los topes

In: SLABACH, F. G. (ed.): The Constitution and Campaign Finance Reform: An Anthology. 2o ed. Carolina Academic Press, USA, 2006. Pp. 317-367.

${ }^{208}$ Sobre la financiación de campañas a nivel estatal en EE.UU., vid. por todos JONES, R. S. "Campaign and Party Finance in the American States". In: GUNLICKS, A. B. (ed.): Campaign and Party Finance in North America and Western Europe. Westview Press, USA, 1993. Pp. 4167 y JONES, R. S. "U.S. State-level Campaign Finance Reform". In: ALEXANDER, H. E.; SHIRATORI, R. (eds.): Comparative Political Finance Among the Democracies. Westview Press, USA, 1994. Pp. 57-76; MOSCARDELLI, V. G.; HASPEL, M.; WIKE, R. S. "Party Building Through Campaign Finance Reform: Conditional Party Government in the $104^{\text {th }}$ Congress". In: The Journal of Politics, vol. 60, no 3, august, University of Texas Press, Austin, 1998. Pp. 691704. En estos tres estudios, se resalta la mencionada descentralización entre los niveles de los partidos, que provoca incluso que no estén coordinados en la financiación de las campañas electorales de sus candidatos. También hay un resumen sobre mecanismos de control de donaciones de PAC's (Party Action Committee) y donantes, y otros detalles de gran interés.

${ }^{209}$ Este aspecto es muy criticado justamente porque fomenta la participación de los PAC's y del lobbying, incluso aumentando su poder en las campañas electorales para el Congreso y Senado. Dichas distorsiones son analizadas en: WERTHEIMER, F.; WEISS MANES, S. "Campaign Finance Reform: A Key to Restoring the Health of Our Democracy [Except One]". In: SLABACH, F. G. (ed.): The Constitution and Campaign Finance Reform: An Anthology. $2^{\circ}$ ed. Carolina Academic Press, USA, 2006. Pp. 164 y ss.

${ }^{210}$ Cfr. BORRELLO, R.: "Finanziamento della Política..." Pp. 39-41, como tendencias de legislación posible.

${ }^{211}$ Exponemos aquí tan solo los rasgos generales del sistema norte americano, sin un análisis específico de cada ley, entre ellas: * 1907 - Tillman Act; *1925 - Federal Corrupt Practices Act; *1936 y 1940 - Hatch Act (compuesta de otras del género); *1943 - Smith Connolly Act; *1950 - Internal Security Act; *1971 - Federal Election Campaign Act (de ahora en adelante, FECA) y Revenue Act (que estimuló la creación de un fondo voluntario de donaciones). Cfr. CRESPI, R.: Op. Cit. Pp. 74 y MONTERO GISBERT, J. R. "La Financiación de los..." Pp. 395-396; y ALEXANDER, H. E.: Financing Politics - Money, Elections and Political Reform. 2o ed, Congressional Quarterly Press, D.C., 1980. Pp. 26-32. Igualmente, véase KEY, V. O.: Politics, Parties and Pressure Groups. 5ำed, ed. Crowell, New York, 1964. Pp. 550 y ss, para un análisis del sistema de financiación de los partidos en Estados Unidos en la época del Hatch Act. El autor destaca que dicha norma contenía diversas lagunas legales que permitían que reglas como la limitación de donaciones y gastos prácticamente no fueran cumplidas, o fueran cumplidas de manera deficiente, incluyendo todos los niveles de los partidos, desde los comités nacionales hasta los municipales. Por fin, también cfr. SÁNCHEZ GONZÁLEZ, S. Op. Cit. Pp. 73. 
fijados, como por la determinación de valores muy bajos para los gastos, que acabaron por ser imposibles de cumplir, principalmente por la falta de su actualización monetaria. Dichas leyes (que se centraban en la prohibición de donaciones de determinados donantes, en límites a las donaciones para evitar la influencia de los grupos de interés, en la limitación de gastos para campañas, o en mecanismos de transparencia, etc.) no fueron tampoco eficaces dada la ausencia de mecanismos de control y de un órgano de fiscalización. En 1966 también se produjeron modificaciones en el sistema, con la introducción de la financiación pública a través del tax check off (sistema que permite a los contribuyentes que hagan donaciones voluntarias a los partidos a través del pago de sus impuestos) ${ }^{212}$, que fue el sistema vigente por costear las elecciones prenominales y generales para presidente, y para los partidos mayoritarios, las primarias, en $1976 .{ }^{213}$

Ante el fracasado intento de limitar los gastos, se inició el cambio de la normativa, a través de un proceso de defensa de la transparencia de la financiación de las campañas electorales, tanto de las fuentes públicas como de las privadas, que culminó con la promulgación de dos nuevas leyes en 1971, la FECA (Federal Election Campaign Act) y la Revenue Act. La FECA ${ }^{214}$ fue una de las innovaciones para las elecciones de la década de los 70 , sufrió diversas modificaciones fruto de hechos ocurridos en la misma época. La Revenue Act fue responsable del establecimiento de las primeras bases para la financiación pública, perfeccionando el sistema de tax check off previsto anteriormente. En 1974 la normativa sufrió cambios para la inclusión de la financiación de las convenciones y las elecciones primarias, estableciendo por consiguiente criterios para la participación de los partidos minoritarios y nuevos

\footnotetext{
${ }^{212}$ FERNÁNDEZ VIVAS, Y.: Op. Cit. Pp.215. Sin embargo, cabe resaltar que la mencionada ley fue suspendida un año después, no pudiendo ser aplicada. Tan solamente en 1976 el sistema fue aplicado, con modificaciones.

${ }^{213}$ ALEXANDER, H. E. "American Presidential Elections Since..." Pp. 95-96.

${ }^{214}$ Cfr. PORTER, T. "Where are we now? The Current State of Campaign Finance Law". In: CORRADO, A.; et al (eds.): "Campaign Finance Reform: a Sourcebook". D.C. 1997. Pp. 6 y ss., para una descripción minuciosa sobre la FECA, comentando incluso problemas como las lagunas que hay en la legislación que trata sobre los PAC's.
} 
en la financiación pública, en un intento de equilibrar las condiciones de financiación entre los partidos políticos. ${ }^{215}$

La financiación pública fue pensada para ayudar o suplir enteramente los recursos necesarios de candidatos con serios propósitos, para la divulgación de sus ideas al electorado. También era una manera de disminuir o eliminar la influencia de los grupos de presión y los donantes sobre los candidatos. Ya en el caso de las primarias, la financiación pública intentó volver más competitivo el proceso y también animar a los candidatos a salir de sus bases, recaudando contribuciones de bajo valor para la contienda electoral. Con todo, el eje principal de dicha financiación pública era el sistema de desgravación fiscal para campañas tanto primarias como presidenciales. ${ }^{216}$ Sin embargo, la financiación pública de campañas todavía es algo ambiguo para los norte americanos, porque aunque las donaciones privadas, PAC's, partidos políticos y candidatos no gocen de gran prestigio entre la sociedad, son aceptados sin entusiasmo por representar una manifestación de la libertad de expresión, en los términos de la $1^{\circ}$ enmienda de la Constitución. Con todo, también se ve una cierta ambigüedad en los candidatos que aceptan la financiación pública en cuanto no fomentan la aprobación de medidas en este sentido o que simplemente no dan soporte a través de políticas públicas para este fin. ${ }^{217}$

215 FERNÁNDEZ VIVAS expone que la igualdad de oportunidades en EE.UU. (equal opportunity) significa igualdad de desarrollo de la competición política entre los candidatos, aplicando el principio sólo durante las campañas electorales. Significa también establecer requisitos jurídicos iguales para todos, posibilitando a todos los candidatos la misma accesibilidad a bienes y servicios, y permitiendo que dichas condiciones iguales permitan a todos los involucrados en la campaña que desarrollen su programa o estrategia electoral en el mismo nivel. Sin embargo, su aplicación es en un sentido formal, existiendo a la vez un fuerte vínculo entre esta idea de igualdad de oportunidades y la equal protection clause, principio este de la $14^{\circ}$ enmienda, que es el más utilizado en los tribunales para la defensa de los derechos individuales. Fue igualmente esta enmienda la responsable de introducir la idea de igualdad formal en los EE.UU., aunque la Supreme Court utilice constantemente la idea de igualdad material. (In: FERNÁNDEZ VIVAS, Y.: Op. Cit. Pp. 203 y ss).

${ }^{216}$ ALEXANDER, H. E. "American Presidential Elections 1976-1992". In: ALEXANDER, H. E.; SHIRATORI, R. (eds.): Comparative Political Finance Among the Democracies. Westview Press, USA, 1994. Pp. 41-42.

${ }^{217}$ Ejemplo de esta falta de colaboración por parte de los candidatos en las políticas públicas que se basa en la financiación pública es Ronald Reagan quien en 1976, 1980 y 1984 optó por la financiación pública, pero no hay noticias sobre cualquier contribución suya a través del tax check off. (SORAUF, F. J.: Op. Cit. Pp. 131-132). 
La situación resultó afectada a partir del conocido caso Watergate ${ }^{218} \mathrm{y}$ otros factores propios del sistema de financiación hasta entonces aplicado. Surgieron nuevas presiones para aplicar nuevamente las limitaciones en los gastos de la política, lo que culminó en modificaciones de la FECA en 1974. Los cambios pretendían eliminar las grandes donaciones y contener los costes de la campaña, imponiendo una limitación bastante rigurosa. Esto motivó su cuestionamiento ante la Supreme Court, que a su vez declaró la norma inconstitucional en el emblemático caso Buckley vs. Valeo ${ }^{219}$, de 30 de enero de $1976 .{ }^{220}$ La decisión se fundamentaba en la defensa de la libertad de expresión de ideas y el libre intercambio tanto de ideas sociales como también políticas - comprendidas en la First Amendment. Afirmaba que, con relación a

${ }^{218}$ HERRNSON expone un resumen del escándalo Watergate, destacando todos los delitos cometidos por el Comité para la reelección de Nixon y su administración en el gobierno, afirmando que hubo aceptación de contribuciones ilegales para la campaña, favorecimiento de grandes donantes, cambio de favores por apoyo electoral a ejecutivos de negocios, de quienes provenían grandes donaciones, además de la histórica invasión de la sede del Partido Demócrata en el Hotel Watergate, lo que realmente desencadenó toda la crisis. (In: HERRNSON, P. J. "The High Finance of American Politics". In: GUNLICKS, A. B. (ed.): Campaign and Party Finance in North America and Western Europe. Westview Press, USA, 1993. Pp. 20).

${ }^{219}$ Cfr. 424 U.S. 1 (1976).

${ }^{220}$ La decisión es largamente citada hasta hoy dentro del contexto de la financiación de la política y la demanda fue fruto del movimiento de diversos individuos y grupos demócratas y republicanos, liderados por el senador republicano de Nueva York James L. Buckley, autor de la demanda. La sentencia - que fue una de las más largas de la historia de este Tribunal declaró tres puntos importantes: a) acerca de la alegación de que la limitación de contribuciones contenida en la FECA estaba afectando a la libertad de expresión defendida por la primera enmienda, y que sin una cantidad considerable de dinero no se puede divulgar un discurso político de manera significativa, la Suprema Corte consideró que esto no era un argumento válido, ya que la ley estaba tratando las fuerzas políticas de manera igual, incluso protegiendo a los pequeños partidos; b) acerca de la limitación de gastos, los argumentos aducidos fueron considerados por la Suprema Corte, a la vez que esta consideró que la FECA sí estaba afectando a la libertad del discurso político, declarando dicho límite como una medida inconstitucional, por afectar el derecho individual de los ciudadanos de participar en el proceso político sobre los asuntos que les importan, incluso cuando utilizaban recursos propios; c) sobre la publicidad de los nombres de los donantes, la Suprema Corte no aceptó el argumento de que esto pueda influir en el derecho de asociación y de libre expresión de los ciudadanos, y mantuvo que la transparencia incluso estaba justificada como un medio de ayudar al elector a decidir qué candidato iba a votar, a partir de los apoyos financieros de cada uno de los candidatos y partidos políticos; d) acerca de la financiación pública de las elecciones para Presidente, según los recursos recolectados por el sistema de tax-check off (opción de elegir donar parte de los impuestos que se debe pagar al Estado para el fondo que financia a los partidos políticos), la Suprema Corte decidió que el Estado puede contribuir a dicha financiación, no siendo ninguna apropiación de los partidos políticos por parte de la maquina estatal, ya que los únicos que deben someterse a la limitación de gastos electorales son los partidos y candidatos que optan por la financiación pública para las campañas, los que optan por la financiación privada no estarían sometidos a límite alguno. El texto integro puede encontrarse en: http://www.supremecourtus.gov/index.html. sobre la sentencia, vid. SÁNCHEZ GONZÁLEZ, S. Op. Cit. Pp. 74. 
las contribuciones y sus limitaciones, la comunicación de ideas no iba a ser mayor si la contribución fuera mayor, siendo el acto de contribuir más simbólico y trascendente que el valor propiamente dicho. ${ }^{221}$ Ahora bien, con relación a la limitación de gastos por parte de los candidatos, la libertad de expresión estaba siendo perjudicada porque la normativa no la protegía e incluso afectaba directamente el numero de temas debatidos en la contienda electoral, a la vez que se consideraba que, para instaurar un debate político, debería haber publicidad de ideas a través de propaganda propiamente dicha. ${ }^{222}$ Tras la sentencia, se produjeron las modificaciones en la FECA, en los términos contenidos en dicha sentencia. ${ }^{223}$

Posteriormente en 1979, y ya con los cambios introducidos en la FECA $^{224}$, se perfiló la idea de soft money y hard money. El primero se refiere al dinero con el que los comités de acción de los partidos contribuyen a la campaña (los denominados Party Action Committees, de ahora por delante PAC's) ${ }^{225}$ de los partidos demócrata y republicano y sus candidatos, o los

${ }^{221}$ Cfr. ISSACHAROFF, S. "Party Funding..." Pp. 187.

${ }^{222}$ El tema es de grande complexidad ya que dicha interpretación no es unánime, además de ser siempre el centro del análisis de la ley sobre la materia. Vid. SKELLY WRIGHT, J. "Politics and the Constitution: Is Money Speech?" In: SLABACH, F. G. (ed.): The Constitution and Campaign Finance Reform: An Anthology. 2o ed. Carolina Academic Press, USA, 2006. Pp. 119-140, donde el autor se posiciona contra la decisión emitida por la Supreme Court, en el sentido de que pluralismo y libertad de ideas no significa exactamente gasto de dinero, aunque esté muchas veces vinculado a él. Vid. también R. BEVIER, L. "Money and Politics: A Perspective on the First Amendment and Campaign Finance Reform". In: SLABACH, F. G. (ed.): The Constitution and Campaign Finance Reform: An Anthology. $2^{\circ}$ ed. Carolina Academic Press, USA, 2006. Pp. 141-155, donde la autora defiende este entendimiento, afirmando que después de dicha decisión fue posible una interpretación completa del derecho de la primera enmienda con la FECA, en la época una ley todavía nueva.

${ }^{223}$ Véase SÁNCHEZ GONZÁLEZ, S. Op. Cit. Pp. 74 y ss, para otros ejemplos de decisiones en términos semejantes.

${ }^{224}$ Hay autores que incluso entienden que después de Buckley v. Valeo, fue necesario reescribir la FECA. No dejan de tener su razón. En este sentido, cfr. ISSACHAROFF, S. "Party Funding..." Pp. 187.

${ }^{225}$ Los PAC's hasta hoy no son una unanimidad. La pluralidad de grupos sociales existentes en los EE.UU. hace la concentración de sus propios recursos para apoyar a candidatos amigos, 0 afines, o hacer de su causa, una voz. Aunque esto produzca una nacionalización (y también una proliferación) de los PAC's, su centralización es lo que acaba por identificar intereses y demandas que existen en todo el país, facilitando de cierto modo la comunicación entre la sociedad y los candidatos. (In: MELCHIONDA, E.: Op. Cit. Pp. 170). Sin embargo, esto también puede ser considerado un lobby, y hay algunos que dicen que los PAC's fueron organizados como una manera de evadirse de las limitaciones a donaciones realizadas por personas jurídicas establecidas por el Tillman Act, y son organizaciones separadas que solicitan fondos para los miembros del partido. O sea, los PAC's fueron un marco que ayudó a las prácticas ilícitas a sobrevivir, ya que la legislación era de ejecución débil. La separación existente entre los candidatos y los partidos políticos hizo que aumentara considerablemente el volumen de 
comités de partido de cada estado. Son recursos económicos que no están limitados por ley, porque se encajan en el issue advocacy, una publicidad, un apoyo al candidato, sin la petición de voto. ${ }^{226}$ El segundo está regulado y limitado por ley y se vincula al express advocacy, una publicidad con ánimo de obtención del voto, con petición expresa del mismo, concediendo dinero directamente al candidato y controlado por el Federal Electoral Commission (por adelante, FEC). La lógica de la ley fue que la garantía era para los candidatos frente de los partidos, en una clara muestra que no se trataba de una ley para proteger a los partidos (como podría ocurrir en Europa). ${ }^{227}$

El soft-money se mantuvo en proporciones relativamente modestas durante varias elecciones, aumentando abruptamente su volumen en el inicio de los años 90, acompañando la proliferación de los PAC's tanto republicanos como demócratas. ${ }^{228}$ Una vez evidenciado el aumento vertiginoso y el uso

donaciones por todos los comités, creando aún otros, transfiriendo la organización de la campaña de los partidos a los respectivos comités. (In: McSWEENEY, D. Op. Cit. Pp.40 y ss). ${ }^{226}$ Cfr. SNYDER JR. J. M. "Long-term Investing in Politicians; or Give Early, Give After". In: The Journal of Law and Economics. vol. XXXV (35) (1), april, University of Chicago Press, 1992. Pp. 15-43, para una simulación del impacto de los recursos recaudados a través de los PAC's sobre la dinámica de la política estadounidense, incluso como se analizan las inversiones hechas por los PAC's en un u otro partido. También, en el caso Colorado Republican Federal Campaign Committee v. FEC (1996), la Corte Suprema ha decidido que los gastos hechos por los partidos políticos resultaban ilimitados no estuvieran coordinados con el candidato, siendo que antes, cuanto más el partido gastaba, menos podría gastar el candidato (a fin de atender a la limitación dispuesta por la FECA). Así, dichos gastos serían considerados como independent expenditure, descritos como un gasto para comunicación que pedía expresamente el voto a un candidato o las elecciones, pero que se realizaba independientemente de la campaña de este. Para ser considerado así, debería no estar coordinado con el candidato, lo que era muy difícil de demostrar en la práctica. Sin embargo, la propaganda bajo dicha clasificación debería contener por fuerza la indicación de su responsable, con la declaración de que dicha propaganda no estaba autorizada por ningún candidato o comité de candidato, aunque haya la petición expresa del voto. (In: KOOLE, R. "Political Finance in the United States". In: NASSMACHER, K-H. (ed.): Foundations for Democracy - Approaches to Comparative Political Finance. ed. Nomos Verlagsgesellschaft, Baden-Baden, 2001. Pp. 37-46).

${ }^{227}$ Sin embargo, me parece acertada la idea de NEUBORNE, que al analizar los efectos prácticos de la sentencia Buckley $v$. Valeo, y considerando las medidas legales tomadas después, entiende que una de las consecuencias más importantes fue que separó el posible dinero en la política estadounidense en "clases" o "categorías", dado que existe el dinero de la élite, el dinero de los electores que ejercen su derecho de voto, y el dinero de los electores que, además de no ejercer el derecho de voto, piensan que no pueden influir en la política. En realidad, acabó por jerarquizar recursos dentro de la dinámica política, y esto fue una elección, una opción por el vínculo con el liberalismo político, no fue por una defensa de la libertad de expresión. Simplificando el análisis: clasificó los recursos en ricos y pobres, literalmente. (In: NEUBORNE, B. “Is Money Different?" In: Texas Law Review. no. 7. vol. 77, june, Austin, 1999. Pp. 1617-1620).

${ }_{228}$ Para las elecciones de 1992, los comités de los partidos republicano y demócrata recaudaron un total de 86.1 millones de dólares, siendo que 4 años después las donaciones de esta naturaleza aumentaron en $204 \%$, traduciéndose en 262.1 millones de dólares, y en las 
ilimitado y prácticamente sin criterios de este tipo de recursos en los años 2000, se produjo la última reforma de la FECA, ocurrida en 2002 con el Bipartisan Campaign Reform Act (BCRA) ${ }^{229}$, que intentó regular y establecer límites para el dinero recibido en concepto de donaciones para gastos ordinarios por los partidos políticos, o sea, su objetivo principal era excluir el soft-money de las campañas electorales de los partidos nacionales, haciendo que todas las contribuciones pasaran por el control del hard-money. ${ }^{230}$

Además de eso, la BCRA trató de regular el criterio de limitación de la publicidad de spots publicitarios en período electoral. Como en la decisión Buckley vs. Valeo, nota 52, la propaganda tenida como publicidad directa (express advocacy) era la que contenía expresiones que pedía los votos, o sea, "vota por", "vota contra", "elige", y otras, y esta estaba prohibida con los

elecciones de 2000, aumentó otros 89\%, pasando a ser de 495.1 millones. (In: ABRAMS, B. A.; SETTLE, R. F. "Campaign-Finance Reform: A Public Choice Perspective". In: Public Choice. vol. 120. no 3-4, sept. Ed. Kluwer, NL, 2004. Pp. 380). El aumento se hace aún más claro en las elecciones de 2000, las últimas presidenciables antes de la BCRA, en la cual ambos partidos mayoritarios recaudaron cuantías exorbitantes de dinero tanto a través del Hard Money, pero principalmente por Soft Money, superando este todas las expectativas. (In: CORRADO, A. "Party Finance in the 2000 Elections: The Federal Role of Soft Money Financing". In: SLABACH, F. G. (ed.): The Constitution and Campaign Finance Reform: An Anthology. $2^{\circ}$ ed. Carolina Academic Press, USA, 2006. Pp. 56).

${ }_{229}$ También puede apuntarse como otra razón indirecta para la reforma del sistema la revelación del caso Enron, en el cual se descubrió que además de las fraudes financieros que había en la empresa, esta también había colaborado con cuantías considerables de dinero para las campañas electorales tanto de los republicanos - que eran más próximos incluso en las elecciones para presidente con el candidato Bush - como también de los demócratas.

${ }_{230}$ Cfr. BRIFFAULT, R. "The Future of Reform: Campaign Finance After the Bipartisan Campaign Reform Act of 2002". In: SLABACH, F. G. (ed.): The Constitution and Campaign Finance Reform: An Anthology. 2ํㅡ. ed. Carolina Academic Press, USA, 2006. Pp. 85 y ss. También es interesante exponer que el soft-money, únicamente, no provocó en encarecimiento de las campañas o el aumento de gastos, como se pude pensar. En realidad, el soft-money no era un problema cuando fue aprobado en 1976, pasando a ser algo preocupante solo cuando lo descubrieron como una real laguna de la ley. Además, el límite de 1000 US\$ para las donaciones determinadas por la FECA no afectaba a tanta gente en 1976 como pasó a afectar en los años 90, incluso porque la inflación hizo que los 1000 US\$ de antes se volvieran 250 US\$, alcanzando a más gente y haciendo presión sobre la legislación, en una constante búsqueda de lagunas legales. Interesa también resaltar que, en una comparación con la FECA y la BCRA, la primera puede ser que no haya atendido al interés público (por limitar gastos en campaña o disminuir la presencia de los grupos de interés), pero atendía mucho más a la teoría económica de la regulación, o sea, buscaba su propio interés, ya que favoreció directamente al partido demócrata. Sin embargo, la BCRA, aunque los demócratas no eran directamente favorecidos con el soft-money de la manera que eran los republicanos, no hubiera sido aprobada sin el apoyo de parte de estos últimos. Lo que explica esto es que los republicanos, considerados individualmente, vieron en la nueva regulación beneficios individuales, como el aumento de los límites para las contribuciones a título de hard-money. Además, los republicanos son los que logran más recursos de esta naturaleza, y aprovecharon también la oportunidad de la aprobación de la ley para cumplir con su promesa electoral de limitar la presencia de intereses privados en la política. (In: ABRAMS, B. A.; SETTLE, R. F. Op. Cit. Pp. 387-392). 
recursos del soft money. Lo que se permitía con dichos recursos era solamente la propaganda indirecta (issue advocacy), es decir, sin las "palabras mágicas". Como se trataba de un criterio bastante débil ${ }^{231}$, que acabó por volver los recursos del soft money como el centro de las campañas electorales, la BCRA determinó un criterio temporal para la publicidad política, que ahora no tiene más distinción que entre express e issue advocacy, pero es electioneering communication que engloba todo el tipo de publicidad televisiva por cable o por satélite refiriéndose a un candidato determinado (no importando si su autor es directamente el candidato o no). Este tipo de transmisión está prohibida 30 días antes de las elecciones para las primarias y 60 días antes de las elecciones generales. Se trata claramente de un intento de bajar los costes de las campañas y también de disminuir la influencia de los mass media sobre la sociedad norte-americana. ${ }^{232}$

Como era esperado, y siguiendo la tendencia iniciada por Buckley vs. Valeo, la BCRA también fue sometida a la Supreme Court (en el caso McConnell vs. Federal Electoral Commission), que la declaró constitucional en aquél momento, o sea, que no violaba las normas constitucionales, principalmente la First Amendment, ya que el combate a la corrupción era tan importante como la defensa de la libertad de expresión. Así, la limitación de las contribuciones estaría justificado en pro de un bien jurídico mayor, controlar la corrupción existente. Además, la Corte consideró que la influencia sobre la libertad de expresión era mínima, comparándolo con los daños provocados con el soft-money, dado que no se trataba de una limitación a los gastos, pero sí a las contribuciones, y el primero no puede traducirse en el segundo. ${ }^{233} \mathrm{Sin}$ embargo, poco a poco este entendimiento ha sufrido algunas modificaciones en los últimos cuatro años, hasta debilitarse tanto como en los modelos anteriores. En 2007 en el caso Federal Electoral Commission vs. Wisconsin Right to Life,

${ }^{231}$ Cfr. CERASE, M. "La Corte Suprema Americana (Fortunatamente) Cambia Idea sul Finanziamento alle Campagne Elettorali". In: II Foro Italiano. Parte IV, vol. 225, 2004.

${ }^{232}$ Cfr. GRATTERI, A. "Soft Money Versus Hard Money: II Congresso USA e II Finanziamento delle Campagne Elettorali". In: Quaderni Costituzionali. Anno XXII. no 4, Dic. Ed. II Mulino, Bologna, 2002. Pp. 789-791. El BCRA también trató de aumentar el límite de contribuciones individuales a título de Hard Money, aumentando al mismo tiempo la posibilidad para contribuciones pequeñas de personas no pertenecientes a las clases más elevadas, pero que acusaban a la élite de utilizar su propio dinero a favor de sus campañas.

${ }^{233}$ Cfr. CERASE, M. Op. Cit. 
la Corte declaró una exención a la prohibición sobre la publicidad a favor de determinado candidato cuando alguna organización realmente involucrada en la discusión de un tema específico fuera importante para el desarrollo de este, debiendo tener amplio espacio para el intercambio de ideas en este sentido y no sometiéndose a las limitaciones temporales establecidas en la BCRA. ${ }^{234}$ Esta decisión ha abierto camino para que se produjera, en un cierto modo, el inicio del desmantelamiento de las disposiciones de la sentencia en McConnell vs. $F E C^{235}$, ya que en 2010 la Suprema Corte acompañó la jurisprudencia en el caso Citizen United vs. Federal Election Commission, justamente en el punto que versa sobre la libertad de expresión en los medios de comunicación de masa. ${ }^{236}$ Lo que sí es cierto es que en la Supreme Court todavía no hay un

${ }^{234}$ En realidad, con la limitación del soft money, dichos recursos pasaron al próximo nivel de actores políticos sin regulación, que eran los independent expenditure committees. Dicho fenómeno empezó a ser visible en las elecciones de 2004 y, por su ambigüedad, no fue difícil que dichos comités entraran en las campañas electorales sin que fueran sometidos a las limitaciones de la ley. Sería como si dichos gastos fueran de ciudadanos comunes, individualmente considerados. Si así no fuera, se podría argumentar la aplicación de las limitaciones legales a estas contribuciones. En este sentido, cfr. ABRAHAM, J. R. "Saving Buckley: Creating a Stable Campaign Finance Framework”. In: Columbia Law Review. vol. 110, ํo. 4, may, NY, 2010. Pp. 1093-1104.

${ }^{235}$ Debido a ello autores como Kenneth JANDA afirma que la BCRA, en la práctica, fue distorsionada. (Cfr. JANDA, K.: Political Parties and Democracy in Theoretical and Practical Perspective. Adopting Party Law. Ed. NDI National Democratic Institute for International Affairs, Washington, 2005. Pp. 7). De hecho, la BCRA suele ser comparada con la FECA en su primera versión, antes de ser "alterada" por la Supreme Court, pues además de concentrarse solamente en establecer límites y sus mecanismos de aplicación, no trató de prever el mejoramiento del sistema de financiación como un todo, dejando sin considerar puntos importantes como una posible ampliación de la financiación pública, por ejemplo. Véase BRIFFAULT, R. Op. Cit. Pp. 504-505.

${ }^{236}$ En 21 de enero de 2010 la mencionada demanda (no 08-205) discutía sobre la legitimidad y el derecho de una fundación independiente para transmitir un documental que criticaba a la entonces Senadora Hillary Clinton dentro del plazo de 30 días antes de las elecciones primarias del partido demócrata. Aunque la BCRA prohíba a cualquier corporación utilizar sus recursos para gastos independientes a favor de algún candidato que represente una comunicación electoral, la Supreme Court decidió en pro de la First Amendment, afirmando que las limitaciones contenidas en dicha ley no podía prevalecer sobre la libertad de expresión, siendo esta decisión muy criticada, ya que indirectamente permite al lobbying actuar a través de corporaciones independientes de modo que dichos gastos no sean controlados 0 contabilizados dentro de los límites económicos que la ley impone a los candidatos. Así, cfr. http://www.supremecourt.gov/opinions/09pdf/08-205.pdf. En realidad, muchos analistas de esta decisión consideraron un error dicha interpretación, que privilegió claramente al lobbying en lugar de la igualdad de oportunidades, aunque en el momento de decidir la causa se provocó una profunda división en la Supreme Court, esto no evitó que la igualdad entre los competidores políticos fuera puesta en segundo plano. En este sentido, véase: CARUSO, C. "II Caso Citizens United v. Federal Commission: Money Must Talk". In: Quaderni Costituzionali. Anno XXX. no 2, Giugno. Ed. II Mulino, Bologna, 2010. Pp. 389-392 y ISSACHAROFF, S. "II Caso Citizens United v. Federal Election Commission: II Finanziamento dei Partiti nel Diritto Americano". In: Quaderni Costituzionali. Anno XXX. no 2, Giugno. Ed. II Mulino, Bologna, 2010. Pp. 392-397. 
consenso sobre el tema ${ }^{237}$, y los diversos casos involucrando cuestiones sobre la financiación de las campañas electorales aún despiertan fuertes debates, dejando una impresión de inseguridad jurídica ${ }^{238}$, ya que la sociedad ahora tiene el camino abierto de intervenir en las campañas a través de los gastos independientes, sin ser considerado un lobbying directo. ${ }^{239}$

Centrándose en la financiación pública prevista en la legislación de EE.UU., a nivel federal existen subvenciones para las elecciones primarias y generales, siempre enfocando y centrándose en los candidatos, que acaban por cubrir las elecciones más importantes en aquél país, aunque sólo alcance a una pequeña parte de las otras, a nivel estatal y municipal. Sin embargo, las críticas al modelo adoptado se ubican en los criterios de acceso a dicha financiación pública. ${ }^{240}$ Los candidatos de los dos principales partidos están automáticamente clasificados para las elecciones, y esto hace que puedan elegir si prefieren la financiación pública o privada. ${ }^{241} \mathrm{Y}$ con el fenómeno de

237 Y esto resulta más evidente si se analizan los votos proferidos en la sentencia del caso
Citizens United vs. Federal Commission Election, que evalúan en profundidad la influencia de
las grandes corporaciones privadas en las elecciones, y su impacto sobre una opinión pública
libre. Cfr. GARCÍA MACEIRAS, O. "Dos Visiones sobre la Financiación Electoral y la Libertad
de Expresión de las Corporaciones Privadas: a Propósito de la Sentencia de la Corte Suprema
"Citizens United v. Federal Election Commission" y el Voto Particular del Juez Stevens". In:
Dereito. Revista Xurídica da Universidade de Santiago de Compostela. no 1 1. v. 19, 2010. Pp. 202-203.

${ }^{238}$ ABRAHAM, J. R. Op. Cit. Pp. 1105.

${ }^{239}$ Para un análisis detallado sobre la sentencia, posibles consecuencias (las cuales estoy de acuerdo, como la pérdida total de los objetivos de la reforma, además de contribuir nuevamente para la incertidumbre en el tema), vid. GARCÍA MACEIRAS, O. Op. Cit. Pp. 207 y ss. Además, véase GNES, M. "Libertà di Espressione e Limiti ai Finanziamenti alle Campagne Elettorali: La Decisione Citizens United v. Federal Election Commission della Corte Suprema Statunitense". In: Rivista Trimestrale di Diritto Pubblico. fasc. 1, anno LXI, ene/mar, ed. Giuffrè, Milano, 2011. Pp. 229 y ss., con la reacción de diversos sectores políticos de los EE.UU., y del propio presidente Obama.

${ }^{240}$ FERNÁNDEZ VIVAS afirma que para los dos mayores partidos no es interesante aceptar la financiación pública que les someterá a limitaciones de gastos, y para los partidos minoritarios será bastante relevante el acceso a los recursos públicos ya que no pueden recaudar tantas donaciones privadas como los dos grandes, el caso de las elecciones que eligieron al candidato Barack Obama confirma este hecho, pues el vencedor de las elecciones utilizó solamente recursos privados y tuvo que someterse a los limites en sus gastos, mientras que su oponente John McCain aceptó la financiación pública, sometiéndose a los límites legales, sin éxito en las urnas. (Cfr. FERNÁNDEZ VIVAS, Y.: Op. Cit. Pp. 239). Se resalte que Obama fue el primero candidato a la presidencia en rehusar los recursos públicos desde la época que se instituyó la financiación pública en aquél país, y acabó por tener una recaudación histórica de recursos gracias a las nuevas tecnologías existentes, como el internet.

${ }^{241}$ Cabe resaltar que en las elecciones de 1976, 1980, 1984 y 1988, todos los candidatos a presidente aceptaron la financiación. (In: SORAUF, F. J.: Op. Cit. Pp. 133). Sin embargo, no se puede ignorar el hecho de que, en la campaña electoral más cara de la historia de los EE.UU. el candidato Barack Obama no aceptó la financiación pública justamente para no necesitar 
encarecimiento de las campañas electorales, las cifras del Estado dedicadas al costo de dichas campañas se dispararon, aliadas con la inflación de la época y la caída significativa de la participación de la sociedad en el sistema de tax check off, lo que agravó aún más la ambivalencia que la financiación pública posee en Norteamérica, considerando el hecho de que las cantidades concedidas a los candidatos siempre aumentan, pero el sistema de tax check off se mantiene igual durante años, comprometiendo la eficacia del modelo. ${ }^{242}$ Desgraciadamente, se puede entender que la BCRA ha debilitado el sistema de financiación pública, porque se preocupó más en establecer límites que en favorecer mecanismos de obtención de fondos para las campañas. Parece claro que el Congreso deberá adecuar la realidad de las campañas electorales - junto con las necesidades de recursos de los partidos - a las nuevas disposiciones y tal vez también a un nuevo sistema de financiación pública, siendo considerada la BCRA únicamente un el primer paso para una reforma completa del modelo existente. ${ }^{243}$

Sin embargo, considerando las disposiciones inicialmente introducidas por la $\mathrm{FECA}^{244}$, se comprueba que la ley ayudó a la fase anterior a las nominaciones a ser más competitiva y posibilitó que candidatos con un acceso pequeño a la financiación privada tuvieran la oportunidad real de competir. ${ }^{245}$ Del mismo modo, los límites establecidos por la ley ayudaron a reducir la influencia que los grandes donantes tenían en las políticas de los partidos hasta un cierto punto. ${ }^{246}$ Con todo, la norma también introdujo problemas, porque con límites tan bajos para contribuciones individuales acabó por hacer que los grandes donantes diluyeran sus montantes en listas de donantes para

someterse a la limitación de gastos descrita en la ley. Dicho hecho hace que, actualmente, se cuestione sobre la real utilidad del sistema de financiación pública existente en aquél país.

${ }_{242}^{24}$ SORAUF, F. J.: Op. Cit. Pp. 136-142.

${ }^{243}$ BRIFFAULT, R. Op. Cit. Pp. 112-116.

${ }^{244}$ Para una descripción detallada de la ley, cfr. PORTER, T. Op. Cit. Pp. 5.24, en el cual el autor trata directamente de los pagos que pueden realizarse en las elecciones federales y los gastos que serán efectivamente considerados como tal, datos muy interesantes para el análisis que el autor propone.

${ }^{245}$ Sobre la financiación de las primarias, cfr. ALEXANDER, H. E. "American Presidential Elections 1976..." Pp. 51.

${ }^{246}$ Sobre el tema de la limitación contenida en la ley, véase ALEXANDER, H. E. "American Presidential Elections 1976..." Pp. 44-45. En el mismo sentido, cfr. ROSE-ACKERMAN, S.: La Corrupción y los Gobiernos: Causas, Consecuencias y Reforma. Siglo XXI, Madrid, 2001. Pp. 192. 
que estos realizaran las contribuciones en su nombre. También dificultó la recaudación de dinero para las campañas por parte de los candidatos, y los bajos límites de gastos en las campañas hicieron que los candidatos pusieran el énfasis en las campañas en los medios, algo que no es necesariamente ventajoso para la información electoral. La dificultad y complejidad de la ley también contribuyó para la mayor profesionalización de las campañas, desmotivando en cierta manera la participación voluntaria de los ciudadanos en la política. ${ }^{247}$

Así, se comprueba que en los EE.UU. predomina a una concepción claramente liberal de democracia, en la cual hay una tendencia a tolerar más las inequidades existentes. ${ }^{248}$ Así, dentro de esta visión, se entiende como derecho de los individuos aquél que permite que cada ciudadano contribuya con sus recursos personales para el sostenimiento de las opciones políticas que defienda sus intereses en la sociedad. ${ }^{249}$ Pero dicha conclusión no permite ignorar el hecho de que las reformas en el sistema de financiación de las campañas electorales en este país se producen claramente a favor de determinados intereses partidistas - tanto el demócrata como el republicano como ocurre en tantos otros países. ${ }^{250}$ Dicha condición permite considerar que el sistema no goza de grandes niveles de apertura, principalmente si se piensa en las facilidades para que los políticos ya electos sean reelegidos, y la gran

\footnotetext{
${ }^{247}$ ALEXANDER, H. E. "American Presidential Elections Since..." Pp. 116.119. HERRNSON también argumenta que la FECA reestructura el sistema de financiación de las elecciones, y que la financiación pública logró reducir los costes de las elecciones presidenciales y minimizó la influencia del dinero en determinados resultados. (In: HERRNSON, P. J. Op Cit. Pp. 20-21). Para otra visión, sobre las consecuencias de la aplicación de la FECA, véase: SÁNCHEZ GONZÁLEZ, Santiago. Op. Cit. Pp. 80-81.

${ }^{248}$ HOPKIN, J. "The Problem with Party Finance - Theoretical Perspectives on the Funding of Party Politics". In: Party Politics. v. 10. no 6. Sage, London, 2004. Pp. 636-641.

249 Argumentos como este son ampliamente utilizados para la defensa del alejamiento del Estado de la cuestión de la financiación de partidos políticos y candidatos. Solamente como ejemplo, dentro del caso suizo, en que se considera que cuanto menos el Estado se involucre en ese asunto, BALMELLI opina que el Estado debería ser un mero árbitro en los problemas que puedan surgir, alterando el mínimo posible la expresión de la voluntad popular, y que la omisión o no de la actividad del Estado no significa una falta de reacción por parte de la sociedad, sino que esta postura favorece el dinamismo y las iniciativas de los actores privados, más libres para adaptarse más rápidamente a las necesidades de la sociedad. (In: BALMELLI, T.: Op. Cit. Pp. 347-348).

250 Tampoco se puede ser injusto, porque después de la BCRA existe una tendencia de favorecimiento de las relaciones entre los partidos y sus bases electorales, justamente con la perspectiva de una mayor recaudación de recursos de acuerdo con dichas disposiciones, como en un cierto modo ocurrió en las elecciones de Barack Obama en 2006. En este sentido, cfr. BRIFFAULT, R. Op. Cit. Pp. 95 y ss.
} 
dificultad para los nuevos de entrar en el sistema, de forma paralela a como ocurre con España, pero considerando los candidatos individualmente y no a sus partidos. ${ }^{251}$

\subsection{Alemania}

Conforme a lo analizado anteriormente, EE.UU. aplicó su concepción del Estado liberal para la normativa referente a la financiación de candidatos en la que, aun siendo mixto, predominan claramente las medidas de financiación privada, consideradas una importante contribución a la política por parte de la sociedad. Entre tanto, no dejó de establecer en su sistema medidas de financiación pública, aun cuando esta esté básicamente orientada a la financiación de los candidatos, principalmente para las elecciones a presidente.

Sin embargo, como es sabido, la opción más importante por los sistemas mixtos, con el predominio de medidas de financiación pública, se produce en los países europeos, que se adhirieron casi en su totalidad a este modelo en el período posguerra, como consecuencia de la consolidación del reconocimiento constitucional de los partidos políticos. Así, en Europa existen en la actualidad muchos ejemplos de sistemas mixtos, basados primordialmente en la financiación pública. ${ }^{252}$ Es de resaltar que la financiación privada en algunos países europeos suscita críticas doctrinales, resultando que en muchas ocasiones existen múltiples restricciones y prohibiciones para este tipo de financiación.

El caso alemán se muestra paradigmático por dos factores: la fuerte consideración del valor constitucional del principio de igualdad de partidos,

\footnotetext{
${ }^{251}$ EE.UU. tiene grandes problemas en su sistema de financiación, no solo de falta de apertura del modelo o incluso por la falta de una extensión de la financiación pública a los demás niveles de poder. La falta de transparencia, la cristalización de la formación del Senado y de la Cámara de Representantes, la concepción de que el dinero compra el resultado de las elecciones (aunque no sin excepciones), y el enorme volumen de recursos utilizados en las campañas hace que esto tenga reflejos en la opinión pública. Además, el poder de los lobbies y de los grupos de presión hace que los políticos en general sean vulnerables a la corrupción, que está presente en el sistema y contribuye aún más para el clientelismo. En este sentido, cfr. SMITH, B. A. "Faulty Assumption and Undemocratic Consequences of Campaign Finance Reform". In: SLABACH, F. G. (ed.): The Constitution and Campaign Finance Reform: An Anthology. $2^{\circ}$ ed. Carolina Academic Press, USA, 2006. Pp. 197 y ss.

${ }^{252}$ Para un panorama general de la financiación de la política en Europa Occidental, cfr. MEZZETTI, L. Op. Cit. Pp. 123 y ss.
} 
claramente reconocido por el Tribunal Constitucional; y la propia disposición constitucional sobre los partidos políticos, muy clara en sus perfiles. ${ }^{253} \mathrm{La}$ normativa constitucional alemana prevé expresamente, además de las funciones constitucionales de los partidos, su financiación pública con la debida rendición de cuentas sobre sus ingresos y de su patrimonio, como obligación de transparencia. ${ }^{254}$ El principio de igualdad de oportunidades posee un peso especial en el momento de analizar la legislación ${ }^{255}$, teniendo en cuenta que el término chancengleichheit tiene dos sentidos para la doctrina: 1) la igualdad de oportunidades como igualdad de partida para la competición y; 2) como igualdad en la competición política. ${ }^{256}$

${ }^{253}$ MORLOK, M. "La Regulación Jurídica..." Pp. 44. Véase también el art. 21 de la Ley Fundamental de la Republica Federal de Alemania (GG): "Artikel 21 (1) Die Parteien wirken bei der politischen Willensbildung des Volkes mit. Ihre Gründung ist frei. Ihre innere Ordnung muß demokratischen Grundsätzen entsprechen. Sie müssen über die Herkunft und Verwendung ihrer Mittel sowie über ihr Vermögen öffentlich Rechenschaft geben. (2) Parteien, die nach ihren Zielen oder nach dem Verhalten ihrer Anhänger darauf ausgehen, die freiheitliche demokratische Grundordnung zu beeinträchtigen oder zu beseitigen oder den Bestand der Bundesrepublik Deutschland zu gefährden, sind verfassungswidrig. Über die Frage der Verfassungswidrigkeit entscheidet das Bundesverfassungsgericht. (3) Das Nähere regeln Bundesgesetze. http://www.bundestag.de/parlament/funktion/gesetze/Grundgesetz/gg.html). Versión en inglés en: http://www.iuscomp.org/gla/. Acceso en 09/05/2011.

${ }^{254} \mathrm{La}$ rigidez de las disposiciones de la ley alemana con relación a la rendición de cuentas y a las sanciones tanto administrativas como penales está clara en la ley de financiación. Además de plazos fijos contando solamente con una hipótesis de prórroga, la ley también establece criterios sobre cómo presentar las cuentas, prevé una verificación preventiva por una auditoría, completada con sanciones de naturaleza administrativa y penal tanto para los casos de error en las cuentas, como también para los casos de financiación ilegal. (Véase arts. 23 a 31 de la ley, que puede ser encontrada en versión italiana en: NARDELLA, D. (a cura di): La Legislazione sui Partiti Politici in Alcuni Paesi dell'Unione Europea - Austria, Francia, Germania, Spagna. Ed. Polistampa, Firenze, 2008). Versión en inglés en: http://www.iuscomp.org/gla/. Acceso en 09/05/2011.

${ }^{255}$ Sobre la tutela de la igualdad en la legislación electoral, cfr. V. ARNIM, H. H. "I Partiti Politici nella República Federale Tedesca". In: Rivista Trimestrale di Diritto Pubblico. fasc. 2, anno XXXVI, abr/jun, ed. Giuffrè, Milano, 1986. Pp. 365-368. Aún, en la opinión de DEL CASTILLO, el sistema alemán es el que mejor garantiza el principio de igualdad de oportunidades. (CASTILLO, P. del. "La Financiación Pública de los Partidos Políticos..." Pp. 81).

${ }^{256}$ FERNÁNDEZ VIVAS expone que la primera concepción está vinculada a la relación de fuerzas originada por los votos de los ciudadanos, que determina la fuerza de cada partido. Así, el Estado no puede interferir en el resultado siempre que todos los involucrados hayan partido de un mismo punto. Por ello, dicha igualdad de oportunidades denominada como "Staatgleichheit" se traduce en la igualdad de condiciones de la que todos los involucrados en la contienda electoral deben disponer, produciéndose una intervención estatal que la garantiza, sin que dicha intervención pueda influir en el resultado de las urnas. Ya en la segunda concepción, el Estado debe preocuparse por los factores involucrados en una campaña (o en el proceso de formación de la voluntad popular, como un continuo), como medios, dinero, para que no influyan de manera negativa sobre el resultado y no provoque distorsiones. (FERNÁNDEZ VIVAS, Y.: Op. Cit. Pp. 40-45). 
Se debe también considerar que el verdadero "Estado de partidos" alemán conforma un sistema político en el cual dichas organizaciones gozan de un alto nivel de estabilidad y disciplina y son protagonistas de las elecciones (al contrario de lo que ocurre en EE.UU., en los que los verdaderos protagonistas electorales son los candidatos), y dicha situación también favorece su permanencia en los diversos niveles de gobierno. ${ }^{257}$ Con un sistema de partidos considerablemente plural, no cerrado y con un régimen parlamentario estable ${ }^{258}$, el modelo de financiación adoptado atiende a las necesidades de un país que ha sufrido directamente la inestabilidad política y la guerra. Con una preocupación constante por establecer un sistema democrático abierto e igualitario, la financiación pública siempre estuvo en el centro del debate, justamente por las funciones que la Grundgesetz atribuyó a los partidos. ${ }^{259}$

Alemania Occidental fue el primer gran país democrático que financió a los partidos de manera directa. ${ }^{260} \mathrm{El}$ sistema alemán se caracterizaba por tener tres fuentes de financiación, representadas por la cuota de afiliados; las donaciones de terceros y los fondos estatales, aunque inicialmente estos no eran directos, ya que eran beneficios fiscales para los que efectuaban donaciones a los partidos. ${ }^{261}$ La cuota de los afiliados, junto a otras fuentes, es

\footnotetext{
${ }^{257}$ VON ARNIM, H. H. "Campaign and Party Finance in Germany". In: GUNLICKS, A. B. (ed.): Campaign and Party Finance in North America and Western Europe. Westview Press, USA, 1993. Pp. 201.

${ }^{258}$ Cfr. V. ARNIM, H. H. Op. Cit. Pp. 357 y ss., en una exposición sobre el sistema de partidos alemán, incluso citando el ejemplo del nacimiento de los Verdes, como demostración de la apertura real del sistema. También véase SOMMA, A. "Aspetti della Disciplina dei Partiti Politici nell'Ordinamento Tedesco: Dal BGB al Parteiengesetz". In: Politica del Diritto. № 1. Anno XXIV, marzo, ed. II Mulino, Bologna, 1993. Pp. 73 y ss, cuando el autor trata del sistema de partidos alemán después de la aprobación de la ley de partidos, abordando soluciones legales adoptadas después de las intervenciones del Tribunal Constitucional, como en el tema de la financiación. Aún, cfr. SCHOLZ, R. "Los Partidos Políticos en el Sistema Constitucional de la República Federal de Alemania. Fundamentos Jurídico-Constitucionales y Realidad Constitucional". In: AA.VV.: Anuario de Derecho Constitucional Latinoamericano. tomo I, ed. Konhad Adenauer Stiftung. Uruguay, 2006. Pp. 180-181.

259 Conforme la redacción de la Ley Fundamental de Bonn se buscaba eliminar las posibilidades de un nuevo régimen autoritario, como ocurrió con Weimar. Así, el art. 20 que establece que la base institucional del Estado alemán - y que se conecta directamente con los partidos políticos - no puede ser objeto de reforma constitucional, conforme la rigidez que le fue atribuida por el art. 79.3. (In: SINGH GHALEIGH, N. "German Constitucional Law and Party Political Financing: The Role of Equality". In: D. EWING, K. (ed.): The Challenge of Party Political Funding: Comparative Perspectives. Ed. CLUEB, Bologna, 2001. Pp. 54-55).

${ }^{260}$ MELCHIONDA, E.: Op. Cit. Pp. 86.

261 Para mayores detalles sobre la aprobación de la legislación de financiación de partidos alemana, véase CRESPI, R.: Op. Cit. Pp. 95 y ss, en la que el autor describe detalladamente
} 
relevante, y se añaden a otras pequeñas fuentes, como las contribuciones especiales de los diputados y las más importantes contribuciones especiales del Estado para las fundaciones de los partidos políticos. ${ }^{262}$ Sin embargo, cabe subrayar que en el sistema alemán las donaciones privadas de carácter individual no son en absoluto comunes, y cuando se producen están dirigidas a los partidos, y no a los candidatos, para garantizar la deducción fiscal originada con la donación. ${ }^{263}$

La primera intervención por parte del Tribunal Constitucional en la legislación afectó al sistema de desgravación fiscal a favor de los partidos, iniciando la discusión en 1957 y 1958, y culminando en la declaración de inconstitucionalidad de dicho sistema en la BVerfGE 6, 273. ${ }^{264}$ La sentencia se basaba en el hecho de que la desgravación fiscal alcanzaba a las donaciones privadas a favor de los partidos, pero resultaba restringida a las donaciones a los partidos con representación parlamentaria, lo que originaba desigualdades. Además, el principio de la igualdad también resultaba lesionado porque las desgravaciones fiscales favorecían claramente a las contribuciones generosas de ciudadanos de extractos sociales elevados, beneficiando de igual manera a los partidos que las apoyan. ${ }^{265}$ Así, y debido a la crisis existente en los partidos por la escasez de recursos para mantenerse, y bajo el entendimiento de que el Estado no tenía el deber de financiar a los partidos políticos, aunque ello podría hacerse siempre que se respetara el principio de la igualdad de oportunidades - conforme a lo declarado en la BVerfGE 8, 51, de 24 de junio de 1958 - el Estado decidió establecer por la primera vez la concesión de ayudas públicas directas a los partidos por sus actividades ordinarias. ${ }^{266}$

todo el procedimiento, que fue acompañado también por el recurso que culminó en la declaración de inconstitucionalidad del sistema de beneficios fiscales a favor de los partidos.

${ }^{262}$ GONZÁLEZ-VARAS, S. La Financiación de los... Pp. 21.

${ }^{263}$ MORLOK, M.; STREIT, T. "Germany". In: GRANT, T. D. (ed.): Lobbying, Government Relations and Campaign Finance Worldwide. ed. Oceana - Oxford University Press, USA, 2005. Pp. 126.

${ }^{264}$ Dicha sentencia tiene fecha de 21 de febrero de 1957.

${ }^{265}$ CRESPI, R.: Op. Cit. Pp. 95. Para mayores detalles sobre el sistema de desgravación anteriormente vigente, cfr. VON ARNIM, H. H. "Campaign and..." Pp. 206-210.

${ }^{266}$ MORLOK, M. "La Regulación Jurídica..." Pp. 55. El proyecto de esta ley fue presentado por la primera vez a finales de 1959, algunos meses después de la aprobación de una subvención a favor de los partidos con el valor de 5 millones de marcos. Aunque no se hiciera alusión directa a la financiación pública, contenía por otro lado algunas disposiciones sobre la publicidad de la financiación privada. El texto del proyecto sufrió fuerte oposición, principalmente por los socialdemócratas. (In: CRESPI, R.: Op. Cit. Pp. 96). 
Esta laguna permitió a los partidos recibir dinero del Estado, como también estableció otro límite de valor para las desgravaciones fiscales de las donaciones privadas. ${ }^{267}$ Sin embargo, en mayo de 1965 también se impugnaron constitucionalmente dichas subvenciones, lo que provocó la decisión del Tribunal Constitucional de 1966 de prohibir al Estado la financiación de las actividades ordinarias de los partidos políticos (la conocida BVerfGE 20, 56 de 19 de julio de $1966^{268}$ ). La sentencia se basó en las dos facetas que confieren la naturaleza de los partidos en la doctrina mayoritaria alemana: la estatal (cuando ejercen actividades en el ámbito estatal, esto es, el carácter público de los partidos), y la social, considerando a los partidos como agentes sociales. Así, el Estado solamente estaría legitimado para financiar a los partidos cuando estos ejercieran sus actividades partidistas con repercusión en el ámbito jurídico estatal, para garantizar precisamente su independencia del Estado. ${ }^{269}$ Con ello se permitía solamente la financiación de las actividades

${ }^{267}$ GONZALES-VARAS IBAÑEZ, S. “La Financiación de los Partidos Políticos..." Pp.300-301.

268 La solicitud presentada por el Lander de Hesse se basaba en que el Estado no era competente para financiar a los partidos; que las contribuciones eran amplias y sin determinar su finalidad, en lo que cambiaría la naturaleza de los partidos y del propio art. 21 de la Ley Fundamental; que las contribuciones solamente alcanzaban a los partidos parlamentarios, formando un cierto oligopolio; y, por último, en que la financiación pública interfiere en el proceso de formación de la voluntad popular y en las esferas internas de las formaciones políticas, violando, consecuentemente el principio de la igualdad de oportunidades. (In: CRESPI, R.: Op. Cit. Pp. 101). La ley cuestionada (ley de 18 de marzo de 1965) determinaba la disposición de 38 millones de marcos destinados a los partidos, en los términos del art. 21 de la Ley Fundamental.

${ }^{269}$ Cfr. CASTILLO, P. del. "La Financiación de los Partidos Políticos en Europa". In: Política Exterior. vol. IV, no 16, Madrid, 1990. Pp. 7-11. La autora afirma que el Tribunal Constitucional alemán consideró que, aunque la formación de la voluntad del pueblo se conecte con la formación de la voluntad del Estado, ese proceso debe producirse de abajo para arriba, es decir, que la voluntad popular debe preceder a la voluntad del Estado. Por ello el Estado, a través de sus órganos, no puede interferir en este proceso, ya que la formación de la voluntad popular es un proceso libre, abierto y ajeno al Estado. Así, financiar las actividades ordinarias de los partidos políticos sería interferir en dicho proceso, pues aunque financiar a los partidos no supondría convertirlos en órganos estatales, dicha financiación los colocaba en una situación de sumisión al Estado. También se reafirmó la idea de naturaleza jurídica de los partidos (que no son órganos estatales, pero que son grupos que pertenecen al ámbito políticosocial); y el argumento de que mencionado sistema de financiación pública ponía en duda la capacidad de los ciudadanos para crear y mantener las organizaciones que sirven para articular y expresar su voluntad política, junto a ello, se daba el hecho de que la democracia liberal privilegia la capacidad de juicio y acción por parte de los ciudadanos. Por otra parte, la financiación pública no puede evitar la influencia de grupos y personas. El argumento de la posible dependencia de los partidos políticos con relación al Estado no fue aceptado en sus estrictos términos por el Tribunal Constitucional. (In: CASTILLO, P. del. "Financiación de los Partidos Políticos: La Reforma Necesaria". In: GONZÁLEZ ENCINAR, J. J. (coord.): Derecho de Partidos. Espasa-Calpe, Madrid, 1992. Pp. 153-154). También, cfr. VALITUTTI, S.; CIAURRO, G. F.: Contro il Finanziamento Pubblico dei Partiti. Ed. Bulzoni, Roma, 1975 (?). Pp. 54 y ss. para el texto integral de dicha sentencia, en el idioma italiano. 
electorales de los partidos, a través del reembolso, o la restitución de gastos, junto con un sistema de adelantos para aquellos que cumplieran con los requisitos exigidos en las anteriores elecciones. ${ }^{270}$ Por otra parte, la sentencia denuncia la violación de la igualdad de oportunidades entre los partidos, al interferirse en el proceso de formación de la voluntad popular, lo que violaría directamente el art. 21 de la Ley Fundamental. ${ }^{271}$ Cabe resaltar que, entre 1959 y 1967, sólo los partidos con representación en el Parlamento recibían subvenciones del Estado. ${ }^{272}$

Este cambio provocó una grave crisis financiera en los partidos, que vieron disminuidas las subvenciones y entraron en claras dificultades financieras. Esto motivó la adopción del sistema de adelanto de recursos anteriormente mencionado para la financiación electoral ${ }^{273}$, y según Pilar del Castillo, acabó por desnaturalizar la sentencia de inconstitucionalidad anterior, ya que, en la práctica, los adelantos concedidos terminaban financiando las actividades ordinarias de las organizaciones partidistas. ${ }^{274}$

En todo caso, esta famosa sentencia fue objeto de múltiples críticas doctrinales, principalmente remarcando la imposibilidad de diferenciar en la

\footnotetext{
${ }^{270}$ GONZALES-VARAS IBAÑEZ, S. "La Financiación de los Partidos Políticos..." Pp. 301. EI Estado, de esta manera, solamente debería financiar las actividades electorales de los partidos políticos, y no incluir las actividades ordinarias, por violar el principio de la soberanía popular, es decir, por sustituir la capacidad de los ciudadanos de sostener las organizaciones partidistas. Dicha decisión fue ampliamente utilizada como parámetro en la discusión sobre qué actividades partidistas debería financiar el Estado. (Cfr.: GONZÁLEZ-VARAS, S. La Financiación de los... Pp. 25-26).

${ }^{271}$ Cfr. KOMMERS, D. P. "Politics and Jurisprudence in West Germany: State Financing of Political Parties". In: American Journal of Jurisprudence. № 16, University of Notre Dame Press, US, 1971. Pp. 223-232 para una interesante discusión sobre la sistemática del art. 21, principalmente sobre las posibles maneras de intromisión del Estado y la financiación de los partidos.

${ }_{272}$ MORLOK, M.; STREIT, T. Germany. Op. Cit." Pp. 128.

${ }^{273}$ El sistema de adelantos consistía en la división de las cantidades, siendo que $10 \%$ sería entregado en el segundo año de la legislatura, $15 \%$ en el tercero y el $35 \%$ en el cuarto año. El restante $40 \%$ seria abonado tras las elecciones a los partidos que hubieran obtenido al menos el 0,5 de 100 de los votos. Cabe subrayar que dicho umbral por ley era de 2,5\%, pero por determinación del Tribunal Constitucional de 22 de julio de 1969, dicho umbral fue aumentado. CRESPI, R.: Op. Cit. Pp. 103. Actualmente el sistema de adelanto de recursos atiende al art. 20 de la ley, lo cual posibilita la entrega de estos de 15/02, 15/05, 15/08 y 15/11 de cada año, y no más de $25 \%$ del valor total debido para el año precedente. Para eso, los partidos debe presentar una garantía real. (In: NARDELLA, D. (a cura di): Op. Cit. Pp. 104).

${ }^{274}$ CASTILLO VERA, P. del: La Financiación de Partidos y Candidatos... Pp. 95. Acompañando la autora, cfr. MELCHIONDA, E.: Op. Cit. Pp. 88.
} 
práctica entre las actividades ordinarias y extraordinarias de los partidos. ${ }^{275} \mathrm{De}$ igual manera, también se criticó el hecho de que, si el Tribunal Constitucional consideraba que los partidos no debían depender de la ayuda estatal para las actividades generales, no había razón para que los partidos no se situaran en igual situación de dependencia en las campañas electorales que utilizan ayuda estatal. ${ }^{276}$

El sistema sin financiación pública para las actividades ordinarias de los partidos siguió vigente por décadas, hasta que resultó disfuncional. La reducción del montante de las cuotas generó un importante endeudamiento de los partidos políticos y los condujo al uso de una financiación irregular que provocó importantes escándalos políticos. ${ }^{277}$ Consecuencia de todo ello fue el establecimiento de una comisión de expertos en marzo de 1982 en el seno del Bundestag para el estudio del sistema general de financiación de los partidos políticos. ${ }^{278}$ Dicho estudio dio origen a un documento utilizado como la base de la reforma del sistema. El nuevo sistema contemplaba un modelo de compensación de oportunidades, que contaba con un tratamiento fiscal diferente a las donaciones y al pago de las cuotas de los afiliados que hubieran obtenido menores ingresos por los canales de financiación privada, dotando al

\footnotetext{
${ }^{275}$ Un autor critico con esta sentencia es STERN, que entiende que, además de que la inconstitucionalidad de la financiación ordinaria (según los criterios establecidos) no era suficientemente clara para generar la anulación de todo un sistema, también el hecho de la falta de definición de lo que serian "los costes necesarios para una campaña electoral adecuada", concepto de muy difícil aplicación en la financiación electoral. La imprecisión de la expresión permite muchas maniobras y tampoco colaboraría con la solución de los problemas de la financiación de los partidos. El autor también cuestiona el análisis hecho del sistema de desgravación. (In: STERN, K.: Derecho del Estado de la República Federal Alemana. ed. Centro de Estudios Constitucionales, Madrid, 1987. Pp. 774-778).

${ }^{276}$ La mencionada decisión fue confirmada en 1968, en una nueva sentencia sobre la nueva ley de partidos, y nuevamente en 1986, en la conocida sentencia de "las fundaciones". (MORLOK, M. "La Regulación Jurídica..." Pp. 56).

${ }^{277}$ La falta de limitación a la financiación pública en otras modalidades (como a las fundaciones y a los grupos parlamentarios) determinó que desde 1966 hasta 1991 se produjera un aumento en el valor de las subvenciones de 30 veces en 25 años. Además, tan solo tras el estallido del caso Flick (un gran escándalo que involucraba evasión fiscal y fraude) se hicieron visibles las lagunas de la ley, principalmente en el tema de financiación ilícita. (In: MELCHIONDA, E.: Op. Cit. Pp. 89-91). También, cfr. SCARROW, Susan E. "Party Decline in the Parties State? The Changing Environment of German Politics". In: WEBB, P.; et al (eds.): Political Parties in Advanced Industrial Democracies. Oxford University Press, UK, 2002. Pp. 88.

${ }^{278}$ Algunos de los componentes de la comisión de 4 de marzo de 1982 fueron: Walter Furst (presidencia); Dr. Hermann Maassen (deputado presidente); Profesor Heino Kaack; Hans Peter-Schneider y Horst Vogel. Aún, cfr. PETER SCHNEIDER, H. "The New German System of Party Funding: The Presidential Committee Report of 1983 and its Realization". In: ALEXANDER, H. E. (ed): Comparative Political Finance in the 1980's. Cambridge University Press, UK, 1989. Pp. 221 y ss, para detalles de la comisión y conclusiones de sus trabajos.
} 
sistema de cierto equilibrio. Por otra parte, también se preveía una cantidad anual en concepto de compensación de desigualdades, siempre que en las últimas elecciones al Bundestag las organizaciones partidistas hubieran alcanzado por lo menos un 0,5 por 100 de los votos a las listas en el nivel de los Länder. ${ }^{279}$ Junto con ello, siguieron vigentes las subvenciones para los gastos de campaña electoral.

Paralelamente al surgimiento político de los "Verdes" ${ }^{280}$, otras pequeñas agrupaciones políticas se unieron para cuestionar el mencionado sistema de financiación ${ }^{281}$, encontrando eco en una opinión pública que tampoco estaba de acuerdo con las altas cuantías de las subvenciones estatales. ${ }^{282}$ Resultado de todo ello fue la sentencia BVerfGE 85, 264 de 09 de abril de $1992^{283}$, en la que el Tribunal Constitucional juzgó inconstitucional ese sistema de compensación de desigualdades, al tratarse también de una interferencia del Estado en diferencias preexistentes entre los partidos, afectando a su capacidad de competición. ${ }^{284}$ De nuevo, el Tribunal Constitucional reformuló su posición, declarando que el Estado podía financiar las actividades generales de los partidos dado que no estaba impedido constitucionalmente para hacerlo, y que, según la nueva interpretación, no existían sólidas barreras entre las actividades electorales y las generales de los partidos. Sin embargo, el mismo Tribunal decidió que dicha financiación pública fuera parcial (para que no afectara al principio de la libertad e independencia de los partidos políticos frente al Estado), y que los partidos deberían esforzarse en encontrar el apoyo social que necesitan, para que no se alejaran de la sociedad y se mantuvieran vivos dentro del tejido social. ${ }^{285}$ De esta manera, la intervención estatal sería

\footnotetext{
${ }^{279}$ FERNÁNDEZ VIVAS, Y.: Op. Cit. Pp. 69-70.

${ }^{280}$ Cfr. SCARROW, S. E. "Party Decline..." Pp. 78-80 y SCHOLZ, R. Op. Cit. Pp. 177.

${ }^{281}$ Cfr. BVerfGE 41, 399 de 1976 y BverfGE 73, 40 de 1986, como ejemplos de contestaciones del sistema de financiación de la época.

${ }^{282}$ MELCHIONDA, E.: Op. Cit. Pp. 92.

${ }^{283}$ Dicha sentencia alteró profundamente el modelo de financiación vigente hasta entonces. Sobre el tema, vid. VON ARNIM, H. H. "Un Nuovo Modello di Finanziamento Pubblico dei Partiti Politici per la Repubblica Federale Tedesca". In: Politica del Diritto. № 4. Anno XXIV, dic, ed. II Mulino, Bologna, 1993. Pp. 665-672, donde el autor analiza detalladamente el nuevo modelo impuesto por el Tribunal Constitucional.

${ }^{284}$ GONZALES-VARAS IBAÑEZ, S. "La Financiación de los Partidos Políticos..." Pp. 303; VON ARNIM, H. H. "Campaign and..." Pp. 216; y FERNÁNDEZ VIVAS, Y.: Op. Cit. Pp. 71.

${ }^{285}$ GONZÁLEZ-VARAS, S.: La Financiación de los... Pp. 28-32. El límite para la desgravación es de 3.300 euros, reservado solamente a las personas físicas. (In: FERNÁNDEZ VIVAS, Y.: Op. Cit. Pp. 74-75, nota 156).
} 
considerada lesiva al principio de libertad de los partidos si dicha financiación no fomentaba que las formaciones políticas se esfuercen por encontrar apoyos financieros por parte de la sociedad, ya que los partidos solamente pueden cumplir sus funciones constitucionalmente establecidas si tienen una base ciudadana dentro de una relación de proximidad. ${ }^{286}$

Establecidos los límites constitucionales por la jurisprudencia del Tribunal Constitucional, el legislador optó por dotar al sistema de financiación de un cierto equilibrio entre las subvenciones públicas y los recursos privados, determinando que la financiación concedida por el Estado no podría ser superior a la financiación privada recaudada. Además, la legislación intentó fomentar las donaciones privadas ${ }^{287}$ - consideradas como fuentes legítimas de financiación - a través del sistema de desgravación fiscal en el impuesto de renta. ${ }^{288}$ Cabe subrayar que el montante de las subvenciones estatales también puede variar conforme la cantidad de donaciones privadas que se logre recaudar, y también posee sus límites, es decir, el valor total absoluto es de 133 millones de euros por partido, y el relativo se determina a través de lo recaudado de las fuentes privadas junto con los anteriores resultados electorales. ${ }^{289}$ Por otra parte, tienen gran importancia las subvenciones destinadas a las fundaciones de los mismos (parteistiftungen), pues colaboran

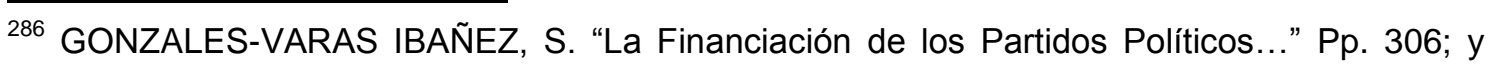
MELCHIONDA, E.: Op. Cit. Pp. 93. Esto deja claro que la incidencia de pequeñas donaciones es mayor porque las grandes fueron sustituidas por la financiación pública, también fomentaba la idea de los partidos de buscar sus propios recursos en la sociedad. (In: NASSMACHER, K-H. "Political Finance in West-Central Europe (Austria, Germany, Switzerland)". In: NASSMACHER, $\mathrm{K}-\mathrm{H}$. (ed.): Foundations for Democracy - Approaches to Comparative Political Finance. ed. Nomos Verlagsgesellschaft, Baden-Baden, 2001. Pp. 109).

${ }^{287}$ Un dato interesante es aportado por MEZZETTI, que afirma que en Alemania cerca de 85, 90 por ciento de las donaciones privadas son de personas físicas. (MEZZETTI, L. Op. Cit. Pp. 138).

288 PETER-SCHNEIDER entiende que solamente hay un fallo en dicho sistema de desgravación, el que no consideró a personas que no contribuyen a través del impuesto de renta, como es el caso de los pensionistas, parados, y otros. El sistema debería ofrecerles ventajas, como si fuera un "impuesto negativo". (In: PETER SCHNEIDER, H. "Los Partidos Políticos..." Pp. 26) También, vid. GONZÁLEZ-VARAS, S. La Financiación de los.... Pp. 62-65.

${ }^{289}$ Con el entendimiento de que la financiación pública debe limitarse a la medida necesaria para que los partidos puedan cumplir sus funciones, establece una financiación parcial a partir de dos criterios: 1) los resultados electorales, para los partidos que pasen por la barrera de 0,5 por 100 en elecciones nacionales o europeas o el 1 por 100 a nivel local; y 0,85 euros por cada voto válido, hasta los primeros 4 millones de votos, siendo los demás 0.70 euros por voto y; 2 ) una cantidad obtenida por cuotas y donaciones, que es 0,38 euros por cada euro recaudado, sólo considerando cantidades hasta 3.300 euros por persona. Sin embargo, con la fórmula de cálculo aplicada, acaba siendo alrededor de 0,66 euros por voto. (Cfr. MORLOK, M.; STREIT, T. "Germany. Op. Cit." Pp. 129). 
de manera significativa en la financiación de los partidos, fortalecen y mejoran el nivel de la política en Alemania ${ }^{290}$, y contribuyen al desarrollo político del tercer mundo.

Con todo ello, se pretende que los partidos gocen del apoyo del Estado, que les ayuda en el cumplimiento de sus funciones constitucionales, pero también que los partidos sigan dependiendo en cierta forma de su base social. ${ }^{291}$ Alemania pues adopta un sistema mixto con distintos criterios en el intento de equilibrar financiación pública y privada sin criminalizar las aportaciones privadas. Merece también subrayarse que las constantes intervenciones del Tribunal Constitucional en la cuestión de la financiación de los partidos tuvieron un impacto positivo en el sistema, tratándose de un modelo que no está cerrado por completo, y que, aun con imperfecciones ${ }^{292}$, privilegia el cumplimiento de los principios constitucionales ${ }^{293}$, entendidos bajo una fuerte diversidad normativa, a través de la interpretación del Tribunal de Karlsruhe. ${ }^{294}$ En donde más se diferiría el modelo alemán del español - como se remarcará en el próximo capítulo - es justamente en la medida de apertura del sistema ${ }^{295}$, porque, mientras en Alemania es posible que un partido "nuevo"

\footnotetext{
${ }^{290}$ MELCHIONDA compara dichas fundaciones alemanas con las estadounidenses, y afirma que el sistema alemán es mejor pues además de permitir un buen funcionamiento del sistema, no suelen tener el soporte económico de grandes corporaciones, como pasa en EE.UU. (In: MELCHIONDA, E.: Op. Cit. Pp. 95).

${ }^{291}$ PETER SCHNEIDER, H. "Los Partidos Políticos..." Pp. 30-31. En el mismo texto, se puede encontrar mayores detalles sobre la opinión del autor en su análisis de la BVerfGE 85, 264. y ss; y FERNANDEZ-LLEBREZ, F. Op. Cit. Pp. Pp. 185. Para una crítica más incisiva a los partidos y al sistema de financiación pública en Alemania de los 80, cfr. VON ALEMANN, U. "Democracia de Partidos y Participación Ciudadana". In: Revista de Estudios Políticos (nueva época), no 20, mar/abr, 1981. Pp. 128 y ss.

${ }^{292}$ Como ejemplo de alguna de las imperfecciones del sistema, cfr. BVerfG 41, 399, de 1976, decisión que trata sobre el caso Daniels, un candidato independiente para las elecciones de 1969, que logró $20 \%$ de los votos en su circunscripción, y que requirió el reembolso de sus gastos electorales a partir de los presupuestos del Estado, pero cuya demanda fue rechazada, porque el art. 21 de la ley trata específicamente de partidos, no de candidaturas independientes.

${ }^{293}$ El Tribunal Constitucional influyó de forma directa para la concreción de este objetivo, y ejemplo de esto son las sentencias 2 BvE 1/02 y 2 BvE 2/02 de 26 de octubre de 2004, en las que se declaró la inconstitucionalidad del art. 18,4 de la ley de partidos alemana, que establecía el umbral de 0,5\% para acceder a la financiación pública general, o el umbral de 1\% en regionales, o 5\% en una región. El argumento, como no podría ser otro, es la igualdad de oportunidades. Aún, en este sentido, véase SCARROW, S. E. "Party Decline..." Pp. 87.

${ }^{294}$ Cfr. CASTILLO, P. del. "La Financiación de los Partidos Políticos en Europa..." Pp. 11.

295 Ejemplo de ello pueden ser las hipótesis previstas en la ley de no aplicación de los criterios de acceso a la financiación en casos de partidos que expresan minorías étnicas, contenida en el art. Art. 18, 4 (traducción de la ley para el italiano in: NARDELLA, D. (a cura di): Op. Cit.; para el inglés http://www.iuscomp.org/gla/), o también la cláusula que determina que partidos
} 
alcance un nivel de importancia considerable, logrando una financiación pública significativa ${ }^{296}$, en España este nivel de apertura, y la consiguiente igualdad de partidos "en el Estado de partidos" parece difícil de alcanzar.

\subsection{Italia}

Antes de abordar las particularidades del sistema italiano, es conveniente subrayar que la regulación de la financiación partidista no ha sido un tema menor dentro de la crisis que sufrió el sistema político y de partidos italiano a finales de los años noventa y que contribuyó fuertemente a la "deslegitimación" del sistema de partidos en aquél país. ${ }^{297}$ Es un hecho que los niveles de corrupción alcanzados y que acabaron por provocar una reacción judicial intensa en las acciones de lo que fue llamado de "Tangentopoli" o "mani puliti”, y que produjo la condena de un sector importante de la clase política ${ }^{298}$, y los sucesivos referendos abrogativos sobre el tema de la financiación de los partidos, constituyen elementos sin los cuales no se entiende la evolución del sistema de financiación de los partidos en Italia. ${ }^{299}$ Cabe destacar también que no hay un reconocimiento formal de los partidos en el ordenamiento italiano, no

que no participaron del reparto de las subvenciones en el año anterior deben confirmar su condición de partidos activos y, así, justificar su contribución para el funcionamiento del sistema de partidos. (In: MORLOK, M.; STREIT, T. "Germany. Op. Cit." Pp. 123-140.128-129).

${ }_{296}$ Para otras informaciones sobre el sistema alemán, véase NASSMACHER, K-H. "Party Funding..." Pp.124.

${ }^{297}$ Es de sobra conocida la peculiar inestabilidad del sistema parlamentario italiano hasta tiempos muy recientes. Sobre la fragmentación y organización del propio sistema de partidos en Italia, cfr. BARDO, L. "Italian Parties: Changes and Functionality". In: WEBB, P.; et al (eds.): Political Parties in Advanced Industrial Democracies. Oxford University Press, UK, 2002. Pp. 46-56.

${ }^{298}$ El nivel de corrupción del sistema no era producto únicamente de conductas particularmente inmorales, sino también fue algo que en cierta forma se institucionalizan a partir del inicio de la legislación sobre la financiación de los partidos, en 1974. La ley poseía tantas lagunas, que en realidad acabó prácticamente por no generar efectos limitativos, dada su ambigüedad y que colaboró al surgimiento de los escándalos en la política italiana de las décadas de 70, 80 y 90. En este sentido, cfr. RHODES, M. "Financing Party Politics in Italy: A Case of Systematic Corruption”. In: West European Politics. vol. 20. no 1, jul, Frank Cass Press, London, 1997. Pp. 54-80.

${ }^{299}$ Como ejemplo de la postura mayoritaria de la literatura jurídica sobre el tema, vid. VALITUTTI y CIAURRO, que tratan de ser irónicos cuando comentan la rapidez con que el proyecto de ley sobre la financiación de los partidos fue aprobado. Además, entienden que se trataba de una ley claramente corporativa. (In: VALITUTTI, S.; CIAURRO, G. F.: Op. Cit. Pp. 10-13). Algunos años después, dichos autores siguieron siendo bastante críticos con relación al tema de la financiación de los partidos. En este sentido, cfr. CIAURRO, G. F. "La "Questione Morale" e il Finanziamento dei Partiti". In: Nuovi Studi Politici. no 2. anno XXII, Bulzone Editore, Roma, 1992. Pp. 61-64. 
produciéndose ni siquiera la atribución de personalidad jurídica a los mismos $^{300}$, como se puede constatar en el art. 49 de la Constitución de la República Italiana. ${ }^{301}$

En el período pre-fascista la financiación de los partidos políticos en Italia era exclusivamente privada. ${ }^{302}$ Sin embargo, al igual que sucedió en el caso alemán, en Italia también se discutió bastante sobre qué actividades partidistas deberían ser financiadas por el Estado. La posibilidad del uso del referéndum popular con poder abrogativo ${ }^{303}$ sobre las leyes promulgadas por el Parlamento permitió que la normativa sobre la financiación de los partidos políticos fuera sometida a consulta popular en diversas ocasiones, para después dar lugar a la intervención de la Corte Constitucional confirmando o no la validez del procedimiento. ${ }^{304} \mathrm{~A}$ fin de entender la incidencia del referéndum

${ }^{300}$ Según BARBERA, se resuelta comprensible porque hasta el día de hoy los partidos en Italia no son reconocidos como en el resto de los países europeos. Considerando que dicho país posee una relación particular con la política, el autor cree que puede ser que exista una preocupación por parte del Estado de que los partidos pierdan su naturaleza de sujeto de la sociedad civil, de un puente entre esta y el Estado. Más aún, existía un recelo de que la Izquierda pudiera reaccionar ideológicamente de manera peligrosa y, por fin, una eventual reglamentación de los partidos permitiría establecer un control. Sin embargo, el autor advierte que la falta de reglamentación de la cuestión hace que en Italia se corra el riesgo de que los partidos se conviertan en un arma en manos de los grupos de presión. (In: BARBERA, A. "La Regolamentazione dei Partiti: Un Tema da Riprendere". In: Quaderni Costituzionali. Anno XXVI. oㅡ 2, Giugno. Ed. II Mulino, Bologna, 2006. Pp. 323-326).

${ }^{301}$ Así es el texto de mencionado artículo: "Art. 49. Tutti i cittadini hanno diritto di associarsi liberamente in partiti per concorrere con metodo democratico a determinare la politica nazionale". (In: << http://www.governo.it/Governo/Costituzione/1_titolo4.html > Acceso en 09/03/2011. También, para una profundización sobre el panorama histórico de la constituyente y los partidos, cfr. MUSUMECI, T. S.: II Costo della Politica ed il Finanziamento ai Partiti. ed. CEDAM, Padova, 1999. Pp. 32-38; CARDINI, A. "I Partiti e la Costituente". In: Studi Senesi. CXX, III Serie, LVII, fasc. 3, Università degli Studi di Siena, Siena, 2008. Pp. 381-388.

302 CIAURRO cita cinco fuentes que los partidos utilizaban para conseguir recursos: 1) contribuciones de socios y simpatizantes; 2) subsidios de organizaciones externas privadas, incluyendo extras en contratos y en el proveimiento de dinero pagado a los partidos que controlaban el poder central y local; 3 ) dinero público de diversas naturalezas, incluso en dinero "negro"; 4) tasas y otros tributos provenientes de los negocios, industrias y el comercio controlados por los partidos a través de cooperativas, financieras y compañías; 5) ayudas financieras venidas del exterior, de gobiernos extranjeros y/o de organizaciones privadas extranjeras. (In: CIAURRO, G. F. "Public Financing of Parties in Italy". In: ALEXANDER, H. E. (ed): Comparative Political Finance in the 1980's. Cambridge University Press, UK, 1989. Pp. 153).

${ }^{303}$ El referendo abrogativo también es un buen indicador para evaluar la antipatía que la sociedad italiana tiene hacia los partidos, principalmente porque representa un canal de manifestación de movimientos antipartidistas o antisistemas, y el sistema de financiación no fue una excepción. Cfr. BARDO, L. Op. Cit. Pp. 56.

${ }_{304}$ PEREZ SOLA, N. "Los Referéndum Abrogativos del 18 de Abril en la Encrucijada de la Crisis Política Italiana". In: Revista de Estudios Políticos (Nueva Época), no 22 , oct/dic, 1993. Pp. 195-197. Sobre el valor del resultado de este tipo de referéndum dentro del sistema de fuentes de derecho en Italia, hay dos vías que son argumentadas por la doctrina, siendo la 
sobre las leyes de financiación, puede ser útil proceder a realizar un pequeño bosquejo histórico acerca de la legislación sobre el tema. Cabe resaltar que la legislación italiana sobre financiación se caracteriza por su fragmentación lo que, junto a su particular inestabilidad, acabó provocando la ineficacia de la mayoría de las normativas. También es necesario recordar la difícil cuantificación de una realidad como la financiación ilegal y su consecuente corrupción política, no ajena aún al sistema partidista italiano. ${ }^{305}$

El debate tuvo su inicio con el proyecto de ley de Luigi Sturzo ${ }^{306}$ que versaba sobre el reconocimiento de la naturaleza jurídica privada de los partidos políticos. ${ }^{307}$ Dicho proyecto fue considerado bastante rígido, incluso considerando las disposiciones sobre la fiscalización de cuentas de los partidos, interpretadas como un arma eficiente puesto en manos de los partidos de oposición frente al partido del gobierno, que gozaba de un amplio margen de impunidad. $^{308}$ Dadas las ya crecientes dificultades financieras de los partidos políticos, no tardó en agregarse a la ley un sistema de financiación

primera considerando que el resultado tiene valor de ley ordinaria, pero que no vincula la actuación del Parlamento sobre el mismo asunto (limitando la conclusión a un punto de vista jurídico formal), o si puede considerarse que el resultado de la consulta popular tiene un poder superior a cualquier otra, excepto la Constitución, definiendo esta expresión de voluntad popular como soberana y irrepetible, dentro de un sistema de control político popular (con características similares a un recall). Sobre el tema, cfr. MUSUMECI, T. S.: Op. Cit. Pp. 75 y ss. ${ }^{305}$ BIANCO, A.; GARDINI, G. "The Funding of Political Parties in Italy". In: EWING, K. D. (ed): The Funding of Political Parties: Europe and Beyond. Ed. CLUEB, Bologna, 1999. Pp. 30. Pp. 131-132. El reconocimiento y afianzamiento político de los partidos políticos ha culminado con el sistema de financiación pública, pero su corrupción no afecta solo a las organizaciones, sino también a toda la democracia. Por ello el caso italiano posee directo interés, por el claro desprestigio de los partidos que hay en aquél país. (In: GIL CASTELLANO, J. Op. Cit. Pp. 250). 306 Luigi Sturzo presentó en el Parlamento un esbozo de ley, denominada "Disposizioni riguardanti i partiti politici e i candidati alle elezione prolitiche e amministrative" ( $\left.n^{\circ} 128\right)$ en 16 de septiebre de 1958. El proyecto constaba solamente de 8 artículos, que abarcaban desde el depósito formal del estatuto del partido, hasta la rendición de cuentas del mismo y la separación de contribuciones para actividades ordinarias y extraordinarias. (In: CRESPI, R.: Op. Cit. Pp. 108 y ss). El proyecto incluía a los partidos en el mismo régimen de las sociedades comerciales, de modo más articulado, con presentación del listado de donaciones recibidas y de los gastos realizados, existiendo también un control de las contribuciones ante el Tribunal competente. Sin embargo, el proyecto no llegó a plasmarse en una norma legal. (In: GAMBINO, S.: Partiti Politici e Forma di Governo - Finanziamento Pubblico e Transformacione del Partito Político. Ed. Liguori, Napoli, 1977. Pp. 117-118).

307 Sobre el tema de la naturaleza jurídica de los partidos políticos en Italia, vid. por todos RESCIGNO, P. "Profili Privatistici del Finanziamento della Política". In: Quaderni Constituzionali. Anno XIX. no 2, Agosto. Ed. II Mulino, Bologna, 1999. Pp. 247-255, trabajo este que el autor expone el carácter privatístico de los partidos y que, por ello, tienen una naturaleza de asociación no reconocida dentro de la postura doctrinal ampliamente mayoritaria en Italia. ${ }^{308}$ Cfr. CRESPI, R.: Op. Cit. Pp. 111. 
estatal $^{309}$, aunque después fuera considerado como una manera de intervención del Estado en la vida interna de las organizaciones. Como resultado de todo ello, fue aprobada la ley 195 de 2 de mayo de 1974 en la cual se establecía una financiación pública de los partidos con carácter complementario a las fuentes privadas. Esta financiación pública se destinaría al funcionamiento del partido, concurriendo con los gastos electorales, y garantizándoles un soporte financiero constante para dichas organizaciones. ${ }^{310}$ Sin embargo, debe destacarse que los criterios de acceso a las subvenciones eran significativamente mantenedores del status quo partidista, en cuanto excluían claramente a los partidos regionales y locales, además de a los minoritarios. Lo mismo ocurría con las subvenciones para los grupos parlamentarios, ya que los que no lograban alcanzar el umbral de votos válidos, no eran incluidos en el reparto. ${ }^{311}$

Dicha ley fue sometida a un referéndum abrogativo en 1978, donde la opinión pública se mostró a favor de la ley 195/74 $4^{312}$, aunque la doctrina especializada criticara muchísimo el modelo de financiación pública adoptado, por la naturaleza jurídica de la que los partidos gozan en Italia (de asociaciones privadas). ${ }^{313}$ Sin embargo, ello no impidió que el Parlamento ampliara la

\footnotetext{
${ }^{309}$ Para una visión general sobre los diversos proyectos de ley sobre la financiación pública en Italia, véase: GAMBINO, S.: Op. Cit. Pp. 122-131.

${ }^{310}$ Según BIANCO, la ley dejó clara la exclusión de los partidos periféricos, la centralización de los partidos políticos con la distribución de los subsidios para los líderes nacionales y el fomento a la formación de un fuerte aparato burocrático. (BIANCO, A.: I/ Finanziamento... Pp. 6-13).

${ }^{311}$ GAMBINO, S.: Op. Cit. Pp. 143.

${ }^{312}$ LANCHESTER opina que el $43 \%$ de los votos que pedían la abrogación de dicha ley en este referéndum no era de todo realista, porque era mucho más una manifestación en contra la partitocracia existente y el sistema de partidos. Por ello el autor cree que la eliminación de la financiación pública no era la solución para el "caos" existente. En su opinión, sería conveniente que se re-pensara el régimen de financiación pública, direccionándola hacia la estructuración del estado de partidos como un todo. (In: LANCHESTER, F. "II Problema del Partito Político: Regolare gli Sregolati". In: Quaderni Constituzionali. Anno VIII. no 3, Diciembre. Ed. II Mulino, Bologna, 1988. Pp. 456). A la vez, CIAURRO afirma que el porcentual de $56,3 \%$ a favor de la ley y $43,7 \%$ en contra dejaba claro que el asunto todavía era muy controvertido entre la sociedad italiana. (In: CIAURRO, G. F. "Public Financing..." Pp. 154). El 43,7\% por 100 de los votos en este referéndum correspondieron a 13.736 .577 votos, con preponderancia en grandes ciudades y también en algunas regiones meridionales e insulares. (BISCARETTI DI RUFFIA, P.: Derecho Constitucional. 3oe ed., Ed. Tecnos, Madrid, 1987. Pp. 792).

313 VALITUTTI y CIAURRO afirman que la introducción de la financiación pública de los partidos en Italia fue un error ya que, además de las críticas comunes sobre este modelo de financiación, entienden que alteraba la naturaleza jurídica de los partidos (como asociaciones voluntarias). Incluso la ley es considerada inconstitucional por ellos, ya que opinan que su texto viola el art. 49 de la Constitución Italiana. (In: VALITUTTI, S.; CIAURRO, G. F.: Op. Cit. Pp. 6-
} 
financiación pública a los niveles regional y europeo con la ley $659 / 81 .^{314}$ La ley preveía dos procedimientos de financiación de los partidos. Una vía directa de hasta 15 mil millones de liras durante toda la legislatura, como subvención de las actividades ordinarias de las organizaciones, y también como ayuda para los gastos electorales. La otra vía financiaba a los grupos parlamentarios de ambas Cámaras, con un valor de hasta 45 mil millones de liras (aumentados a 72.630 millones de liras en 1980 y 82.886 millones, en 1981), como subvención a las actividades de los mismos. En todo caso, resultaba claro que eran los propios partidos los destinatarios finales de la subvención. ${ }^{315}$ Es evidente que la gran cantidad de enmiendas a dicha ley referidas a la financiación indirecta de los partidos (espacios en los medios de comunicación, mailing, e incluso gastos telefónicos que debían ser abonados por el Estado) pretendían encubrir el aumento considerable en las subvenciones públicas destinadas a los mismos, intentando alcanzar la mayor financiación ordinaria posible. ${ }^{316}$

Los veinte años que siguieron a la ley 195/74 contemplaron un proceso de fuerte deterioro del sistema de financiación de los partidos políticos, pues además del creciente alejamiento entre dichas organizaciones y la sociedad, de la falta de transparencia con relación a los recursos ${ }^{317}$ y de la consecuente deslegitimación que originó todo ello, los partidos se adentraron en el camino de la ilegalidad en su financiación, y, junto a la falta de intervención legislativa

20. Las criticas más comunes según BISCARETTI DI RUFFIA eran: la falta de detalles sobre las tareas que deberían ser subvencionadas (ya que existía el temor de burocratizar aun más los partidos y de fortalecer los órganos centrales de estos, en detrimento de los periféricos), la ineficacia e insuficiencia de los mecanismos de control, y la dificultad del acceso a las subvenciones por parte de las formaciones políticas que no tuvieran por lo menos un escaño en el Parlamento. (In: BISCARETTI DI RUFFIA, P.: Op. Cit. Pp. 792). LANCHESTER afirmará que todo ello ha constituido un buen ejemplo de los defectos y de la limitación de la modernización del sistema político italiano, reflejando a su ver la casi unanimidad de la clase política a favor de incrementar sus propios recursos financieros. (In: LANCHESTER, F. "Finanziamento della Política e Uguaglianza..." Pp. 128-129).

${ }^{314}$ BIANCO, A.: I/ Finanziamento... Pp. 14-15. El valor de estas subvenciones eran de hasta 15 mil millones de liras, para los partidos con por al menos un representante en el Parlamento Europeo.

315 BISCARETTI DI RUFFIA, P.: Op. Cit. Pp. 792.

${ }^{316}$ DE LUCA, R.: La Nuova Normativa del Finanziamento dei Partiti. Ed. CEDAM, Padova, 1983. Con un análisis muy detallado de la ley 659/81.

317 Es justo en este punto PANARA subraya que las leyes siguientes a la ley de 1974 , contienen tanto lagunas que además de no favorecer la igualdad de oportunidades (como puede ser el caso de la falta de limitación a las contribuciones privadas), tiende a favorecer a los partidos preponderantes, no favoreciendo tampoco la transparencia. Sin embargo, el autor donde considera un avance las leyes posteriores, en cuanto al establecer de algún límite de gastos. (In: PANARA, C. Op. Cit. Pp.197). 
respecto al crecimiento desenfrenado de las subvenciones públicas, la amenaza a la propia estabilidad del sistema político creció, originando en la sociedad un fuerte sentimiento antipartidista y un descontento que contaminó incluso los mecanismos de democracia representativa de aquél país. ${ }^{318}$ Todo ello vino acompañado de un aumento más que considerable de la cantidad de los recursos traspasados a los partidos (con la vigencia de las leyes 195/74 y 659/81 los valores llegaban a 45 millones de liras, para aumentar a 82 millones de liras poco después), sin garantías de control y sin tener en cuenta, obviamente el fenómeno de la financiación ilícita. Parece claro que sostener una financiación con tales características no era viable a medio plazo, y más aún dadas las consecuencias indirectas del sistema, como las constantes prácticas clientelistas, la ocupación por los partidos de la Administración Pública y la formación de una estructura partidista compleja que contribuía al espectacular aumento del costo de la política. ${ }^{319}$ Con los partidos como "super partes" en la institución de la financiación pública, sin obligaciones y con todos los derechos, Italia acabó por traspasar su acentuado pluralismo social a un rígido pluralismo institucional, determinado por la dinámica del sistema de partidos, incapaz de lidiar con la nueva complejidad de la sociedad. Todo ello, como también ocurrió en otros países, pero de manera más evidente en Italia, acabó por generar la distorsión del diseño constitucional y la fragmentación aguda del sistema político frente al social. ${ }^{320}$

Como consecuencia de todo ello, a propuesta de Marco Pannela, la ley 195/74 fue nuevamente sometida a referéndum, y por un porcentaje de 90,3 por $100^{321}$ fue derogada la financiación ordinaria destinada a los partidos,

${ }^{318}$ Cfr. VAN BIEZEN, I.; NASSMACHER, K-H. "Political Finance in Southern Europe (Italy, Portugal and Spain)". In: NASSMACHER, K-H. (ed.): Foundations for Democracy - Approaches to Comparative Political Finance. ed. Nomos Verlagsgesellschaft, Baden-Baden, 2001. Pp. 140142, con una exposición de cómo el intercambio de favores entre partidos y empresas; y BARDO, L. Op. Cit. Pp. 58-59, donde el autor cita las constantes evidencias de que la financiación ilegal era un problema endémico.

319 BIANCO, A. "Brevi Note a Margine dell'abolizione del Finanziamento Pubblico ai Partiti Politici". In: Regione e Governo Locale: Bimestrale di Studi Giuridici e Politici della Regione Emilia-Romagna. Anno XVI. no 7. Ed. Maggioli, Rimini, 1995. Pp. 1228.1229.

${ }^{320}$ MARTINES, T.: Opere: Libertà e Altri Temi. Tomo IV, ed. Giuffrè, Milano, 2000. Pp. 94-95.

${ }^{321}$ BIANCO entiende que la opinión pública evaluó de manera deficiente las consecuencias de la supresión de la financiación ordinaria, a partir de una simplificación del sistema político. En su opinión, el Estado no supo confrontar la cuestión del gasto ordinario, ya que deja a los partidos en un limbo entre su formación social y la falta de una legislación especial constitucional de dichas asociaciones de hecho. Además, existía un impase entre la necesidad 
manteniéndose las subvenciones a título de reembolso de carácter electoral. ${ }^{322}$ Con ello, no se vio afectado todo el régimen de financiación de partidos, y ante la proximidad de las elecciones de 1994, se aprobó la ley no 515/93, complicando aún más el panorama ${ }^{323}$, ya que dicha ley determinó un límite de gastos para las elecciones que se avecinaban ${ }^{324}$, pero dichos límites tendrían vigencia únicamente durante el período electoral y para gastos que estuvieran directamente relacionados con la campaña, confundiendo los conceptos de actividades electorales y ordinarias, perdiendo la distinción de la ley 195/74. ${ }^{325}$

Cabe subrayar que las contribuciones privadas también se contemplaban en la ley, permitiendo que los sujetos políticos dispusieran de ellas sin límites, aunque estando prohibido utilizarlas en la campaña electoral. Esto redireccionó la discusión en torno a la libertad de los ciudadanos de contribuir a la política y de los partidos de utilizar dichos recursos dentro del contexto de la campaña electoral, motivando la aprobación de la ley 02/97 que instituía el sistema de opción de donación privada en la declaración del impuesto de la renta de las personas físicas (según el modelo del maching funds norteamericano), siendo válido solamente para personas físicas. ${ }^{326} \mathrm{El}$

de regular la campaña electoral y el interés por controlar dichos gastos. Sin embargo, el autor no entiende por qué los partidos recibían un trato jurídico peor que las demás asociaciones, si ellos aseguran la libertad política, atribuyendo al resultado de dicho referendo precisamente a esta ausencia de regulación (In: BIANCO, A. "Brevi Note..." Pp. 1229-1233).

${ }^{322}$ PEREZ SOLA, N. Op. Cit. Pp. 221. La sentencia que declaró la validez de la decisión popular es la no 30 , de 04 de febrero, de 1993.

${ }^{323}$ Para una exposición crítica sobre la evolución normativa a partir del referéndum de 1993 , véase: PINELLI, C. "II Punto su Disciplina e Finanziamento dei Partiti". In: Diritto Pubblico. fasc. 1, ed. CEDAM, Padova, 2000. Pp. 162-165. TEODORI entiende que durante 20 años, los partidos italianos no conocían realmente otra forma de financiarse que no fuera con recursos públicos, cambiando esta situación (y no para mejor) solamente a partir de referendo de 1993. Otro dato que añade el autor es que hasta 1993 no hay datos oficiales significativos sobre los gastos de los candidatos. (In: TEODORI, M.: Soldi \& Partiti - Quanto Costa la Democrazia in Italia? ed. Ponte Alle Grazie, Milano, 1999. Pp. 41-55).

324 Dichos límites alcanzaban principalmente a la propaganda electoral contratada en los medios de comunicación, que se prohibía, como también determinar el reembolso solamente de los gastos justificados. La ley también aportó algunas medidas en relación al control de dicha financiación, con la institución de la figura del mandatario financiero, siendo este el único autorizado a recaudar fondos, junto con el registro de todas las operaciones económicas realizadas, y la obligatoriedad del uso de una única cuenta bancaria para la administración de dichos valores. (In: MURILLO DE LA CUEVA, L. "La Financiación de los Partidos..." Pp. 701).

${ }^{325}$ BIANCO, A.: /l Finanziamento... Pp. 18-21. Por ello el autor afirma que el sistema italiano es un sistema "híbrido". (In: BIANCO, A. "Brevi Note..." Pp. 1232).

${ }^{326}$ Fueron muchos los debates doctrinales sobre dicha ley, que incluía en su título la "contribución voluntaria a los partidos y movimientos políticos". Así, cfr. PUOTI, G. "Alcune Considerazioni Tecniche". In: Nomos. fasc. 3, ed. Istituto Poligrafico e Zecca dello Stato, Roma, 1996. Pp. 69-74 con críticas a la elección de la deducción del impuesto de renta para la 
montante recaudado sería repartido en base a los resultados obtenidos por cada partido o movimiento político en las elecciones a la Cámara, por el método proporcional, sin sobrepasar los 110 millones de liras. La norma de "salvaguardia" generó intensos debates doctrinales, principalmente en torno a la posibilidad de regular una materia que ya había sido sometida a consulta popular. La Comisión Promotora del referéndum de 1993 - que opinaba que este sistema era, en realidad, el retorno indirecto de la financiación ordinaria intentó presentar un recurso constitucional en contra de dicha ley, sin éxito. ${ }^{327}$ Cabe destacar que la ley consideraba dicho sistema de recaudación de fondos como financiación privada, y por ello el Estado estaría "legitimado" a instituirlo $^{328}$, pero estaba claro que el consenso alrededor de la medida buscaba reintroducir mecanismos de financiación pública ordinaria de los partidos, pese el resultado del referéndum. ${ }^{329}$

Junto con la aprobación de la ley, se produjeron una serie de medidas del gobierno a fin de salvar las necesidades de los partidos con relación a sus actividades ordinarias. ${ }^{330}$ La presión por parte de los partidos que estaban

financiación de los partidos, en el mismo sentido que las críticas al primer modelo de desgravación fiscal alemán; también resultan interesantes las conclusiones sobre la posible inconstitucionalidad de la ley en relación con el resultado del referéndum (In: AA.VV.: "Dibattito". In: Nomos. fasc. 3, ed. Istituto Poligrafico e Zecca dello Stato, Roma, 1996. Pp. 74$78)$;

${ }^{327}$ Merece destacarse que el hecho de que fueron escasas las fuerzas políticas que se pronunciaren en contra del resultado del referéndum citado. (BIANCO, A.: II Finanziamento... Pp. 21-27). La sentencia sobre el caso es la no 338 de 08 de octubre de 1996 y no 9 de 14 de enero de 1997. Vid. TROCCOLI, G. "La Legge 2 Gennaio 1997, $n^{\circ} 2$ ed il Finanziamento dei Partiti”. In: Rassegna Parlamentare. №. 3. anno XXXIX, luglio/sett, ed. Giuffrè, Milano, 1997. Pp. 629.

${ }^{328}$ BIANCO, A.; GARDINI, G. "The Funding of..." Pp. 23-24.

329 Vid. TROCCOLI, que afirma que, aunque haya habido un consenso en relación a la aprobación de la ley 2/1997, existían pocas voces que no estuvieron de acuerdo, por el temor a la opinión pública, porque veían en las medidas el retorno de la financiación pública ordinaria, y sabían que los electores podrían no perdonarlo. Así, cfr. TROCCOLI, G. Op. Cit. Pp. 626. Otro autor que comparte la misma opinión es GASPARINI CASARI, que además critica la ley afirmando que viola el derecho al voto al no permitir elegir al partido beneficiado, como tampoco no respeta la capacidad contributiva de los ciudadanos. También, y dada la previsión de la escasa adhesión a dicho sistema por parte de los contribuyentes, el autor temía que las fuerzas políticas manipularan el resultado final, o sea, entregaran a los partidos cantidades que no era resultado directo de dicho sistema. (In: GASPARINI CASARI, v. "La Legge sul Finanziamento dei Partiti: Considerazioni Critiche". In: II Diritto dell'economia. no 3, ed. Mucchi, Modena, 1997. Pp. 510-512). Ya sobre la discusión sobre los efectos de las decisiones fruto de referendos sobre las normas en el sistema italianos, vid. MUSUMECI, T. S.: Op. Cit. Pp. 168 y ss.

${ }^{330}$ En realidad no fueron solamente iniciativas legislativas fueron utilizadas como intento de conseguir recursos públicos para la financiación de partidos. Además de eso, también hubo 
sufriendo una fuerte crisis financiera interna de manera general hizo que, en 1997 a través de una disposición transitoria insertada en la 02/97 (art. 4ํ), se autorizara al Ministerio del Tesoro a repartir entre los partidos y los movimientos políticos que recibieron votos válidos en las elecciones de 1996 de manera proporcional (cerca de 27) una suma de 160 millones de liras $^{331}$, algo que sin duda podía ser considerado como financiación ordinaria y generaba una contribución de doble naturaleza. ${ }^{332}$ Junto a ello, la bajísima adhesión al sistema de contribución por el impuesto de la renta ${ }^{333}$ (cerca de 10$15 \%$ del valor máximo establecido para dicho fondo) suscitó un temor a la bancarrota completa de las organizaciones partidistas, forzando a un nuevo aporte, una contribución de 110 millones de liras para el ejercicio financiero de 1998, que debía ser repartido según el esquema de la Ley 02/1997, acompañada del aumento de las ayudas electorales.

Aunque sin intervención inicial del Presidente de la República - que se negaba a sancionar una ley que iba en contra del resultado de un referéndum se produjo la aprobación de la ley 146/98 que establecía la contribución de 110 millones de liras como contribución pública, independientemente de la cantidad obtenida a título de los impuestos. ${ }^{334}$ La financiación privada no estaba

apoyos económicos a sindicatos y organizaciones vinculadas a los partidos, o subsidio para la publicación de diarios de los mismos. (In: TEODORI, M.: Op. Cit. Pp. 124 y ss).

${ }^{331}$ LANCHESTER, al analizar la normativa, afirma que dicho artículo entraba en contradicción con el título de la ley, ya que los 160 millones de liras no eran una contribución voluntaria, por lo menos no en el primer año de vigencia de la ley. Cfr. LANCHESTER, F. "La Legge Sulla Contribuzione Volontaria ai Partiti e ai Movimenti Politici". In: Nomos. fasc. 3, ed. Istituto Poligrafico e Zecca dello Stato, Roma, 1996. Pp. 57. A su vez, SABATTINI considera que la inserción de dicho artículo en la ley fue un "acto de coraje" por parte del Parlamento, pero que fue la situación crítica de los partidos frente las campañas electorales que se aproximaban lo que motivó dicha decisión. (In: SABATTINI, S. "Una Legge de Transizione". In: Nomos. fasc. 3, ed. Istituto Poligrafico e Zecca dello Stato, Roma, 1996. Pp. 64).

332 TROCCOLI, G. Op. Cit. Pp. 656-657.

${ }^{333}$ La baja adhesión al sistema de contribución establecido a través del impuesto de la renta se atribuye al hecho de que no se podía elegir qué partido se beneficiaría con la donación, es decir, todas las cantidades recaudadas con este modelo iban a un fondo común, repartido entre todos los partidos, lo que no agradó a gran parte de los contribuyentes activos de la época. Además de eso, no se puede ignorar el impacto negativo de dicha medida contraria en cierta forma a la decisión del referéndum de 1993. (Cfr. SALVI, C.; VILLONE, M.: II Costo della Democrazia: Eliminare Sprechi, Clientele y Privilegi per Riformare la Politica. ed. Mondadori, Milano, 2005. Pp. 11-13).

${ }^{334}$ BIANCO entiende que la baja adhesión al tax check off y la constante batalla con los medios de comunicación de masa (que iban a disminuir aún más esa adhesión popular a la contribución voluntaria), provocó la propuesta de la Ley Balocchi en 1998, que sugería un fuerte incremento en la contribución para las campañas electorales en lugar del sistema de 4\% de devolución de impuestos para las elecciones generales, regionales y europeas. Además, 
sometida a límites, solamente las contribuciones individuales mayores de 5 millones de liras deberían ser declaradas al Parlamento y ser registradas, lo que raramente ocurría. ${ }^{335}$ Dicha ley también fue sometida a referéndum popular, siendo rechazada, pero debido a la baja participación popular en el proceso (cerca de $32,2 \%$, y eran necesarios el $51 \%$ de los votantes), la Corte Constitucional invalidó su resultado. ${ }^{336}$

El resultado del referendo sobre la financiación pública para gastos electorales hizo que el legislador cambiara la tendencia del sistema, dirigiéndolo hacia las contribuciones privadas para las actividades electorales, con medidas formales de transparencia y fijación de límites. Sin embargo, con un sistema de difícil manejo, el Estado no logró dichos objetivos, dado que ni siquiera la Ley 02/1997 podía garantizar un sistema eficaz de control. De esta forma, la aplicación de dicha ley y la necesidad obvia de una intervención normativa de carácter estructural, junto con la proliferación de regímenes transitorios, terminó generando un perjuicio a la credibilidad del sistema de partidos, reflejado en la ineficacia del sistema de tax check off. El aumento de las subvenciones públicas ${ }^{337}$ y el resultado del referéndum de 1999 demuestran que dicha desafección se debe a un sentimiento de inutilidad del voto y de la distorsión por el legislador de la opinión pública. ${ }^{338}$

El fracaso del referéndum de 1999 incluso suscitó el debate de un sistema puramente privado, pero con mecanismos de transparencia y

buscaba introducir una medida fiscal que ayudara en la transición, para el cerrado y complicado sistemas de débitos y créditos ocasionado por la sucesiva antelación a la aprobación de la Ley 02/1997. (In: BIANCO, A.: II Finanziamento... Pp.28-38).

${ }^{335}$ Además, la ley 02/97 permitía que empresas o personas físicas autorizaran sus contribuciones fiscales de $22 \%$ de sus impuestos, no existiendo ninguna otra limitación de valores o fuentes. La única limitación se refería a las donaciones para campañas electorales, que un contribuyente no podría donar a un candidato (no a un partido) cantidades superiores a 23 millones de liras. (In: BIANCO, A.; GARDINI, G. "The Funding of..." Pp. 23-24).

${ }^{336}$ NASSMACHER entiende que hubo un "hueco" significativo en las reformas para la ley de financiación de partidos, siendo que la legislación inicial, de 1974, sólo fue alterada en 1997. Cfr. NASSMACHER, K-H. "Party Funding..." Pp. 117 y 123.

${ }_{337}$ De igual forma, el sistema de financiación pública es fuertemente criticado, y por su conservadurismo al relacionar representación parlamentaria y sufragio para el reparto de las subvenciones. Ello puede obstaculizar nuevas formaciones políticas, aunque dicha fórmula posee evidencias de equidad. (In: BIANCO, A.: Il Finanziamento... Pp. 94-96).

${ }^{338}$ Para una crítica consistente del sistema de financiación de los partidos políticos italianos, cfr. LOMBARDI, G. "El Financiamiento de los Partidos Políticos y la Equidad en la Competencia Electoral". In: AA.VV.: Administración y Financiamiento de las Elecciones en el Umbral del Siglo $X X I$ - Memoria del III Congreso Internacional de Derecho Electoral. Tomo II, Instituto de Investigaciones Jurídicas, DF, México, 1999. Pp. 545-550. 
control. ${ }^{339}$ Sin embargo, se inició un nuevo período de silencio del legislador, ya que los partidos políticos ahora cuentan con la consistencia del sistema de contribuciones para las campañas electorales. Ante ello, se puede decir que la contribución estatal a la financiación de los partidos en Italia es centralizada, sin control y distorsionada en su realización, con la pérdida de fuerza de las disposiciones de la ley, y culminando en una financiación pública aditiva y no sustitutiva de las fuentes ilegales. ${ }^{340}$

En la ley de 3 de junio de 1999, № 157, se siente la inspiración de la tendencia mayoritaria - común en el sistema electoral italiano y en teoría usada para disminuir la fragmentación partidista - basándose en los colegios uninominales. ${ }^{341}$ Se trata de una normativa sobre el reembolso electoral a los partidos $^{342}$, determinando criterios de acceso a las subvenciones donde se combinan resultados electorales y representación, basándose el reparto en la proporción de los votos válidos, a partir de un umbral o de haber obtenido un representante elegido en los colegios uninominales, pero sin excluir a las minorías lingüísticas del cumplimiento de dichos criterios. ${ }^{343}$ Existen también

\footnotetext{
${ }^{339}$ Se podría pensar que, con el descenso de las contribuciones privadas y los problemas en establecer la financiación pública, los afiliados se habrían convertido en la fuente principal de recursos de los partidos, aunque esto no se pueda comprobar en la práctica, considerando que el reembolso electoral adoptado "maquilla" la financiación general. Sobre el tema, cfr. BARDO, L. Op. Cit. Pp. 72.

${ }^{340}$ LANCHESTER, F. "II Problema del Partito..." Pp. 454.

${ }^{341}$ Se debe tomar en cuenta que por un largo período de tiempo el sistema de partidos italiano no sufrió cambios, dada la escasa apertura en el sistema. (In: TEODORI, M.: Op. Cit. Pp. 58).

${ }^{342}$ A dicho reembolso atiende al art. 1.6, que determina que cada día 31 de julio serán adjudicados los recursos debidos, siendo la $1^{\circ}$ parte del $40 \%$ del total, y en los demás años, $15 \%$. No es necesario presentar garantía, como ocurre en Alemania.

${ }^{343}$ Participan del reparto los grupo de candidatos que logran elegir por lo menos 1 de su base nacional, o que alcancen por lo menos el 5 por 100 de los votos válidos expresados en ámbito regional; y los candidatos no afiliados a algún grupo que resultó elegido o que logren por lo menos el 15 por 100 de los votos válidos, no especificando si regional o nacional. El reparto se basa en la proporción de los votos conseguidos para el escaño, entre movimientos y partidos que han superado el umbral de $4 \%$ de los votos válidos, o de haber un elegido en colegios uninominales y haber conseguido por lo menos el $3 \%$ de los votos válidos en el ámbito nacional (antes de la reforma de 2006 el umbral era del 1\%). Dichos criterios no son exigibles para los movimientos que hayan presentado candidaturas propias en circunscripciones dentro de una región en donde exista protección a las minorías lingüísticas, conforme determina el art. 9 de la ley de 10 de diciembre de 1993. Como se puede observar, muchos partidos recibían recursos, incluso algunos que tenían un perfil personal, territorial, y de pequeño tamaño y relevancia política, lo que ha comprometido la credibilidad de este sistema ya tan carente de efectividad. Sin embargo, se puede entender que los partidos mayoritarios han aceptado dichas condiciones para aprobar dicha ley, aunque la opinión pública fuera contraria. Se produjo aumento de la financiación de los partidos justamente para formar la mayoría para la aprobación de la ley, dando como resultado un amplio consenso. (Cfr. SALVI, C.; VILLONE, M.: Op. Cit. Pp. 13).
} 
elementos sobre la financiación indirecta (que generalmente atienden a criterios de representatividad para su acceso), incentivos fiscales para la financiación privada y la apertura de límites para las donaciones privadas, como también algunas determinaciones sobre el control de las finanzas de los partidos, que no van más allá de la verificación de la regularidad de las cuentas de acuerdo con la documentación presentada. ${ }^{344}$ Con la reforma del sistema en $2005^{345}$ (que se orientaba a las elecciones de 2006), se modificó la normativa, como por ejemplo el aumento del umbral para el acceso a las subvenciones (del $1 \%$ al $3 \%$, y un representante en un colegio uninominal), así como también la garantía a los partidos de que, en caso de disolución anticipada del Parlamento, éstos seguirían recibiendo normalmente los recursos todavía pendientes, como si fuera una "cláusula de seguridad". 346

De igual forma que el resto del modelo, el sistema de contribución voluntaria para los partidos que la ley 157/99 instituyó a través de un sistema con los rasgos del tax check off también fue bastante criticado, pues aunque se refiera solamente al "reembolso electoral", pretende aumentar las cantidades asignadas para que los partidos puedan sostenerse con dichos recursos ${ }^{347}$, o sea, significa otra manera de financiar a los partidos con fondos públicos, considerando que no se puede elegir el partido al que se destina la donación. Se critica que, de esta manera, se produce una cierta violación de la voluntad popular, que ya se había pronunciado por el fin de la financiación pública en el referéndum abrogativo anteriormente citado. ${ }^{348}$ Esta ley también ya fue objeto de consulta popular, pero sin éxito. ${ }^{349}$

\footnotetext{
${ }^{344}$ BORRELLO, R. "La Disciplina del Finanziamento della Vita Politica in Italia". In: Giornale di Diritto Amministrativo, № 12, 2008. Pp.1290-1295.

${ }^{345}$ Con la ley de 21 de diciembre de 2005, ํㅡㄴ 270.

346 PÉREZ FRANCESCH, J. L. "La Financiación de los Partidos Políticos en España. Consideraciones a Partir de los Informes del Tribunal de Cuentas y de la Nueva Ley Orgánica 8/2007, de 4 de julio". In: Papers - Revista de Sociología. no 92, ed. UAB, Barcelona, 2009. Pp. 253.

${ }^{347}$ En 2002 el valor debido a los partidos era de poco menos de 125 millones de euros, pero la Area-Agenzia Ricerca Economico-sociale ha hecho un cálculo, que estima que los partidos recibirán en la XVI Legislatura, entre elecciones europeas, regionales y legislativas las cantidades por un valor aproximado de mil 809 millones de euros. (In: BORRELLO, R. "La Disciplina del..." Pp. 1291).

348 STROPPIANA, L. "Finanziamento dei Partiti: Una Legge Contestata". In: Quaderni Costituzionali. Anno XIX. no 3. Diciembre. Ed. II Mulino, Bologna, 1999. Pp. 652. Sin embargo, el autor admite que dichas contribuciones voluntarias favorecen el sistema de partidos como un todo, incluso porque, aunque los ciudadanos pudieran elegir a los partidos que desearían
} 
Con todo, aunque se haya retirado la financiación pública ordinaria, manteniendo solamente la electoral, es evidente que el aumento de recursos aportado por la reforma de la ley del 2006 ayuda de manera determinante al sostenimiento de los partidos en sus actividades generales, contrariando la decisión popular expresada en el referéndum. ${ }^{350}$

De esta forma resulta claro que todas las modificaciones legales no estaban destinadas a reforzar los principios de pluralismo político o de la igualdad de oportunidades, sino tan solo, lo que no es poco, al combate contra la corrupción, como la mayoría de los proyectos de ley que sobre estos temas se encuentran en trámite en el Parlamento. Se constata pues que en el caso italiano prevalece la financiación pública, aún con toda la polémica generada, y aunque dado que prevalece la idea de que los partidos poseen una naturaleza privada, se reconozca una considerable libertad para las donaciones privadas. $^{351}$ Lo que resulta cuestionable es si el resultado práctico del referéndum de 1993 fue el surgimiento del fenómeno "Berlusconi" dentro de la esfera política formal, o si los moldes de las leyes a partir de 1997 no conducirán a todo el sistema a su indirecta privatización, como ha ocurrido en EE.UU. ${ }^{352}$ Hay un proceso en marcha de cambio del sistema de partidos dado que en los últimos 20 años, como es sabido, se produjo la desaparición de los

financiar, dicha elección carecería de garantías de su genuidad. (Idem). En el mismo sentido, cfr. RESCIGNO, F. "II Finanziamento ai Partiti: la Storia si Ripete?" In: Giurisprudenza Italiana. 8-9, 2000.

${ }^{349}$ En la sentencia no 32 de 07 de febrero de 2000 fue autorizada la realización del referendo, pero por su falta de quórum necesario, no fue considerado válido. esto deja claro que la población no fue a las urnas porque seguramente se sintió incapaz de decir "no" a una decisión antes no respetada. En este sentido, véase: RESCIGNO, F. Op. Cit.

${ }^{350}$ La evolución normativa a partir del concepto de gastos electorales está muy bien expuesta por DI MARTINO, que se sugiera la lectura: DI MARTINO, G. "Spese Elettorali (Rimborsi)". In: Rassegna Parlamentare. №. 4. anno XLVIII, oct/dic, ed. Giuffrè, Milano, 2006. Pp.1207-1218.

${ }^{351}$ FERNÁNDEZ VIVAS, Y.: Op. Cit. Pp. 137-139.

${ }^{352}$ MELCHIONDA, E.: Op. Cit. Pp. 204 y ss; y BIANCO, A.: // Finanziamento... Pp.42-46. EI tema ya fue objeto de análisis, al que se indica la lectura: HOPKIN, J. "Towards a Chequebook Democracy? Business, Parties, and the Funding of Political in Italy and the United States". In: Journal of Modern Italian Studies. v. 1. no 10, UK, 2005. Pp. 43-58. Aunque el autor concluya al final que no hay la "americanización" de la política en Italia, se destaca que las reglas de control fueron sistemáticamente violadas, y que la corrupción de los partidos italianos siempre estuvieron enfocadas a sostener sus estructuras permanentes, no las campañas, como ocurre en EE.UU. Además, en Europa se usa mucho más recursos públicos para hacer política, mientras que en Italia (al menos actualmente), el primer ministro es millonario que dispone de recursos suficientes para mantenerse en el poder, invirtiendo la lógica del sistema europeo. 
principales partidos que articularon la Italia de la posguerra. ${ }^{353}$ Pero lo que realmente condiciona al sistema italiano antes del "período Monti" fue el uso de los medios de comunicación y la relación entre poder privado mediático y poder político, con sus evidentes repercusiones a la hora de evaluar el verdadero "coste" de la política para los distintos actores. ${ }^{354}$

\section{5) El Desequilibrio entre la financiación pública y la privada y sus consecuencias}

Si el punto clave de la legislación sobre la financiación de los partidos es encontrar el justo equilibrio entre las medidas de financiación pública y privada, también es claro que no es una tarea que se concluya fácilmente, ni que pueda generalizarse a demasiados supuestos, ni a distintas situaciones temporales dentro del mismo ordenamiento.

Desde una perspectiva teórica, el modelo de financiación pública de partidos tiende a la igualdad de oportunidades entre los competidores, que depende de la capacidad de restricción de la influencia de los recursos privados y de equilibrar las oportunidades de estos actores políticos. Este modelo intenta eliminar una posible dependencia de los partidos de recursos privados. Y es aquí donde los debates están centrados en los modelos privado y público, y en su capacidad de ir en contra de las circunstancias de la moderna democracia: el aumento de la demanda de recursos económicos. Además, el modelo elegido también atiende a la separación existente entre el poder o la forma de gobierno y el sistema de partidos. Cuando dichas organizaciones son "semi estatales", es importante que desempeñen funciones no menores también en los periodos entre las elecciones. Sin embargo, en

\footnotetext{
${ }^{353}$ BIANCO, A.; GARDINI, G. "The Funding of..." Pp. 19 y SALVI, C.; VILLONE, M.: Op. Cit. Pp. 141 y ss. Como se puede citar la Lega Nord y su discurso separatista y frecuentemente xenófobo.

${ }^{354}$ Cfr. SARTORI, G.: Homo Videns: La Sociedad Teledirigida. ed. Taurus, Madrid, 1997. Pp. 130 y HOPKIN, J. "Towards a Chequebook..." Pp. 53.
} 
regímenes presidencialistas, no es este el caso, porque los partidos sirven principalmente a los propósitos electorales en la campaña presidencial. ${ }^{355}$

Lo normal es que se produzca un desequilibrio inestable entre estos modelos "ideales", provocando a lo largo del tiempo distorsiones que pueden marcar profundamente el sistema democrático. Por esto, lo aconsejable es que, en el momento de de la elaboración de la legislación sobre la materia, se observan algunos principios básicos. El primer principio es el de la subsidiariedad, que significa que el Estado actúa por medio de la población representada por el cuerpo electoral, siendo auxiliados por los partidos en esta tarea, lo que no quiere decir que los partidos sustituyan a la voluntad popular. Así, los modelos de financiación de la política influyen determinantemente en la representación de los grupos sociales en el gobierno. Y como compete a los ciudadanos evitar que el sistema de partidos no implante dentro del sistema una clase política totalmente autónoma, el Estado reconoce a los partidos como intermediarios entre el mismo y sociedad, favoreciendo el buen funcionamiento del sistema. Es en esta intermediación en donde se debe centralizarse el combate a la corrupción.

El segundo principio es el de la concurrencia, concebido como síntesis entre la igualdad y libertad. Como situación de referencia consiste en una confrontación libre y completa de todos los agentes presentes en un sistema político, aún más en el proceso electoral, para elegir libremente dentro de las opciones ofrecidas a determinados representantes. Para la financiación de la política, el principio es importante porque busca limitar el "poder privado" y sus efectos negativos, y promover el pluralismo del debate y la competición política.

El tercer principio es el de la transparencia, fundamental para el funcionamiento del Estado, pues permite un control del sistema. La transparencia puede colaborar a recuperar la confianza de la opinión pública y es indispensable para el control de los representantes políticos. De igual forma ayuda a expresar mejor la voluntad popular, como también su formación. Está finalmente el principio del combate contra la corrupción, que se alía con el

\footnotetext{
355 SMILOV, D. "Structural Corruption of Party Funding Models: Governmental Favoritism in Bulgaria and Russia". In: KOTKIN, S.; SAJÓ, A. (eds.): Political Corruption in Transition - A Skeptic's Handbook. CEU Press, Hungary, 2002. Pp. 328-329.
} 
principio de la dignidad de las elecciones, legitimando todo el proceso democrático. ${ }^{356}$

Además de esto, se debe evitar que dicho sistema de financiación sea utilizado como un arma poderosa para la exclusión de los partidos minoritarios o para provocar la concentración de los recursos en los partidos mayoritarios y los que tienen mayor éxito en las urnas, con el objetivo de estrangular económicamente las opciones políticas menores. ${ }^{357}$ En realidad, dicho modelo debería comprender un conjunto de reglas que fomenten la creación y el desarrollo de los partidos representativos, involucrando a la vez a la sociedad, en una verdadera medida de discriminación positiva para la disminución de las diferencias existentes entre las fuerzas políticas y la promoción de la legitimidad democrática de las instituciones representativas. ${ }^{358}$

Aunque sin conexión directa, tampoco el sistema de financiación puede generar fragmentación en el gobierno. Es sabido que dicho sistema debe coadyuvar al pluralismo político, base de la democracia. Con todo, pluralismo político no significa siempre existencia de fragmentación política e ingobernabilidad ${ }^{359}$, pero la inexistencia de algún umbral para el acceso a las subvenciones públicas deja el sistema de partidos demasiado abierto y muy vulnerable a partidos creados solamente para obtener recursos públicos y

\footnotetext{
${ }^{356}$ BALMELLI, T.: Op. Cit. Pp. 349-372. También en este mismo sentido, cfr. NASSMACHER, K-H. "Introduction..." Pp. 5; 9-13.

${ }^{357}$ Cfr. WARE, A. "Conclusions. Op. Cit." Pp. 243. Lo cierto es que el papel de las minorías es de extrema importancia en cualquier sistema de partidos. Los minoritarios tienen un papel esencial de agregar la demanda política que no es reconocida por los mayoritarios, y cuando son excluidos, acaban por dejar dicha demanda desarticulada, generando incluso una discriminación que involucra el derecho de participación política entre los ciudadanos. (In: GAMBINO, S.: Op. Cit. Pp. 149-152).

${ }_{358}$ En este sentido, estoy de acuerdo con BORRELLO, que entiende que no se trata de separar o alejar la democracia del dinero, sino de seleccionar el dinero "bueno", que es necesario para el funcionamiento de la democracia, del "malo" o mal intencionado, que busca alterar el equilibrio en la competición en la política o en la relación competición económica e interés colectivo. Además, la posibilidad de acceder y utilizar los recursos necesarios para competir es una de las formas de barrera idónea para seleccionar cuantitativamente y también cualitativamente los competidores en la arena política, determinando, conforme la vía elegida, un cierto tipo de competición, condicionando del mismo modo la calidad de la democracia. (In: BORRELLO, R.: Finanziamento della Política... Pp. 20-22). También en este sentido, cfr. GONZÁLEZ-AURIOLES, J. A. Op. Cit. Pp. 219-220.

${ }^{359}$ La fragmentación partidista puede tener muchas causas, y sin que siempre signifique una polarización ideológica. Puede ser que existan a la vez muchos partidos que son expresiones de los sustratos sociales, pero que no haya un conflicto ideológico entre ellos, disminuyendo sobremanera la relevancia de la fragmentación presente. (In: BARTOLINI, S. "Partidos y Sistemas de Partidos". In: AA.VV.: Manual de Ciencia Política. ed. Alianza, Madrid, 1988. Pp. 235-236).
} 
colaborar con el crecimiento de la corrupción. La excesiva fragmentación puede representar, muchas veces, un pluralismo ficticio, en lo cual no existan intereses realmente diversificados, $y$, a su vez, genera un aumento en el coste del mantenimiento de un sistema de partidos complejo, pero que no contenga diferencias sustanciales al punto de cumplir con la función de articular demandas sociales variadas. ${ }^{360}$

Sin embargo, se debe pensar también que la financiación pública de los partidos no fue ideada solamente para garantizar la existencia de diferentes opciones políticas que componen el gobierno, sino también para posibilitar la oposición de los minoritarios. ${ }^{361}$ Los pequeños partidos deben tener una real posibilidad de acceder a los recursos públicos, a fin de que se posibilite su participación en la competición electoral con alguna previsión de éxito. ${ }^{362}$ Es por lo que generalmente se mantiene que la barrera electoral debe ser baja, permitiendo la apertura del sistema de partidos. ${ }^{363}$ Un sistema compuesto por diversos partidos no funciona bien solamente con una competencia real, a través de competidores con reales posibilidades de triunfo, sino también debido a la existencia de una competencia tenida como "virtual", que hace que los partidos "de gobierno" sepan que, si no realizan correctamente sus funciones pueden perder su cuota en el poder en beneficio de fuerzas políticas que no lograron anteriormente representación sustantiva, ${ }^{364}$ o que reflejaría un verdadero pluralismo y una verdadera realización de la democracia, y a ello debe colaborar el sistema de financiación. ${ }^{365}$

Lo que se debe tener en cuenta es que la financiación pública no produce corrupción, pero tampoco la impide. Pasa lo mismo con la financiación

\footnotetext{
${ }^{360}$ En este sentido, cfr. PASQUINO, G. Op. Cit. Pp. 51.

${ }^{361}$ BLANCO VALDÉS, R. L: Los Partidos Políticos. Op. Cit. Pp. 199.

362 SANTAOLALLA, F. "Regulación de Campañas..." Pp. 177.

${ }^{363}$ Aquí algunas observaciones deben ser hechas. Si un partido no es capaz de establecer y mantener lazos entre la sociedad civil y los políticos que deciden en nombre del pueblo que ellos representan, el partido por sí solo desaparecerá. (In: NASSMACHER, K-H. "Introduction..." Pp. 3). Y debido a ello creo que la estabilidad política, aunque sea una razón legitima, no puede ser privilegiada frente a principios constitucionales, por el riesgo de comprometer la propia democracia. En este sentido, véase SÁNCHEZ MUÑOZ, O.: La Igualdad... Pp. 231.

${ }^{364}$ Cfr. MORLOK, M. “La Regulación Jurídica...” Pp. 52.

${ }^{365}$ En este sentido, cfr. GUNTHER, R.; RAMÓN MONTERO, J.; BOTELLA, J.: Democracy in Modern Spain. Ed. Yale University Press, USA, 2004. Pp. 223; y GARCíA VIÑUELA, E. "Financiación Pública de los..." Pp. 89.
} 
privada, que más bien genera corrupción en lugar de reducirla si no viene acompañada de medidas que reduzcan su impacto. ${ }^{366}$ La salida es la financiación mixta, pero si no está bien nivelada una y otra, los efectos colaterales pueden ser de significativa importancia.

\subsection{La financiación de los partidos y la corrupción}

La protección de libertades civiles como la libertad de expresión y el derecho al sufragio (que forzosamente acompañan a las elecciones democráticas) hace posible un gobierno transparente y abierto. La corrupción depende tanto de la organización de los procesos legislativos y electorales, como de la extensión que los intereses de los más poderosos económicamente buscan en el sistema político. Si ningún gran partido controla la legislatura, puede haber una serie de pequeños, pero bien organizados, partidos, que pueden usar de su poder de negociación para obtener beneficios fijos. Junto a esto, hay dos factores que determinan el interés de los bienes públicos en una legislatura, siendo el primero los incentivos producidos por las reglas electorales; y el segundo el camino por el que estas reglas interactúan con el presidente o el Parlamento. ${ }^{367}$

En los sistemas proporcionales, los partidos centralizados y sus candidatos operan de manera muy distinta. El aspecto central consiste en el nivel de competición política y la tolerancia de los votantes ante la corrupción. $^{368}$

A fin de sistematizar la exposición de este difícil y denso tema, lo que se tendrá en cuenta principalmente es la corrupción a partir de un sistema con medidas centradas en la financiación privada de los partidos. Hay autores que identifican eventos y comportamientos corruptos en sistemas con una financiación predominantemente pública, como es el caso de VILLORIA MENDIETA cuando trata de la evolución de los partidos al tipo catch-all y al consecuente comportamiento en cartel, o los acuerdos pactados sobre los

\footnotetext{
${ }^{366}$ En este sentido, cfr. VILLORIA MENDIETA, M.: Op. Cit. Pp. 212.

367 ROSE-ACKERMAN, S. "Political Corruption and Democratic Structures". In: JAIN, A. K. (ed.): The Political Economy of Corruption. ed. Routledge, NY, 2001. Pp. 35-40.

${ }^{368}$ ROSE-ACKERMAN, S. "Political Corruption..." Pp. 40-45.
} 
intereses en común de los partidos mayoritarios. Esto, según el autor, abriría un espacio para la corrupción. ${ }^{369}$ No puedo estar totalmente de acuerdo con este punto de vista porque el soborno y otras prácticas de corrupción son, en este sentido, más comunes en sistemas con una cantidad desmedida de financiación privada. Además, la evolución de los partidos catch-all a partir de la centralización de su ideología para los partidos en cartel es más una disfunción por la eventual exageración de la financiación pública, siendo ese uno de los criterios para su surgimiento.

Con todo, aquí cabe otra advertencia: al tratar de corrupción, no se puede caer en la tentación de evaluarla con la pretensión de eliminarla. Es una utopía pensar que la corrupción podrá ser extinguida totalmente, como tampoco es posible de tratarla en todos sus aspectos. La corrupción se da básicamente y únicamente porque el individuo ha decidido practicar una conducta corrupta ${ }^{370}$, independientemente de su entorno, y es justamente por esto que siempre habrá corrupción: no es posible construir un sistema de control eficaz al extremo como para impedir que un individuo tome la decisión de corromperse. Dicho sistema es mucho más eficaz cuando es interno al individuo que solamente externo. ${ }^{371}$

Además, hay casos de corrupción que son más graves que otros, lo que no significa decir que se deba tratar del tema con excesos de alarmismo. ${ }^{372}$ Junto a eso, no se puede hacer un análisis de la corrupción basándose en nociones de moral personal. Esto altera de manera profunda la conclusión del examen. $^{373}$

\footnotetext{
${ }^{369} \mathrm{cfr}$. VILLORIA MENDIETA, M.: Op. Cit. Pp. 205.

${ }^{370}$ Cfr. BROOKS, R. C. "The Nature of Political Corruption". In: HEIDENHEIMER, A. J. (ed.): Political Corruption - Readings in Comparative Analysis. ed. Transaction, New Jersey, 1978. Pp. 59.

371 J. LAPORTA, F. "La Corrupción Política: Introducción General". In: J. LAPORTA, F.; ÁLVAREZ, S. (eds.): La Corrupción Política. ed. Alianza, Madrid, 1997. Pp. 28.

${ }^{372}$ Esta también es la opinión de MURILLO DE LA CUEVA en AA.VV. "Encuesta: Corrupción Política". In: Teoría y Realidad Constitucional. № 25, 1ํ semestre. UNED, Madrid, 2010. Pp. 23. Sobre el tema, cfr. GARCíA, E.: El Estado Constitucional ante su 'Momento Maquiavélico'. ed. Civitas, Madrid, 2000. Pp. 71 y ss.

${ }^{373}$ Cfr. GARCÍA, E. "Istorie fiorentini de Maquiavelo: Uma primera definición moderna de corrupción". In: Teoría y Realidad Constitucional. ํㅡ 25, 1ํ semestre. UNED, Madrid, 2010. Pp. 62-63; y BUSTOS GISBERT, R. "Corrupción Política: Un Analisis desde la Teoría y la Realidad

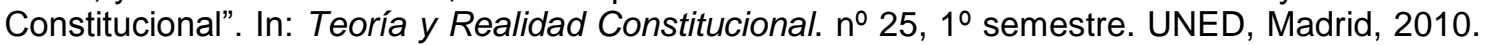
Pp. 72-74.
} 
Finalmente, limitémonos aquí a tratar de la corrupción política, a partir de una conceptualización adecuada a la financiación de partidos políticos. Como la corrupción política se ubica entre el derecho y la política propiamente dicha, es importante destacar la idea de que es corrupta la acción que alguien produce para obtener algo, y que por tanto traicione sus principios en favor de quien proporciona el beneficio, dañando al interés público, no siendo necesario estrictamente que esté tipificada en ley penal. ${ }^{374}$

\subsubsection{El Problema del concepto de corrupción política}

El problema de la corrupción no es nuevo. Ha acompañado la evolución de las sociedades desde siempre y se relaciona con parámetros del ámbito de la moral, la justicia, la ética, y otros. La corrupción puede surgir entre agentes privados, públicos, privados y públicos, no tiene destinatario o titular cierto, tampoco campo preferente de actuación. Que la corrupción se constituya o no en un delito penal es una cuestión relativa, porque hay situaciones basadas en la corrupción que pueden ser que no merezcan reproche jurídico, sino quizás uno de carácter moral. Y esta es la punta de un gran iceberg, considerando el vasto alcance de su concepto. ${ }^{375}$

El concepto de corrupción continúa siendo redefinido a partir de nuevos intereses y conflictos, y también por la emergente conceptualización de accountability, y de los mandatos de transparencia para los partidos y políticos sobre sus finanzas. La democracia como política no sólo descansa sobre las ideas de igualdad institucionalizada, sino también sobre la de una competición abierta. Cuando se involucra con intereses privados, la competición democrática también se relaciona con la idea de lo "justo", para agregar los intereses en común y convertirlos en políticas públicas. Los mercados ya incorporan pocos presupuestos de igualdad, tanto en su procedimiento como

\footnotetext{
${ }^{374}$ Esto es importante principalmente en la financiación de los partidos, donde hay muchas hipótesis de conductas que no son tipificadas en ley, pero que seguramente pueden ser clasificadas como corruptas. En este sentido, cfr. VILLORIA MENDIETA, M.: Op. Cit. Pp. 38-41. ${ }^{375}$ MALEM SEÑA, J. F.: La Corrupción. Aspectos Éticos, Económicos, Políticos y Jurídicos. Ed. Gedisa, Barcelona, 2002. Pp. 12-16.
} 
en su resultado. ${ }^{376}$ Si esta asimetría no existiera, la corrupción no sería un problema. Por ello, se debe pensar en la corrupción como un problema político o concepto no resuelto, centrándose en su contenido más que solucionar sus definiciones. ${ }^{377}$ Las nociones que aportan la propia sociedad influyen de manera directa en esta conceptualización (ya que corrupción no es sinónimo de escándalo $\left.{ }^{378}\right)$, estando también relacionada con la vitalidad del propio proceso político. No es solamente un proceso analítico, sino también un proceso político propiamente dicho. La noción clásica del término corrupción acuñada desde Aristóteles, Platón y Maquiavelo se vinculaba más a un sentido moral que a acciones individuales. Era una cuestión de la distribución de las riquezas y del poder. ${ }^{379}$ Sin embargo, con las sociedades modernas fragmentadas, dicha noción se ha hecho más estrecha y alcanza solamente algunas acciones específicas de ciertos individuos (como los que ocupan cargos públicos, por ejemplo). De esta manera, dicho concepto de corrupción acabó por basarse también en torno a un proceso de clasificación de conductas. ${ }^{380}$

Parece claro que la corrupción implica también la violación de un deber, según una normativa aplicable, realizada con discreción a fin de obtener un beneficio ajeno a aquellos obtenidos legítimamente a través del cargo ocupado. ${ }^{381}$ Aunque se establezca este como el marco inicial del análisis, es también probablemente una base insuficiente, porque hay conductas que son corruptas y que no dependen del ordenamiento jurídico para que sean así

\footnotetext{
${ }^{376}$ Aquí la corrupción sería como un maximizador de lucros. (In: VAN KLAVEREN, J. "The Concept of Corruption". In: HEIDENHEIMER, A. J. (ed.): Political Corruption - Readings in Comparative Analysis. ed. Transaction, New Jersey, 1978. Pp. 38).

377 JOHNSTON, M. "The Definitions Debate - Old Conflicts in New Guises". In: JAIN, A. K. (ed.): The Political Economy of Corruption. ed. Routledge, NY, 2001. Pp. 24-26.

378 En este sentido, cfr. MALEM SEÑA, J. F. "EI Fenómeno de la Corrupción". In: J. LAPORTA, F.; ÁLVAREZ, S. (eds.): La Corrupción Política. ed. Alianza, Madrid, 1997. Pp. 84 y BUSTOS GISBERT, R. Op. Cit. Pp. 105.

${ }^{379}$ De hecho, según BUSTOS GISBERT, el concepto de corrupción y poder son inseparables, porque toda forma de poder ha sufrido corrupción, siendo esta a veces mayor, a veces menor. (In: BUSTOS GISBERT, R. Op. Cit. Pp. 71).

${ }^{380}$ JOHNSTON, M. "La Búsqueda de Definiciones: La Vitalidad de la Política y el Problema de la Corrupción". In: Revista Internacional de Ciencias Sociales. $n^{\circ} 149,1996$. Disponible en: $<$ http://www.fsa.ulaval.ca/personnel/vernag/eh/f/ethique/lectures/RISS/definiciones.html> Acceso en: 06.11.2011. En el mismo sentido, cfr. CAGGIANO, M. H. S. "Corrupção e financiamento das Campanhas Eleitorais". In: Revista de Direito Constitucional e Internacional. $n^{\circ}$ 41, a. 10, out./dez. São Paulo, RT, 2002. Pp. 219.

${ }^{381}$ Cfr. MALEM SEÑA, J. F.: La Corrupción... Pp. 35.
} 
consideradas. ${ }^{382}$ Aquí también cabe la observación de que el ordenamiento jurídico no es capaz de abarcar todas las hipótesis posibles de actos corruptos. $^{383}$ Lo que sí se puede afirmar es que hay dos puntos clave en la corrupción, siendo el primero el interés público como bien jurídico protegido, y el segundo la violación legal, en caso de tratarse de la noción jurídica de corrupción.

Si la conceptualización del término corrupción por si solo ya conlleva a dificultades, el significado de la corrupción política lo es aún más. Las definiciones más comunes (como puede ser el uso de cargos públicos para obtener beneficios privados ${ }^{384}$ ) algunas veces no pueden ser aplicadas en todos los supuestos, por no englobar todas las formas de financiación política. ${ }^{385}$ Sin embargo, hay algunos elementos que deben estar presentes en la corrupción política que manejamos: la conducta debe ser practicada por personas o grupos que estén en el ejercicio de algún cargo público, sea este de naturaleza representativa o de nombramiento indirecto; dicho cargo público debe implicar el ejercicio de una autoridad pública, con algún margen de decisión sobre la gestión de recursos; además, debe haber un interés personal del individuo que practica la conducta, y este interés puede ser directo o indirecto y el beneficio, a su vez, debe ser otorgado a un tercero o a sí mismo, en caso de ser beneficiario directo. Por último, el individuo debe ser consciente de que la conducta es contraria a las reglas establecidas por las que se le ha otorgado la confianza para el ejercicio del cargo público, y debido a ello, la conducta será practicada de manera secreta. ${ }^{386}$

Junto a dichas características, la corrupción política también es identificada a partir del bien esencial dañado, porque el elemento moral no es la ética profesional, sino la ética pública, pasando esto también por el

\footnotetext{
${ }^{382}$ Es aquí que MALEM SEÑA hace la observación de que, siendo en la financiación irregular, ilegal o corrupta, el elemento común es el comportamiento que entra en contradicción con los fines deseados por el derecho. Cfr. MALEM SENA, J. F.: La Corrupción... Pp. 115.

${ }^{383}$ BUSTOS GISBERT, R. Op. Cit. Pp. 77.

${ }^{384}$ En este sentido, cfr. VANUCCI, A. "Corruzione, Partiti e Competizione Politica: Osservazioni Sul Caso Italiano". In: Quaderni di Scienza Política. a. IV. n 1. abr. Pavia: Giufrè Editore, 1997. Pp. 121; KUNICOVA, J.; ROSE-ACKERMAN, S.: Electoral Rules as Contraints on Corruption. 2. ed. Yale University Press, New Haven, 2002. Pp. 4; y AA.VV. "Encuesta: Corrupción Política. Op. Cit.". Pp. 18.

${ }^{385}$ PINTO-DUSCHINSKY, M. Op. Cit. Pp. 70-71.

${ }^{386}$ BUSTOS GISBERT, R. Op. Cit. Pp. 83.
} 
incumplimiento de un deber no sólo profesional, sino más bien cívico. Lo que se daña con la corrupción política es la política, porque se olvida su fin último, su razón de ser y se violan los principios que la fundamentan. ${ }^{387} \mathrm{El}$ mayor coste de la corrupción en la democracia es que tiende a beneficiar a aquellos más poderosos, en claro perjuicio de aquellos que tienen menos, tanto con relación a la riqueza propiamente dicha, como también a los recursos políticos. ${ }^{388}$

Considerando todo ello, creo que el concepto que mejor se aplica a la corrupción política en el campo de la financiación de los partidos coincide con el de ZOVATTO, que la define como el mal uso y el abuso del poder, tanto de origen público como privado, con fines partidistas o personales, a través de la violación de normas legales. ${ }^{389}$ Aquí, la corrupción política siempre incluirá supuestos como las contribuciones privadas que violen normas existentes de financiación de partidos; el uso para las campañas o partidos de dinero que el representante del partido haya recibido debido a una transacción corrupta; un uso no autorizado de recursos del Estado para fines partidistas; la aceptación de recursos a cambio de un favor no autorizado en el caso de la victoria de dicho partido en las elecciones; contribuciones venidas de fuentes de financiación de carácter poco acorde con la ética pública; y el gasto de recursos en propósitos prohibidos, como la compra de votos. ${ }^{390}$

Es evidente que la corrupción en la financiación de los partidos es una corrupción política porque aunque los sujetos pueden ser tanto los partidos como los entes privados; el bien dañado es siempre el interés público; y su carácter viene marcado por producirse tanto en el seno de los partidos, como también por ser un medio de influencia en la agenda política. $Y$ es aquí donde se ubica la popular clasificación de corrupción hecha por HEIDENHEIMER, que se encaja muy bien para lo que se refiere a la financiación de los partidos. La corrupción negra, condenada como corrupta; la gris, que son situaciones

\footnotetext{
${ }^{387}$ VILLORIA MENDIETA añade esta idea afirmando que el combate a la corrupción política no puede darse sin medidas de fortalecimiento de la democracia, sino no será exitosa. (In: VILLORIA MENDIETA, M.: Op. Cit. Pp. 104-130.

${ }^{388}$ MALEM SEÑA, J. F. "EI Fenómeno de..." Pp. 88.

389 ZOVATTO, D. "Financiamento dos Partidos e Campanhas Eleitorais na América Latina: Uma Análise Comparada". In: Opinião Pública. v. 11. n² 2. Campinas, 2005. Disponível em: < http://www.scielo.br/scielo.php?script=sci_arttext\&pid=S0104-62762005000200002 > Acceso en 16.12.2011.

${ }^{390}$ PINTO-DUSCHINSKY, M. Op. Cit. Pp. 70-72.
} 
ambiguas en las que no hay consenso sobre el reproche de dicha conducta, pero donde tampoco hay un rechazo abierto; y la corrupción blanca, que está libre de reproche por la sociedad. Es lo que se tiene que tener en mente al analizar la corrupción dentro de la financiación de los partidos. ${ }^{391}$

\subsubsection{Los incentivos de los partidos en la práctica de actos de corrupción a partir del sistema de financiación}

Cuando las instituciones democráticas funcionan de la manera debida, la corrupción tiende a disminuir, y la afirmación inversa también es verdadera, o sea, cuando las instituciones no cumplen adecuadamente su finalidad, la corrupción encuentra su campo de actuación. Se trata de una correlación que no puede ser ignorada. Junto con esto, no es posible analizar la corrupción política sin pensar en la relación que los partidos políticos mantienen con los grupos de presión. ${ }^{392} \mathrm{Si}$ los partidos son corruptos, los grupos de presión estarán presentes.

Las reglas de financiación de los partidos son comúnmente violadas en países de democracia desarrollada. Es algo sistemático. En otros países que tienen reglas dirigidas a actores específicos, no hubo una violación de reglas específicas, sino mayormente de principios constitucionales relacionados con el proceso democrático, como la igualdad de oportunidades, la transparencia de las actividades gubernamentales, y otros. ${ }^{393} \mathrm{Sin}$ embargo, la financiación corrupta puede que no sea ilegal - como se ha dicho anteriormente - aunque lo normal es que sea en todo caso en fraude de ley. Con todo, esto no descarta la idea de que la financiación sea legal, pero corrupta, porque atenta en contra de la naturaleza y de los fines de la política. ${ }^{394}$

391 Cfr. HEIDENHEIMER, A. J. "Perspectives on the Perception of Corruption". In: HEIDENHEIMER, A. J.; JOHNSTON, M. (eds.): Political Corruption - Concepts \& Contexts. 3o ed. ed. Transaction. New Jersey, 2002. Pp. 152; MALEM SEÑA, J. F.: La Corrupción... Pp. 37; y VILLORIA MENDIETA, M.: Op. Cit. Pp. 41 y ss.

${ }^{392}$ Cfr. SCOTT, J. C. "Corruption, Machine Politics and Political Change". In: HEIDENHEIMER, A. J. (ed.): Political Corruption - Readings in Comparative Analysis. ed. Transaction, New Jersey, 1978. Pp. 549.

${ }_{393}$ SMILOV, D. Op. Cit. Pp. 327.

${ }^{394}$ VILLORIA MENDIETA, M.: Op. Cit. Pp. 197. Como ejemplo se podría citar a la financiación de partidos proveniente de narcotraficantes, lamentablemente tan común en Latinoamérica. 
Los escándalos políticos de corrupción están frecuentemente asociados a la financiación de los partidos y las campañas. Las elecciones tienen que financiarse y son muchos los que tienen interés en financiarlas, como también hay interesados en los resultados de dicho proceso, siendo este resultado vulnerable en este punto. Una de las razones que pueden citarse para la proliferación de casos de corrupción es justamente la globalización de la economía y la centralización ideológica de la política. ${ }^{395}$ Con la centralización de las ideologías, la función del marketing político ha aumentado exponencialmente, haciendo que sea un elemento determinante para lograr votos. ${ }^{396} \mathrm{Si}$ a ello se acompaña un sistema que tenga reglas muy estrictas con respecto a las contribuciones privadas para las campañas electorales puede simplemente motivar pagos ilegales, los cuales a la vez son mantenidos en secreto frente a los votantes y los controladores. A la vez, los votantes no tienen como actuar si no saben cómo actúan sus representantes y quien les ha dado recursos económicos. ${ }^{397}$

La financiación legal también ejerce un efecto corruptor en las campañas, porque los donantes esperan ser favorecidos en el proceso legislativo, y aunque el sistema electoral pueda combatir este tipo de influencia ${ }^{398}$ y el votante pueda castigar a los involucrados (no votando por ellos), los votantes no pueden actuar sin saber quiénes son. ${ }^{399}$

Para que una financiación pueda ser considerada como corrupta, se deben de tener presentes tres supuestos. El primero es el de la financiación de captura, sea esta legal o ilegal, de puestos relevantes, políticas públicas o decisiones del gobierno. Sería como un pago anticipado por providencias que beneficiarían a los contribuyentes/financiadores del partido, también caracterizado por un acuerdo voluntario. El segundo es el de la financiación ventajista, realizada a través de lagunas legales para obtener ventaja en la competición electoral. Basta con la ventaja, no es necesaria la captura antes

\footnotetext{
${ }^{395}$ Describiendo las fases que acompañan la centralización de la política y la organización de la corrupción en la búsqueda del electorado, véase SCOTT, J. C. Op. Cit. Pp. 558-559.

${ }^{396}$ VILLORIA MENDIETA, M.: Op. Cit. Pp. 205.

${ }^{397}$ ROSE-ACKERMAN, S. "Political Corruption...." Pp. 47-48.

${ }^{398}$ En este sentido, cfr. DELLA PORTA, D.; VANNUCCI, A.: Corrupt Exchanges. ed. Aldine de Gruyter, NY, 1999. Pp. 119.

${ }^{399}$ ROSE-ACKERMAN, S.: La Corrupción... Pp. 183-184
} 
citada. Y la tercera es la financiación coercitiva, la más grave, que es hecha a través de extorsión y/o amenaza. ${ }^{400}$

Así, los intereses de los donantes poderosos alcanzan protagonismo sólo en aquellos sistemas políticos que predisponen a la consecución de beneficios a través de políticas públicas. ${ }^{401}$ Como ejemplo, se podría pensar que es mejor que los representantes sean responsables ante circunscripciones pequeñas, porque los votantes podrán controlar y conocer sus acciones, o que quizás, a la inversa sea mejor, que los representantes tengan un papel secundario ante partidos nacionales con amplias agendas y que los candidatos no tengan el compromiso con grupos particulares o con votantes. El riesgo del primer escenario es que se gobierne con la vista puesta en grupos específicos, ignorando asuntos públicos generales. Ya en la segunda situación, los partidos "nacionales" también pueden comportarse de innumerables maneras, volviéndose corruptos 0 , por lo menos, manteniendo a los donantes enriquecidos. ${ }^{402}$

Los partidos de perfil nacional en el gobierno no significan una protección en contra de la corrupción en la financiación de campañas (pensando más específicamente sobre las donaciones). Pueden incluso facilitar la práctica permitiendo políticas para organizar una especie de "extorsión de regalos". ${ }^{403}$ Son necesarios límites estrictos, pero serán efectivos sólo si el sistema no es muy competitivo y los votantes no están escasamente informados. Sin un límite de gastos, los políticos tienen mucha libertad de acción para favorecer a los grandes donantes. Se debe intentar evitar la imposición de restricciones que por sí solas conduzcan a la ilegalidad. Los límites en las donaciones se justifican como un camino para bloquear influencias perniciosas. ${ }^{404}$ Sin embargo, unos límites muy estrictos pueden provocar transferencias ilegales y no registradas. ${ }^{405}$

\footnotetext{
${ }^{400}$ VILLORIA MENDIETA, M.: Op. Cit. Pp. 199-200.

${ }^{401}$ En este sentido, cfr. DELLA PORTA, D.; VANNUCCI, A.: Op. Cit. Pp. 112-113.

${ }^{402}$ ROSE-ACKERMAN, S. "Political Corruption..." Pp. 48-49.

${ }^{403}$ Cfr. SCOTT, J. C. Op. Cit. Pp. 552.

404 Aunque se debe reconocer que, en teoría, las empresas también tienen derecho a manifestar sus preferencias y apoyarlas económicamente, independientemente si dicho derecho es limitado o no. (In: ARGANDOÑA, A. Op. Cit. Pp. 13).

${ }^{405}$ ROSE-ACKERMAN, S. "Political Corruption..." Pp. 50-51.
} 
Además, los costes de campaña podrían reducirse con la reducción del tiempo de las mismas, pero la eficacia de la medida depende de otros factores. En sistemas parlamentarios, la fecha de las próximas elecciones es incierta, se puede disminuir dicho tiempo, pero la clave es la dificultad de hacer valer esto en la práctica. ${ }^{406}$ Junto a ello, una fuerte publicidad puede permitir a los ciudadanos no solo votar en contra de las candidaturas que reciban mayores recursos con carácter interesado, sino que también puede hacer posible que se sepa cuáles son los "regalos" o comportamientos que son cercanos y dañosos. ${ }^{407}$

Y este es el punto clave: la financiación corrupta prevalece por la falta o ineficacia de los mecanismos de control, tanto como por la opacidad y el ocultamiento de datos. Sin embargo, no es suficiente con que exista un sistema de control. Con el desarrollo de conceptos como el de accountability, la transparencia debe contar con un sistema simplificado y de fácil divulgación, porque introducir herramientas que acaban por dificultar el acceso a los datos por parte del público es algo muy poco eficaz de cara a los objetivos que se persiguen. ${ }^{408}$ De hecho, es perceptible que la mayoría de los países de democracia occidental cuentan con mecanismos de control, generalmente fruto de reformas legislativas poco reflexivas sobre cómo realizar dicho control. Puede mantenerse que hay demasiadas leyes para tan poco control. ${ }^{409}$

Por ello, el reto principal de los sistemas democráticos es justamente conciliar la necesidad de financiación sin que ello facilite la venta de políticas a los donantes. La financiación de los partidos es una pieza fundamental para determinar la dirección de su conducta. Dicha decisión puede influir en el resultado de las urnas, y no es igual si dichas fuerzas políticas reciben periódicamente una cantidad considerable de contribuciones de pequeño valor

\footnotetext{
${ }^{406}$ Igual se debe pensar que en las campañas electorales de corta duración hay una asimetría entre los candidatos "oficialistas" o que eligen intentar la reelección, y aquellos de la oposición, porque estos últimos suelen ser menos reconocidos habiendo una diferencia entre su nombre y su imagen, ya que su aparición al público a través de los medios puede ser que sea menor. Esto acorta aún más el tiempo de que los electores lo conozcan, lo que genera a la vez más "tentación" de recurrir a recursos irregulares para financiar una campaña más agresiva en determinados sistemas no europeos del Estado de partidos. (In: MALEM SEÑA, J. F.: La Corrupción... Pp. 132).

${ }^{407}$ ROSE-ACKERMAN, S. "Political Corruption..." Pp. 51-52.

408 VILLORIA MENDIETA, M.: Op. Cit. Pp. 238-239.

${ }^{409}$ PINTO-DUSCHINSKY, M. Op. Cit. Pp. 80-81.
} 
o si reciben pocas donaciones, pero de elevado valor. ${ }^{410}$ Estos aspectos deben ser detenidamente evaluados en el momento de la elaboración de las reglas sobre la financiación de los partidos. ${ }^{411}$

En este sentido, se hace referencia a la necesidad de transparencia, ya que dicha influencia que es pretendida por los donantes privados refleja bien la idea de que el dinero es un elemento determinante para el éxito electoral de un político. ${ }^{412}$ Es innegable que la trayectoria histórica de España ha influido en el desarrollo de su sistema de financiación de los partidos. ${ }^{413}$ La práctica desaparición de los partidos debido a la larga dictadura, que a la vez causó la baja afiliación tras su vuelta a la legalidad y el poco enraizamiento de los mismos en la sociedad tras la democracia, junto con una cierta cultura antipartidista que hasta hoy aparece en el comportamiento político español fueron, sin duda, factores determinantes en la elección de algunas de las medidas que caracterizan la legislación actual. ${ }^{414}$ No obstante no pueden ignorarse algunas de las consecuencias de una regulación poco atenta a este fenómeno. Basta una breve comparación con otros sistemas para concluir que el modelo de financiación vigente no solo continúa manteniendo las puertas abiertas a la corrupción, sino que ha terminado por institucionalizar las desigualdades de un sistema de partidos que por sí solo ya era desigual a través de la no regulación de puntos inseparables a la financiación de las fuerzas políticas. ${ }^{415}$

Parece claro que el régimen normativo sobre este tema contiene lagunas importantes que permite a los partidos la obtención y también el desvío de

\footnotetext{
${ }^{410}$ WEBER, M.: Economía y Sociedad I: Teoría de la Organización Social. Ed. Fondo de Cultura Económica, Derechos Fundamentales, México, 1944. Pp. 301.

${ }^{411}$ Para WARE, en un sistema ideal, se debería atender simultáneamente a tres aspectos. El primero se refiere a proveer a los partidos de los recursos suficientes para que establecieran conexiones con los votantes. Además, se debe hacer que la recaudación de recursos no sea la principal actividad de dichas organizaciones, dándoles al mismo tiempo un cierto grado de autonomía en relación a los grupos de intereses. Enfocando dichos objetivos, el autor sugiere que hayan informes públicos de las contribuciones para los partidos políticos y candidatos y sus gastos, juntamente con la prohibición de contribuciones de determinadas fuentes, adquisición de algunos servicios y la limitación de algunos tipos de gastos, completando con medidas de financiación pública. (In: WARE, A. "Conclusions. Op. Cit." Pp. 234-235).

${ }^{412}$ ROSE-ACKERMAN, S.: La Corrupción... Pp. 183-184

${ }^{413}$ Cfr. PRADERA, J. "La Maquinaria de la Democracia. Los Partidos en el Sistema Político Español”. In: J. LAPORTA, F.; ÁLVAREZ, S. (eds.): La Corrupción Política. ed. Alianza, Madrid, 1997. Pp. 162.

${ }^{414}$ BLANCO VALDÉS, R. L.: Las Conexiones... Pp. 74-75.

${ }^{415}$ Cfr. MONTERO GISBERT, J. R. "La Financiación de los..." Pp. 389.
} 
recursos públicos para fines a veces poco éticos. Además, el desequilibrio entre ingresos y gastos a nivel local también colabora en la proliferación de conductas corruptas. ${ }^{416}$ Es evidente que un sistema de financiación será insuficiente si el régimen de transparencia y control es deficiente. Esto permite a los partidos que no sólo no rindan sus cuentas, sino también que amplíen su base de captación de recursos privados, como puede pasar con las fundaciones y asociaciones vinculadas a las organizaciones partidistas. ${ }^{417}$ Éstas suelen captar grandes cantidades de recursos, sin que hasta hace muy poco existía un efectivo control jurídico sobre estas fuentes. Otro ejemplo lo constituyeron los acuerdos para la condonación de deudas establecidos por los partidos con entidades financieras. No se sabe cómo se producen, ni tampoco los términos en que se produce la condonación de dichas deudas. Sin embargo, son bastante comunes en la deficiente rendición de cuentas que hacen los partidos frente al Tribunal de Cuentas. Todo ello se complementa con la ausencia de sanciones para muchas violaciones de las reglas de financiación. ${ }^{418}$ Quizás sea esta la mayor motivación que los partidos tienen para seguir con este tipo de comportamiento que no hace nada más que deteriorar la democracia como un todo.

Al tratar sobre la financiación de los partidos (tanto la electoral como la ordinaria), el legislador español logró efectos totalmente diversos, ya que había un sistema peculiar que contaba con una financiación pública demasiado generosa, a partir de una normativa muy restrictiva respecto a la financiación privada. Y, aunque fuera generosísima, la financiación pública no fue capaz de hacer frente a todos los crecientes gastos de los partidos, pero en cambio ha convertido a los partidos en muy dependientes de las subvenciones estatales. Consecuentemente, ante unos ingresos insuficientes y unos gastos incontrolables, los partidos, como en otros países de Europa, acabaron por recurrir a fuentes irregulares de financiación privada y provocaron (todavía provocan) los grandes escándalos de dicha naturaleza. ${ }^{419}$ Así, resulta lógico

\footnotetext{
${ }^{416}$ En este sentido, bajo un panorama general, cfr. DELLA PORTA, D.; VANNUCCI, A.: Op. Cit. Pp. 117 y ss.

${ }^{415}$ MALEM SEÑA, J. F.: La Corrupción... Pp. 106-107.

${ }^{418}$ AA.VV. "Encuesta: Corrupción Política. Op. Cit." Pp. 25-37.

419 Cfr. PRADERA, J. "La Maquinaria..." Pp. 165; y DELLA PORTA, Donatella; VANNUCCI, Alberto: Corrupt Exchanges. ed. Aldine de Gruyter, NY, 1999. Pp. 120-121.
} 
que la opinión pública muestre claros síntomas, al menos como tal opinión, de desconfianza en los partidos y su actuación en estos temas. ${ }^{420}$ Además de que la financiación pública se ha vuelto aditiva (porque acabó por sumarse a la ilegal) y no sustitutiva, como era lo esperado, se causó un problema mucho mayor: el alejamiento de los partidos de la sociedad, junto con su dependencia de los recursos del Estado. ${ }^{421}$

La financiación pública permite exigir la publicidad de los gastos e ingresos de los partidos, concentrando el principio de la transparencia. ${ }^{422} \mathrm{Sin}$ embargo, en España acabó por ser al revés, justamente por las lagunas legales existentes, como también por la deficiente previsión del régimen de control. Así que, ante ello, se puede indicar que la mayor motivación de los partidos para practicar conductas corruptas es la falta de transparencia, la no publicidad de los datos internos de sus finanzas, y la correspondiente ausencia de sanciones, tanto para la aceptación de financiación privada irregular, como para el propio desvío de recursos públicos. ${ }^{423}$ Lo que se debe considerar también es que el sistema de sanciones penales es la última pieza de una larga cadena, porque si la verificación, comprobación y enjuiciamiento de las irregularidades no son eficaces, las penas resultaron igualmente ineficaces. Hay un gran desequilibrio entre la cifra de supuestos delitos que son investigados y las conductas que terminan siendo sancionados penalmente, y esto también es peligroso para la estabilidad del sistema. ${ }^{424}$

\footnotetext{
${ }^{420}$ Cfr. BLANCO VALDÉS, Roberto L. "Veinte Años de Partidos: de la Constitucionalización a la Contestación". In: TRUJILLO, G.; et al (dir.): La Experiencia Constitucional (1978-2000). Ed. CEPC, Madrid, 2000. Pp. 115.

${ }^{421}$ Cfr. HOLGADO GONZÁLEZ, M.: La Financiación de los... Pp. 147.

${ }^{422}$ MALEM SEÑA, J. F. "El Fenómeno de..." Pp. 99.

${ }^{423}$ Ejemplo de escándalos que marcaron la historia de la corrupción política en la financiación de los partidos en España se pueden citar el caso Filesa (el más notorio, involucrando al PSOE); el caso Naseiro, Sóller y más recientemente el caso Gürtel (involucrando el PP); y el Tragaperras (involucrando el PNV).

${ }^{424}$ Por esto estamos de acuerdo con MALEM SEÑA, J. F.: La Corrupción... Pp. 108. Además, según PRADERA, PSOE, PP, CDC y el PNV no han asumido sus responsabilidades políticas, administrativas y penales cuando han sido flagrados en situaciones de financiación ilegal. Al revés, han puesto en marcha estrategias para la obstrucción procesal y de desprestigio moral de los jueces involucrados. (In: PRADERA, J. “La Maquinaria...” Pp. 174).
} 


\subsection{Predominio de la financiación pública y cambios en la dinámica partidista - ¿partidos cartel?}

La teoría de los partidos cartel elaborada por KATZ y $\operatorname{MAIR}^{425}$ es una de las que hasta ahora generan mayores polémicas dentro de la financiación de partidos. No se trata solamente de constatar una eventual - casi cierta evolución de los partidos catch-all al modelo cartel, sino también de reconocer que los partidos ya no se encuentran en la misma medida separados del Estado como se encontraban anteriormente, o por lo menos como se deseaba que se encontrasen. ${ }^{426}$

Es una condición de la existencia de los partidos cartel la presencia de medidas de financiación pública de fuerte impacto. Sin embargo, no es correcto afirmar que la teoría de los partidos cartel es general y aplicable a todos los casos en que existen medidas de financiación pública. Esta consecuencia no es automática, pero sí es cierto que casos así son más comunes en países que tienen una transferencia considerable de recursos públicos para los partidos. ${ }^{427}$ Lo que es evidente es que la oligarquización de los partidos se ha originado en organizaciones estructuradas y con la garantía de la financiación pública. La burocratización de dichas asociaciones genera un coste creciente, que se refleja en su financiación ordinaria, también creciente. Pero dicho proceso se

\footnotetext{
${ }^{425}$ Cfr. KATZ, R. S.; MAIR, P. "Changing Models of Party Organization and Party Democracy: The Emergence of the Cartel Party". In: Party Politics. v. 1. no 1. Sage, London, 1995. Pp. 5-28. Versión en español: KATZ, R. S.; MAIR, P. "EI Partido Cartel". In: Las Transformaciones de los Modelos de Partidos y de la Democracia de Partidos - Zona Abierta, № 108/109, Madrid, 2004. Pp. 9-42.

${ }^{426}$ Se quiere subrayar aquí que existe una aproximación de los partidos y del Estado, a partir de la mayor dependencia que se tiene de los recursos públicos actualmente, haciendo que sus bases sociales se vuelvan frágiles, incluso debido al fuerte envolvimiento de dichos recursos. (In: POGUNTKE, T. "Ci Sono Prove Empiriche a Sostegno della Tesi del Cartel Party? Partiti e Società nell'Europa Occidentale". BARDI, L. (a cura di): Partiti e Sistemi di Partito: II Cartel Party e Oltre. ed. II Mulino, Milano, Bologna, 2006. Pp. 105).

${ }^{427}$ Esta aclaración es necesaria porque sí que hay casos en que se ha logrado evitar este resultado. No se puede generalizar y pensar que todos los sistemas que cuentan con medidas de financiación pública tendrán, automáticamente, un sistema de partidos cartel. En Alemania los partidos han resistido a este estándar de comportamiento y han buscado construir bases sociales sólidas, habiendo incluso casos de partidos nuevos que han tenido éxito electoral y que han crecido en el Parlamento. Debido a ello, se trata de una teoría muy controvertida y muy debatida en el plan empírico. Así, cfr. MELCHIONDA, E.: Op. Cit. Pp. 126-128; NASSMACHER, H.; NASSMACHER, K-H. "Major Impacts of Political Finance Regimes". In: NASSMACHER, K-H. (ed.): Foundations for Democracy - Approaches to Comparative Political Finance. ed. Nomos Verlagsgesellschaft, Baden-Baden, 2001. Pp. 191-192; CASAS-ZAMORA, K.: Op. Cit. Pp. 53; y POGUNTKE, T. Op. Cit. Pp. 120-121.
} 
produce al mismo tiempo que el declive de otros medios de financiación y la necesidad de la presencia del marketing en la política. Esto favorece o abre la posibilidad de la existencia del comportamiento cartel típico, dificultando el reparto de las subvenciones con otras opciones políticas distintas de las beneficiadas por el sistema. Además, los partidos que se benefician tampoco rinden cuentas y entran en acuerdos mutuos para protegerse. Los votantes, sin embargo, no tienen opciones de cambio, y algunas veces acaban desinteresándose por la política como un todo. ${ }^{428}$ Es decir que, con el surgimiento de los partidos catch-all, muchos de los problemas concernientes a los mismos afectaron al propio sistema de partidos como un todo. ${ }^{429}$

Debido al incremento constante de las subvenciones públicas para gastos ordinarios, los partidos beneficiados cuentan con más recursos (tanto materiales como humanos) para competir mejor en otras áreas, como en la precampaña. Ello los mantiene siempre a la vista del público y competir en ese tipo de gastos es mucho más difícil que competir en campañas electorales, ya que la implantación social de los partidos subvencionados también desempeña un papel importante en la formación de la identidad partidaria. ${ }^{430}$

No todas las implicaciones de la financiación pública de los partidos para la distribución de poder entre ellos son claras y, como es sabido, generan un fuerte debate. En teoría, las subvenciones han sido introducidas para proteger a los representantes de la presión de los grupos interesados en comprar influencia política y para aumentar la responsabilidad de los líderes de los partidos en relación a los votantes y simpatizantes. Con todo, en la práctica, la financiación pública parece haber contribuido a la concentración del poder en manos de los líderes partidistas nacionales, haciéndoles menos sensibles con relación a la necesidad de algún enraizamiento social y frente al electorado en general, como también ha favorecido esta nueva forma de organización partidista en cartel entre las élites. ${ }^{431}$ Ligado a todo ello, la democracia con los partidos organizados en cartel no es ya vista como una posibilidad de

\footnotetext{
${ }^{428}$ VILLORIA MENDIETA, M.: Op. Cit. Pp. 206.

${ }^{429}$ Cfr. KATZ, R. S. "Party Organizations and Finance". In: LE DUC, L.; G. NIEMI, R.; NORRIS, P. (ed.): Comparing Democracies: Elections and Voting un Global Perspective. Ed. Sage, London, 1996. Pp. 120.

${ }^{430}$ GARCíA VIÑUELA, E. "Financiación Pública de los..." Pp. 80.

${ }^{431}$ MULÉ, R. Op. Cit. Pp. 70.
} 
sucesivos cambios políticos y sociales, sino como un mecanismo para la estabilidad del sistema, siendo las elecciones una parte del mismo. ${ }^{432}$

Sin embargo, hay estudios que demuestran que la conexión entre los partidos organizados en cartel (o sea, reforzados por su oligarquización y que detentan una gran cantidad de recursos públicos transferidos desde el Estado) con los grupos de interés ha disminuido significativamente. Con los partidos catch-all, los grupos de interés tenían más espacio en la agenda política, como también más fuerza e influencia en las finanzas de estos. Ahora ya no se trata tanto de este aspecto, sino que existe una conexión debilitada, justamente por la necesidad actualmente no tan acentuada de dichas organizaciones partidistas de los recursos privados de estos grupos. Con todo, hay un debilitamiento de esta conexión, como ocurrió también con los canales de apoyo social de los partidos, pero no su extinción. ${ }^{433}$

No parece que el caso español se encuentre muy lejos de este modelo teórico ${ }^{434}$, y que haya logrado evitar los perniciosos efectos provocados por la adopción de los fuertes subsidios públicos en la política. Los partidos no supieron renunciar a algunos de los beneficios obtenidos en sucesivas regulaciones, y ahora les resulta difícil, cuando no imposible, adecuarse a las nuevas fórmulas que están siendo demandadas por la sociedad. El descrédito de los partidos parece claro y para cambiar la situación deberán sacrificar muchos de sus privilegios actuales para poder otra vez constituirse como piezas claves de la democracia, promoviendo el pluralismo político en lugar de sustituirlo, como se está produciendo de hecho. ${ }^{435}$ En los años 70 y 80 los

\footnotetext{
432 MAIR, P.: Party System Change: Approaches and Interpretations. Clarendon Press, Oxford, 1997. Pp. 115.

${ }^{433}$ ALLERN, E. H.; BALE, T. "Political Parties and Interest Groups: Disentangling Complex Relationship". In: Party Politics. v. 18. № 1. Sage, London, 2012. Pp. 16. No se puede entrar aquí en un análisis profundizado de las posibles razones del debilitamiento de dicha relación entre partidos y grupos de interés. Sin embargo, la falta de contacto con la sociedad civil como un todo y la nueva estructura oligarquizada de dichas organizaciones contribuye sobremanera a este efecto. Apoyando la tesis de que todavía existe una conexión razonable entre partidos y grupos de interés, independientemente de si se trata de partidos cartel o no, cfr. VERGE, T. "Party Strategies Towards Civil Society in New Democracies: The Spanish Case". In: Party Politics. v. 18. no 1. Sage, London, 2012. Pp. 46.

${ }^{434}$ Debido a las evidencias, estoy de acuerdo con la posición de VAN BIEZEN, al clasificar así el caso español. Así, cfr. VAN BIEZEN, I.: Political Parties in New... Pp. 198 y ss.

${ }^{435}$ HERRERO R. DE MIÑN, M. "Los Partidos como Estamentos Privilegiados: Ideas para su Reforma". In: La Democracia Constitucional. Estudios en Homenaje al Prof. Francisco Rubio Llorente. Ed. CEPC, Madrid, 2003. Pp. 216.
} 
partidos europeos y españoles estaban más preocupados por su consolidación en el sistema político a partir de la construcción de una estructura interna organizada que de controlar a sus gastos electorales. Sin embargo, su endeudamiento y los escándalos producidos por casos de financiación irregular solamente han servido para motivar cambios muy puntuales en la legislación, que al fin y al cabo terminaban favoreciéndolos, sin solucionar los antiguos problemas. $^{436}$

Lo más preocupante con relación a la financiación pública disponible por los partidos es que, al final los coloca permanentemente en una situación de sumisión ante el aparato estatal, que por otra parte controlan, sin que les ayude a desarrollar maneras de establecer conexiones con la sociedad, siendo las consecuencias lesivas al sistema democrático como un todo inevitables y ello, a la vez, acaba por favorecer en determinados supuestos a movimientos políticos antisistema y de dudosa lealtad democrática, lo que es muy peligroso. ${ }^{437}$ Así, la generosidad del modelo adoptado en torno a las subvenciones públicas y la escasa colaboración privada en la financiación de los partidos - no llegando ni siquiera al bajísimo límite establecido en ley determinan un sistema contradictorio con el que desarrolla la jurisprudencia constitucional sobre la naturaleza jurídica y las funciones de los partidos, como también distorsiona elementos centrales del buen funcionamiento de dichas organizaciones políticas, a partir del fomento de su burocratización central y el no incentivo a la búsqueda de sus bases sociales y además no les obliga a vigilar mejor sus finanzas, colaborando muchas veces a la realización de gastos sin fundamento y de tamaño desproporcionado. ${ }^{438}$

En contrapartida, hay estudios que apuntarían también a una cierta resistencia del vínculo entre los partidos españoles y los ciudadanos desde un punto de vista diacrónico. A través de algunas estrategias utilizadas por dichas organizaciones a fin de aumentar tanto el número de afiliados, como también

\footnotetext{
${ }^{436}$ ARTÉS CASELLES, J.; GARCÍA VIÑUELA, E. « La Economía Política de las Reformas de la Financiación Electoral”. In: Revista Española de Ciencia Política. № 15, octubre, 2006. Pp. 5961.

${ }^{437}$ Cfr. CASTILLO, P. del. "Objetivos para una Reforma de la Legislación sobre Financiación de los Partidos Políticos". In: La Financiación de los Partidos Políticos. Cuadernos y Debates, oㅡ 47, Centro de Estudios Constitucionales, Madrid, 1994. Pp. 53.

${ }^{438}$ Cfr. CASTILLO, P. del. "La Financiación de los Partidos Políticos en Europa..." Pp. 7 y CASTILLO, P del. "Objetivos para una..." Pp. 59.
} 
de simpatizantes, desde la transición política hasta los días de hoy, se percibiría que la conexión entre partidos y sociedad civil ha aumentado desde un nivel bajísimo posterior a la dictadura, a un 4,36\%, contrariando la tendencia de los demás países de nuevas democracias. Pero todavía se encuentra por debajo de la media europea, que se encuentra en claro declive, y que es del $4,7 \%{ }^{439}$ Igualmente se percibe que este crecimiento también ha permitido una compatible aproximación a los grupos de interés, los cuales a su vez también han contribuido en sus campañas. Es un tipo de estrategia típico de democracias que mantienen una financiación pública en los esquemas de España - es decir, generosa en recursos públicos - junto con un alejamiento considerable de la sociedad, y puede ser una conexión poco favorable para el sistema democrático español. ${ }^{440}$

La precoz adopción del sistema de fuerte financiación pública todavía vigente ha contribuido fuertemente al resultado que ahora se observa, pues precisamente en los momentos iniciales de la democracia en España, la implantación de dicho sistema fue una invitación a la no preparación de los partidos para los retos que llegarían. Además, el gran volumen de recursos estatales hace que los partidos dejen de ser en la práctica una "asociación privada" para ser una asociación semi-pública, prácticamente una parte del Estado. ${ }^{441}$ Si ello es así, en lugar de incentivar a los partidos a cumplir con sus funciones establecidas por la Constitución y a ser lo que el ordenamiento jurídico ha determinado que sean, los incentiva al comportamiento de un cartel, dejando en un segundo plano su papel en la democracia. ${ }^{442}$

\footnotetext{
${ }^{439}$ De hecho, España es el único país con nueva democracia que ha logrado aumentar el nivel de afiliación a los partidos por parte de ciudadanos. Pero todavía puede ser clasificado como bajo. Cfr. VAN BIEZEN, I.; MAIR, P.; POGUNTKE, T. "Going, Going, ... Gone? The Decline of Party Membership in Contemporary Europe". In: European Journal of Political Research. v. 1. no 1, UK, 2012. Pp. 27-36.

${ }^{440}$ VERGE, T. "Party Strategies..." Pp. 55-56. Además, como complementa KATZ y MAIR, ningún partido puede ser totalmente independiente de los grupos de interés, porque no hay como haber partidos tan bien sostenidos económicamente como para eso. (In: KATZ, R. S.; MAIR, P. "Parties, Interest Groups and Cartels: A Comment". In: Party Politics. v. 18. ํo 1. Sage, London, 2012. Pp. 109).

${ }_{441}$ Cfr. VAN BIEZEN, I. "Political Parties as Public Utilities". In: Party Politics. v. 10. no 6. Sage, London, 2004. Pp. 711-712 y; FERREIRA RUBIO, D. Op. Cit. Pp. 10.

${ }^{442}$ Cfr. VAN BIEZEN, Ingrid. Party Finance in New Democracies: Spain and Portugal. In: Party Politics. v. 6. no 3. Sage, London, 2000. Pp. 337.
} 


\section{CAPÍTULO III}

\section{EL SISTEMA DE FINANCIACIÓN DE PARTIDOS POLÍTICOS EN ESPAÑA}

Realizadas las anteriores reflexiones sobre los modelos de financiación de partidos políticos existentes, se puede analizar con más claridad el modelo adoptado en España. ${ }^{1}$ Antes de nada, cabe resaltar que España posee una trayectoria un tanto peculiar, desde el punto de vista histórico, en lo referente a la elaboración de la legislación sobre la materia. Hay que tener en cuenta que, en la evolución de los partidos en Europa, éstos cada vez fueron aproximándose más al Estado como aparato. ${ }^{2}$ Dicha transformación no siguió en España las mismas etapas que en los demás países de democracia occidental, es decir, los partidos modernos en España, surgidos jurídicamente en la transición, a fines de los 70 , nacieron ya a la fase que podría incluirse dentro del modelo de "Estado de partidos" ${ }^{3}$

Parece claro que no se produjo un largo desarrollo de un sistema de partidos fuertemente enraizados en la sociedad en el caso de España, y que, como se verá a continuación, la separación de la ley de partidos y la ley del régimen electoral y de financiación, junto con el presupuesto anual y el carácter del régimen descentralizado, determinaron en parte el escenario de la política española. ${ }^{4}$ El sistema adoptado en España contiene un modelo de financiación

\footnotetext{
${ }^{1}$ Se pueden encontrar breves notas sobre el sistema de financiación de partidos español hasta 1995 en SOLER, M. "La Disciplina del Finanziamento del Partiti Politici in Spagna". In: Regione e Governo Locale: Bimestrale di Studi Giuridici e Politici della Regione Emilia-Romagna, anno XVI, no 7, ed. Maggioli, Rimini, 1995. Pp. 1251-1265, que apunta de manera sucinta los problemas que a continuación serán expuestos.

${ }^{2}$ Se quiere subrayar que el caso español de financiación de partidos es contrario a la tendencia de las democracias occidentales en fortalecerlos dentro o sobre el Estado, pues parece que es el Estado el que se fortalece sobre los partidos, justamente por la dependencia de estos de los recursos públicos, como también por la falta de otros canales para conseguir dichos fondos. Otro dato interesante es que los costes de las campañas electorales no han aumentado tanto como los gastos ordinarios, lo que también refleja la actual estructura partidista. (In: VAN BIEZEN, I. "Party Finance in New Democracies: Spain and Portugal". In: Party Politics. v. 6. no 3. Sage, London, 2000. Pp. 336-337).

3 VAN BIEZEN, I.; KOPECKY, P. "The State and the Parties - Public Funding, Public Regulation and Rent-Seeking in Contemporary Democracies". In: Party Politics. v. 13. № 2. Sage, London, 2007. Pp. 237.

4 NASSMACHER, K-H. "Party Funding in Continental Western Europe". In: AUSTIN, R.; TJERNSTRÖM, M. (eds.): Funding of Political Parties and Election Campaigns. International IDEA, Stockholm, 2003. Pp. 117.
} 
fuertemente público, con la particularidad de que las fuentes económicas venidas directamente de las bases (grass-roots) son casi inexistentes. ${ }^{5}$

En el sistema democrático español se produjo un proceso de creciente estatalización en la financiación de los partidos políticos debido a las ayudas públicas que fueron ampliándose, hasta ser la primera y casi única fuente de financiación de los "grupos mayoritarios". A partir de ello, las subvenciones públicas desempeñan un papel de mayor importancia en España que en otros países por diversas razones como la juventud de su democracia ${ }^{6}$ y la debilidad de los partidos en su organización, junto con la imposibilidad de organizarse como partidos de masas en el corto plazo. ${ }^{7}$ Dentro de este panorama, también se deben considerar los efectos a largo plazo del modelo de financiación de los partidos, ya que las críticas responden principalmente a los efectos que tuvieron sobre la calidad de la democracia, al fomento de una excesiva concentración de poder en manos de partidos oligarquizados, y también al ineficiente régimen de control de dicha financiación. ${ }^{8}$

Cabe constatar también como las vicisitudes de la historia española influyeron firmemente en el modelo de financiación aún vigente. ${ }^{9}$ Sin embargo,

\footnotetext{
${ }^{5}$ NASSMACHER, K-H. "Party Funding..." Pp. 119. Como se abordará en el punto siguiente, las razones históricas son muy importantes para entender la motivación real de la elaboración de dicho modelo de financiación. Antonio BAR, por ejemplo, comenta que el sistema de partidos de España tuvo problemas para consolidarse por la historia reciente de la mayor parte de los partidos en España; la falta de consolidación en la estructura de los partidos y de su ubicación ideológica; por métodos operacionales sobrepasados en la relación entre los partidos; por el miedo o desconfianza en los partidos por parte de la sociedad; por las dificultades en establecer relaciones duraderas entre los partidos; también la relevancia mayor de otros elementos que los partidos en la transición democrática; y finalmente por la existencia de sistemas de partidos regionales. (In: BAR, A. "The Emerging Spanish Party System: Is there a Model?" In: BARTOLINI, S.; MAIR, P. (ed.): Party Politics in Contemporary Western Europe. Ed. Frank Cass, Great Britain, 1984. Pp. 131-134).

${ }^{6}$ Hay que considerar que en 2010 la democracia en España ha completado poco más de 30 años, frente a 40 de la dictadura. Lógicamente que ello no impide que España cuente con una democracia consolidada, pero en mi opinión todavía puede ser considerada como una democracia relativamente joven.

7 CASTILLO, P. del. "La Financiación de los Partidos Políticos ante la Opinión Pública". In: Revista de Derecho Político. oㅜ 31. UNED, Madrid, 1990. Pp. 125-126. La autora, para complementar, afirma que en la época no había limitaciones a las cantidades de recursos para transferir a los partidos desde los presupuestos generales del Estado, permitiendo un aumento de dichos valores como realmente pasó. Sin embargo, no parece esta la causa de que las fuentes privadas de financiación fueran escasas.

${ }^{8}$ GILLESPIE, R. "Party Funding in a New Democracy: Spain". In: BURNELL, P., WARE, A. (eds.): Funding Democratization, Manchester University Press, UK, 1998. Pp. 73.

9 Por todos, BLANCO VALDÉS destaca que los países europeos sufrieron las crisis estructurales de partidos, pero que en España además de esto, dichas organizaciones eran aún más débiles debido a su herencia histórica, es decir, el hecho de que los partidos
} 
aunque la doctrina afirme que el sistema responde a un modelo mixto de financiación ${ }^{10}$ - y que los modelos mixtos pueden tener aún más variantes -, se analizará como la inclinación de dicho sistema hacia las vertientes públicas es bastante evidente. ${ }^{11}$

Dadas las diversas matizaciones que la regulación de la materia ha tenido, como primer paso parece conveniente exponer la evolución histórica del modelo de financiación de partidos adoptado en España, para poder comprender mejor la situación actual. ${ }^{12}$

españoles sufrieron con una larga dictadura, la falta de capacidad de la derecha en articularse dentro del régimen, la persecución que los partidos políticos de izquierda sufrieron en ese período, acompañada con la crisis en las afiliaciones, que ya eran bajas, se alcanzó el menor nivel de toda Europa. Por ello, los partidos en España son aún más dependientes de las subvenciones estatales. (In: BLANCO VALDÉS, R. L. "Consideraciones sobre la Necesaria Reforma del Sistema Español de Financiación de los Partidos Políticos". In: La Financiación de los Partidos Políticos. Cuadernos y Debates, no 47, Centro de Estudios Constitucionales, Madrid, 1994. Pp. 41; BLANCO VALDÉS, R. L. "La Problemática de la Financiación de los Partidos Políticos en España: Regulación Jurídica y Propuestas de Reforma”. In: Revista de Estudios Políticos, no 87, ene/mar, ed. Centro de Estudios Constitucionales, 1995. Pp. 189 y ss). También, cfr. CORTÉs BURETA, P.: Recursos Públicos y Partidos Políticos: Balances y Perspectivas de Reforma. Centro de Estudios Políticos y Constitucionales, Madrid, 2003. Pp. 56-57, en una narrativa de la situación de los partidos durante la dictadura.

${ }^{10}$ Vid. SOLER SÁNCHEZ (In: SOLER SÁNCHEZ, M. "La Campaña Electoral en España". In: RUIZ-RICO, G.; GAMBINO, S. (coord.): Formas de Gobierno y Sistemas Electorales (la Experiencia Italiana y Española). Ed. Tirant lo Blanch, Valencia, 1997. Pp. 234) y HOLGADO GONZÁLEZ (In: HOLGADO GONZÁLEZ, M.: La Financiación de los Partidos Políticos en España. Tirant lo Blanch, Valencia, 2003. Pp. 134).

${ }^{11}$ DEL CASTILLO entiende que, aunque el sistema sea mixto a través de subvenciones estatales a partir de la representación parlamentaria de cada partido, algunas con naturaleza de compensación por gastos en las diferentes elecciones y otras por las actividades ordinarias de los partidos, y considerando la existencia de la cuota de afiliados, donaciones privadas limitadas, etc., la legislación española es la única que penaliza las donaciones privadas de la manera como lo hace, con limitaciones rígidas tanto para elecciones como también para las actividades ordinarias. Además, la legislación española se centra en la financiación pública, llevando a la conclusión de que los partidos son, de hecho, casi exclusivamente financiados por el Estado, diferenciándose de los otros ordenamientos europeos y, a su vez, entrando en contradicción con el tratamiento de los partidos dado por el ordenamiento español. (In: CASTILLO, P. del. "Financiación de los Partidos Políticos: La Reforma Necesaria". In: GONZÁlEZ ENCINAR, J. J. (coord.): Derecho de Partidos. Espasa-Calpe, Madrid, 1992. Pp. 155-158).

${ }^{12}$ Sobre el tema, vid. MARTíNEZ SOSPEDRA, M. "La Financiación de los Partidos Políticos. Ensayo de Aproximación". In: Cuadernos Constitucionales de la Cátedra Fadrique Furió Ceriol, no 11/12, Valencia, 2o época, 1995. Pp. 25. Aunque de fácil comprensión, se optó por no utilizarlo aquí por contener puntos que no se aplican al modelo español. 


\section{1) El desarrollo histórico del modelo español y las razones de su adopción}

Del mismo modo que en los demás países de democracia occidental, la historia de la legislación sobre la financiación de los partidos en España se inicia conjuntamente con el reconocimiento legal de los mismos en 1977, año de las primeras elecciones democráticas, coincidiendo también con el año de la primera norma legal general sobre los partidos y las elecciones en general, previendo una escueta regulación para el tema de la financiación.

Antes del reconocimiento legal de los partidos en la historia española del régimen liberal, difícilmente podría haber una norma que versara sobre financiación de los mismos, pero ya había un régimen electoral que se basaba en candidatos individuales e independientes, sin siglas y financiados con su fortuna personal, lo que favorecía a los más privilegiados económicamente hablando, aunque debido a las restricciones del derecho de sufragio existentes, la campaña electoral no tenía el mismo carácter masivo que actualmente. A partir de las elecciones surgían los grupos parlamentarios, que formaban a la vez los comités electorales para la organización de los nuevos votantes, creando de este modo un círculo ininterrumpido. En último término, la principal preocupación era instaurar comités electorales en circunscripciones donde todavía no estuvieran presentes. ${ }^{13}$

Las primeras normas que versan sobre la financiación de los partidos son de la II República, y se presentan a través de órdenes ministeriales referentes a las campañas electorales y a los medios de comunicación, pero no en relación directa con la financiación propiamente dicha. La orden ministerial de 7 de noviembre de 1933 trataba sobre la prohibición en periodo electoral de anuncios de candidaturas, campañas, manifiestos y discursos políticos en emisoras de radio (o sea, propaganda política). Acabó por hacerse extensiva a otros medios de comunicación de la época. La orden ministerial del 9 de febrero de 1934 versó sobre la prohibición de la emisión por radio de propaganda con finalidad política. Posteriormente se produjo la promulgación de la ley de radiodifusión, el 26 de junio de 1934. Todas estas normas se basan

\footnotetext{
${ }^{13}$ CORTÉS BURETA, P. Los Recursos Económicos de los Partidos Políticos... Pp. 109-111.
} 
en la neutralidad ideológica de las emisoras de radio, mencionando lo que se denominó en la época "entidades políticas", esto es, indirectamente los partidos, pero todavía sin la forma que tendrían en un momento posterior. Sin embargo, no se planteaba la idea de referirse directamente al asunto de su financiación. ${ }^{14}$

En el periodo posterior, la guerra civil y la dictadura de Franco, responsable de instaurar un régimen que prohibió totalmente los partidos políticos en 1937, formando un sistema de partido único, dejaron una serie de secuelas visible hasta hoy en la cuestión de la financiación que no se produjeron en otros países, como el impacto negativo de la cultura franquista sobre el comportamiento político de la sociedad, o la baja afiliación ${ }^{15}$, desmovilización, apatía y sentimiento de antipartidismo, causando resultados directos sobre una posible autofinanciación de los partidos. ${ }^{16}$ A partir de ello, se observa que los partidos españoles, después de un largo período prohibidos por el régimen franquista, no lograron constituirse como partidos de masas en su formato clásico, como sucedió en un primer momento en otros países de democracia occidental. Esta fase de los partidos fue significativamente obviada al pasar directamente al formato catch all, lo que hizo que las organizaciones

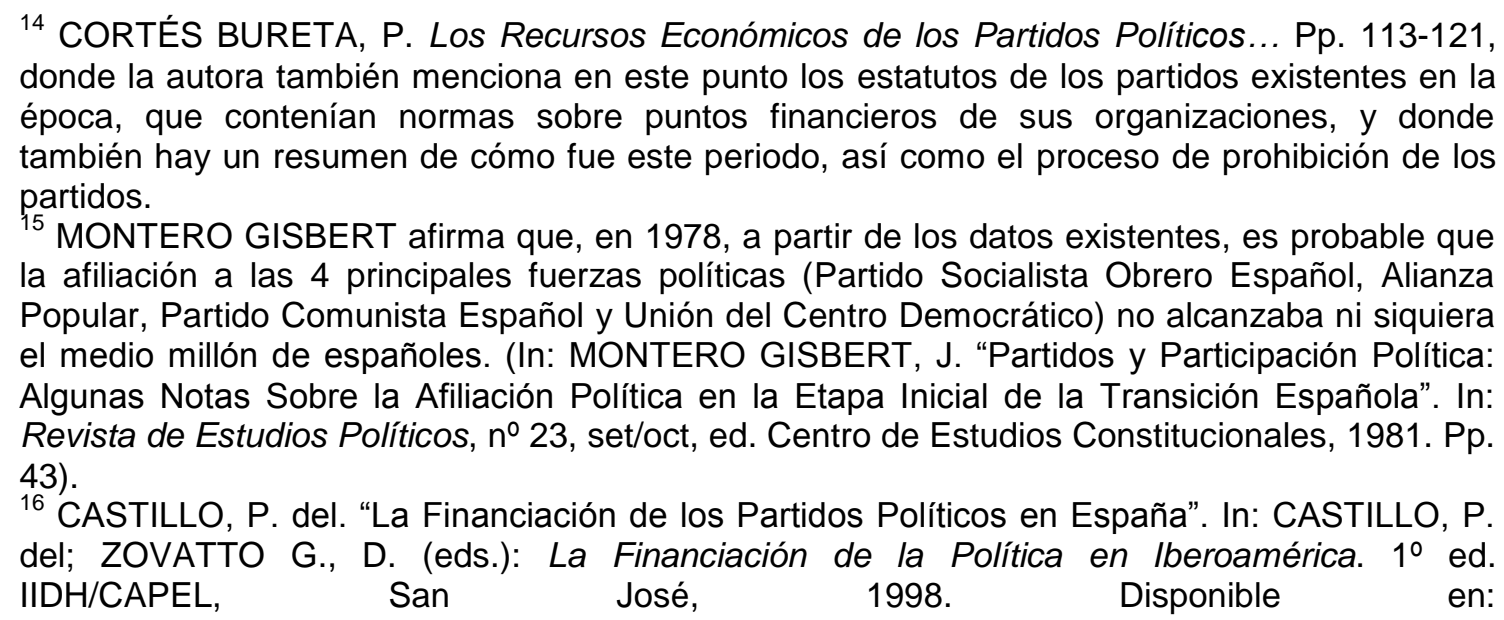
<<http://www.iidh.ed.cr/comunidades/redelectoral/docs/red_publinea/indice-financiacion.htm>> Acceso en 17 de junio de 2009. En el mismo sentido, cfr. MARÍN LEIVA, F. "Financiamiento y Fiscalización de los Recursos de los Partidos Políticos en España". In. AA.VV.: Administración y Financiamiento de las Elecciones en el Umbral del Siglo XXI - Memoria del III Congreso Internacional de Derecho Electoral - Tomo II. Derechos Fundamentales, México, 1999. Pp. 555. 
no lograran conservar las características típicas de los partidos de masas, a lo que se le añade la desmovilización y la poca afiliación. ${ }^{17}$

Otras decisiones afectaron sobremanera a los partidos en el momento de la redemocratización de España, porque aunque el esquema 'transition by transaction' (término utilizado por GILLESPIE) permitió que el proceso de redemocratización fuera más tranquilo ${ }^{18}$, también determinó la toma de decisiones relevantes respecto al sistema de financiación de los partidos. Así, no se puede decir que se innovara especialmente respecto a los modelos de financiación, sino que se construyó un modelo en parte improvisado, que acabó por estar en vigor mucho más tiempo del previsto, y dicha improvisación, que se produjo justamente como respuesta a las demandas de las fuerzas políticas de la época, acabó por mantenerse porque al final atendía a las prioridades de los interesados, y también porque favorecía claramente a los partidos que obtuvieron un éxito electoral inmediato, lo que no suscitaba precisamente su posible interés por realizar cambios normativos. ${ }^{19}$

Paralelamente, el sistema electoral fue también diseñado para favorecer a los grandes partidos, es decir, la intención fue clara, simplificar el campo político que contaba con más de cien grupos que estaban en la competición, además de evitar la fragmentación del sistema, pues también se temía la ingobernabilidad de una España recién redemocratizada. Sin embargo, el sistema - diseñado con cierto carácter de provisionalidad en sus últimos detalles ${ }^{20}$ - acabó prolongándose, y como eran los partidos los que manejaban

\footnotetext{
${ }^{17}$ MONTERO GISBERT argumenta que, la época de la transición, con la conocida debilidad asociativa de los partidos españoles, juntamente con la acuciante necesidad de articular canales de participación ciudadana en la política, acabó por hacer de los partidos un camino único y excluyente de dichas demandas sociales. Además, después de la dictadura, los españoles estaban "huérfanos" de organizaciones políticas, lo que contribuyó a fomentar un comportamiento apático en relación a temas partidistas. (In: MONTERO GISBERT, J. "Partidos y Participación..." Pp. 33-37).

${ }^{18}$ GONZÁLEZ-AURIOLES indica que la transición en España de la dictadura a la democracia contó con partidos recién salidos de la clandestinidad, o retornados del exilio, o fundados hacia tan solo pocos meses. Y ello aumentó los problemas de los partidos, así como la escasez de recursos materiales y la afiliación limitada. (GONZÁLEZ-AURIOLES, J. A. "El Problema Público de Regular Jurídicamente la Financiación Partidaria". In: Teoría y Realidad Constitucional. oㅡ 6, 2 semestre. UNED, Madrid, 2000. Pp. 214).

${ }^{19}$ GILLESPIE, R. Op. Cit. Pp. 75.

${ }^{20}$ La idea de un sistema provisional fue abordada por BERNAT CEBOLLO, que, en el momento en el que se discutía sobre el futuro sistema de financiación de partidos políticos, declaró que el sistema provisionalmente podría conceder a los partidos una cantidad mínima de recursos en proporción al número de escaños, lo que respetaría a la vez los partidos nacionalistas y las
} 
el presupuesto a favor de sí mismos, permitiéndoles arreglar sus problemas económicos sin que el Estado tampoco tuviera sistemas de control efectivo. Todo ello motivó que existiera un alto nivel de consenso interpartidista para mantener el sistema hasta mitad de la década de los 80, y así la "reforma" reflejada en la LOREG, aprobada por unanimidad en el Congreso, terminaría reproduciendo en gran medida el sistema de $1978 .{ }^{21}$

Pilar DEL CASTILLO describe tres periodos en la evolución de la legislación. El primero, de 1977 a 1985, que se caracterizaría por la coexistencia tanto de la financiación pública como de la privada; el segundo, de 1985, año que fue aprobada la Ley Orgánica del Régimen Electoral General (Ley Orgánica 5/1985 de 19 de junio, de ahora por delante, LOREG), que limitó por primera vez las donaciones privadas, a 1987, año de aprobación de la Ley Orgánica de Financiación de Partidos Políticos (Ley Orgánica 3/1987 de 2 de julio), que estableció un sistema de financiación predominantemente público ${ }^{22}$; y el tercero y último, desde mediados de los 90 , período este en que la autora creía que existía una tendencia hacia el fortalecimiento de formas de financiación privada, algo que no se confirmó con la aprobación de la nueva Ley Orgánica de Financiación de Partidos Políticos (Ley Orgánica 8/2007 de 4 de julio, de ahora por delante, LOFPP). ${ }^{23}$ Bajo su análisis, entre 1977 y 1985 coexistían los sistemas público y privado porque las contribuciones privadas no tenían limitación alguna cuando eran destinadas a actividades ordinarias de los partidos, y cuando eran destinadas a sufragar las elecciones, las limitaciones eran pequeñas. Sin embargo, el escenario cambia con la creación de las reglas que hasta hoy regulan el sistema de distribución de las subvenciones. Una de

coaliciones, pero que ello no excluiría que en un futuro se cambiara el sistema para que se basara en la proporción de número de votos de cada organización. (In: JIMENEZ DE PARGA, M.; et al. "Debates. La Financiación de los Partidos". In: AA.VV.: Ley Electoral y Consecuencias Políticas. Ed. CITEP, Madrid, 1977. Pp. 158).

${ }^{21}$ GILLESPIE, R. Op. Cit. Pp. 77.

22 Debatiendo las posibles opciones para una ley de financiación de partidos políticos, JIMENEZ DE PARGA refleja bien el pensamiento que se tenía en la época de la transición. El autor, además de estar a favor de la financiación tanto de las actividades extraordinarias como de las ordinarias de los partidos por entender que dichas organizaciones siempre están en continua campaña, y que las normas para limitar gastos y orígenes de algunos recursos suelen ser ineficaces, opina que la solución es la financiación estatal, que sería el procedimiento menos malo para equilibrar las fuerzas políticas, además de ser una buena alternativa contra la corrupción. (In: JIMENEZ DE PARGA, M.; et al. "Debates. Op. Cit." Pp. 154). Como se verá más adelante, dicho pensamiento no se ha confirmado en la realidad.

${ }^{23}$ CASTILLO, P. del. "La Financiación de los Partidos Políticos en España..." 
estas reglas es que las subvenciones solo serían concedidas a los partidos que hubieran logrado representación en el Parlamento, teniendo en cuenta que para la valoración del montante a recibir deberían considerarse únicamente los votos en las circunscripciones que hubieran logrado escaño, y que no todos los votos a nivel nacional serían contabilizados a los fines de la financiación. ${ }^{24}$ Así, en cierto modo se puede afirmar que la legislación española ha partido de la supuesta necesidad de limitar o prohibir las fuentes de financiación privada, con la finalidad última de convertir a la financiación pública en el elemento central de todo el diseño legal. ${ }^{25}$

Y en torno a esta idea girará el sistema de financiación de partidos en España. Teniendo en cuenta que los efectos de un sistema de financiación deben de ser evaluados por su capacidad de generar suficientes recursos para mantener la competitividad de los partidos políticos, puede comprobarse que en España, mientras los grandes partidos empezaron a endeudarse a niveles muy altos, los partidos pequeños luchaban por su supervivencia, muchas veces sin éxito. A partir de ello los partidos se dieron cuenta de que tenían poca capacidad para generar dinero internamente, ya que ni siquiera PSOE (la organización con mejor resultado en 1982) logró conseguir recursos suficientes para cubrir el coste total de su campaña política. ${ }^{26}$ Debido a ese escenario, el Estado asumió una gran parte de la financiación de los partidos, llegando a aportar incluso más del $90 \%$ del total de ingresos de dichas organizaciones. ${ }^{27}$

\footnotetext{
${ }^{24}$ DEL CASTILLO destaca que, entre 1977 y 1983 dicho sistema funcionó normalmente, hasta la denuncia del caso Flick, responsable de llamar la atención al tema de la financiación de partidos en España. (In: CASTILLO, P. del. "La Financiación de los Partidos Políticos en España...”). También, para un resumen sobre el caso Flick y su repercusión, cfr. CORTÉS BURETA, P.: Recursos Públicos y Partidos Políticos...Pp. 82 y ss.

${ }^{25}$ Cfr. PAJARES MONTOLIO, E.: La Financiación de las Elecciones. Congreso de los Diputados, Madrid, 1998. Pp. 292 y HOLGADO GONZÁLEZ, M.: La Financiación de los... Pp. 146.

${ }^{26}$ HOLGADO GONZÁLEZ entiende que por su trayectoria histórica, los partidos españoles pueden ser considerados débiles, incluso porque en la II República tampoco se logró consolidar un sistema de partidos. (In: HOLGADO GONZÁLEZ, M. La Financiación de los... Pp. 26-27).

${ }^{27}$ GILLESPIE entiende que no sólo la irresponsabilidad de los partidos fomentaron que se agravase su situación financiera. La opción de la reconstrucción de los partidos a partir de modelos costosos, con redes estables de sedes y funcionarios también contribuyeron a ello. (In: GILLESPIE, R. Op. Cit. Pp. 76-80). SANTANA CASTAÑOS también sigue esta línea de pensamiento, afirmando que la carencia de una cultura de partidos colaboró directamente para dicho resultado. (In: DÍAZ-SANTANA CASTAÑOS, H. "Experiencia con el Financiamiento de los Partidos Políticos en In: www.cepchile.cl/dms/archivo_3516.../refor1_05_diaz_santana.pdf. <<Acceso en 25.11.2009>>
} 
Esto deja claro que no fue posible para los partidos españoles desarrollarse exactamente como partidos de masas ${ }^{28}$, disminuyendo bastante las posibilidades de sostenerse con la militancia ${ }^{29}$, aunque ello no signifique que dichas organizaciones no fueran capaces de agregar simpatizantes fieles dentro del electorado o de consolidar un nivel más alto de identificación partidista, aunque parece claro que, con la financiación pública de los partidos desde el inicio de la redemocratización, se produjo una desincentivación de sus esfuerzos para el aumento de los niveles de afiliación. ${ }^{30}$

Pp. 173). También en este sentido, véase HOLGADO GONZÁLEZ, M.: La Financiación de los...Pp. 136.

${ }^{28}$ DEL CASTILLO expone el resultado de una encuesta que demuestra todas las consecuencias de la falta de desarrollo de los partidos para el modelo de masas, y también las secuelas del régimen franquista. Según el resultado de dicha encuesta, los españoles reconocen el papel relevante de los partidos en el sistema democrático, pero creen que solamente buscan sus propios intereses, alejados de la sociedad, haciendo que las personas en general pierdan interés por la propia política, y que los dirigentes partidistas sean vistos con desconfianza y descrédito. Incluso las propias organizaciones son vistas como sin ideología alguna, lo que provoca la volatilidad del voto entre los españoles. Más específicamente sobre la financiación pública, no toda la población tiene conocimiento de que el Estado financia a los partidos, y creen que estos deberían sostenerse con contribuciones de sus militantes y simpatizantes, aunque no exclusivamente. Sin embargo, no se verifica una disposición clara por parte de la sociedad en ayudar a financiar a los partidos. (CASTILLO, P. del. "La Financiación de los Partidos Políticos ante..." Pp. 126-137). Este resultado está de acuerdo con la idea de que los partidos deberían sostenerse solamente a través de sus militantes, véase la opinión de SUÁREZ GONZÁLEZ en: AA.VV. "Encuesta Sobre la Regulación Jurídica de los Partidos Políticos". In: Teoría y Realidad Constitucional. no 6, 2o semestre. UNED, Madrid, 2000. Pp. 36 y MARTíN FERRAND, M.: La Financiación de los Partidos. ABC, 29 de septiembre de 2005, que, aunque sea una crónica no doctrinaria, refleja bien el pensamiento de la sociedad sobre el asunto.

${ }^{29}$ Este punto es bastante discutido entre la doctrina, pues aunque la opinión mayoritaria es que los partidos necesitan de la financiación pública porque la autofinanciación es inviable, autores como Aragón Reyes llegan a cuestionar si la baja afiliación a dichas organizaciones es una causa de la financiación pública, o un efecto de esta. Cfr. MURILLO DE LA CUEVA, P. L.; VEGA GARCIA, P. de; ALCUBILLA, A.; et al. "Debate". In: AA.VV.: Anuario de Derecho Constitucional y Parlamentario. № 5. Asamblea Regional de Murcia - Universidad de Murcia, Murcia, 1993. Pp. 147 y ss. También, MEZZETTI afirma que, entre 1975 y 1993, España era el país con la menor tasa de adhesión a algún partido político, siendo de tan solo $2 \%$ de los ciudadanos, dato este que alimenta todavía más el debate. (MEZZETTI, L. "Finanziamento e Condizionamiento del Partito Político". In: AA.VV.: Anuario 2008: Partiti Politici e Società Civile a Sessant'anni dall'entrata in Vigore della Costituzione - Atti del XXIII Convegno Annuale Alessandria, 17-18 Ottobre, 2008. ed. Jovene, Napoli, 2009. Pp. 124).

${ }^{30}$ MONTERO GISBERT, J. "Partidos y Participación..." Pp. 68-70. 


\section{2) La fragmentaria ubicación normativa de la regulación sobre financiación y su evolución histórica}

Antes de adentrarse en la normativa sobre la financiación de los partidos en España, es importante resaltar su carácter fragmentario. Junto de las principales leyes estatales, que serán objeto de mayor detalle en la exposición, existen leyes autonómicas, a parte de los reglamentos del Congreso de los Diputados y del Senado que también tratan la materia, dada la transferencia de competencias realizadas en la Constitución. ${ }^{31}$ También, se planteó doctrinariamente en algunos momentos la posible conveniencia de una legislación específica sobre la financiación de las elecciones y de las actividades ordinarias de los partidos, siendo incluso objeto de debate en los trabajos de elaboración de la LOREG. ${ }^{32}$ Sin embargo, la dispersión legislativa continua, sin perspectivas de cambio, y continúan también las críticas, principalmente en relación a la diversa regulación de la financiación de las elecciones y de las actividades ordinarias de los partidos, algo que permite que el sistema sea inestable desde el punto de vista de la eficacia de la norma.

Como se apuntó anteriormente, la legislación española sobre la financiación de partidos puede encuadrarse en tres fases. ${ }^{33}$ La evolución

\footnotetext{
${ }^{31}$ FERNÁNDEZ VIVAS, Y.: Igualdad y Partidos Políticos: Análisis Constitucional y Comparado de la Igualdad de Oportunidades de los Partidos Políticos. ed. Congreso de los Diputados, Madrid, 2007. Pp. 321.

32 PAJARES MONTOLIO, E.: La Financiación de las... Pp. 62-64.

${ }^{33}$ DEL CASTILLO, P. "La Financiación de los Partidos Políticos: 1977-1997". In: Revista de las Cortes Generales, no 41, 2ำ cuatrimestre, Madrid, 1997. Pp. 154. En otro de sus trabajos, la autora enmarca algunos períodos de la evolución de la financiación de los partidos, juntándolos con la evolución legislativa. Así, antes de todo la autora destaca las deficiencias en la normativa entre 1977 y 1985 (periodo que todavía estaba en vigor el Decreto-Ley 20/1977 y la Ley Orgánica 54/1978), para luego diferenciar entre diferentes intervalos. En que va de 1977 y 1979, caracterizado por la transición hacia la democracia, con recursos públicos, donaciones privadas de asociaciones de negocios y bancos (a través del perdón de préstamos) y contribuciones de organizaciones extrajeras (partidos nacionales, organizaciones internacionales de partidos y fundaciones de partidos, como era el caso de las alemanas). Luego entre 1979 y 1984, caracterizado por la reducción de ayudas internacionales y la marginalización de las cuotas de miembros, debido al bajo nivel de afiliación. Fue en este período en el que se produjo la revelación del llamado caso Flick en Alemania, con consecuencias en España por la financiación de campañas electorales de PSOE. Nadie fue condenado. El de 1985, caracterizado por la aprobación de la LOREG, y 1987, caracterizado por la aprobación de la Ley Orgánica 3/1987, LOFPP anterior, marcando la limitación de donaciones privadas y el aumento de subsidios por parte del Estado. Y en 1991, evidenciando que, cuanto más disminuyen los gastos de los partidos, más aumentan los subsidios provenientes del Estado, como es el caso del Mailing. (In: CASTILLO, P. del. "Problems in
} 
legislativa sobre la financiación comienza con la ley 21/1976, del 14 de junio ${ }^{34}$, ley de asociación política, que no reconocía a los partidos (ilegales en esta época). La financiación se componía únicamente de recursos privados (como ocurre con las asociaciones), aportaciones de afiliados, donaciones, créditos concertados, herencias, legados, recursos producto de actividades de la asociación, acompañada de prohibiciones sobre recursos de origen extranjero, tanto de personas físicas como jurídicas. La financiación pública se preveía de manera genérica, permitiendo al Estado financiar las actividades ordinarias con recursos de los presupuestos generales del Estado. ${ }^{35}$ Los criterios de distribución de los recursos se remetían a una futura ley de desarrollo que nunca fue aprobada. En un momento posterior, correspondía al Ministerio de Gobernación la tarea de controlar las cuentas, con identificación de todos los donantes involucrados. Cabe destacar que dicha ley fue derogada por la ley 06/2002 de partidos políticos. ${ }^{36}$

\subsection{La normativa sobre la financiación de las campañas electorales}

Partiendo de este punto, se adoptará aquí el modelo planteado por el prof. Murillo DE LA CUEVA, que aboga por la existencia de tres distintos

\footnotetext{
Spanish Party Financing". In: ALEXANDER, H. E.; SHIRATORI, R. (eds.): Comparative Political Finance Among the Democracies. Westview Press, USA, 1994. Pp. 97-99).

${ }^{34}$ Para un examen histórico de la ley de reforma política (1/1977 de 4 de enero) cfr. FERNANDEZ SEGADO, F.: Aproximación a la Nueva Normativa Electoral. ed. Dykinson S.L., Madrid, 1986. Pp. 15-24. Aún, para algunos comentarios sobre dicha Ley Orgánica de Asociaciones Políticas, cfr. ESPARZA MARTÍNEZ, B. "Estructura y Funcionamiento Democrático de los Partidos Políticos Españoles". In: Revista de las Cortes Generales, 끄 43, $1^{\circ}$ cuatrimestre, Madrid, 1998. Pp. 108, y CORTÉS BURETA, P.: Recursos Públicos y Partidos Políticos.... Pp. 57 y ss, que realiza buena síntesis sobre la norma.

${ }^{35}$ Los términos de la ley, en su artículo 4.2, eran: "Los recursos económicos de las asociaciones políticas estarán constituidos por las cuotas, las aportaciones voluntarias de sus miembros, los rendimientos de su patrimonio, los productos de las actividades de la asociación, las donaciones, herencias legados y subvenciones que reciba y los créditos que concierte". Se verifica así la falta de claridad en relación a la financiación pública de las denominadas "asociaciones políticas".

${ }^{36}$ La doctrina cita otras leyes que se conectan con el objeto de estudio, como es el caso de las Leyes Orgánicas 39/1978 de elecciones locales; 6/1983 que la altera posteriormente; 8/1991 y 13/1994 (las cuales alteran la LOREG con medidas de reducción de costes en las campañas electorales, como también adaptando la mencionada normativa al Tratado de Maastricht), y otras leyes que modificaron las normas principales de financiación de partidos, que serán citadas en los comentarios que se hagan a cada una de las leyes más importantes, como es el caso de la Ley Orgánica 01/2003 de 10 de marzo, que modificó la Ley Orgánica 3/1987, ley de financiación de partidos políticos anterior.
} 
niveles de financiación, siendo estos la electoral, la ordinaria, seguida por la financiación indirecta, la autonómica y la de los grupos parlamentarios. ${ }^{37}$ No se expondrá la financiación, tanto electoral como la ordinaria, a nivel municipal ${ }^{38}$, por sobrepasar el objeto de este trabajo.

El análisis de la legislación sobre el tema se iniciará con el examen de las leyes que tratan sobre la financiación de las actividades extraordinarias de los partidos políticos, es decir, sobre las campañas electorales. Esto creemos que permitirá en parte comprender, de manera retrospectiva, la legislación en vigor. $^{39}$

La evolución de los partidos de masas - verdaderos fenómenos de la actividad propagandística - hacia el modelo catch all y la creciente utilización de los medios de comunicación, hicieron que los correspondientes gastos sufrieron un importante incremento, forzando también a los partidos a organizarse para ser capaces de afrontarlos. ${ }^{40}$ Dicho cambio empezó a evidenciarse en España durante la transición política y la constitucionalización de los partidos, siendo la tarea aún más difícil de concretar. Dado que el principio de la igualdad de oportunidades debe estar presente en cualquier democracia, y considerando del mismo modo el aumento desmesurado de los costes electorales, el Estado tuvo que intervenir tanto de manera negativa como positiva en la cuestión. ${ }^{41}$ Con todo, las intervenciones estatales

\footnotetext{
${ }^{37}$ MURILLO DE LA CUEVA, P. L.; VEGA GARCIA, P. de; ALCUBILLA, A.; et al. "Debate. Op. Cit." Pp. 135.

${ }^{38}$ Aunque no sea objeto de la tesis, véase el trabajo de SERRANO MÁĺLOO, que trae una compilación sobre la financiación de las campañas electorales, abordando también las elecciones municipales. Cfr. SERRANO MAílLO, M. I. "La Financiación de los Partidos Políticos en España". In: Teoría y Realidad Constitucional. oㅡ 12-13, 2o semestre, 2003, 1은 semestre, UNED, Madrid, 2004. Pp. 449-467.

${ }^{39}$ FERNANDEZ SEGADO, F.: Aproximación a la... Pp. 15.

${ }^{40}$ Sobre el aumento de gastos por parte de los partidos políticos para la propaganda a través de los medios de comunicación de masas, LÓPEZ GUERRA afirma que dichos gastos reflejan el panorama moderno de enfrentamiento electoral, donde los que no disponen de abundantes recursos no podrán competir de manera comparable con los que tienen más condiciones económicas de hacerlo, y esto incluye recursos personales, o derivados del apoyo de organizaciones empresariales o sindicales. Por ello, el Estado tiene el deber de combatirlo y garantizar la neutralidad electoral. (In: LOPEZ GUERRA, L. "Sobre la Evolución de las Campañas Electorales y la Decadencia de los Partidos de Masas". In: Revista Española de la Opinión Pública, oㅡ 45, jul/sept, Madrid, 1976. Pp. 103).

${ }^{41}$ Las campañas electorales deben ser organizadas de manera que sea posible el intercambio de ideas de los diversos competidores, asegurando la igualdad de condiciones y el igual acceso a los medios de comunicación. (In: ARNALDO ALCUBILLA, E. "Procesos Electorales y Opinión Pública”. In: Revista de las Cortes Generales, № 34, 1ํㅡㄹ cuatrimestre, Madrid, 1995. Pp. 175).
} 
realizadas en momentos como los de redemocratización de un país implican el riesgo de estar motivadas por intereses parciales, olvidándose de las posibles consecuencias que puedan generarse a largo plazo.

La competitividad se constituye como uno de los rasgos principales del proceso electoral en un sistema democrático, y merece protección, no concediendo o permitiendo ninguna "ventaja" o "privilegio institucional" a ninguno de los involucrados. Además, también requiere una limitación temporal del poder y la de una alternancia, con campañas electorales que posibiliten unas elecciones libres y dotadas de una auténtica competencia. ${ }^{42}$ En este sentido, en cualquier competición se debe diferenciar factores relevantes (importantes para el acceso de un determinado bien u objetivo) de los factores irrelevantes (que no pueden ser elemento distintivo, como raza, sexo, y otros). Trasladando esta idea a la competición electoral, los factores relevantes serían aquellos que se relacionan con la sociedad, como puede ser la propaganda partidista y la capacidad de los partidos para canalizar los intereses y necesidades de los ciudadanos. Factores irrelevantes serían, por ejemplo, los recursos económicos de dichas fuerzas políticas para la obtención de ventajas electorales. Es este el punto central de la legislación sobre las campañas. ${ }^{43}$

La regulación jurídica de las campañas electorales no estaba contemplada en la ley electoral de 1907 y sus posteriores reformas de 1931 y 1933, aunque existían órdenes ministeriales que trataron de la utilización de la radio y de los medios de propaganda en la II República. ${ }^{44}$ La legislación referente a la financiación de la política en general fue iniciada con circulares, como ya se mencionó anteriormente. Se puede citar aquí la Circular de 06/10/1933; seguida de la Orden Ministerial de 07/11/1933; Orden Ministerial de 09/02/1934 y de la ley de radiodifusión de 16/06/1934. Dichas regulaciones no se referían sin embargo a partidos o a grupos parlamentarios, y tampoco a

\footnotetext{
${ }^{42}$ SOLOZÁBAL ECHAVARRÍA entiende que el sistema democrático es algo abierto, donde en cada elección realizada exista una alternativa, aunque la alternancia propiamente dicha no se concrete, pero implica que el cambio es posible. (In: SOLOZABAL ECHAVARRÍA, J. J. "Una Visión Institucional del Proceso Electoral". In: Revista Española de Derecho Constitucional, año 13, no 39, sep/dic, 1993. Pp. 67-76. Por ello, el autor considera que una campaña electoral adecuada democráticamente, debe garantizar las condiciones de igualdad entre los competidores, posibilitando una decisión razonable por parte del ciudadano.

${ }^{43}$ En este sentido, cfr. SÁNCHEZ MUÑOZ, O.: La lgualdad de Oportunidades en las Competiciones Electorales. CEPC, Madrid, 2007. Pp. 13 y ss.

${ }^{44}$ DEL CASTILLO, P. "La Financiación de los Partidos Políticos: 1977..." Pp. 155.
} 
campañas electorales, sino que se referían a los diputados, considerados individualmente. ${ }^{45}$

Posteriormente, en el período franquista no hubo lógicamente ninguna referencia al asunto hasta el Decreto Ley de 21/12/1974 (ley de asociaciones). Ya en el período de la transición política, fue aprobada la Ley de Asociaciones Políticas de 14 de junio de 1976, que es la primera regulación de financiación tanto privada como pública, acompañada de la Ley para la Reforma Política de 4 de enero de $1977^{46}$, y el Decreto Ley 20 de 18 de marzo de 1977, que establece la financiación estatal de los gastos electorales bajo el doble criterio de escaños y votos. ${ }^{47}$ Dicho Decreto-Ley fue el que posibilitó la financiación pública de los partidos en las elecciones de 1977. Dadas las graves dificultades financieras de estos en esos momentos. Así, esta primera normativa electoral siguió siendo utilizada para las elecciones de 1979 y las posteriores, a la vez que solamente con la LOREG se adoptaron otras reglas con un carácter más completo y detallado. ${ }^{48}$ Dentro de la normativa para determinar algunas medidas de financiación, también se puede citar la Ley 39/1978 de 17 de junio, sobre las elecciones locales. ${ }^{49}$

Existen algunas características comunes a la normativa sobre la financiación electoral. Se trata de disposiciones con ámbito de aplicación limitado, es decir, solo se aplican a las elecciones con sufragio directo, y no indirecto (con excepción de las juntas electorales del Territorio Vasco y los Cabildos Insulares Canarios), y es así porque es justo en este momento en el

\footnotetext{
45 ÁlvareZ CONDE, E.: El Derecho de Partidos. Colex, Madrid, 2005. Pp. 374. Para un resumen sobre las materias abordadas por dichos órdenes ministeriales, cfr. punto 3.4 sobre financiación indirecta.

${ }^{46}$ Un buen análisis de esta ley, su contexto histórico y una evaluación de sus efectos se puede encontrar en PEÑA GONZÁLEZ, J. "La Ley para la Reforma Política como Factor Legitimador del Cambio". In: PEÑA GONZÁLEZ, J. (Coord.): Libro Homenaje a Iñigo Cavero Lataillade. ed. Tirant lo Blanch, Valencia, 2005. Pp. 449-464.

47 También el Decreto-Ley 12 de 8 de febrero de 1977 que alteró la Ley de Asociaciones Políticas de 14 de junio de 1976, eliminando de su texto el control preventivo para la fundación de partidos políticos, suprimiendo exigencias con origen en la filosofía de las Leyes Fundamentales de la época franquista. Dicho Decreto también es apuntado como una de las normas pioneras en el reconocimiento legal de las organizaciones partidistas. (In: CORTÉS BURETA, P.: Recursos Públicos y Partidos Políticos... Pp. 61.

48 HOLGADO GONZÁLEZ añade que la STC 72/1984 de 14/06/1984 logró que los parlamentarios se sintieron compelidos a aprobar una nueva ley electoral con carácter orgánico, la LOREG, que reguló la financiación electoral para los partidos políticos con mayor precisión. (In: HOLGADO GONZÁLEZ, M.: La Financiación de los... Pp. 29).

${ }^{49}$ BLANCO VALDÉS, R. L. "La Problemática..." Pp. 180.
} 
que se busca captar los votos de los ciudadanos. Sin embargo, el referéndum se incluye aquí porque las normas electorales de la LOREG también se aplican a este tipo de consulta popular, permitiendo así la utilización de la financiación indirecta, pero no las subvenciones directas. ${ }^{50}$ Además, son disposiciones moderadamente continuistas, aunque en comparación, el Decreto-Ley 20/1977 y la LOREG mantienen una misma línea, como se analizará posteriormente, a pesar de que la LOREG contenga reglas más detalladas. Junto a ello, poseen un contenido heterogéneo y bastante amplio, porque tratan de la prohibición, limitación, publicidad de las contribuciones, limitación de gastos, centralización de las responsabilidades de las operaciones y del sistema estatal de financiación, y poseen una estructura compleja, en cuanto al modo en que dentro de la LOREG están expuestas las reglas comunes (para todas las elecciones), y las especiales (para cada una de las elecciones). Entre las primeras, se pretende una primera identificación de qué reglas se aplican a todas las elecciones por sufragio universal (reglas generales) y cuáles se aplican a nivel autonómico (establecidas a través de su competencia por cada Comunidad Autónoma), considerando también la incidencia de las reglas contenidas en la LOFPP. Finalmente, se trata de normas sujetas a constantes revisiones, pues aunque se trate de una materia reservada a Ley Orgánica, sus disposiciones ya han sufrido cambios continuos para ajustar o afinar el sistema, como es el caso de la adhesión de España a las Comunidades Europeas. ${ }^{51}$

\subsubsection{La Ley de Asociaciones $21 / 1976$, de 14 de Junio}

Previamente a las leyes que más directamente regularon el tema de nuestro estudio, la ley de asociaciones aprobada en los momentos iniciales de la transición política fue la responsable de derogar el Estatuto Jurídico de 21 de

\footnotetext{
${ }^{50}$ PAJARES MONTOLIO, E.: La Financiación de las... Pp. 75-76. El autor cita la Ley Orgánica $3 / 1984$ de 26 de marzo, que regula la posibilidad de subvención para costear los gastos referentes a la promoción y recogida de firmas para proyectos de leyes de iniciativa popular. El texto del artículo 15 de dicha ley es: "Articulo decimoquinto. Compensación estatal por los gastos realizados: 1. El Estado resarcirá a la Comisión Promotora de los gastos realizados en la difusión de la proposición y la recogida de firmas cuando alcance su tramitación parlamentaria. 2. Los gastos deberán ser justificados en forma por la Comisión Promotora. La compensación estatal no excederá, en ningún caso, de 30 millones de pesetas. Esta cantidad será revisada periódicamente por las Cortes Generales".

${ }^{51}$ PAJARES MONTOLIO, E.: La Financiación de las... Pp. 79-88.
} 
diciembre de 1974. Y no solo eso: se trata de una ley que persigue claramente abrir el sistema político a fin de preparar el país para las elecciones de 15 de junio de 1977.

Aunque con carácter sumario, dicha norma contemplaba algunas reglas sobre financiación y fiscalización. Las fuentes de financiación establecidas por la ley no difieren mucho de las asociaciones en general, comprendiendo la cuota; las aportaciones voluntarias de los miembros; los rendimientos del patrimonio; los productos de la actividad desarrollada por la asociación; las donaciones; las herencias; los legados y las eventuales subvenciones que percibieran y los créditos. Como se puede comprobar, se trata prácticamente de las mismas fuentes de financiación reconocidas hoy en día, con la diferencia de que estas fuentes de recursos tienen una connotación privada, contando con la participación de los miembros y simpatizantes para el mantenimiento de la asociación.

Otro dato que llama la atención es la preocupación por parte del legislador por fijar un esquema de transparencia en el régimen económico de las asociaciones. Su justificación en la exposición de motivos de la ley aborda el tema desde el punto de vista de la autonomía y la libertad de dichas asociaciones, sin desvirtuar los fines que les son propios (haciendo clara referencia a grupos económicos o a finalidades ideológicas que no sean las de la sociedad española), e incluyendo así una sistemática considerablemente detallada para la época, siendo ciertamente un punto innovador en su vertiente jurídico y político. La obligatoriedad de declaración del origen de los recursos manejados es contemplada minuciosamente, junto con la obligación de llevar los libros de tesorería, inventarios y balances de la manera descrita en su art. 4․ Las asociaciones deberían tener un inventario anual de todos sus bienes, cuenta de ingresos con respectivas cantidades tanto en metálico como en bienes recibidos, con el nombre y dirección del responsable de la transmisión. ${ }^{52}$

Además de estas especificaciones, el apartado $4^{\circ}$ del artículo disponía los plazos para cumplir con dichas exigencias contables. Existía un plazo de tres meses iniciales durante los cuales las asociaciones deberían remitir al

\footnotetext{
52 De hecho, estas obligaciones tan específicas tardaron en volver a la legislación sobre la materia, porque posteriormente a la derogación del referido artículo por la Ley Orgánica 54/1978, solamente con la Ley Orgánica 8/2007 se reintrodujeron medidas de tal naturaleza.
} 
Ministerio de la Gobernación una copia autorizada del inventario y de las cuentas de ingresos y gastos. Estos serían trasladados al Tribunal de Cuentas y, en el mismo plazo, las cuentas deberían hacerse públicas y comunicadas a todos los miembros, que podrían examinar el dossier en cualquier momento. El examen oficial debería hacerse o por una de las Salas del Tribunal Supremo sin especificar cuál - o por el Tribunal de Cuentas, que podría requerir la inspección de oficio a instancia de parte o del Ministerio de la Gobernación.

En el apartado $5^{\circ}$ se contempla la posibilidad de que los presupuestos del Estado consignen una cuantía determinada para subvencionar dichas asociaciones, aunque no hay mención de criterios o cantidades y tampoco se contempla como una obligación jurídica. Sin embargo, era una vía que permitía al Estado hacerlo, remitiendo dichos puntos a la ley específica.

Al final, se consagra la prohibición de que dichas asociaciones reciban fondos procedentes del extranjero o de entidades o personas extranjeras. Dicha prohibición acompañará a la legislación hasta los días de hoy.

Aunque sucintamente, dicha norma destaca por abordar temas que incluso a días de hoy son importantes, como es el caso de la transparencia. Además, considerando que el reconocimiento de las asociaciones políticas era un hecho inédito jurídicamente hablando, destaca la firmeza del legislador en fijar reglas claras y la adopción de reglas que siguen vigentes a través de otras leyes. Junto con ello, por más que las asociaciones políticas se concibieran como organizaciones de carácter privado, destaca la preocupación por la transparencia y por establecer la posibilidad de que el Estado les otorgara algún tipo de subvención, lo que denota el reconocimiento de la importancia de su papel en la sociedad. Puede que no fuera tan clara la cuestión en aquel momento como lo es hoy en día, pero es un dato que no puede ser ignorado.

\subsubsection{El decreto-Ley 20/1977 de 18 de Marzo}

Tras la muerte del general Franco, la discusión sobre la construcción de un sistema electoral para España resultaba inevitable. Sin embargo, la experiencia de la II República acabó por hacer que parte de la élite involucrada en la transición política pensara que ciertos elementos componían una especie 
de "antimodelo". En este caso, el sistema electoral republicano se derivaba del principio mayoritario, escasamente adoptado ya en los años de posguerra por los países europeos y, sumados a los problemas que normalmente un proceso de redemocratización de un país conlleva, es comprensible que dicho modelo republicano - entendido como elemento potencial de fragmentación política, de polarización partidista y de inestabilidad gubernamental - fuera dejado de lado. Frente a ello, la Ley para la Reforma Política ${ }^{53}$ asentó los primeros acuerdos para el desarrollo de la legislación electoral, desarrollados en el Decreto-Ley 20/1977. ${ }^{54}$ En este contexto, parece claro el difícil pacto del gobierno Suárez con elementos provenientes del antiguo sistema y, a su vez, con la oposición democrática entonces en la semiilegalidad. ${ }^{55}$

Los principios electorales existentes en la Ley 1/1977 tenían naturaleza vinculante, y dejaba poco margen de decisión. Sin embargo, aún faltaban puntos importantes para la estructuración de un sistema. A partir de ahí, se empezó una negociación a través de una comisión de 10 representantes de las formaciones que integraban la oposición, que llegó incluso a influir en la opinión pública de la época. De ello resultó un acuerdo con el gobierno Suárez que culminó en el Real Decreto-Ley 20/1977. ${ }^{56}$ Ya con la legislación necesaria, fue

${ }^{53}$ Para algunas consideraciones sobre la Ley de Reforma Política, véase FERNÁNDEZ SEGADO, F. "Las Distorsiones de los Principios de Igualdad de Voto y Proporcionalidad en el Decreto-ley de Normas Electorales". In: Revista de Derecho Público. o 105-106. Editoriales de Derecho Reunidas, Madrid, 1986. Pp. 18 y ss, donde el autor describe el conflicto de intereses entre los grupos políticos de la época.

${ }^{54}$ RAMÓN MONTERO, J.; J. LLERA, F.; TORCAL, M. "Sistemas Electorales en España: Una Recapitulación". In: Revista Española de Investigaciones Sociológicas - REIS, no 58, abr/jun, CIS, Madrid, 1992. Pp. 16-17.

${ }^{55}$ ORTEGA GUTIERREZ, D. "La Inercia en los Antecedentes y el Desarrollo del art. 68 de la Constitución Española". In: Revista de la Facultad de Derecho de la Universidad Complutense de Madrid. no 86, Madrid, 1996. Pp. 363-364. La negociación de dichos criterios involucraron no solamente sectores que provenían del régimen franquista y gobierno, sino que también el gobierno y los primeros partidos democráticos, dando cabo a un sistema que agradara a los franquistas (que pretendían la adopción del principio mayoritario, reforzando las probabilidades de la victoria conservadora en las elecciones) con la adopción de la provincia como circunscripción electoral, concreción del número de diputados y criterios de proporcionalidad para la elección para el Congreso de los Diputados combinados con dispositivos correctores de dicha proporcionalidad y una barrera mínima de votos. Juntamente con eso, Suárez logró realizar acuerdos con la oposición democrática, no concediéndoles totalmente sus peticiones, pero incluyendo en la ley algunos puntos que ellos solicitaban, como es el caso de los criterios para la distribución de escaños entre las circunscripciones electorales. Cfr. RAMÓN MONTERO, J.; RIEVA, P. "Informe sobre la Reforma del Sistema Electoral". Disponible en << http://www.consejo-estado.es/pdf/ANEXOII.pdf>> Acceso en 24.01.2012. Pp. 7-8.

${ }^{56}$ Cfr. FERNÁNDEZ SEGADO, F. "Las Distorsiones de los..." Pp. 34-35. 
posible la organización de las elecciones de 1977, que darían luz a unas Cortes que, "de facto", todos sabían constituyentes. ${ }^{57}$

Por otra parte, a partir de estas elecciones se delinearon las primeras normas de financiación de los partidos políticos en sus actividades electorales, que fueron renovadas hasta ser definitivamente consolidadas en la Ley Orgánica del Régimen Electoral (a partir de ahora LOREG), como es el caso del criterio doble de escaños/votos para el acceso a la financiación pública. ${ }^{58}$ Cabe recordar que, debido a la condición frágil en que se encontraban los partidos en España, el sistema se inclinó significativamente hacia la financiación pública como su principal soporte. La apatía política ${ }^{59}$ ya existente en el período franquista generó a la vez un déficit de legitimidad de las organizaciones, que ya se plasmaba en niveles bajísimos de afiliación, comprometiendo directamente la sostenibilidad de la estructura partidista como un todo. Debido a ello, la financiación pública de los partidos políticos fue vista

${ }^{57}$ Durante este periodo hubo un debate sobre una posible constitucionalización del sistema electoral. El argumento en contra era principalmente el de dar a las normas electorales un margen amplio de maniobra con el fin de adaptarlas cuando lo demandaran las circunstancias, sin que fuera necesario reformar la Constitución, además de ajustar la fórmula electoral y distribuir las circunscripciones electorales conforme la dinámica de los movimientos migratorios. Sin embargo, lo que destacaba era el enfrentamiento de posiciones entre los partidos sobre el tema, dejando ver que la falta de un acuerdo profundo entre las fuerzas políticas. (In: JIMENEZ DE CISNEROS CID, F. J.: Ley Electoral. Imprenta Nacional, Madrid, 1983. Pp. 41-42). También, cfr. Diario de Sesiones del Congreso de los Diputados no 78 y 93, de 1 de junio y 20 de junio, respectivamente, disponible en $<$ http://www.congreso.es/public_oficiales/L0/CONG/DS/C_1978_069.PDF>> y $\quad<$ http://www.congreso.es/public_oficiales/L0/CONG/DS/C_1978_093.PDF>>

${ }_{58}$ MORODO, R.: La Transición Política. 1ํoed. reimp. Tecnos, Madrid, 1985. Pp. 153-166. En otro trabajo, el autor entiende que actualmente los partidos no tienen las mismas dificultades que tenían en los tiempos de la transición, y que, debido a ello, deberían tomarse algunas medidas graduales, en el sentido de extender el acceso a la financiación pública para formaciones que hubieran concurrido en las elecciones de modo significativo, y que aunque no hubieran logrado escaño, recibirían subvenciones. (In: AA.VV. "Encuesta Sobre la Regulación..." Pp. 35-36). Como evidencia del acuerdo tomado en la materia, se pueden consultar los Pactos de la Moncloa que contienen el acuerdo sobre el programa de actuación jurídica y política en que se fija el ejercicio del derecho de asociación, aprobado en 27 de octubre de 1977. Dicho derecho debería poseer un sistema de financiación estatal de los partidos a través de un sistema objetivo de subvenciones basado en los resultados electorales de cada uno. (In: COTARELO, Ramón (comp.): Transición Política y Consolidación Democrática. España (1975-1986). CIS, Madrid, 1992. Pp. 489).

${ }^{59}$ RODRÍGUEZ DÍAZ afirma que algunos de estos comportamientos heredados de la dictadura pueden afectar negativamente la calidad de la democracia, y la ausencia de participación en el proceso democrático causada por la apatía política, o quizás por el sentimiento antipartidista, constituyen factores que aumentan aún más la responsabilidad del sistema es involucrar a la ciudadanía en el proceso de consolidación democrática, generando así una nueva cultura política. (In: RODRIGUEZ DIAZ, A. Transición Política y Consolidación Constitucional de los Partidos Políticos. Centro de Estudios Constitucionales, Madrid, 1989. Pp. 90). 
en la época como la única alternativa que permitía a las organizaciones estructurarse para las elecciones que estaban por venir. Otro factor que debe comentarse es que, también debido al régimen franquista, el reconocimiento legal de los partidos ocurrió tardíamente en España, es decir, juntamente con la transición política se inició también el proceso de constitucionalización de los partidos, reconociéndolos jurídicamente para posibilitar su consolidación dentro del nuevo régimen. ${ }^{60}$ Sin embargo, los dos eventos coinciden, culminando en la formación de un verdadero Estado de Partidos a partir de organizaciones que no pudieron ser consideradas de masas, pero sí que estaban ya sufriendo directamente el fenómeno de la moderación/difuminación de las ideologías de los partidos, o lo que vulgarmente se puede decir como "catcholización" 61 de las estructuras partidistas. ${ }^{62}$ Junto a ello, cabe recordar que el artículo 6ำ de la Constitución Española no contempla la financiación pública en su redacción final, aunque hayan existido enmiendas en ese sentido por parte de grupos parlamentarios en la Constituyente, generándose posteriormente nuevas discusiones acerca de la opción legislativa de la financiación pública como modelo absolutamente preponderante.

Antes de nada, es conveniente exponer que en el Decreto Ley 20/1977, al tratarse ante todo de una norma con carácter temporal/ocasional ${ }^{63}$, elaborada únicamente para instrumentalizar las primeras elecciones que elegirían las Cortes Generales en la transición política, no se hizo hincapié en

\footnotetext{
${ }^{60}$ Sobre el tema de la constitucionalidad de los partidos políticos, cfr. punto 1.1 del Capítulo I del presente trabajo.

${ }^{61}$ Gramaticalmente esta palabra no existe en el vocabulario español. Sin embargo, sirve para denominar el proceso por lo cual los partidos dejan de ser de masas y pasan a ser del modelo catch all. Acerca de este tipo de partidos, cfr. KIRCHHEIMER, O. "El Camino Hacia el Partido de Todo el Mundo". In: LENK, K.; NEUMANN, F. (eds.): Teoría y Sociología Críticas de los Partidos Políticos. Ed. Anagrama, Barcelona, 1980. Pp. 331. La traducción para el español sería de los partidos "de todo el mundo".

${ }^{62}$ RODRÍGUEZ DÍAZ recuerda que en el inicio de la transición política en España tuvo lugar el surgimiento de innumerables partidos, grupos y "grupúsculos", de dimensiones desproporcionadas. Sin embargo, en poco tiempo hubo un proceso de concentración de muchas de esas fuerzas, basadas más en personalidades locales o grupos que en alternativas políticas e ideológicas reales. Esto significó la reducción del número de partidos y, a nivel nacional, a menos de seis organizaciones. (In: RODRIGUEZ DIAZ, A.: Transición Política... Pp. 99-105).

63 FERNÁNDEZ SEGADO afirma que, aunque dicho Decreto-Ley tenía una vigencia determinada - o sea, las elecciones generales de 1977 - como todo sistema electoral, tiende a perpetuarse, y debido a ello la ley siguió siendo aplicada, justamente por los intereses en juego que había en caso de que fueran a hacer una reforma. Así, el autor destaca la parcialidad de la ley a favor de los grandes partidos y en contra de los competidores más débiles. (In: FERNANDEZ SEGADO, F.: Aproximación a la... Pp. 23).
} 
profundizar en la financiación de los partidos (como tampoco en los demás temas que se relacionan con el derecho de partidos). Y ello por una razón muy sencilla: lo realmente importante para los partidos en aquel momento era garantizar las subvenciones públicas para realizar la campaña electoral próxima, ya que todas las organizaciones carecían de recursos financieros en ese periodo. Con las subvenciones garantizadas por ley, aspectos como las donaciones privadas, los gastos electorales, la fiscalización y la transparencia de ese procedimiento pasaron a un segundo plano. ${ }^{64}$

En el mencionado Decreto-Ley tuvo lugar la primera aparición de los partidos políticos como "cuasi-constitucionales", siendo la primera norma electoral que se publica oficialmente y que acepta un sistema de sufragio electoral directo desde la II República. ${ }^{65}$

Así, brevemente y a través de 5 artículos, se puede decir que el Decreto Ley 20/1977 había regulado el régimen de financiación de los partidos, que en un futuro determinaría las bases del modelo actual.

Las subvenciones estatales para los gastos electorales serían concedidas a favor de los partidos que lograsen escaños bien en el Congreso, bien en el Senado, contabilizando solamente los votos que originasen dichos escaños en el cómputo de las subvenciones. ${ }^{66}$ Este criterio acabó por no

${ }^{64}$ Según ARNALDO ALCUBILLA, aunque dicho Decreto-Ley se constituyera como una ley preconstitucional aprobada solamente para las elecciones siguientes, la disposición 8.3 de la Constitución Española posibilitó su aplicación posterior, legitimando su vigencia incluso después del plazo anteriormente establecido por el hecho de que, siendo una norma electoral, fue aprobada como si fuera una Ley Orgánica. (In: ARNALDO ALCUBILLA, E. "Las Reformas Posibles del Régimen Electoral Español". In: Cuadernos de Derecho Judicial, no 11, 2001. Pp. 42-43).

${ }^{65}$ RODRIGUEZ DIAZ, Á.: Transición Política... Pp. 128-129. Sin embargo, el autor resalta que en esta norma no se verifica la incorporación de los partidos políticos como actores electorales, ya que la normativa presta atención en no llamarles así, sino que utiliza otros términos jurídicos para referirse a ellos, como "asociaciones", "federaciones" y "coaliciones". De hecho, entre las referencias que hace el Decreto-Ley de los partidos, la palabra "partido" solamente está insertada en los artículos 44.2 y 46.3, justamente la parte que trata de la financiación de los mismos. Con todo, prevalece la falta de reconocimiento expreso de los partidos. También es de resaltar que, para RODRÍGUEZ DÍAZ, el Decreto-Ley deja claro el protagonismo de los partidos políticos en las elecciones, tanto por el diseño del sistema electoral (como listas cerradas y bloqueadas) como también por disposiciones que destacan su papel en el proceso electoral, y por el sistema de reembolso de gastos que, según el autor, favorece sobre todo a los grandes partidos.

${ }^{66}$ En el art. 44 está descrito que cada escaño obtenido daba el derecho a un millón de pesetas, como también 45 pesetas por votos que generaron escaño en el Congreso de los Diputados, y 15 pesetas por votos en el Senado. Se nota que desde el principio el Senado ya sufriría una discriminación, en este aspecto algo que posteriormente se volvería común en todo el sistema de financiación. 
limitarse sólo a esta norma provisional, y se aplica en la actualidad, tanto en las leyes de financiación electoral como también en la ordinaria, y constantemente es blanco de críticas, dada la inequidad que provoca al diferenciar votos que deberían ser considerados iguales por completo, y también por perjudicar a los partidos que tienen actuación nacional, favoreciendo a los partidos de perfil regional. Está claro que dichas críticas se refuerzan dado el origen de la normativa en un periodo tan particular, como es la democratización del país. Instaurar diferencias entre votos de manera no claramente justificada es aún más peligroso cuando ni siquiera se cuenta con un comportamiento político a favor del voto o de los partidos. Así, no se pueden ahorrar críticas a esta parte del Decreto-Ley, y aún más por la continuidad de la medida. ${ }^{67}$

Una medida bastante particular se contempla en el art. 44.2, en el que el Estado da la posibilidad a los beneficiarios de las subvenciones de dirigirlas directamente a las instituciones financieras que eventualmente hayan realizado alguna negociación de anticipo de recursos o créditos, para posteriormente lo que reste de las subvenciones destinarse a las organizaciones políticas. Llama la atención que exista una previsión normativa sobre la posible realización de negociaciones de esta naturaleza, pero sin ningún otro criterio - como ocurre hasta el día de hoy - y ciertamente esta ausencia de reglas, junto con la autorización implícita a la existencia de créditos de las entidades bancarias como medio de la financiación de campañas ha fomentado el endeudamiento precoz de las fuerzas políticas, tan fragilizadas en 1977. Está claro que la preocupación principal era dotar a dichas fuerzas de las condiciones económicas necesarias para llevar a cabo las campañas de la época de la redemocratización, pero como tantas otras decisiones tomadas en este período, no se pensó en las consecuencias de dicha medida a largo plazo.

También se previeron una serie de medidas de financiación indirecta, como el derecho de los partidos a tarifas postales especiales para el envío de impresos de propaganda electoral, regularizado a través de orden ministerial; la posibilidad de utilización de locales públicos para la realización de actos electorales (con por candidatura, por un máximo de dos horas); la cesión por

${ }^{67}$ En este sentido, cfr. LOPEZ GARRIDO, D. "La Financiación de los Partidos Políticos. Diez Propuestas de Reforma". In: La Financiación de los Partidos Políticos. Cuadernos y Debates, no 47, Centro de Estudios Constitucionales, Madrid, 1994. Pp. 65. 
parte de los ayuntamientos de espacios gratuitos para carteles, sin límite geográfico, excepto los monumentos. ${ }^{68}$ Durante los 21 días en que quedaba establecida la duración de la campaña electoral, el acceso a los espacios en la televisión, radio y prensa de modo gratuito también se encontraba regulado, fijando también criterios de reparto de dichos espacios, incluyendo incluso las candidaturas de las agrupaciones de electores, lo que resulta significativo. Otro punto que llama la atención es que para la colocación de carteles, todas las candidaturas tienen el derecho a la misma superficie, dependiendo de las solicitudes realizadas por cada fuerza política. ${ }^{69}$ Se trata de una regla particularmente plural, considerando los rasgos básicos del modelo elegido. ${ }^{70}$

De manera concisa, el Decreto-Ley en cuestión preveía una fiscalización de los gastos de los partidos bajo responsabilidad de la Junta Electoral Central, o de las juntas provinciales en el caso de candidaturas independientes o partidos que presentaran su candidatura en un solo distrito. Era obligatorio mantener una contabilidad especial y documentada de los gastos de la presentación de candidaturas y de la propaganda electoral, teniendo en cuenta que la correspondiente junta electoral debería pronunciarse sobre la regularidad de las cuentas en el plazo de treinta días, rindiendo cuentas públicas transcurrido dicho plazo. ${ }^{71}$ Sin embargo, la medida no estaba acompañada de eventuales sanciones en caso de su incumplimiento o de irregularidades constatadas, y mucho menos de los procedimientos que deberían adaptarse para esta fiscalización. Lo único que podía ocurrir era que el supuesto pasase a la jurisdicción competente (sin especificar cuál) para la depuración de eventuales responsabilidades. Esto demuestra la fragilidad de la

\footnotetext{
${ }^{68}$ Dichas disposiciones se encuentran respectivamente en: art. 44.3; 41.1; 39.2; y 41 . En este sentido, cfr. CASTILLO, P. del. "La Financiación Pública de los Partidos Políticos y su Impacto en las Instituciones Representativas". In: GARRORENA MORALES, A. (ed.): El Parlamento y sus Transformaciones Actuales - Jornadas Organizadas por la Asamblea Regional de Murcia (11-13 de abril de 1988), ed. Tecnos, Madrid, 1990. Pp. 262. También sobre el tema, véase: GARCIA VIÑUELA, E.; ARTÉS CASELLES, J. "La Financiación de las Elecciones Generales en España, 1977-2000". In: Documentos - Universidad Complutense de Madrid. Instituto de Estudios Fiscales, no 24, Madrid, 2004. Pp. 6.

${ }^{69}$ Cfr. 39.2.

${ }^{70}$ Ya en la LOREG, esto cambiaría para la distribución de espacios conforme la cantidad de votos obtenidos en las elecciones anteriores.

${ }^{71}$ Como el Decreto-Ley determina que la junta electoral correspondiente podrá hacer públicos los "datos que estimen oportunos", DEL CASTILLO afirma que sólo se divulgaba la cuantía de los fondos electorales, sin decir las fuentes de recursos o la identidad de donantes. (In: CASTILLO, P. del. "La Financiación Pública de los Partidos Políticos..." Pp. 265).
} 
regla y su inevitable ineficacia. Además, aunque dicha norma tuviera un carácter provisional, se procedió mal desde el inicio, porque si los partidos se sintieron libres para actuar como quisieran con relación a su financiación electoral desde la primera normativa sobre el tema, posteriormente revertir la situación sería muy complicado, como pronto pudo constatarse. La ausencia de una normativa que realmente compeliera a los partidos a comportarse dentro de la legalidad bajo el riesgo de la aplicación de alguna sanción de real carácter punitivo acabó por hacer que se sintieran como "super-partes", autorizados a proceder de la manera que más convenía a sus intereses o necesidades económicas. Los daños de esta negligencia resultan aun visibles.

En cuanto a los procedimientos para la gestión de los recursos recaudados por los partidos en sus campañas, la norma determinaba la apertura de cuentas bancarias específicas para este fin, con la identificación de los donantes con su nombre, domicilio y la cuantía de la aportación. La apertura de dichas cuentas era obligatoria, como sigue siendo en la LOREG. La correspondiente identificación del donante en el caso de aportaciones privadas también estaba prevista en la ley y, en caso de recursos aportados por el partido, este debería señalar el origen del mismo. Cabe subrayar que, respecto a las donaciones privadas, no existía un límite máximo, resultando prohibidas solamente las aportaciones realizadas por administraciones del Estado, entidades locales, organismos autónomos, entidades paraestatales, empresas nacionales, provinciales, municipales y de economía mixta, así como las entidades o personas extranjeras. La responsabilidad por los recursos de las cuentas sería del titular, respondiendo por cualquier fondo de procedencia ilícita o prohibida, y las juntas electorales podrían, en principio, solicitar datos sobre los valores a las entidades financieras en cualquier momento. Por otra, dichos recursos sólo podrían ser destinados a los gastos de presentación y proclamación de candidatos y a la propaganda electoral, teniendo en cuenta que, pasadas las elecciones, el saldo positivo de las cuentas no podría ser utilizado antes de la declaración de regularidad de éstos por parte de la junta.

Considerando la normativa en su conjunto, se puede afirmar que dichas medidas muy posiblemente fueron sistemáticamente violadas, justamente por la debilidad del sistema de fiscalización antes descrito, y por la inexistencia de 
sanciones en caso de incumplimiento de dichas reglas. Se trató de una norma de carácter provisional, que acabó por establecer muchos de las debilidades que hasta hoy afectan a la financiación electoral de los partidos. Es fácilmente perceptible que la norma, además de ser demasiado concisa, no se pronuncia en cuestiones claves, como el del hipotético límite para las donaciones privadas o las sanciones para casos de ilegalidades o irregularidades en los gastos electorales.

También está claro que muchas cuestiones de dudosa oportunidad de la ley actual ya se encontraban en la legislación desde la época de la transición, como es el caso del doble criterio para el acceso a las subvenciones estatales. Entretanto, en ese caso, dicho criterio combinado fue adoptado porque en la transición se temía que hubiera una proliferación de partidos, causando problemas de gobernabilidad y fragmentación parlamentaria, fenómenos que no ayudarían a estabilizar un sistema de partidos en una democracia recién restaurada. ${ }^{72}$ No obstante, considerando la época en que dicha norma fue aprobada y su importancia dentro de la reinstauración democrática en el país, parece claro que la insuficiencia en sus disposiciones fue consciente y no involuntaria, y que desde el inicio de la transición los grupos políticos mayoritarios pudieran obtener ventajas a largo plazo.

Por otra parte, un hecho que llama la atención es que, en la época en que se discutía la reforma de la legislación electoral, algunos puntos que siguen constituyendo objeto de debate hoy en día ya habían aparecido, reflejando que poco tiempo después de la aplicación del Decreto-Ley 20/1977 algunas consecuencias de su funcionamiento ya habían sido identificadas. Así, no solamente las exigencias constitucionales en torno al rango normativo para la regulación del sistema electoral fueron los responsables del retraso en la aprobación de la siguiente ley electoral ${ }^{73}$, sino que también el enfrentamiento

\footnotetext{
72 JIMÉNEZ CAMPO entiende que la financiación de los partidos políticos no puede ser tratada como un factor más de estabilidad política, a la vez que la estabilidad parlamentaria no constituye un principio constitucional, mientras que otros principios involucrados con la financiación sí lo son. (JIMÉNEZ CAMPO, J. "Los Partidos Políticos en la Jurisprudencia Constitucional". In: GONZÁLEZ ENCINAR, J. J. (coord.). Derecho de Partidos. Espasa-Calpe, Madrid, 1992. Pp. 224).

${ }^{73}$ Según AZPITARTE SÁNCHEZ, aunque es recomendable la rigidez constitucional para que el sistema electoral se quede a merced de las pretensiones de cualquier gobierno en un determinado momento, también es un hecho que un menor grado en esta rigidez colabora para
} 
con tales temas fue de difícil manejo. La doctrina, por su parte, sugería que la nueva ley electoral debería atenuar las desigualdades de representación producidas por el modelo del Decreto-Ley; permitir un mayor protagonismo de los electores a través de mecanismos de personificación de la representación adoptar una distinta fórmula electoral para el Senado. ${ }^{74}$

Es un hecho que la evolución histórica en el futuro es determinante para consolidar el resultado y hacer más difícil un cambio, y los partidos hegemónicos tenían conocimiento de ello. En resumen, lo que es posible constatar es que tanto el sistema electoral como el propio sistema de financiación de las fuerzas políticas fueron estructurados para tener una fuerza centrípeta, sin mayor apertura hacia un pluralismo partidista que se juzgó disfuncional cuando no peligroso.

\subsubsection{La LOREG - Ley Orgánica $5 / 1985$ de 19 de Junio}

Como es sabido, el Decreto-Ley 20/1977 terminó por estar vigente en el sistema español mucho más tiempo de lo inicialmente previsto, generando disfuncionalidades justamente por sus diversas lagunas. ${ }^{75}$ En las elecciones

\footnotetext{
su adaptación a los cambios producidos en la sociedad. (In: AZPITARTE SÁNCHEZ, M. "La Dimensión Constitucional del Procedimiento Electoral”. In: Teoría y Realidad Constitucional. no 11-12, $1^{\circ}$ semestre. UNED, Madrid, 2002-2003. Pp. 443). Dicha condición fue ampliamente abordada en el informe elaborado por el Consejo del Estado para la reforma de la LOREG, en 2011.

${ }^{74}$ Cfr. JIMENEZ DE CISNEROS CID, F. J.: Op. Cit. Pp. 49-50. Acorde con estas sugerencias, hubo también una proposición de ley de modificación del Decreto-Ley, presentada por el Grupo Centrista, en 1 de septiembre de 1981.

${ }^{75}$ CAZORLA PRIETO afirma que el preámbulo de la LOREG se constituye como una respuesta a la experiencia del art. 81 de la Constitución Española, de aprobar una ley orgánica en sustitución al Decreto-Ley 20/1977. Pero dicho artículo constitucional despertó diversas interpretaciones, motivando un pronunciamiento del Vicepresidente del Gobierno, señor Guerra González, que resaltó: "Como saben SS.SS., la normativa que ha seguido vigente en las anteriores elecciones de 1977 con ese Decreto-Ley y posteriormente la Constitución, en 1978, estableció un mandato a las Cámaras para elaborar una ley orgánica del régimen electoral general. Así se decía exactamente en el artículo 81 de la Constitución. Sin embargo, establecía una disposición transitoria, octava, en su número 3, que permitía que, en el caso de disolución anticipada, se pudiera todavía celebrar las elecciones siguiendo la normativa del Decreto-Ley de marzo de1977. Así ocurrió en el año 1977, en que fueron disueltas las Cámaras antes de desarrollar los artículos 68 y 69 de la Constitución en materia electoral, y, por tanto, en el año 1979 se sigue con la misma normativa. En la siguiente legislatura, sin embargo, era obligado que para las futuras elecciones se elaborara esta Ley Orgánica del Régimen Electoral General; no se hizo así y en 1982, en octubre, se acudió a otro proceso electoral siguiendo la normativa entonces no se sabe bien si vigente, aunque sólo fuera por el horror al vacío jurídico que se puede argumentar". (In: CAZORLA PRIETO, L. M. "Preámbulo". In: CAZORLA PRIETO, L. M.
} 
que siguieron a las de 1977 surgieron nuevos problemas, y por diversas circunstancias, el Decreto-Ley siguió siendo aplicado hasta el punto de no ser posible mantenerlo.

\section{a) La aprobación de la normativa, su estructura y reformas}

La doctrina apunta múltiples causas para el surgimiento de la LOREG, entre ellas también pudo jugar sus papeles la revelación de casos de corrupción sobre la financiación de los partidos políticos aun bajo el soporte económico del Estado. Los recursos no fueron suficientes para costear los crecientes gastos de los partidos, y no quedó otra alternativa que cambiar la legislación relacionada con este punto. Con el cambio en la legislación, la financiación pública se consolidó en el sistema español, con un incremento importantísimo de las subvenciones anuales, contabilizando tanto la electoral como la ordinaria. ${ }^{76}$ En todo caso, la aprobación de la LOREG es consecuencia en gran parte de la necesidad de aprobar una ley de incompatibilidad de diputados y senadores, que a la vez es fruto del artículo 70 de la Constitución Española con conocida interpretación del Tribunal Constitucional proferida en la STC $72 / 84^{77}$ de 14 de junio. ${ }^{78}$ Así, fue por determinación del Tribunal

(dir.): Comentarios a la Ley Orgánica del Régimen Electoral General. Ed. Civitas, Madrid, 1986. Pp. 25-26). Es de resaltar que el diputado Alzaga Villaamil mantuvo el Decreto-Ley 20/77 ya se encontraba derogado por la disposición transitoria 8.3 de la Constitución Española.

76 DÍAZ-SANTANA CASTAÑOS, H. Op. Cit. Pp. 174.

${ }^{77} \mathrm{La}$ rreferida sentencia trata de un recurso previo de inconstitucionalidad, donde el punto central está en fijar las inelegibilidades e incompatibilidades de diputados y senadores en la Ley Electoral, conforme dispone el art. 70 de la Constitución Española. Sin embargo, el Tribunal Constitucional entiende que, para que una ley pueda ser considerada electoral (ya que el art. 70 hace justamente esta reserva de ley), en palabras del Tribunal, "es necesario que contenga por lo menos el núcleo central de la normativa atinente al proceso electoral, materia en la que se comprende lo relativo a quiénes pueden elegir, a quiénes se puede elegir y bajo qué condiciones, para qué espacio de tiempo y bajo qué criterios organizativos desde el punto de vista procedimental y territorial". Así, "existe un contenido esencial de la Ley Electoral que no se cumple cuando el legislador se milita a establecer las incompatibilidades de Diputados y Senadores, sino cuando regula las antes referidas materias". (F.J. 4). Según ARNALDO ALCUBILLA, en esta sentencia, el Tribunal Constitucional acabó por exceder sus competencias porque, en su opinión, el Tribunal opinó políticamente por sus preferencias legislativas. (In: ARNALDO ALCUBILLA, E. "Las Reformas Posibles..." Pp. 44).

${ }^{78}$ RODRIGUEZ-VERGARA DÍAZ, A. "El Estado de Partidos y Algunas Cuestiones de Derecho Electoral". In: La Evolución del Derecho en los Diez Últimos Años. Ed. Tecnos, Madrid, 1992. Pp. 404-405. Argumenta también en este mismo sentido BASSOLS COMA. Así, cfr. BASSOLS COMA, M. "El Sistema Electoral Español: Balance y Perspectivas". In: PAU I VALL, F. (coord.): Parlamento y Sistema Electoral - VI Jornadas de la Asociación Española de Letrados de Parlamentos. ed. Aranzadi, Pamplona, 1999. Pp. 32-33. 
Constitucional por lo que se aprobó la LOREG, incluyendo puntos que el Decreto-Ley 20/1977 debería haber previsto, y también aportando cambios importantes, como ocurrió con el tema de la financiación de partidos.

En este período, se llegó a discutir sobre la relevancia de prever en la Ley Electoral reglas sobre la financiación de los partidos, incluso con la presentación de una enmienda ( $n^{\circ}$ 613) en la discusión del anteproyecto en el Pleno, que suprimía el capítulo dedicado a los gastos y subvenciones electorales a los partidos. La justificación de tal enmienda era que se pensaba que sería mejor redactar una ley específica sobre el tema de la financiación, buscando la unificación de la legislación. Al final, se optó por la retirada de la enmienda, debido al hecho de que la preocupación por la limitación y la posible reducción de los gastos electorales fue mayor, y se concluyó que dichas medidas deberían estar en vigor justo para las elecciones siguientes. Considerando estos hechos, se podría pensar que las reglas sobre financiación electoral tendrían carácter provisional, lo que no se confirmó, porque durante toda su vigencia no se produjo la pretendida unificación de las reglas de financiación, como tampoco sufrieron estos cambios significativos. ${ }^{79}$

Dicha unificación del conjunto normativo sobre la materia fue apuntada ya en distintas ocasiones, pese al silencio de la Constitución a este respecto. ${ }^{80}$ Aquí cabe destacar que con ocasión de la aprobación de la actualmente vigente Ley Orgánica 6/2002 también se produjo la misma discusión sobre una eventual inclusión de las reglas de financiación de partidos en la propia ley de partidos, amparada incluso por la sugerencia hecha por el Consejo del Estado (aunque de forma discreta ${ }^{81}$ ), pero al final resultó indiferente, pues debido a la urgencia en la aprobación de dicha ley dada la proximidad de las elecciones municipales, el debate fue minimizado, siguiendo separadas ambas

\footnotetext{
${ }^{79}$ CORTÉS BURETA, P: Recursos Públicos y Partidos Políticos... Pp. 79.

${ }^{80}$ ÁLVAREZ CONDE, E. "Algunas Propuestas sobre la Financiación de los Partidos Políticos". In: AA. VV.: La Financiación de los Partidos Políticos. Cuadernos y Debates, no 47, Centro de Estudios Constitucionales, Madrid, 1994. Pp. 28-29.

${ }^{81}$ De hecho, el Consejo del Estado resaltó que las disposiciones de la Ley Orgánica 54/1978 eran insuficientes, y que el esfuerzo de la jurisprudencia por "completar" dichas disposiciones dejaban clara esta insuficiencia, además de la falta de pretensión "codificadora" de dicho anteproyecto. Por lo tanto, en lugar de contener solamente un artículo remitiendo la materia de la financiación de partidos para la Ley Orgánica 3/1987 (como sigue constando en la ley de partidos en vigor), la materia debería ser pormenorizada. Sin embargo, la apelación no tuvo éxito. (In: http://www.boe.es/aeboe/consultas/bases_datos_ce/doc.php?coleccion=ce\&id=2002$911<<$ Acceso en 16.01.2012>>).
} 
legislaciones, al igual que sucede con la separación entre financiación electoral y ordinaria, que, como se verá, posee un alto nivel de ambigüedad. ${ }^{82}$

Otro punto que merece la pena destacarse es la falta de modificaciones importantes entre el Decreto-Ley 20/1977 y la LOREG, ya que era una buena oportunidad para aprobar una normativa capaz de atender a las necesidades del sistema existente post-transición. Con todo, aunque se pueda mantener que entre el Decreto-Ley 20/1977 y la LOREG no hay diferencias sustanciales, existen autores que consideran que se produjo una uniformización de la legislación, considerando que existían otras normas que trataban de temas electorales y que se encontraban dispersas. Pero está claro que no se aprobó una nueva ley electoral, sino una ley que se caracteriza por la continuidad ${ }^{83}$ de las reglas contenidas en la legislación anterior. ${ }^{84}$ Este es un dato muy importante en el momento de analizar la LOREG, pues aunque se utilicen criterios eminentemente jurídicos para realizar dicha tarea, no se puede olvidar que la LOREG es directamente deudora del Real Decreto-Ley 20/1977 y, que por lo tanto, su aprobación estuvo muy relacionada a aquel momento político. ${ }^{85}$ El espíritu del Decreto-Ley 20/1977 sigue en la LOREG, pero para algunos autores esto no se debe a una supuesta inercia del legislador, sino a una clara voluntad política del mismo, como demostrarían las declaraciones de

\footnotetext{
${ }^{82}$ Sobre el tema, véase: MARTín DE LA VEGA, A. "Los Partidos Políticos y la Constitución de 1978. Libertad de Creación y Organización de los Partidos en la Ley Orgánica 6/2002". In: Revista Jurídica de Castilla y León, no extraordinario, enero, 2004. Pp. 212; ALVARÉZ CONDE, E "Veinticinco Años de Derecho de Partidos". In: PEÑA GONZÁLEZ, J. (Coord.): Libro Homenaje a Iñigo Cavero Lataillade. ed. Tirant lo Blanch, Valencia, 2005. Pp. 74 e IGLESIAS BARÉZ, Mercedes: La llegalización de Partidos Políticos en el Ordenamiento Jurídico Español. Comares, Granada, 2008. Pp. 4. Sobre la separación entre financiación electoral y ordinaria, véase punto 3.3 de este capítulo.

${ }^{83}$ En este sentido, cfr. GAVARA DE CARA, J. C. "La Distribución de Competencias en Materia Electoral en el Estado de las Autonomías". In: Cuadernos de Derecho Público. № 22-23. may/dic. Madrid, 2004. Pp. 57.

${ }^{84}$ FERNANDEZ SEGADO, F.: Aproximación a la... Pp.26-47. Sin embargo, el autor todavía mantiene su posición en el sentido de que hubo una innovación por parte de la LOREG en comparación con el Decreto-Ley 20/77, ya que la LOREG trae la ordenación de los gastos y subvenciones electorales, así como reglas de control. Con todo, la mayor innovación está en la limitación de los gastos. También en este sentido, cfr. ARNALDO ALCUBILLA, que afirma que la LOREG puede ser definida como una "sistematización y unificación de normas que antes existían en forma dispersa", pero que no significa una reforma en las normas electorales. Así, véase: ARNALDO ALCUBILLA, E.: El Régimen Electoral de España. Ed. Imprenta Nacional BOE - Centro de Estudios Políticos y Constitucionales, Madrid, 1999. Pp. 23.

${ }^{85}$ ALVAREZ CONDE, E. "Las Reformas Estatutarias y los Sistemas Electorales Autonómicos". In: Cuadernos Constitucionales de la Cátedra Fadrique Furió Ceriol, № 60/61, Valencia, 2007. Pp. 5.
} 
muchos diputados en las sesiones parlamentarias ${ }^{86}$ de la LOREG.$^{87}$ Se trataría, así, no de decisiones mal tomadas o no tomadas, sino de una voluntad de mantener el status del sistema de partidos del momento. ${ }^{88}$ Pese a ello, otros autores consideran la permanencia de las bases del Decreto-Ley 20/1977 en la LOREG como positiva, porque la LOREG respondería a una voluntad codificadora que integraría en un texto único normas de todos los procesos electorales. Por ello, la LOREG no correspondería a una reforma del sistema, sino a la reproducción del contenido de la norma anterior de modo unificado y sistematizado. ${ }^{89}$

${ }^{86}$ Aquí se pueden exponer el pronunciamiento de Alfonso Guerra, y una opinión en contra, la
del diputado Bandrés, que afirmó que no hubo una reforma, porque todos estaban conformes
con su funcionamiento, alejando a descontentos y $\sin$ profundizando la legitimidad del sistema,
cfr. CAZORLA PRIETO, L. M."Preámbulo. Op. Cit." Pp. 27). Ya en tono de justificación, se cita
al pronunciamiento del vicepresidente del Gobierno, Alfonso Guerra, que justificó la semejanza
entre las normas diciendo que, si los españoles han aprendido a votar bajo los preceptos del
Decreto-Ley 20/1977, no sería tarea fácil reformar todo el sistema en la LOREG, la vinculación
entre mencionadas normas sería, en su opinión, necesaria. (In: RODRIGUEZ-VERGARA DÍAZ, A. Op. Cit. Pp. 405). En misma línea, cfr. BASSOLS COMA, M. Op. Cit. Pp. 34.

87 RODRIGUEZ-VERGARA DíAZ, Á. Op. Cit. Pp. 405. A la vez, PAJARES MONTOLío entiende que, aunque después de la STC 72/84 el Gobierno tenga enviado a las Cortes Generales el proyecto de lo que sería la futura LOREG casi de manera obligatoria, dicho procedimiento tiene otras características, como el marco del consenso en su aprobación por los partidos políticos mayoritarios ( $1^{\circ}$ votación: total de 243 votos, 239 favorables, 2 contra y 2 abstenciones; 2o votación: total de 265 votos, 261 a favor, 1 contra, 3 abstenciones). Además, el autor entiende que no puede ser considerada continuista porque hubo mejoras significativas de las reglas en comparación con las normas preconstitucionales, como también tiene la estructura de un código electoral, que intenta superar la fragmentación existente en la materia. (In: PAJARES MONTOLIO, E.: La Financiación de las... Pp. 54-55).

${ }^{88}$ Considerando el entendimiento de RODRíGUEZ VERGARA DíAZ de que el art'6o de la Constitución Española posee dos principios, el principio de la constitucionalización de los partidos (correspondiente al primer párrafo, como una justificativa de la razón que los partidos están en la Constitución Española) y el principio de la constitucionalidad de los mismos (traducido en el segundo párrafo, que implicaría que para considerar a los partidos constitucionales, deben cumplir determinadas tareas), el autor opina que la LOREG confirma el principio de la constitucionalización de los partidos, destacando su protagonismo en todo el proceso electoral, pero no confirma el principio de constitucionalidad de los mismos. (RODRIGUEZ-VERGARA DÍAZ, Á. Op. Cit. Pp. 405-407). También, SOLER SÁNCHEZ enumera las funciones principales de los partidos en la normativa electoral en España, siendo estas: los prioritariamente legitimados para presentar candidaturas; los que elaboran y aprueban programas electorales y fijan la estrategia (o agenda) de campaña y determinan los temas relevantes a ser discutidos; los que determinan qué afiliados y simpatizantes participan en la campaña y cómo lo harán, dentro de su maquinaria que apoya líderes y candidatos ante el electorado; y los que también fiscalizan el proceso electoral y la votación; también están legitimados para interponer recursos en derecho electoral, así como interpretan los resultados electorales ante la opinión pública, como "campaña post-electoral". (In: SOLER SÁNCHEZ, M.: Campañas Electorales y Democracia en España. Universitat Jaime, [s.I.], 2001. Pp. 56-57).

89 ARNALDO ALCUBILLA, E. "Las Reformas Posibles..." Pp. 45-47. Con todo, no hay unanimidad sobre la inclusión de la financiación electoral de los partidos en una ley electoral, porque hay autores que consideran la materia, como no electoral strictu sensu. Así, el proyecto de la LOREG sufrió enmiendas en este sentido. Así, cfr. MARIN ARIAS, M. "Arts. 121 al 134". 
Pero, independientemente de esta cuestión, la LOREG es la responsable de regular el proceso electoral hasta el día de hoy, sobreviviendo a diversas reformas ${ }^{90}$, incluso en la parte que se refiere al sistema de financiación de partidos políticos, que ha sufrido cambios significativos en esos 25 años de vigencia. ${ }^{91}$ Se puede afirmar que dichas reformas no han sido de carácter estructural, sino más bien motivadas por necesidades de los sucesivos procesos electorales, con algunas excepciones como la reforma que atendió a las modificaciones introducidas por la Ley Orgánica 6/2002. ${ }^{92}$

Con la aprobación de la LOREG, la normativa electoral adquirió un carácter mucho más detallado y completo, atendiendo a muchas de las cuestiones que estaban ausentes en la normativa anterior, además de agregar algunos puntos referentes a temas que surgieron en los años de vigencia del Decreto-Ley y que carecían de solución legal, siendo decididos a partir de interpretaciones judiciales. De esta manera, se puede entender que la LOREG, en nuestro tema de investigación, fue establecida bajo cuatro principios, siendo uno el de la compensación parcial del coste de las elecciones por el Estado; el segundo, la imposición de límites para el gasto electoral; el tercero, la consecuente limitación de las contribuciones privadas; y el cuarto, la fiscalización y publicidad de la contabilidad de los partidos políticos que reciben subvención estatal. Todo ello bajo la justificación de la búsqueda de la equidad y la prevención de la corrupción. ${ }^{93}$

In: CAZORLA PRIETO, L. M. (dir.): Comentarios a la Ley Orgánica del Régimen Electoral General. Ed. Civitas, Madrid, 1986. Pp. 1031.

${ }^{90}$ ARTÉS CASELLES y GARCÍA VIÑUELA, al analizar las reformas en la LOREG llevadas a cabo en los 90 sobre gastos electorales, afirman que los partidos que las apoyaron fueron beneficiados directamente al solucionar sus problemas financieros y al mismo tiempo intentar mejorar su imagen dañada por los diversos escándalos involucrando casos de financiación irregular en los ochenta. Esto, según los autores, provocó un avance que fue la limitación de gastos electorales, que antes no era posible por la falta de motivación que los partidos tenían para controlar sus gastos. (In: ARTÉS CASELLES, J.; GARCÍA VIÑUELA, E. "La Economía Política de las Reformas de la Financiación Electoral". In: Revista Española de Ciencia Política. no 15, octubre, 2006. Pp. 48-49).

${ }^{91}$ ARNALDO ALCUBILLA cita ocho reformas parciales en la LOREG (hasta 2001), en las que el autor destaca el consenso generalizado. Hubo por parte de la Coalición Popular (grupo parlamentario) un intento de reducir gastos electorales y reducir también los adelantos, pero no hubo aprobación de la iniciativa. (In: ARNALDO ALCUBILLA, E. "Las Reformas Posibles..." Pp. 51-54). Las reformas que se vinculan al tema de la financiación de partidos son: Ley Orgánica $1 / 87,8 / 91,13 / 94$ y $1 / 03$.

${ }^{92}$ ALVAREZ CONDE, E. "Las Reformas Estatutarias..." Pp. 6-7.

${ }^{93}$ ARTÉS CASELLES, J; GARCíA VIÑUELA, E. Op. Cit. Pp. 49. 
Recientemente en 2011 la LOREG sufrió cambios significativos, reflejando lo que supuestamente sería el "compromiso de los mismos [partidos] con la reducción del gasto en la actual situación de crisis económica". Dicha afirmación consta en la Exposición de Motivos de la Ley Orgánica 02/2011 de 28 de enero, responsable de dicha reforma. ${ }^{94}$ Debido a ello, la presente exposición tratará las nuevas disposiciones conjuntamente con sus disposiciones anteriores, a fin de intentar realizar un pronóstico sobre la posibilidad de realización efectiva de los cambios que la reforma ha objetivado. ${ }^{95}$ Sin embargo, puede subrayarse ya que los cambios aplicados no atienden a la necesidad de equiparación de dichas normas con las reglas contenidas en la Ley Orgánica 8/2007, lo que no deja de ser un elemento negativo. ${ }^{96}$

\section{b) El administrador electoral y la organización de la contabilidad de} la campaña

La LOREG comienza su regulación sobre la financiación electoral a partir de la obligatoriedad del nombramiento de un administrador electoral, que será el responsable por todos los ingresos y gastos habidos durante el periodo de campaña. Si la fuerza política cuenta con candidaturas en más de una provincia, deberá también tener un administrador general. Además, la contabilidad deberá seguir el Plan General de Contabilidad ${ }^{97}$ vigente (en este

\footnotetext{
${ }^{94}$ En esta parte, la Exposición de Motivos cita la ley también reciente 8/2007 de financiación de partidos, encajándolas en el nuevo contexto económico de España, donde la crisis presiona el erario público.

${ }_{95}$ Cabe subrayar que la Ley Orgánica 3/2011, de 28 de enero, que también reformó la LOREG no tiene disposiciones que se refieran a la financiación electoral de los partidos. Por ello no será tratada aquí.

${ }_{96}$ En este sentido, estoy de acuerdo con SÁNCHEZ MUÑOZ in: SANCHÉZ MUÑOZ, Ó. "Cuestiones Relativas a la Financiación de los Gastos Electorales y al Desarrollo de Comunicación". In: AA.VV.: El Informe del Consejo de Estado sobre la Reforma Electoral. CEPC, Madrid, 2009. Pp. 625.

97 PAJARES MONTOLIO entiende que este Plan General de Contabilidad no debería ser utilizado en los partidos porque no se corresponde con su naturaleza, y tampoco con la naturaleza de las operaciones realizadas por los mismos durante el proceso electoral. (In: PAJARES MONTOLIO, E.: La Financiación de las... Pp. 331). También, GOMEZ SÁNCHEZ afirma que, como las finanzas de los partidos se someten a los principios generales contenidos en el Plan General de Contabilidad, y no al Plan General propiamente dicho, esto acaba por generar una inseguridad contable, la cual también está parcialmente transferida para la contabilidad de la financiación ordinaria de los partidos. (In: GÓMEZ SANCHEZ, Y.: El Tribunal
} 
caso, sería el PGC 2007, ya adaptado al PGC internacional y regulado por el RC 1514/2007). No se trata de la misma sistemática para el control de la financiación ordinaria de los partidos, reflejada en la Ley Orgánica 8/2007, ya que esta dispone sobre un plan de contabilidad específico para los partidos, elaborado por el Tribunal de Cuentas, órgano responsable de esta fiscalización. Ambas soluciones acarrean problemas, porque no es solo el control contable el que acaba por no ser uniforme y por no atender a los mismos parámetros, sino que puede ser que por lo mismo los datos aportados por los partidos no atiendan ni a uno ni a otro. La "confusión" en el mantenimiento y organización de los datos contables de los partidos es una constante, y la uniformización de normas podría colaborar en simplificar este procedimiento, o por lo menos no lo complicaría. ${ }^{98}$ Por otra parte, si el Plan General de Contabilidad se dirige en mayor medida a las empresas y asociaciones privadas (algo que se corresponde del todo con la naturaleza jurídica de los partidos), el Plan de Contabilidad específico para los partidos todavía no ha sido aprobado por el Tribunal de Cuentas, que, a fecha de hoy, únicamente ha organizado un grupo de trabajo para dicho fin. ${ }^{99}$ Cabe subrayar que el plazo previsto en la ley para la elaboración y aprobación de dicho plan de contabilidad era de 6 meses desde la aprobación de la referida norma, no habiéndose respetado dicho tiempo. ${ }^{100}$

El administrador puede ser cualquier ciudadano, menos los candidatos, que son los únicos vedados para el ejercicio de esta función. Esta prohibición de que los candidatos puedan ejercer esta tarea parece no tener mucha razón de ser, porque en muchos sistemas electorales internacionales, los candidatos desempeñan también esta función, como también son responsables por

de Cuentas: El Control Económico - Financiero Externo en el Ordenamiento Constitucional Español. Universidad Nacional de Educación a Distancia. Ed. Marcial Pons, Madrid, 2001, Pp. 245-246). Y dicha inseguridad puede ser que aumente con el plan general que deberá ser elaborado por dicho tribunal para la fiscalización de la financiación ordinaria de los partidos políticos, todavía no aprobado.

${ }^{8}$ Además, pienso que la oportunidad para la uniformización de dichas normas debería ser justamente con la reforma de la LOREG recién aprobada, pues si la ley de financiación ordinaria de partidos tiene fecha de 2007, ya era de conocimiento del Parlamento este dato. Esto demuestra que, o hubo la falta de iniciativa para la uniformización, o simplemente falta de atención al tema de la fiscalización de partidos, hipótesis esa bastante frecuente cuando se trata de la materia.

${ }_{99}$ Resolución de 18 de abril de 2011 del Instituto de Contabilidad y Auditoría de Cuentas del Tribunal de Cuentas.

${ }^{100}$ Conforme disposición adicional octava de la Ley Orgánica 8/2007. 
cualquier irregularidad detectada en las finanzas de sus campañas. Por un lado, está bien que se comparta la responsabilidad por eventuales irregularidades con los candidatos, porque son ellos los principalmente beneficiarios de los recursos que integran sus campañas. Sin embargo, quizás en España sea así por la fuerza que los partidos tienen, dada la configuración de las candidaturas en listas cerradas y bloqueadas, lo que demuestra que el sistema se centra en la institución partidista, sin un perfil excesivamente personalista. ${ }^{101}$

Junto con la obligatoriedad del nombramiento de un administrador electoral, existe también el deber de la apertura de cuentas bancarias específicas para el flujo de ingresos y gastos a titulo de campaña electoral por parte de las fuerzas políticas. Al final del proceso electoral, el saldo positivo de dichas cuentas solamente podrá ser utilizado en gastos electorales previamente contraídos únicamente en los 90 días siguientes a la fecha de votación. Esta regla implica una laguna importante que permite que donaciones privadas a través de bienes y servicios se efectúen de manera que defraudan la ley, pues basta con que una empresa preste algún tipo de servicio que se configure como un gasto electoral, y que no sea pagada, para que esto pueda figurar como una donación. De igual forma que ocurre con los créditos concedidos a los partidos - como se verá - considerando que después de los 60 días siguientes a la votación, no se podrá reclamar el pago de dichos gastos. Parece una laguna intencional para que sean realizadas donaciones fuera del régimen dispuesto en la normativa, y que debido a ello sería más adecuado su exclusión, pues como para cualquier otro sujeto que presta algún servicio, la deuda debe ser pagada por parte del partido o de su beneficiario, no simplemente ser declarada nula y no pagadera, en los términos del art. 125.4.

\section{c) La financiación privada de la campaña electoral}

Acompañando a las demás normas sobre el tema, la LOREG trata brevemente sobre la financiación privada para las campañas electorales. Son

101 Como ejemplo de sistema que también responsabiliza el candidato por eventuales irregularidades, se puede citar a Brasil. Con todo, este país cuenta con un sistema altamente personalista, donde los partidos en general carecen de fuerza. 
solamente tres los apartados que directamente se relacionan con la materia y consagran un régimen considerablemente rígido que inclina todo el sistema hacia la financiación pública.

Son interesantes las reglas del art. 126 y sus 3 apartados, donde consta la obligatoriedad de identificación de los que aporten recursos a dichas cuentas bancarias de los partidos. Es necesario que se informe del número del documento nacional de identidad o pasaporte, nombre, y domicilio a la entidad financiera. Si la titularidad del envío de recursos correspondiera a una persona jurídica, u otra persona física, deberá igualmente constar sus nombres, como también en el caso de que el ingreso sea hecho por el partido. ${ }^{102}$ La regla estaría de acuerdo con los parámetros de publicidad de datos, tan necesaria en el caso de la financiación de partidos, pero pierde su razón de ser cuando se piensa que dichos datos están protegidos por la Ley Orgánica de protección de datos personales bancarios, y que siempre que el Tribunal de Cuentas solicita informaciones a las entidades bancarias sobre esto (o también sobre las operaciones de crédito que realizan con los propios partidos, como se verá), acaba por no ser atendida justamente porque existen estos bloqueos legales para el acceso de datos. Al fin, los datos solo constan para las entidades bancarias, sin que sirvan para su finalidad real, que sería la de control y transparencia en la financiación de los partidos. Incluso el propio Banco de España dispone de normas que vetan al Tribunal tener acceso a dichos datos, lo que constituye una contradicción del sistema. ${ }^{103}$

\footnotetext{
102 Sobre la identificación de los donantes, la LOREG mantuvo la obligatoriedad de la medida, pero esto fue algo muy discutido en el Parlamento (principalmente con el Grupo Centrista, Minoría Catalana y Vasca), con tres enmiendas que sugerían la supresión de la obligatoriedad de identificación; o que solamente haya que identificarse si la donación fuera superior a un determinado valor. Eso, según DEL CASTILLO, es muy difícil de resolver, porque el votante/donante tiene el derecho de ser anónimo, y si la identificación fuera obligatoria, podrían disminuir mucho las donaciones. Sin embargo, como argumento a favor, la medida ayuda a saber qué intereses y corrientes políticas que están representadas, además del derecho de los votantes de conocer esta información, ayudando a decidir su voto y fortaleciendo su confianza en el sistema democrático, que se vuelve más transparente. (In: CASTILLO VERA, P. del. "Financiación de las Elecciones Generales de 1986". In: Revista de Derecho Político. № 25. UNED, Madrid, 1989. Pp. 132-13). No puedo estar de acuerdo con la posibilidad de hacer donaciones anónimas. Al contrario, creo que dicha medida debería contar con más garantías, como la efectiva publicidad de los datos. Sin embargo, la cuestión es más debatida con más profundidad en la Ley Orgánica 3/1987, la cual permitía la realización de donaciones anónimas, y por esto remito esta discusión al punto 2.2.2."d" de este capítulo.

3 Justamente visando la eliminación de esta contradicción, el Tribunal de Cuentas aprobó en 24 de febrero de 2011 una moción ( $n^{-0}$ 887) sobre el perfeccionamiento del deber de
} 
En este punto, es trasladable el debate sobre la posible revelación o no del nombre de los donantes producido posteriormente con ocasión de la aprobación de la Ley Orgánica 3/1987, que trata sobre la financiación ordinaria de partidos (anterior a la Ley Orgánica 8/2007) y que permitía a la vez donaciones anónimas. ${ }^{104}$ Sin embargo, lo importante no es sólo destacar la rigidez de dichas reglas, sus límites considerablemente bajos y la tendenciosa inclinación del sistema hacia la financiación pública, sino también visualizar los problemas que ello causa, pues si la ley versa sobre obligaciones de identificación de donantes de recursos para fines electorales, sin que tenga efectos prácticos, se trata de una letra muerta de ley y que merece o ser pensada en un nuevo formato, 0 apoyada por otras reglas que faciliten/posibiliten su cumplimiento. $\mathrm{O}$ falla las intenciones del legislador, $\mathrm{O}$ fallan sus previsiones.

\section{d) La financiación pública de la campaña electoral}

La financiación de las campañas electorales, tal como ocurre desde el inicio de la transición política, se basa fundamentalmente en la fuerte presencia de recursos públicos en las finanzas de los partidos. En el momento de la aprobación de la LOREG, se destacó la importancia que los partidos tenían para la democracia, y el hecho de que fuera esencial proveerles de los medios económicos suficientes para la realización de sus tareas políticas, y una garantía de concederles estos recursos era que el Estado se hiciera responsable de los mismos. Además, también se subrayó el peligro de la influencia indebida de las entidades privadas, en cuanto estas pudieran contribuir al sostenimiento partidista. Sin embargo, en las escasas discusiones sobre el tema, el argumento más utilizado en contra de la financiación pública era que los partidos reflejaban intereses parciales, lo que impedía la supresión total de la financiación privada. ${ }^{105}$ En su época, quizás se podría justificar el

colaboración de terceros en la función fiscalizadora ejercida por este Tribunal. En este documento, el Tribunal denuncia estos impedimentos materiales que bloquean la eficacia de su tarea. Así, cfr. << http://www.tcu.es/uploads/l887.pdf>> Acceso en 31.07.2011.

${ }_{104}$ Por dicha razón que esta discusión no será expuesta aquí en la LOREG, sino en la parte referente a la Ley Orgánica 3/1987.

${ }^{105}$ En este sentido, véase MARIN ARIAS, M. “Arts. 121..." Pp. 1063. 
fuerte peso de las subvenciones públicas en la financiación de las organizaciones políticas, pero está claro que dichas razones ya no tienen la misma base actualmente. Como se constatará, los efectos generados por esta presencia tan aguda de la financiación pública en los partidos han provocado mucho más problemas que los eventualmente ocasionados por una financiación privada más permisiva, y la elevada financiación pública perdurable hasta hoy acabó por volverse una "hierba dañina" en la política española.

En relación a las disposiciones sobre la financiación pública, estas siguen la misma dirección que el Decreto-Ley 20/1977, es decir, las subvenciones estatales son distribuidas a través del doble criterio escaños/votos, siendo este también el criterio para acceder a los recursos. ${ }^{106}$ Son numerosas las criticas en la doctrina a este doble criterio, pues las distorsiones se originan a partir del sistema electoral, y a su vez son transferidas al sistema de financiación, afectando a elementos vitales para los partidos, como son el resultado electoral y el soporte económico para seguir en la lucha política. ${ }^{107} \mathrm{Y}$ todo ello se hace evidente en un breve análisis donde se constata que estos dos criterios imponen conjuntamente un tratamiento fuertemente penalizador para los partidos extraparlamentarios y los parlamentarios minoritarios. Por no haberse considerado su efecto conjunto con el sistema electoral vigente (al menos no se ha explicitado dicha relación)

\footnotetext{
${ }^{106}$ Los valores debidos y que están establecidos en la LOREG (art. 175) fueron objeto de actualización con la reforma habida en la ley en 2011 y corresponden a 21.167,64 euros por cada escaño obtenido tanto en el Congreso de Diputados como en el Senado, siendo que los votos que generaron dichos escaños en el Congreso contabilizan 0,81 euros, y en el Senado 0,32 euros. Ya a título de mailing, el valor actual es de 0,22 euros por envío realizado. Se verifica que hubo un incremento importante con relación al valor anterior porque, por ejemplo, antes de la reforma cada escaño daba el derecho a recibir sólo 12.020,24 euros, convirtiendo el antiguo valor de 2.000 .000 de pesetas. Pilar CORTÉS, analizando los valores anteriores, opina que son bajos, y que hacen que los partidos tengan que disponer de recursos de su fondo general para los gastos de campaña. Pero no puedo estar de acuerdo con la autora, pues se trata de un valor importante para una campaña tan corta como la existente. Esto sirve de alerta, quizás, para un mal uso de los recursos por parte de las fuerzas políticas en campañas no tan eficientes. En este sentido, cfr. CORTÉS BURETA, P.: Recursos Públicos y Partidos Políticos... Pp. 160. Ya refiriéndose al mailing, GAVARA DE CARA entiende que las subvenciones concretas son más efectivas, y por esto deberían haber otras, considerando que la financiación pública directa se aleja mucho de la real campaña electoral. (In: GAVARA DE CARA, J. C. "La Financiación Electoral en el Ámbito Autonómico". In: GÁLVEZ MUÑOZ, L. A. (Dir.): El Derecho Electoral de las Comunidades Autónomas. Revisión y Mejora. Cuadernos y Debates, Centro de Estudios Constitucionales, Madrid, 2009. Pp. 309-310).

${ }^{107}$ Sobre las distorsiones del sistema electoral, véase Cap. I, punto 3.3.1.
} 
compartimos la opinión de que dichos criterios deberían ser revisados. Si siguen considerándose los escaños junto con los votos, permanecerán las situaciones de desequilibrio de los partidos estatales en relación a los de ámbito autonómico, y de los mayoritarios en relación con los minoritarios. ${ }^{108}$ Junto a ello, está claro que aquí hay una influencia directa de la financiación sobre el sistema de partidos, a la vez influye determinantemente en qué partido sobrevivirá económicamente y cuál no. ${ }^{109}$ Esto también provoca efectos directos sobre el peso o la igualdad de los votos emitidos, ya que para los partidos extraparlamentarios no hay ningún tipo de subvención, diferenciando el voto entre los ciudadanos y haciendo que existan votos "que no valen nada". ${ }^{110}$

La financiación electoral pública se destina a hacer frente a los gastos electorales que la LOREG enumera, siendo así que la subvención correspondiente a las fuerzas políticas no podrá en ningún caso sobrepasar el valor establecido para el límite de los gastos electorales declarados y justificados por el Tribunal de Cuentas. Además, el devengo o pago de valores a título de subvención a otros destinatarios que no sean los propios partidos sufre aquí modificaciones en relación al Decreto-Ley 20/1977, estableciendo que la Administración Electoral podrá exigir la justificación de la adquisición por los electos de la condición plena de tales. Antes de la reforma del 2011, esta justificación era necesaria, no existiendo ninguna discrecionalidad por parte de la administración electoral en esta exigencia. Tratándose de una medida

\footnotetext{
${ }^{108}$ Vid. ejemplo de ello es subrayado por DEL CASTILLO, que afirma que PSOE y Coalición Popular tienen recompensa por prácticamente todos sus votos, sin embargo, para el CDS y IU, la recompensa estaba entre $60 \%$ y $30 \%$ de los votos, respectivamente, considerando las elecciones de1986. (In: CASTILLO VERA, P. del. "Financiación de las Elecciones Generales de 1986..." Pp. 123). Otro ejemplo que podría ser citado no se relaciona con el sistema electoral, pero sí con los partidos extraparlamentarios. En las elecciones de 1996, Izquierda Unida no ha logrado un escaño en el Senado, no obstante fuera la $3^{0}$ mayor fuerza política en la competición en términos de número de votos recibidos a nivel nacional. Como consecuencia, el partido no recibió ninguna compensación económica por sus 6.8 millones de votos, aproximadamente. Sin embargo, partidos de mucho menor número de votos como Convergencia i Unió y Partido Nacionalista Vasco, que han obtenido cerca de 1.5 y 0.6 millones de votos, respectivamente, han obtenido representación en la Cámara Alta con 8 y 4 escaños, habiendo asegurado la recompensa en la financiación. (In: VAN BIEZEN, I.: Political Parties in New Democracies: Party Organization in Southern and East Central Europe. Ed. Palgrave, MacMillan, Great Britain, 2003. Pp. 181).

${ }_{109}$ GILLESPIE, R. Op. Cit. Pp. 81.

110 MARTíneZ CUEVAS, M. D.: El Régimen Jurídico de los Partidos Políticos. ed. Marcial Pons, Madrid, 2006. Pp. 106-137. Con dicho punto de vista, la autora condena el sistema actual, lo que debería asegurar en mayor medida la igualdad de trato entre todos los partidos.
} 
inseparable de la legislación sobre partidos relacionada con el campo de su ilegalización para prácticas antidemocráticas. ${ }^{111}$

e) Procedimientos para la concesión de adelantos de las subvenciones públicas

La ley, como es sabido, prevé también la posibilidad de conceder adelantos de las subvenciones destinadas a las fuerzas políticas ${ }^{112}$, y para ello considera los resultados de los partidos en las elecciones precedentes. Dicho adelanto no podrá sobrepasar el $30 \%$ del valor de las subvenciones recibidas por la organización en las elecciones pasadas, a partir del criterio escaños/votos.

Como es notorio, si la aplicación de este doble criterio provoca distorsiones en el acceso y distribución de dichas subvenciones, esta discriminación entre las fuerzas políticas acaba por ser transferida también al sistema de adelantos, ya que priva a las nuevas organizaciones de ese beneficio de la ley, y también gratifica una vez más a los partidos mayoritarios, que pueden obtener una mayor cantidad de recursos antes del inicio de la campaña electoral propiamente dicha. ${ }^{113}$ El problema de utilizar los recursos adelantados para cubrir deudas de períodos pasados es algo que afecta a todos los partidos en general, formando así un ciclo constante de pagos y deudas constantes. ${ }^{114}$ Sin embargo, también puede darse una caída en el

\footnotetext{
${ }^{111}$ Sobre el tema de la ilegalización de partidos y sus consecuencias en las subvenciones de partidos ilegalizados, véase punto 4.2 de este capítulo.

${ }_{112}$ Dicho beneficio puede ser solicitado entre el $21^{\circ}$ al $23^{\circ}$ después de la convocatoria de las elecciones, siendo a partir del $29^{\circ}$ posterior a la convocatoria cuando la Administración los pone a disposición de los administradores electorales. Junto a la devolución del excedente de recursos transferidos a título de adelanto a las organizaciones que no lograren cantidad de subvención superior, también hay la posibilidad de que se tenga que devolver la totalidad del adelanto en el caso de que no se acredite la adquisición de la condición plena del cargo electivo por lo que estaba concurriendo, y el ejercicio efectivo del cargo, condición descrita en el art. 133.4.

${ }^{113}$ La cuestión de los adelantos siempre ha generado mucha controversia, porque justamente adopta como criterio los resultados anteriores del partido en las elecciones. Acerca de este punto, cfr. ÁLVAREZ CONDE, E.: El Derecho de Partidos. Op. Cit. Pp. 392.

114 PAJARES MONTOLÍO critica el sistema de adelantos existente, porque, como se trata de $30 \%$ de la subvención total que se puede tener derecho, la importancia para las campañas puede no ser irrelevante, pero tampoco es determinante. Así, el autor cita las modificaciones hechas por la Ley Orgánica 13/94, determinando el mismo sistema de adelanto para los envíos postales, ya que estos deberían considerarse ya incluidos en el valor adelantado, ya
} 
rendimiento electoral de determinada fuerza política con relación a las elecciones pasadas, ocasionando que esta no pueda hacer frente a la devolución de los valores concedidos anticipadamente. La LOREG guarda silencio al respeto y, considerando la evolución del sistema electoral vigente, es una cuestión importante que puede afectar a los partidos en general. En este caso se debe tener en cuenta que la contribución de tal medida al endeudamiento de los partidos es importante, pues además de poseer normalmente deudas con las entidades bancarias (hecho que forma parte de la rutina electoral de muchas organizaciones), la fuerza política afectada también contraería deudas con el Estado, estando condenada a una bancarrota casi inevitable en un breve periodo de tiempo.

\section{f) La prohibición a ciertos entes de realizar donaciones}

El art. 128 establece la prohibición de que algunos entes aporten recursos para campañas electorales, tales como la Administración Pública en general, los organismos autónomos y las entidades paraestatales del Estado, de las Comunidades Autónomas, provincias y municipios, como también las empresas de economía mixta o que mantengan contratos con la Administración Pública. ${ }^{115}$ La prohibición también versa sobre recursos procedentes del exterior $^{116}$, con excepción de los aportados por el presupuesto de las

reglamentado antes. El autor critica la forma de devolución del adelanto, que juzga muy ineficaz y desigual, sugiriendo que fueran adoptadas en el reparto reglas más igualitarias para fomentar la competitividad en la campaña, incluso para aliviar la carga financiera de las formaciones políticas y no para crear más deudas en caso de devolución. Debería exigir de las formaciones políticas una efectiva participación con justificante de gastos, o denegar la devolución de una fianza dada en el momento de formalizar las candidaturas, y permitir también al Tribunal de Cuentas que fiscalice la razón para el adelanto de recursos. (In: PAJARES MONTOLIO, E.: La Financiación de las... Pp. 273-277).

${ }^{115}$ Es de resaltar que dicha prohibición también es masiva en países de América Latina. Acerca del tema, cfr.: ZOVATTO, D.: Dinero y Política en América Latina: Una Visión Comparada. International IDEA, Lima, 2003. Pp. 20.

${ }^{116}$ DEL CASTILLO critica mucho dicha prohibición, porque considera que esta ya no tiene sentido. Acerca del punto, cfr. CASTILLO VERA, P. del: La Financiación de Partidos y Candidatos en las Democracias Occidentales. CIS Siglo XXI, Madrid, 1985. Pp. 264-266; CASTILLO VERA, P. del. "Financiación de las Elecciones de 1986..." Pp. 133, y HOLGADO GONZÁLEZ, M.: La Financiación de los... Pp. 118-119. 
Comunidades Europeas, para la financiación de las elecciones del Parlamento Europeo. ${ }^{117}$

La discusión sobre la conveniencia de dichas prohibiciones también es una constante en la doctrina sobre el tema, ya que se tiene la idea de que las medidas tienen efectos colaterales, como la búsqueda de formas de burlar las barreras a través de algún tipo de financiación indirecta o de gastos independientes, difíciles de controlar. ${ }^{118}$ La doctrina entiende en general que las prohibiciones tienen la función de evitar la dependencia política que puedan producir las donaciones extranjeras o la dependencia económica de donantes nacionales. Sin embargo, también es cierto que determinadas medidas que permiten la donación de recursos de origen extranjero puede corresponder también a una participación política a nivel globalizado, acompañando la dinámica actual del mundo. ${ }^{119}$ Diversos autores se posicionan en contra de tal prohibición porque entienden que puede producirse una identidad ideológica entre los partidos en el espacio comunitario, por ejemplo, traducida en una actuación conjunta como puede ocurrir en el Parlamento Europeo, y el grado de cooperación puede justificar el apoyo financiero. ${ }^{120}$ Sean nacionales 0 extranjeros, las donaciones pueden acarrear las mismas desventajas. Las afirmaciones de que las donaciones extranjeras son más nocivas que las nacionales pueden ser fruto del temor a que se pueda comprometer la seguridad nacional con presiones exteriores, pero ello también puede ocurrir a través de los donantes nacionales ${ }^{121}$, y se puede cuestionar también hasta qué punto dichas donaciones podrían condicionar la política futura del partido

\footnotetext{
117 Según el constante en el art. 128.2.

${ }^{118}$ En el ejemplo de las limitaciones para donaciones de organismos extranjeros, CRESPI afirma que es difícil constatar su existencia porque los recursos no pasan por la sede central del partido, siendo muchas veces remitidos a las sedes locales, o para financiar una actividad o alguna de sus corrientes. (In: CRESPI, R.: Lo Stato deve Pagare i Partiti? II Problema del Finanziamento dei Partiti Politici in Italia. Ed. Sansoni, Firenze, 1971. Pp. 32). A la vez, ZOVATTO defiende la publicidad, incluso para que les sea posible a los propios partidos una vigilancia mutua. (ZOVATTO, D.: Dinero y... Pp. 47-48).

${ }^{119}$ Cfr. GARCÍA-ESCUDERO MÁRQUES, P.; PENDÁS GARCIA, B. "Consideraciones sobre la Naturaleza y Financiación de los Partidos Políticos". In: Revista de Administración Pública, no 115, ene/abr, 1988. Pp. 385.

120 CASTILLO VERA, P. del. "Financiación de las Elecciones Generales de 1986..." Pp. 133.

${ }^{121}$ En este sentido, cfr. GARCíA COTARELO, R.: Los Partidos Políticos. ed. Sistema, Madrid, 1985. Pp. 199. El autor complementa diciendo que no es posible prohibir los donativos, e incluso esto atentaría al derecho de las asociaciones de aumentar su presupuesto por vía libre y privada.
} 
elegido. $^{122}$ Resultaría muy difícil aislar a los partidos del proceso de globalización y multiplicación de relaciones internaciones, principalmente entre partidos que comparten las mismas ideologías, o entidades y asociaciones afines de perfil internacional. ${ }^{123}$

Es más, no se puede olvidar que hay un debate importante sobre el voto de extranjeros en territorio español y el consecuente derecho de realizar donaciones a las organizaciones que compiten, como también de la posibilidad de españoles no residentes de poder donar recursos a la formación política de su preferencia. ${ }^{124}$ Se trata de puntos que deben ser tenidos en cuenta, o por lo menos deberán serlo en un futuro próximo. ${ }^{125}$ Lo que está claro es que no resulta posible seguir ignorando la cuestión y limitar las donaciones extranjeras solamente a la esfera del Parlamento europeo.

\section{g) Las limitaciones a la financiación privada}

Refiriéndose a la posibilidad de realizar donaciones por parte de personas físicas y jurídicas, la LOREG ${ }^{126}$ adopta una política de un claro perfil restrictivo. ${ }^{127}$ Además del hecho de que todas las donaciones deban realizarse a través de la cuenta bancaria abierta para el flujo de los recursos que financian la campaña electoral del partido, contemplando también la identificación del donante, el valor en todo caso no podrá ultrapasar los 10.000

\footnotetext{
${ }^{122}$ SÁNCHEZ-POBRE, P. C. "La Financiación de los Partidos Políticos: Estudio de su Régimen Tributario". In: Revista Española de Derecho Financiero Civitas. oㅡ 143, jul/sept, ed. Aranzadi, Navarra, 2009. Pp. 698.

${ }^{123}$ PAJARES MONTOLIO, E.: La Financiación de las... Pp. 305-306.

${ }^{124}$ SÁNCHEZ-POBRE, P. C. Op. Cit. Pp. 700.

${ }^{125}$ En contra de anular esta prohibición, se posiciona ZOVATTO, que teme que tal apertura pueda comprometer y dificultar aún más el control de las finanzas de los partidos. Cfr. ZOVATTO, D.: Dinero y.... Pp. 48.

126 HOLGADO GONZÁLEZ cita la misma clasificación tanto para la limitación de gastos electorales como para las donaciones. Las limitaciones cualitativas se refieren a los sujetos que pueden realizar una donación y las que no pueden, y los cuantitativos se refieren a los topes máximos para las donaciones. (In: HOLGADO GONZÁLEZ, M.: La Financiación de los... Pp. 166).

${ }^{127}$ Este punto fue criticado por SÁNCHEZ MUÑOZ, que entiende que carece de sentido que haya donaciones privadas regidas por la LOREG y que el tema debería haber sido reformado ahora con la Ley Orgánica 02/2011, dejando en vigor tan solo las disposiciones de la Ley Orgánica 8/2007. (In: SANCHÉZ MUÑ̃Z, Ó. "Cuestiones Relativas... Pp. 637).
} 
euros $^{128}$ a un mismo partido, federación, coalición o agrupación, no teniendo dicho valor ninguna previsión de actualización. Ante ello, lo cierto es que la reforma del 2011, que alcanzó a este artículo, todavía impide un sano aprovechamiento de las fuentes privadas de financiación, pues se trata de una política muy reductiva desde el punto de vista del actual Derecho Comparado, además de encontrarse este valor muy por de abajo del permitido en la ley de financiación ordinaria, agravado por la ausencia aquí de un índice para su actualización. Dentro de algún tiempo, este valor que ya es bajo estará desvalorizado. Son este tipo de lagunas y de restricciones las que tenían por atribuir al Estado casi en exclusividad el deber de financiar a los partidos, prescindiendo indirectamente de la participación de la sociedad en este proceso, y provocando efectos ya conocidos.

Otra de las limitaciones que generan polémica guarda relación con las donaciones realizadas por personas jurídicas. Hay autores que se posicionan por su prohibición total porque los partidos deben ser sostenidos por sus miembros y no por personas jurídicas, que frecuentemente incluso burlan sus propios procedimientos internos para realizar la donación, como es común en los bancos que no informan a sus inversores del partido al que financiaron o en caso de proceder a la donación, no les conceden la oportunidad de elegir. ${ }^{129}$ Con todo, hay autores que no están de acuerdo con dicha prohibición, porque piensan que esta no servirá para solucionar dichos problemas, al resultar ineficaz para acabar efectivamente con dichas donaciones. Lo importante en todo caso sería, a nuestro juicio, adoptar medidas de transparencia. ${ }^{130}$ También

\footnotetext{
${ }^{128}$ Antes de la reforma de 2011 , el valor previsto era de 1.000 .000 de pesetas, correspondiente a $6.010,12$ euros.

${ }_{129}$ Este es el caso de SATRUSTEGUI GIL-DELGADO en: AA. VV.: "Debates". In: La Financiación de los Partidos Políticos. Cuadernos y Debates, № 47, Centro de Estudios Constitucionales, Madrid, 1994. Pp. 99.

${ }_{130}$ Opinión de BLANCO VALDÉS en: AA. VV.: "Debates". In: La Financiación... Pp. 106-111. En el mismo sentido, DEL CASTILLO entiende que la opinión pública no censuraría con las donaciones realizadas por personas jurídicas, siempre que se realizara de manera transparente. En esta misma línea, ROSE-ACKERMAN entiende que, en una reforma de la legislación referente al tema, hay que evitar poner restricciones que por sí solas provoquen la ilegalidad, como es el caso de la limitación de la donación por personas jurídicas, aunque admite que cada sistema reacciona de una determinada manera. (In: ROSE-ACKERMAN, S.: La Corrupción y los Gobiernos: Causas, Consecuencias y Reforma. Siglo XXI, Madrid, 2001. Pp. 191).
} 
algún autor defiende las donaciones por personas jurídicas, pero sin ninguna deducción fiscal. ${ }^{131}$

Por otra parte, y sin limitarse a las donaciones realizadas por personas jurídicas, el tema de la financiación privada siempre despierta intensos debates. Es un hecho que la financiación privada posee beneficios innegables y de vital importancia para el sistema político, pues promueve la participación ciudadana en la política; posibilita el surgimiento de nuevas fuerzas políticas; y disminuye la presión sobre el erario público, destinando dichos recursos para otros fines también relevantes para la sociedad como un todo. A su vez, la regulación de fuentes de financiación pretende restringir o prohibir aquellas que posen una peligrosidad significativa, incentivando otras que se consideran beneficiosas para el sistema. ${ }^{132}$ Aunque se cuestione mucho la eficacia de su aplicación, muchos países están adoptando dos formas de limitación, una, que partiendo de la libertad de fuentes de donación privada, las condiciona a su total transparencia pública para posibilitar su control público; y otra, que permite únicamente las donaciones a las personas físicas y no a las personas jurídicas. ${ }^{133}$ Lo cierto es que las restricciones actuales dificultan muchísimo la explotación de dicha fuente de financiación, y acaban por generar en los

\footnotetext{
${ }^{131}$ Vid. PRESNO LINERA, M. Á.: Los Partidos y las Distorsiones Jurídicas de la Democracia. Ed. Ariel, Barcelona, 2000. Pp. 95-96. El autor también sugiere la obligación de la apertura de una cuenta bancaria solamente para donaciones superiores a 50.000 pesetas (alrededor de 300 euros y 50 céntimos). Ya en el entendimiento de GARCÍA VIÑUELA y ARTÉS CASELLES subrayaban que la prohibición de donaciones por las personas jurídicas no iba a favorecer a las pequeñas empresas, pero si a los grandes grupos que tienen estructura para influir desde dentro del partido, teniendo el efecto contrario de la prohibición. (In: GARCíA VIÑUELA, E.; ARTÉS CASELLES, J. "El Gasto Público en Financiación Política: Las Subvenciones para el Funcionamiento Ordinario de los Partidos". In: Revista de Estudios Políticos, no 128, abr/jun, ed. CEPC, Madrid, 2005. Pp. 287).

${ }_{132}$ GRUENBERG, C.: El Costo de la Democracia: Poder Económico y Partidos Políticos. Ed. Capital Intelectual, [s.I.], 2007. Pp. 20-25.

${ }^{133}$ En este sentido, cfr. SÁNCHEZ MUÑOZ, O.: La lgualdad... Pp. 203-207. El autor destaca en este punto la dificultad de dicha transparencia, y que es constitucional que sólo personas físicas puedan donar recursos para los partidos, porque estos sólo pueden representar a personas físicas, y no a personas jurídicas. Por otra parte, el autor entiende que no hay violación a la libertad de expresión o a la liberad de empresa (ya que la financiación de los partidos no entran en esa esfera), y también que es una medida que busca evitar la corrupción y la influencia del poder económico, incluyendo a las personas jurídicas no empresariales, como asociaciones y sindicatos. De hecho, según dicho autor, las donaciones hechas por personas jurídicas ni siquiera se justifican con el argumento de la independencia respecto del Estado de los partidos porque lo que se busca es, según el autor, impedir la influencia del poder económico.
} 
partidos una dependencia de las ayudas estatales. ${ }^{134}$ Por tratarse de un rasgo bastante presente en la legislación española de financiación de partidos como un todo, la doctrina destaca las desventajas que una política tan cerrada trae para el sistema, pues además del difícil control compartan siempre estas medidas negativas, se puede entender que el control de la entrada de recursos es más fácil de realizar que la de su gasto. ${ }^{135}$

El tema de las donaciones privadas no generó un debate de calado en la época de la aprobación de la LOREG, justamente por la desconfianza que ya se tenía en torno a este tipo de financiación. ${ }^{136}$ Las diversas limitaciones y prohibiciones contenidas en dicha ley demuestran que España ha decidido

\footnotetext{
${ }^{134}$ VIÑUELA afirma que muchos argumentan que las donaciones privadas ejercen influencia sobre la política, pero el dinero público también lo hace, porque las decisiones de los partidos son autorreferenciales, con la ventaja de tener una menor fluctuación que los privados, y de la menor necesidad de estar de acuerdo con los planteamientos de miembros y simpatizantes del partido, perjudicando al mismo tiempo la democracia interna. (In: GARCíA VIÑUELA, E. "Financiación Pública de los Partidos y Cartelización de la Oferta Política". In: Revista Española de Ciencia Política. no 20, abril, ed. Cyan, Madrid, 2009. Pp. 91).

135 SANTAOLALLA, F. "Regulación de Campañas Electorales y Financiación de Partidos Políticos". In: Documentación Administrativa. no 173, ene/mar, Madrid, 1977. Pp. 160. La discusión sobre la eficacia de estas medidas de carácter negativo es permanente desde los tiempos de la transición, y ejemplo de ello es GARRORENA MORALES, que al tratar de las desventajas de tratar a través del derecho de las disfunciones de los partidos políticos, entiende que determinadas intervenciones normativas en esferas poco o dudosamente juridiciables hacen que se caiga en el desuso o inaplicación de la norma, cuando no en su fraude. Se Cita como ejemplo los límites de donación privada. También, el autor entiende que incluso hay casos que, además de no solucionar la disfunción, la intervención normativa acaba por agravar la ya existente o generar una añadido, como ocurre con la financiación pública y las dificultades que se tiene para que no haya problemas de cristalización del sistema de partidos, falta de independencia de los partidos ante el Estado, etc. (In: GARRORENA MORALES, A. "Hacia un Análisis Democrático de las Disfunciones de los Partidos Políticos". In: VEGA, P. de (ed.): Teoría y Práctica de los Partidos Políticos. Edicusa - Cuadernos para el Diálogo, Madrid, 1977. Pp. 81). Como otro ejemplo abordando un panorama comparativo, HARO BÉLCHEZ afirma que estas medidas limitativas tampoco son bien vistas porque no permiten un control efectivo. (In: HARO BÉLCHEZ, G. "La Financiación de los Partidos Políticos". In: Revista de Administración Pública. no 86, Derechos Fundamentales, 1994. Pp. 163-185. Disponible en: <<www.juridicas.unam.mx/publica/librev/rev/rap/cont/86/pr/pr10.pdf >>. Acceso en 21.10.09. Pp. 169). Completando la idea de reproche a las limitaciones de las donaciones, PAJARES MONTOLIO opina que, además de ser difícil aplicación y dudosa eficacia (una vez que se puede fraccionar la donación y entregarla a través de terceros, tampoco se deben justificar tales límites en la intención de fomentar donaciones pequeñas e individuales, porque parecería que antes se produciría donaciones grandes y concentradas, y no es el caso. La justificación única de estos límites es la reprobación moral a ellas, sin amparo teórico. Y por ello se debería plantear su reforma. (In: PAJARES MONTOLIO, E.: La Financiación de las... Pp. 295).

${ }^{136}$ DEL CASTILLO comenta que no hubo una gran discusión acerca del tema en el Parlamento, presentándose únicamente con una enmienda de la minoría catalana cuestionando tal limitación. Los argumentos se relacionaban con motivos de carácter económico liberal sobre el derecho de usar el patrimonio de manera libre. Hubo también otra enmienda por parte del Grupo Popular, pero que fue retirada en el Pleno. (In: CASTILLO VERA, P. del. "Financiación de las Elecciones Generales de 1986..." Pp. 128).
} 
inclinarse por la financiación pública, y es esta la opción que despierta las críticas más numerosas de la doctrina. ${ }^{137}$ Sin embargo, el debate en la doctrina parece encontrar un punto de encuentro mayoritario en torno a la opinión de que los límites contenidos en la LOREG, además de ser rígidos, provocan problemas importantes que comprometen el funcionamiento del sistema en su totalidad. Muchos de los argumentos que sostenían este modelo anteriormente ya no sirven para justificar el mantenimiento de tantas barreras porque justamente estas limitaciones no fueron capaces de acabar con los problemas que pretendían resolver. No se puede sostener que toda financiación privada es perjudicial y no todas las donaciones privadas que se realizan son perjudiciales. Es más, no se puede eliminar el derecho del electorado de saber de dónde provienen dichas donaciones, por ello hoy en día parecen centrales las medidas de transparencia y no de restricción de la financiación privada, pues los partidos actualmente dependen de las subvenciones oficiales estatales, siendo que los recursos legales de origen privado suponen un porcentaje mínimo de sus finanzas. ${ }^{138}$ Con todo, todavía hay autores que defienden la existencia de limitaciones, pues la total libertad de la financiación privada puede generar un desequilibrio muy fuerte entre las fuerzas políticas, violando directamente el principio de la igualdad de oportunidades que debe garantizar todo el proceso democrático. ${ }^{139}$

\footnotetext{
137 La autora que más critica esa "criminalización" de las donaciones privadas es DEL CASTILLO, quién siempre enfatiza la necesidad de volver más flexible las limitaciones y prohibiciones, como forma de mejorar la legislación vigente. Cfr. CASTILLO VERA, Pilar del. "Financiación de las Elecciones Generales de 1986..." Pp. 128, en que la autora entiende que dicha limitación es un atentado a la libertad de expresión y conlleva a una limitación del funcionamiento y actividad de los partidos políticos, pues son asociaciones privadas que están en el ámbito político-social.

${ }^{138}$ CASTILLO VERA, P. del. "Financiación de las Elecciones Generales de 1986..." Pp. 129. Por ello la autora defiende un sistema de desgravación fiscal para la LOREG. Cabe resaltar que en la LOFPP de 2007 ya hay un sistema de desgravación fiscal, que será analizado a continuación. En otro de sus trabajos, la autora afirma que, además de ser España el único lugar en Europa en "penalizar" las donaciones privadas a los partidos, limitando las cuantías en toda su legislación sobre el tema, afirma que "pero, y aún cuando estas limitaciones no tienen correspondencia en otras legislaciones europeas, la singularidad más notable de la ley española se encuentra en el papel predominante que de forma explícita atribuyen a la financiación pública". (In: CASTILLO, P. del. "La Financiación de los Partidos Políticos en Europa". In: Política Exterior. vol. IV, no 16, Madrid, 1990. Pp. 6). En esta línea está ÁLVAREZ CONDE, que opina que se debería suprimir las restricciones a la financiación privada, y cambiarlas por medidas de desgravación fiscales, que deberán ser acompañadas por topes máximos para no favorecer a las clases sociales con más recursos. (In: ÁLVAREZ CONDE, E. "Algunas Propuestas..." Pp. 29).

${ }^{139}$ SÁNCHEZ MUÑOZ, O.: La lgualdad... Pp. 202.
} 
Por todo ello, aquí se sostiene que se debería urgentemente abrir el sistema de financiación privada, no sólo para fomentar la entrada de recursos por parte de la sociedad en las finanzas de los partidos, sino también para despertar la voluntad popular de participación en la política, intentando incluso revertir la situación de cartel en que ellos viven actualmente. La cartelización de la política, junto con el alejamiento de la sociedad de los asuntos públicos provoca, a largo plazo, secuelas muy difíciles de eliminar, y los síntomas de un sistema político deficitario son evidentes. El desinterés de los jóvenes, la falta de movilización social en pro de cuestiones sociales y las constantes - y fuertes - críticas a la clase política no se hacen por casualidad. Una sociedad educada políticamente y participativa en cuestiones públicas es mucho más importante que un sistema de partidos consolidado - o petrificado - en el espectro político.

\section{h) Gastos electorales}

La LOREG, en su art. 130, determina qué será considerado como gasto electoral, de cara a su reembolso por parte del Estado. ${ }^{140}$

La clasificación de HOLGADO GONZÁLEZ divide el art. 130 sobre los gastos electorales en ocho categorías, siempre que estos sean efectuados por partidos (sean federaciones, coaliciones o agrupaciones), dentro del período electoral, y que se presenten a las elecciones. Además de la denominación de los gastos, también existen los requisitos subjetivos y temporales para que el gasto se configure como un gasto electoral en los términos de la LOREG. Sobre el requisito subjetivo, cabe subrayar que según el texto de la ley, los gastos realizados directamente por el candidato están excluidos del concepto de gasto electoral, como también ocurre con las personas jurídicas que no se encuentran entre las mencionadas en el inicio del art. $130 .{ }^{141}$ Aunque ello pueda parecer de dudosa constitucionalidad, parece claro que la finalidad es

\footnotetext{
140 PAJARES MONTOLIO afirma que los gastos electorales son el pilar de la regulación electoral, porque se conecta directamente con el principio de la igualdad de oportunidades. (In: PAJARES MONTOLIO, E.: La Financiación de las... Pp. 99).

${ }^{141}$ La autora hace dicha mención y hace la observación de que las personas jurídicas, por fuerza del art. 50.3 de la LOREG, no pueden apoyar una candidatura en el periodo electoral. (In: HOLGADO GONZÁLEZ, M.: La Financiación de los... Pp. 37).
} 
determinar los beneficiarios de las subvenciones públicas, y que no se trata de una expresa prohibición de que exista un apoyo a alguna candidatura por parte de las organizaciones sociales. ${ }^{142}$ Desde el aspecto temporal, lo cierto es que los gastos electorales stricto sensu son más amplios que la campaña electoral propiamente dicha, ya que los gastos electorales son contabilizados desde el día de la convocatoria de las elecciones hasta la proclamación de los electos. La campaña electoral tiene una duración de quince días, y empieza solamente en el $38^{\circ}$ día después de la convocatoria, acabando justo a las cero horas del día siguiente de la votación, conforme dispuesto en el art. $51 .^{143}$

En el art. 130 también existe una descripción un tanto lacónica acerca de lo que debe ser considerado como gasto electoral, permitiendo que en algunos puntos se produzcan lagunas legales y que se confundan con los gastos ordinarios. ${ }^{144}$ Sin embargo, aunque la interpretación más correcta para dicho artículo sería la interpretación restringida, o sea, numerus clausus ${ }^{145}$, se percibe que parte de los apartados no son cerrados, lo que permite a los partidos realizar gastos que pueden no ser electorales, pero que son reembolsados como tales. Dicha posibilidad cuestiona aún más la polémica distinción entre las actividades ordinarias y extraordinarias de los partidos. ${ }^{146}$ 142 El Tribunal Superior tuvo la oportunidad de pronunciarse sobre el tema, y que son de
interesante análisis, ya que trata claramente de la identificación de una real campaña electoral
o de un apoyo social para el partido y de la licitud de otras entidades de hacer actos que
podrían ser configurados de esta manera. Así, véanse las conocidas SSTS $5411 / 1982$ de 14 de
julio, y SSTS $7542 / 1982$ de 9 de diciembre, en las cuales se discute la posibilidad de la
Confederación de Empresarios de Andalucía en realizar actos de campaña electoral en las
elecciones al Parlamento Andaluz.
${ }_{143}$ HOLGADO GONZÁLEZ, M.: La Financiación de los... Pp. 38. Este tema se conecta
directamente con lo que es gasto electoral y gasto ordinario de los partidos, y sus
correspondientes limites. GARCÍA VIÑUELA y ARTÉS CASELLES afirman que los gastos
realizados en la precampaña deben ser considerados como gastos ordinarios, y no como
electoral, no estando, por lo tanto, sometidos a los restrictivos límites para los gastos realizados
en el periodo de la campaña. (In: GARCIA VIÑUELA, E.; ARTÉS CASELLES, J. "La
Financiación de las Elecciones..." Pp. 10).
144 MARIN ARIAS comenta que hay muchas dificultades en acomodar dicho artículo a la
práctica política. (In: MARIN ARIAS, M. "Arts. 121..." Pp. 1074-1075). También en este sentido,
cfr. SÁNCHEZ MUNOZZ, O.: La lgualdad... Pp. 189.
145 TORRES FERNANDEZ, J. J. "EI Control de las Subvenciones a los Partidos Políticos". In:
XV Jornadas de Estudio: El Sistema Económico en la Constitución Española - Vol. II.
Secretaria General Técnica - Centro de Publicaciones, Ministerio de Justicia, Madrid, 1994. Pp.
1871.
146 PAJARES MONTOLíO separa los gastos electorales en dos grupos: los actos de campaña
(que sería la confección de sobres y papeletas electorales; la propaganda y publicidad y el
alquiler de locales para celebración de actos de campaña), y los gastos de organización
(gastos con personal, transporte y desplazamiento, la correspondencia y franqueo, los 
Sobre la confección de papeletas y sobres electorales, se producen múltiples problemas en torno a su gasto, porque el Estado provee las papeletas oficiales basándose en el número del censo electoral, y los partidos políticos, a su vez, confeccionan otras papeletas para enviar a los electores en general, "facilitando" el voto, lo que implica un aumento del gasto. ${ }^{147}$ Junto a este doble gasto, sobre las tarifas diferenciadas a título de financiación indirecta, las críticas de la doctrina son constantes, principalmente si consideramos el comportamiento de la sociedad española, que está acostumbrada en llevar la papeleta confeccionada por los partidos ya completada al local de votación. ${ }^{148}$

El art. 130, b es uno de los más problemáticos en relación a los gastos electorales, porque contempla los conocidos "disparadores" de costes de las campañas. Los mass media son ampliamente utilizados, principalmente en sociedades complejas y territorios grandes para la divulgación de las propuestas de las fuerzas políticas. Se trata de mensajes emitidos para el mayor número de personas posible, y ejemplo contemporáneo de ello es el internet, que todavía no cuenta con una regulación detallada ${ }^{149}$, pero que está siendo ampliamente utilizada en las campañas. ${ }^{150}$ Es notorio el hecho de que la propaganda electoral, aunque vital para las campañas, también las ha vuelto sin ideologías y con técnicas de tinte psicológicas para que sus efectos sean amplificados. Las estrategias de marketing que son empleadas en la elaboración de los slogans se centran mucho más en la imagen del candidato o del partido que en sus propuestas, que a la vez contienen una alta indeterminación para poder ampliar lo máximo posible sus nichos electorales. ${ }^{151}$ Sin embargo, sin propaganda no hay campaña electoral, y

intereses de los créditos recibidos para campaña y los gastos necesarios para la organización y funcionamiento de oficinas y servicios para las elecciones).(In: PAJARES MONTOLIO, E.: La Financiación de las... Pp. 114). El tema también objeto de propuesta para su modificación por parte del Tribunal de Cuentas, cuando fue aprobada la nota relativa a las propuestas de modificaciones en materia electoral. Así, véase moción aprobada en 24 de junio de 2010.

${ }^{147}$ Cfr. PAJARES MONTOLIO, E.: La Financiación de las... Pp. 114.

148 PAJARES MONTOLIO, E.: La Financiación de las... Pp. 114-116. El autor complementa la idea, sugiriendo que dicho envío sea hecho por la administración, y aún en las administraciones municipales, esto no sería un problema como se podría pensar en un primer momento. Vid. también HOLGADO GONZÁLEZ, M.: La Financiación de los... Pp. 38-40.

${ }^{149}$ HOLGADO GONZÁLEZ, M.: La Financiación de los... Pp. 42.

150 Ejemplo reciente es la impresionante campaña electoral de Barack Obama para la presidencia de los EE.UU., siendo el internet el principal vehículo de pequeñas donaciones privadas por parte de la sociedad.

${ }^{151}$ PAJARES MONTOLIO, E.: La Financiación de las... Pp. 119. 
aunque se conozcan bien las desventajas provocadas por la larga utilización de los medios por la política, la información es un derecho de todos los ciudadanos, que deben ser libres para elegir su opción política preferida. Así, se observa bien la relevancia de dichos gastos. El problema reside justamente en la eficacia de dicha propaganda, pues a partir del momento en que junto a la escasa diferenciación entre una opción política y otra, todas utilizan de manera masiva los medios, acaban por provocar a la vez un sentimiento de rechazo por parte de la sociedad de toda propaganda de carácter político. El exceso en el envío de mensajes virtuales, telefónicos, postales, y la larga presencia en los medios televisivos acaban más por "cansar" a los electores que propiamente informarlos sobre las propuestas de cada partido. Debido a ello, quizás sería necesaria una seria reflexión sobre la actual manera de hacer campaña política, no solo por no cumplir cabalmente ya su pretendida función ante el electorado, sino también con la intención de evitar el despilfarro de recursos que en nada colaboran para los fines en que están siendo empleados.

Resulta absolutamente remarcable que la propaganda electoral solamente esté autorizada en los medios de titularidad pública, estando prohibida la contratación de espacios tanto en los medios televisivos públicos como privados. Los espacios concedidos a las fuerzas políticas forman parte de la financiación indirecta, regulada por los arts. 60 y siguientes de la LOREG. Como ya se ha dicho, en el caso español sería aconsejable utilizar más este tipo de medios en sus campañas electorales, justamente como medida de disminución de los costes de estas. Los debates entre candidatos pueden ser útiles, además de tener un perfil más adecuado a una concepción deliberativa de la democracia.

La letra "c" del art. 130 trata sobre el alquiler de locales para la celebración de actos de campaña electoral, aunque los mítines no tengan más el sentido que tenían con el partido de masas, y tampoco representan grandes gastos electorales. Si se realizan actos partidarios que no sean para pedir voto, no son considerados como gastos electorales, sino si como gastos ordinarios. ${ }^{152}$ Es verdad que el gasto generado es muy bajo en comparación

152 HOLGADO GONZÁLEZ, M.: La Financiación de los... Pp. 42-43. Aquí cabe la critica hecha sobre la falta de especificación de la LOREG de lo que es gasto electoral y que no es, como 
con la cantidad de mítines, y también que actualmente su misión de captación del voto es mínima, pero la existencia de mítines durante la campaña también tiene un papel de transmisión de informaciones pasadas a través de los medios de comunicación, siendo beneficiosa para el proceso democrático.

Los gastos del personal no permanente que trabajan o ayudan en la realización de las campañas electorales están previstos en la letra "d" del referido artículo porque actualmente son necesarios en el moderno modelo de campaña. Dichos profesionales son indispensables dentro de una idea de profesionalización de la política. Son los responsables de los sondeos, del marketing político, además de los expertos que auxilian en la formación de los programas electorales, que pueden ser interdisciplinarios. Teniendo esto en mente, el papel de la militancia pierde mucho de su valor. ${ }^{153}$ Este tipo de gasto sólo puede ser considerado electoral cuando se destina a gastos con personal no permanente, o sea, contratado justamente para el período electoral, sin integrar posteriormente la "plantilla" del partido. ${ }^{154}$

Ya en la letra "e" está previsto como gasto electoral el desplazamiento de candidatos, dirigentes partidistas, de asociaciones, de federaciones o de coaliciones, incluso del personal que hace servicios en la campaña. Se trata de una necesidad natural en grandes territorios, y mucho más presente en España porque no hay una exploración adecuada de los medios de comunicación en la campaña electoral. Así, dichos desplazamientos se vuelven aún más necesarios. No es necesario añadir que el desplazamiento de electores, de ocurrir, no puede ser considerado en términos legales como un gasto electoral.

La correspondencia y franqueo engloba también el envío de la propaganda y de papeletas y sobres electorales, y está previsto en la letra "f" del mencionado artículo. Las tarifas son diferentes y suponen una medida de financiación indirecta. ${ }^{155}$ Debido a polémica que involucra tanto el beneficio de tarifas diferenciadas para el envío de las correspondencias, como también la

también la discusión sobre gastos electorales y gastos ordinarios. Sin embargo, PAJARES MONTOLÍO llama la atención sobre la cantidad de mítines realizados después de convocadas las elecciones, pero antes de la campaña electoral, es decir, en la precampaña, no siendo contabilizados para fines de gastos electorales. (In: PAJARES MONTOLIO, E.: La Financiación de las...Pp. 121).

${ }_{153}$ HOLGADO GONZÁLEZ, M.: La Financiación de los... Pp. 44.

154 PAJARES MONTOLIO, E.: La Financiación de las... Pp. 121.

${ }^{155}$ HOLGADO GONZÁLEZ, M.: La Financiación de los... Pp. 45. 
confección de papeletas por los propios partidos, se puede sostener que son demasiados beneficios alrededor de un único elemento a favor de los partidos. Esto es, los partidos tienen subvenciones para la confección de las papeletas, para su envío, y, aún más, todo ello con tarifas especiales. El doble gasto en papeletas (tanto por parte del Estado, como también por los partidos políticos), junto con las tarifas especiales, y dado que dicho gasto no es tomado en cuenta a los fines de limitación de gastos electorales, es algo que provoca una reacción prevalente negativa entre la doctrina. ${ }^{156}$ Quizás las tarifas especiales tengan un efecto beneficioso para la campaña electoral, porque facilitan el envío de propaganda a los electores en general y, dado que son los recursos públicos los que pagarán por el envío, a partir del momento que se tiene una tarifa especial, el Estado también pagará menos. Sin embargo, la subvención para la confección de papeletas encuentra mayores dificultades de justificación.

Además, cuando se trata de propaganda electoral, la acumulación de ambos beneficios puede representar un gasto innecesario, por ineficaz. La propaganda electoral por correspondencia puede terminar saturando al elector y provocar un sentimiento de rechazo en el electorado.

Los intereses de los créditos recibidos para la campaña electoral, vienen por el art. 130, g, delimitados a los que se devengan hasta la fecha de percepción de la subvención correspondiente. Sin embargo, existen dos momentos para la entrega de las subvenciones, produciéndose en el primero la entrega al partido del $90 \%$ del total debido después de presentar la rendición de cuentas al Tribunal de Cuentas, y únicamente finalizado el proceso de fiscalización, el partido recibe la cantidad restante. Por ello, resulta difícil determinar exactamente cuál es la fecha límite para contabilizar dichos intereses, y también para no sobrepasar el límite de gastos. ${ }^{157}$ Por otra parte, cabe recordar la acostumbrada falta de transparencia tanto en las condiciones de la concesión del crédito, así como también en las propias informaciones que se puede obtener sobre los mencionados intereses. ${ }^{158}$ Además, se da también el problema de que un préstamo de recursos para los partidos puede constituirse también en una donación "disfrazada", resultando difícil saber

\footnotetext{
${ }^{156}$ Ejemplo de la doctrina, véase PAJARES MONTOLIO, E.: La Financiación de la... Pp. 117.

157 PAJARES MONTOLIO, E.: La Financiación de las... Pp. 123-124.

${ }^{158}$ HOLGADO GONZÁLEZ, M.: La Financiación de los... Pp. 46.
} 
exactamente cuánto corresponde a la deuda principal y cuanto a los intereses, y más considerando los problemas de fiscalización por parte del Tribunal de Cuentas, el constante silencio por parte de las entidades bancarias en proveer dichas informaciones, y también la deficiente contabilidad entregada por los partidos para su fiscalización. Se trata, pues, de un gasto electoral que permite múltiples lagunas y fraudes, y puede ser claramente una puerta abierta para irregularidades en la rendición de cuentas de los partidos. ${ }^{159}$

La última categoría de gastos electorales resulta, en mi opinión, la más problemática, porque es demasiado amplia para posibilitar un control efectivo de los gastos, además de permitir que un gasto especifico que no se encuadre en los otros anteriores, sea considerado como un gasto ordinario, no sujeto a los límites de la ley electoral y abonado con recursos de la financiación ordinaria. ${ }^{160}$ Está claro que la LOREG se basó en un modelo de campaña electoral ya sobrepasado actualmente, y por ello no existe una específica regulación para muchos gastos que pueden ser considerados electorales ${ }^{161}$, generando problemas de difícil solución y perjudicando directamente la actividad de fiscalización ejercida por el Tribunal de Cuentas. ${ }^{162}$

\section{i) La limitación de los gastos electorales}

Como cierre del tema de los gastos electorales, la LOREG prevé en su art. 131 una limitación para estos gastos, que varía conforme al nivel de la elección. La ley establece dos tipos de limitaciones, una relativa (referente a un

159 PAJARES MONTOLíO afirma que es común que el Tribunal de Cuentas rechace la clasificación de algunos gastos como electorales basándose en esta hipótesis. El autor cita ese problema de definición en las leyes autonómicas, por ejemplo. (In: PAJARES MONTOLIO, E.: La Financiación de las... Pp. 127).

160 GARCÍA-MONCÓ sostiene que dicho apartado es lo mismo que no decir nada, dejando clara cuál es su opinión sobre esta disposición. (In: GARCíA-MONCÓ, A. "La Financiación Electoral. Los Avales de los Partidos". Conferencia proferida en 24 de marzo de 2011 en el Seminario Internacional sobre la Reforma de la Ley Orgánica del Régimen Electoral General. Universidad Rey Juan Carlos, Madrid, 2011. Pp. 7).

${ }_{161}$ HOLGADO GONZÁLEZ, María: La Financiación de los... Pp. 46-47 y MARTIN DE LA VEGA, A. "Censo Electoral y Campañas de Publicidad Institucional en la Proposición de Ley de Reforma de la LOREG de 22 de Octubre de 2010". In: Cuadernos de Derecho Público. ㄲo 146. ene/abr. Madrid, 2009. Pp. 127-133.

${ }_{162}$ Además, una de las sugerencias hechas por SÁNCHEZ MUÑOZ es que se deberían haber incluido gastos realizados en el extranjero por los partidos que obtienen los votos de los residentes en el exterior. Considerando los gastos actuales de esta naturaleza, sería una buena alternativa. Cfr. SANCHÉZ MUÑOZ, Ó. “Cuestiones Relativas...” Pp. 630. 
porcentaje que no puede ser sobrepasado dado un determinado gasto, como es el caso de la limitación de 20 por 100 del límite global para gastos con publicidad, art. $55.3^{163}$ ) y un límite global, que se refiere a todos los gastos permitidos, calculado a partir del número de habitantes en cada circunscripción en que el partido haya presentado candidaturas (y no de electores, algo que es susceptible de críticas). ${ }^{164}$ Se puede utilizar la clasificación establecida por HOLGADO GONZÁLEZ sobre limitaciones cualitativas (que se refiere a gastos que los partidos políticos no pueden hacer ${ }^{165}$ ), y limitaciones cuantitativas (que se refieren a los topes máximos de gastos ${ }^{166}$ que los partidos pueden hacer). ${ }^{167}$ Las reglas de limitación de gastos sirven para evitar el esfuerzo económico por parte de los partidos políticos, o también la presión sobre los electores a través de una utilización excesiva de los medios de comunicación. ${ }^{168}$ Sin embargo,

${ }^{163} \mathrm{El}$ artículo fue objeto de reforma en 2011, antes el porcentual era de 25 por 100 del límite global, ahora es $20 \%$.

${ }^{164}$ HOLGADO GONZÁLEZ, M.: La Financiación de los... Pp. 58-59.

${ }^{165}$ Como ejemplo de estas limitaciones cualitativas se pueden citar la prohibición de efectuar propaganda con pancartas y banderolas fuera de los lugares designados gratuitamente por el ayuntamiento, lo que no significa prohibición de contratación de espacios comerciales. La autora cuestiona si esta medida no es más por limpieza y estética de las ciudades o si es para atender a la igualdad de oportunidades. (In: HOLGADO GONZÁLEZ, M.: La Financiación de los... Pp. 51). Aquí yo añadiría, además del principio de la igualdad de oportunidades, la cuestión ambiental que no puede ser olvidada o relativizada, porque es sabido que en países como Brasil, antes de la prohibición de confección de publicidad para ser distribuida directamente entre los electores, siendo que los candidatos o partidos no se responsabilizaban de la misma. Sin embargo, desde que la ley 11.300 de 2006 prohibió su distribución, el problema parece haber sido resuelto. Este tipo de prohibiciones de propaganda intenta primar también un determinado tipo de comunicación política, no solo preocupada con la imagen de los candidatos, sino centrada en el debate de ideas y de propuestas, verdadero origen de las campañas electorales. Sobre el punto, véase PAJARES MONTOLIO, E.: La Financiación de las... Pp. 128. Cabe resaltar también que existe una prohibición de contratar publicidad en las cadenas privadas de medios de comunicación de masas, como televisión y radio, estando disponible las cadenas públicas, configurándose como forma de financiación indirecta por parte del Estado. Con todo, estoy de acuerdo con SÁNCHEZ MUÑOZ que entiende que, aunque hayan dichas prohibiciones y limitaciones, en el caso del art. 55.2 se produjo una violación del principio de igualdad, porque favorece a determinados grupos. (In: SANCHEZ MUÑOZ, O.: La lgualdad... Pp. 196-197).

${ }^{166}$ Ejemplo de ese tipo de limitación es la específica para publicidad exterior y en los medios de comunicación privados, siendo su objetivo directo la limitación del gasto. Para ello, dichos límites no pueden tener topes muy altos, aunque esto parezca afectar al derecho de libertad de expresión, opinión que no comparto. (In: PAJARES MONTOLIO, E.: La Financiación de las... Pp. 139).

${ }_{167}$ HOLGADO GONZÁLEZ, M.: La Financiación de los... Pp. 49.

168 PAJARES MONTOLIO, E.: La Financiación de las... Pp. 99. SÁNCHEZ MUÑOZ afirma que, con la limitación absoluta de los gastos electorales, se busca evitar que los partidos se embarquen en una escalada de gastos y que eventualmente desarrollen unas ciertas dependencias de las fuentes de financiación, tanto legales como irregulares. Además, en su opinión, esta limitación es la que más favorece la igualdad de oportunidades, pero que el límite 
como todas las limitaciones previstas en las leyes de financiación de partidos, su eficacia no es tan ni mucho menos garantizada, porque existen dificultades para clasificar lo que debe ser considerado como un gasto electoral, además de no preverse sanciones "reales" en caso de su incumplimiento.

Por todo ello, las medidas limitativas terminan desacreditándose, y convirtiéndose en letra muerta. ${ }^{169}$ Por otra parte, en la adopción de dichas medidas, no son tomados en consideración muchos otros efectos, como puede ser el caso de la sustitución de medidas reguladoras, como por ejemplo el gasto de campaña (que es regulado) por el gasto de precampaña (que no está regulado). Ocurre lo mismo con la limitación de gastos, dado que los partidos beneficiados por las subvenciones públicas siempre se encuentran en una posición ventajosa para eludir dichos límites. ${ }^{170}$ Además, en relación a las elecciones municipales, generalmente la limitación de gastos en los entes territoriales de menor tamaño es bastante bajo, provocando un casi forzoso incumplimiento de la ley. Pero en estos supuestos, el propio Tribunal de Cuentas no aplica ninguna penalización. ${ }^{171}$ Sin embargo, dichas medidas

debe estar siempre por debajo de la capacidad económica de las fuerzas políticas más potentes. (In: SÁNCHEZ MUÑOZ, O.: La lgualdad... Pp. 185).

169 PAJARES MONTOLIO, E.: La Financiación de las... Pp. 99-101. También en ese sentido, cfr. SÁNCHEZ MUÑOZ, O.: La Igualdad... Pp. 188-196. El autor argumenta que para ser gasto electoral, debe también ser efectuado por uno de los legitimados para realizar campaña electoral, aunque en la práctica dichos gastos puedan ser realizados por cualquiera, favoreciendo al partido sin que cuente para el límite de gastos previsto en ley. Sin embargo, PAJARES MONTOLíO también subraya la problemática de limitar los gastos y el derecho fundamental de libertad de expresión. Así, el autor entiende que la regulación sobre esta materia debe respetar: 1) la libertad de acción e independencia de las candidaturas; 2) debe variar según el tipo y nivel de las elecciones o campaña electoral que se trate; 3) variar conforme el número de candidatos; 4) debe ser consciente de que partidos y candidatos desarrollarán técnicas para eludir dichas reglas, que son de difícil detección y represión. ARGANDOÑA también cuestiona la eficacia de dichas medidas de limitación de gastos electorales, manteniendo que "aunque todos los candidatos podrían desear la limitación de esos gastos, ninguno tendrá interés en hacerlo primero - y todos desearán incumplir esa limitación, si los demás la aceptan". (In: ARGANDOÑA, A. "La Financiación de los Partidos Políticos y la Corrupción en las Empresas". In: Papeles de Ética, Economía y Dirección. oㅡ 6, [s.I.], 2001. Pp. 6). En el mismo sentido, cfr. URIARTE, E.: La Ley más Tramposa. ABC. 15 de noviembre de 2005, nota en la que la autora destaca la inconveniencia de las medidas limitativas de las donaciones privadas, que acaban por provocar situaciones como la condonación de la deuda de PSC por parte de La Caixa. Sin embargo, yo entiendo que, aunque las limitaciones puedan ser bastante rígidas, la tentación de los partidos de recurrir a la financiación irregular no se conecta exactamente con la existencia de límites. El comportamiento corrupto puede tener innumerables orígenes.

170 GARCÍA VIÑUELA, E. "Financiación Pública de los..." Pp. 90-91.

${ }^{171}$ En este sentido, cfr. CUÑADO AUSIN, G. "La Fiscalización de los Partidos Políticos: Una Síntesis de las Actuaciones Practicadas por el Tribunal de Cuentas". In: Revista Española de Control Externo, vol. 3, no 9, 2001. Pp. 160. 
todavía son apoyadas por parte de la doctrina, constituyendo un rasgo común de las leyes sobre financiación en diversos países del mundo, probablemente porque se parte del entendido de que la campaña electoral debe cumplir su función en un corto espacio de tiempo, sostenida por la financiación pública indirecta y por una parte de la financiación privada. ${ }^{172}$

\title{
j) Control y Fiscalización de la Financiación Electoral
}

\author{
Una de las innovaciones de la LOREG en relación al Decreto-Ley
} 20/1977 es el procedimiento de control de la contabilidad electoral, donde solo se preveía la supervisión de la Juntas Electoral Central y provinciales. Las elecciones de 1986 serán las primeras elecciones generales en donde se produce la intervención del Tribunal del Cuentas en la fiscalización de ingresos y gastos de los partidos políticos La Junta Electoral Central o la correspondiente Junta Provincial continúa teniendo la función de velar por el cumplimiento de las normas electorales desde la fecha de la convocatoria

\footnotetext{
${ }^{172}$ Esta es la opinión de ÁLVAREZ CONDE, E. "Algunas Propuestas..." Pp. 29. Antes del autor, DEL CASTILLO ya se posicionaba a favor de la limitación de gastos para combatir el encarecimiento de las campañas y para controlar el uso desproporcionado de los medios de propaganda de impacto dudoso. Según esta autora, puede parecer una limitación de la libertad de la actividad de los partidos políticos, pero hay que racionalizar la gestión de los recursos, que en grande parte son públicos. Sin embargo, junto con la limitación, se debe preservar el derecho de expresión del partido, y dicho equilibrio no es sencillo. (In: CASTILLO VERA, P. del. "Financiación de las Elecciones Generales de 1986..." Pp.139-140). La cuestión de la libertad de expresión y de las medidas de limitación de los gastos electorales ya fue ampliamente tratada y, solamente como ejemplo, se expone el entendimiento de BALMELLI, que dentro del contexto suizo narra el posicionamiento del Tribunal Federal Suizo sobre el conflicto de la libertad de expresión y la limitación de gastos, y según el cual la libertad de expresión no puede ser absoluta, y puede ser objeto de restricción por exigencias constitucionales. Así, dicha restricción debe estar contenida en ley y estar justificada por un interés público o por el Derecho Fundamental, y, obviamente realizarse cumpliendo las exigencias del principio de proporcionalidad. Sin embargo, todo debe ser hecho dentro del principio de la proporcionalidad. (In: BALMELLI, T.: Le Financement des Partis Politiques et des Campagnes Électorales: Entre Exigences Démocratiques et Corruption. Universitaires Fribourg, Suisse, 2001. Pp. 394-395). Lógicamente se sabe que, a partir del momento en que un partido empieza a gastar más en su campaña, este aumento de gasto será acompañado por todos los demás, y los recursos no serán nunca suficientes. Sin embargo, es importante la presencia de medidas así, pero que cuenten con efectividad para que sus propósitos se concreticen. En este sentido, cfr. BLANCO VALDÉS, R. L.: La Bolsa o la Vida - ¿Deben prohibirse las donaciones anónimas a los partidos políticos?. El País. 18 de diciembre de 2005. Más recientemente, cfr. SÁNCHEZ MUÑOZ, O.: La lgualdad... Pp. 199-200, que el autor está a favor de las medidas de limitación, pero que de alguna manera el conjunto de dichas medidas también favorecen a los partidos del status quo.
} 
hasta el $100^{\circ}$ día posterior a las elecciones, debiendo informar el Tribunal de Cuentas sobre los resultados de dicha actividad. ${ }^{173}$

Sin embargo, aunque se perciban avances en el tema del control de las finanzas de los partidos ${ }^{174}$, también se produjo un retroceso en este tema, ya que la LOREG solamente determina la obligatoriedad de tener una contabilidad detallada y documentada ${ }^{175}$ para los partidos políticos que obtengan representación parlamentaria y, consecuentemente, acceso a las subvenciones públicas $^{176}$, y no para todos los partidos competidores, como preveía el anterior Decreto-Ley 20/1977. Este aspecto de la ley resulta criticable, porque los electores tienen el derecho de obtener información acerca de las organizaciones sin representación en el Parlamento, y de conocer sus fuentes de financiación. Aun así, si dichos partidos no envían por su propia voluntad los datos referentes a las mismas al Tribunal de Cuentas, dichos datos no serán públicos. Cabe destacar el hecho de que esta falta de obligatoriedad de todas las fuerzas políticas de rendir cuentas también está presente en la financiación ordinaria de los partidos actualmente vigente (Ley Orgánica 8/2007).

En el plazo de doscientos días después de las elecciones, el Tribunal de Cuentas debe pronunciarse sobre la regularidad de las cuentas presentadas por los partidos, en sus diferentes niveles si fuera el caso. Si se constatasen irregularidades el Tribunal puede proponer la reducción o la no adjudicación de las subvenciones electorales del partido involucrado. También en el mismo plazo, el Tribunal de Cuentas debe enviar un informe sobre el resultado de su actividad fiscalizadora tanto para el Gobierno y para la Comisión de relaciones del propio Tribunal con las Cortes Generales. A su vez, en el mes siguiente, el

173 CASTILLO VERA, P. del. "Financiación de las Elecciones Generales de 1986..." Pp. 119120. Es de resaltar que, conforme el art. 132.4 , si la fiscalización hecha por las Juntas culminara en indicios de conductas delictivas, deberán comunicarse al Ministerio Fiscal. Con relación al Tribunal de Cuentas, ya se adelanta que dicho órgano no tiene ninguna potestad sancionatoria, lo que resulta lamentable, ya que los efectos reales del sistema de fiscalización disminuyen considerablemente con la falta de aplicación de sanciones.

${ }^{174}$ MARÍN ARIAS afirma que en España se privilegia más el control del dinero de los partidos ante el Estado que ante la sociedad, ya que la publicidad no es contemplada de manera detallada tanto en la LOREG como en la LOFPP. (In: MARIN ARIAS, M. "Arts. 121..." Pp. 1038).

${ }^{175}$ Al comentar el art. 133, MARÍN ARIAS llama la atención sobre la falta de definición y criterios para la entrega de los documentos, haciendo (o permitiendo que se haga) que cada partido entregue la documentación como quiera, dificultando el proceso de fiscalización. (In: MARIN ARIAS, M. "Arts. 121..." Pp. 1085).

${ }^{176}$ Según lo dispuesto en el art. 133.1, LOREG. 
Gobierno remite a las Cortes Generales un proyecto de crédito extraordinario con el importe correspondiente a las subvenciones electorales. ${ }^{177}$

Este modelo de fiscalización está vigente desde 1986 y desde entonces ya se conocían sus deficiencias, pero este hecho no fue suficiente para que se incluyeran en la reforma de 2011 cambios reales capaces de mejorar la fiscalización. Hay aspectos donde tanto el procedimiento como la posible aplicación resultan debilitados (como pueden ser la conceptualización de los gastos electorales o la aplicabilidad de los límites de los mismos). Los partidos entregan su rendición de cuentas no porque están cumpliendo la ley y con este ánimo, sino solamente para recibir el $90 \%$ del total de las subvenciones debidas, y para ello les resulta indiferente entregar documentos incompletos y de difícil control. Por otra parte, disposiciones como el art. 133.5 son sistemáticamente incumplidas porque, como se verá en el análisis directo de los datos contables de los partidos, muchas de las empresas que han facturado con los partidos por un valor superior a 10.000 euros por gastos electorales no informan al Tribunal de Cuentas sobre ello, abriendo una puerta al comportamiento fraudulento. ${ }^{178}$

Por último, aun cuando el Tribunal de Cuentas deba limitarse a proponer sanciones por infracciones a la legislación, como puede ser la reducción o la no adjudicación de las subvenciones, uno de los escasos delitos previstos en la LOREG y que se conectan con la financiación electoral consta en el art. 149 y 150 , que prevé penas a los administradores generales y provinciales (si es el caso) que falseen las cuentas electorales, omitiendo indebidamente donaciones o gastos, o que utilicen diversas técnicas que impliquen un aumento o disminución real del montante de titularidad del partido. Para esta conducta está prevista una pena de prisión de 1 a 4 años y multa de 24 meses. ${ }^{179}$ La segunda conducta tipificada contempla que los administradores generales o personas autorizadas dispongan de las cuentas electorales, que se apropien o que distraigan valores para otros fines que no sean el determinado

\footnotetext{
177 CASTILLO VERA, P. del. "Financiación de las Elecciones Generales de 1986..." Pp. 120121. También, directamente en la LOREG, véase arts. 133 y 134, detallando el procedimiento. ${ }^{178}$ Se resalte que dicho artículo fue objeto de la reforma de 2011 solo para actualizar el valor, que antes era de un millón de pesetas.

179 El art. 149 ha sufrido modificaciones con la reforma de 2011, a fin de aumentar las sanciones antes previstas.
} 
por la LOREG. En este caso, la sanción es de prisión menor y multa. Hasta el momento, no hay registros importantes de la aplicación de dichas penas por parte de los tribunales.

Resulta claro que, en realidad, la reforma del 2011 obvió la trascendencia del tema, adoptó medidas menores y rehusó incluir un tratamiento más detallado, en línea con la Ley Orgánica 8/2007, que hubiera debido de servir como referente. Aunque se verifique una mayor eficacia en este control (o quizás un grado menor de ineficacia), es un hecho que el procedimiento resulta obsoleto, y que no cubre las necesidades que el principio de la transparencia impone. Por otra parte, se mantienen las disparidades entre los gastos electorales y ordinarios, cada uno contando con sus propios límites y requisitos. La reforma no se ha preocupado de especificar mejor dichas diferencias a fin de facilitar el control de los recursos, tampoco los criterios materiales ya existentes en la ley anterior ayudaban en esta labor. Desafortunadamente, la situación tiende a permanecer. ${ }^{180}$

La adjudicación tanto del adelanto concedido como del resto de la subvención a favor de los partidos beneficiarios se efectuará conforme el Real Decreto 1907/1995, de 24 de noviembre.

Aun cuando la mencione, la LOREG no reguló la financiación de las actividades ordinarias de los partidos políticos, y así, únicamente con la LOFPP se desarrolló una normativa completa sobre este ámbito de financiación de los partidos.

\subsection{La regulación de la financiación de las actividades ordinarias de los partidos políticos}

Más allá de la discusión sobre si el Estado debe financiar las actividades ordinarias o permanentes de los partidos políticos, lo cierto es que muchos de los países prevén una regulación al respecto. En este sentido, España también dispone de una legislación sobre la financiación de las actividades ordinarias, una normativa que ha venido evolucionando en las últimas tres décadas posteriores a la transición. Como sucedió con el Decreto-Ley 20/1977, la

\footnotetext{
${ }^{180}$ En este sentido, véase SANCHÉZ MUÑOZ, Ó. “Cuestiones Relativas...” Pp. 627.
} 
primera norma con rango legal sobre la materia también fue el inicio de la regulación sobre este tema, determinando sus rasgos principales, rasgos que hasta hoy definen el perfil del modelo adoptado. $Y$ por ello, a pesar de los cambios producidos, tan solo con la última reforma legal a través de la Ley Orgánica aprobada en 2007 - se han introducido modificaciones sustanciales en las características generales del sistema de financiación ordinaria.

En todo caso, un análisis de la evolución legislativa en la materia puede resultar útil a efectos de detectar los elementos centrales a discutir y las modificaciones introducidas en el modelo.

\subsubsection{Ley Orgánica 54/1978 de 4 de Diciembre}

La Ley 54/1978 fue pionera en establecer la financiación permanente a favor de los partidos políticos y, como el resto de la legislación sobre financiación, es también resultado del clima político de consenso que predominó en la época de la transición política. Dicha ley trataba de desarrollar el artículo $6^{\circ}$ de la Constitución Española, todavía pendiente de entrar en vigor $^{181}$. Se puede concluir pues que el proceso de constitucionalización de los partidos y el establecimiento de su financiación pública fueron fenómenos simultáneos y pacíficos, contando con una aprobación casi unánime, donde del total de 292 votos, 290 lo fueron a favor de la aprobación del proyecto. ${ }^{182}$

\footnotetext{
${ }^{181}$ Al Igual que el propio art. 6, la Ley 54/1978 tampoco fue objeto de detenido debate, es decir, la adopción del modelo de financiación pública para los partidos políticos no fue algo analizado pormenorizadamente, por el contrario, existieron prácticamente una unanimidad en la aprobación de la norma, con 290 votos de los 292 posibles. (In: CASTILLO VERA, P. del. "La Financiación Pública de los Partidos en España". In: Revista de Derecho Político. no 22. UNED, Madrid, 1986. Pp. 166). En este sentido, MARTíN DE LA VEGA, al analizar la evolución del Derecho de Partidos en España, subraya que la regulación de los partidos existente pasó siempre sin enmiendas por el Senado, con el habitual propósito de acelerar su entrada en vigor de cara a las inmediatas elecciones. Desde el punto de vista del bicameralismo, este hecho no es común. (In: MARTíN DE LA VEGA, A. "Los Partidos Políticos y la Constitución de 1978..." Pp. 210). El autor se refiere en su artículo a la Ley Orgánica 06/2002, sucesora de la Ley Orgánica 54/78.

${ }^{182}$ CASTILLO VERA, P. del. "La Financiación Pública...". Pp. 166. El proceso de elaboración del texto del proyecto de ley y de la propia Constitución fueron paralelos, y esto permitió que en la elaboración de dicho proyecto de ley, también se tuvieran en cuenta los trabajos desarrollados en la Comisión de Asuntos Constitucionales y Libertades Públicas. (In: CASTILLO VERA, P. del: La Financiación de Partidos y Candidatos... Pp. 210-211). Una de las escasas enmiendas presentadas trató de la financiación de los partidos para las elecciones siguientes, y su autoría era del Grupo Parlamentario Progresista y Socialistas Independientes, a través del Senador Villar Arregui. El texto de la enmienda era: "El Reglamento de ejecución
} 
La ley, pues, tan solo es formalmente anterior a la Constitución, como se deduce tanto de su propósito material, desarrolla el art. 6, como de su propia cronología, tal y como dio a entender el propio Tribunal Constitucional. ${ }^{183}$

en el articulo 6 [que en texto de la Ponencia era artículo único], las candidaturas que correspondan a los partidos actualmente reconocidos, cuyos miembros hubieran participado en aquellas elecciones en virtud de presentación por una agrupación de electores durante el período en que el módulo para la financiación haya de referirse a las elecciones legislativas celebradas el 15 de junio de 1977". Linde Paniagua destaca que se trata de una enmienda de gran valor, aunque pueda tener problemas de carácter técnico. (In: LINDE PANIAGUA, Enrique. El Régimen Jurídico de los Partidos Políticos en España (1936-78) In: MORODO, Raúl; et al: Los Partidos Políticos en España. Labor Politeia, Barcelona, 1979. Pp. 140). Para mayores detalles sobre la intervención de dicho Senador, incluso sobre su contundente opinión de que había partidos extraparlamentarios, pero que contaban con una significativa militancia que mecerían tener acceso a las subvenciones estatales, véase CORTÉS BURETA, Pilar: Recursos Públicos y Partidos Políticos: Balances y Perspectivas de Reforma. Centro de Estudios Políticos y Constitucionales, Madrid, 2003. Pp. 67. Dicha enmienda decía que todos los partidos políticos que tuvieron votos aunque no hubieran logrado escaños tendrían derecho a la financiación estatal, atendiendo asó al principio de igualdad de voto, sin discriminar a nadie. Sin embargo, dicha enmienda ni siquiera fue defendida en la Comisión, porque la propia Ponencia reconsideró su posición y sugirió la aprobación del texto del proyecto, dado al temor de que un eventual retraso impidiera su aplicación a las próximas elecciones. (Vid. LINDE PANIAGUA, E. "El Régimen Jurídico de los Partidos Políticos en España (1936-78)" In: MORODO, R.; et al: Los Partidos Políticos en España. Labor Politeia, Barcelona, 1979. Pp. 140-141). La votación en el Senado fue 130 votos a favor del proyecto de ley original; 1 voto en contra y 19 abstenciones. (Vid. CORTÉS BURETA, P.: Recursos Públicos y Partidos Políticos... Pp. 68). Sin embargo, al analizar el resultado de la votación en el Pleno del Senado del proyecto de ley provocado por la falta de dos tercios del quórum en mencionada votación en el Senado, y abierto plazo para la presentación de enmiendas, la votación del art. 6으 de la ley en el Pleno del Senado fue mucho más polémica que en el Congreso, que contaba con un resultado de 83 a favor, 72 en contra y 5 abstenciones. Debido a tal contraste entre una casa y otra, se cuestiona cual fue realmente la interpretación que el doble criterio para la asignación de los subsidios causó en los partidos, si fue que la medida no beneficiaba a todas las organizaciones y la estructura funcional diferenciada del Senado con relación al Congreso que los separó más de los propios partidos, o la propia composición política de las casas legislativas de la época. Con todo, desgraciadamente no hay como saber cuál fue la verdadera motivación para tal diferencia entre los resultado. (In: CORTÉS BURETA, P.: Recursos Públicos y Partidos Políticos... Pp. 70-71). Me atrevería a decir que el Senado fue prácticamente obligado a proceder de esta manera, justamente para acelerar la aprobación de esta ley que debe haber generado muchos desacuerdos en el Congreso, y esto explicaría aunque no con seguridad - esta diferencia tan grande entre una votación y otra.

${ }^{183}$ Considerando que dicha ley fue aprobada en el mismo año que la Constitución Española, y que solamente se difiere en fechas en una diferencia de 20 días (La Constitución Española fue promulgada en 29/12/1978, mientras que la ley fue en 09/12/1978), SANTAMARÍA PASTOR entiende que materialmente la ley es posterior a la Constitución. (In: SANTAMARIA PASTOR, J. A. "Artículo 6". In: GARRIDO FALLA, F. (coord.). Comentarios a La Constitución. ed. Civitas, Madrid, 1980. Pp. 76). MORODO LEONCIO subraya que ambas normas provienen del mismo legislador, diferenciándose únicamente en la fecha de aprobación, lo que no impide considerar a la ley materialmente posterior, albergando los valores establecidos en el art. 6o de la Constitución Española. (In: MORODO LEONCIO, R. "Artículo 6". In: ALZAGA VILLAAMIL, O. (dir.): Comentarios a las Leyes Políticas - Constitución Española de 1978. Tomo I, preámbulo y artículos 1 a 9. ed. Edersa, Madrid, 1983. Pp. 244). Cabe destacar que, en la STC 85/86, el Tribunal Constitucional consideró que la Ley Orgánica 54/1978 debe ser conforme los preceptos constitucionales, aunque que sea considerada una ley preconstitucional. Véase F.J. 4. 
No obstante, y a pesar de tratarse de una ley cuya finalidad principal consistía en desarrollar de manera inmediata el art. 6ำ, en un intento de facilitar los cauces para la evolución de la vida política de una España aún en transición, así como intentar consolidar lo más pronto posible el sistema de partidos, la norma fue objeto de numerosas críticas no sólo por sus defectos técnicos sino también por sus evidentes lagunas en campos como la regulación de la democracia interna de los partidos, por su excesiva concisión en determinadas previsiones, que permitían así un amplio margen a la interpretación, añadiendo al sistema un significativo grado de inseguridad jurídica. $^{184}$

En relación a la financiación de partidos, dicha ley es más que lacónica. ${ }^{185}$ Únicamente existe un artículo sobre el tema (art. 60186), estableciendo que los partidos recibirían una cantidad fija por cada escaño obtenido en las elecciones, contabilizándose solamente los votos que generaron dicho escaño para el cálculo de las subvenciones. Así, en los presupuestos generales del Estado existiría una cantidad global destinada a este fin, dejando el resto del procedimiento y requisitos en manos de un ulterior desarrollo normativo.

Uno de estos aspectos era el del control de las finanzas de los partidos, dado que con la derogación de la Ley Orgánica 21/1976 tras la aprobación de la Ley Orgánica 54/1978, la materia careció de regulación legal, pues no existía

\footnotetext{
${ }^{184}$ PÉREZ ROYO entiende que la ley 54/1978 logró objetivos importantes para el momento de su aprobación, entre ellos estabilizar el sistema de partidos políticos. El autor entiende que si no fuera por la constante amenaza de ETA, organización esta que aprovechó todas las lagunas de dicha norma para infiltrarse en el Estado español, quizás esta ley aun permanecería en vigor, y la ley 06/2002 no existiría. (In: PÉREZ ROYO, J.: Curso de Derecho Constitucional. 10ํㅡㄴ ed. rev. Marcial Pons, Madrid, 2005. Pp. 639).

${ }^{185}$ Según CORTES BURETA, la Comisión de Justicia del Congreso de los Diputados elaboró un dictamen sobre el proyecto de la Ley Orgánica 54/78, y mantuvo la redacción del art. 6․․ Ya en el Pleno, el diputado Meilángil de UCD, afirmó que la vía de financiación elegida estaba de acuerdo con el Decreto-Ley 20/1977, demostrando su satisfacción con el texto recién aprobado. (In: CORTÉS BURETA, P.: Recursos Públicos y Partidos Políticos... Pp. 65).

${ }^{186}$ El texto del artículo rezaba: "Artículo Sexto. La Administración del Estado financiará las actividades de los Partidos con arreglo a las siguientes normas: 1) Cada Partido percibirá anualmente una cantidad fija por cada escaño obtenido en cada una de las dos cámaras y, asimismo, una cantidad fija por cada uno de los votos obtenidos por cada candidatura a cada una de las dos cámaras. 2) En los Presupuestos Generales del Estado se consignará la cantidad global destinada a estos fines, así como los criterios para distribuirla con sujeción a lo dispuesto en el apartado anterior. 3) Reglamentariamente se determinará el régimen de distribución de las cantidades mencionadas en el apartado a cuando los Partidos hubieran concurrido a las elecciones formando parte de federaciones o coaliciones".
} 
ninguna disposición a este respeto en la recién aprobada Ley Orgánica $54 / 1978$. Así se produjo un vacio que solamente se colmaría con la aprobación de la norma posterior, la Ley Orgánica 3/1987. Y no era únicamente el tema del control el que carecía de regulación. Puntos como la limitación de las donaciones quedaba fuera del texto, dejando evidencias de que la causa de esta omisión respondía a la idea de que los partidos políticos deberían autofinanciarse, más allá de las subvenciones públicas empleadas para el gasto en campañas electorales, algo que resultó claramente imposible por la escasa militancia y el gran número de campañas electorales en que los partidos debían participar. ${ }^{187}$

No se desarrollará aquí pues un análisis detenido de la norma, dada esta falta de contenido sobre el tema de financiación de los partidos. Lo que se lamenta es que, a partir de dicha norma, el doble criterio votos/escaños para acceder a las subvenciones públicas se consolidaba, y consecuentemente pasaba a la legislación posterior, cerrando el sistema de financiación en uno de sus rasgos más permanentes. En todo caso, los partidos no prestaron la debida atención a esta materia, intencionadamente o no, y muchos de los problemas que han surgido tras su aprobación (como la inscripción de partidos, su eventual ilegalización, la democracia interna, y otros) ni siquiera fueron previstos. La ley, pues, se presenta en el fondo, más que como un desarrollo normativo del art. 6, como una ocasión estratégica para cerrar el sistema de partidos y garantizar el status quo partidista.

\subsubsection{Ley Orgánica $3 / 1987$ de 2 de Julio}

La LOREG únicamente contiene la regulación de la financiación electoral de los partidos, careciendo de cualquier disposición sobre la financiación ordinaria o no finalista de estas organizaciones. Tuvo que producirse el llamado "caso Flick", que acabó por motivar la instauración de la primera Comisión de Investigación en el Congreso de los Diputados específicamente sobre la financiación de los partidos, para que se empezara a delinear, por la propia Comisión, los rasgos básicos de lo que debería ser la normativa sobre el

${ }^{187}$ GARCÍA VIÑUELA, E.; ARTÉS CASELLES, J. "El Gasto Público..." Pp. 258-259. 
tema. ${ }^{188}$ Así, la Ley Orgánica 3/1987 reguló ya el régimen de financiación de las actividades ordinarias de los partidos, y lo hizo de manera más detallada que la contenida en las breves disposiciones de la Ley Orgánica 54/1978. El resultado de la votación fue sin embargo similar, 242 votos a favor, 3 en contra y 22 abstenciones.

A pesar del consenso básico sobre el texto de la proposición, fueron presentadas 15 enmiendas, 2 por parte del grupo Mixto, 7 del grupo Vasco y 6 de la minoría Catalana, reflejando las divergencias que estos dos grupos habían expuesto en sus correspondientes intervenciones. ${ }^{189}$

Un grupo de enmiendas pretendían incluir en la financiación pública las subvenciones concedidas por las comunidades autónomas, compatibilizando ambas. ${ }^{190}$ Un segundo grupo, pretendía incluir los votos obtenidos en el

${ }^{188}$ Sobre las propuestas relacionadas con el tema, cfr. BOURSAULT, L. T. "La Financiación de los Partidos Políticos". In: AA.VV.: Jornadas de Estudios sobre el Título Preliminar de la Constitución. vol. III. Secretaria General Técnica - Ministerio de Justicia, Madrid, 1988. Pp. 1932-2028; BALLAGUER CALLEJÓN, F. "Il Finanziamento dei Partiti Politici in Spagna". In: LANCHESTER, F. (a cura de): Finanziamento della Política e Corruzione. Giuffrè, Milano, 2000. Pp. 153-157. También hay una traducción para el español del mismo artículo in: BALAGUER CALLEJÓN, F. "La Financiación de los Partidos Políticos en España". In: Nomos. fasc. 1, ed. Istituto Poligrafico e Zecca dello Stato, Roma, 1999. Pp. 21-35.

${ }^{189}$ La iniciativa de la proposición de ley fue del grupo Socialista, suscrita por los grupos parlamentarios de Coalición Popular, CDS, Mixto, agrupación de diputados PDP y agrupación de diputados Izquierda Unida - Esquerra Catalana. En la mencionada proposición de ley, se reflejaban reunidas las orientaciones que la Comisión de Investigación del caso Flick había emitido, junto con otras sugerencias apuntadas tradicionalmente por los distintos grupos parlamentarios. (Vid. CORTÉS BURETA, P.: Recursos Públicos y Partidos Políticos... Pp. 99). Cabe resaltar únicamente el Grupo Vasco y la minoría Catalana no suscribieron dicha proposición de ley. Aunque no hubiera problemas para su aprobación - dado el consenso existente, cabe destacar la intervención hecha por el diputado Echeverría Monteberría, representando el grupo Vasco - PNV, que deja claro el desacuerdo que su grupo tenía en relación a la proposición, por entender que no se consideraba suficiente la división territorial que determinaba algunas veces el campo de actuación de los partidos; que no se respetaba las competencias de las Comunidades Autónomas en ámbitos no nacionales, que no se compatibilizara las subvenciones estatales con las autonómicas. También se juzgaba excesivo el alcance de las medidas de inspección y fiscalización concedidas al Tribunal de Cuentas y; finalmente se censuraba la ausencia de mención de la situación real de endeudamiento de los partidos. El grupo Vasco se abstuvo de la votación, aunque resaltó que dichas razones podrían justificar un eventual voto en contra a la proposición. Acompañando la postura del grupo Vasco, la minoría Catalana, representada por el diputado López de Lerma i López, también expuso sus discrepancias con la proposición de ley presentada, ya que entendía que acababa por alterar profundamente el sentido del art. $6^{\circ}$ de la Constitución Española, no especificando los aspectos que supuestamente serían alterados. Por otra parte, consideraba que el momento no era el más adecuado para discutir una proposición de ley que únicamente afectaba a los intereses de los partidos. Sin embargo, CIU optó por abstenerse de la votación, y no por el voto negativo. (Vid. DSCD, № 29, de 11 de febrero de 1987. Pp. 1573-1574).

190 La minoría Catalana incluso intentó añadir las subvenciones recibidas por los partidos a título de ayudas de cualquier entidad del sector público, como son los grupos parlamentarios, en sus diversos niveles. 
Senado y en las Asambleas Legislativas de las Comunidades Autónomas en el cómputo del montante de las subvenciones, así como también que los diputados con un partido de origen distinto pudieran recibir las subvenciones por escaño en el partido actual, siempre que este partido hubiera concurrido en las elecciones autonómicas o municipales, obteniendo representación parlamentaria. También se intentó aumentar el límite establecido para las donaciones anónimas de un 5 a un 30 por ciento por cada ejercicio económico anual, con la justificación de que así se evitaría la diferencia existente entre pequeños y grandes partidos. En esta misma línea, se formularon enmiendas tendentes a suprimir la limitación a los partidos para la amortización de sus operaciones de crédito con las instituciones financiadoras hasta el 25 por 100 del montante total de las subvenciones estatales, o para incluir las subvenciones autonómicas en el cálculo de este límite.

Por otra parte, alguna enmienda intentó suprimir la obligación de los partidos de llevar libros contables, con la constancia de un balance anual de bienes y la descripción de ingresos y gastos, por entenderse que dicha medida era innecesaria y afectaba a la prerrogativa concedida a los partidos de autoorganización, y alguna otra que, aunque mantuviera esta obligación contable de los partidos, limitaba la fiscalización del Tribunal de Cuentas únicamente a las subvenciones estatales, o bien proponía que la fiscalización se limitase a verificar si dichas subvenciones fueron empleadas en gastos de funcionamiento ordinario.

Por último, algunas enmiendas proponían añadir una disposición adicional al texto, previendo mecanismos de financiación estatal a largo plazo, como también costes reducidos de mantenimiento para los partidos que tienen derecho a recibir las subvenciones previstas en la ley para los grupos parlamentarios, tanto de las Cortes Generales como en las Asambleas Autonómicas. Se intentó también ampliar la financiación estatal para permitir a los partidos pagar las deudas acumuladas hasta la entrada en vigor de la ley, justificando sus deudas ante el Tribunal de Cuentas. ${ }^{191}$

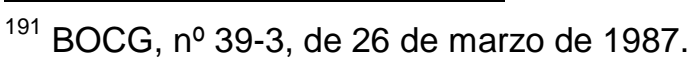


Tras la defensa de las enmiendas en el Pleno y el rechazo de todas ellas, la votación fue de 244 votos a favor de la proposición de ley, 16 en contra y 2 abstenciones. ${ }^{192}$

Ya en el Senado, las enmiendas se repitieron, junto con sus argumentos (por parte del grupo parlamentario de senadores nacionalistas Vascos y el grupo parlamentario de Convergència i Unió, y otra presentada por Coalición Popular, que pedía la inclusión de los votos dados a las coaliciones de partidos en el cómputo de las subvenciones a titulo de financiación pública). Todas fueron rechazadas, manteniendo el texto de ley recibido del Congreso.

La ley en cuanto tal, al igual que su antecesora 54/1978, también se caracterizaba por su brevedad - aunque no tanto como en la norma anterior dejando sin regular pormenorizadamente aspectos importantes como el de la fiscalización de las finanzas de los partidos. Sus 12 artículos no fueron capaces de solucionar los problemas ya antes existentes en el sistema, y quizás hayan colaborado a generar otros nuevos, siendo también determinantes para consolidar otros rasgos de la legislación existentes hasta hoy, que han fomentado el "cierre" del modelo elegido. Con todo, la ley fue considerada un avance en temas como el del endeudamiento de las organizaciones partidistas, a la vez que fijaba un límite para dicho endeudamiento. ${ }^{193}$ Arbitró también subvenciones a los grupos parlamentarios, diferenció los niveles del Congreso de Diputados y Senado; alteró la división de los presupuestos del Estado entre escaños y votos; y creó también mecanismos de control de los partidos que recibían subvenciones. Tales cambios, valorados positivamente por parte de la

\footnotetext{
${ }^{192}$ Llama la atención que, después de la votación, el diputado Cavero Lataillade, representando la agrupación de diputados PDP solicitó intervenir, para subrayar el hecho de que su autofinanciación es imposible, como también que la financiación pública electoral tampoco es suficiente para costear todo el funcionamiento de una organización partidista. (In: DSCG, no 48, de 07 de mayo de 1987. Partidos políticos. 2866-2868).

${ }^{193}$ Conforme dispone el art. 9 de la Ley Orgánica 3/1987 fijando el límite de 25 por 100 de las subvenciones públicas concedidas al partido. Se trata de una regla importante destinada a frenar la velocidad de endeudamiento de los partidos. En 2005 se sabía que el nivel de endeudamiento de los partidos llegó a 39 millones de euros, y que una posible condonación de deudas o la concesión de créditos no estaba regulado por la ley. Lo que sí es cierto es que la vinculación de los partidos con los órganos de dirección de las cajas de ahorro (principales entidades financiadoras) es un indicio de incertidumbres sobre la transparencia de estas fuentes de financiación. En este sentido, cfr. Los Partidos Políticos dejan sin pagar un tercio de sus deudas bancarias. La Voz de Galicia. 27 de noviembre de 2005.
} 
doctrina ${ }^{194}$, no resultaba a la postre, como se analizará posteriormente, de gran eficacia práctica. ${ }^{195}$

\section{a) Fuentes de financiación ordinaria de los partidos políticos}

La Ley Orgánica 3/1987 disponía en su art. 2ํu listado de recursos económicos que componían los fondos partidistas, y esto permitía afirmar que seguía existiendo un sistema mixto, pero que continuaba inclinándose claramente hacia la financiación estatal, ya que las fuentes privadas aún eran muy marginales y restringidas. ${ }^{196}$

Uno de los aspectos que más llamó la atención de la doctrina era la inclusión de las subvenciones a los grupos parlamentarios como parte integrante de los fondos económicos de los partidos, algo que en su época fue bastante criticado por toda la literatura jurídica española. ${ }^{197}$

Además, la ley 01/2003 de 1 de Marzo instituyó otra fuente de financiación pública de los partidos para actividades no finalistas: son los recursos para sufragar los gastos de seguridad que los partidos asumen por mantener su actividad política e institucional. ${ }^{198}$ La principal justificación de esta

\footnotetext{
${ }^{194}$ En este sentido, cfr. MARÍN LEIVA, F. Op. Cit. Pp. 557-558.

195 ESPARZA MARTíNEZ, al tratar de la Ley Orgánica 3/1987, entiende que es una ley carente de fundamentación jurídica, además de ser incompleta para asegurar la necesaria transparencia financiera. (In: ESPARZA MARTÍNEZ, B. Op. Cit. Pp. 99).

${ }^{196}$ Es lo dispuesto en el citado artículo: "art. 2. los recursos económicos de los partidos políticos estarán constituidos por: 1. recursos procedentes de la financiación publica: a) las subvenciones públicas por gastos electorales, en los términos previstos en la ley orgánica $5 / 1985$, de régimen electoral general. b) las subvenciones estatales a los grupos parlamentarios de las cámaras de las cortes generales, en los términos previstos en los reglamentos del congreso de los diputados y del senado, y las subvenciones a los grupos parlamentarios de las asambleas autonómicas, según establezca su propia normativa. c) las subvenciones estatales anuales reguladas en la presente ley. 2. recursos procedentes de la financiación privada: a) las cuotas y aportaciones de sus afiliados. b) los productos de las actividades propias del partido político y los rendimientos procedentes de su propio patrimonio. c) los ingresos procedentes de otras aportaciones en los términos y condiciones previstas en la presente ley. d) los créditos que concierten. e) las herencias o legados que reciban, y, en general, cualquier prestación en dinero o especie que obtengan".

${ }_{197}$ Dicha financiación será tratada específicamente en el punto 9 de este capítulo.

198 El artículo 3.1 tiene el siguiente tenor: "Artículo 3. Modificado por Ley Orgánica 1/2003 1. El Estado otorgará a los partidos políticos con representación en el Congreso de los Diputados, conforme a lo dispuesto en la Ley Orgánica 5/1985, de Régimen Electoral General, subvenciones anuales no condicionadas, con cargo a los Presupuestos Generales del Estado, para atender sus gastos de funcionamiento ordinario. Igualmente, podrá incluirse en los Presupuestos Generales del Estado una asignación anual para sufragar los gastos de
} 
subvención era que algunos miembros de los partidos corrían riesgos por ejercer la actividad política, principalmente en territorios donde el terrorismo era una realidad cotidiana. Lo que no se justifica es que dicha subvención también atiende al doble criterio de acceso de escaños/votos. No parece lógico que dicho beneficio económico se conceda según los mismos criterios de acceso que las demás subvenciones, porque es notorio que hubo víctimas de este tipo de violencia en todo el país, y podría darse el caso de que fuerzas políticas que tuvieran gastos reales de seguridad, pero que no hubieran logrado escaños, o que sean nuevas fuerzas políticas. Por eso aquí se podría defender algunos criterios propios para este beneficio, como ocurre con el mailing, en la legislación electoral, pero posibilitando que los beneficiarios sean los que realmente necesitan de dichos recursos para ejercer sus funciones políticas. ${ }^{199}$ Cabe subrayar que no se defiende de ningún modo que se use los mismos criterios del mailing, pues como se ha visto, se tratan de criterios que producen la fuerte discriminación de muchas de las fuerzas políticas existentes o emergentes.

A partir de un sistema considerablemente generoso con la financiación pública de los partidos, se puede afirmar incluso que la verdadera intención de la aprobación de la ley era consolidar el claro sesgo hacia la financiación a cargo de los presupuestos estatales, haciendo prácticamente innecesaria la financiación privada. ${ }^{200}$ Debido a ello se puede entender que no es posible la eliminación de la financiación pública para las actividades ordinarias de los partidos, o que por lo menos que es una tarea muy difícil, ya que, considerando el bajo nivel de afiliación de las organizaciones, seria abrir demasiado espacio

seguridad en los que incurran los partidos políticos para mantener su actividad política e institucional".

199 Dicha subvención se dirige a ayuntamientos y concejales, principalmente, en áreas afectadas por el terrorismo. Hay sitios en España donde los cargos electos necesitan de escolta, o su familia o de protección a sus bienes, generando un alto coste, y también limitando - y a veces impidiendo - el pleno ejercicio del cargo y de su derecho de participación política. Cfr. CORTES BURETA, P. "La Financiación de los Partidos Europeos y la Financiación de los Gastos de Seguridad: Últimas Novedades". In: AA.VV.: Derecho Constitucional para el Siglo $X X I$ - Actas del VIII Congreso Iberoamericano de Derecho Constitucional, Tomo II. Ed. Thompson - Aranzadi, Sevilla, 2006. Pp. 2893-2894; FERNÁNDEZ VIVAS, Y.: Op. Cit. Pp. 343-344; y SÁNCHEZ-POBRE, P. C. Op. Cit. Pp. 696.

${ }^{200}$ GARCÍA VIÑUELA, E.; ARTÉS CASELLES, J. “El Gasto Público...” Pp. 261. 
para la actuación de los grupos de presión, algo que puede perjudicar aun más a las minorías. ${ }^{201}$

\section{b) Criterios de acceso y distribución de las subvenciones}

La ley fue innovadora en la cuestión del acceso y reparto de las subvenciones, considerando los criterios escaños/votos para el acceso a las subvenciones estatales ya insertos en la financiación electoral junto con un nuevo elemento: un umbral de $3 \%$ de los votos válidos. El mecanismo de división del presupuesto fue alterado para ser separado en tres partes iguales, siendo que $1 / 3$ será repartida proporcionalmente según el número de representantes del partido en el Congreso de los Diputados (sin considerar al Senado), y los otros 2/3 según los votos obtenidos por cada uno de los partidos en las elecciones. Cabe resaltar que en las circunscripciones en que las organizaciones políticas no alcancen el umbral de 3\% de los votos válidos, dichos votos no serán contabilizados a los efectos de obtener subvenciones ordinarias. $^{202}$ Es interesante subrayar que aún introduciendo dichas reglas, la ley fue aprobada sin mayores debates que pudieran plantear objeciones a la doble restricción en los requisitos escaños/votos, o acerca del umbral electoral, y dado que todas las formaciones políticas mayoritarias se beneficiarían de este limitado número de organizaciones que podrían optar por las ayudas. Sorprende, sin embargo, que ni siquiera coaliciones como IU (Izquierda Unida) planteara objeciones, dado que era directamente una de las perjudicadas por dichas condiciones. ${ }^{203}$

En este modelo, además del trato diferente provocado por el doble criterio escaños/votos destaca, el problema de la aplicación del umbral electoral, que aliada con la exclusión del Senado del computo de los escaños, significa que, si el partido logra tan sólo un escaño en el Senado, y ninguno en el Congreso, dicho partido no tendrá derecho a subvenciones ordinarias. La

\footnotetext{
201 MORODO, R.; MURILLO DE LA CUEVA, P. L.: El Ordenamiento Constitucional de los Partidos Políticos. $1^{0}$ ed. UNAM - Instituto de Investigaciones Jurídicas, Derechos Fundamentales, 2001. Pp. 182 y MURILLO DE LA CUEVA, P. L.; VEGA GARCIA, P. de; ALCUBILLA, A.; et al. "Debate. Op. Cit." Pp. 166.

202 Dicha sistemática se encuentra en el art. 3‥

${ }^{203}$ GARCÍA VIÑUELA, E.; ARTÉS CASELLES, J. “El Gasto Público...” Pp. 260-261.
} 
exclusión del Senado en el cómputo del valor de los recursos debidos parece criticable, dado que aparentemente no existe ninguna razón para mantener esta diferenciación con respecto a la financiación ordinaria. De hecho, al tratarse de un problema que alcanza a una de las Cámaras del Legislativo y que fomenta una crisis estructural que el Senado, por otros motivos más importantes, ya sufre desde hace tiempo, el tema merece una mínima atención. No cabe tampoco olvidar que el partido que logre escaños en el Senado posee un tipo de representatividad que no está presente en el sistema proporcional, ya que se trata de un voto mayoritario, que muchas veces es más costoso y más difícil de obtener por esta vía que en el sistema proporcional.

\section{b.1) El problema de la configuración del Senado y su efecto en la financiación ordinaria de partidos}

Como es sabido, la actual configuración del Senado es uno de los aspectos del diseño constitucional sujetos a un permanente debate sobre su posible reforma. ${ }^{204}$ Desde el propio proceso constituyente de 1978, la configuración del Senado suscitó numerosas discusiones. ${ }^{205}$ Se suele mantener que en España existe un bicameralismo débil y fuertemente asimétrico. ${ }^{206}$ Se sabe que el modelo constitucional elegido para el Senado no

\footnotetext{
${ }^{204}$ Por todos, se menciona la contundente afirmación de Jesús LEGUINA VILLA, en la cual el autor manifiesta que "(...) el Senado es la pieza más defectuosa de nuestra arquitectura constitucional. La más defectuosa y quizás también la menos útil". (In: LEGUINA VILLA, J. "La Reforma del Senado y los Hechos Diferenciales". In: Revista de Administración Pública. n. 143, may/ago, Madrid, 1997. Pp. 7). También, para una visión más amplia y detallada, véase: PUNSET, R.: Estudios Parlamentarios. CEPC, Madrid, 2001. Pp. 89 y ss.

${ }^{205}$ Con el desequilibrio existente entre las Cámaras, muchos autores cuestiones cual es el verdadero papel del Senado dentro de la estructura de las Cortes Generales en España. Como hay asimetría entre las mismas, diferencias fuertes entre las funciones de una y otra, y también un cierto desprestigio frente a su figura, CARRERAS SERRA pregunta si no se trata, en realidad, de una Cámara "inútil", dados tantos problemas. (In: CARRERAS SERRA, F. "EI Senado en la Constitución Española". In: PAU I VALL, F. (coord.). El Senado, Cámara de Representación Territorial - III Jornada de la Asociación de Letrados de Parlamentos. Ed. Tecnos, Madrid, 1996. Pp. 32-35).

${ }^{206}$ En este sentido, cfr. PORTERO MOLINA, J. A. "Contribución al Debate sobre la Reforma del Senado". In: Revista de Estudios Constitucionales (Nueva Época), no 87, ene/mar, Madrid, 1995. Pp. 84. A la vez, MARTíNEZ SOSPEDRA clasifica el bicameralismo en España como siendo un "bicameralismo desigual" en lo cual el Senado se subordina al Congreso, además del Senado tener una posición inferior en el proceso legislativo, excluyéndose de esto solamente el procedimiento de reforma constitucional, lo cual hasta hoy no ha pasado, y tampoco se cree que pasará. (In: MARTÍNEZ SOSPEDRA, M.: Las Instituciones del Gobierno Constitucional: Sistemas de Gobierno y Órganos Constitucionales. 2o ed. ed. Fundación Universitaria San
} 
agradó a casi nadie en los primeros años de su aplicación, y tampoco logró mejorar con el tiempo dicha impresión. ${ }^{207}$ Con todo, considerando que dicha cuestión no afecta directamente el objeto del presente trabajo, no se analizará aquí la literatura jurídica acerca de la posible la reforma del Senado. ${ }^{208}$ En todo caso, la reivindicación de una reforma constitucional se centra en la remodelación del Senado para dotarlo de un efectivo carácter de cámara de representación territorial. ${ }^{209}$ Una nueva forma de elección y representación debería llevar aparejada un nuevo diseño de sus competencias constitucionales acorde con su definición constitucional. ${ }^{210}$

Centrándonos en el problema del desequilibrio entre el Senado y el Congreso de los Diputados en el sistema de financiación de partidos políticos, se constata que, además del hecho de que sólo accederán a los recursos públicos los partidos que logran escaños en el Congreso de los Diputados excluyendo objetivamente al Senado - los votos obtenidos por estos partidos en la Cámara Alta no poseen ningún valor para el cálculo de las subvenciones. Y ello, aunque no esté constitucionalmente justificado, sería una consecuencia estructural de las demás disposiciones del actual diseño del sistema político. ${ }^{211}$

Lo cierto es que dicha discriminación del Senado en la legislación sobre financiación de partidos políticos no parece justificada, y por ello termina por

Pablo C.E.U., Valencia, 1994. Pp. 243 y ss.). También, vid.cfr. HERRERO DE MIÑON, M. "En Pro de un Senado Innovador". In: El Valor de la Constitución. ed. Critica, Barcelona, 2003. Pp. 266.

${ }^{207}$ PORTERO MOLINA, J. A. “Contribución al Debate..." Pp. 104.

${ }^{208}$ El debate sobre la reforma del Senado es demasiado amplio para ser resumido en tan pocas líneas y excede mucho en el ámbito de este trabajo. Sin embargo, es posible afirmar que la mayor preocupación en la doctrina es modificar la estructura del Senado, para que este realmente se configure como una Cámara de las Comunidades Autónomas, atendiendo de esa manera, el criterio de la territorialidad. También se propugna una reforma en las funciones del Senado, para que este tenga más influencia en el Poder Legislativo. En ese sentido, véase: la contribución elaborada por especialistas en el tema, compilados en AA.VV.: La Reforma del Senado. Cuadernos y Debates, № 53, Centro de Estudios Constitucionales, Madrid, 1994.

${ }^{208}$ Véase art. 69, Constitución Española. Sobre la constitucionalización de dicho modelo, cfr. MARTINÉZ LÓPEZ-MUNIZ, J. L. "EI Senado de la España Vertebrada". In: Revista Española de Derecho Constitucional, no 49, año 17, ene/abr, Madrid, 1997. Pp. 119-144, artículo que trae la evolución del debate en la Constituyente.

${ }^{209}$ En ese sentido, véase MARTINÉZ LÓPEZ-MUNIZ, J. L. Op. Cit. Pp. 132 y ss.

${ }^{210}$ RIPOLLES SERRANO trae un resumen de todas las funciones que se inclinan a favor de la Cámara Baja en: RIPOLLES SERRANO, M. R. "La Funcionalidad del Senado en el Estado de las Autonomías". In: Revista Española de Derecho Constitucional. nํ37, año 13, ene/abr, Madrid, 1993. Pp. 101-103.

${ }^{211}$ GARCÍA-ESCUDERO MÁRQUES, P.; PENDÁS GARCIA, B. Op. Cit. Pp. 387. 
ser una de las críticas más frecuentes de la doctrina especializada. ${ }^{212}$ Más aún, dicha discriminación fue agravada con la Ley Orgánica 3/1987, que no se limitó a la diferenciación en cuanto a los valores determinados para un escaño en general, y un escaño en el Congreso de los Diputados, conforme art. 227, a y $b$, pues aunque aquellos que obtengan un escaño en el Senado tiene el derecho a los valores referentes al valor de un escaño, el escaño de Diputado todavía tiene mayor valor económico para fines de reembolso. Son dos mecanismos que discriminan al Senado a través de cauces distintos, pero que al final establecen una importante diferencia en el valor de las subvenciones que reciben los partidos políticos. ${ }^{213}$

Hay que tener en cuenta que, según el art. 3 de la nueva LOFPP, los partidos que tengan solamente representación en el Senado, o incluso se puede incluir en esta hipótesis, en el Parlamento Europeo, no tienen derecho a acceder a las subvenciones públicas. $Y$ ello va en contra de los objetivos trazados para un modelo de financiación pública, ya que no se puede ignorar la representatividad real de grupos sociales que a través del partido han logrado alcanzar escaños en el Senado o en el Parlamento Europeo.

Podría pues considerarse un nuevo parámetro de representatividad de las formaciones políticas en el Senado, aunque se mantenga que la representatividad contenida en la Cámara Baja resulte de mayor peso. Si el motivo principal de las ayudas públicas es colaborar con los partidos para que puedan realizar su función en periodos no electorales, no debería existir una diferencia entre partidos con representación en el Senado o en la Cámara, ya que ambos ejercen sus tareas de manera permanente. ${ }^{214}$ La ley de financiación de esta forma contribuye a disminuir el ya escaso protagonismo del Senado. ${ }^{215}$

${ }^{212}$ Como ejemplo de autores que comentan el tema, cfr. ÁLVAREZ CONDE, E. "Algunas Propuestas..." Pp. 19; CORTÉS, P. "Últimas Propuestas sobre la Financiación de los Partidos Políticos". In: Teoría y Realidad Constitucional, no 6, 2ำ semestre, ed. UNED, 2000. Pp. 212; y también las diversas críticas hechas por BLANCO VALDÉS en sus trabajos.

${ }^{213}$ Cfr. BLANCO VALDÉS, R. L. "Consideraciones sobre..." Pp. 49.

214 DIAZ-SANTANA CASTAÑOS añade que no sería justo que se otorgara la misma financiación a ambas cámaras legislativas porque el Senado vive actualmente una fase de cuestionamiento de su propia existencia y función. Aun más considerando la diferencia entre los sistemas mayoritario y proporcional que rigen en cada una de ellas. (In: DÍAZ-SANTANA CASTAÑOS, H. Op. Cit. Pp. 181).

${ }^{215}$ CASTILLO, P. del. "La Financiación Pública de los Partidos Políticos..." Pp. 84. La autora señala que la constitucionalidad de la exclusión del Senado en la LOFPP de 1987 fue cuestionada por los grupos parlamentarios nacionalistas y minoría catalana, pero que la 


\section{c) Otras características de la financiación pública ordinaria}

Otro punto muy polémico de la Ley Orgánica 3/1987 es la ausencia de un límite para la cantidad total de dichas subvenciones, permitiendo un incremento ilimitado de los recursos destinados a los partidos políticos. Entre 1986 y 1987, las ayudas a los partidos pasaron de 3102 millones de pesetas a 7500 millones de pesetas, significando un incremento de más del 100\%. Todo ello confirma que el sistema se encuentra orientado hacia la financiación pública, la cual era ya un hecho consumado al tiempo de la promulgación de la ley, agregándole entonces aun más facilidades de manipulación por parte de los partidos. ${ }^{216}$ Ante esto fueron constantes las sugerencias para la imposición de un límite en el incremento del total disponible de subvenciones fueron constantes. En aquella época, España era el único país europeo que no preveía ninguna limitación en este sentido, contribuyendo así a que partidos no se esforzaran para controlar sus gastos u optimizar sus recursos, dado que podían solucionar fácilmente sus problemas financieros. ${ }^{217}$ Sin embargo, otras voces señalaron el escaso montante total de la financiación de los partidos ${ }^{218}$, lo que supuestamente no permitía afirmar que hubiera un uso abusivo de recursos por parte de dichas organizaciones.

cuestión no llegó al Tribunal Constitucional. Sin embargo, la autora considera que su constitucionalidad es "dudosa".

${ }^{216}$ GARCÍA VIÑUELA, E.; ARTÉS CASELLES, J. "El Gasto Público...” Pp. 261

${ }^{217}$ CASTILLO, P. del. "Financiación de los Partidos Políticos: La Reforma..." Pp. 165). En el mismo sentido, cfr.: GONZÁLEZ-VARAS, S.: La Financiación de los Partidos Políticos. Dykinson, Madrid, 1995. Pp. 144. En esta línea, ARIÑO ORTIZ afirma que la falta de necesidad de militancia o voluntariado aumenta la necesidad de los partidos políticos de estar siempre en los medios, generando la necesidad de fondos públicos ilimitados. Así, el autor entendía la financiación pública ilimitada como totalmente perjudicial para el funcionamiento de la democracia. (In: ARIÑO ORTIZ, G.: La Financiación de los Partidos Políticos. Documentos del Foro de la Sociedad Civil. ㄲo 1. Ed. Foro de la Sociedad Civil, Madrid, 2009. Pp. 24).

${ }^{218}$ Según MURILLO DE LA CUEVA, dicho porcentual no alcanzaba el $15 \%$ por 100 de este en 1993. Véase MURILLO DE LA CUEVA, P. L. "La Financiación de los Partidos y de las Elecciones: La Legislación Interminable". In: Revista Vasca de Administración Pública. № 37, sep/dic, IVAP, Bilbao, 1993. Pp. 23-24. Está de acuerdo con el autor BALAGUER CALLEJÓN, F. "La Financiación..." Pp. 25. 


\section{d) La financiación ordinaria privada y el debate sobre la posibilidad de donaciones anónimas}

En relación a las aportaciones privadas, el carácter "sospechoso" que la normativa española alienta sobre dichas fuentes de financiación se confirma y se fortalece. Sin embargo, el escenario se complica si se compara la LOREG y dicha ley, porque existían grandes diferencias entre esta y aquella, que acabaron por causar problemas en el momento de su aplicación.

Las divergencias empezaron por la disposición contenida en la Ley Orgánica 3/1987 que permitía a los partidos recibir aportaciones privadas no finalistas dentro de los límites descritos también en la ley. Con todo, los límites contenidos en la LOREG eran mucho más restrictivos que los límites dispuestos en la Ley Orgánica 3/1987, ya que en el caso de esta última, los partidos podrían recibir recursos tanto de personas físicas como jurídicas, las cuales podían donar anónimamente (y teniendo en cuenta que el valor total de las donaciones anónimas no podría sobrepasar el 5 por 100 de la cantidad total destinada a los partidos por el Estado). ${ }^{219}$ También se constata que la limitación de donaciones por persona física o jurídica era mucho mayor en la ley de 1987 que la establecida en la LOREG, alcanzando las $10.000 .000^{220}$ pesetas al año. Ante ello, fácilmente se concluye que era mucho más ventajoso hacer donaciones por la Ley Orgánica 3/1987, o que las donaciones electorales sean tratadas así, ya que no existía manera misma de saber cuál era la verdadera naturaleza de la donación. Por otra parte, la combinación de un límite y la permisión de realizar donaciones anónimas hacia que las reglas no

\footnotetext{
${ }^{219}$ El texto del art. 5을 de la Ley Orgánica 3/1987 es: "Artículo 5: 1. Los partidos políticos podrán recibir aportaciones no finalistas, dentro de los límites y con arreglo a los requisitos y condiciones establecidos en la presente Ley. 2. Las aportaciones procedentes de personas jurídicas requerirán acuerdo adoptado en debida forma por el órgano social competente al efecto. 3. No obstante lo anterior, los partidos no podrán aceptar o recibir, directa o indirectamente: a) Aportaciones anónimas, cuando la cuantía total de las recibidas en un ejercicio económico anual sobrepase el 5 por ciento de la cantidad asignada en los Presupuestos Generales del Estado en ese ejercicio para atender la subvención pública a los partidos políticos prevista en el artículo anterior. b) Aportaciones procedentes de una misma persona física o jurídica, superiores a la cantidad de 10.000 .000 de pesetas al año. c) Aportaciones procedentes de empresas públicas ni de empresas que, mediante contrato vigente, presten servicios o realicen obras o suministros para alguna Administración Pública" Se observa claramente la diferencia de parámetro entre esta ley y la LOREG.

${ }_{220}$ Son $60.101,21$ Euros.
} 
tuvieran eficacia alguna, debido a la dificultad de controlar el respeto a dicho límite. $Y$ en este punto no importaba que la LOREG estableciera límites inferiores, haciendo que las reglas sobre el tema fueran doblemente ventajosas para los partidos. ${ }^{221}$

La regulación de las donaciones anónimas siempre fue un aspecto polémico. ${ }^{222} \mathrm{Al}$ tratarse de un tema recurrente, principalmente en momentos de negociación de una nueva legislación sobre financiación de partidos en cualquier de sus actividades, el debate involucra muchas otras cuestiones y todavía no ha encontrado un consenso que se pueda considerar como consolidado en la doctrina. ${ }^{223}$

Uno de los puntos que despiertan mayores controversias es el relativo a la hipotética obligación de identificación del donante y su posible interferencia en el carácter secreto del voto, pues se piensa que el donante votará por la opción política a la que ayudó económicamente, aunque eso no es un hecho absoluto, considerando que los lobbies utilizan grandes montantes de recursos y los depositan sobre muchas múltiples fuerzas políticas, precisamente para aumentar su posibilidad de influencia en la agenda pública, en caso de la vitoria

221 GARCÍA VIÑUELA, E. "La Regulación del Dinero Público". In: Revista Española de Investigaciones Sociológicas - REIS, no 118, abr/jun, CIS, Madrid, 2007. Pp. 79).

${ }^{222}$ HOLGADO GONZÁLEZ narra que las discusiones sobre la obligatoriedad de identificación del donante y el derecho a la intimidad y al voto secreto, se planteó en la aprobación de la LOREG, cuando hubo dos enmiendas: 1) Mardones Sevilla, que cuestionaba la exhaustiva identificación del donante, ya que para campañas benéficas no es exigida ninguna identificación; 2) López de Lerma, que la identificación alejaría los donantes que quieren ser anónimos. En el Pleno, se presentó una enmienda para suprimir la necesidad de votación para personas que donaran menos de 5000 pesetas (Vizcaya Retana), y también otra que intentaba demostrar que dicha medida compromete el secreto del voto (Sancho Rof). Sin embargo, la autora no cree que el secreto del voto no es afectado, porque no se publica el listado de donantes, por lo menos no en la época de la Ley Orgánica 3/87. (In: HOLGADO GONZÁLEZ, María: La Financiación de los... Pp. 123-124). Para una narración más detallada sobre el tema en la ocasión de aprobación de la LOREG, cfr. MARIN ARIAS, M. "Arts. 121..." Pp. 1054-1057, donde el autor se posiciona a favor de la identificación genera de todos los donantes. Con opinión contraria, DEL CASTILLO indirectamente se posiciona a favor de las donaciones anónimas, por el riesgo que la identificación completa de los donantes acabara por disminuir fuertemente este tipo de contribución. Así, la autora opina por un porcentual o valor bajo que, hasta este, sería permitido que el donante no necesitara identificarse. (In: CASTILLO, P. del. "La Financiación de los Partidos Políticos: 1977..." Pp. 167). Por otras experiencias, fijar un porcentual máximo para donaciones anónimas es una providencia totalmente ineficaz, pues no es difícil diluir grandes donaciones en muchas pequeñas, solo para que entren en el límite establecido.

${ }^{223}$ Es de considerar que incluso en la Ley Orgánica 21/1976 de asociaciones políticas había la obligación de la identificación clara de donantes de bienes o recursos, como complemento de la obligación de identificar el origen de los fondos. Después de la derogación de esta ley, no hubo otra disposición con tanta fuerza como esta, incluyendo la Ley Orgánica 8/07. En este sentido, véase CORTÉs BURETA, P.: Recursos Públicos y Partidos Políticos... Pp. 60. 
electoral de una de las beneficiadas. Algunos autores entienden que, de igual manera que las formaciones políticas gozan de un régimen privilegiado a la hora de concurrir en la competición política, también deberían soportar las consecuencias de la relevación de sus colaboradores financieros, considerando la importancia de las funciones que ejercen. ${ }^{224}$

Desde esta perspectiva, la importancia de las funciones asignadas a los partidos es mucho más relevante que la hipotética afectación al derecho individual privado, debiéndose también tener en cuenta por otra parte el principio de transparencia y derecho a la información. Ponderando los derechos en juego, parece prevalecer el derecho del cuerpo electoral de conocer quién está invirtiendo en la política. Los beneficios de este tipo de información al electorado pueden contribuir no sólo a la mejora de la calidad de la democracia, y se puede incluso decir que el buen donante, aquél que desea verdaderamente contribuir de manera sana a la política y a su fuerza política, no dejará de realizar la donación, lo hará por convicción y por el deseo de participar en la política de esta manera. Ahora bien, las donaciones con fines espurios tienen muchas razones para ocultar las cantidades abonadas a los partidos, como también los motivos reales de la elección de determinada fuerza política. Todo lo que es de dudosa licitud, se desea ocultar a la sociedad, y eso sí puede ser considerada una máxima en la financiación de los partidos políticos. ${ }^{225}$

Se debe añadirse que todas las donaciones deberían ser realizadas en una cuenta bancaria específica para ello, según dispone el art. 7 de dicha ley, al igual que establece la LOREG.

\section{e) Prohibición de algunas fuentes de financiación}

Las prohibiciones clásicas de las donaciones de algunas entidades como empresas públicas, contratantes con la Administración Pública de servicios u obras, sea la administración de cualquier nivel, también aparecían en el texto de la Ley Orgánica 3/1987, en el art. 6.2. Con todo, una ventaja que la norma

\footnotetext{
${ }^{224}$ PAJARES MONTOLIO, E.: La Financiación de las... Pp. 300.

${ }^{225}$ En este sentido, y también condenando eventuales donaciones anónimas, cfr. ROSEACKERMAN, S.: La Corrupción... Pp. 185.
} 
ofrecía, comparada con la LOREG, era la posibilidad de recibir recursos del extranjero, es decir, los partidos políticos podrían recibir aportaciones procedentes de personas extranjeras, respetando los mismos requisitos fijados para las donaciones privadas nacionales. Dicho permiso excluía aportaciones de gobiernos y organismos públicos, con excepción del Parlamento Europeo. ${ }^{226}$ Sobre las críticas y argumentos en contra y a favor de dichas prohibiciones, se remite a lo expuesto en el momento anterior de este trabajo.

\section{f) Control y Fiscalización}

En su parte final, la Ley Orgánica 3/1987 incluía algunas disposiciones acerca de la fiscalización financiera de los partidos políticos, y quizás aquí se encuentre el punto más criticable de esta norma.

Hoy parece claro que los mecanismos de control que la ley imponía eran ineficaces y carecía de aplicación práctica, a la vez que durante el tiempo en que estuvo vigente, la Ley Orgánica 3/1987 no logró alcanzar los objetivos que se propuso en el momento de su aprobación. Aunque la ley disponía que los partidos políticos estaban obligados a mantener registros contables detallados sobre toda su situación financiera, art. 10, las reglas fijadas no eran suficientes para permitir una buena fiscalización por parte del Tribunal de Cuentas. El hecho es que la gran mayoría de las veces el Tribunal de Cuentas no logró realizar de manera satisfactoria su función fiscalizadora por las dificultades que surgían a la hora de aportar y fiscalizar la documentación. Por falta de reglas uniformes, prácticamente cada partido político enviaba de una determinada manera su documentación, causando muchos problemas de análisis de las cuentas, y consecuentemente afectando fatalmente a la eficacia del sistema de fiscalización previsto en la ley. ${ }^{227}$

Las imperfectas condiciones en que se ha realizado el control de la contabilidad de los partidos aparecen en todos los informes del Tribunal de Cuentas. Y no solo la falta de uniformidad de las informaciones afectaba a dicha tarea, sino ante todo la propia falta de un diseño institucional adecuado

\footnotetext{
${ }^{226}$ Según la disposición del art. 6, 1 y 2, de la Ley Orgánica 3/1987.

${ }^{227}$ En este sentido, cfr. GARCÍA VIÑUELA, E.; ARTÉS CASELLES, J. "EI Gasto Público..." Pp. 262.
} 
de dicho órgano, especialmente para poder detectar los posibles fraudes contables. Por otra parte, la autorización de las donaciones anónimas permitía no solo eludir el límite fijado para las donaciones, sino que también permitía encubrir donaciones de entidades que lo tenía prohibido por ley. En resumen, las deficiencias en el control y la evidente ausencia de previsiones realistas y efectivas respecto a las sanciones, llevaron al sistema de control a una ineficacia casi completa.

Además, en el art. 12.2 de la Ley Orgánica 3/1987 se disponía que solamente los partidos políticos que recibieran las subvenciones para fines ordinarios deberían presentar la documentación contable referente a cada ejercicio, exponiendo el histórico de ingresos y gastos. ${ }^{228}$ Dada la semejanza con la regulación de la LOREG, las críticas apuntadas en aquella ocasión cabe reproducirla aquí, lo que, nuevamente, torna vulnerable el sistema de fiscalización externa de los partidos, a la vez que excluye que muchos partidos tengan la obligación de rendir cuentas, como los partidos políticos extraparlamentarios, o aquellos que poseen representantes únicamente en el Senado, en el Parlamento Europeo o en las Asambleas Autonómicas. A todo esto se añade la falta de potestad del Tribunal de Cuentas para cualquier tipo de sanción, sea de carácter administrativo o penal. Le cabía, tan solo pronunciarse acerca de la regularidad de las cuentas enviadas por los partidos, según se extrae del art. 12.3. ${ }^{229}$

Debido a este escenario, la mayoría de la doctrina no ha ahorrado críticas a dicha norma y ha sugerido que se reformase el sistema de fiscalización y sanciones. ${ }^{230}$ Las propuestas fueron muy diversas, y se puede

\footnotetext{
${ }^{228}$ El texto es: "art. 12. uno. la fiscalización externa de la actividad económico-financiera de los partidos políticos, corresponderá exclusivamente al tribunal de cuentas. dos. Ios partidos políticos que reciban la subvención estatal regulada en el artículo 3. presentaran ante el tribunal de cuentas, en el plazo de seis meses, a partir del cierre de cada ejercicio, una contabilidad detallada y documentada de sus respectivos ingresos y gastos. asimismo, el tribunal de cuentas podrá requerir a los partidos políticos para que, en el plazo que les indique, presenten una relación de las aportaciones a que se refieren los artículos 4. y 5., que contendrá el importe de cada una de ellas y, en su caso, los nombres y direcciones de las personas que las han realizado".

${ }^{229}$ Así dispone el citado artículo: "(...) tres. el tribunal de cuentas, en el plazo de ocho meses desde la recepción de la documentación señalada en el número anterior, se pronunciara sobre la regularidad y adecuación a lo dispuesto en la presente ley, exigiendo, en su caso, las responsabilidades que pudieran deducirse de su incumplimiento".

${ }^{230}$ Como ejemplo de sugerencias de medidas para la reforma, cfr. BLANCO VALDÉS, R. L. "La Problemática..." Pp. 196-197.
} 
citar la aplicación a los partidos de un sistema como el que consta en la Ley de Sociedad Mercantiles, que no resultaría del todo contrario a la naturaleza jurídica de dichas organizaciones ${ }^{231}$ o la realización de una auditoria previa a la entrega de la rendición de cuentas de los partidos. ${ }^{232}$ Sin embargo, el problema se hizo tan profundo que el propio Tribunal de Cuentas envió para su debate al Congreso de Diputados un Informe con sugerencias acerca de posibles reformas en la ley, teniendo en mente que si no se cambiaba la normativa al respecto, tampoco el órgano podría hacer mucho en la función fiscalizadora que le fue atribuida.

Tendrán en todo caso que pasar veinte años hasta que se promulgara una nueva normativa que intentara colmar las múltiples deficiencias y los defectos técnicos señalados por la doctrina en la Ley Orgánica 3/1987.

\subsubsection{Ley Orgánica $8 / 2007$, de 4 de Julio}

La normativa posterior a la Ley Orgánica 3/1987 implicó algunos cambios considerables en el sistema de financiación de las actividades ordinarias de los partidos, aun cuando cabe lamentar que dicha evolución legislativa no se vea acompañada por cambios en la regulación electoral que afecta a esta materia.

Como se puede deducir del análisis realizado hasta ahora, diseñar una legislación eficaz sobre la financiación partidista implica también enfrentarse con problemas en la estructura del sistema político vigente, principalmente con el sistema electoral vigente que contempla un fuerte corrector, aunque esto se justificara en su época para combatir una eventual "proliferación de partidos". ${ }^{233}$ De esa manera, es conveniente aclarar que la nueva ley aprobada en 2007 fue fruto de un largo período de negociaciones previas, ya que aborda temas centrales fuertemente relacionados con intereses vitales de los propios

\footnotetext{
${ }^{231}$ DÍAZ-SANTANA CASTAÑOS, H. Op. Cit. Pp. 202.

${ }^{232}$ HOLGADO GONZÁLEZ. M.: La Financiación de los... Pp. 248-249.

${ }^{233}$ Cfr. AA.VV. "Debates con Maurice Duverger". In: AA.VV.: Ley Electoral y Consecuencias Políticas. Ed. CITEP, Madrid, 1977. Pp. 124-126. Además, sobre este tema, me remito al Cap. I, punto 3.1.1.
} 
partidos. ${ }^{234}$ El largo período trascurrido para su elaboración es indicativo del escaso entusiasmo de las fuerzas políticas, más allá de declaraciones públicas, y de la dificultad para lograr un amplio consenso. ${ }^{235}$

\section{a) El proceso de elaboración de la Ley}

La reforma pretendida en la década de 90 fracasó porque los propios partidos prefirieron mantener el status quo existente, ya que el consenso deseado no era posible, pues en puntos como la transparencia, el rechazo de la izquierda hacia las donaciones empresariales se unía a la posición de algunos partidos que no querían revelar la identidad de sus donantes por cuestiones de seguridad económica. Así, resultaba más ventajoso para todos los partidos disfrutar de la financiación pública a la vez que se mantenían fuentes de financiación fuera del control de cualquier organismo. ${ }^{236}$

Los problemas existentes durante la vigencia de la Ley Orgánica 3/1987 eran permanentes y de una diversidad enorme. ${ }^{237}$ La normativa simplemente no logró alcanzar su principal objetivo, que era controlar la financiación ordinaria de los partidos políticos. También se trató de una ley muy permisiva, que hizo posible que el flujo de dinero procedente de las aportaciones privadas para fines electorales no fuera sometido al sistema previsto en la LOREG - que era más rígido - y fuera desviado hacia las cuentas de la financiación ordinaria, que contaba con una ley mucho más flexible. ${ }^{238}$

\footnotetext{
${ }^{234}$ En los primeros meses de la VI legislatura se presentaron varias iniciativas por parte de los grupos parlamentarios para reformar la ley de 1987. Sin embargo, las iniciativas fracasaron, y una vez pasada la crisis originada por los diversos escándalos políticos, se produjo un consenso tácito sobre la continuidad de las normas. Fue este el que impidió verdaderamente una reforma. Vid. GARCÍA VIÑUELA, E.: Un Tigre de Papel - ¿Deben prohibirse la donaciones anónimas a los partidos políticos?. El País. 18 de diciembre de 2005.

${ }^{235}$ ARIÑO ORTIZ, G.: Op. Cit. Pp. 15-17.

${ }^{236}$ GARCÍA VIÑUELA, E.; ARTÉS CASELLES, J. "El Gasto Público...” Pp. 270

237 Respecto a algunos de los problemas de la Ley Orgánica 3/1987, GARCía VIÑUELA destaca que no siempre la obligación de los partidos de ingresar los recursos donados en una cuenta bancaria exclusiva es obedecida, tampoco se aporta el acuerdo societario del órgano competente, y aunque los informes del Tribunal de Cuentas verifiquen dicha omisión, los partidos no fueron sancionados por ello. (In: GARCÍA VIÑUELA, E.: Un Tigre....

${ }^{238}$ En este sentido, véase SÁNCHEZ MUÑOZ, que explica pormenorizadamente la existencia de fraudes en ese sentido. Así, el autor afirma que en los informes del Tribunal de Cuentas evidencian la casi inexistencia de las donaciones electorales, y una cantidad importante donaciones para las actividades ordinarias, aún más considerándose la permisión de donaciones anónimas, que eran la gran mayoría. Para demostrarlo, el autor expone que en el
} 
Bajo la presión social - que demostraba la completa insatisfacción con el sistema por la explosión de innumerables escándalos políticos en torno a la financiación de partidos políticos ${ }^{239}$ - y con iniciativas del Tribunal de Cuentas, que declaraban públicamente que era incapaz de realizar un buen servicio de fiscalización ante una normativa que no colaboraba a tal fin, estaba claro que era necesaria alguna actitud por parte del Parlamento, a fin de superar dicha situación. Junto a ello, los escándalos sobre financiación acababan por afectar la relación de los partidos con los electores, que no solo pedían legitimidad y respaldo social, sino que sumaban a esto una imagen de corrupción que asolaba el espectro político, y que todavía continúa.

Ante ello, en 1994 el Congreso de los Diputados creó una Comisión de Estudio para la financiación de los partidos políticos, teniendo como objetivo elaborar un texto producto de un consenso entre los partidos para promover la reforma del sistema. ${ }^{240}$ Sin embargo, el deseado consenso no fue posible, lo que motivó la presentación de propuestas individuales por parte de cada grupo parlamentario. ${ }^{241}$

Lo que se desprende de un análisis de todas estas propuestas es que las mismas coinciden en puntos bastante relevantes, como la importancia de la

ejercicio de 2003, de un total recibido por los partidos políticos que estaban sujetos a la fiscalización por el Tribunal de Cuentas - un montante de 12,1 millones de euros - las donaciones privadas anónimas no finalistas llegaron a 9,4 millones de euros, y ello cuando en dicho ejercicio las aportaciones privadas anónimas no forman el $100 \%$ de todo el montante recibido por el partido, comprobando así que las lagunas contenidas en la LOFPP de 1987 resultaban ya insostenibles. (In: SÁNCHEZ MUÑOZ, O.: La lgualdad... Pp. 210).

${ }_{239}$ Para mayores detalles sobre la $2^{0}$ Comisión de Investigación del Congreso de los Diputados, motivada por los casos como Filesa, Tragaperras, y otros, véase CORTÉS BURETA, P.: Recursos Públicos y Partidos Políticos... Pp. 123 y ss.

${ }^{240}$ La Comisión comenzó a funcionar el 18/05/1994, y sus trabajos finalizaron en 09/01/1996. Sus miembros eran: Presidente Luis Mardones Sevilla (Grupo Coalición Canaria); Vocales: Luis Felipe Alcaraz Masats (Grupo Izquierda Unida - Iniciativa per Catalunya); Jaime Ignacio del Burgo Tajadura (Grupo Popular); Fernando Gimeno Marín (Grupo Socialista); Joxe Joan González de Txabarri Miranda (Grupo Vasco-PNV); Joseph López de Lerma i López (Grupo Catalán-CiU); Pilar Rahola i Martínez (Grupo Mixto) (In: http://www.congreso.es/portal/page/portal/Congreso/Congreso/Organos/Comision?_piref73_22 18049_73_1339256_1339256.next_page=/wc/composicionOrgano\&idOrgano=333\&iDecreto-

Leyegislatura=5). Cábe destacar que juntamente con la comisión mencionada, también fue instaurada una comisión de investigación de los casos de corrupción en que estaban involucrados varios partidos, como los casos Filesa, Naseiro, Tragaperras, y otros. Para detalles sobre dicha comisión, cfr. CORTÉS BURETA, P.: Recursos Públicos y Partidos Políticos... Pp. 129 y ss.

${ }^{241}$ Desgraciadamente no se produjo la creación de una comisión de expertos, como ocurrió en otros países, como Alemania. Para un resumen de las actividades de mencionada comisión, cfr. CORTÉS BURETA, Pilar: Recursos Públicos y Partidos Políticos... Pp. 130 y ss. Ya acerca de las propuestas presentadas, véase: CORTÉS, P. “Últimas Propuestas..." Pp. 202-203. 
transparencia en dicho proceso de financiación, la publicidad y el control del sistema, etc. Sin embargo, aunque todas las propuestas mantengan un sistema mixto de financiación, ninguna intenta equilibrar la relación entre fuentes públicas y privadas, manteniendo el sistema tal como estaba previsto en la Ley Orgánica 3/1987. Por otra parte, las disposiciones contenidas en los textos propuestos no modificaban el criterio de distribución de las subvenciones (manteniéndose el doble criterio escaños/votos, considerando únicamente el resultado en las elecciones anteriores para el Congreso de los Diputados). Ante este panorama, ninguna de las proposiciones representaba un cambio radical en el sistema. Más bien, lo que se percibe era un cierto consenso entre las fuerzas políticas, inclinándose por la continuidad del sistema, a la vez que las discrepancias se concentraban en puntos de la financiación privada, pues aunque todos estaban de acuerdo en que había que fomentar dicha fuente de financiación a través de medidas como las desgravaciones fiscales de las donaciones y las cuotas de los afiliados, no hubo un acuerdo sobre la licitud o no de donaciones por parte de personas jurídicas o de las donaciones anónimas. $^{242}$

\footnotetext{
${ }^{242}$ Así, cada grupo parlamentario ha presentado sus propuestas, difiriendo en distintos puntos. El grupo socialista propuso la obligatoriedad de la identificación de los donantes; que los partidos no pudieran realizar actividades de carácter mercantil; desgravación fiscal para las cuotas en dos naturalezas, siendo una para los partidos con representación, teniendo esta un régimen especial, y otra para los demás, que entrarían en el régimen de desgravación fiscal de las entidades sin fines lucrativos. Además, se proponía permitir las donaciones de personas físicas extranjeras, un régimen fiscal propio para los partidos y, con relación al control, uno de origen interno, y otro de externo, no introduciendo muchas novedades sino más bien reproduciendo - con otras palabras - la situación existente con la Ley Orgánica 3/1987 (BOCG, no 39, de 14 de junio de 1996). El grupo popular intervino con la ampliación de las fuentes de financiación de los partidos, aunque la financiación pública contaba con los mismos criterios de acceso, la posibilidad de donaciones privadas anónimas; y de creación de asociaciones vinculadas al partido, también susceptibles de recibir donaciones a partir de las mismas reglas que las donaciones privadas; sanciones por la violación de reglas sobre donaciones privadas con multa por el doble del valor de los recursos recibidos indebidamente, régimen tributario propio para los partidos, con desgravación fiscal para las donaciones privadas, procedimientos de contabilidad detallado con control interno y externo, siendo que este solamente constaba la fiscalización por el Tribunal de Cuentas, sin cualquier atribución de potestad sancionadora. (BOCG, no 43-1, de 4 de julio de 1996). El grupo catalán presentó una proposición de ley con una desgravación fiscal generosa para las donaciones de personas físicas, que atienden a una escala de límites, como también para donaciones de personas jurídicas, igualmente susceptible de deducción fiscal; posibilidad de creación de asociaciones vinculadas al partido, con posibilidad de donaciones para estas; autorización de donaciones de personas extranjeras, control interno y externo, siendo que hay la posibilidad de que el partido someta sus cuentas a una auditoría externa previa a la entrega de su dossier al Tribunal de Cuentas; y una cláusula muy particular, que posibilitaba a los partidos a tener gastos no justificados hasta el límite de $5 \%$ de sus presupuestos, con finalidad de cubrir ámbitos del territorio que, por su reducido
} 
De este modo, siendo ese el perfil unificador de las propuestas, el intento de reforma fracasó, y no volvió a ser abordado en toda la VII Legislatura (2000-2004). ${ }^{243}$

Con la victoria de PSOE en las elecciones generales de 2004, partido este que tenía en su programa electoral diversas medidas de reforma tanto de los partidos políticos como de su financiación ${ }^{244}$, el asunto nuevamente empezó a aparecer en el debate público. Será a partir de la proposición de ley del Grupo Ezquerra Republicana de Cataluña ${ }^{245}$ cuando sea posible construir un acuerdo de las fuerzas políticas en dirección a una nueva ley. ${ }^{246}$ La proposición de ley del grupo catalán preveía una ampliación de las fuentes de financiación, con desgravación fiscal tanto para cuotas como para donaciones; la identificación de los donantes, la autorización de donaciones extranjeras, un régimen tributario propio para los partidos; la obligación de una contabilidad

tamaño y dispersión, son de difícil control (BOCG, no 44-1, de 4 de julio de 1996). A su vez, el grupo vasco propuso asegurar la autorización para recibir subvenciones de origen autonómico, donaciones extranjeras; anónimas, y de sociedades públicas y organismos públicos, como también de empresas o entidades en régimen de concesión; preveía un Plan General de Contabilidad para las cuentas del partido, control interno y externo, con la opción entre el Tribunal de Cuentas estatal o autonómico, dependiendo de la naturaleza de la subvención que se controla. No hay atribución de sanciones (BOCG, no 45-1 de 4 de julio de 1996). Por fin, el grupo de Izquierda Unida - Iniciativa per Catalunya propuso la ampliación de las fuentes de financiación; el control de gastos para endeudamiento en hasta I 25\%; la desgravación fiscal para donaciones, la autorización de donaciones extranjeras, un régimen fiscal propio para los partidos; una contabilidad detallada, y un control interno y externo, acompañado con un régimen sancionador modesto (BOCG, no 51-1, de 16 de septiembre de 1996). También, sobre las propuestas, cfr. CORTÉS, P. “Últimas Propuestas..." Pp. 202-205.

${ }^{243}$ En dicha legislatura, era una promesa de José María Aznar, entonces elegido presidente del Gobierno, afrontar el problema de la financiación de los partidos políticos y reformar la normativa aplicable. Sin embargo, dicha promesa no fue cumplida, dejando para la legislatura siguiente el problema. De hecho, aunque constara en la agenda política de los partidos en la época de las elecciones a las Cortes Generales en 2004, el procedimiento de reforma de la ley fue iniciado solamente por ERC (Esquerra República Catalana), y una de las suposiciones que se atribuye a dicha iniciativa es que el mencionado partido, uno de los que antes se beneficiaba de la ley vigente, pasó a no beneficiarse más, siendo este un momento conveniente para iniciar el trámite de un proyecto de ley. En este sentido, cfr. Opinión. Más Transparencia. El País. 28 de septiembre de 2005 y MARTíN FERRAND, M.: Op. Cit.

244 Dicho programa puede examinarse en: www.psoe.es/download.do?id=37214

245 Cfr. BOCG, 165-1, de 1 de abril de 2005. Aún, hubo 176 enmiendas al proyecto de ley presentado por ERC. Cfr. BOCG, 165-35, de 10 de abril de 2007.

${ }^{246}$ Un resumen de las propuestas presentadas por los partidos en dicha legislatura puede ser analizada en http://turan.uc3m.es/uc3m/dpto/PU/dppu02/nov1.htm. También es de destacar que en la votación sobre la toma en consideración de la proposición de ley presentada por ERC, el portavoz del grupo popular dejó claro su postura reticente con la reforma, aunque votó favorable a admisión a trámite de dicho proyecto, como también a favor de la prohibición de las donaciones anónimas. Sin embargo, durante las negociaciones, no fue esa exactamente la postura de dicho Grupo Parlamentario. (In: BOCG, no 114, de 27 de septiembre de 2005. Pp. 5752). 
detallada y un control interno y externo, con su correspondiente régimen sancionador. Dicho proyecto generó un debate que produjo un acuerdo entre los partidos y su resultado, ya en 2007 , fue la aprobación de la nueva ley de financiación de partidos políticos, no 8 de 4 de julio. Sin embargo, todo análisis global de la nueva ley debe tener en cuenta que fueron los partidos con representación las que la elaboraron y la aprobaron, y es una utopía pensar que aprobarían una regla que les resultara fuertemente disfuncional. Por ello, frente a algunos avances indiscutibles contenidos en la nueva ley, también hay que considerar que existen otras disposiciones que compensan las pérdidas económicas que acarreaba la nueva regulación a los partidos. Esto es, si la ley prohíbe ahora las donaciones anónimas, también incluye fuentes de financiación pública que antes no estaban previstas. ${ }^{247}$

\section{b) Las fuentes de financiación}

La primera evidencia que se desprende de la nueva ley 8/2007 es la de que la regulación de la financiación ordinaria de partidos políticos crece considerablemente respecto a la anterior ley.

En el listado de los recursos económicos que los partidos políticos, federaciones, coaliciones o agrupaciones de electores pueden utilizar para su sostenimiento, la Ley Orgánica 8/2007 añade algunas fuentes de recursos que antes no estaban previstas en la $3 / 1987$, pero que eran libremente utilizadas por las organizaciones para dicho fin. Así, la nueva ley mantiene las subvenciones anteriores, y agrega los recursos concedidos por las Comunidades Autónomas, Territorios Históricos Vascos y corporaciones locales. También están previstas las aportaciones que reciben los grupos parlamentarios, tanto los de las Cortes Generales como las de las Asambleas Legislativas y los grupos políticos representados en las Administraciones

247 PÉREZ FRANCESCH, J. L. "La Financiación de los Partidos Políticos en España. Consideraciones a Partir de los Informes del Tribunal de Cuentas y de la Nueva Ley Orgánica 8/2007, de 4 de julio". In: Papers - Revista de Sociología. no 92, ed. UAB, Barcelona, 2009. Pp. 252. Existe también opiniones como de GARCíA-MONCÓ, en el sentido de que la Ley Orgánica 8/2007 es una mera actualización de la legislación anterior, no una reforma, y que pese a su reciente aprobación, ya necesitaría cambios. (In: GARCíA-MONCÓ, A. Op. Cit. Pp. 5). 
Locales, y las subvenciones concedidas para otras modalidades de campaña, como es el caso del referéndum. Como otra novedad, cabe subrayar la mención de los productos de las actividades propias del partido, sus consecuentes rendimientos en la gestión de su patrimonio y los beneficios de las actividades promocionales, como también los servicios que los partidos políticos puedan realizar, pero solo los que tengan relación con los fines específicos de dichas organizaciones, estando excluidas las eventuales actividades de perfil comercial.

Como se puede deducir de dichas innovaciones, fueron finalmente atendidas en sede legislativa algunas de las sugerencias del Tribunal de Cuentas, a la vez que se contempla la previsión acerca de las subvenciones concedidas por las Comunidades Autónomas, rendimientos y beneficios de las actividades de los partidos, y también una autorización legal expresa para la utilización de los recursos concedidos a los grupos parlamentarios, pues aunque el Tribunal de Cuentas hubiera recomendado su no utilización por parte de los partidos políticos, al menos ahora existe una especifica previsión normativa. Lo mismo ocurre con los recursos para la campaña del referéndum, algo que la Ley Orgánica 3/1987 no preveía. No consideramos correcta la utilización de fondos de los grupos parlamentarios a favor de los partidos porque entendemos que son entes jurídicos distintos, y que los recursos destinados a los grupos parlamentarios tienen una finalidad diferente a la de los recursos destinados a los partidos. Lógicamente era previsible que los partidos no renunciaran a estas vías de financiación, y más teniendo en cuenta las pérdidas ocasionadas por los cambios provocados por la ley. Por otra parte, además de jurídicamente incorrecto, el perfil moral de esta decisión es patente.

Una valoración aun menos positiva puede hacerse en relación al artículo 2.2, d, referente a los créditos concedidos a los partidos, que siguen sin limitación. Ello permite que se perpetúe el endeudamiento endémico de las organizaciones, y no contribuye a resolver ese problema que ya alcanza proporciones preocupantes, el hecho de que no se prevean mecanismos de transparencia en el proceso de concesión del crédito por parte de las entidades 
bancarias, como se apuntó anteriormente. ${ }^{248}$ El problema se ha vuelto tan relevante que hay autores como LÓPEZ GARRIDO que afirma indirectamente que se oculta el endeudamiento de los partidos en España porque se teme que radique ahí la dependencia de las organizaciones que tanto se quería evitar. ${ }^{249}$

\section{c) La financiación pública - criterios de acceso y reparto}

Ya dentro de la sistemática de la distribución de las subvenciones no finalistas para los partidos políticos, desgraciadamente muchas de las sugerencias tanto de la doctrina como del Tribunal de Cuentas, no fueron tenidas en consideración por el Parlamento, a la vez que se optó por mantener el doble criterio escaños/votos, como también la consideración únicamente del Congreso de los Diputados para el acceso y cómputo de las cantidades destinadas a las fuerzas políticas, excluyendo nuevamente el Senado. ${ }^{250} \mathrm{Sin}$ embargo, como avance en el tema, fue retirada la barrera de 3 por 100 de votos que los partidos deberían conseguir para acceder este tipo de financiación. Aunque no sea suficiente, porque es sabido que el umbral provocado por el sistema electoral es mucho mayor que 3 por 100, representa un cambio significativo en el modelo antes aplicado. También existen nuevas disposiciones sobre la posibilidad de las Comunidades Autónomas de otorgar fondos a los partidos políticos con representación en sus respectivas Asambleas Legislativas, estableciendo reglas generales para conceder dichas ayudas. La nueva norma atiende a las sugerencias que en ese sentido realizó el Tribunal de Cuentas, a fin que se intentara uniformar la legislación nacional con las leyes autonómicas. Cabe también resaltar que la disposición acerca de la imposibilidad de los partidos políticos que bajo procedimiento de ilegalización de recibir las subvenciones a las que tienen derecho, se mantiene en la nueva ley.

\footnotetext{
${ }^{248}$ Acerca del tema, véase SÁNCHEZ MUÑOZ, O.: La lgualdad... Pp. 219.

249 LOPEZ GARRIDO, D. Op. Cit. Pp. 69.

250 SÁNCHEZ-POBRE entiende que el criterio debe mantenerse así, porque son los escaños los que determinan si un partido es o no representativo. Sin embargo, admite que, considerando otros factores, como la formula de distribución de las subvenciones y la fórmula D'Hondt en el sistema electoral, el doble criterio acaba por no ser justo, y que lo más adecuado sería determinar solamente el criterio de votos para el acceso a las subvenciones. (In: SÁNCHEZ-POBRE, P. C. Op. Cit. Pp. 715).
} 


\section{d) La financiación privada}

El tratamiento de los recursos privados experimentó una serie no pequeña de cambios, ya que muchos de los problemas provocados en la anterior legislación se referían justamente a este punto. En primer lugar cabe resaltar que no se prohibió a las personas jurídicas realizar donaciones - como defendía una parte de la doctrina ${ }^{251}$ - pero estas podrán hacerlo únicamente bajo un acuerdo adoptado por el órgano social competente, haciendo constar una declaración clara del cumplimiento de la ley. Dicho documento será siempre exigido sea cual sea el valor de la donación, una medida que favorece la transparencia ya que no prevé la posibilidad de hacer excepciones a la obligación. Las aportaciones de las entidades públicas (excepción hecha de las subvenciones ordinarias y extraordinarias concedidas) y de las empresas que tengan contrato con la Administración Pública siguen estando prohibidas, tanto como donación directa como indirecta.

Sin embargo, la prohibición de donaciones de empresas con contratos con la Administración Pública presenta lagunas, dado que sigue existiendo la posibilidad de que se negocie un contrato futuro a cambio de una donación. Teniendo esto en mente, se podría imponer un "período cautelar", de 3, 4 años en los que tras la donación, la Administración Pública no podría contratar con la empresa que realizó la donación. ${ }^{252}$ Aun siendo conscientes de la posibilidad de que el interés de las empresas por donar recursos a los partidos disminuya significativamente, esta sería una forma de garantizar la "limpieza" de las donaciones realizadas. Existen otras lagunas en la limitación de donaciones por parte de las personas jurídicas, ya que existe la posibilidad de que empresas de un mismo grupo efectúen diversas donaciones, que pueden permitir, además de burlar el límite establecido en la ley, que alguna empresa contratante con el Estado efectúe donaciones en nombre del grupo empresarial, desviándose de la prohibición legal. ${ }^{253}$ Esta crítica también es

\footnotetext{
${ }^{251}$ Como es el caso de GIL-DELGADO en AA. VV.: "Debates". In: La Financiación... Pp. 99

252 Sugerencia aportada por SÁNCHEZ-POBRE, y que debería integrar una nueva propuesta de reforma del sistema. Cfr. SÁNCHEZ-POBRE, Pilar Cubiles. Op. Cit. Pp. 698.

${ }^{253}$ Hipótesis también aportada por SÁNCHEZ-POBRE, que considerando la organización moderna del mercado, se trata de una posibilidad muy presente. Cfr. SÁNCHEZ-POBRE, P. C. Op. Cit. Pp. 698.
} 
aplicable respecto a empresas participantes en grupos extranjeros, vulnerando la prohibición que, por sí solo, parte de la doctrina ya cuestiona, dado el mundo globalizado en el que se vive actualmente.

En relación a las personas físicas, el cambio trascendental consiste en la total imposibilidad de realizar donaciones anónimas. Se trataba de un tema muy controvertido entre los mismos partidos políticos, y la propia proposición de ley tuvo origen en uno de los partidos que se beneficiaba directamente de las donaciones anónimas. En todo caso, se trata de un cambio significativo en la normativa aplicable. ${ }^{254}$ Por otro lado, buena parte de la doctrina entendía que no había ninguna violación a derechos como el derecho al voto secreto o a la intimidad, considerando que al final del proceso no existía una publicación de dichas informaciones. Sin embargo, la falta de publicidad también podría ser un obstáculo importante para alcanzar la transparencia. Los datos permanecían custodiados por el Tribunal de Cuentas, lo que para ciertos autores no se justifica tratándose de personas físicas y jurídicas con donaciones por encima de una determinada cuantía. ${ }^{255}$ En todo caso, no cabe olvidar que antes de esta interdicción de las donaciones anónimas, existió un consenso para aumentar los recursos públicos destinados a los partidos en un $20 \%$, además de autorizar a las Comunidades Autónomas, territorios históricos Vascos y corporaciones locales a otorgar ayudas, sin que hubiera un límite preestablecido, en aras de garantizar la "suficiencia" de recursos, algo que, ante la opinión pública, transfiere una imagen que solo perjudica a los propios partidos. $^{256}$

Con todo, como ha sido apuntado por la doctrina, además de ser una medida tardía, probablemente fue motivada por otras razones que no era propiamente mejorar el sistema de financiación. Aunque no se puede afirmar

\footnotetext{
${ }^{254}$ Según el periódico El País, partidos como PP (Partido Popular), CiU (Convergència i Unió) y PNV (Partido Nacional Vasco) eran los mayores beneficiados por las donaciones anónimas. El periódico también indica que dicha posibilidad de donación era mirada con desconfianza por parte de la sociedad como un todo, ya que muchas veces se traducían en una señal de la existencia de corrupción. En ese sentido, véase: Dineros de los Partidos. El País. 18 de agosto de 2004; El 90\% de los Donativos que Reciben las Arcas de los Partidos Políticos son Anónimos y Opacos. El País. 19 de octubre de 2003; y No Más Demoras. El País. 29 de marzo de 2005.

${ }^{255}$ Ante todo porque se debe preservar el principio de la igualdad de oportunidades y el voto libre del electorado. Por ello, para el autor, la medida de prohibir las donaciones anónimas no fue suficiente. En este sentido, véase SÁNCHEZ MUÑOZ, O.: La lgualdad... Pp. 216-217. ${ }^{256}$ Cfr. PÉREZ FRANCESCH, J. L. Op. Cit. Pp. 251-252.
} 
con seguridad, todo indica que la exclusión de las donaciones anónimas fue un remedio para "tranquilizar" a la sociedad, un intento de reforzar la confianza de la sociedad en los partidos, tan desvalorada en parte por el tema de su financiación. Lo ideal quizás hubiera sido la imposición de la correspondiente publicación de datos de las donaciones a fin de privilegiar la libertad de voto y la transparencia. Aquí, una vez más, se debería privilegiar el derecho de los electores, y no de los partidos, pues de nada sirve que las donaciones no puedan ser anónimas, si no son divulgados los nombres de los donantes.

Un aspecto que se mantuvo en la ley fue que el flujo de dichas aportaciones privadas deberá producirse a través de cuentas bancarias específicas y exclusivas para tal fin, con toda la documentación necesaria para poder comprobar la identificación del donante y la cuantía real. El límite a las donaciones también ha aumentado considerablemente, siendo ahora el tope máximo de 100.000 euros. $^{257}$ Dicho límite es muchísimo mayor que el establecido en la LOREG, siendo aún superior al valor que estaba previsto en la Ley Orgánica 3/1987, lo que puede contribuir al conflicto ya existente entre las dos normas, y coadyuvar a que continúen los fraudes, como denunció el Tribunal de Cuentas en su informe dirigido al Congreso de los Diputados. Cabe resaltar que la Ley Orgánica 8/2007 obligaba igualmente al depósito en una cuenta bancaria específica de las cuotas y aportaciones de los afiliados, no pudiendo confundirse con los otros tipo de donaciones, aunque en la práctica habrá que esperar para observar el comportamiento efectivo respecto a esa separación de recursos de un mismo partido.

Otra innovación que vino a atender una sugerencia del Tribunal de Cuentas es la de la especificación de que los partidos políticos no podrán ejercer actividades de carácter mercantil de ninguna naturaleza. Los partidos solamente pueden desarrollar actividades propias de una organización de esta naturaleza, y también realizar servicios relacionados con los fines partidistas. Cuando se produzca una transmisión patrimonial de 300 euros o superior, será necesaria la identificación del responsable de la transmisión, atendiendo al criterio de la transparencia. Nada más natural que esta determinación, porque

257 SÁNCHEZ-POBRE entiende que se trata de un valor muy elevado para un ciudadano medio, pero aun así es aceptable. (In: SÁNCHEZ-POBRE, P. C. Op. Cit. Pp. 715). 
como se ha dicho anteriormente, los partidos no existen para generar ganancias o funcionar bajo los cánones del mercado. Además, no siempre desempeñaron un papel provechoso cuando se aventuraron en este mundo. Los partidos deben concentrarse en su tarea principal que es la de servir a la democracia, y si desean ejercer alguna actividad mercantil para aumentar sus ingresos y fomentar su financiación, lo aconsejable sería que se limitaran a sus funciones constitucionales y que fomenten sus ingresos a partir de actividades acordes con su misión, desarrollando lazos sociales con sus bases electorales, motivando a la participación política a través de donaciones, y otros medios, que corresponden mucho más a sus propios fines.

Un punto que merece atención es la novedad de la nueva ley en relación con las donaciones realizadas por entes extranjeros, excluyendo recursos de Gobiernos y organismos, entidades y empresas públicas extranjeras. Aunque restrictiva respecto a las donaciones no finalistas, y siendo obligatoria la observancia de los límites legales, requisitos y estricta observancia de las normas referentes al control de cambios y movimiento de capitales, se entiende que los partidos políticos podrán recibir recursos privados del extranjero. Con ello se hace realidad las reivindicaciones de una parte de la doctrina, aunque tampoco su inclusión ha suscitado unanimidad, una vez que la disposición es confusa, y será necesaria una cierta interpretación en el momento de aplicar la regla. $^{258}$

\section{e) Régimen tributario de los partidos y beneficios fiscales}

La ley actualmente vigente también dispone un régimen tributario específico para los partidos políticos, estableciendo algunas exenciones de impuestos. Los partidos políticos están exentos del impuesto de sociedades por las rentas que obtengan para la financiación de las actividades que les son propios. Dicha exención engloba las cuotas de afiliados, las subvenciones concedidas por los poderes públicos, las donaciones privadas tanto de personas físicas como de las personas jurídicas, y los posibles rendimientos obtenidos en el ejercicio de sus actividades propias, u originadas por bienes y

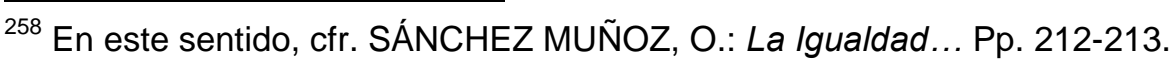


derechos que integran el patrimonio de las organizaciones. Los rendimientos fruto de actividades económicas propias, deberán ser declarados a la Administración Tributaria. La exención también alcanza a la transmisión onerosa de bienes o derechos relacionados con la finalidad propia del partido, siempre que se aplique a nuevas inversiones, dentro del plazo establecido en la ley del impuesto sobre sociedades. A las rentas no exentas de impuesto se les aplicara un tipo del 25 por ciento, permaneciendo la obligatoriedad de realizar las correspondientes declaraciones de su impuesto sobre sociedades sobre esta parte de los ingresos. ${ }^{259}$

El régimen que regula las cuotas, aportaciones y donaciones también detalla cómo serán los beneficios fiscales accesibles para aquellos que así lo desean. Las cuotas de los afiliados tendrán incidencia sobre la base imponible del impuesto sobre la renta de las personas físicas, y la deducción tiene un límite de hasta 600 euros. La cuestión está en que las cuotas generalmente se quedan muy por de debajo de esta cantidad, por tanto, sería mejor que la reducción incidiera en la cuota del impuesto directamente, en un porcentaje de la cantidad abonada por el contribuyente. ${ }^{260}$ Las donaciones inciden también sobre el régimen fiscal de las entidades sin ánimo de lucro y de incentivos fiscales al mecenazgo ${ }^{261}$, en sus arts. 19, 20 y 21. Según el art. 19, el contribuyente tiene derecho a una reducción de $25 \%$ de la base de deducción que, en caso de donaciones en metálico seria su importe, y de donaciones en especie, seguirían las reglas del art. 18. La base de deducción por todos los donativos que el contribuyente pueda realizar - y dentro de estos para los partidos políticos - no podrá exceder $10 \%$ de la base liquidable del mismo. Si el donante es sujeto pasivo del impuesto sobre sociedades, se podrá deducir el $35 \%$ de la base citada anteriormente. ${ }^{262}$ Estarán afectadas beneficiadas las

\footnotetext{
${ }^{259}$ GARCÍA GUERRERO opina que dichas exenciones son excesivas, no colaborando a unas elecciones competitivas. Cfr. GARCÍA GUERRERO, J. L.: Escritos sobre Partidos Políticos (como mejorar la democracia). Ed. Tirant lo Blanch, Valencia, 2007. Pp. 212.

${ }^{260}$ Crítica aportada por SÁNCHEZ-POBRE, en el análisis de los arts. 51, 53, 54 y 55 de la Ley de Impuesto sobre la Renta de las Personas Físicas. Cfr. SÁNCHEZ-POBRE, P. C. Op. Cit. Pp. 706-707.

261 Ley Ordinaria 49/2002, de 23 de diciembre.

262 Un análisis tributario detallado puede verse in: SÁNCHEZ-POBRE, P. C. Op. Cit. Pp. 707 y ss. Aunque no esté claro en la ley, por su silencio da a entender que tanto personas físicas como jurídicas podrán beneficiarse con las desgravaciones, aunque mencione que el impuesto deducible será el impuesto sobre la renta de las personas físicas. Hay autores que critican la
} 
cuotas y donaciones que no superen 600 euros anuales ${ }^{263}$. Solamente podrán requerir la desgravación las personas físicas y jurídicas que posean la justificación tanto de la cuota como de las donaciones acreditadas por el partido receptor.

El tema de la desgravación fiscal siempre estuvo presente en la doctrina. ${ }^{264}$ Aunque sea un tema controvertido, en cuanto a su concreta articulación, y más confrontándose con el principio de la igualdad, su adecuación puede ser problemática, pues aunque teóricamente todos los ciudadanos puedan efectuar las donaciones a cualquier partido, hay dos puntos apuntados por SANTAOLALLA relevantes, que son la "clientela" distinta que los partidos tienen, y esta diferencia se centra aquí principalmente en la renta de sus simpatizantes, con casos en los que el partido se beneficia con la donación de pocos pero importantes contribuyentes. Por eso es muy necesario que se controle esta diferencia de naturaleza sociológica, ya que beneficiaría a los partidos con simpatizantes más acaudalados, y que con las ventajas de la desgravación fiscal, se encontrarían más motivados para realizar donaciones. ${ }^{265}$ Quizás un sistema progresivo sería lo más adecuado, limitando a una cantidad máxima donada el objeto de la deducción, para no discriminar a

posibilidad de las personas jurídicas puedan beneficiarse de las desgravaciones, porque dicha medida debería restringirse solamente para las personas físicas con pequeñas donaciones. En este sentido, cfr. HOLGADO GONZÁLEZ, M.: La Financiación de los... Pp. 181 y SÁNCHEZ MUÑOZ, O.: La lgualdad... Pp. 214-215. Lo que resulta aun dudoso es el supuesto de una persona jurídica que efectúa la donación, y si entonces el socio mayoritario o el propietario de la entidad puede solicitar la deducción del impuesto de su titularidad. Así, se entiende que el artículo podría haber evitado esa inseguridad en la interpretación de su texto, aunque en la discusión sobre la aprobación del texto para el inicio del trámite del proyecto de ley, Puigcercós I Baixassa afirma que la desgravación fiscal sería solamente para las personas físicas, o sea, donantes, militantes o simpatizantes personas físicas. (In: BOCG, № 114, de 27 de septiembre de 2005. Pp. 5746).

${ }^{263}$ SÁNCHEZ MUÑOZ entiende que el valor es muy pequeño, y que está claro que la intención del legislador fue fomentar las afiliaciones y no las donaciones de personas físicas de pequeño valor (ya que las cuotas de miembros también son deducibles) (In: SÁNCHEZ MUÑOZ, O.: La Igualdad... Pp. 214-215).

264 ABAD LÓPEZ entiende que la providencia de desgravación fiscal puede fomentar la creación de los partidos políticos, por este ser un procedimiento fácil y meramente formal. (In: AA. VV.: "Debates". In: La Financiación... Pp. 102). A su vez, BALLAGUER CALLEJÓN no está totalmente de acuerdo con la desgravación fiscal, porque acaba siendo el Estado el que financia de todos modos, lo que no contribuye al pluralismo político o la igualdad entre ellos en los moldes deseados. (In: BALLAGUER CALLEJÓN, F. "Il Finanziamento..." Pp. 159).

${ }^{265}$ SANTAOLALLA, F. "Regulación de Campañas..." Pp. 166. El autor cita aquí el caso de la sentencia del Tribunal Constitucional Alemán, que declaró el sistema de desgravación fiscal inconstitucional justamente por dichas razones. 
los pequeños y medios donantes frente a los grandes. ${ }^{266}$ Pero se constata también que, aunque con estos cambios en el sistema de donaciones privadas, el legislador ha mantenido la idea de penalización de las donaciones, establecer un valor realmente bajo para poder beneficiarse de las desgravaciones. Quizás con un límite más alto, se podría avanzar algo en el fomento de las aportaciones privadas.

\section{f) Obligaciones contables y control externo}

Las grandes novedades aportadas por la Ley Orgánica 8/2007 se centran en las obligaciones contables, la fiscalización y el control y en el régimen sancionador. Aunque se pueda pensar que las innovaciones podrían ser mucho más osadas, hay que reconocer que la ampliación de esta parte de la ley permite algunos cambios importantes, o por lo menos es lo que se espera.

En cuanto a las obligaciones contables, a pesar de la insistencia tanto del Tribunal de Cuentas como de la doctrina, no se produjeron modificaciones en relación al deber de rendir cuentas solamente para los partidos políticos que reciben subvenciones en la forma prevista en ley. De esta forma, el legislador perdió una buena oportunidad de articular una verdadera fiscalización de las finanzas de todos los partidos políticos. La ausencia de cambios en este punto sigue comprometiendo fuertemente la función de fiscalización y el combate a la corrupción, como mantiene gran parte de la doctrina y el propio Tribunal de Cuentas. $^{267}$ Para que la Ley Orgánica 8/2007 pudiera extender el elenco de personas obligadas a someter al Tribunal sus cuentas, en primer lugar, se debería alterar tanto la Ley Orgánica 02/1982 de 12 de mayo - que regula el Tribunal de Cuentas - como también la Ley 07/1988 de 05 de abril, que regula

${ }^{266}$ HOLGADO GONZÁLEZ, M.: La Financiación de los... Pp. 179-181.

267 Como ejemplo, PAJARES MONTOLÍO cita el caso de partidos que participaron en elecciones y que han realizado un significativo trabajo electoral, tomando recursos de bancos, pero no pasan por control ninguno, o el caso de partidos que concurren a las elecciones y que puedan negarse a recibir las subvenciones como medio para eludir la fiscalización. (In: PAJARES MONTOLIO, E.: La Financiación de las... Pp. 356 y PAJARES MONTOLIO, E. "EI Tribunal de Cuentas y los Límites del Control de la Financiación de los Partidos Políticos". In: AA.VV.: Derecho Constitucional para el Siglo XXI - Actas del VIII Congreso Iberoamericano de Derecho Constitucional, Tomo II. Ed. Thompson - Aranzadi, Sevilla, 2006. Pp. 2737, respectivamente). 
aspectos de su funcionamiento, o adoptar definitivamente la teoría de la incorporación constitucional de los partidos, lo que en mi opinión es lo más adecuado, considerando las consecuencias jurídicas de este acto.

En el mismo punto, la ley también especifica cómo tiene que ser elaborado el dossier de documentación que debe remitirse al Tribunal de Cuentas, detallando la forma en que los órganos centrales de los partidos políticos deben rendir cuentas y presentarlo. Así, el dossier estará compuesto de un balance, una cuenta de resultados y una memoria, que deberá reflejar todo el movimiento financiero del partido, y también los contratos firmados con las entidades bancarias para la concesión de créditos o de cualquier tipo de préstamo, acreditándose todas las condiciones del negocio jurídico realizado entre las partes. Como posibilidad, la Ley Orgánica 8/2007 permite que las leyes autonómicas también regulen la materia, algo que podrá generar conflictos normativos en el momento del manejo de la documentación por parte del Tribunal de Cuentas. Cabe añadir que, conforme a la disposición adicional octava, el Tribunal de Cuentas deberá elaborar un plan específico de cuentas para las formaciones políticas, de acuerdo con los criterios que han sido establecidos por este tribunal en sus sucesivos informes de fiscalización de los partidos políticos. Hasta estas fechas (02/02/12), no hay noticias sobre la aprobación de este plan, lo que implica una laguna importante. ${ }^{268}$ Lo único que el Tribunal de Cuentas ha dispuesto es la constitución de un grupo de trabajo en colaboración con el Instituto de Contabilidad y Auditoría de Cuentas, que pretende elaborar el anteproyecto del plan de contabilidad en el marco de la Ley Orgánica 8/2007, con fecha de 18 de abril de 2011, no habiendo noticias posteriores. $^{269}$

\footnotetext{
${ }^{268}$ La aprobación debe darse conjuntamente por el Tribunal de Cuentas y la Comisión Mixta Congreso-Senado para las relaciones con aquél Tribunal. El retraso en esta se subraya en los recientes trabajos de RODRIGUES LÓPEZ, en los cuales se recomienda la lectura. Así, cfr. RODRIGUEZ LOPEZ, A.; FIDALGO CERVIÑO, E. "La Necesidad de un Modelo Contable Normalizado para los Partidos Políticos en España: ¿De la Utopía a la Realidad?” In: AECA: Revista de la Asociación Española de Contabilidad y Administración de Empresas. no 86. [s.l.], 2009. Pp. 2-3 y; RODRIGUEZ LÓPEZ, A. "La Financiación de la Actividad Ordinaria de los Partidos Políticos en la Legislación Española". In: Actualidad Administrativa. tomo 2. ㄲo 13, quincena del 1/15 de julio, ed. La Ley, 2010. Pp. 1567.

269 Dicha resolución puede ser encontrada en <<http://www.tcu.es/uploads/RESOLUCIONGRUPOTRABAJOCP.PDF>> Acceso en 01/08/2011.
} 
En relación con la fiscalización y el control, la ley determina que los partidos tengan un sistema de control interno que facilite las informaciones que deben enviarse al Tribunal de Cuentas de las actas y documentos de contenido económico. También dicho órgano interno del partido deberá enviar al Tribunal de Cuentas un informe que acompañará al dossier destinado a la fiscalización. El control externo sigue en el Tribunal de Cuentas, sin perjuicio de la atribución de dicha competencia a órganos de fiscalización a nivel autonómico.

\section{g) Régimen sancionador}

Otra novedad de la ley, lógicamente reclamada, es el régimen sancionador previsto en la Ley Orgánica 8/2007. ${ }^{270}$ El responsable de aplicar las sanciones será el Tribunal de Cuentas, aunque este hubiera sugerido que no le fuera concedida dicha competencia, para no afectar negativamente a su función fiscalizadora. Las sanciones podrán tener naturaleza pecuniaria, y serán establecidas a partir del acuerdo del pleno del Tribunal para los partidos que incumplieren las normas referentes a la rendición de cuentas. La Ley Orgánica 8/2007 dispone de un proceso de toma de decisiones para sanciones bastante detallado, observando el debido proceso legal y el principio contradictorio ${ }^{271}$, permitiendo en diversas ocasiones que el partido justifique su incumplimiento de las normas y que subsane la irregularidad antes de la ejecución de la sanción. Todas las decisiones serán tomadas por el pleno del Tribunal de Cuentas, y las sanciones serán susceptibles de recurso contencioso-administrativo ante el Tribunal Supremo.

Sobre las infracciones previstas, cabe subrayar la insuficiencia - y porqué no la incoherencia - de la previsión de solamente dos conductas susceptibles de punición, ya que la propia ley contempla otras diversas

${ }^{270}$ FERNÁNDEZ VIVAS califica el nuevo sistema de control de partidos en la Ley Orgánica 8/2007 de "severo" (In: FERNÁNDEZ VIVAS, Y.: Op. Cit. Pp. 353), no se comparte aquí esta opinión. Es necesario esperar un tiempo para determinar los efectos reales de las medidas, ya que la ley todavía posee lagunas que pueden comprometer la eficacia del control y de la función fiscalizadora del Tribunal de Cuentas. La transparencia no está asegurada por completo y hasta que no se alcance dicho punto, el sistema no podrá ser considerado como severo. Incluso porque para ser considerado así, las medidas sancionatorias deben actuar frente a la violación de las normas de financiación en general.

${ }^{271}$ En este sentido, cfr. SÁNCHEZ-POBRE, P. C. Op. Cit. Pp. 713. 
prohibiciones que también deberían ser consideradas punibles. Las únicas infracciones previstas se aplican cuando el partido político reciba algún tipo de donación prohibida por la ley - sancionada con una multa del doble del valor de la aportación indebidamente recibida - y cuando el partido no presente la rendición de cuentas sin causa justificada, o cuando dichas cuentas se presentan de manera tan deficiente que impidan la realización de la función fiscalizadora, estando prevista para este último comportamiento la sanción consistente en la no liberación de las subvenciones anuales. El primer problema que se diagnostica es la imprecisión de la letra de la ley, ya que se refiere solamente a los partidos políticos, pero en el ámbito de aplicación de la ley se incluye también a las federaciones, coaliciones o agrupaciones de electores. Así que la interpretación más correcta es incluir a todos los destinatarios de esta ley en la previsión de las sanciones. Otro problema es señalado por SÁNCHEZ-POBRE, quién al analizar la sanción sobre la no liberación de las subvenciones en caso de no entrega de la rendición de cuentas por parte de la formación política, se pregunta si dicha no liberación afecta solamente a las subvenciones del año siguiente 0 a todas las subsiguientes. ${ }^{272}$ En mi opinión, se deberían suspender las subvenciones hasta la total regularización de las cuentas de la organización, dejando a cargo de esta la prolongación o no de la sanción impuesta. Ello ayudaría a una mayor responsabilidad por parte de dichas formaciones, que deben considerar la obligación de entregar las cuentas como un deber jurídico seriamente asumido.

Por otra parte, prever sanciones tan sólo para dos de los comportamientos prohibidos plantea otros problemas. La asunción de las cuentas de la formación política por terceros o el ejercicio de actividades de naturaleza mercantil por las organizaciones, también deberían ser acreedoras de una sanción, en lugar del silencio de la ley, haciendo que dichas prohibiciones pierdan fuerza en la práctica. Además de ello, no solamente las cuentas muy deficientes deberían ser motivo de la suspensión de las subvenciones, sino también las cuentas que obstaculicen la fiscalización, principalmente a través del incumplimiento del art. 14 de la ley. El retraso en la

${ }^{272}$ SÁNCHEZ-POBRE, P. C. Op. Cit. Pp. 711. 
entrega de las cuentas también debería ser susceptible de una sanción de alguna naturaleza. ${ }^{273}$

\section{h) Deber de colaboración}

Existe también en la ley una nueva disposición acerca del deber de colaboración de los partidos políticos, entidades y terceros que mantuvieron relaciones de perfil económico con organizaciones partidistas de proveer toda y cualquier documentación e información que fuera necesaria para la mejora de la función de fiscalización. La ley aclara el deber de sigilo existente por parte del Tribunal de todos los datos que puedan afectar a la intimidad de las personas afectadas, sometiéndolas incluso a responsabilidades administrativas y penales derivadas de la quiebra de dicho sigilo. Dentro de este tema, es de lamentar una vez más el caso omiso que se hizo de las sugerencias del Tribunal de Cuentas, ya que la ley impone el deber de colaboración, pero no contempla ninguna sanción, de cualquier naturaleza, que condiciona a dichas entidades a obedecer realmente la demanda formulada por el Tribunal. Así, es de temer que la situación continúe como hasta el momento, es decir, que las entidades sigan ignorando los requerimientos del Tribunal de Cuentas, como comúnmente hacen. ${ }^{274}$

Considerando las lagunas legales existentes, otros puntos de la LOFPP como el permiso de donación de recursos a fundaciones y asociaciones, o la autorización para condonaciones de deudas también quedan comprometidas,

\footnotetext{
${ }^{273}$ En este sentido, cfr. SÁNCHEZ-POBRE, P. C. Op. Cit. Pp. 712. Para corroborar con la opinión de que las disposiciones en general no fueron de todo satisfactorias, el grupo de Estado en contra de la corrupción, perteneciente al Consejo de Europa señala en su informe que muchas de las recomendaciones hechas por dicho órgano no fueron suficientemente cumplidas. Como ya era previsible, este grupo apunta deficiencias importantes en la realización de la transparencia en la financiación de los partidos en España, y lo que fue incluso noticia en los medios de comunicación. Así, véase el informe en <<http://www.tcu.es/uploads/Tema_II_GRECO_6mayo2011.pdf. Acceso en 02/08/2011>> y <<http://www.elpais.com/articulo/espana/Consejo/Europa/suspende/Espana/oscura/financiacio n/partidos/elpepunac/20110425elpepinac_2/Tes. Acceso en 02/08/2011 >> Sobre el contenido de dichas recomendaciones, cfr. punto 10 de este capítulo, que trata sobre la financiación de partidos a nivel europeo.

${ }^{274}$ Las lagunas en la ley del Tribunal de Cuentas son evidentes según TORRES FERNÁNDEZ, que entiende que la frecuencia de dicho incumplimiento deja clara la insuficiencia legislativa, ya que la misma obligación estaba mejor prevista en los arts. 7.3 y 42 de Ley Orgánica 2/1982 y arts. 30.4 y 5 de la Ley 07/1988. (In: TORRES FERNANDEZ, J. J. Op. Cit. Pp. 1870-1871). También, cfr. RODRIGUEZ LÓPEZ, Á. “La Financiación de...” Pp. 1568.
} 
puesto que dichos procesos no solo son de difícil fiscalización, sino que ante la falta de rigidez en el deber de colaboración por parte de las entidades bancarias en general, el control se vuelve casi imposible, además del hecho de que, existiendo únicamente la información al Tribunal de Cuentas sobre la realización de la negociación de la deuda, se puede entender que hay una financiación de los partidos mayor que la fijada anteriormente. ${ }^{275}$ Es de resaltar que, con fecha de 24 de febrero de 2011, el Tribunal aprobó una moción que trata sobre el deber de colaboración de las personas físicas y jurídicas con la función de fiscalización, en la cual apunta no solo los fallos de la Ley Orgánica 8/2007, sino también otros impedimentos para la realización de este deber, como las barreras legales que sufren los arts. 7 de la LOTCU (Ley Orgánica del Tribunal de Cuentas) y 30 de la LFTCU (Ley Orgánica del Funcionamiento del Tribunal de Cuentas), considerando que estos datos bancarios están protegidos por la Ley Orgánica 15/1999 (de protección de datos de carácter general), aun cuando ya está consignado en la LOTCU (art. 33.1) y en la LFTCU (art. 5.1) el sigilo de los datos. Lo que se pide es que se pueda utilizar los datos cuando el Tribunal esté realizando su tarea fiscalizadora, para poder asegurar una buena verificación de dichas informaciones y el cumplimiento de la ley. ${ }^{276}$

La adjudicación de los valores debidos a título de subvención sigue el trámite descrito en el Real Decreto 1907/1995, de 24 de noviembre.

\section{i) Asociaciones y fundaciones vinculadas a los partidos políticos}

Como ya se ha mencionado, otra novedad relevante consiste en la normativa acerca de las fundaciones y asociaciones vinculadas a partidos políticos, que anteriormente carecían de cualquier tipo de regulación. Estas también deberán someterse a la rendición de cuentas en los mismos términos que los partidos, sin perjuicio de las normas de control que les son propias. ${ }^{277}$

\footnotetext{
${ }^{275}$ SÁNCHEZ-POBRE, P. C. Op. Cit. Pp. 702.

${ }^{276}$ Moción no 887, disponible en <<http://www.tcu.es/uploads//887.pdf>>

277 Dicho punto fue muy debatido por el PP que defendía la ausencia de control sobre las fundaciones. Sin embargo, PSOE defendía el control con transparencia, focalizando la Fundación Pablo Iglesias, ya que deseaba que dicha fundación continuara siendo financiada por el Estado. Debido a ello, el PP no aprobó dicho control para la Ley Orgánica 8/2007.
} 
También podrán recibir donaciones tanto de personas físicas como jurídicas de hasta 150.000 euros por año y, en el caso de donaciones realizadas por personas jurídicas de más de 120.000 euros, será necesario un documento público constatando la razón de la donación. ${ }^{278}$ Dicha innovación es un tema bastante controvertido, sobre el cual no hay un consenso todavía firmado, pero donde se debe resaltar la escasa atención doctrinal que ha recibido hasta ahora. Se puede considerar que es una posible vía para burlar controles en las contribuciones, sean dichos recursos nacionales o extranjeros. ${ }^{279}$ Sin embargo, lo que llama más la atención es el elevado límite de la donación, considerando que para las actividades electorales es mucho menos, y que para las actividades ordinarias financiadas con donaciones privadas se constituye en 100.000 euros anuales. ${ }^{280}$

Así, aparentemente la LOFPP indica que su objetivo es el fomento de la actividad de dichas asociaciones y fundaciones, pero como los medios de control del flujo de recursos entre estas entidades y los órganos centrales de los partidos suelen ser resultar ineficaces, puede ser que se esté incubando un sistema similar al estadounidense, es decir, existirá un dinero "duro", sometido

También como dato importante, en 2007, la FAES, vinculada al PP, fue la que más recursos recibió a título de ayudas del Ministerio de Cultura. En este sentido, véase: La FAES, a la Cabeza de las Fundaciones Políticas con más ayudas del Estado. El País. 08 de agosto de 2007; y Otro Choque entre PSOE y PP bloquea el Acuerdo sobre la Ley de Financiación de Partidos. El País. 23 de febrero de 2007.

${ }^{278}$ SÁNCHEZ MUÑOZ critica ese punto, afirmando que el tratamiento especial impuesto acaba por convertir a las fundaciones y asociaciones en un canal de donación empresarial con permisión legal, posibilitando incluso el fraude a los límites antes fijados, ya que eleva el tope máximo para 150.000 euros por persona/año. También posibilita el envío de recursos de empresas que tienen contratos con la Administración Pública y de las demás que están impedidas para donar por otras vías. (In: SÁNCHEZ MUÑOZ, O.: La lgualdad... Pp. 220). El problema se agrava aún más si se considera la cuestión de la realización de campaña electoral por parte de dichas fundaciones y asociaciones, algo que no está prevista en la LOREG. Acerca de ello, cfr. SOLER SÁNCHEZ, M.: Campañas Electorales... Pp. 85.

${ }^{279}$ ALBERTO CORDERO, L. "La Fiscalización del Financiamiento de los Partidos Políticos: un Asunto de Conciencia Crítica". In: AA.VV.: Administración y Financiamiento de las Elecciones en el Umbral del Siglo XXI - Memoria del III Congreso Internacional de Derecho Electoral. Tomo II, Instituto de Investigaciones Jurídicas, DF, México, 1999. Pp. 395. Como ejemplo práctico de la utilización de dicha autorización para burlar la ley, VON ALEMANN destaca que las fundaciones de los partidos políticos sirven parcialmente para la financiación oculta de los mismos, con recursos del presupuesto federal, en el caso alemán. (In: VON ALEMANN, U. "Democracia de Partidos y Participación Ciudadana". In: Revista de Estudios Políticos (nueva época), no 20, mar/abr, 1981. Pp. 128). También siguiendo esa línea, SÁNCHEZ MUÑOZ afirma que, junto con el trato especial, esto se volverá un canal de donación empresarial a los partidos, con permisión legal, frustrando otras limitaciones que están por debajo de 150.000 euros. Además, posibilita el envío de dinero de empresas con contratos con la Administración Pública y demás impedidas de donar. (SÁNCHEZ MUÑOZ, O.: La lgualdad... Pp. 220).

${ }^{280}$ Cfr. RODRIGUEZ LÓPEZ, Á. “La Financiación de..." Pp. 1568. 
a reglas más rígidas, y un dinero "flexible", que aunque tenga un límite, favorecerá directamente a las finanzas de los partidos, siendo este un hecho admitido o no por los poderes públicos. Es de resaltar que el GRECO (grupo de Estados contra la corrupción) del Consejo de Europa ha condenado estas disposiciones, por no favorecer en nada la transparencia y, por lo tanto, por no cumplir con las recomendaciones hechas por dicho órgano.

\section{j) Posibilidad de renegociación de deudas y actualización de valores}

También un punto nuevo en la ley es la autorización para que los partidos políticos negocien acuerdos económicos con las entidades bancarias a fin de pagar sus deudas, respetando los usos y costumbres del tráfico mercantil entre las partes y teniendo conocimiento de dicha transacción el Tribunal de Cuentas y el Banco de España. ${ }^{281}$ Como antes eran considerados como aportaciones extraordinarias ${ }^{282}$, se sometían al límite descrito en la LOREG, sin embargo, ahora, a lo que parece, no hay más limitaciones, y eso puede ser una puerta para burlar la normativa, dejándola nuevamente inoperante. ${ }^{283}$ Dicha innovación plantea la cuestión de cual sea la "mejor" solución para el problema del endeudamiento de los partidos, si es la condonación de deudas o si lo es el fomento de las donaciones privadas, ya que entre 1993 y 2003, PP y PSOE declararon 24 millones de euros cada uno aproximadamente, siendo así que 90\% de dicho valor el PP afirma haberlo obtenido a través de donaciones, y el

\footnotetext{
${ }^{281}$ La posibilidad de negociación de sus deudas por parte de los partidos con las entidades bancarias era defendida por SATRUSTEGUI GIL-DELGADO, in: SATRUSTEGUI GIL DELGADO, M. "La Reforma Legal de los Partidos Políticos". In: Revista Española de Derecho Constitucional. año 16, № 46, ene/abr, 1996. Pp. 99-100.

282 En realidad, dicha interpretación de que las condonaciones de deudas eran como aportaciones extraordinarias era del Tribunal de Cuentas. Sin embargo, aunque dicho mencionado órgano denunció muchas veces la existencia de esta práctica, ningún partido fue sancionado o advertido por ello. Y la frecuencia era tan alta que el tema fue objeto de atención periodística, principalmente después del caso La Caixa y PSC (Partido Socialista Catalán). En este sentido, cfr. PRADERA, J.: Voracidad Insaciable. El País. 23 de noviembre de 2005; Los Partidos Acuerdan Prohibir las Donaciones Anónimas pero Discrepan sobre las Condonaciones. El País. 28 de noviembre de 2005; y SAN MARTíN, E.: Demasiados Agujeros Negros. ABC. 24 de noviembre de 2005.
}

${ }^{283}$ SÁNCHEZ MUÑOZ, O.: La lgualdad... Pp. 217-218. 
PSOE afirma haberlo recibido como condonación de deuda. Así, ¿qué sería peor: depender de grandes donantes o de las entidades bancarias? ? $^{284}$

La verdad es que la cuestión de las condonaciones de deudas es algo complicado de fiscalizar, porque el Tribunal de Cuentas no puede garantizar que los acuerdos fueron hechos basándose en los usos y costumbres del tráfico mercantil. $Y$ también, considerando que las reglas que serán utilizadas serán las reglas del mercado, muy probablemente ocurrirá lo que sucede con la concesión de créditos a los partidos, es decir, no habrá criterios claros, permitiendo indirectamente el favorecimiento de los mayores partidos $y$, consecuentemente, generando aún más factores de discriminación entre partidos grandes y pequeños. Es de resaltar que tampoco existe un límite de endeudamiento de los partidos, como se preveía en la ley anterior en el art. 9o, no contribuyendo así a una concreta transparencia. ${ }^{285}$

Por fin, la Ley Orgánica 8/2007 prevé el IPC como índice de corrección del límite para las donaciones privadas, pero no arbitra ningún mecanismo de corrección del montante presupuestario para las subvenciones públicas, no atendiendo a las sugerencias de la doctrina en ese sentido. ${ }^{286} \mathrm{Y}$, una vez más la doctrina critica esta falta de límites para el aumento de las subvenciones públicas, por el hecho de no estar justificado que los partidos puedan negociar de forma discrecional subvenciones que van a favorecerles directamente. ${ }^{287}$ Así, desgraciadamente no hubo avances en este punto, y se perdió una buena oportunidad de fomentar la ya escasa confianza que se tiene en los partidos.

Ante este panorama, se puede decir que se ha producido un cierto avance en el sistema de financiación ordinaria de los partidos políticos, pero

\footnotetext{
${ }^{284}$ PÉREZ FRANCESCH, J. L. Op. Cit. Pp. 253.

${ }^{285}$ SÁNCHEZ MUÑOZ, O.: La Igualdad... Pp. 220.

${ }^{286}$ Para una señal de que la falta de limitación de aumento del montante general destinado a los partidos era algo que la sociedad no estaba de acuerdo. En este sentido, cfr. Los Partidos se Incrementan un 2\% la Asignación Presupuestaria. El País. 22 de noviembre de 2004.

${ }^{287}$ HARO BÉLCHEZ, G. Op. Cit. Pp. 170-171. En esta línea, Vid. FERNÁNDEZ VIVAS afirma que además de que nuevamente la ley no dispone sobre la corrección de los valores a título de subvenciones públicas - condición que ya permitió a los partidos el incremento de dichos recursos un 140 por 100, también se permite entender que, como la ley determina el IPC para la corrección de los valores de donaciones de personal físicas o jurídicas (conforme a la disposición transitoria novena), dicho índice de corrección también deberá ser utilizado para la corrección de los valores a título de subvenciones públicas. Sin embargo, se trata de una posición doctrinaria, no jurisprudencial sobre el tema. De igual manera, la autora resalta que es curioso que la ley haya sobre la corrección de los valores estatales. (In: FERNÁNDEZ VIVAS, Y.: Op. Cit. Pp. 341-342, y también nota de píe № 952).
} 
que se está muy lejos de resolver los problemas que ya fueron identificados e indicados por la doctrina y el propio Tribunal de Cuentas. Desgraciadamente el Parlamento perdió otra vez la ocasión de construir un modelo eficaz y presentable ante la sociedad. Con ello, es inevitable pensar que existe, en realidad, una inercia política dispuesta a prolongar el status quo del sistema de partidos en España, aunque el precio a pagar por ello sea alto. Por más que la nueva ley haya innovado en el sentido de aumentar la transparencia y el control, quedan aún numerosas cuestiones pendientes de reforma y no atendidas por la nueva normativa.

\section{3) ¿Es posible separar la financiación de las actividades extraordinarias de las ordinarias de los partidos políticos? El problema de su diferenciación}

Como es sabido, las formaciones políticas tienen derecho a dos tipos de financiación pública, tanto para las actividades que se relacionan con la realización de la campaña electoral y las elecciones, como para las actividades cotidianas.

En primer lugar, es obvio que la cuestión, aunque teóricamente sencilla, provoca alguna complicación cuando se desciende al caso concreto, principalmente si se considera que también podrá afectar a otros elementos que se relacionan con el Derecho de Partidos, como es el caso de su función de formación de la voluntad popular se restringe solamente al periodo de elecciones. Por ello puede ser útil analizar la discusión doctrinaria existente.

El hecho de que en España haya una norma que disponga sobre la financiación electoral y otra para la financiación ordinaria es prueba de la intención del legislador de delimitar cada una de ellas, aun con escaso éxito. En realidad, lo que parece evidente es que no se deseó realizar una uniformización normativa, situación esta que permanece hasta la actualidad. Esto puede fomentar la existencia de disparidades como las existentes en los valores de límites de gastos (para actividades electorales hay límites, pero para las ordinarias no) o en los límites para las donaciones privadas, dado que para las actividades electorales el valor es mucho más bajo que para las actividades 
ordinarias. $^{288}$ Ello conlleva que más allá de la teoría, las actividades de los partidos no tengan una distinción clara, mezclándose con facilidad y haciendo que el objetivo de las leyes se frustre, añadiendo dificultades, por ejemplo, a la comprobación del respeto a los límites electorales. ${ }^{289}$

Nunca se ha cuestionado la necesidad de financiar a las actividades extraordinarias o electorales de los partidos o formaciones políticas en general, porque se trata de su fin último, la razón última de la existencia de dichas organizaciones. En compensación, se ha debatido la legitimidad - y por qué no decir conveniencia - de que el Estado financie los demás gastos de los partidos, los que se producen cotidianamente. ${ }^{290}$ La doctrina en general no subraya la "importancia" de esta cuestión ${ }^{291}$, ante todo porque la mayoría entiende que la actividad electoral no se restringe únicamente al periodo de campaña política, sino que traspasa la barrera del tiempo, y se mezcla con el día a día de las formaciones políticas, en una búsqueda incesante por el mantenimiento o la ampliación de su electorado. ${ }^{292}$ Al fin y al cabo, en la práctica no hay diferencia, pues todas las actividades políticas están dirigidas a la conquista del apoyo electoral. ${ }^{293}$

Sin embargo, justamente por la imposibilidad de diferenciar qué es exactamente actividad ordinaria y que no lo es, se entiende que el Estado debe

\footnotetext{
${ }^{288}$ Sobre el tema, cfr. SÁNCHEZ MUÑOZ, O.: La lgualdad... Pp. 201-202.

289 Esto queda bastante claro en los informes del Tribunal de Cuentas, pues ya que la inobservancia del límite de donaciones privadas genera una sanción por parte de este órgano, los partidos simplemente declaran la aportación como destinada a las actividades ordinarias, pero la utilizan para sufragar gastos electorales, y desgraciadamente no existen formas eficaces de controlar esto o de comprobar la transferencia indebida de recursos.

${ }^{290}$ HOLGADO GONZÁLEZ, M.: La Financiación de los... Pp. 32-33.

291 Incluso autores como vid. LANCHESTER, F. "II Problema del Partito Político: Regolare gli Sregolati”. In: Quaderni Constituzionali. Anno VIII. no 3, Diciembre. Ed. II Mulino, Bologna, 1988. Pp. 448, que entiende que la utilización del reembolso electoral para las actividades ordinarias y viceversa es muy común, variando solamente la forma en que cómo esta misma financiación se ha desarrollado y en cómo el Estado la controla. En el mismo sentido, MURILLO DE LA CUEVA, por entender que no hay manera de separar las actividades ordinarias de las electorales de los partidos, ya que estos están en campaña constantemente. (In: MURILLO DE LA CUEVA, P. L. "La Financiación de los Partidos y de..." Pp. 22). VON ARNIM afirma a su ver que tampoco el electorado logra distinguir cuáles son las actividades ordinarias y las electorales, porque la campaña electoral se prolonga en el tiempo. (Cfr. VON ARNIM, H. H. "Campaign and Party Finance in Germany". In: GUNLICKS, A. B. (ed.): Campaign and Party Finance in North America and Western Europe. Westview Press, USA, 1993. Pp.210). ${ }^{292}$ SOLER SÁNCHEZ, M.: Campañas Electorales... Pp. 223.

293 TORRES DEL MORAL, A. "El Estado Español de Partidos". In: Revista del Centro de Estudios Constitucionales, no 8 , ene/abr, 1991. Pp. 125; y SÁNCHEZ MUÑOZ, O.: La Igualdad... Pp. 179.
} 
financiar ambas, pues la igualdad económica debe ser garantizada continuamente, dada la labor de la formación de la voluntad popular de las formaciones políticas. ${ }^{294}$ Incluso se puede pensar que es ineficaz el intento de separar dichas actividades y financiar con fondos públicos solamente una de ellas, porque después de tomar la decisión que el Estado financie ambas - y revertir esta decisión es prácticamente imposible - la experiencia alemana demuestra que cualquier separación podrá ser tan solo teórica, ya que los partidos siempre estarán desembolsando recursos con vistas a las próximas elecciones, no existiendo ningún otro motivo. ${ }^{295} \mathrm{Si}$ se analizara las críticas hacia para la sentencia alemana sobre el tema de 1966, se nota que gran parte de la doctrina se posicionó en contra esta supuesta distinción, por su propia inutilidad práctica. ${ }^{296}$

De hecho, quizás la única influencia existente es sobre la adecuación entre el término "subvención" utilizado en la norma sobre financiación ordinaria y su noción administrativa-jurídica. CORTÉS BURETA trató la cuestión afirmando que, como la subvención es concedida por un ente de Derecho Público a otro de Derecho Privado (en este caso los partidos políticos), no se cumple el requisito de discrecionalidad del ente público tanto en su concesión (pues a partir del momento que la formación política alcanza los requisitos necesarios para obtener la subvención tendrá este derecho), como tampoco en el montante a ser entregado (ya que es variable conforme los escaños y el número de votos logrado por la organización, determinada tanto por la LOREG como por la LOPFF). De esta forma, la autora concluye que el término subvención no es el más adecuado en este caso. ${ }^{297}$

\footnotetext{
${ }^{294}$ CASTILLO VERA, P. del. "La Financiación Pública..." Pp. 152.

295 JIMENEZ DE PARGA, Manuel. La Financiación de los Partidos. In: AA.VV.: Ley Electoral y Consecuencias Políticas. Ed. CITEP, Madrid, 1977. Pp. 152.

${ }^{296}$ Se puede citar como ejemplo de esta línea doctrinal a un autor como HÄBERLE, que aportó bastantes críticas a este respecto. Cfr. HÄBERLE, P. "Unmittelbare Staatliche Parteienfinanzierung Unter dem Grundgesetz. BVerfGE 20,56. In: Juristische Schulung. ㄲo 7, 1967. Pp. 64-74.

${ }^{297}$ CORTÉS, P. "Aproximación al Concepto de Subvención y su Adecuación en la Ley 3/1987, de 2 de julio, de financiación de Partidos Políticos". In: Cuadernos Constitucionales de la Cátedra Fadrique Furió Ceriol, oㅡ 38/39, Valencia, 2002. Pp. 219-222; y SAMANIEGO RIAÑO, P. "Las Subvenciones Electorales". In: Anuario Jurídico de La Rioja. no 11, Logroño, 2006. Pp. 80-82. Igualmente GONZÁLEZ-AURIOLES, que entiende que las subvenciones ordinarias no condicionadas pagadas por el Estado algo contradictorio con lo que dispone el principio de la justificación de las subvenciones estatales. Debido a ello, el autor opina que son indebidas y no deberían ser concedidas. (GONZÁLEZ-AURIOLES, J. A. Op. Cit. Pp. 217). Desde luego no
} 
De todos modos, entendemos que es innecesario distinguir entre una financiación y otra, si ambas acaban destinadas al el mismo fin. Quizás fuera mejor que se elimine de la LOREG y la LOFPP las diferencias entre las reglas - como es el caso del límite de donaciones privadas por ejemplo - por tratarse de un punto que solamente contribuye a la ineficacia de las leyes, no favoreciendo la estricta regulación que el tema exige. Si el único motivo de la diferenciación entre las actividades políticas es este, y dado que únicamente es aplicada por el Tribunal de Cuentas para los fines de fiscalización de las organizaciones, resultaría mucho más sensato que se excluyera dicha diferencia, incluso considerando que no ayuda al Tribunal a ejercer su función fiscalizadora, sino bien al contrario, acaba por frustrar el objetivo de la ley, volviendo la tarea del mencionado Tribunal aún más complicada, como si ya no lo fuera.

\section{4) El impacto de la financiación de partidos en determinados aspectos del Derecho de Partidos}

Parece no haber dudas a la hora de afirmar que la financiación de los partidos se integra en el núcleo del derecho de partidos. Por su propia naturaleza, y debido a la relación intima que tiene con otros elementos de esta rama científica, la financiación acaba por influir (o ser influida) por estos, y por lo tanto, estas consecuencias no pueden ser aisladamente tratadas. ${ }^{298}$

Tanto la financiación pública como la privada producen determinados resultados en otros aspectos del derecho de partidos. Sin embargo, como nos centramos en el sistema español, el desarrollo posterior se enfocará específicamente hacia financiación pública de los partidos, dada la preponderancia de la misma, lo perdurable de su existencia y la no escasa literatura jurídica-política sobre el tema.

De todos los aspectos pertenecientes al derecho de partidos, se analizará el impacto de la financiación pública en la democracia interna de los

estoy de acuerdo con el autor, por entender que la financiación para las actividades ordinarias es debida, por el hecho de que la voluntad popular es incesantemente formada por las organizaciones políticas.

${ }^{298}$ ALVARÉZ CONDE, E. “Veinticinco Años...” Pp. 91. 
partidos, y también los efectos prácticos en la disolución de los mismos. Aunque la disolución de partidos puede producirse en otros supuestos, nos centraremos básicamente en la disolución por decisión de autoridad judicial, debido a la ilegalización de la organización política, en los supuestos del art. 10 de la Ley Orgánica 06/2002.

\subsection{La influencia de la financiación de partidos sobre la democracia interna de las organizaciones partidistas}

El tema de este epígrafe es de relevancia reconocida y, aunque no forme parte del objeto central del presente trabajo, no creemos que deba ser ignorado. La cuestión de la democracia interna de los partidos políticos involucra muchos otros aspectos, tanto sobre la naturaleza jurídica de los partidos, como también sobre la financiación de los mismos y el cumplimiento de las obligaciones impuestas por la Constitución. ${ }^{299}$

\footnotetext{
299 Desde hace tiempo se acusa a los partidos de tender a una estructura oligárquica, contrariando las respectivas disposiciones constitucionales. Desde los doctrinadores clásicos como OSTROGORSKI y Robert MICHELS el problema sigue siendo debatido casi en los mismos términos que en aquella época. En el inicio del siglo XX, OSTROGORSKI ya había escrito que los partidos eran democráticos solo externamente y propone otro modelo que sustituya la figura de los partidos, originada a partir de la acción social de la sociedad. (In: OSTROGORSKI, M.: La Democracia y los Partidos Políticos. ed. Trotta, Madrid, 2008. Pp. 35 y ss). MICHELS es más contundente en el asunto, pues al analizar los partidos políticos bajo una perspectiva sociológica, el autor entiende que, sin organización no hay democracia, y que estas organizaciones, conocidas como partidos, se estructuran para la búsqueda de un fin, e inevitablemente por la cantidad de miembros en la masa, los líderes tendrán que imponer procedimientos burocráticos para que esta máquina agigantada funcione. A partir de este momento, se generan dentro de la organización clases de personas, similares a la estructura de clases que hay en el capitalismo, y esto según el autor es inevitable, porque en la mayoría siempre tendrá que existir (o existirá forzosamente) una minoría que sea la clase gobernante de la masa. Ese proceso desencadena una evolución oligárquica dentro del partido, componiendo de esta manera lo que el autor denomina "ley de hierro" de los partidos políticos. (In: MICHELS, R.: Los Partidos Políticos 2 - Un Estudio Sociológico de las Tendencias Oligárquicas de la Democracia Moderna. Ed. Amorrortu, 5 reimp. Buenos Aires, 1996. Pp. 170181. Para entender el razonamiento utilizado por el autor, cfr. MICHELS, R.: Los Partidos Políticos 1 - Un Estudio Sociológico de las Tendencias Oligárquicas de la Democracia Moderna. Ed. Amorrortu, 5o reimp. Buenos Aires, 1996). Sin embargo, en otros de sus trabajos, MICHELS utiliza un lenguaje más fuerte para exponer su posición sobre el tema. Así, el autor presenta una visión pesimista y negativa de la relación existente entre dirigentes, líderes y miembros de los partidos, que llega a reducir el papel de los afiliados a meros votantes esporádicos de algún representante para la estructura burocrática de la organización. Así, aunque el fundamento de los partidos fuera algo externo y democrático, acaba por ser limitado en su esfera interna, con tendencias oligárquicas. (In: MICHELS, R. "Democracia Formal y Realidad Oligárquica". In: LENK, K.; NEUMANN, F. (eds.): Teoría y Sociología Críticas de los Partidos Políticos. Ed. Anagrama, Barcelona, 1980. Pp. 242). Como una contra-opinión a la de Michels, cfr. trabajo de SCHIFRIN, en que el autor entiende que los males de la oligarquización
} 
Es cierto que el tema de la democracia interna de los partidos fue introducido en el texto constitucional sin mayores debates, en línea con el consenso que se produjo sobre una parte importante de los contenidos de la Constitución Española. Esto fue así porque se consideraba que el principio democrático no debería estar solamente en el Estado, sino que también debería regir para todas las organizaciones que lo componen, o por lo menos aquellas que representan los intereses de la sociedad como un todo ante los entes públicos, dotándoles de una autentica representación. ${ }^{300}$ Es por ello que los partidos políticos, encargados de esta función, también tienen la obligación de organizarse democráticamente en su estructura interna. ${ }^{301}$

en un partido no son inevitables, y que para combatirlas, la democracia interna es una de las herramientas principales, haciendo que el partido ascienda. Así, la democracia interna debe estar compuesta por tres puntos, o sea, la libertad de expresión, que es la condición principal de la democracia interna; una intensa autonomía y vida propia de las organizaciones locales, como protección en contra del centralismo exagerado, conduciendo a una politización del partido; y la constitución democrática del partido a través de un proceso democrático en toda la organización, a partir de las reglas establecidas en los estatutos. (In: SCHIFRIN, A. "Aparato de Partido y Democracia Interna - Una Crítica Socialista de Michels". In: LENK, K.; NEUMANN, F. (eds.): Teoría y Sociología Críticas de los Partidos Políticos. Ed. Anagrama, Barcelona, 1980. Pp. 275-276). A la vez, WEBER entiende que dentro de los partidos siempre habrá una estructura oligárquica, basándose en un principio semejante al de la jerarquía administrativa, y esto es así porque los partidos como un todo se constituyen, en sus palabras, a partir de una "estructura pura de dominación del cuadro administrativo", esto es, de la burocracia. (In: WEBER, M.: Economía y Sociedad I: Teoría de la Organización Social. Ed. Fondo de Cultura Económica, Derechos Fundamentales, México, 1944. Pp. 228). Otro autor relevante que trata del asunto es LOMBARDI, que afirma que los partidos, aunque indispensables para la democracia, producen claramente una lucha interna que está aparte de la sociedad, formando una oligarquía que los aleja de su base social. (In: LOMBARDI, G. "Corrientes y Democracia Interna de los Partidos Políticos". In: Revista de Estudios Políticos (Nueva Época), no 27, may/jun, ed. Centro de Estudios Constitucionales, 1982. Pp. 15). También, cfr. GONZÁLEZ ENCINAR, J. J. "Democracia de Partidos "versus" Estado de Partidos". In: GONZÁLEZ ENCINAR, J. J. (coord.): Derecho de Partidos. Espasa-Calpe, Madrid, 1992. Pp. 51 y ss, sobre un resumen de las obras clásicas sobre el tema.

${ }^{300}$ PRESNO LINERA, M. Á: Los Partidos y las Distorsiones... Pp. 62 y ss.

${ }^{301} \mathrm{El}$ deber de los partidos de estar regulados también por reglas que aseguren la democracia interna se vincula directamente con el derecho de los afiliados en participar activamente del proceso de toma de decisiones y en la elección de sus dirigentes, en todos los niveles en que el partido actúa. Significa decir que los partidos deben abrir espacios para el eventual pluralismo de posiciones e ideologías que pueden adaptar sus miembros, y respetar dicha diversidad, en pleno respeto a la dinámica política. Si no hay dicha tolerancia en el seno de estas organizaciones, la función de concretización de la democracia falla desde su inicio, porque si no hay respeto al pluralismo dentro de los partidos, difícilmente lo habrá fuera, en su ámbito externo. Sin embargo, la existencia de las disposiciones constitucionales acerca del tema no evita que su contenido sea en múltiples ocasiones reducido a una ficción jurídica, por la imposibilidad de su concretización y su control efectivo. En este sentido, vid. por todos, tempranamente, ESTEBAN, J. de; LÓPEZ GUERRA, L.: El Régimen Constitucional Español 1. $1^{\circ}$ ed. reimp. ed. Labor, Barcelona, 1983. Pp. 79-80 y MARTíNEZ CUEVAS, M. D.: Op. Cit. Pp. 37. 
Como ocurre con el registro de partidos, muchas posiciones doctrinales fueron elaboradas bajo la vigencia de la Ley Orgánica 54/1978, ley esta que también era insuficiente en su regulación sobre la materia. ${ }^{302}$ En todo caso, este "clamor doctrinal" no consiguió que la LOPP regulara de manera incisiva esta materia ${ }^{303}$, aunque se debe reconocer que se ha avanzado en su tratamiento. $^{304}$

Las aproximaciones más recientes a este tema, subrayan las ventajas de adoptar un concepto "mínimo", susceptible de consenso y aplicación efectiva por parte de las organizaciones políticas. ${ }^{305}$ Así, la democracia interna

${ }^{302}$ Su artículo cuarto - único destinado a la democracia interna de los partidos políticos - y sus tres puntos, por su brevedad, no serían capaces de abarcar toda la problemática advenida de un tema tan denso como este. Y, como no podría ser de otra manera, las disposiciones contenidas en dicha ley adolecen de abstracción y de difícil interpretación jurídica, lo que dejaba un margen muy grande para que los partidos no fueran obligados a cumplir lo dispuesto en ley. Debido a ello, la literatura se preocupó preliminarmente en conceptuar lo dispuesto en el artículo 6을 en un intento de comprender mejor el contenido material de dicho deber.

${ }^{303}$ TAJADURA TEJADA entiende que la ineficacia e insuficiencia de la Ley Orgánica 54/1978 puede incluso haber fomentado el déficit democrático dentro de los partidos políticos, provocando el alejamiento de muchos ciudadanos de las organizaciones partidistas. Sin embargo, el autor entiende que en la LOPP se podría haber avanzado más en la materia, ya que aún se considera una regulación bastante básica acerca de democracia interna. (In: TAJADURA TEJADA, J.: Partidos Políticos y Constitución: Un Estudio de la LO 6/2002 de 27 de junio, de Partidos Políticos, y de la STC 48/2003, de 12 de marzo. Ed. Civitas, Madrid, 2004. Pp. 72). En este sentido MARTÍN DE LA VEGA, que afirma que participación, garantías y derechos se convierten en los pilares de dicha democracia interna, como ocurre con la democracia en general. Con todo, la ley es solo una parte de la normativa para los partidos políticos, siendo completada por los estatutos. Una de las principales lagunas de la LOPP es en este tema consistiría en la omisión de cualquier regulación del ejercicio de la libertad de expresión del afiliado, un elemento clave en el tema. Así, véase MARTíN DE LA VEGA, A. "Los Partidos Políticos y la Constitución de 1978..." Pp. 213-227. También, en el mismo sentido, cfr. SÁNCHEZ FERRO, S. "El Complejo Régimen Jurídico Aplicable a los Partidos Políticos tras la aparición de la Ley Orgánica de Partidos Políticos de 27 de Junio de 2002". In: Revista Jurídica de la Universidad Autónoma de Madrid, no 12, 2005. Pp. 249 y ss.

${ }^{304}$ Es cierto que la doctrina se mostraba casi unánimemente bastante crítica con las disposiciones de la Ley Orgánica 54/1978. Sin embargo, PRESNO LINERA afirma que no hay una inconstitucionalidad por omisión en las leyes, lo que no autoriza que se declare 'per se' la nulidad de dichos preceptos. (In: PRESNO LINERA, M. Á.: Los Partidos y las Distorsiones... Pp. 71). Algunos ejemplos sobre la democracia interna bajo la vigencia de la Ley Orgánica 54/78 en BLANCO VALDÉS, R. L. "Crisis en los Partido, Partidos en la Crisis: La Democracia en los Partidos en la Frontera del Fin de Siglo". In: ASENSI SABATER, J. (coord.): Ciudadanos e Instituciones en el Constitucionalismo Actual. Ed. Tirant Lo Blanch, Valencia, 1997. Pp. 129 y ss. Una muy buena crítica de la normativa anterior, vid. ESPARZA MARTíNEZ, B. Op. Cit. Pp. 140 y ss, para un panorama general sobre el tema y MANUEL ABELLÁN, Á. "Problemas Representativos y Participación de los Ciudadanos: La Democratización de los Partidos Políticos y la Perspectiva Electoral". In: ASENSI SABATER, J. (coord.): Ciudadanos e Instituciones en el Constitucionalismo Actual. Ed. Tirant Lo Blanch, Valencia, 1997. Pp. 286 y ss.

${ }^{305}$ Sin embargo, la Ley Orgánica 54/1978 solo proveía algunos medios, no todos, para lograr dicho objetivo, el resto debía ser concretado por el intérprete. En mi opinión, la LOPP no ha modificado mucho esta necesidad, aunque haya establecido algunos procedimientos que 
podría ser entendida como un conjunto de reglas que determinan por quién y cómo estará estructurado el poder dentro de un partido, siendo así que dichas reglas deben intentar evitar la oligarquización "natural" que puede surgir en los órganos directivos de los partidos, involucrando a mayorías y minorías en los debates existentes. ${ }^{306}$

Más allá de definiciones, lo cierto es que, como es sabido, el pluralismo político en el interior del partido es algo difícil de conseguir porque el poder, por su propia naturaleza, tiende a la concentración. ${ }^{307} \mathrm{~A}$ través de la democracia interna se intenta no obstante acercar al afiliado al proceso de toma de decisiones del partido, obligando a este, a través de los estatutos y normas internas, a traducir en la práctica la voluntad de los integrantes de la organización; y también a evitar el comportamiento oligárquico, en cuanto posible, sin que esta disidencia comprometa el triunfo electoral, un objetivo que tampoco puede ser ignorado. ${ }^{308}$

puedan colaborar en la concretización de esta obligación. Sin embargo, no es posible profundizar este análisis en el presente trabajo, por traspasar sus límites.

${ }^{306}$ NAVARRO MENDEZ, J. I.: Partidos Políticos y "Democracia Interna". CEPC, Madrid, 1999. Pp. 32 y ss.

${ }^{307}$ DE VEGA GARCÍA, A. S. "Constitución, Pluralismo Político y Partidos". In: Revista de las Cortes Generales, № 26, 2ำ cuatrimestre, Madrid, 1992. Pp. 95-97. El autor entiende que el problema de la democracia interna no puede ser visto solo desde el punto de vista jurídico o político porque no se trata de un problema que posee solo un lado. También hay en conflicto entre el principio de la libertad de los afiliados, que se choca con el principio de autonomía del partido.

${ }^{308}$ Dentro de esta dinámica, existen dos aspectos de la democracia interna, el electivo y el carácter democrático de esta estructura interior; como también el aspecto participativo y de funcionamiento democrático, ambos acogidos por el artículo 6ำ de la Constitución Española. Así, la democracia interna adoptada por el constituyente no es un rasgo sino una condición constitucional impuesta a los partidos, con la finalidad de cumplir fielmente las funciones que les fueron atribuidas. (Cfr. DE VEGA GARCÍA, A S. "Constitución, Pluralismo..." Pp. 99-101). El mismo autor, en otro de sus trabajos, afirma que dentro de la cuestión de la democracia interna de los partidos se inserta el conflicto entre dos principios, el de la libertad de los miembros del partido y su derecho a la participación en la vida política, frente a la autonomía de los partidos. Así, el encaje entre el interés individual y el colectivo requiere la democracia interna, legitimando las funciones del partido. (In: SANCHEZ DE VEGA, A. "Notas para un Estudio del Derecho de Partidos". In: ASENSI SABATER, J. (coord.): Ciudadanos e Instituciones en el Constitucionalismo Actual. Ed. Tirant Lo Blanch, Valencia, 1997. Pp. 321). Junto a ello, la condición democrática en la estructura de los partidos políticos es una condición necesaria para su existencia y cumplimiento de sus funciones, porque cuando un partido no es democrático internamente, se podría pensar en autorizar la denegación de su inscripción registral. Una organización partidista incompatible con los díctamos de la ley no se puede considerar como democrático, incluso porque sólo puede verle como un partido político si se configura de esta manera, y si no es así, se podría incluso justificar su no inscripción como partido, ya que no tiene unos parámetros que atiendan tal exigencia, lo que, consecuentemente, evitaría que se beneficie de las ventajas que el ordenamiento otorga a los partidos, tenidos como tal, como puede ser la financiación pública. (Cfr. MORODO, R.; MURILLO DE LA CUEVA, P. L.: El Ordenamiento Constitucional... Pp. 114-115-119). Sin 
Los datos actuales demuestran que la afiliación partidista en España sigue siendo muy baja, lo que de alguna manera también colabora a que las estructuras oligárquicas sobrevivan y no cambien a través de reforma de los estatutos. Sin embargo, la ausencia de una democracia interna en los partidos acaba también por originar consecuencias para todos los ciudadanos, que resulta indirectamente afectados por la ausencia de transparencia en las estructuras partidistas y en su funcionamiento, y más aun en un sistema de listas electorales bloqueadas. No hay garantía de una selección justa y honesta de los candidatos, y dicha inseguridad acaba por transferirse también a los votantes. ${ }^{309}$

Sin embargo, no son sencillos de encontrar, ni existe consenso doctrinal sobre los posibles mecanismos de control de la democracia interna de dichas organizaciones. En este debate, hay opiniones que entienden que el control debería ser más incisivo, incluyendo quizás una intervención judicial, a diferencia del ejercido sobre el registro de partidos, donde se limita a un control formal de los estatutos presentados. Se podría agrupar la literatura jurídica sobre el tema en torno a dos posiciones: quienes ven que los mecanismos jurídicos son centrales para que los partidos políticos funcionen democráticamente; y otro que, desconfiado claramente de la eficacia de cualquier adecuación jurídica en este tema, fían alcanzar los niveles mínimos en la propia capacidad de partido y de sus grupos para autorregularse sin llegar a la lucha endogámica. ${ }^{310}$

Lo cierto es que los partidos políticos están estructurados de manera piramidal $^{311}$, considerando que actualmente son organizaciones de alto carácter profesional. ${ }^{312}$ Consecuentemente, la elite gana influencia e

embargo, los autores reconocen que dicho control siempre es difícil, más allá del examen final de las estructuras, y debe respeto siempre a la autonomía política del partido.

309 SORIANO DÍAZ, Ramón L. "EI Dominio de los Partidos Políticos: Partidos y Sociedad". In: Revista de Estudios Políticos (nueva época), no 105, jul/sep, 1999. Pp. 268-269. En este punto, BAUTISTA PLAZA, quien realiza un estudio comparado entre los principales partidos españoles en este aspecto. Así, véase BAUTISTA PLAZA, D.: La Función Constitucional de los Partidos Políticos. ed. Comares, Granada, 2006.

${ }^{310}$ NAVARRO MENDEZ, J. I.: Op. Cit. Pp. 151.

${ }^{311}$ VAN BIEZEN entiende que en España se da una forma muy centralizada de la actuación de los partidos. Cfr. VAN BIEZEN, I.: Political Parties in New... Pp. 93-95 y 99-101.

312 Dicho proceso de profesionalización es bastante frecuente y tiene estrecha relación con la burocracia partidista, ya que el "profesional" del partido no se dedica solamente a la actividad administrativa del partido, pero también a la actividad externa, esto es, a actividades públicas. 
importancia, dificultando altos niveles de democracia interna real. ${ }^{313}$ Es evidente que la élite de los partidos no suele acudir a sus militantes para pedirles una opinión o compartir con ellos la toma de las decisiones. ${ }^{314}$ Frente a ello, la tutela judicial de derechos consagrados en la ley o en los estatutos, no constituye en todo caso una panacea y puede acabar por generar una judicialización de la vida interna de dichas organizaciones. ${ }^{315}$ Sin embargo, la

La existencia de una burocracia fuerte dentro del partido acaba por ser causa de la centralización en la toma de decisiones políticas, y tiende a consolidar de manera horizontal en el aparato funcional interno, pues también coincide con el propio surgimiento de los "funcionarios" - generalmente "frutos" del partido - formando una coalición dominante, que dispone de muchas ventajas a que las minorías no alcanzan, funcionando más o menos como partido del gobierno y partido de la oposición. Sin embargo, cuando hay un cambio en dicha estructura funcional, esto tiende a favorecer la re-institucionalización de la organización y tiende a la pérdida de cohesión y de la estabilidad de la coalición dominante, pudiendo incluso afectar el sentimiento de lealtad que el grupo pueda sentir con relación al partido. (In: PANEBIANCO, A.: Modelli di Partiti: Organizzazione y Potere nei Partiti Politici. Bologna, 1982. Pp. 417-424). También sobre el tema, considerando una estructura de partido tipo catch all, ese tipo de partido favorece la falta de democracia interna porque, en las palabras de LÓPEZ GUERRA, frente a la debilidad ideológica de los votantes, los líderes partidistas prefieren estar libres de los controles de una militancia efectiva, la cual puede ser que dificulte esta flexibilidad de pensamiento político que sirve para adaptarse a las preferencias del electorado. (In: LÓPEZ GUERRA, L. "EI Carácter Instrumental de las Organizaciones Partidistas de Masa". In: VEGA, P. de (ed.): Teoría y Práctica de los Partidos Políticos. Edicusa - Cuadernos para el Diálogo, Madrid, 1977. Pp. 109).

${ }^{313}$ Enfocando en el caso italiano, LOMBARDI entiende que los principales partidos de este país tienen en sus estatutos una prohibición expresa en contra de las corrientes internas organizadas. Y por ello, el autor admite la existencia de corrientes, pero reconoce que sin organización de las mismas, aunque logren manifestarse en debates y a veces en votaciones, dicha corriente actuará en condiciones de clandestinidad, no siendo esto algo democrático. Ya tratando del caso español, el autor tiene una visión pesimista sobre el asunto, ya que bajo su punto de vista, aunque las corrientes existen para las iniciativas individuales, esto no ocurre porque cada corriente se apodera de su posición, volviéndose un partido 'de poder', no dejando espacio para manifestaciones individuales. Ello acaba por agudizar aún más el problema de la oligarquización a nivel micro-organizacional. (LOMBARDI, G. "Corrientes y Democracia..." Pp. 18-23).

314 GARCÍA-ESCUDERO MÁRQUEZ y PENDAS GARCÍA sostienen que los partidos entendidos como eje de la vida parlamentaria no poseen dentro de sí un "Parlamento", ya que sus eventuales congresos tienen mucho más un perfil de asamblea 'ad hoc, lo que no posibilita el empleo de medios de control. (In: GARCÍA-ESCUDERO MÁRQUES, P.; PENDÁS GARCIA, B. Op. Cit. Pp. 376). En el mismo sentido, cfr. SORIANO DÍAZ, R. L. "El Dominio de los..." Pp. 266. La dificultad al abordar el tema es subrayada por GARCÍA ROCA, F. J.; MURILLO DE LA CUEVA, P. L. "Democracia Interna y Control de los Partidos Políticos". In: Revista de Estudios Políticos (nueva época), no 42, nov/dic, 1984. Pp. 248-249; y por NAVARRO MÉNDEZ, que considera que el problema de la democracia interna es algo así como "cuadrar un círculo", ya que la Constitución Española la impone, pero de manera formal, y el control del cumplimiento de dicho límite constitucional a la autonomía de los partidos plantea problemas de posible intromisión estatal en la vida interna partidista. (In: NAVARRO MENDEZ, J. I.: Op. Cit. Pp. 24). Aún bajo esta perspectiva, véase AA. VV.: "Debates". In: Régimen Jurídico de los Partidos Políticos y Constitución. Cuadernos y Debates, no 51, Centro de Estudios Constitucionales, Madrid, 1994. Pp. 63 y ss.

${ }^{315}$ Entre tanto, las voces que defienden un control externo de dichas organizaciones, realizado por el Poder Judicial afirman que un posible control hecho por la jurisdicción contenciosaadministrativa, haría que los órganos responsables tuvieran un papel fiscalizador. Esto sería 
existencia de garantías de libertad interna en los partidos fomenta claramente a la democracia como un todo, y para ser efectiva, requiere al menos de un mínimo de plasmación a nivel legislativo. ${ }^{316}$ De hecho y debido a la posición determinante de los partidos en el ordenamiento jurídico, las funciones que les fueron atribuidas y su importancia en los sistemas democráticos justifican la posible intervención legislativa sobre ellos, que deberá tener como límite la propia libertad de auto-organización de las formaciones políticas, así como también su funcionalidad para el sistema como un todo. ${ }^{317}$

No parece en todo caso que la disolución del partido que contempla el art. 10.2 b, de la LOPP, sin más providencias sea una medida realmente aplicable, en un tema en que ejerce un papel determinante la jurisdicción civil y, en último término, el Tribunal Constitucional a través del recurso de amparo. ${ }^{318}$ Detrás de una mayor o menor intervención normativa aparece la concepción

posible a partir de la interpretación de que el contenido de los estatutos integran el ordenamiento, y dicha condición autoriza la intervención del Poder Judicial en caso de violación de las normas estatutarias. Esto es, si hay alguna violación del estatuto, hay una violación del ordenamiento jurídico, permitiendo un control estatal externo, más allá de la consagración legal de determinadas obligaciones y de los derechos de los afiliados. (Cfr. FERNANDEZ-MIRANDA CAMPOAMOR, A. "El "Control Estructural-Funcional de los Partidos Políticos en la Jurisprudencia Contencioso-administrativa". In: Revista Española de Derecho Constitucional, año 2, no 4, vol. II, ene/abr, 1982. Pp. 127. En igual sentido GARCÍA COTARELO, incluso para que el propio Poder Judicial defina qué es 'principio democrático', algo bastante difícil bajo el punto de vista de la hermenéutica. Cfr. GARCíA COTARELO, Ramón: Los Partidos Políticos. Op. Cit. Pp. 165). Si la ley de partidos determina lo que debe componer el contenido de los estatutos a partir de principios 'indispensables' para el legislador, esto sería susceptible de control por parte del contencioso-administrativo, lo que, lamentablemente, todavía no podría garantizar que los partidos fueran realmente democráticos internamente. Aún sobre este problema, véase SATRUSTEGUI GIL-DELGADO, que entiende que ante las garantías jurisdiccionales, y también para evitar que la vida intrapartidista siempre sea resuelta por los tribunales, la ley debe regular la cuestión previendo un procedimiento interno para los partidos, estableciendo un carácter subsidiario del control judicial. (In: SATRUSTEGUI GIL DELGADO, M. Op. Cit. Pp. 98).

${ }^{316}$ GARCÍA-PELAYO, M.: El Estado de Partidos. Ed. Alianza, Madrid, 1986. Pp. 62-63.

317 FLORES GIMÉNEZ, F.: La Democracia Interna de los Partidos Políticos. ed. Congreso de los Diputados, Madrid, 1998. Pp. 74 y ss. En opinión del autor, la actuación normativa de la democracia interna se ve favorecida por una legislación mínima del tema, y que al mismo tiempo sea flexible, para que no interfiera en el núcleo esencial de la libertad y funcionalidad de los partidos políticos. En este sentido, el autor entiende que los partidos políticos deben ser objeto de una regulación de mínimos, y adecuada a su naturaleza social, y tampoco se debe intentar regular todos los aspectos de la organización y su funcionamiento.

${ }^{318}$ BLANCO VALDÉS, R. L: Los Partidos Políticos. Tecnos, Madrid, 1990. Pp. 168-170. Con igual posición, véase CARRERAS SERRA, F. de. "Los Partidos en Nuestra Democracia de Partidos". In: Revista Española de Derecho Constitucional, año 24, № 70, ene/abr, 2004. Pp. 99, donde el autor, aunque opta por el control judicial de la democracia interna, no cree en su efectividad, considerando que los jueces prefieren abstenerse de resolver dichos conflictos, por juzgar que estos tienen una naturaleza más de disputa de poder que de conflicto jurídico propiamente dicho. También, vid. LOMBARDI, G. “Corrientes y Democracia..." Pp. 25-27. 
que se tenga sobre la naturaleza jurídica de los partidos. ${ }^{319}$ En todo caso, nos encontraremos ante una de las "aporías" clásicas del Derecho de Partidos: una regulación normativa que pretende limitar las sinergias de la vida organizativa de los partidos, retirándoles autonomía, pero que igualmente debe ser establecida por los mismos partidos. ${ }^{320}$

Actualmente la jurisprudencia ya no escasa del Tribunal Constitucional parece dejar claro que la democracia interna constituye una de las cargas impuestas a los partidos por la Constitución, y que la configuración legal de dicha democracia interna debe ponderarse con el derecho de autoorganización de los partidos, que a su vez también tiene su límite en el derecho de los afiliados en su participación política. En todo caso, y dado el principio de autoorganización de los partidos, estos pueden ampliar el catálogo de derechos de los afiliados a través de sus estatutos, y estos derechos deberán de estar dotados de su correspondiente tutela judicial ordinaria. ${ }^{321}$

De lo que no hay duda es de que existe una cierta relación entre democracia interna de los partidos y financiación de los mismos. Una de las

${ }^{319}$ En este sentido, cfr. GARCÍA-ESCUDERO MÁRQUES, P.; PENDÁS GARCIA, B. Op. Cit. Pp. 383 y NAVARRO MENDEZ, J. I.: Op. Cit. Pp. 255.

${ }^{320}$ En este sentido, cfr. SATRUSTEGUI GIL DELGADO, M. Op. Cit. Pp. 86.

${ }^{321}$ En este sentido, existe una abundante jurisprudencia que puede citarse, empezando por la conocida STC 56/1995 de 6 de marzo (principalmente F.J. 3); y las más recientes que discuten la relación autoorganización de los partidos y de los derechos fundamentales TS 595/2009 de 05 de octubre y TS 683/2011, de 27 de septiembre. Sobre la STC 56/1995, GALLARDO MOYA cita la conexión que el Tribunal Constitucional hizo entre los artículos 6 ํ y 22 de la Constitución Española, y entiende que dicha combinación produce resultados exagerados porque al vincular dichos derechos, hace que los derechos de los miembros del partido sean derechos fundamentales, que por naturaleza son universales. O sea, significa conceder el derecho de participación interna en los partidos a todos los ciudadanos, traspasando su condición o no de afiliado. (In: GALLARDO MOYA, R. "Derecho de Asociación y Exigencia de Democracia Interna de los Partidos Políticos. (Comentarios a la STS 56/1995, de 6 de marzo)". In: Derecho Privado y Constitución. № 8, ene/abr, 1996. Pp. 247). Dicha posición muestra un espacio entre los partidos y sus miembros que todavía carece de tutela, y en este caso el Poder Judicial, es bastante cauteloso en este análisis, por el temor de intervenir de manera indebida en la vida interna de los partidos. Si hay derechos que están insertados en los estatutos, y tanto el partido como el afiliado han acordado en su cumplimiento, está claro que entre las partes dichas disposiciones son norma jurídica, y deben ser estrictamente observadas, como ocurre en un contrato normal. Sin embargo, puede ser que dichas reglas puedan afectar de manera indirecta el ejercicio de otros derechos de perfil constitucional, y es en este espacio en el cual la tutela debe estar presente. Una la ausencia de garantías en este campo, la imagen de que no hay mayores consecuencias, permitiendo la proliferación de este tipo de actuación. Por ello, si la negación de derechos fundamentales no es tolerada en los otros tipos de asociación, tampoco debería serlo en los partidos, lo que reflejaría una quiebra además del principio democrático establecido en el art. 6ำ de la Constitución Española. (Véase HERRERO R. DE MIÑÓN, M. "Los Partidos como Estamentos Privilegiados: Ideas para su Reforma". In: La Democracia Constitucional. Estudios en Homenaje al Prof. Francisco Rubio Llorente. Ed. CEPC, Madrid, 2003. Pp. 211). 
evidencias apuntadas por la doctrina es que la financiación pública de partidos acaba por fomentar la estructuración de oligarquías internas y, en paralelo a la distribución de las subvenciones públicas, provoca una fuerte dependencia de los demás niveles del partido se encuentren bastante dependientes de la sede central. ${ }^{322}$ Generalmente la financiación pública acompaña a la centralización de los recursos del partido, y ello, aunque no sea algo novedoso, colabora fuertemente para la consolidación de élites oligarquizadas en su seno. Vale recordar que el sistema de listas cerradas colabora ya de por sí de manera muy importante a esta relación de dependencia entre los niveles del partido de las subvenciones públicas y a la formación de oligarquías, pues considerando que las campañas electorales son costeadas básicamente por recursos públicos, no es difícil visualizar que su puesto, o su ausencia en las listas puede ser utilizado o como premio para una conducta deseada por la organización, o como castigo, cuando el miembro se muestra contrario a alguna decisión tomada. Por su parte el control de la caja resulta básico a la hora de alcanzar el poder interno y mantenerlo en una lucha interna que tan solo se "finaliza" en los sucesivos congresos del partido.

Con todo, no solamente la financiación pública de partidos tiene reflejo en la democracia interna de los mismos. Dichas organizaciones ocupan una posición privilegiada en el Estado, sea dentro del Parlamento (a través de los grupos parlamentarios), sea en la conexión entre Estado y la sociedad. Se trata de un espacio adecuado para la actuación de grupos de presión y de la corrupción propiamente dicha ${ }^{323}$, y en el momento que el partido constata que las subvenciones públicas no serán suficientes para hacer frente a sus gastos, muy probablemente no dudará en utilizar esta influencia para fines propios. ${ }^{324}$ Todo ello resulta bastante facilitado cuando hay una considerable desideologización de estas opciones políticas, que permiten a los grupos de

\footnotetext{
322 Sobre el punto, véase Cap. II, punto 2.2.

${ }^{323}$ DELLA PORTA, D.; VANNUCCI, A.: Corrupt Exchanges. ed. Aldine de Gruyter, NY, 1999. Pp. 104 y ss.

${ }^{324}$ Según MALEM SEÑA, esto puede implicar en la violación de la democracia igualitaria (por la defensa casi en exclusiva de los intereses de los donantes, abandonando las demás demandas sociales), y también compromete el principio de la representación, rompiendo con la igualdad de peso del voto, imponiendo indirectamente un estilo de voto censitario y la relativización de la prohibición del mandato imperativo, porque los partidos acaban por decidir siempre a favor de sus donantes. (Cfr. MALEM SEÑA, J. F.: La Corrupción. Aspectos Éticos, Económicos, Políticos y Jurídicos. Ed. Gedisa, Barcelona, 2002. Pp. 121-122).
} 
presión actuar no solo en uno, sino en diversos partidos a la vez, sin comprometer sus objetivos. ${ }^{325}$

Como parte de las élites de los partidos son, en mayor o menor medida, por omisión o acción, responsables por los supuestos de corrupción ocurridos en su interior, sea ocultando su existencia, o directamente favoreciendo la práctica de estos hechos. ${ }^{326}$ Basta con constatar la permanencia en las listas electorales de personas que no encajan perfectamente en un perfil ético para el ejercicio de funciones públicas, pero sí en un perfil de captación de recursos. Por otra parte, dependiendo de cómo se configure el sistema electoral, hay nombres que son los que captan un mayor montante de donaciones, o aquellos que mantienen un mayor margen de movimiento entre los grupos de presión, posibilitando obtener o donaciones o algún tipo de financiación irregular. Esto muchas veces conduce a la conclusión de que existe una separación entre los dirigentes del partido y sus bases, abriendo el camino para estrategias determinadas por los grupos de presión. ${ }^{327}$

La creación de organizaciones dentro y fuera de los partidos para la recaudación de fondos genera una grande red, a partir de intermediarios, comisionados, y otros, que no solo aumenta las conductas corruptas, sino que dificulta sobremanera la verificación e investigación de las mismas. ${ }^{328}$ Junto a ello, dentro de los partidos es común que se formen "facciones", y que luchen para hacerse con el control total del poder en la organización, tendiendo a la utilización de los recursos no para todo el partido, sino para la parte de su propia facción. ${ }^{329}$ Esto también refuerza la percepción de que el partido suele

\footnotetext{
${ }^{325}$ COLOMBO, G. "Sanctions and Remedies in Cases of llegal Financing of Political Parties". In: AA.VV.: Trading in Influence and the Illegal Financing of Political Parties. Programme of Action Against Corruption - Third European Conference of Specialised Services in the Fight Against Corruption. Council of Europe Press. Germany, 2000. Pp. 60. Tratando del caso italiano, comentando la falta de ideología de los partidos como condición que facilitó la proliferación de la corrupción en aquél país, cfr. DELLA PORTA, D.; VANNUCCI, A.: Op. Cit. Pp. 96 y ss.

${ }^{326}$ AA.VV. "Encuesta: Corrupción Política". In: Teoría y Realidad Constitucional. no 25, 1o semestre. UNED, Madrid, 2010. Pp. 27.

${ }_{327}$ Cfr. MURILLO DE LA CUEVA, P. L.; VEGA GARCIA, P. de; ALCUBILLA, A.; et al. "Debate. Op. Cit." Pp. 30.

${ }^{328}$ Cfr. DELLA PORTA, D.; VANNUCCI, A.: Op. Cit. Pp. 99.

${ }^{329}$ MALEM SEÑA, J. F.: La Corrupción... Pp. 122-124.
} 
estar más ocupado en su propia administración que en la administración del Estado a favor de la sociedad. ${ }^{330}$

En cierta manera, la idea de autonomía partidista también acaba por alejar a la sociedad de la toma de decisiones, y el proceso de oligarquización (una consecuencia del derecho de los partidos para autoorganizarse) resulta también favorecido por la ocultación inherente a la presencia de financiación ilegal o irregular. $^{331}$ No basta obtener los recursos, también se debe acomodarlos dentro de la contabilidad de la organización, algo de lo que la tesorería es responsable. Siendo un órgano importante para el funcionamiento del partido, no raras veces los componentes de la tesorería están implicados en los escándalos de corrupción dentro de los partidos. ${ }^{332}$ Ello junto con la deficiencia de los controles internos de los propios partidos en relación a sus dirigentes, refleja el bajo grado de democracia interna existente en dichas organizaciones, como también la escasa regulación del tema por el legislador. ${ }^{333} \mathrm{Y}$ parece constatarse que las disposiciones de la LOPP, aun más detalladas que las de la Ley Orgánica 54/1978, no ha tenido un fuerte impacto en este sentido.

De nuevo se siente la necesidad de la existencia de transparencia en las estructuras internas del partido. Actualmente, es el arma más eficaz en contra de la corrupción. Sin embargo, la ausencia o deficiencia de los mecanismos de control interno de los partidos - obligación establecida por la LOPP para la selección de candidatos, como también por la LOFPP con relación a su

330 PRADERA, J. "La Maquinaria de la Democracia. Los Partidos en el Sistema Político Español”. In: J. LAPORTA, F.; ÁLVAREZ, S. (eds.): la Corrupción Política. ed. Alianza, Madrid, 1997. Pp. 171.

${ }^{331}$ En este punto, está claro que pocos invierten en una campaña electoral sin esperar ningún retorno, sea a medio o largo plazo. No es necesario que sea de manera inmediata. Además, los dirigentes del partido pueden pedir a alguna empresa o grupo de presión algún apoyo en la campaña o para el partido, a cambio de un tratamiento preferencial en determinados asuntos. (In: LEQUESNE, M. "Trading in Influence and llegal Financing of Political Parties". In: AA.VV.: Trading in Influence and the Illegal Financing of Political Parties. Programme of Action Against Corruption - Third European Conference of Specialised Services in the Fight Against Corruption. Council of Europe Press. Germany, 2000. Pp. 51-54).

${ }^{332}$ Debido a la corrupción, se ha subrayado la existencia de diversas estructuras "escondidas" de los partidos, mantenidas solamente para dicho fin. Es decir, se trata de una estructura volcada en los negocios, y no exactamente en la política, como parte de la organización interna del partido. Dada su importancia, no es de sorprender que las élites partidistas no compartan este espacio con muchos de sus miembros. (In: DELLA PORTA, D.; VANNUCCI, A.: Op. Cit. Pp. 96-97).

${ }^{333}$ AA.VV. "Encuesta: Corrupción Política. Op. Cit." Pp. 32. 
contabilidad - ya fue denunciada muchas veces por el Tribunal de Cuentas en sus informes de fiscalización de partidos. Con todo, las apelaciones del citado órgano no han tenido lamentablemente mayores efectos sobre el legislador.

\subsection{Los efectos económicos de la disolución de los partidos}

Con la aprobación de la Ley Orgánica 06/2002 - responsable de las innovaciones más destacables del Derecho de Partidos actual, cual es la posibilidad de la ilegalización de organizaciones partidistas por realizar determinado tipo de actividades - se introdujeron también determinadas disposiciones referidas a la economía de los partidos que acompañarían los nuevos mecanismos adoptados. Considerando que dicha ilegalización de partidos era algo novedoso, parecía lógico adoptar otras medidas que ayudarían a cerrar esta cuestión tan delicada.

El proceso de ilegalización de un partido solo podrá culminar en una disolución formal de dicha organización a través de una decisión de la autoridad judicial, y su consecuencia inmediata posterior a la sentencia (la cual no es susceptible de recurso, salvo el recurso de amparo ante el TC, según el dispuesto en el art. 11.7) es la apertura de un proceso de liquidación patrimonial ${ }^{334}$, que deberá ser llevado a cabo por tres liquidadores nombrados por la Sala sentenciadora, además de determinar que el patrimonio neto que resulte de dicho proceso sea destinado a la financiación de actividades de interés social o humanitario, a cargo del Tesoro. ${ }^{335}$

Con todo, no solo las medidas posteriores a la decisión judicial de disolución de un partido eran importantes. El cierre económico de organizaciones que incurrieran en conductas que justificarían su ilegalización también tuvo su reflejo en las reglas sobre financiación de los partidos, sea esta electoral u ordinaria. Tanto la LOREG ${ }^{336}$ como en su época la Ley

\footnotetext{
${ }^{334}$ Dicha consecuencia también se da en el derecho alemán, el cual dispone de una abundante literatura jurídica sobre el tema. En este sentido, cfr. STERN, K.: Derecho del Estado de la República Federal Alemana. ed. Centro de Estudios Constitucionales, Madrid, 1987. Pp. 411 e IÑIGUEZ, D.; FRIEDEL, S. "La Prohibición de Partidos Políticos en Alemania". In: Claves de Razón Práctica. № 122. Madrid, 2002. Pp. 33.

${ }^{335}$ En este sentido, cfr. art. 12.1, apartado c.

${ }^{336}$ Cfr. art. 127.3.
} 
Orgánica $3 / 1987^{337}$, de la que pasan a la actual Ley Orgánica 8/2007 $7^{338}$, contempla que con los recursos correspondientes a dicha financiación no se subvencionarán los gastos de estas organizaciones, así como tampoco les serán entregadas las cantidades no devengadas. Una medida que fue extendida en el caso de que la organización tenga en sus órganos directivos, grupos parlamentarios o políticos, o listas electorales personas condenadas por sentencia, aunque no firme, por delitos de naturaleza violenta como puede ser el terrorismo, rebelión, y otros apuntados en la legislación penal. Dichas condiciones son válidas para todos los niveles estatales y serán apreciadas por el Ministro del Interior o a un alto cargo en que este delegue, respetando el derecho al contradictorio. La diferencia entre la Ley Orgánica 3/1987 y la 8/2007 es que en esta última se admite que se produzca la suspensión cautelar de la entrega de recursos económicos al partido que está involucrado en un procedimiento para su ilegalización, a petición del Ministro del Interior, ${ }^{339}$ por lo que la posibilidad de ejecutarlo está debidamente prevista en ley. Ya en el ámbito europeo, se aprobó la resolución en 13 de diciembre de 2007, que no tiene naturaleza vinculante en los Estados Miembros, sugiriendo que estos prevean la opción de retirar los fondos públicos a los partidos que no condenen la violencia y el terrorismo. ${ }^{340}$

Volviendo a la legislación española, existen otras normas que igualmente tipifican el delito contemplado en la Ley Orgánica 20/2003, que se refiere a la financiación ilegal de partidos disueltos o suspendidos o grupos que de hecho continúen su actividad. La Ley Orgánica 38/2003, referente al régimen general de subvenciones también se mueve en esta línea, lo que permite concluir que no son solamente los partidos, grupos parlamentarios 0 agrupación de electorales los sujetos pasivos de dicha conducta, sino que además de comprender cualquier subvención o ayuda a dichos entes, se aplica extensivamente a asociaciones, personas físicas o jurídicas, y entes sin personalidad jurídica. ${ }^{341}$

\footnotetext{
${ }^{337}$ Cfr. art. 4 y apartados.

${ }^{338}$ Cfr. art. 3.5.

${ }^{339}$ Cfr. art. 3.5, Ley Orgánica 8/2007.

${ }^{340}$ IGLESIAS BARÉZ, M.: Op. Cit. Pp. 267, nota de pié.

${ }^{341}$ Cfr. VIANA BALLESTER, C. "Comentario a la LO 20/2003, de 23 de Diciembre (los Nuevos Delitos de Convocatoria llegal de Elecciones o Referéndum y de Financiación llegal de Partidos
} 
La liquidación patrimonial provocada por la disolución judicial de un partido, se producirá durante la fase de ejecución de la sentencia. Con todo, al regular el tema de la disolución, la Ley Orgánica 06/2002 contempla, como es sabido, tres hipótesis que autorizan dicha medida de disolución, siendo una de carácter penal (que se refiere a la asociación ilícita); otra cuando hay vulneración continuada y reiterada de la exigencia de una estructura y funcionamiento interno democráticos y la tercera la que prevé una actividad reiterada y grave que atente los principios democráticos o que intente eliminar el régimen de libertades o el sistema democrático a partir de las conductas descritas en la ley (siendo está la hipótesis con más relevancia), pero no aborda si en todos estos casos se aplica la liquidación patrimonial.

Con relación a la primera y a la tercera hipótesis, no hay dudas de que se aplicará la liquidación patrimonial ${ }^{342}$, pero no se puede afirmar categóricamente con relación al segundo caso. Como vimos, la cuestión de la democracia interna carece de una solución concreta y capaz de dirimir dichos conflictos. Y, considerando las incertidumbres que afectan a la propia categoría legislativa, resulta difícil imaginar supuestos ordinarios de liquidación patrimonial en esta situación. No hay ninguna conducta de perfil penal, tampoco parece que se pueda atribuir a la Sala Especial el establecimiento de criterios generales para decidir si ha habido o no la vulneración de la democracia interna de un partido, siendo que dichos criterios que tampoco el legislador ha fijado en la ley. En este caso, se puede entender que el derecho de asociación prevalece, debiendo mantener el patrimonio intacto, aunque se decida por suspender las actividades del partido. Ahora bien, por la ausencia

Políticos Disueltos o Suspendidos o Grupos que de Hecho Continúen su Actividad". In: Revista General de Derecho Penal. o 1, mayo 2004 . Disponible en: $<<$ http://www.iustel.com/v2/revistas/detalle_revista.asp?id=8\&numero=1 >>

${ }^{342}$ En este punto no entraremos en la discusión sobre si, en el tercer caso, los miembros del partido podrían seguir unidos como una asociación común, manteniendo su patrimonio. En mi opinión, a partir del momento en que un partido es disuelto por dichos supuestos, se debe promover la asignación de sus bienes al destino acordado, encaminando la organización a su completa extinción. No se puede garantizar que, manteniendo el patrimonio, los actos apuntados como antidemocráticos no se repitan. Así lo apunta tanto el Consejo del Estado (In: BOCG, Congreso de los Diputados, № 93-1, de 24 de abril de 2002) como la jurisprudencia sobre el tema (Cfr. la celebrada STS de 27 de marzo de 2003). Vale recordar que la financiación pública debe ser destinada a partidos que cumplan sus funciones constitucionales, y su supresión está justificada cuando dichos recursos están siendo indebidamente utilizados para el patrocinio del terrorismo. 
de parámetros de comparación, la liquidación en este caso podría ser considerada un acto desproporcionado. ${ }^{343}$

En todo caso, en los otros supuestos, y justificada la liquidación patrimonial, el destino de dichos bienes debe decidirlo el Tesoro, cumpliendo con fines sociales y humanitarios. Con todo, hubo autores que se preguntaron si estos bienes podrían ser encaminados a los fines partidistas determinados vía constitucional (es decir, expresar el pluralismo político, concurrir a la formación y manifestación de la voluntad popular y ser instrumento de la participación política). ${ }^{344}$ En este punto, estamos de acuerdo con las consideraciones realizadas por el Consejo de Estado, de que no sería lo más indicado que los indirectamente autorizados a iniciar la disolución de dicho partido fueran a la vez beneficiados por la liquidación de sus bienes. Además, se podría generar problemas que afectarían incluso a las reglas de financiación de partidos, como reajustes y distribución por las determinaciones de los liquidadores nombrados judicialmente. ${ }^{345}$ Por lo tanto, nos sumamos a la doctrina que juzga como la más acertada la decisión del legislador de destinarlos al Tesoro para fines sociales y humanitarios, siendo este un mero depositario. No se puede considerar que se trate de una medida confiscatoria porque la liquidación patrimonial es la única solución que posibilita la disponibilidad de los bienes de partidos que fueron declarados ilegales y que han contribuido con sus acciones han herido el principio democrático. Constituye su ensayo un defecto teórico de la Ley Orgánica 06/2002 no haber previsto ningún mecanismo cautelar para prevenir la dilapidación o desaparición de dichos bienes. En este caso, lo más acertado es aplicar las reglas procesales generales. ${ }^{346}$

\footnotetext{
${ }^{343}$ En este punto, IGLESIAS BÁREZ apunta que la LODA también determina que las asociaciones en general tienen que contar con un funcionamiento democrático. En este supuesto, no habría como identificar los aspectos que configurarían el carácter democrático en dichas asociaciones. El problema alcanza una zona gris ya cuando se trata de los partidos, con las asociaciones comunes es aun más complicado de analizar la cuestión. Sin embargo, estoy de acuerdo con la autora en el sentido de que el legislador no se ha planteado esta hipótesis solo para el caso de la disolución del partido, como también para su liquidación patrimonial. (In. IGLESIAS BARÉZ, M.: Op. Cit. Pp. 268).

${ }^{344}$ En este sentido, cfr. IGLESIAS BARÉZ, M.: Op. Cit. Pp. 270.

${ }^{345}$ Cfr. Informe del Consejo del Estado, in: BOCG, Congreso de los Diputados, no 93-1, de 24 de abril de 2002.

${ }^{346}$ Cfr. ECHARRI CASI, F. J.: Disolución y Suspensión Judicial de los Partidos Políticos. ed. Dykinson, Madrid, 2003. Pp. 88-89.
} 
Con todo, hay autores que entienden que dicho destino elegido por el legislador tiene causas políticas, pues se trataba de una alternativa para solucionar el problema del impago de subvenciones a Herri Batasuna. Por otra parte, en el proceso de disolución el gobierno al ejecutar las sentencias en que fue condenado a pagar dichas subvenciones al partido, pudo destinar estos recursos a la ayuda a las víctimas del terrorismo, esto es, a un fin humanitario, como dispone la ley. ${ }^{347}$

Como caso pionero, seguramente el caso de Herri Batasuna es el más emblemático de la historia de la disolución judicial de partidos políticos. Fue el primer caso de ilegalización de una organización política en el país, y el principal objeto de la LOPP aprobada en 2002. En este caso, antes de la aprobación de la referida ley, la ausencia de previsión legal motivó que el Gobierno adoptara algunas actitudes irregulares desde el punto de vista jurídico. Posteriormente dicho partido sufriría el procedimiento de liquidación patrimonial que está descrito en la ley en vigor.

En 1987 el gobierno del PSOE adoptó la decisión de no más volver a abonar los pagos correspondientes a la financiación, tanto a titulo de reembolso por los gastos en las elecciones como por las actividades ordinarias, al partido Herri Batasuna, justamente por los indicios de que referido partido era el brazo político de ETA, aunque no hubiera pronunciamiento judicial en este sentido.

Dicha postura por parte del Gobierno se produjo a lo largo de catorce años, período en el que Batasuna se mantuvo en la competición electoral en todos los niveles y obteniendo escaños. Entre tanto, seguía sin recibir ninguna de las subvenciones públicas a titulo de financiación a las cuales tenía derecho.

Ante esto, el partido interpuso demanda judicial que llegó hasta el Tribunal Supremo ${ }^{348}$, que condenó al Gobierno al pago de la cantidad total no abonada. La justificación para dicha decisión es que la medida del Gobierno no poseía soporte legal y que, además, violaba la ley entonces vigente.

\footnotetext{
${ }^{347}$ Esta es la opinión de IGLESIAS BÁREZ, con la que concordamos. Cfr. IGLESIAS BARÉZ, M.: Op. Cit. Pp. 271.

${ }_{348}$ Audiencia Nacional de 10/02/1988 confirmada por el Tribunal Supremo en 23/10/1990; y audiencia nacional de 25/10/1991, confirmada por el Tribunal Supremo en 10/03/1997 y 28/10/1991.
} 
Sin embargo, el Gobierno no cumplió la sentencia ${ }^{349}$, y finalmente optó por el camino de una modificación legislativa en la disposición adicional 23ํㅡㄹ de la Ley Orgánica 24/2001 de 27 de diciembre de medidas fiscales, administrativas y del orden social. En mencionada disposición había una serie de excepciones al pago de las subvenciones a los partidos políticos "que se superponen a la legislación general de la materia".

${ }^{349}$ Dicha postura por parte del gobierno fue noticia en algunos de los principales periódicos de España. Como ejemplo, cfr. El Estado no paga a HB desde 1987, a pesar de las Sentencias del Tribunal Supremo. El Mundo. 28 de noviembre de 2001.

${ }^{350}$ BOIX PALOP, A. "Sobre la Constitucionalidad de la Reforma de la Financiación de Partidos Políticos: Reparos al Carácter Convalidador de la Misma". In: Revista General de Derecho Administrativo, no $1, \quad$ nov. 2002. Disponible en $<$ http://www.iustel.com/v2/revistas/detalle_revista.asp?id=1 >> Acceso en 18.01.2009. Pp. 1-4. El texto de dicha disposición es: "Disposición adicional vigésima tercera. Pago de subvenciones a partidos políticos 1. No habrá lugar al pago a los partidos políticos, federaciones, coaliciones 0 agrupaciones de electores, o a cualquier otra persona o entidad a las que, por cualquier título, se hubiere transmitido el crédito correspondiente, de las subvenciones devengadas o que se devenguen conforme a lo previsto en los artículos 127 de la Ley Orgánica 5/1985, de 19 de junio (RCL 1985, 1463 y RCL 1986, 192; ApNDL 4080), de Régimen Electoral General y 3 de la Ley Orgánica 3/1987, de 2 de julio (RCL 1987, 1559), sobre Financiación de los Partidos Políticos, mientras no se justifique la adquisición por los electos pertenecientes a dichas formaciones políticas de la condición plena de Diputado, Senador, miembro del Parlamento europeo o miembro de la correspondiente Corporación local y el ejercicio efectivo del cargo para el que hubiesen sido elegidos y por cuya elección y desempeño se hayan devengado o se devenguen las citadas subvenciones, aun cuando este devengo derive de su reconocimiento por sentencia judicial firme. El supuesto a que se refiere el apartado anterior constituirá, a los efectos previstos en el artículo 105 de la Ley 29/1998, de 13 de julio (RCL 1998, 1741), Reguladora de la Jurisdicción Contencioso-Administrativa, causa de imposibilidad legal de ejecutar las sentencias que reconozcan el derecho a percibir las referidas subvenciones, sin que tal inejecución dé lugar a indemnización alguna. 2. Tampoco habrá lugar al pago de las referidas subvenciones a los partidos políticos, federaciones, coaliciones o agrupaciones electorales a cuyo favor se hubieren devengado las mismas, cuando en las listas electorales del proceso electoral determinante de dicho devengo o en los órganos directivos existentes en ese momento figuren personas que hayan sido condenadas por sentencia firme por pertenencia, actuación al servicio o colaboración con banda armada, si no hubieren rechazado públicamente los fines y los medios de la organización terrorista a la que pertenecieron o con la que colaboraron o apoyaron o exaltaron. Este supuesto constituirá, igualmente, a los efectos previstos en dicho artículo 105 de la citada Ley 29/1998, causa de imposibilidad legal de ejecución de las sentencias que declararen o hubiesen declarado el derecho de tales partidos políticos, federaciones, coaliciones o agrupaciones de electores, o de cualquier otra persona $o$ entidad a la que, por cualquier título, se hubiere transmitido el crédito correspondiente, a percibir las referidas subvenciones, sin que tal inejecución dé lugar a indemnización alguna. La misma inexigibilidad de pago e imposibilidad legal para la ejecución de estas sentencias constituirá la circunstancia de que en el momento en que deba procederse al pago de las referidas subvenciones, los partidos políticos, federaciones, coaliciones o agrupaciones de electores a cuyo favor se hubieren devengado las mismas, figuren en sus órganos directivos o grupos parlamentarios en cualesquiera asambleas representativas o listas electorales que en dicho momento estén presentadas en procesos electorales en curso, personas, incluidos también quienes tengan la condición de electos que hayan sido condenadas en virtud de sentencia firme por pertenencia, actuación al servicio o colaboración con banda armada, si no hubieren rechazado públicamente los fines y los medios de la organización terrorista a la que pertenecieron o con la que colaboraron o apoyaron o exaltaron, sin que tal inexigibilidad de pago e imposibilidad legal de ejecución dé lugar a indemnización alguna 3. Todo ello entrará 
De esta manera, y ayudado por la aprobación de la Ley Orgánica 06/2002, el gobierno consiguió "esquivar" el cumplimiento de las sentencias que lo condenaron a pagar las cantidades debidas a Herri Batasuna en relación con las subvenciones destinadas a su financiación, a la vez que pretende evitar una indemnización por la no ejecución de las sentencias del Tribunal Supremo. ${ }^{351}$

Posteriormente, se produjo la ilegalización de HB, con la consecuente disolución de la organización partidista y su liquidación patrimonial, en los términos descritos en la sentencia del Tribunal Superior, de 27 de marzo de 2003.

Se trataba de un conflicto entre el ordenamiento jurídico y la realidad política. Existían indicios claros de que Batasuna actuaba de manera contraria a la ley, y que soportaba a la organización terrorista. ${ }^{352}$ En todo caso, lo que definitivamente llama la atención es la postura del Gobierno ante el pronunciamiento judicial del Supremo.

Posteriormente a la aprobación de la Ley Orgánica 06/2002, en el 27 de marzo de 2003 la Sala Especial del Tribunal Supremo declara la ilegalización y disolución de Batasuna ${ }^{353}$, ordenando que se procediera a su liquidación patrimonial. ${ }^{354}$ De esta manera, el auto de 24 de abril de 2003, ya en fase de ejecución de sentencia, determina el embargo de dichos bienes y derechos a través del dispuesto en el art. 590 de la Ley de Enjuiciamiento Civil. De esta

en vigor, sin perjuicio de la consecuente adaptación a estas previsiones de la Ley Orgánica 5/1985, de 29 de junio, de Régimen Electoral General, en la Ley Orgánica 3/1987, de 2 de julio, de Financiación de los Partidos Políticos y la Ley Orgánica 6/1985, de 1 de julio (RCL 1985, 1578, 2635; ApNDL 8375), del Poder Judicial."

${ }^{351}$ Por otra parte, en enero de 2002 hubo una decisión de la Audiencia Nacional, sancionando la Subsecretaría de Interior al pago de cinco multas de 300 euros. Ya en febrero de 2006, el Ministro de Justicia envío instrucciones a la Abogacía del Estado, a fin de que este dispusiera en la Sala Especial dos millones de euros, siendo que en abril de 2006 dichos recursos fueron pasados al Tesoro, para que estuvieran a disposición de los liquidadores, obedeciendo a los fines previstos en el art. 12.1, c de la Ley Orgánica 06/2002.

${ }^{352}$ La conclusión por la antijuridicidad de la norma puede basarse en el hecho de violar una decisión judicial que ya no admitía recurso, además de atentar contra la seguridad jurídica, a través de la retroactividad de la medida. También acabó por violar la tutela judicial efectiva, en la doctrina del Tribunal Europeo de Derechos Humanos; y el legislador sobrepasó su competencia al aprobar la disposición adicional 23‥ (cfr. BOIX PALOP, A. Op. Cit. Pp. 9 y ss).

353 Para mayores detalles de cómo se ha desarrollado dicho proceso, véase ÁLVAREZ CONDE, E.; CATALÁ I BAS, A. H. "Los Efectos Directos y Colaterales de La Disolución de Herri Batasuna". In: Foro. Nueva Época. oㅡ 2, 2005. Pp. 131-151.

${ }^{354}$ Para un resumen de los autos de la Sala Especial, véase IGLESIAS BARÉZ, M.: Op. Cit. Pp. 272-277. 
forma, sería posible hacer un inventario completo del patrimonio. A su vez, ha designado a los tres liquidadores, y se amplió los efectos de la liquidación a todas las organizaciones vinculadas a Batasuna que se encontraban notificados por su disolución.

Dichos liquidadores han elaborado un informe tres años después, siendo este valorado por el auto de 19 de octubre de 2006. Dicho auto no finaliza la liquidación patrimonial y se destina más al análisis del propio informe, a la vez que establece algunas medidas cautelares para asegurar el cumplimiento de la sentencia de ilegalización. ${ }^{355}$ Dichas medidas cautelares buscaban evitar la desaparición de los bienes (considerando que no hay reglas concretas en la Ley Orgánica 06/2002) y podían ser ejecutadas por la Sala Especial de manera plena, lo que culminó en el auto de 19 de octubre de 2006, determinando el embargo de los bienes que componían el patrimonio tanto del partido como de todos los vinculados a él.

Con todo, con posterioridad a la decisión de la sala de realizar la medida de aseguramiento de bienes inaudita parte a través de la elaboración de un inventario de los bienes de Herriko Tabernas (asociación con un patrimonio importante), en el 23 de octubre de 2006, la misma Sala determina la suspensión de dicha medida por la exigencia vehemente de conexión de dicha asociación con Batasuna-ETA, por medio del auto de 12 de diciembre de 2007.

$\mathrm{Ya}$ en 24 de enero de 2008, los liquidadores presentaron un nuevo informe, ya con el balance del patrimonio y con la orden de transferencia para el Tesoro del patrimonio neto resultante. Dicha providencia vino acompañada por la solicitud de algunas entidades financieras reclamaban algunos créditos, sin ninguna manifestación por parte del partido ilegalizado. Con ello, los liquidadores tuvieron que presentar un nuevo informe con el balance final, en 11 de julio de 2008. Y, finalmente, el 20 de noviembre de 2008 (exactamente 5 años después de la sentencia de ilegalización de Batasuna), la Sala decidió concluir este proceso de liquidación patrimonial, ordenando tanto el pago a los

\footnotetext{
${ }^{355}$ Aquí se produjo un debate sobre si las asociaciones conocidas como Herriko Tabernas (asociaciones culturales y restaurantes, siendo su titularidad de terceros) eran un canal de financiación de Batasuna. Si realmente era así, el patrimonio estaría afectado por las disposiciones de la Ley Orgánica 06/2002. La Sala consideró probada la existencia de indicios que conectaban a dicha asociación con Batasuna, incluyendo dichos bienes en la liquidación. En este sentido, cfr. F.J. 7 de referido auto.
} 
acreedores reconocidos en la demanda, como la transferencia del resto al Tesoro. ${ }^{356}$

Es conocido el hecho de que el principio de proporcionalidad no es exclusivo del Derecho de Partidos, pero es comúnmente aplicable a casos de medidas cautelares de suspensión de partidos, y consecuentemente de su financiación pública, cuando un partido todavía no haya sido disuelto. ${ }^{357}$ En el presente caso, es el conflicto entre la propia democracia y la posibilidad de su limitación, a fin de protegerla. No se trata de un examen sencillo, y al involucrar diversos derechos, la proporcionalidad del sacrificio de dichos derechos debe ser considerada con especial cautela. ${ }^{358}$

Sin embargo, en el presente caso sobre el no abono de las subvenciones la flagrante inobservancia de principios básicos del derecho como es el de la irretroactividad, aún con la seguridad de la culpabilidad de Batasuna actualmente conduce a la conclusión que el Gobierno se aventuró conscientemente a una actuación contraria a los pilares del Derecho. ${ }^{359}$ Por otra parte, la forma en que ha trascurrida la liquidación de bienes poco ha satisfecho a los fines perseguidos en la Ley Orgánica 06/2002, considerando que la proporción entre el número de víctimas del terrorismo provocado y el valor ingresado en el Tesoro es mínima o inexistente.

\section{5) La financiación indirecta a nivel estatal de los partidos políticos}

Dentro del sistema de financiación de los partidos, ya se ha mencionado que las medidas de financiación indirecta refuerzan sus finanzas de una

\footnotetext{
${ }^{356}$ Aunque haya sido cinco años después de la sentencia de 27 de marzo de 2003, el auto pronunciado para la conclusión de la liquidación patrimonial ha apurado valores bastante reducidos. Para Herri Batasuna, activo de 1.946.625,52 euros, y pasivo de 5.920.993,52; Euskal Herritarrok, activo de 544,82 y pasivo de 0 euros; y Batasuna, activo no disponible, y pasivo de 191.575,72 euros. Al final, pagados los acreedores y embargados bienes inmuebles que podrían tener algún valor, fue transferido al Tesoro el valor de 544,82.

${ }^{357}$ ALVARÉZ CONDE, E. "Veinticinco Años..." Pp. 76.

358 GONZÁLEZ BEILFUSS, M. "Últimas Tendencias en la Interpretación de Proporcionalidad". In: Revista Jurídica de Catalunya. any Cl, № 4, Barcelona, 2002. Pp. 166.

${ }^{359}$ Por lo demás, en 13 de diciembre de 2011 el Tribunal Constitucional resolvió dos cuestiones de inconstitucionalidad respecto a la disposición adicional vigésima tercera de la Ley 24/2001 de 27 de diciembre (STC 200/2011 y 201/2011). Batasuna ha argumentado que dicha disposición violaba los principios de la seguridad jurídica y a la tutela judicial efectiva en lo que se refería al régimen de subvenciones para los partidos políticos. En palabras del Tribunal, dicha disposición no es aplicable al caso, y por lo tanto, desestima ambas demandas.
} 
manera importante, a la vez que la financiación directa se implica en el principio de la igualdad de oportunidades. ${ }^{360}$ Se puede afirmar en cierto modo que las medidas indirectas ayudan en el ahorro de estos recursos directos transferidos a los partidos. ${ }^{361}$ En realidad, el Estado sigue asumiendo de alguna forma la financiación de estos bienes y servicios, aunque de distinta forma que con la entrega directa de recursos económicos, ya que en el caso español las tarifas postales especiales y el espacio en los medios de comunicación de titularidad estatal tienen su valor en la dinámica política, y son de gran valía para las organizaciones políticas. ${ }^{362}$ Sin embargo, no son solo ventajas económicas que el Estado puede conceder a los partidos políticos, sino que también existen prestaciones materiales que integran el listado de beneficios a las que las formaciones políticas pueden tener acceso de manera indirecta. ${ }^{363}$ Dependiendo de los elementos que componen se integran en estos beneficios, algunos de los servicios podrán ser aún más importantes que la transferencia directa de recursos, económicamente hablando. ${ }^{364}$

Considerando que muchas de las medidas de financiación indirecta ya fueron tratadas en las leyes comentadas en este trabajo, nos limitaremos en este punto a exponer las previsiones legales sobre las medidas, acompañadas de algunos breves comentarios enfocados hacia la valoración de la garantía del pluralismo político en los criterios de acceso, sin profundizar en cada uno de los beneficios ofrecidos, ya que su tratamiento detallado sobrepasaría el objeto de este trabajo. ${ }^{365}$

\footnotetext{
${ }^{360}$ BALLAGUER CALLEJÓN entiende que la distinción entre financiación pública y privada es ficticia, porque el Estado termina asumiendo algún coste siempre, como pasa con la desgravación fiscal, que se trata de un beneficio para los donantes privados, pero que tiene consecuencias de financiación pública indirecta. (In: BALLAGUER CALLEJÓN, F. "II Finanziamento..." Pp. 145).

${ }^{361}$ GARCÍA-ESCUDERO MÁRQUES, P.; PENDÁS GARCIA, B. Op. Cit. Pp. 386.

362 Según NAVAS, es obvio que los espacios en la radio y televisión estatales implican a una importante ayuda. Sin embargo, si ello no viene acompañado de regulaciones sobre tarifas de los espacios en radios y televisiones privadas, o incluso de su posibilidad, puede ser que la primera medida no tenga tanta fuerza. Cfr. NAVAS, X. "La Financiación Electoral: Subvenciones y Gastos". In: NOHLEN, D.; PICADO, S.; ZOVATTO, D. (comp.): Tratado de Derecho Electoral Comparado de América Latina. Ed. Fondo de Cultura Económica, DF, México, 1998. Pp. 464-466.

${ }^{363}$ HOLGADO GONZÁLEZ, M.: La Financiación de los... Pp. 31.

364 ÁLVAREZ CONDE, E. "Algunas Propuestas..." Pp. 21; MARTínEZ SOSPEDRA, M. "La Financiación..." Pp. 27.

${ }^{365}$ Las medidas de financiación indirecta a nivel autonómico serán tratadas el punto sobre financiación electoral autonómica, tópico 7.2 de este capítulo.
} 
El nacimiento de las medidas de financiación indirecta acompañan el inicio de la regulación jurídica de las campañas electorales, y se remontan a la época de la II Republica, momento en que los medios de comunicación empezaron a tener un peso muy significativo sobre el comportamiento electoral. Las órdenes ministeriales emitidas en esta época buscan garantizar la igualdad de oportunidades a través de medidas negativas, esto es, prohibitivas o limitativas de la posibilidad de utilizar estos medios de comunicación. Se puede considerar que dichas medidas comienzan con la Circular de 6 de octubre de 1933, que trataba sobre la obligatoriedad de permiso gubernativo para la retransmisión de conferencias y/o discursos políticos, con intervención de la Dirección General de Telecomunicaciones. Dicha norma fue seguida por otras órdenes ministeriales con el mismo objeto, como la de 7 de noviembre de 1933 que prohibía en periodo electoral los anuncios de candidaturas, campaña electoral, manifestaciones políticas y discursos afines realizadas en estudios de emisoras o gabinetes privados ${ }^{366}$, y también la segunda orden ministerial de la misma fecha que la anterior, que trataba sobre la prohibición de utilización de aeródromos y servicios de aviación para fines de propaganda electoral o comercial durante el período electoral. La orden ministerial de 9 de febrero de 1934 versaba sobre la prohibición de emisión por radio con fines de propaganda política de anuncios de asambleas, reseñas de estas, conferencias, discursos, mítines, reuniones, hechos en estudios, gabinetes particulares o locales a que se celebren actos públicos y acabó por dar origen a la Ley de radiodifusión de 26 de junio de 1934, que autorizaba la propaganda política con previo pago de tarifas, con tiempo limitado. ${ }^{367}$ Como se queda claro, la preocupación por el acceso a los medios de los entes políticos. ${ }^{368}$

\footnotetext{
${ }^{366}$ La norma permitía transmitir dichos actos políticos con autorización previa de las autoridades locales, pero solamente respecto a discursos realizados en actos públicos debidamente autorizados.

${ }^{367}$ Cfr. CORTÉS BURETA, P.: Recursos Públicos y Partidos Políticos... Pp. 48-50.

368 Sin embargo, entre 1977 y 1982, aunque la legislación electoral no regulara sistemáticamente la cuestión, el Real Decreto-Ley 967/1977 de 3 de mayo - lo cual vino a concretar el art. 40 del RD 20/1977 - fijó los criterios para el acceso a la radio y televisión por las formaciones políticas. El criterio era el del número de circunscripciones electorales en las que la organización política presentaba candidaturas, a partir de un número mínimo de distritos y concesión de espacios en la programación regional. (In: GARCIA LLOVET, E. "EI Derecho de Antena y las Campañas Electorales". In: Revista de Derecho Político. ํㅡ 25. UNED, Madrid,
} 
La financiación indirecta se suele clasificar en cuatro tipos: ${ }^{369}$ en primer lugar los servicios en especie, que es cuando el Estado facilita el acceso a un determinado servicio, así como es el espacio en los medios de comunicación de titularidad pública o las tarifas postales especiales; en segundo término, los incentivos fiscales, que versan sobre la exención fiscal de algunos actos del partidos o incluso sobre un régimen tributario especial ${ }^{370}$, o incluso en beneficio de los contribuyentes, pero al final es el Estado el que acaba por comprometer parte de su recaudación en pro de los partidos (medida muy utilizada para incentivar el pago de cuotas de afiliados y donaciones privadas de pequeño valor); en tercer lugar, subvenciones relacionadas con las organizaciones vinculadas a los partidos, como pueden ser las fundaciones y asociaciones; y hay autores que dentro de este listado incluyen el "impuesto" partidario para miembros que tienen cargos representativos públicos ${ }^{371}$, lo que en mi opinión no debe ser considerado como financiación indirecta, ya que no se trata de una facilidad que tienen los partidos, sino de una donación con carácter más o menos voluntario por parte de los titulares de dichos cargos.

1987. Pp. 164-166). Estos requisitos fueron modificados por el RD 2076/1982, fijando criterios de proporcionalidad, aunque carezca de aclaraciones.

369 MELCHIONDA entiende que lo importante para clasificar las fuentes de financiación es quien aporta los recursos, y no quien transfiere, y debido a ello la desgravación fiscal sería una financiación privada, y no pública indirecta como sostiene la mayoría de la doctrina. (In: MELCHIONDA, E.: // Finanziamento della Politica. Ed. Riuniti, Roma, 1997. Pp. 108). En línea, ZOVATTO entiende que en la financiación pública indirecta hay siete medidas: el acceso a los medios, los beneficios tributarios, el transporte (que en el contexto de Latinoamérica se vuelve más importante), el apoyo a la divulgación (que en el caso español se puede catalogar el mailing), los incentivos a la participación electoral, el uso gratuito de infraestructuras del Estado, y las subvenciones a los grupos parlamentarios. discrepamos en este último, puesto que el fin de esta subvención es apoyar la realización de las funciones de los grupos dentro de la dinámica del Parlamento, no siendo posible que los partidos dispongan libremente de estos recursos. Además de no existir regulación legislativa sobre el tema, es un hecho que las formaciones políticas se apoderan de dichos recursos de manera inmediata, muchas veces para costear sus gastos ordinarios. Lo que sí es cierto es que no se trata de recursos públicos transferidos a los partidos de manera indirecta, sino de un comportamiento irregular por parte de estas organizaciones que acabó por ser "aceptado" debido a su frecuencia. (cfr. ZOVATTO, D.: Dinero y... Pp. 41-42).

${ }^{370}$ Cfr. HOLGADO GONZÁLEZ, M.: La Financiación de los... Pp. 108 y ss. La autora también incluye el acceso por las formaciones políticas al censo electoral, pero en nuestra opinión este último no puede considerarse como financiación indirecta, porque sin este dato, la organización de las elecciones estaría comprometida, no afectando a los partidos en sí, sino a la fiabilidad de este proceso. Es mucho más una medida administrativa para ahorrar recursos públicos gastados en la realización de las elecciones que para disminuir costes de los partidos.

371 FERNANDEZ-LLEBREZ, F. "La Financiación de los Partidos Políticos: Evolución y Rasgos Principales". In: VV.AA.: Curso de Partidos Políticos. Ed. Akal, Madrid, 2003 (¿). Pp. 182-183. 
Así, en el presente trabajo se entiende que en la legislación española hay tres medidas que pueden ser genuinamente consideradas como de financiación indirecta, y prácticamente todas están vinculadas a las campañas electorales: son los espacios de tiempo en la programación de cadenas de titularidad pública, la concesión de locales para publicidad visual y la realización de mítines o actos de campaña en lugares públicos, y los subsidios a las organizaciones dependientes de los partidos, como asociaciones y fundaciones, para actividades de prensa y de fomento de la democracia. ${ }^{372}$ Después de la aprobación de la Ley Orgánica 8/2007, se puede incluir en este listado la desgravación fiscal para las donaciones privadas para actividades ordinarias que, aunque no estén relacionados directamente - por lo menos en la teoría - a la realización de campañas electorales, busca motivar la participación política de ciudadanos en general y, así, promocionar el enraizamiento de los partidos en la sociedad, por lo menos de una determinada manera. $^{373}$

La sección contenida en la ley electoral sobre la utilización de los medios de comunicación de titularidad pública para fines de campaña electoral constituye en parte un desarrollo del art. 20.3 de la Constitución Española ${ }^{374}$, que es un Derecho Fundamental. ${ }^{375} \mathrm{El}$ art. 60 trata de la prohibición de

\footnotetext{
372 Para esta última hipótesis, aunque sea una prestación representada por transferencia de recursos públicos a estas asociaciones y fundaciones relacionadas a los partidos, se decidió incluirla también como una posibilidad de financiación indirecta porque, aunque dichos recursos tengan como fundamento el fomento de la democracia - en una remisión a la idea desarrollo de una estructura del partido a los moldes de partido de masa - es cierto que el propio partido utiliza dichos valores para hacer frente a gastos de mantenimiento.

${ }^{373}$ Se hace dicha observación porque los efectos de la desgravación fiscal pueden variar mucho conforme a valor del límite máximo de donaciones privadas que podrán generar el beneficio al contribuyente. El caso alemán demuestra que la intención de fomentar la movilización política puede ser distorsionado si dicho límite fuera muy alto, e igualmente al contrario, pues valores muy bajos promocionarán como mucho el pago de las cuotas de afiliados, y no pequeñas donaciones. Sobre el tema, cfr. punto 2.2.3."e".

${ }_{374}$ Una reflexión sobre la reserva de ley para el desarrollo de este artículo constitucional puede ser encontrado en: MILLÁN RAYNAUD, C. "El Derecho de Acceso de los Partidos Políticos y Grupos Sociales más Significativos en los Medios de Comunicación Social de Titularidad Pública: el Artículo 20.3 de la CE, su Aplicación y Desarrollo Legislativo". In: AA.VV.: Derecho Constitucional para el Siglo XXI - Actas del VIII Congreso Iberoamericano de Derecho Constitucional, Tomo II. Ed. Thompson - Aranzadi, Sevilla, 2006. Pp. 2897-2904.

${ }^{375} \mathrm{El}$ art. 20.3 trata de prever la protección a la libertad de expresión en los medios de comunicación, posibilitando el acceso a estos canales a todos, tanto en su faceta social como la política. En el caso de la ley electoral, se enfoca el perfil político y democrático de dicha garantía constitucional. Dicho derecho de antena en periodo electoral tiene un perfil distinto y busca garantizar el pluralismo inmediato en los medios de comunicación. (cfr. GARCIA LLOVET, E. Op. Cit. Pp. 154).
} 
contratación de espacios de publicidad en los medios de titularidad pública y privada $^{376}$, en un claro intento de contrapesar el poder económico de las formaciones políticas mayores. Además, la publicidad electoral en emisoras de televisión privada también está totalmente prohibida desde la Ley Orgánica 2/1988, de 3 de mayo, que aun cuando derogada por la reforma de la LOREG habida en $2011^{377}$, deja subsistente.

Una de las cuestiones más polémicas se encuentra en el art. 66 de la LOREG, que se refiere a la obligación de los medios de comunicación de respetar el pluralismo político y social en su función informativa durante el período electoral. Antes de la reforma del 2011, solamente los medios de titularidad pública estaban obligados a respetar esta condición, siendo fiscalizados por la Junta Electoral Central. ${ }^{378}$ Sin embargo, dicha obligatoriedad se amplió también a los medios de titularidad privada. Hay autores que desde hace un tiempo ya se opusieron a dicha medida, por entender que el Estado no puede influir en el modo de transmisión de las informaciones o limitarlas. ${ }^{379}$ Con todo, no puedo estar de acuerdo con dicho punto de vista.

Aunque se entienda que la contratación de espacios en los medios de comunicación tanto públicos como privados supone un ahorro importante de recursos económicos por parte de los partidos, ello no impide en todo caso que dichos medios sirvan de diversas formas a objetivos electorales. Y quizás esté aquí la clave del tema, porque los partidos no pueden contratar espacios, pero tampoco resulta efectivo el control de la propaganda indirecta a favor de una opción política o el control de la compra irregular de espacios o programas. ${ }^{380}$

\footnotetext{
${ }^{376}$ Ítem este añadido por la última reforma de la LOREG en el art. 60.

${ }^{377}$ Cfr. Art. 60.1, LOREG.

${ }^{378}$ En su época, había algunas herramientas de control y rectificación de informaciones, considerando que dicha regla ya existía para los medios de titularidad pública. Sin embargo, no se puede afirmar que dichas medidas fueran eficaces, por poseer un perfil muy genérico. Pretendían más bien garantizar la veracidad de las informaciones emitidas, como también el respeto por los principios citados. Las normas que establecían este procedimiento de control fueron las instrucciones JEC de 4 de noviembre de 1986, siendo esta derogada por la instrucción de 13 de septiembre de 1999. Actualmente, está vigente la instrucción de 24 de marzo de 2011, determinando nuevamente un sistema genérico y muy abierto en sus interpretaciones, lo que puede comprometer su eficacia.

${ }^{379}$ En este sentido, cfr. HOLGADO GONZÁLEZ, M. "El Papel de los Medios de Comunicación en la Campaña Electoral". In: Ámbitos - Revista Internacional de Comunicación. no especial 910, $2^{\circ}$ sem. 2002, [s.I.], 2003. Pp. 477.

${ }^{380}$ Como ejemplo, el informe de fiscalización de la contabilidad electoral del Tribunal de Cuentas de las elecciones de 2000, sobre la adquisición de de espacios de publicidad electoral
} 
La legislación recién reformada guarda silencio sobre este punto, y aquí hay un conflicto importante entre la libertad de expresión versus pluralismo político e igualdad de condiciones. ${ }^{381}$

Es un hecho que los medios de titularidad pública disponen de menos cuota que la programación total de los medios privados. Estos ejercen una influencia muy importante sobre la opinión pública que no es posible de mensurar, y participan activamente en el periodo electoral. ${ }^{382}$ Muchas veces, son determinantes para el éxito o la derrota de alguna opción política. Indirectamente, es un servicio público ejercido por un ente privado, por lo tanto, posee una cierta responsabilidad en el normal desarrollo del proceso electoral. ${ }^{383}$ El principio de la democracia, del voto libre y de la igualdad de condiciones electorales debe prevalecer ante la libertad de información en cadenas de medios privados en periodo electoral, y eso es perfectamente defendible utilizándose la ponderación. ${ }^{384}$ Más que como una limitación o una intromisión en el derecho a la información, se trataría de un ajuste de todo el sistema en pro de la democracia. ${ }^{385}$

en emisoras de televisión local por ondas terrestres por parte del Partido Independiente de Lanzarote, algo totalmente prohibido por la legislación en vigor. Sobre esto, véase p. 481 del cap. IV de este trabajo.

${ }^{381}$ Aquí llamo la atención para el caso estadunidense ya descrito en el cap. II.

${ }^{382}$ Cfr. L. SWANSON, D. "El Campo de Comunicación Política. La Democracia Centrada en los Medios". In: MUÑOZ-ALONSO, A.; IGNACIO ROSPIR, J. (dir.): La Comunicación Política. ed. Universitas, Madrid, 1995. Pp. 20. Tanto es así que es muy conocida la técnica por la cual, durante un mitin, los candidatos saben cuándo se realiza una conexión en directo con algún programa informativo, ya que se enciende una luz que indica dicha conexión, y en este momento se aprovecha para atacar más directamente a los demás candidatos, o más bien exponer una de sus propuestas más importantes, para que ambos actos tengan una mayor repercusión de la que se obtiene por medios de comunicación públicos. (Cfr. RALLO LOMBARTE, A. "Debates Electorales y Televisión". In: Revista de las Cortes Generales, № 44, $1^{\circ}$ cuatrimestre, Madrid, 1998. Pp. 67; HOLGADO GONZÁLEZ, M. "El Papel de los..." Pp. 472 y; FERNÁNDEZ VIVAS, Y.: Op. Cit. Pp. 406).

${ }^{383}$ No existe un régimen jurídico específico más allá de las disposiciones de la LOREG: Sobre el tema, cfr. ARNALDO ALCUBILLA, E. "Procesos Electorales y Opinión Pública". In: PAU I VALL, F. (coord.): Parlamento y Opinión Pública. ed. Tecnos, Madrid, 1995. Pp. 59-61.

${ }^{384}$ Así, se comparte aquí la posición de RALLO LOMBARTE. Cfr. RALLO LOMBARTE, A. "Neutralidad y Pluralismo de los Medios de Comunicación en las Campañas Electorales en España: La Reforma de la LOREG por Ley Orgánica 2/2011". Disponible en << http://www.te.gob.mx/ccje/iv_obs/materiales/ARTEMI\%20RALLO.pdf>> Acceso en 24.01.2012. Pp. 30-31. En este mismo sentido, aunque de manera más permisiva en pro de los medios, cfr. PEREZ ROYO, J. "EI Parlamento Contemporáneo y los Medios de Comunicación". In: PAU I VALL, F. (coord.): Parlamento y Opinión Pública. ed. Tecnos, Madrid, 1995. Pp. 27-28.

${ }^{385}$ Cfr. CARRILLO, M.: Los Límites a la Libertad de Prensa en la Constitución Española de 1978. ed. PPU, Barcelona, 1987. Pp. 186 y ss; CREMADES, J.: Los Límites de la Libertad de Expresión en el Ordenamiento Jurídico Español. ed. La Ley, Madrid, 1995. Pp. 126 y ss; y SARTORI, G.: Homo Videns: La Sociedad Teledirigida. ed. Taurus, Madrid, 1997. Pp. 105 y 
Cabe destacar la falta de debate político sobre esta cuestión. Se percibe un consenso importante sobre este punto, ya que gran parte de las enmiendas presentadas versaban mucho más sobre la mejora técnica de dicho artículo, que sobre su contenido. ${ }^{386}$ Por otra parte, otro factor relacionado con el tema y que no ha producido un gran debate público relacionado con el pluralismo y de la neutralidad en los medios tanto públicos como privados en la realización de debates entre los candidatos. ${ }^{387}$ Antes de la reforma lo que se verificaba era la ausencia de distinción entre el régimen adoptado para la televisión pública y para la privada. La necesidad de neutralidad en la televisión pública acababa por fallar y el pluralismo en la televisión privada mucho más. ${ }^{388} \mathrm{La}$ Junta Electoral Central no ha logrado controlar este requisito y, considerando el poder de influencia sobre los electores, es esencial para la garantía de la democracia el control sobre la organización de dichos debates, y suplir en parte la actual ausencia de su regulación. ${ }^{389}$

ss.; En países como Brasil e Italia ya fue muy polémica la actitud de medios de comunicación privados. Basta citar al presidente Fernando Collor de Mello o Silvio Berlusconi, respectivamente. Ambos fueron muy favorecidos por algún medio de comunicación y alcanzaron el poder ayudados por la capacidad de persuasión que los medios privados de televisión poseían. Sobre el tema en general, vid. MAYOR MENÉNDEZ, P. "Consideraciones Generales sobre el Marco Normativo de la Televisión Actualmente Vigente en España. Apuntes para una Reforma". In: VILLAR URÍBARRI, J. M. (dir.): El Régimen Jurídico de las Telecomunicaciones, Televisión e Internet. ed. Aranzadi, Navarra, 2002. Pp. 149, donde el autor afirma que resulta indispensable que el poder público defina de manera clara el contenido del servicio público de la televisión, tanto para asegurar valores que deben estar presentes en dicho servicio, como también para evitar abusos por parte del Estado. También, sobre la libertad de expresión y el derecho a la información, cfr. HERREROS LÓPEZ, J. M. "Libertad de Información y Derecho a la Información". In: AA.VV.: El Régimen Jurídico del Audiovisual. ed. Marcial Pons. Barcelona, 2000. Pp. 357 y ss, donde el autor trata directamente de la influencia de los medios sobre la opinión pública, afectando la democracia y la formación de opinión.

${ }^{386}$ Cfr. en el Congreso de los Diputados: BOCG no 438, de 04/08/2010; BOCG no 282-1, de 22/10/2010; DS Congreso no 202, de 10/11/2010. En el Senado, DS Pleno, no 107, de $19 / 01 / 2011$.

${ }^{387}$ Cfr. ARNALDO ALCUBILLA, E. "La Interpretación de la Normativa Electoral por la Junta Electoral Central (1977-1997)". In: Revista de las Cortes Generales, ํo 41, 2o cuatrimestre, Madrid, 1997. Pp. 191; SOLOZABAL ECHAVARRIA, J. J. "Sobre la Constitucionalización de los Partidos Políticos en el Derecho Constitucional y en el Ordenamiento Español". In: Revista de Estudios Políticos, no 45, may/jun, 1985. Pp. 75-76 y RALLO LOMBARTE, A. "Debates Electorales..." Pp. 68.

${ }^{388}$ En este sentido, véase GONZÁLEZ ENCINAR, J. J. "Derechos y Medios de Comunicación. Hacia un Cambio de Paradigma". In: AA.VV.: La Democracia Constitucional. Estudios en Homenaje al Prof. Francisco Rubio Llorente. Ed. CEPC, Madrid, 2003. Pp. 598; y SANCHÉZ MUÑOZ, Ó. "Cuestiones Relativas..." Pp. 644-645.

389 Un ejemplo de la necesidad de prestar mayor atención normativa al tema puede ser lo ocurrido en las últimas elecciones generales de 2011, cuando se produjo una polémica por la ausencia de UPyD en el debate organizado por las formaciones políticas antes del 20-N. Sintiéndose lesionado, dicho partido ha recurrido ante la Junta Electoral Central, sin éxito. En este sentido, véase acuerdos de la sesión de 10/11/2011 de la Junta Electoral Central. Aún, 
La posibilidad de adquirir espacios de publicidad en la prensa periódica y en las emisoras de radio de titularidad privada está prevista en el art. 58, condicionada a un límite de gastos bajo este concepto de 20 por 100 del límite global de gastos de cada formación política, considerando el proceso electoral de que se trate. ${ }^{390}$

Los espacios de tiempo en la programación son distribuidos según el total de votos obtenido por cada partido, federación o coalición en las anteriores elecciones equivalentes, conforme a lo dispuesto en el art. 61 de la LOREG, tomando solo en cuenta para elecciones a las dos Cámaras de las Cortes Generales, los votos al Congreso de los Diputados. En caso de simultaneidad de elecciones a las Cortes Generales y a las Asambleas Legislativas, se considerarán los votos al Congreso, y en casos de simultaneidad de elecciones de las Asambleas Legislativas y municipales, prevalece el resultado de votos para la Asamblea Legislativa. En caso de simultaneidad de elecciones al Parlamento Europeo y las Cortes Generales, Asambleas Legislativas o municipales, se considerarán los votos al Congreso, o Asamblea, o en las elecciones municipales, si fuera el caso. Aquí se verifica nuevamente la exclusión del Senado para el cómputo de votos en la distribución del espacio en los medios, lo que no se justifica, ya que puede ser que la formación política no haya conseguido buenos resultados en el Congreso, o incluso no haya presentado candidatos con relevancia política por determinadas razones, $u$ obteniendo un porcentual bastante reducido en dicha Cámara, pero haya participado sin embargo en el proceso electoral y haya cumplido con su función de formación de la voluntad popular. Nuevamente la norma repite la discriminación entre las Cámaras de las Cortes Generales, por lo que las mismas críticas expresadas a la Ley Orgánica 3/1987 son totalmente aplicables aquí. ${ }^{391}$

véase ARNALDO ALCUBILLA, E. "Procesos Electorales y Opinión..." Pp. 59 y ss, donde el autor destaca la importancia de la realización de debates.

${ }_{390}$ Además, el artículo determina que las tarifas de esta publicidad de carácter electoral no podrán ser superiores a las de publicidad comercial, así como la prohibición de hacer discriminaciones entre las candidaturas en cuanto a su inclusión, tarifas, y ubicación de estos espacios de publicidad, debiendo las condiciones estar expresamente y claramente expuestas.

${ }^{391}$ GARCí́ LLOVET trata de justificar la exclusión del Senado en el cómputo, afirmando que la combinación de votos de las dos Cámaras originaba problemas, dado que para el Senado las listas son abiertas y la movilidad de votos es mayor. (In: GARCIA LLOVET, E. Op. Cit. Pp. 170). 
Como es sabido, las franjas de tiempo poseen escalas, dependiendo de los votos y de los escaños obtenidos por la organización política. No es necesario haber logrado escaños, y tampoco haber participado en las elecciones pasadas para concurrir en la distribución de los espacios mediáticos, lo que es un punto elogiable, considerando el mundo moderno y la influencia de los medios sobre la opinión pública, además de no excluir a las nuevas formaciones políticas, lo que favorece el posible - aunque difícil surgimiento de nuevas opciones en el espectro político. En todo caso, el reparto del momento de emisión entre los partidos distorsiona esta apertura al pluralismo inevitablemente. El art. 64 dispone sobre esta escala de tiempo, determinando 10 minutos para las formaciones políticas que no han concurrido o no obtuvieron representación en las elecciones anteriores; 15 minutos para los que hayan obtenido representación alcanzando el umbral de 5 por 100 de los votos válidos emitidos en territorio nacional o en las circunscripciones limitadas por el art. 62; 30 minutos para los que hayan alcanzado entre el 5 y el 20 por 100 del total de votos válidos; 45 minutos para los que hayan alcanzado al menos un 20 por 100 del total de votos. Dichos espacios son gratuitos y en medios de comunicación de titularidad pública, no englobando medios privados. Sin embargo, dicha cuantificación de tiempo es solamente para las formaciones políticas que hayan presentado candidaturas en más del 75 por 100 de las circunscripciones en el ámbito de difusión. Los que no cumplan dicho requisito, aplicarán esta escala a nivel autonómico, no siendo esto acumulable con el tiempo logrado a nivel nacional. En el caso de las agrupaciones de electores, el tiempo será de 10 minutos, cuando cumplan con el requisito de presentar candidaturas en más de 75 por 100 de las circunscripciones, en los moldes descritos antes.

La critica que cabe sobre el tiempo concedido, bajo el punto de vista del pluralismo político es que se trata de un espacio demasiado escaso ante a un modelo de distribución que se puede clasificar como pluralista $^{392}$, considerando

No podemos estar de acuerdo con el autor, puesto que no se puede hacer diferencia entre votos o atribuir en abstracto una mayor importancia diferenciada entre los votos al Congreso o del Senado.

${ }^{392}$ Aunque hay que apoyar la opinión de GARCÍA LLOVET que el mínimo de circunscripciones descrito en la ley acaba por atenuar los efectos pluralistas que el mecanismo debería de tener, 
el número posible de partidos que puedan cumplir con los requisitos ${ }^{393}$, que no perjudica exactamente la campaña electoral, pero sí perjudica la optimización de los recursos disponibles para ello. ${ }^{394}$ Es decir, en el siglo XXI donde los medios tienen un papel tan importante dentro de la competición electoral ${ }^{395}$, si la información no llega a los electores, no les ayudarán a elegir la opción que juzguen la más correcta. ${ }^{396}$ Hay un fallo entre la formación de la voluntad popular y la aclaración de propuestas y opciones políticas que están en juego, lo que compromete la propia calidad de democracia e incluso la libertad de voto. ${ }^{397}$ Sería planteable repensar la aplicación de esta distribución de tiempo entre los partidos en los canales de televisión privados, pues tratándose de una concesión de un servicio público, parece justo que los medios privados estuvieran obligados a conceder parte de su tiempo en la programación a favor de la campaña electoral, con los mismos parámetros que en la televisión pública. ${ }^{398}$

Aquí el debate ya toma otro camino: el de la conveniencia del modelo de campaña electoral utilizado en España. ${ }^{399}$ La mala utilización de los canales de comunicación de masa para fines políticos acaba por generar, en términos

provocando la concentración de la oferta pública y tendiente a un bipartidismo corregido. (cfr. GARCIA LLOVET, E. Op. Cit. Pp. 181).

${ }^{393}$ También es la opinión de Holgado González. Cfr. HOLGADO GONZÁLEZ, M. "El Papel de los..." Pp. 475.

${ }^{394}$ Cfr. DONSBACH, W. "Contenidos, Utilización y Efectos de la Comunicación Política". In: MUÑOZ-ALONSO, A.; IGNACIO ROSPIR, J. (dir.): La Comunicación Política. ed. Universitas, Madrid, 1995. Pp. 43; y GONZÁLEZ ENCINAR, J. J. "Derechos y Medios..." Pp. 604-605.

${ }^{395}$ Aunque DEL CASTILLO cuestiona hasta qué punto que las nuevas técnicas de propaganda corresponden o sustituyen al trabajo de los militantes del partido durante la campaña electoral, una de las causas de la decadencia de la concepción de los partidos como partidos de masas. (In: CASTILLO, P. del. "La Campaña del Referéndum Constitucional". In: Revista de Estudios Políticos. no 6. Ed. Centro de Estudios Constitucionales, 1978. Pp. 155).

${ }^{396}$ LOWENSTEIN destaca bien el factor de la propaganda partidista. El autor afirma que la era tecnológica conlleva mayor desigualdad en las campañas electorales, ya que la propaganda de los candidatos de los partidos políticos llega a la masa a través de los medios de comunicación y no con el contacto personal entre candidato y electorado, haciendo que el papel del dinero sea infinitamente más relevante. Sin embargo, el autor cree que es incorrecto decir que el partido político con mayores recursos gane con seguridad las elecciones, pero sí considera correcto considerar que ese partido tiene una muy importante ventaja sobre los demás. (In: LOWENSTEIN, Karl: Teoría de la Constitución. 2o ed, reimp. Ariel, Barcelona, 1979. Pp. 343344).

${ }^{397}$ Y ello porque el elector, mal informado, no elige su opción de manera libre y consciente. Vid. GARCÍA LLOVET cuando entiende que el elector solamente será capaz de elegir libremente cuando dispone de una información mínimamente adecuada. Cfr. GARCIA LLOVET, E. Op. Cit. Pp. 159.

${ }^{398}$ Dicho modelo es aplicado en Brasil, y obtiene buenos resultados en cuanto a implicar a la sociedad en el debate de las propuestas políticas.

${ }^{399}$ La cuestión será analizada con más detalle en el punto 6.2.3 de este capítulo. 
prácticos, el encarecimiento de las campañas. La adopción de un modelo de campaña anticuado fuerza al aumento de desplazamientos por parte de los candidatos, lo que tan solo aumenta los costes de una campaña que podría ser simplificarse con la transmisión de las propuestas a través de medios más eficientes. Sucede exactamente al revés, el efecto de los mítines muchas veces no va más allá de la militancia normal o un poco aumentada por la "emoción" que genera alguna ideología política, siendo así que el mensaje transmitido por canales de comunicación de masas alcanza incluso aquellos que no están son politizados, pudiendo, quizás, provocar el aumento de la movilización política, resultado de la implicación del electorado en la competición. Es un hecho que en muchos países de voto no obligatorio - como es el caso español - la disputa electoral llevada a los medios motiva a la participación política mucho más por el temor a que gane la opción que no se desea que por tendencias políticas personales. Acaba también por promocionar el propio pluralismo político, pues al tener la oportunidad de exponer sus ideas ante a un público considerable, la formación política misma es considerada como una opción viable, posible en la realidad. ${ }^{400} \mathrm{Sin}$ embargo, con la actual legislación, hay situaciones que llegan a carecer de sentido, porque mientras que el partido cuelgue un cartel de su campaña fuera de los espacios que le fueron destinados es un delito, transmitir un anuncio electoral en una televisión local no lo es. Por lo tanto, la reciente reforma legal debería haber planteado mejor la cuestión sobre la prohibición de publicidad electoral en la televisión. ${ }^{401}$

Otra medida mencionada como de financiación indirecta de los partidos es la concesión gratuita por ayuntamientos de lugares especiales para la colocación de carteles, pancartas y carteles colgados a postes o farolas para las formaciones políticas en campaña electoral, aunque también es cuestionable la importancia de dichos actos en la propaganda electoral. Su contenido de igual manera se vincula al art. 20 de la Constitución Española, aunque de manera diferenciada, por tratarse de lugares públicos, y no medios

\footnotetext{
${ }^{400}$ Aunque esto también puede generar problemas, como el surgimiento de outsiders, que fueron elegidos justamente por saber cómo utilizar de manera estratégica los medios de comunicación. Sin embargo, esta posibilidad se aleja cuando existen límites o prohibiciones en la opción de adquisición de espacios publicitarios en medios de titularidad privada.

${ }^{401}$ En este sentido, cfr. SANCHÉZ MUÑOZ, Ó. "Cuestiones Relativas..." Pp. 647.
} 
de comunicación. El art. 55 de la LOREG dispone sobre la obligatoriedad de los ayuntamientos en reservar dichos locales, delimitando también la utilización de otros espacios comerciales debidamente autorizados. Seguidamente, el artículo fija el límite de gastos que la organización política puede realizar bajo este título, que no podrá exceder el 25 por 100 del límite de gastos previstos en el límite global arbitrado al partido en cada proceso electoral que se trate. Un dato que llama la atención es que en el art. 56.2 está dispuesto que los espacios serán distribuidos entre el total de votos obtenido por cada partido, federación o coalición, resultado de las elecciones anteriores equivalentes. No hay mención a las agrupaciones de electores, como existe para la distribución de espacios de tiempo en los medios de comunicación pública. Bajo el punto de vista del pluralismo político, la ausencia de esta mención no debe significar la exclusión directa de las agrupaciones, dentro de una interpretación favorable a la efectividad del art. 20.3 de la Constitución. Es decir, además de no existir una razón clara para que las agrupaciones concurran a la distribución de espacios en los medios de comunicación para fines de campaña electoral pero no participaran en la distribución de lugares públicos para propaganda electoral, se estaría afectando a un Derecho Fundamental. De esta forma, creo que debe realizarse una inclusión tácita vía interpretativa de las agrupaciones de electoral en el listado del art. 56.2 de la LOREG.

Sin embargo, la exclusión del listado contenido en el art. 56.2 de las nuevas formaciones políticas afecta directamente el pluralismo político y el juego democrático, pues nuevamente la ausencia de estos en la distribución de los lugares para publicidad electoral, contrariando su mención en los que repartirán los espacios de tiempo en los medios de comunicación públicos carece de sentido, además de agregarles un gasto adicional en la campaña electoral a sus candidaturas, en un claro detrimento de los menos, en principio, capacitados económicamente.

Ya sobre la distribución de los lugares, en situaciones de coincidencia de solicitudes por un mismo local, se atenderá al criterio expuesto en el art. 57.3 de la LOREG, en el que se considerará los parámetros de igualdad - sin mencionar exactamente cuales, lo que es muy arriesgado - y de manera subsidiaria a la preferencia de las formaciones políticas con mayor número de 
votos en las elecciones anteriores equivalentes en la misma circunscripción. El criterio elegido, aunque tenga su significado lógico, contraria el propio principio de igualdad y acaba por facilitar el monopolio de lugares por los partidos mayoritarios. Lo que parece recomendable, en primer lugar, es que se definan claramente cuáles son los criterios de igualdad a que el artículo se refiere, para combinarlo con otros que no sean solamente de representatividad, como podría ser la cantidad de eventos realizados por la organización, la cantidad de lugares considerados privilegiados concedidos a cada partido, y otros tantos que permitirían un mayor equilibrio en este reparto.

A su vez, el art. 59 de la LOREG regula las tarifas especiales para el envío de propaganda electoral ${ }^{402}$, junto con las tarifas especiales para el envío de papeletas electorales traducido como mailing, que es subvencionado directamente por el Estado. Las tarifas son determinadas a través de orden ministerial, publicada antes de cada pleito, variando según el peso de las correspondencias.

\section{6) Las bases para la adopción del modelo actual de campaña electoral y cuestiones conflictivas en su financiación}

A partir del análisis de las normas sobre financiación de partidos en España, es posible iniciar un estudio más detenido sobre los problemas a los que se enfrenta actualmente, ya que estos son consecuencia de un sistema aplicado por largo tiempo, y, deseados o no, son fruto directo de decisiones políticas tomadas en su momento.

Aunque la realidad parezca en ocasiones desmentirlo, el sistema de financiación de partidos políticos español se basa en tres principios como la libertad de los partidos ante el Estado y ante los entes privados; el principio de la igualdad de oportunidades entre ellos; y el necesario principio de la transparencia. ${ }^{403} \mathrm{Y}$, sumado al hecho de la débil institucionalización de los partidos en la historia política de España, e incluso la propia evolución del

\footnotetext{
402 Según HOLGADO GONZÁLEZ, las tarifas para el envío de propaganda electoral, prácticamente llegan a la gratuidad, alcanzando este beneficio todas las organizaciones. (In: HOLGADO GONZÁLEZ, María: La Financiación de los... Pp. 85).

${ }^{403}$ FERNÁNDEZ VIVAS, Y.: Op. Cit. Pp. 314.
} 
concepto de partido político habida en todo el mundo, el escenario que propició la adopción del modelo de financiación no fue el más adecuado, aun cuando no se podía ignorar la necesidad de dichas medidas.

Sin embargo, la propia realidad que había en España y Europa acabó por condicionar la elección de qué medidas compondrían el sistema. Como ocurre en todos los casos de "importación" jurídica, no se puede aplicar un mismo modelo a realidades distintas, dejando de verificar los rasgos específicos de cada país. Un ejemplo de ello es que el modelo norte americano, por sus bases y otros factores muy distintos a los encontrados en Europa como un todo, no podría ser aplicado en España, principalmente porque en EE.UU. los partidos tienen un origen interclasista y un peso infinitamente menor en el juego político, mientras que en Europa, los partidos nacen mucho más vinculados a grupos y clases sociales, y aun cuando este origen se difume en la actualidad, no deja de guardar relación con el planteamiento en torno a la igualdad de oportunidades que marca el sistema de financiación del Estado de partidos en Europa. ${ }^{404}$

Teniendo eso en cuenta, la tendencia de España hacia la financiación pública era casi inevitable, y más cuando era también la orientación de gran parte de los países europeos, y actualmente se puede decir que de los países latinos también. Esta opción por la financiación pública conlleva la idea de acciones positivas y negativas, componiendo el soporte estatal para los partidos. Medidas propias de la financiación pública son las acciones positivas para garantizar la igualdad de oportunidades, ya que las medidas negativas como las limitaciones o prohibiciones - no fueron capaces de asegurar dicho principio.

\footnotetext{
404 TORQUEMADA, B.: Las Cuentas Oscuras de los Partidos. ABC. 6 de marzo de 2005. Un ejemplo de la diferencia entre Europa y EE.UU. aparece la consideración que hace Herbert ALEXANDER sobre los límites de gastos. Se trata de un problema que hay confrontando el límite de gastos electorales a nivel nacional y en nivel estatal. Así si se suma el límite de los 50 estados existentes, se supera en mucho el límite nacional. Ello hace que el candidato tenga que elegir cuales serán los estados que tendrán más atención, y que también piensen en subterfugios para mantenerse debajo de este límite sin parar la campaña electoral y en todo por el peculiar sistema de elección presidencial por votos de estados. (In: ALEXANDER, H. E. "American Presidential Elections Since Public Funding - 1976-1984". In: ALEXANDER, H. E. (ed): Comparative Political Finance in the 1980's. Cambridge University Press, UK, 1989. Pp. 100).
} 
Además, el reconocimiento constitucional del papel de los partidos en la formación de la voluntad popular hizo que el Estado fuera "obligado" a participar de este proceso, atendiendo al art. 9.2 de la Constitución Española. ${ }^{405}$ Sin embargo, se adoptó un modelo muy caro de campaña electoral, sin que ello se traduzca en una campaña exitosa desde el punto de vista de la participación democrática, y esto acaba por comprometer el apoyo popular a la financiación pública de los partidos políticos, aún más cuando no hay racionalización del gasto y sí un continuo crecimiento, acompañado también de un sentimiento de futilidad de las múltiples campañas electorales. ${ }^{406}$

Ante esto, es natural que haya puntos conflictivos en el sistema aplicado en España y analizando el conjunto de problemas existentes, quizás merezcan especial consideración en el estudio propuesto en el presente trabajo.

Como es sabido, las elecciones son hoy el momento más importante para la función de la voluntad popular en un país democrático. Debido a ello, la financiación de las actividades electorales - o extraordinarias - de los partidos tiene un especial relieve. El sistema que rige la financiación de las actividades electorales de los partidos en España es mixto, aunque se pueda considerar que está fuertemente inclinado para la financiación pública. Consecuentemente, el factor más importante para ser evaluado es el doble criterio elegido para el acceso de los partidos a las subvenciones estatales.

Se puede destacar que las subvenciones estatales poseen dos rasgos claros, o sea, tanto las ayudas electorales como las ordinarias son independientes entre sí, aunque compatibles (incluso con las subvenciones para los grupos políticos), ya que son destinados a fines específicos. También se juzga que las subvenciones deberían ser suficientes, atendiendo a la trascendencia y fundamento de las elecciones. La modalidad de reembolso de los gastos concretos ocasionados por la campaña se puede considerar como igualitaria, no solo porque alcanza a todas las formaciones políticas, sino

\footnotetext{
405 SÁNCHEZ MUÑOZ, O.: Op. Cit. Pp. 221. Dicho pensamiento está bastante claro en el pronunciamiento de Puigcercós I Baixassa, a favor de la ley que se encuentra en el dispuesto de la Ley Orgánica 8/07: "(...) si son órganos casi públicos requieren financiación pública y control público". (In: BOCG, oo 114, de 27 de septiembre de 2005. Pp. 5745).

${ }^{406}$ CASTILLO, P. del. "La Financiación de las Elecciones Legislativas de 1982". In: LINZ, J. J.; MONTERO, J. R. (eds.): Crisis y Cambio: Electores y Partidos en la España de los Años Ochenta. Ed. Centro de Estudios Constitucionales, Madrid, 1986. Pp. 283-287.
} 
también porque se relaciona con el coste directo de la actividad ejercida por las organizaciones, que merece una detallada regulación. Así, se comprueba que la clave de un sistema con dichas características es, indudablemente, el criterio de acceso a las subvenciones. El formato más común en el derecho comparado es el reembolso genérico y global de los gastos, aunque existan divergencias en los criterios, que coinciden al exigir por lo menos un porcentaje mínimo de votos para acceder a las ayudas. ${ }^{407}$

Es justamente sobre esta posible apertura o cierre del sistema sobre la que se basará nuestra siguiente exposición, en un intento de demostrar que algunas de las posibles disfunciones anunciadas ya por parte de la literatura jurídica en los inicios del sistema están paulatinamente concretizándose. ${ }^{408}$

\subsection{El mailing (art. 175.3 de la LOREG) y la cuestión del comportamiento político existente}

Uno de los mecanismos más polémicos dentro de la financiación de los partidos políticos en España es el mailing, la subvención específica para el envío de papeletas electorales y sobres a los electores, así como de la propaganda y publicidad electoral. Es decir, además de estar subvencionada, la confección de las papeletas y los sobres electorales - ya que se trata específicamente de un gasto electoral, conforme a lo dispuesto en el art. 130, "a" de la LOREG - los partidos también cuentan con esta subvención, además de tarifas postales especiales - dispuestas en el art. 59 de la LOREG - como financiación indirecta. ${ }^{409}$ Dicha subvención se concede a los partidos políticos

\footnotetext{
${ }^{407}$ PAJARES MONTOLIO, E.: La Financiación de las... Pp. 234-241.

408 Antes de todo, es necesario advertir que cuestiones relacionadas a la financiación de federaciones y coaliciones en elecciones que no compiten juntos no serán tratadas, por traspasar el objeto del presente análisis. Sin embargo, no deja de ser una cuestión interesante, pues vincula no sólo el aumento de posibilidades de acceder a las subvenciones estatales por parte de partidos de menor expresión política, pero también con factores como disciplina partidista, fidelidad ideológica, que culmina en asuntos referentes al comportamiento político de una sociedad. Además, debido a la forma peculiar de organización del Estado español, las Comunidades Autónomas también pueden legislar sobre el tema de la financiación de partidos, lo que provoca una inevitable fragmentación legislativa.

409 Según HOLGADO GONZÁLEZ, como se trata de una subvención específica, debe ser considerada como financiación directa y finalista, y no como indirecta, como ocurre con las tarifas especiales del art. 59, LOREG. (In: HOLGADO GONZÁLEZ, M.: La Financiación de los... Pp. 74-75).
} 
que presentan candidatura en ambas Cámaras (en elecciones generales), y que hayan alcanzado el número de votos y escaños exigidos para formar un grupo parlamentario en una u otra Cámara, conforme dispone el art. 175, 3, a, de la LOREG. Por otra parte, las cantidades gastadas en este envío no se someten al límite de gastos del art. 175, 2, conforme art. 175, 3, b. ${ }^{410}$

Con este formato, difícilmente se encuentra en la doctrina algún defensor de dicha subvención. Al contrario, el mailing es duramente criticado, principalmente por su carácter discriminatorio respecto a los partidos minoritarios y extraparlamentarios. ${ }^{411} \mathrm{Y}$ ello sucede porque aunque el partido no sea extraparlamentario, si no cumple con las exigencias para formar un grupo parlamentario, no será posible acceder a dicha subvención. Y, engrosando el coro de críticas, el hecho de que el gasto de dicho envío de papeletas y sobres no se someta al límite de gastos previsto en la LOREG hace pensar que dicho límite fue relativizado, esto es, que el objetivo del art. 175, 2 de la LOREG acaba por verse ser frustrado a través de la exclusión de estos gastos del cómputo total de los gastos de campaña. ${ }^{412}$

En la época de la aprobación de la Ley Orgánica 13/1994 - ley responsable de la introducción del mailing - se mantuvo que se produciría una reducción del gasto a partir de la adopción de esta subvención. Sin embargo, dada su configuración, se verificó posteriormente que en realidad los partidos querían "desentenderse" de este gasto, y utilizar los subsidios públicos como herramienta para la disminución de su endeudamiento. Por ello no se declaró que habría un aumento en el gasto público para las subvenciones destinadas a los partidos. ${ }^{413}$

\footnotetext{
${ }^{410}$ Cfr. ARNALDO ALCUBILLA, E. “Las Reformas Posibles..." Pp. 65.

${ }^{411}$ CASELLES y VIÑUELA, en opinión compartida, in: ARTÉS CASELLES, J.; GARCíA VIÑUELA, E. Op. Cit. Pp. 57.

${ }^{412}$ Así se posiciona SÁNCHEZ MUÑOZ, cuando afirma que el límite de gastos fue desvirtuado por la exclusión de los valores del mailing del total de gastos a ser considerado, abriendo espacio para fraudes, facturas falsas, incluso desviando los recursos destinados al mailing para otras actividades del partido. Así, el autor afirma que dicha subvención es "un elemento perturbador dentro del sistema de financiación pública de los partidos", y que no es compatible con el principio de la igualdad de oportunidades, favoreciendo una vez más a los grandes partidos. (In: SÁNCHEZ MUÑOZ, O.: La Igualdad... Pp. 233).

${ }^{413}$ Cfr. GARCIA VIÑUELA, E.; ARTÉS CASELLES, J. "La Financiación de las Elecciones..." Pp. 15. En otro de sus trabajos, a partir de un análisis de datos, los autores entienden que la reforma de 1993 contribuyó poco a la disminución del gasto electoral, pero que la de 1994 sí ayudó a reducir costes. Sin embargo, el gasto con las subvenciones evolucionó en sentido contrario, ya que la primera reforma hizo que el valor de las subvenciones aumentara un $50 \%$,
} 
La crítica más frecuente al mailing se centra en sus exigencias para el acceso a dichas subvenciones. Además de las discriminaciones ya existentes para el acceso a otras subvenciones, este beneficio genera otra que no está justificada, ya que excluye partidos políticos sin un grupo parlamentario propio, y no se justifica aun más porque la actividad subvencionada cuesta lo mismo para todos. ${ }^{414}$ No cabe pues duda de que el mailing colabora significativamente a la perpetuación del status quo del sistema de partidos.

Aun cuando se dude sobre la eficacia de este tipo de propaganda electoral, no se puede ignorar por otra parte el impacto que esto tiene sobre el comportamiento político de los electores. ${ }^{415}$

Pero no solo de aspectos negativos vive el mailing. Antes de la reforma de la LOREG, no existía ningún requisito para la presentación de candidaturas, lo que condujo a autores como Soler Sánchez a la conclusión que este tipo de beneficio se destinaba a cualquier candidatura que se presentase. ${ }^{416} \mathrm{Sin}$ embargo, actualmente con el dispuesto en el art. 169.3, tanto agrupaciones de electores como también partidos que no hayan logrado representación en ninguna de las Cámaras en la anterior convocatoria necesitan de aval de los ciudadanos para la presentación de candidaturas, expresado a través de la obtención de $0,1 \%$ de firmas de los inscritos en el censo electoral de la circunscripción, alejando dicha conclusión. ${ }^{417}$

Otro elemento positivo que se puede extraer del mailing es que los criterios de reparto de dicha subvención tienen un carácter igualitario, a la vez que no establece diferencias entre los partidos que la reciben, pues se financia por envío hecho, sin distinción. ${ }^{418}$ Esto no mitiga las más variadas críticas de la

\footnotetext{
y a partir de ahí no ha parado de crecer. También se constata un aumento considerable en el porcentaje del gasto electoral que es subvencionado, llegando a $93,4 \%$ en las elecciones de 2000, es decir, después de la segunda reforma. Así, se puede afirmar que dicha reforma ha ayudado a las fuerzas políticas a aliviar sus cuentas, pasando al poder público prácticamente la totalidad de los costes de las convocatorias electorales. Cfr. ARTÉS CASELLES, J.; GARCÍA VIÑUELA, E. Op. Cit. Pp. 51-53.

${ }_{414}$ HOLGADO GONZÁLEZ, M.: La Financiación de los... Pp. 75.

415 Se destaca este aspecto en ARNALDO ALCUBILLA. Cfr. ARNALDO ALCUBILLA, E. "Procesos Electorales y Opinión..." Pp. 62-63.

${ }_{417}$ SOLER SÁNCHEZ, M.: Campañas Electorales... Pp. 103-104.

417 Sobre posibles críticas a esta exigencia, véase SANCHÉZ MUÑOZ, Ó. "Cuestiones Relativas..." Pp. 624.

${ }_{418}$ SÁNCHEZ MUÑOZ, O.: La lgualdad... Pp. 232. Siguiendo en este sentido, GARCíA VIÑUELA y ARTÉS CASELLES concluyen que la reforma que instituyó el mailing acabó por favorecer al IU, que no contaba con los mismos criterios de acceso a las otras subvenciones.
} 
doctrina sobre el mecanismo. Al analizar el art. 175.3 de la LOREG, se puede verificar que la cantidad "subvencionada" no es conocida antes del resultado de las elecciones. Por otra parte este no se considera dentro del límite de gastos introducido en la ley, con lo que no contribuye al abaratamiento de las campañas, y genera, a su vez, una inseguridad en lo que se refiere a la decisión del partido de cuanto gastar, ya que depende de la proclamación de los electos para determinar las cantidades permitidas. ${ }^{419}$

Ante esto, el mailing se vuelve un elemento no proporcional, que no solo no utiliza como criterio diferenciador la cantidad de votos o escaños, sino que también implica una fuerte distinción entre partidos con y sin grupo parlamentario, sobrevalorando este elemento sin que quepa justificado, dado que los partidos pueden llegar a recibir una cantidad mucho mayor que el coste real provocado. ${ }^{420}$

Dadas las críticas, algunos autores se pronuncian por la eliminación definitiva del mailing, como es el caso de BLANCO VALDÉS ${ }^{421}$, MARTíNEZ CUEVAS $^{422}$ y SOLOZÁBAL ECHAVARRÍA. ${ }^{423}$ Es de resaltar que las críticas también alcanzan a la imposibilidad real de que las agrupaciones de electores puedan recibir dicha subvención, ya que, aunque la ley contemple esta

Sin embargo, PSOE y PP no fueron tan beneficiados bajo el punto de la tasa de ventaja financiera, pero acabaron apoyando la reforma porque los autores entienden que los dos grandes partidos ganaron al poder transferir casi el $100 \%$ de sus gastos al presupuesto público y así librarse de la carga de la financiación irregular. (In: ARTÉS CASELLES, J.; GARCíA VIÑUELA, E. Op. Cit. Pp. 55-56).

${ }^{419}$ PAJARES MONTOLIO, E.: La Financiación de las... Pp. 143.

420 PAJARES MONTOLIO añade que dicho gasto es demasiado elevado para su objeto, pues simplemente hay un envío de una papeleta y una carta de titularidad de la formación política, sin cualquier orientación para el elector, lo que seguramente beneficia algunos partidos más que otros, y genera un resultado disfuncional con relación al límite de gastos. Por ello, el autor es partidario de su supresión radical, o que se siguiera el envío, pero con papeletas institucionales, elaboradas por el Estado. Con todo, en caso de supresión y de que las formaciones políticas siguieran necesitándolo sería mejor que se incluyera en el límite de gastos, estando sometido también a los votos recibidos. (In: PAJARES MONTOLIO, E.: La Financiación de las... Pp. 257-261).

${ }^{421}$ AA. VV.: "Debates". In: La Financiación... Pp. 106-107, y BLANCO VALDÉS, R L. "La Problemática..." Pp. 187 y ss.

${ }^{422}$ MARTíNEZ CUEVAS, M. D.: Op. Cit. Pp. 138. La autora aboga por ello para abaratar las campañas. También sugiere el no reparto por la calle de tantos impresos de propaganda, que acaban en la basura (la supresión sería esto también una medida ecológica), incrementado a su ver el número de debates de las fuerzas políticas por radio y TV.

${ }^{423}$ SOLOZABAL ECHAVARRÍA, J. J. "Una Visión Institucional..." Pp. 78. El autor sugiere que las papeletas deberían ser enviadas por la Administración Pública, porque se ahorraría recursos, prevaleciendo la competición y la igualdad de condiciones. 
posibilidad, la probabilidad de que una agrupación de electores constituya un grupo parlamentario es pequeña.

Sin embargo, el problema de una eventual supresión del mailing se ubica dentro del comportamiento político de la sociedad española, ya que muchos electores están acostumbrados a recibir las papeletas electorales en sus casas y llevarlas a los locales de votación ya marcadas. Aunque no haya encuestas específicas sobre el tema, la práctica de los procesos electorales demuestra que muchos electores se encaminan a las urnas de votación con las papeletas enviadas a través del correo por los partidos. Se da así la paradoja de que, en el caso de supresión de este beneficio, los partidos más fuertes seguramente no cambiarían su manera de actuar en la promoción de su campaña y seguirían enviando las papeletas, sea con la tarifa que sea, mientras que el impacto mayor lo sentirían los partidos menores, que no poseen recursos suficientes para mantener dicha práctica.

Considerando este escenario, lo que se puede suponer es que la supresión del mailing de modo repentino y no gradual perjudicará aún más a los partidos minoritarios pero que todavía poseen un determinado número de parlamentarios como para formar un grupo parlamentario, empeorando las condiciones de igualdad en la competición electoral. Podría en cambio plantearse una mejora de su mecanismo, especialmente en los criterios de acceso y también de su conexión con la subvención para la confección de sobres y papeletas o propaganda y publicidad. Los problemas que circundan la cuestión del mailing no radican solo en su existencia o no, aunque dicho punto también puede generar cierto debate. La polémica se centra mucho más en los problemas que este beneficio genera cuando es aplicado conjuntamente con la subvención para los sobres y papeletas o propaganda y publicidad, considerando el sistema de financiación en su cómputo. No estaríamos únicamente ante un trato discriminatorio entre partidos mayoritarios y minoritarios, agravando el de algunos aspectos de la financiación pública destinada a los partidos, sino ante una clara relativización del límite de gastos electorales impuesto a las organizaciones. Si la función del límite de gastos es justamente controlar el flujo de recursos del que los partidos pueden disponer, en un intento de garantizar la igualdad de condiciones en la competencia 
electoral, su relativización implica un agravamiento sustancial de dicha igualdad.

Además, cabe la posibilidad de que las subvenciones para la confección de las papeletas y la publicidad sean utilizadas para otros fines, o que sean sobrevaloradas justamente para que el partido recaude más recursos para la campaña o pueda hacer frente a otros costes. Se trata de una laguna de la ley que posibilita el fraude, al tratarse de una subvención finalista que jurídicamente no puede ser empleada para otro fin.

Quizás, de cara a una reforma, el sistema del mailing y de confección de sobres, papeletas, propaganda y publicidad debería optarse, ante todo, por aplicar o uno u otro tipo de subvención, ya que parece claro que su utilización conjunta provoca distorsiones innecesarias en un sistema de financiación que ya padece otros problemas de gran envergadura. Si se optara por la subvención de la confección de sobres y propaganda - la cual ciertamente sería la elección de los partidos, en una improbable pero necesaria reforma debería por lo menos se contabilizarse dicho gasto en el límite global asignado a cada partido, condicionando toda la dinámica de envío de propaganda y papeletas al cumplimiento de este límite.

Sin embargo, pensamos que la mejor medida consistiría en dejar subsistentes solo las tarifas especiales, sin ninguna otra subvención relacionada con las mismas, flexibilizando los criterios de acceso a dicho beneficio. Aunque ello significara un aumento en los costes que los partidos tendrían que afrontar en una campaña electoral, puede que dicha medida contribuyera a la racionalización del gasto, pues además de incluir la confección de sobres y propaganda en el límite establecido por ley, también podría provocar una mayor cautela por parte de las organizaciones en el momento de planear sus gastos, objetivo este que contribuiría mucho más a los fines democráticos de una verdadera campaña electoral. También se podría considerar la flexibilización de los criterios de acceso a las subvenciones para la confección de estos materiales, sin la aplicación de las tarifas especiales. Con todo, esta no sería la opción óptima porque implicaría un mayor gasto para el erario público. Aun considerando el hecho del envío de sobres, papeletas y propaganda pueda fomentar la participación ciudadana en el proceso electoral, 
y facilite en cierta manera la emisión del voto, no se puede ignorar el hecho de que, una parte importante de dichas papeletas se desechan, representando únicamente un ejemplo de recursos ineficientemente empleados. ${ }^{424}$

\subsection{La precampaña y la campaña}

El modelo adoptado en España distinguió, como es sabido, dos periodos distintos en el proceso electoral, la precampaña y la campaña propiamente dicha. Se trata de un punto problemático en la legislación electoral y, como se verá, no ha tenido los efectos pretendidos en la práctica. Aunque este tema haya sido objeto de la reforma de la LOREG en 2011, quizás los efectos de dicha reforma no resulten tan significativos de inmediato.

\subsubsection{El concepto de campaña electoral y el problema de la diferenciación con la precampaña}

En la estructura de la LOREG, la campaña electoral propiamente dicha no se confunde con la campaña de carácter institucional, o la denominada precampaña, ya que cada una tiene una razón de existencia, conforme describe el art. 50.1. ${ }^{425}$ En todo caso, el concepto de campaña electoral es bastante pacífico en la doctrina, siendo considerada como un conjunto de actos permitidos por la ley realizados por los candidatos, partidos y demás habilitados para la competición electoral, en la búsqueda por votos. ${ }^{426}$ Así, caracteriza por

\footnotetext{
${ }^{424}$ En este sentido. Cfr. MARTíNEZ SOSPEDRA, M. "La Financiación..." Pp. 40, quien no solo aboga por la supresión del mailing, sino que también estima excesiva la cantidad de recursos económicos destinados bajo este concepto, sugiriendo un sistema electrónico de votación.

${ }^{425}$ Así es el tenor de referido artículo: "50.1. Los poderes públicos que en virtud de su competencia legal hayan convocado un proceso electoral pueden realizar durante el período electoral una campaña de carácter institucional destinada a informar a los ciudadanos sobre la fecha de la votación, el procedimiento para votar y los requisitos y trámite del voto por correo, sin influir, en ningún caso, en la orientación del voto de los electores. Esta publicidad institucional se realizará en espacios gratuitos de los medios de comunicación social de titularidad pública del ámbito territorial correspondiente al proceso electoral de que se trate, suficientes para alcanzar los objetivos de esta campaña".

${ }^{426}$ MARÍN LEIVA, F. Op. Cit. Pp. 569; MORENO MARTINEZ, C. "El Efecto de la Campaña para las Elecciones Generales Españolas de 2008 sobre la Información Política y la Participación Electoral de los Votantes: ¿Se Puede Hablar de una Función de Legitimación de las Campañas Electorales?" In: Revista Española de Ciencia Política. no 24, diciembre, 2010. Pp. 55. Las campañas electorales antes de los partidos de masa y de la ampliación del electorado estaban
} 
la difusión masiva de información de carácter político ${ }^{427}$, y debido a ello, cumple una función no solo de propaganda de los programas de partido o candidatos, a fin de que los electores se informen, se identifiquen y decidan su voto, legitimando todo el proceso electoral. ${ }^{428}$ Por ello, no sólo la cuestión de los gastos electorales resulta relevante en la regulación jurídica de la campaña, sino también la tutela jurídica de la oportunidad que tienen los electores para acceder a las propuestas de los candidatos o partidos.

La campaña institucional tiene otro perfil, y otros objetivos y se conecta con lo dispuesto en el art. 9.2 de la Constitución Española ${ }^{429}$, que determina que los poderes públicos deben facilitar la participación de los ciudadanos en la vida política. ${ }^{430}$ Se trata de una categoría jurídico-electoral claramente determinada en sus sujetos, objeto y finalidad, tanto por la norma jurídica como por los múltiples pronunciamientos de las Juntas Electorales ${ }^{431}$, lo que no excluye que siga siendo objeto de múltiples controversias partidistas en cada proceso electoral. ${ }^{432}$

Aun cuando la distinción entre precampaña y campaña electoral respondía a un criterio de contener los gastos, lo cierto es que dicha

mucho menos organizados. Posteriormente, con el partido de masas y la ampliación del sufragio universal, las campañas sufrieron grandes transformaciones, organizadas por el mayor número de personas posible, movilizadas en la "batalla electoral". Esto provocó el hecho que los partidos de masas tuvieron que hacer propaganda con estructuras destinadas solamente a la captación de votos. La inserción de los partidos en ese proceso también modificó el concepto de campaña electoral y las centró en la discusión ideológica. Con la transformación de los partidos de masa para los partidos "catch-all", en realidad los partidos se han convertido en verdaderas agencias electorales. Así, la autora afirma que las transformaciones de los partidos políticos fue motivada (junto con otros factores) por la necesidad de participar en las elecciones. Por esto la autora insiste en que los partidos, en buena medida, se han convertido en meras máquinas electorales, ya que es la función electoral lo que diferencia el partido de otros tipos de asociación. (SOLER SÁNCHEZ, M.: Campañas Electorales... Pp. 31-38).

${ }^{427}$ CASTILLO, P. del. "La Campaña del Referéndum... Pp. 153.

${ }^{428}$ PAJARES MONTOLIO, E.: La Financiación de las... Pp. 68.

${ }^{429}$ BALLARIN IRIBARREN, aunque no aborde el problema de la separación entre campaña institucional y la electoral, subraya los problemas de una propaganda que incentiva a la participación. (In: BALLARIN IRIBARREN, J. "Art. 50". In: CAZORLA PRIETO, L. M. (dir.): Comentarios a la Ley Orgánica del Régimen Electoral General. Ed. Civitas, Madrid, 1986. Pp. 438-439).

${ }^{430}$ SOLER SÁNCHEZ, M.: Campañas Electorales... Pp. 22-23.

${ }^{431}$ Dicha regla no se encuentra en la ley, pero si fue objeto de un acuerdo de la Junta Electoral Central, resolución de 24 de febrero de 1995. Debido a ello, la autora cuestiona la legitimidad de dicha regla. (SOLER SÁNCHEZ, M.: Campañas Electorales... Pp. 24-26).

${ }^{432}$ Según GAVARA DE CARA, la campaña regulada por ley busca más actuar sobre los abstencionistas y los electores no fieles, porque la campaña real se dedica a asegurar y reforzar el voto de los fieles. En todo caso, la campaña que se siguió a la transición y en los primeros años democráticos representaría un modelo de campaña no direccionado. (In: GAVARA DE CARA, J. C. “La Financiación Electoral...” Pp. 263). 
delimitación ha tendido a difumarse extremadamente en la práctica política, lo que, desde el punto de vista jurídico y de la financiación determina que creen más problemas que los que se pretendían solucionar. ${ }^{433}$ Una normativa clara sobre el tema afronta también problemas prácticos, pues delimitar dichos periodos sin que se limite la utilización de los medios es algo complicado, en tiempos en que la campaña electoral, desde la perspectiva política, parece ser muchísimo más amplia, por no decir continua. Además, las nuevas tecnologías de marketing electoral, principalmente el internet en los días actuales, complican aun más cualquier distinción basada en la "petición expresa" del voto. ${ }^{434}$

Un punto clave en la discusión sobre la campaña y la precampaña electoral es justamente la utilización de los medios de comunicación, que suelen ser acusado de los "disparadores" de gastos. Lo que ocurre es que, además de perjudicar la cuestión del control de gastos electorales ${ }^{435}$, la nítida falta de delimitación entre dichos periodos causa también distorsiones en la igualdad de oportunidades, pues si la campaña empieza de manera velada durante la precampaña, la eficacia de las reglas de igualdad en la campaña de la LOREG se vuelve muy cuestionable. Aunque relacionado directamente con la cuestión de los gastos electorales, nos detendremos aquí en las oportunidades que los partidos tienen de burlar dichas reglas, y en la tendencia de la precampaña a favorecer a los partidos mayoritarios.

Desde este punto de vista, gran parte de la doctrina considera que la limitación temporal de la campaña electoral es una medida dudosa utilidad, ya que la división hecha por el art. 51, LOREG, no es realista, y el período de "precampaña" acaba por falsear la norma. Incluso se puede pensar que el art. 53, de la LOREG por sí sólo frustra a los objetivos del art. 50 y 51, una vez que

\footnotetext{
${ }^{433}$ Cfr. SANCHÉZ MUÑOZ, Ó. “Cuestiones Relativas...” Pp. 628.

${ }^{434}$ SOLER SÁNCHEZ, M. "La Campaña Electoral..." Pp. 301-302; y GAVARA DE CARA, J. C. "La Financiación Electoral..." Pp. 262.

${ }^{435}$ Hecho este subrayado por el propio Tribunal de Cuentas, en su informe de propuestas para la reforma de la legislación en materia de financiación electoral de partidos, aprobado en 24 de junio de 2010.
} 
intenta separar las actividades habituales de los actores políticos de su intención de lograr votos, y eso es una tarea casi imposible en la práctica. ${ }^{436}$

La duración de la campaña electoral de solamente 15 días es una ficción difícil de sostener por su potencial conflicto con el ejercicio de las funciones constitucionales de los partidos y con el derecho fundamental de la libertad de expresión. A causa de ello, lo cierto es que la Junta Electoral Central ha tenido que reducir la cuestión de la diferencia entre actos practicados en cada uno de estos periodos a partir de la petición expresa del voto ${ }^{437}$, criterio este que como demuestra la práctica política, no parece que resulte operativo. Además, la propia reforma de la LOREG no ha considerado la posibilidad de que asociaciones $\mathrm{u}$ organizaciones conectadas a los partidos puedan realizar campaña, a partir del texto de la Ley Orgánica 8/2007. Dicha ley silencia sobre esta posibilidad, pero ha autorizado que estas reciban donaciones - de la misma manera que los partidos, aunque en condiciones significativamente mejores - lo que presupone que habrá algún tipo de publicidad por su parte.

En definitiva, un sector doctrinal importante cuestiona la necesidad de limitar el período de campaña electoral, ya que actualmente la información electoral es recibida de manera permanente y de manera casi involuntaria. ${ }^{438}$

Siendo esta delimitación de tiempo entre la precampaña y la campaña electoral algo muy poco perceptible ${ }^{439}$, y comprobada por su ineficiencia en la práctica, se podría defender en su eliminación de la ley, como expone algún autor. $^{440}$ En todo caso, la última reforma de la LOREG puede obtener algún

${ }^{436}$ Cfr. HOLGADO GONZÁLEZ, M.: La Financiación de los... Pp. 61 y SÁNCHEZ MUÑOZ, O.: La lgualdad... Pp. 180-182.

${ }_{437}$ Cfr. DELGADO IRIBARREN, en AA.VV. "Encuesta: Régimen Electoral". In: Teoría y Realidad Constitucional. ํㅡㄹ 22, 2을 semestre. UNED, Madrid, 2008. Pp. 60.

${ }^{438}$ PAJARES MONTOLIO, E.: La Financiación de las... Pp. 69. Con todo, el autor cuestiona la eficacia de dicha norma de limitación del periodo de campaña electoral.

${ }^{439}$ GARCÍA VIÑUELA afirma que hay efectos de la regulación que no son percibidos antes de su implementación. Un ejemplo de ello es el acortamiento de la campaña electoral, y la aplicación de dicho límite a la práctica. Han transferido actividades de campaña electoral para la precampaña, no disminuyendo los gastos y aún empeorando la situación, pues gastos efectuados en precampaña no son considerados gastos electorales sometidos a los límites de la LOREG, pero son considerados gastos ordinarios, no sujetos a límite ninguno. (In: GARCíA VIÑUELA, E. "La Regulación del..." Pp. 80).

${ }^{440}$ Esta es la posición de CORTÉS MARTíN, que entiende que de nada sirve que se acorte las campañas electorales si en la precampaña (que dura en la práctica tres meses en contra de los 15 días del otro tipo de campaña) se realizan los mismos actos, pero sin la palabra "vota". (In: AA. VV.: "Debates". In: La Financiación... Pp. 75). ARNALDO ALCUBILLA, E. "Procesos Electorales y..." Pp. 179. 
resultado positivo, principalmente en el abaratamiento de los costes de campaña de los partidos, pero para esto, es necesaria la actuación conjunta de la Juntas Electorales ante todo de la Central, a través de una "jurisprudencia" constante y clara, y de la voluntad de aplicar las sanciones previstas, por más desproporcionales que sean, con la intención de demostrar que la ley tiene efectividad y de evitar que genere la sensación de inseguridad jurídica, hasta ahora predominante. ${ }^{441}$

Así, perceptible en los debates parlamentarios sobre la Ley 8/2007 la consciencia de que la distinción entre los dos periodos resultaba en parte fútil, cuando no contraproducente, era ya el parlamentario Esteban Bravo, integrante del Grupo Vasco hace la siguiente declaración: "ya sabemos que la campaña electoral es mucho más que eso, es toda la precampaña, algunos partidos políticos se tiran hasta un año de precampaña". 442 Algo que también quedó claro durante el proceso de elaboración de la LOREG, aunque en lugar de suprimir la distinción, se optó por imponer prohibiciones, quizás sin el soporte necesario para ser eficaces. El problema de la separación de ambos plazos fue ampliamente abordado también en la reforma de la LOREG del 2011, siendo aquí prácticamente la opinión unánime que se debería establecer una regla más rígida para la cuestión ${ }^{443}$, que resultó ya aplicada en las elecciones de 2011. Con todo, la evolución legislativa deja traslucir las debilidades de un sistema de campañas de difícil configuración.

Aunque la Ley Orgánica 2/2011 de 28 de enero haya modificado el art. 50 que trata sobre el asunto, la actual regulación no deja de encubrir ciertas lagunas. Se añadió una prohibición más general para realizar propaganda por parte de los partidos en el período entre la convocatoria de las elecciones y el inicio de la campaña propiamente dicha, obviando que muchas de estas actividades forman parte de las funciones ordinarias de estas organizaciones. ${ }^{444}$ Sin embargo, dicha medida no vino acompañada de una

\footnotetext{
${ }^{441}$ Cfr. ARNALdO AlCUBilla, E. "Las Reformas Posibles...” Pp. 65-66.

442 BOCG, no 114, de 27 de septiembre de 2005. Pp. 5750-5751.

${ }^{443}$ En este sentido, cfr. pronunciamientos y votos de los grupos parlamentarios en los debates sobre la reforma de la LOREG en DS Congreso de los Diputados, no 588, IX Legislatura, de 30/06/2010; BOCG no 426, de 09/07/2010 y BOCG n 282-6, de 14/12/2010.

444 El texto insertado por la Ley Orgánica 2/2011 es: "No obstante lo anterior, desde la convocatoria de las elecciones hasta el inicio legal de la campaña, queda prohibida la
} 
previsión acerca de posibles sanciones aplicables en caso de violación de la norma.

La única sanción ahora prevista consta en el art. 144 de la LOREG, que determina, de manera un tanto ambigua, que serán sancionados los responsables por propaganda indebida, y fuera del plazo de la campaña electoral. El problema reside en el hecho de que se trata de sanciones de carácter penal, no las más adecuadas, ni las más efectivas, para corregir la situación de ventaja que se obtiene en el proceso electoral. ${ }^{445}$ En la hipótesis de incumplimiento de las normas referentes a la propaganda electoral y a la campaña electoral, suelen ser más efectivas las sanciones de carácter económico o la inmediata reparación de la desigualdad conseguida fraudulentamente.

Parece claro que no es tarea fácil realizarse una investigación de dichas reglas, justamente considerando los elementos antes citados aliados a las tecnologías contemporáneas que mantienen los potenciales competidores permanentemente en los medios. ${ }^{446}$ También, quizás sea un momento para la reflexión si dicha separación entre ambos plazos realmente ha servido para disminuir los gastos electorales, porque, por más que se críen normas con connotación negativa en el sentido de regular las campañas electorales, es un hecho que estas seguirán empezando mucho antes del establecido en ley. ${ }^{447}$

En todo caso, no cabe olvidar que muchos autores afirman que actualmente la campaña empieza justamente cuando las elecciones terminan, y que eso lógicamente genera una demanda de recursos muy grande. ${ }^{448} \mathrm{Y}$ ello coincide con el hecho de que la campaña electoral propiamente dicha tiene hoy

realización de publicidad o propaganda electoral mediante carteles, soportes comerciales o inserciones en prensa, radio $u$ otros medios digitales, no pudiendo justificarse dichas actuaciones por el ejercicio de las actividades ordinarias de los partidos, coaliciones $o$ federaciones reconocidas en el apartado anterior."

${ }^{445} \mathrm{~A}$ ello, en todo caso, deben sumarse también el dispuesto en el art. 153 sobre infracciones electorales (que prevén a la vez multas pecuniarias para actos que violen las reglas electorales que no sean delitos específicos), simplemente se espera que sean aplicadas debidamente ${ }_{446}$ SOLER SÁNCHEZ, M. "La Campaña Electoral..." Pp. 302-303.

${ }^{447}$ En este sentido, cfr. CRESPO, I.; MARTíNEZ, A.; OÑATE, P. "¿Tienen las Campañas Electorales Efectos sobre la Decisión del Elector?" In: CRESPO, I. (dir.): Las Campañas Electorales y sus Efectos en la Decisión del Voto. vol. II. ed. Tirant lo Blanch, Valencia, 2004. Pp. 505.

${ }^{448}$ Como ejemplo, cfr. S. KATZ, R. "Party Organizations and Finance". In: LE DUC, L.; G. NIEMI, Richard; NORRIS, P. (ed.): Comparing Democracies: Elections and Voting in Global Perspective. Ed. Sage, London, 1996. Pp. 126 y BALMELLI, T.: Op. Cit. Pp. 46-48. 
en día su operatividad muy escasa, principalmente si se considera que gran parte del electorado forma su opinión a través de movimientos a largo plazo, y no en un periodo tan corto como es la campaña. ${ }^{449}$

Debido a lo expuesto, el tema tiene un impacto indudable sobre la financiación de los partidos, porque compromete la diferenciación entre los gastos electorales y los gastos ordinarios. Si anteriormente se analizaba el problema de la separación de las actividades electorales y ordinarias de los partidos, en la separación entre la precampaña y la campaña electoral nos encontraremos también en una zona "gris" en cuanto a la financiación electoral. La propia ausencia de sanciones que anteriormente caracterizaba a la legislación reforzaba la debilidad de esta distinción. Actualmente, el escenario es otro, pero considerando el tipo de sanciones que fueron insertadas en la ley y el comportamiento precedente de la Junta Electoral Central, se debe ser cauteloso al evaluar las consecuencias de la nueva normativa.

\subsubsection{El problema de la definición de gastos electorales - el problema de la propaganda política y la propaganda electoral}

Este punto quizás sea el más problemático dentro del campo de las campañas electorales. La propaganda hecha por los partidos en tiempos electorales constituye el famoso "disparador" de gastos, y la situación se agrava cuando se considera la confusión - muchas veces voluntaria - entre la propaganda electoral y la propaganda política.

Como es sabido, actualmente prevalecen las técnicas del marketing político en las campañas electorales, con la aplicación de nuevos métodos de estudio del mercado, publicidad especializada, elaborada con técnicas sofisticadas para la identificación del público, con elementos sociológicos, psicológicos y estadísticos, y todo ello dirigido hacia la elaboración de una propuesta electoral capaz de englobar el mayor número de votantes posible. ${ }^{450}$

Ante esto, está claro que el volumen de recursos, que necesitan los partidos para desarrollar las campañas electorales es muy alto, un problema

\footnotetext{
449 GAVARA DE CARA, J. C. “La Financiación Electoral..." Pp. 308.

450 PAJARES MONTOLIO, E.: La Financiación de las... Pp. 119.
} 
agravado en España por la proliferación de las citas electorales. Dentro de este marco, los partidos que no tengan capacidad económica suficiente para sufragar los nuevos instrumentos de campaña se encuentran en clara desventaja ante la competición electoral. ${ }^{451}$ En definitiva, el coste de las campañas, y el modelo de financiación existente forman un "ritornelo" que tiende a cristalizar el sistema de partidos existente. ${ }^{452}$ Todo ello, en el contexto español hizo que los partidos asumieran costes que muy probablemente no asumirían si no fueran extremamente necesarios, generando el problema del endeudamiento de las organizaciones, con su correlato de financiación ilegal, fraude a la ley, y en último término corrupción. ${ }^{453}$

${ }^{451}$ PINTO-DUSCHINSKY hace una observación interesante, cuando destaca que, aunque en los EE.UU. se gaste mucho en propaganda mediática en general, existen muchos otros continentes que la televisión, por ejemplo, no tiene un papel tan determinante, como puede pasar en partes de la América Central, Asia y África. Sin embargo, hay que considerar que la vieja manera de hacer política cara a cara puede ser mucho más costosa que la campaña realizada en los medios. (In: PINTO-DUSCHINSKY, M. "Financing Politics: A Global View". In: Journal of Democracy. ํㅡ 4, vol. 13, oct. ed. John Hopkins University Press, Washington, 2002. Pp. 83).

${ }^{452}$ Cfr. WILLIAMS, R. "Conclusions: Problems and Prospects". In: WILLIAMS, R. (ed.): Party Finance and Political Corruption. McMillan Press, London, 2000. Pp. 200 y FISHER, J.; EISENSTADT, T. A. "Introduction Comparative Party Finance. What is to be Done?" In: Party Politics. v. 10. oㅡ 6. Sage, London, 2004. Pp. 622.

453 ÁLVAREZ CONDE considera que el endeudamiento también se debe a las actividades ordinarias de los partidos políticos, generando un abuso en las solicitudes de créditos a las instituciones financieras, como también a la mayor frecuencia en la búsqueda de fuentes de financiación no permitidas por ley, volviendo a la financiación descontrolada y vulnerable a la corrupción. (In: ÁlVAREZ CONDE, E.: El Derecho de Partidos. Colex, Madrid, 2005. Pp. 383). Sin embargo, aunque los partidos políticos no suelan solicitar préstamos para las actividades ordinarias, si lo hacen siempre para las actividades electorales, ya que existe la perspectiva de pagar con posterioridad a las elecciones, tras la entrega de las subvenciones debidas a los partidos. Considerando también el problema del endeudamiento, GARCíA VIÑUELA y ARTÉS CASELLES entienden que los límites a los gastos electorales buscaban fomentar la competitividad entre los partidos políticos, pero que debido al alto valor aplicado inicialmente, no fueron capaces de evitar el endeudamiento de las organizaciones partidistas (considerando las elecciones de 1986 y 1989, analizados por los autores). En este sentido, véase: ARTÉS CASELLES, J.; GARCÍA VIÑUELA, E. Op. Cit. Pp. 50. Con todo, en mi opinión, el comportamiento de los partidos políticos tampoco puede ser excluido de este análisis, porque la legislación determina un valor máximo, un límite para los gastos, no se trata de valores "orientativos" para el cálculo del presupuesto de los partidos para las campañas electorales. Lo que sí es cierto es que mientras el límite sea alto, los partidos gastarán mucho, porque se permite y cuanto más sea permitido que gasten, lo harán justamente buscando los resultados electorales favorables. Como destacan los autores anteriormente citados, la Ley Orgánica 13/1994 trató de reducir los valores de los límites de gastos electorales, determinándolos en 24 céntimos por habitante donde existía candidaturas del partido. Sin embargo, eliminó la cantidad fija antes existente. Los autores creen que dicha medida estaba orientada a solucionar problemas como el endeudamiento y la falta de credibilidad de los partidos, considerando los diversos casos de corrupción revelados en esta época. (In: ARTÉS CASELLES, J.; GARCíA VIÑUELA, E. Op. Cit. Pp. 51-52). Es importante destacar que en la nueva reforma de la LOREG, el valor por elector para el cálculo de dicho límite fue aumentado para 37 céntimos, contrariando la meta antes deseada. Por otra parte, BALMELLI afirma que los actores políticos 
En todo caso, gran parte de la literatura jurídica sobre el tema destaca que el modelo de campaña electoral utilizado en España agrava aún más el "coste" de la política. ${ }^{454}$

Sin embargo, previo al problema de la gran demanda de recursos que provoca la necesidad de hacer propaganda, se suscita la cuestión en el ordenamiento español de la diferencia entre la propaganda electoral y la propaganda política. La propaganda electoral sería estrictamente el conjunto y actos realizados por parte de los partidos principalmente durante el tiempo de la campaña electoral con la finalidad de convencer a los electores para que voten a una determinada fuerza política. ${ }^{455}$ Con todo, la diferenciación entre propaganda electoral y propaganda política resulta extremadamente difusa, considerando que esta última se realiza de manera permanente, es considerada la actividad normal de los partidos fuera del período electoral. Esta

deberían llegar en un acuerdo sobre la propaganda electoral y su confección. Como la tendencia al aumento de los costes de campaña es constante, hace falta una regulación ante la ausencia de reglas autoimpuestas por los autores. (In: BALMELLI, T.: Op. Cit. Pp. 376-378).

${ }^{454}$ Cfr. CASTILLO, P. del. "La Financiación de los Partidos Políticos en Europa..." Pp. 14-15. La autora afirma que España, en comparación con Reino Unido o EE.UU., tiene una campaña electoral muy costosa, y que la mala gestión económica de los recursos empleados sumada a la poca optimización de los mismos, serían las razones más probables de todo. Estas críticas encuentran eco en muchos autores, véase: SANCHÉZ-CUENCA, I.: El Dilema del Prisionero. El País. 06 de febrero de 2000, que critica el modelo de campaña por no fomentar el debate político; PÉREZ ROYO, J.: Exigencia Insoslayable. El País. 07 de marzo de 2004, que critica la no existencia de debates electorales en los medios de comunicación en masa; PRADERA, J.: El Debate en TV es un Deber. El País. 19 de diciembre de 2007, en que el autor afirma que no se da el debido valor a los debates electorales; PRADERA, J.: A Cara de Perro. El País. 24 de febrero de 2008, que destaca la realización de un debate electoral en la televisión en las elecciones de 2008, resaltando la importancia de la herramienta; ALCARAZ RAMOS, M.: Ética y Estética de los Gastos Electorales. El Correo. 20 de febrero de 2008, en donde critica el formato de campañas electorales con costes muy altos y poco eficaces; y JIMENEZ DE PARGA, M.: Campañas Electorales en el Siglo XXI. ABC. 05 de febrero de 2008, que el autor destaca que las campañas actuales no surten el efecto deseado, fomentando el abstencionismo. En una visión comparada con Reino Unido y EE.UU., JOHNSTON estudia cual es el verdadero impacto de las campañas electorales sobre el electorado, considerando un número fijo de electores y el valor gastado por cada partido, en un intento de comprobar la afirmación de que aquél que gasta más gana las elecciones. Así, cfr. JOHNSTON, R. J.: Money and Votes: Constituency Campaign Spending and Election Results. Ed. Croom Helm, UK, 1987. Pp. 15 y ss. También, HEYWOOD, P. "The Electoral and Party Systems". In: The Government and Politics of Spain. Ed. Macmillan Press, London, 1995. Pp. 172; CASASZAMORA, K.: Paying for Democracy: Political Finance and State Funding for Parties. ECPR Press, UK, 2005. Pp. 23; GALVEZ MUÑOZ, L. A. "El Regimen Electoral de la Propaganda Institucional Ordinaria". In: Corts - Anuario de Derecho Parlamentario. no 24, Valencia, 2011. Pp. 63-80; y SANTOLAYA, P. "Algunos Problemas de la Regulación de las Campañas Electorales". In: Corts - Anuario de Derecho Parlamentario. no 24, Valencia, 2011. Pp. 257-278, que son dos aportaciones muy interesantes para el cuestionamiento del modelo de campaña aplicado actualmente.

${ }^{455}$ SOLER SÁNCHEZ, M.: Campañas Electorales... Pp. 62. 
diferenciación se vuelve aún más nebulosa porque los destinatarios son prácticamente los mismos, como también lo es el contenido de cada tipo de propaganda, que sólo difiere en la petición implícita o explícita del voto, y el período legal de realización de la propaganda. ${ }^{456}$

Los gastos electorales se contabilizan a partir de la convocatoria para las elecciones, y no sólo respecto a la campaña electoral. Pero la propaganda política se realiza cotidianamente, justamente por ser un derecho que tienen los partidos políticos. Y considerando que la propaganda política forma parte de las actividades ordinarias de los partidos, no se somete a la limitación de gastos fijada para los gastos electorales, y ello constituye una laguna legal muy relevante dentro del sistema. El hecho ha sido subrayado por el Tribunal de Cuentas en múltiples ocasiones en sus informes de fiscalización. Con todo, con la falta de uniformización de la legislación, sumada a las dificultades de control, no permite avanzar realmente en este campo.

Con la reforma de la LOREG del 2011 y su intento de reforzar la separación entre precampaña y campaña electoral, se intentó también determinar con precisión el contenido de cada uno de estos periodos. Sin embargo, la nueva redacción dada al art. 53 es igualmente lacónica. La excepción contemplada por el legislador justificando la propaganda ordinaria en el periodo de precampaña acaba por vaciar de contenido normativo la prescripción y vuelve en este aspecto banal a la reforma. No hay criterios para distinguir una y otra, y si se aplica el criterio elaborado con anterioridad por la Junta Electoral Central (la petición expresa de voto), se sigue careciendo de reglas para solucionar realmente el problema.

Por otra parte, aun cuando también haya sido incluido en el texto legal la prohibición de propaganda a través de los medios digitales, persisten los problemas para fiscalizar dicha política en un mundo tan amplio y veloz como el cibernético, junto con la propia falta de estructura orgánica de la Junta Electoral Central para ejercer esta vigilancia, y concretar sanciones efectivas, sin las cuales la fiscalización continua siendo incompleta. ${ }^{457}$ Junto a todo ello persiste

\footnotetext{
456 SOLER SÁNCHEZ, M.: Campañas Electorales... Pp. 74-77.

457 Cabe subrayar la observación del Senador Tiñon San Martín, del grupo mixto, en una sesión de debates sobre la reforma de la LOREG, afirmando que, si no hay control en la cuestión de la
} 
el problema de la realización por terceros de actos de propaganda en periodo electoral. $^{458}$

El principal factor que contribuyó a la adopción del modelo actualmente aplicado para la financiación electoral fue el fenómeno mundial del encarecimiento de las campañas electorales. Dicho encarecimiento provocado tanto por la gran cantidad de elecciones celebradas como por la creciente importancia de las técnicas de marketing y publicidad y su constante innovación, genera la idea de que si un candidato no acompaña la evolución tecnológica del otro, estará en desventaja en la competición. ${ }^{459}$ Dicha lógica también se aplica a los gastos ordinarios de los partidos, porque aunque se pueda considerar que entre la convocatoria y las elecciones propiamente dichas se de un corto periodo de tiempo, existe una presión "invisible" para que las formaciones políticas estén siempre presentes de un modo u otro en los medios de comunicación. ${ }^{460}$

Por otra parte, la redemocratización de España coincidió temporalmente con la gran revolución de las técnicas del marketing, haciendo que los partidos, aunque débiles, debieran utilizar de dichas técnicas para lanzarse en el

precampaña y campaña, la situación continuará. (Cfr. DS Senado, Pleno, no 107 de 19/01/2011)

${ }^{458}$ Cabe destacar que las nuevas prohibiciones de propaganda dispuestas en el art. 50, así como también en el art. 53 introducidos en la LOREG por la nueva reforma no tratan del problema de la propaganda realizada por terceros, dirigiéndose únicamente a los poderes públicos, lo que deja claro que la preocupación de las medidas es la de impedir el abuso del poder político por parte del gobierno. Soler Sánchez a su vez no considera que las asociaciones y fundaciones puedan realizar gastos electorales, justamente porque no están sometidas al control del Tribunal de Cuentas. Pero en la época del trabajo de la autora estaba en vigor la Ley Orgánica 3/1987, que no poseía ninguna disposición sobre el tema. Sin embargo, si se considera su pensamiento a la luz de la legislación ahora vigente, actualmente las asociaciones y/o fundaciones podrán efectuar gastos electorales, porque según el tenor de la disposición adicional séptima de la Ley Orgánica 8/2007, ambas están sometidas a la fiscalización del Tribunal de Cuentas. (cfr. SOLER SÁNCHEZ, M.: Campañas Electorales... Pp. 85). También, cfr. HOLGADO GONZÁLEZ, M.: La Financiación de los... Pp. 161-162 y SÁNCHEZ MUÑOZ, O.: La lgualdad... Pp. 188. En otro de sus trabajos, el autor analiza diversas propuestas para una reforma de la LOREG, considerando que la mejor alternativa sería la reformulación de los sujetos activos de la campaña electoral a cambio de que dichos gastos se computaran algún partido o agrupación, o que dicha decisión viniera adoptada desde la Junta Electoral Central, a petición de alguno de los demás partidos. Con todo, el autor reconoce la ineficacia de control de dichas medidas, y concluye que no es posible un tratamiento que limite este tipo de campaña. (In: SANCHÉZ MUÑOZ, Ó. "Cuestiones Relativas..." Pp. 633).

${ }_{459}$ SOLER SÁNCHEZ, M.: Campañas Electorales... Pp. 223.

${ }^{460}$ MURILLO DE LA CUEVA, P. L. "La Financiación de los Partidos Políticos: Materiales para un Debate". In: AA.VV.: Anuario de Derecho Constitucional y Parlamentario. ํㅜ 5. Asamblea Regional de Murcia - Universidad de Murcia, Murcia, 1993. Pp. 111-112. 
mercado político. Era un momento en lo cual en Europa se daba también un cambio en el sentido social y político de los partidos, más próximos al Estado que anteriormente, y que buscan fuertemente un éxito electoral, cada vez más independiente del número, ya escaso, de los militantes. Lo que importaba era el atractivo electoral de los dirigentes de las organizaciones políticas, el desempeño electoral y la financiación pública. ${ }^{461}$

No obstante, como es sabido, no existe una relación directa entre el coste de ciertas técnicas electorales, y su éxito a la hora de captar el voto. ${ }^{462}$ En todo caso, en la última reforma de la LOREG tampoco se ha intentado ninguna reformulación en la configuración de la campaña electoral, aunque haya sido un tema argumentado en los debates sobre el proyecto de ley. ${ }^{463}$

Cuando se produce un proceso de encarecimiento de las campañas como se dio en España (aunque de manera no exclusiva), existe una tendencia a la adopción de medidas de financiación pública de campañas que a la vez también provoca cambios en la propia forma de realizar la actividad política. Los electores se ven bombardeados por mensajes que muchas veces no son eficaces en el proceso de decisión del voto, pero que producen un gran incremento de los gastos electorales. Ante esto, no queda otra alternativa sino la de adoptar límites legales para estos gastos, haciendo que una acción positiva siempre sea acompañada con una acción restrictiva. ${ }^{464}$

El modelo actual de campañas electorales es bastante costoso, escasamente moderno, y nada acorde con las tecnologías más básicas existentes actualmente. ${ }^{465}$ Algo es lo que existe casi unanimidad por parte de la doctrina, y valga como ejemplo el vacío legal en torno al uso de la red, o la ausencia de una práctica habitual de debates televisivos. ${ }^{466}$

\footnotetext{
${ }^{461}$ TORRES DEL MORAL, A. “EI Estado Español...” Pp. 116.

462 GILLESPIE, R. Op. Cit. Pp. 81.

${ }^{463}$ Como ejemplo de esto, se puede citar al pronunciamiento hecho por el portavoz de Coalición Canaria, en el Senado. Cfr. DS, no 459, Senado, de 11, de enero de 2011.

464 ALCANTARA, M.; RAMÓN MONTERO, J. "Las Subvenciones y Gastos Electorales". In: Legislación Electoral de Iberoamérica - Análisis Comparativo - I Seminario sobre Organización y Ejecución de Procesos Electorales. Vol. III, Madrid, 1992. Pp. 400-401 y MORENO MARTINEZ, C. Op. Cit. Pp. 55-58.

${ }^{465}$ Característica muy bien remarcada por SANCHÉZ MUÑOZ, Ó. Cuestiones Relativas..." Pp. 618.

${ }^{466} \mathrm{Y}$ esto compromete el actual modelo, dada la fuerza actual de internet en la dinámica electoral. (cfr. GONZÁLEZ ENCINAR, J. J. "Derechos y Medios..." Pp. 606). Incluso hay campañas donde los partidos están articulando canales de comunicación con los electores,
} 
Se sabe que, en el caso de que se autorizara la contratación de espacios publicitarios en los medios televisivos privados, con seguridad que se multiplicaría exponencialmente los gastos electorales. En todo caso, su prohibición seguramente implica no solo una medida de control de gastos, sino también una cierta concepción del modelo de campaña, ya que en los países donde su contratación está permitida, el formato de constantes spots televisivos genera, como es sabido, el mismo sentimiento de rechazo en los electores. ${ }^{467} \mathrm{Y}$ es, quizás, este "modelo europeo" de campaña electoral el que parece no haberse adecuado suficientemente a los cambios sociales ${ }^{468}$, lo que se refleja la poca o mínima influencia que las campañas actuales ${ }^{469}$ basadas en propaganda enviada por correos, pancartas y carteles tienen sobre el electorado, e incluso refleja la crisis en el debate de las propuestas políticas provocadas por herramientas anticuadas de hacer política. ${ }^{470}$ Parece claro que lo que se hace en la campaña electoral es actualizar las informaciones sobre la gestión del gobierno y las actividades de la oposición, pero que no se fomenta un debate público sobre cuestiones importantes que siguen pendientes, ni tampoco colabora en una reflexión sobre el sentido del voto. ${ }^{471}$

para que estos les envíen algunas propuestas para la agenda política a través de la web, como fue el caso de la campaña electoral de La Rioja en 2006. (In: MUÑOZ ARNAU, J. A. "La Campaña Electoral en las Elecciones Autonómicas de La Rioja 2007". In: Anuario Jurídico de La Rioja. no 11, Logroño, 2006. Pp. 41-42). Debido a ello que FERNÁNDEZ VIVAS entiende que la obligatoriedad de los debates contribuiría directamente a la cuestión de los gastos de campaña. Como el coste del actual modelo de campaña es desproporcionado en comparación con sus efectos, reformulando la campaña con un modelo basado en el uso de la televisión, atendiendo a condiciones de igualdad, con el fomento de debates electorales, aunque se mantuvieran los mítines y demás actos actualmente vigentes, se lograrían disminuir costes en relación a la difusión de las propuestas de los partidos. (In: FERNÁNDEZ VIVAS, Y.: Op. Cit. Pp. 412).

${ }^{467}$ Remito al ejemplo de EE.UU.

468 Incluso porque, según BASSOLS COMA, considerando el periodo en que dicho modelo de campaña fue adoptado por la legislación electoral española, esta fue muy generosa en sus objetivos. (In: BASSOLS COMA, M. Op. Cit. Pp. 43). También, cfr. MARTIN DE LA VEGA, A. "Censo Electoral..." Pp. 146.

469 De hecho, MARTINEZ I COMA añade el efecto de la desincentivación que puede ser atribuido a la actual campaña electoral. (In: MARTINEZ I COMA, F. "¿Cuáles Fueron los Efectos de la Campaña Electoral Española de 2000?" In: Revista Española de Investigaciones Sociológicas - REIS, no 112, oct/dic, CIS, Madrid, 2006. Pp. 231-257).

${ }^{470}$ Cfr. MELLIZO SOTO, M. F. "¿Para qué Sirven las Campañas Electorales? Los Efectos de la Campaña Electoral Española de 1993”. In: Revista Española de Investigaciones Sociológicas REIS, n 93, ene/mar, CIS, Madrid, 2001. Pp. 83-84. Como el modelo de campaña electoral apenas ha cambiado desde 1993, su análisis sigue siendo válido.

${ }^{471}$ Cfr. GAVARA DE CARA in: AA.VV. "Encuesta: Régimen Electoral. Op. Cit." Pp. 66. 
Entre las medidas posibles para actualizar la campaña, podría encontrarse un nuevo diseño en la utilización del medio televisivo. Dicha modificación en la utilización de espacios, centrados en las televisiones privadas, no debería consistir en la liberación de la comercialización de espacios publicitarios, dado que elevaría costes y probablemente, implicaría una mayor desigualdad en la campaña. Pero sí se podría pensar era que, fruto de ser una concesión de servicio público, todas las televisiones privadas podrían ser obligadas a conceder un periodo diario a los partidos, en línea con el formato aplicado a las televisiones públicas. Es decir, dicho espacio no podría ser objeto de comercio por hacer parte del servicio público que el Estado ha otorgado a la iniciativa privada, y sería repartido entre las fuerzas políticas conforme se reparten los espacios en La RTE. ${ }^{472}$ La reformulación de las actuales prohibiciones respecto a los medios de comunicación privados podría colaborar en la calidad del procedimiento electoral, ya que el modelo de la LOREG parece poco compasado con una nueva realidad social, y prevé una campaña, en sentido jurídico, que no se corresponde con la "campaña electoral" real en sentido político. ${ }^{473}$ La campaña, como concepto politológico, parece haber perdido su significado e importancia, convirtiéndose de alguna manera en algo irrelevante para la sociedad, pero indispensable para los políticos. ${ }^{474}$ Se podría decir que la campaña electoral ha perdido su centralidad dentro de las reglas referentes a la competición política, agravado por la existencia de un cierto déficit regulativo. ${ }^{475}$ El "modelo europeo" se concibió como un periodo de tiempo que se debería velar especialmente por el principio de igualdad de oportunidades electorales, pero que al final, acaba por imponer

\footnotetext{
472 Dicho modelo es aplicado en Brasil y sus efectos se notan, ya que involucra mucho más al debate público las agendas políticas propuestas por los candidatos. Además, se ha enseñado como una medida eficaz ante el tamaño continental que Brasil posee.

${ }^{473}$ En este sentido, cfr. ARIÑO ORTIZ y GAVARA DE CARA in: AA.VV. "Encuesta: Régimen Electoral. Op. Cit." Pp. 58-66.

${ }^{474}$ Aquí se puede citar el estudio realizado por LAGO y MARTINEZ, que evidencia el escaso efecto de las campañas electorales. Analizando las campañas electorales entre 1993 y 2000, los autores detectan una influencia en el voto de los electores alrededor del 3 por 100. Cfr. LAGO, I.; MARTINEZ, F. "Una Metodología Alternativa para Estimar los Efectos de las Campañas Electorales". In: Revista Española de Ciencia Política. no 11, octubre, 2004. Pp. 119. ${ }^{475}$ En este sentido, cfr. ARNALDO ALCUBILLA in: AA.VV. "Encuesta: Régimen Electoral. Op. Cit." Pp. 59; RALLO LOMBARTE, A. "Neutralidad y..." Pp. 5.
} 
aun más trabas para la entrada de nuevas fuerzas políticas, colaborando a la falta de apertura del sistema. ${ }^{476}$

Las propias previsiones de la LOREG, y de su reforma, muestra este desfase. En el articulado encontramos un regulado detalladamente sobre la ubicación en espacios públicos de carteles, pancartas, el uso de espacios públicos, etc., pero continúan existiendo situaciones de "anomia" en torno a aspectos centrales como los debates en radio y televisión, tanto en televisiones públicas como privadas, y el propio internet, que en días de hoy tienen una acentuada relevancia. Aunque la propia Junta Electoral Central haya afirmado que, por más que los debates electorales no tengan una regulación específica, no hay obstáculos para su realización ${ }^{477}$, si dicho evento carece de las mínimas reglas necesarias para cumplir con su función en la campaña, puede terminar incluso perjudicando la siempre vulnerable igualdad de oportunidades existente entre las fuerzas políticas. ${ }^{478}$

Y, con esta falta de reglamentación de los medios actualmente utilizados, se abre igualmente un espacio donde necesariamente deben actuar las Juntas Electorales a través de sus Acuerdos e Instrucciones, ante las lagunas legales. Se trata de una práctica de difícil generalización, que convierte los Acuerdos de las Juntas en una verdadera "fuente atípica" del derecho electoral. $^{479}$

\footnotetext{
${ }_{476}$ Cfr. MARTIN DE LA VEGA, A. "Censo Electoral..." Pp. 146-148.

477 Según disposición del acuerdo de la JEC de 22 de octubre de 1982 y Instrucción de la JEC de 13 de septiembre de 1999. Se destaca el apoyo a los debates por parte de dicho órgano.

${ }^{478}$ Cfr. ARNALDO ALCUBILLA, E. "Procesos Electorales y Opinión..." Pp. 59; y FERNÁNDEZ VIVAS, Y.: Op. Cit. Pp. 412. También, cfr. RALLO LOMBARTE, A. "Debates Electorales..." Pp. $50-51$.

479 Cfr. SANTOLAYA MACHETTI, P. "EI Modelo Español de Administración Electoral". In: BIGLINO CAMPOS, P.; DELGADO DEL RINCÓN, L. E. (eds.): La Resolución de los Conflictos Electorales: Un Análisis Comparado. Cuadernos y Debates, Centro de Estudios Constitucionales, Madrid, 2010. Pp. 43-45. También, cfr. MARTIN DE LA VEGA, A. "Censo Electoral..." Pp. 146. Los debates constituyen un ejemplo de un tema que aún carece de regulación y que ha sufrido directa intervención de las Juntas Electorales. Muchas de las normas aplicables venían de la Instrucción de 13 de septiembre de 1999 de la Junta Electoral Central, la cual trataba ante todo de garantizar la igualdad, el pluralismo y la neutralidad. Dicha norma sentaría las bases para el Acuerdo de 23 de noviembre de 2010. Así, véase SÁNCHEZ MUÑOZ, O.: La Igualdad... Pp. 35-38. En este sentido, cfr. STC 136/1999 de 20 de julio, F.J. 4.
} 


\section{7) La financiación electoral a nivel autonómico}

Desarrollando las competencias previstas en sus respectivos Estatutos, las Comunidades Autónomas han elaborado su propia legislación electoral, donde se incluyen aspectos sobre la financiación electoral de los partidos. Apuntaremos aquí tan sólo algunos aspectos generales de este "derecho electoral autonómico", para luego tratar específicamente el tema de la financiación electoral en cada Comunidad Autónoma.

\subsection{Breves apuntes sobre el sistema electoral autonómico}

La potestad de las comunidades autónomas para legislar sobre la materia electoral está limitada por la Constitución Española (arts. 68 y 70) y la LOREG (disposición adicional primera). Hay puntos como el derecho de sufragio y la igualdad de oportunidades entre los competidores que deben ser preservados y que son de competencia exclusiva de las Cortes Generales. ${ }^{480}$ La competencia legislativa autonómica sobre la materia fue delimitada en la STC 89/1984, de 28 de septiembre, cuando se declaró que las Comunidades Autónomas tenían la potestad de la elaboración de un sistema electoral para sus Asambleas Autonómicas, de acuerdo con el art. 148.1 de la Constitución Española. De esta forma, la LOREG fue declarada como norma supletoria en relación a la legislación autonómica, pero fijando las materias que serían de competencia del Estado, conforme disposición transitoria 10. ${ }^{481}$ Sin embargo,

\footnotetext{
480 Cfr. TRUJILLO FERNÁNDEZ, G.: Lecciones de Derecho Constitucional Autonómico. ed. Tirant lo Blanch, Valencia, 2004. Pp. 195 y PRESNO LINERA, M. Á. "Nuevos Estatutos de Autonomía con Viejos Sistemas Electorales". In: Revista de Estudios Autonómicos y Federales. o 5, [s.I.], 2007. Pp. 115-116. En este sentido, véase STC 154/1988, de 21 de julio.

${ }^{481}$ El art. 1.2 del título preliminar de la LOREG dispone: "Asimismo, en los términos que establece la disposición adicional primera de la presente Ley, es de aplicación a las elecciones a las asambleas de las Comunidades Autónomas, y tiene carácter supletorio de la Legislación Autonómica en la materia". El tema de la supletoriedad de la LOREG con relación a la legislación autonómica ha sido una cuestión polémica, dando lugar a diversas intervenciones del Tribunal Constitucional, tanto afirmando que la propia ley electoral no podía declararse como supletoria (por reserva constitucional), como también posteriormente estableciendo matices a su declaración. En este sentido, véase por todas STC 214/1989 de 21 de diciembre, F.J. 30 y en otra posición, por todas, STC 147/1991, de 4 de julio, F.J. 7. Al final, el Tribunal Constitucional cambia su jurisprudencia, para declarar que el principio de la supletoriedad es un criterio interpretativo en caso de lagunas en la ley, o sea, una regla de conflicto. En este sentido, véase STC 118/1996 de 27 de junio, F.J. 6, por todos.
} 
con posterioridad a la aprobación de la LOREG, se ha suscitado un no cerrado debate doctrinal sobre el concreto ámbito de dicha potestad autonómica. Desde entonces, parece mayoritaria la opinión que entiende que quizás sea excesivo el entendimiento en este campo de la competencia estatal, considerando que, a partir de su disposición adicional 1ำ gran parte del título I de la LOREG se aplica a nivel autonómico. ${ }^{482}$

Los argumentos de aquellos que mantienen que el carácter básico de la LOREG es excesivo en términos constitucionales, se centran en la crítica a la interpretación amplia del art. 81.1 de la CE, que realiza la jurisprudencia del Tribunal Constitucional, sobre lo que sea el régimen electoral general. ${ }^{483}$ Aquí se entiende que, debido a esta interpretación extensiva, aspectos como la campaña electoral no deberían (o podrían dejar de ser) de competencia estatal, y sí de las Comunidades Autónomas. ${ }^{484}$ Cabe recordar que, con algunas de las reformas estatutarias realizadas a partir del 2007, las disposiciones de la LOREG sobre la fecha de realización de las elecciones han sufrido cambios, permitiendo que algunas de las Comunidades Autónomas las anticipen, generando consecuentemente un conflicto de normas que la reforma de 2011 en la LOREG intenta estabilizar, con la inclusión de los arts. 50.1, 2 y 3 en el listado de las competencias autonómicas. ${ }^{485}$

\footnotetext{
${ }^{482}$ Cfr. BIGLINO CAMPOS, P. "La Legislación Electoral Estatal y el Margen del Legislador Autonómico". In: GÁLVEZ MUÑOZ, L. A. (Dir.): El Derecho Electoral de las Comunidades Autónomas. Revisión y Mejora. Cuadernos y Debates, Centro de Estudios Constitucionales, Madrid, 2009. Pp. 17-18.

${ }^{483} \mathrm{Ya}$ aquellos que no se ponen de acuerdo con la afirmación de que hay una cierta exageración en la aplicación de la LOREG sobre las CC.AA. se basan principalmente en el consenso habido para la aprobación de la ley general, que contó incluso con la participación de fuerzas políticas nacionalistas. Además, cabe recordar que en el caso de Cataluña, aunque la LOREG haya sido estipulada como norma supletoria a nivel autonómico, allá es de aplicación directa, por la inexistencia de ley electoral propia. En este sentido, cfr. BIGLINO CAMPOS, P. Op. Cit. Pp. 20.

${ }^{484}$ El tema fue tratado en el informe elaborado por el Consejo del Estado para la reforma de la LOREG, que se detuvo en el alcance normativo de esta. Existirían dos corrientes doctrinales sobre el ámbito de aplicación general de la LOREG, siendo una la maximalista, que entiende que el régimen general posee un mínimo normativo para todas las elecciones representativas; y otra, la relativa, que afirma que el régimen general solo se refiere a las elecciones de ámbito estatal, las europeas y las locales, lo que estaría en línea con la STC 38/1983. De esta manera, la LOREG posee una combinación de criterios materiales y territoriales, con un régimen general común, y posibilitando que cada CC.AA. intervenga en la modulación del régimen, disponiendo también de medidas especiales para el nivel estatal, local y europeo. (In: http://www.consejo-estado.es/pdf/REGIMEN-ELECTORAL.pdf. Pp. 22-23). Sobre cada una de estas corrientes, véase GAVARA DE CARA, J. C. “La Distribución..." Pp. 14-15.

${ }^{485}$ La LOREG, como es sabido, tiene normas básicas que deben ser aplicadas también a nivel autonómico, como los arts. 125, 126, 127, 130, 131 y 132, conforme a lo dispuesto en la
} 
En todo caso, por más que se defienda la idea de que existe un entendimiento demasiado generoso del concepto constitucional de "régimen electoral general", lo cierto es que no se ha producido un aprovechamiento del espacio que tienen las CCAA otorgado para regular un sistema electoral propio. Hay una ausencia evidente de originalidad o, lo que algunos autores llaman, hay una predominante homogeneidad en la legislación autonómica sobre el tema, que también puede ser traducida como una renuncia a adoptar otras reglas que no fueran las que constan en la LOREG. Es cierto, el espacio para legislar es limitado, pero de igual formal la inercia también tiene su presencia en este contexto. ${ }^{486}$

Ante esto, la legislación electoral autonómica se caracteriza por ser redundante, reglamentaria y minimalista, según las palabras de PRESNO LINERA. ${ }^{487}$ La redundancia se debe al hecho de que se observa una similitud significativa entre las disposiciones de la LOREG, y las disposiciones de las leyes autonómicas. Por más que exista un margen no depreciable de actuación del legislador autonómico, este no lo ha utilizado. De ahí, la homogeneidad que se atribuye a la legislación electoral autonómica respecto a la estatal y que, según ÁLVAREZ CONDE se debe a cuatro factores, siendo uno la incidencia de dicha legislación sobre algunos derechos fundamentales que son de competencia estatal $^{488}$; otro la delimitación realizada por la Constitución

disposición adicional primera mencionada. Dichas normas limitan el alcance de las normas autonómicas en la materia, cediéndolas a aspectos organizativos, como designación y competencias de los administradores electorales, sistemas de control y la determinación de los valores para las subvenciones electorales. Gran parte de las normas acaban por reproducir las reglas contenidas en la LOREG, y en el caso de la financiación electoral, a adecuar el valor de las subvenciones a la realidad de cada Comunidad Autónoma. (Cfr. GAVARA DE CARA, J. C. "La Financiación Electoral..." Pp. 268-269). También discutiendo el punto, véase ARNALDO ALCUBILLA, E. "El Procedimiento Electoral en Leyes Electorales Autonómicas". In: GÁLVEZ MUÑOZ, L. A. (Dir.): El Derecho Electoral de las Comunidades Autónomas. Revisión y Mejora. Cuadernos y Debates, Centro de Estudios Constitucionales, Madrid, 2009. Pp. 374 y PRESNO LINERA, M. Á. "Nuevos Estatutos..." Pp. 117-123. PRESNO LINERA entiende que se debe interpretar de manera restrictiva la aplicación de la LOREG en el ámbito autonómico.

${ }^{486}$ Cfr. ARNALDO ALCUBILLA, E. "El Procedimiento Electoral..." Pp. 374-375.

${ }^{487}$ Cfr. PRESNO LINERA, M. Á. "Nuevos Estatutos..." Pp. 117-123. En línea, GAVARA DE CARA entiende que debido a la aplicación de muchos de los preceptos de la LOREG directamente sobre las leyes autonómicas, acaba por producirse un nivel elevado de disposiciones puramente reglamentarias, de mero detalle, que se limitan a materializar el proceso electoral. (In: GAVARA DE CARA, J. C.: La Homogeneidad de los Regímenes Electorales Autonómicos. CEPC, Madrid, 2007. Pp. 94-95).

${ }^{488}$ Sobre el punto, centrándose principalmente en la igualdad de voto y el derecho de sufragio, véase GAVARA DE CARA, J. C. "La Distribución..." Pp. 30 y ss.; y GAVARA DE CARA, J. C.: 
Española y la LOREG; un tercero la interpretación realizada de dicha delimitación ${ }^{489}$; y por último, a lo que aquí respecta, la ya mencionada inercia por parte del legislador autonómico. ${ }^{490}$

La característica reglamentaria de la legislación autonómica viene determinada por el hecho de que, por más que se haya producido un importante mimetismo, también se verifica una intención codificadora, con disposiciones detalladas sobre múltiples asuntos, como los debates electorales o la paridad de género en las listas. Esto demuestra que existe una cierta desconfianza por parte del legislador autonómico y una pretensión acentuada, más recientemente, "blindar" su respectivo sistema electoral frente a la hipotética intervención del legislador estatal. ${ }^{491}$

A la vez, el rasgo minimalista, que puede ser justificado por los factores ya expuestos, también es resultado de las reglas contenidas en los propios estatutos de autonomía, que algunas veces no permiten al legislador autonómico actuar de otra manera. Sin embargo, esta característica no siempre es percibida como negativa por parte de la doctrina, que argumenta que facilita la interpretación, el conocimiento y la aplicación de las normas jurídicas, además de dejar claro que hay principios comunes de Derecho Electoral. ${ }^{492}$ En todo caso, tras las últimas reformas estatutarias habidas quizás se pueda entender que este mimetismo está cambiando. ${ }^{493}$

En relación al tema de la financiación electoral, al ser un tema considerado como competencia compartida o concurrente, admite especificaciones en ámbito autonómico, en lo que no está regulado por la

La Homogeneidad de los Regímenes Electorales Autonómicos. CEPC, Madrid, 2007. Pp. 51 y ss.

${ }_{489}$ Aquí, el Tribunal Constitucional acabó por restringir el concepto de régimen electoral general y, por lo tanto, acabó por confirmar el espacio del legislador autonómico, basándose en el art. 81.1, Constitución Española. En este sentido, véase SSTC 4/1981, de 18 de diciembre y 38/1983, de 16 de mayo.

${ }^{490}$ ALVAREZ CONDE, E. "Las Reformas Estatutarias..." Pp. 12.

${ }^{491}$ Cfr. BIGLINO CAMPOS, P. Op. Cit. Pp. 21.

492 ARNALDO ALCUBILLA incluso afirma que las leyes electorales autonómicas son simples a fin de evitar reiteraciones innecesarias. O sea, lo que se destaca como aspecto positivo es la utilización responsable de esta potestad legislativa por parte de las comunidades autónomas (a fin de no generar problemas para el electorado de tener que enterarse de las reglas para cada juego electoral), pero como aspecto negativo, se añade la falta de búsqueda de nuevas soluciones de técnica o procedimiento, oportunidad que podría ser utilizada para este fin. (In: AA.VV. "Encuesta: Régimen Electoral. Op. Cit." Pp. 49).

${ }^{493}$ Cfr. BIGLINO CAMPOS, P. Op. Cit. Pp. 23-24. 
norma estatal. ${ }^{494}$ Hay aspectos que son de aplicación directa de la LOREG, como son las normas generales sobre subvenciones, límites a las aportaciones privadas, y los gastos electorales. No se someten a dicha aplicación directa las reglas referentes al control, como el procedimiento de fiscalización por el Tribunal de Cuentas, pero sí el control por las Junta Electoral Central. ${ }^{495}$ Según el prof. GAVARA, por más que no sea un ámbito muy amplio de actuación el que corresponde al legislador autonómico, se constata la voluntad autonómica de disponer de una normativa completa, que se refleja en la reiteración de las disposiciones de la LOREG (tanto las de aplicación directa, como también algunas supletorias), junto con una cierta innovación en otras cuestiones. ${ }^{496}$

Un punto que ha despertado cierta polémica es lo dispuesto en el art. 131.2 de la LOREG, de aplicación directa, en donde se determina que, en caso de celebración conjunta de dos o más elecciones por sufragio directo y universal, las formaciones políticas que concurran a diversos de ellos no podrán realizar gastos electorales suplementarios en cuantías superiores a $25 \%$ de los máximos permitidos para las elecciones a las Cortes Generales. La instrucción de 15 de marzo de 1999 de la Junta Electoral Central fue uno de los intentos de aclarar la cuestión, sin que se haya logrado adoptar un criterio claro. ${ }^{497}$

En todo caso, y quizás por no contar con un amplio margen de actuación, pocas sorpresas se encontrarán en la legislación de las Comunidades Autonómicas, aunque hay notables excepciones. Con todo, de una manera general, los mecanismos permanentes de la LOREG también están presentes en dichas leyes, que a su vez también se ha mantenido otros beneficios, diversamente articulados, como es el caso del mailing. ${ }^{498}$

\footnotetext{
${ }^{494}$ Cfr. GAVARA DE CARA, J. C. “La Distribución...” Pp. 16.

495 Cfr. PAJARES MONTOLIO, E. "La Financiación y la Campaña Electoral en los Regímenes Electorales Autonómicos". In: Cuadernos de Derecho Público. № 22-23. may/dic. Madrid, 2004. Pp. 253.

${ }_{496}$ Cfr. GAVARA DE CARA, J. C.: La Homogeneidad de los Regímenes Electorales Autonómicos. CEPC, Madrid, 2007. Pp. 263.

${ }^{497}$ Cfr. PAJARES MONTOLIO, E. “La Financiación y la..." Pp. 257.

498 En este punto, PAJARES MONTOLIO repite las críticas realizadas al mailing de la LOREG. Cfr. PAJARES MONTOLIO, E. “La Financiación y la...” Pp.260.
} 


\subsection{Una ojeada a la legislación autonómica}

Para comprobar lo dicho anteriormente, se hace necesario un breve repaso de toda la legislación autonómica referente a la financiación electoral. Aunque exista Comunidades Autónomas que carecen de una doctrina que se ha interesado específicamente en el análisis de las leyes sobre financiación electoral propiamente dichas, es cierto que no hay mucho que añadir considerando el bajo nivel de innovación legislativa.

En el caso de Andalucía ${ }^{499}$, la figura del administrador electoral aparece bajo dos niveles: un administrador general para el caso de partidos, federaciones, coaliciones y agrupaciones en más de una provincia; y el administrador provincial, en una clara referencia al sistema existente en la LOREG. La misma similitud se puede constatar en la obligación de la apertura de una cuenta única para manejar los ingresos y gastos durante el periodo electoral. La financiación directa pública a cargo de la CC.AA. se basa en el doble criterio escaños/voto, considerando solamente los votos en candidaturas que originaron al menos un escaño. ${ }^{500}$ También hay límites de gastos electorales y la previsión de anticipaciones de las subvenciones debidas de $30 \%$ máximo de lo que el partido, federación y coalición haya recibido en las últimas elecciones. Existe la previsión de una subvención para el envío de sobres y propaganda directamente a los electores, cuando el partido, federación, coalición y agrupación de electores obtenga al menos un escaño en el Parlamento andaluz y supere el umbral de $5 \%$ del total de votos válidos emitidos. ${ }^{501}$ Con relación al control de las cuentas, todo partido, federación, coalición y agrupación de electores que hayan cumplido con los requisitos necesarios para acceder a la financiación electoral deberá presentar contabilidad detallada de los ingresos y gastos, acompañada de la correspondiente documentación.

\footnotetext{
${ }^{499}$ Cfr. Ley $1 / 86$, de 2 de Enero.

${ }^{500}$ En el valor de 2.300 .00 pesetas por escaño, y 85 pesetas por voto que la candidatura haya logrado, al menos, un escaño, en el art. 45. (13.823,27 y 0,51 euros).

${ }^{50} \mathrm{C}$ Cr. art. 47. Dicho valor no estará incluida en el límite global de gastos electorales, y los valores de las subvenciones varían conforme el porcentaje de votos que los partidos hayan logrado.
} 
La Cámara de Cuentas tiene un plazo de 30 días para verificarlos, y mientras tanto, será entregado a los respectivos administradores electorales el 90\% del importe de las subvenciones a los que cada entidad tiene derecho, considerando ya los nuevos resultados de las urnas. Sin embargo, en el acto de entrega de este anticipo, los partidos, coaliciones y federaciones deberán presentar un aval bancario de $10 \%$ del valor total de la subvención percibida, conforme también dispone el art. 133 de la LOREG. ${ }^{502}$

En Murcia ${ }^{503}$, también es necesario un administrador electoral general, sin que exista la previsión de un administrador provincial, independientemente del número de candidaturas presentadas. Permanece a sí mismos la obligatoriedad de apertura de una cuenta para manejar los ingresos y gastos de recursos durante el periodo electoral. ${ }^{504}$ La financiación electoral autonómica obedece al doble criterio de escaños/votos ${ }^{505}$, como también las subvenciones a los partidos, federaciones, coaliciones y agrupaciones de electores para el envío directo de sobres y papeletas electorales, o propaganda y publicidad. El criterio para acceder a dicha subvención es obtener al menos a un escaño en la Asamblea Regional, y tales valores no son considerados en el límite de gastos. ${ }^{506}$ El anticipo también está presente en la ley, en la cantidad de $30 \%$ del total a que el partido, federación, coalición y agrupación de electores hubiera tenido el derecho en las elecciones anteriores. Sin embargo, los partidos, federaciones, coaliciones y agrupaciones de electores que dispongan de representación en el Parlamento autonómico podrán solicitar un anticipo de 50\% para sufragar los gastos de envío de sobres y papeletas electorales, propaganda y publicidad, considerando los mismos criterios determinados para el anticipo anterior. ${ }^{507}$ Se trata de una disposición no común, ya que representa un anticipo de carácter finalista, que no puede ser utilizado para costear otros gastos, interpretándose la ley de manera restrictiva.

\footnotetext{
502 Cfr. art 48.3.

${ }^{503}$ Cfr. Ley 2/87, de 12 de Febrero.

${ }^{504}$ Cfr. arts. 32 y 34.

${ }^{505}$ Cfr. art. 35.1. Son 750.000 pesetas por escaño, y 40 pesetas por voto en candidaturas que dieron origen al menos a un escaño. Corresponde a 4.507,59 y 0,24 euros, respectivamente.

${ }^{506}$ Se considerará 25 pesetas $(0,15$ euros) por elector en cada circunscripción en la que haya candidaturas. Cfr. art. 35.3.

${ }^{507}$ Cfr. art. 36.2.
} 
El control de las cuentas debe ser hecho ante el Tribunal de Cuentas, con la entrega de la contabilidad detallada y debidamente documentada por parte de las organizaciones, en el plazo de 4 meses desde el fin de las elecciones. $^{508} \mathrm{La}$ administración autonómica entregará a los que tienen derecho a las subvenciones los recursos en su totalidad, pudiendo ser entregadas a los administradores electorales designados, o directamente a las entidades financieras que así hubieran sido notificados por la Junta Electoral para compensar créditos o anticipos existentes. Entretanto, antes de eso, en el plazo de 30 días, los partidos, federaciones, coaliciones y agrupaciones de electores podrán recibir el $90 \%$ del valor debido a titulo de subvención, aunque deberán presentar aval bancario de $10 \%$ sobre el valor a ser adelantado. ${ }^{509}$

En las Islas Baleares ${ }^{510}$, es obligatoria la indicación de un administrador de candidaturas para la gestión de las cuentas de la campaña, y si hay más de una candidatura, es necesario también un administrador general. El doble criterio permanece para la financiación electoral autonómica, a partir de los escaños obtenidos y de los votos que dieron origen por lo menos a un escaño. ${ }^{511}$ Además de esto, las subvenciones para el envío de sobres y papeletas electorales, como también de propaganda y publicidad también están a disposición de las organizaciones que hayan obtenido por lo menos un escaño en las circunscripciones en que presentaran candidaturas. Dicho gasto no se contabiliza en el límite global de gastos establecidos para el periodo electoral. ${ }^{512}$ También existe una disposición para permitir recibir un anticipo de las subvenciones, hasta el máximo de $30 \%$ del total a que cada organización tuvo derecho, considerando los anteriores resultados electorales.

Sobre el control, serán aplicados los plazos de la LOREG, y en el plazo de 30 días a partir del fin de las elecciones los partidos, federaciones, coaliciones y agrupaciones podrán obtener el anticipo de $90 \%$ del total de las

\footnotetext{
${ }^{508}$ Cfr. art. 37.

${ }^{509}$ Cfr. art. 38.3.

${ }^{510}$ Cfr. Ley 8/86, de 26 de Noviembre.

${ }^{511}$ Cfr. art. 29.1. Será de 1.500 .000 de pesetas por escaño, y 50 pesetas por votos que dieron origen al menos a un escaño. Corresponde a $9.015,18$ y 0,30 euros, respectivamente.

${ }^{512}$ Cfr. art. 29.3. La subvención era de 20 pesetas por elector, correspondiente a 0,12 euros.
} 
subvenciones a que tienen derecho, considerando los nuevos resultados electorales, siendo necesario el aval bancario de $10 \%$ sobre este valor. ${ }^{513}$

En la Comunidad Valenciana ${ }^{514}$ se producen algunas diferencias con relación al sistema articulado por la LOREG. Es necesario tanto el administrador de candidaturas, como el administrador general, en el caso de existir candidaturas en más de una circunscripción. La obligación de la cuenta bancaria para manejar el flujo de ingresos y gastos también permanece. La diferencia con las demás leyes es que la financiación autonómica directa no atiende al doble criterio escaños/votos, ya que serán subvencionados los votos a cada candidatura que haya logrado al menos un escaño y también los votos a las candidaturas que hayan alcanzado por lo menos el 3 por 100 emitidos válidamente en toda la Comunidad Autónoma. ${ }^{515}$ Esto es, no existe el requisito de lograr un escaño para acceder a la subvención electoral, lo que disminuye considerablemente la discriminación entre los partidos tan evidente en el resto de leyes sobre la materia, incluida la LOREG. Sin embargo, no existe subvención a título de envío de sobres y papeletas, propaganda y publicidad. La posibilidad de solicitar el anticipo de $30 \%$ considerando los resultados anteriores de las organizaciones se prevé en la ley autonómica, y el mecanismo de control de cuentas atiende más a las reglas contenidas en la LOREG. En el plazo de 30 días desde el cierre del período electoral, los partidos, federaciones, coaliciones y agrupaciones de electores que hubieran alcanzado los requisitos para acceder a las subvenciones deberán enviar la contabilidad y una documentación detallada de las cuentas, y no existe previsión para cualquier anticipo de subvenciones, siendo la cantidad total entregada al final del proceso. ${ }^{516}$

\footnotetext{
${ }^{513} \mathrm{Cfr}$. art. 31. Dicha normativa no innova mucho respecto a las disposiciones contenidas de la LOREG.

${ }^{514}$ Ley $1 / 87$, de 31 de Marzo.

${ }^{515} \mathrm{Cfr}$. art. 41. Para cada escaño, la administración les otorga 1.000 .000 de pesetas, y para los votos a ser contabilizados, 50 pesetas, correspondiendo a 6.010,12 y 0,30 euros, respectivamente.

${ }^{516}$ Cfr. art. 44.3.
} 
Lo que destaca en esta legislación autonómica es la densidad normativa sobre el control, incluyendo eventuales ilícitos que puedan ser detectados, con la previsión de que se dé cuenta al Ministerio Fiscal. ${ }^{517}$

En Castilla La Mancha ${ }^{518}$, es necesario tanto el administrador electoral como también el administrador provincial, en caso de presentar candidaturas en más de una provincia, y estos deberán indicar la cuenta bancaria abierta exclusivamente para la gestión de los recursos empleados en la campaña electoral. ${ }^{519}$ La financiación pública autonómica sigue la tendencia del doble criterio escaños/votos ${ }^{520}$, como también se determina una subvención para el envío directo de sobres, papeletas, propaganda y publicidad para los electores. Es de resaltar que, en línea con las demás normativas autonómicas, los gastos de dicho envío no serán contabilizados en el límite global de gastos electorales. Lo que llama la atención es la disposición de que las subvenciones electorales no puedan sobrepasar el valor de los gastos electorales. En este caso, la diferencia de valores será detraída de las subvenciones debidas. También es posible solicitar un anticipo de $30 \%$ del valor de las subvenciones debidas considerando los resultados pasados.

Con relación al control, entre los 100 y 125 días posteriores al proceso electoral, los partidos, federaciones, coaliciones y agrupaciones de electores que hubieran alcanzados los requisitos para acceder a la financiación pública deben entregar una contabilidad detallada y debidamente documentada, ante la Sindicatura de Cuentas. Con todo, en el plazo de 30 días posteriores a la presentación de las cuentas, las organizaciones pueden solicitar un anticipo de las subvenciones a los que tienen derecho, considerando los resultados obtenidos, en un $90 \%$ del valor total, lo que solamente será aprobado si la solicitud viniera acompañado de un aval bancario. ${ }^{521}$ No hay previsiones de

\footnotetext{
517 Cfr. art. 45.3.

${ }^{518}$ Cfr. Ley $5 / 86$, de 23 de Diciembre.

${ }^{519}$ Cfr. art. 45,46 y 49.

${ }^{520}$ Cfr. art. 50, que determina valores de 1.500 .000 de pesetas por escaño y 70 pesetas por voto en las circunscripciones donde se haya obtenido al menos a un escaño, lo que corresponde a $9.015,18$ y 0,42 euros, respectivamente.

${ }^{521}$ Cfr. art. 53.
} 
sanciones para el incumplimiento de las leyes de financiación por parte de las entidades. $^{522}$

En Castilla y León ${ }^{523}$ existe la previsión del administrador electoral y provincial, para candidaturas en más de una circunscripción, pero no la obligatoriedad de la apertura de una cuenta bancaria para el control y registro de ingresos y gastos. ${ }^{524}$ A la hora de interpretar dicha ausencia, se debe considerar que las lagunas en las leyes autonómicas deben ser suplidas por las reglas contenidas en la LOREG, es decir, se mantendrá la obligatoriedad de la apertura de la cuenta bancaria, existiendo o no disposición expresa en este sentido a nivel autonómico. La financiación pública atiende también al doble criterio de escaños/votos ${ }^{525}$, como también se mantiene las subvenciones para el envío de sobres, papeletas, propaganda y publicidad directamente a los electores. Es de destacar que no existe ninguna la mención sobre si dicho gasto será o no contabilizado en el límite de gastos global en que cada organización debe cumplir. Dada dicha ausencia, se entiende que dicho gasto no deberá ser considerado en el valor total, dado el valor supletorio de la LOREG. Del mismo modo, existe la posibilidad de obtener anticipos de las subvenciones, en el máximo de $30 \%$ del total debido considerándose los resultados de las elecciones anteriores. ${ }^{526}$

En relación al control de las cuentas, el plazo es de 100 a 125 días desde el fin de las elecciones para que los partidos, federaciones, coaliciones y agrupaciones de electores entreguen la contabilidad y la documentación correspondiente al Tribunal de Cuentas, y en el plazo de 30 días desde el fin del periodo electoral existe la posibilidad de solicitar el anticipo de las subvenciones debidas en el importe de 45\%, sin la necesidad de aval

\footnotetext{
${ }^{522}$ En este punto, MAGÁN PERALES entiende que, en el afán de detallar los gastos electorales a fin de facilitar el control de estos por parte de la entidad fiscalizadora, la LOREG en su art. 130 ha dejado mucho margen para la indeterminación, lo que acabó por ser transferido a las reglas de financiación de Castilla-La Mancha. Cfr. MAGAN PERALES, J. M. A. "Derecho Electoral y Partidos Políticos en Castilla-La Mancha". In: Revista Jurídica de Castilla-La Mancha. no 42. Sept. 2007. Pp. 161 y ss.

${ }^{523}$ Cfr. Ley $3 / 87$, de 30 de Marzo.

${ }^{524}$ Cfr. art. 44.

${ }^{525}$ Cfr. art. 45.1. Los valores otorgados son 1.000 .000 de pesetas por escaño y 40 pesetas por voto en las candidaturas que hayan obtenido un escaño al menos, lo que representa 6.010,12 y 0.24 euros, respectivamente.

${ }^{526}$ Cfr. art. 46.
} 
bancario. ${ }^{527}$ Cabe subrayar que la cantidad otorgada por esta Comunidad Autónoma es la mitad de la que comúnmente se posibilita en otras legislaciones en este nivel, lo que puede ser positivo, ya que mientras las organizaciones tengan deudas que afrontar, intentarán que el resultado del proceso de fiscalización termine cuanto antes, y entregarán notablemente con más diligencia una contabilidad detallada acompañada de la documentación necesaria para su evaluación.

El sistema previsto en Extremadura ${ }^{528}$ es bastante semejante al aplicable en Castilla y León, con algunas variantes significativas. No existe la figura del administrador provincial, sino sólo la del administrador electoral, y se vuelve a prever la obligatoriedad de apertura de una cuenta bancaria para el manejo de los valores durante el periodo electoral. ${ }^{529} \mathrm{El}$ doble criterio de escaños/votos persiste ${ }^{530}$, sin la previsión de cualquier otra subvención, pero viene acompañada con la posibilidad de solicitar el anticipo de valores, basados en los resultados de las elecciones anteriores, en el montante máximo de $30 \%$ sobre el valor total de subvenciones anteriormente debidas. Ya con relación al control de las cuentas, en el plazo máximo de 4 meses, las organizaciones que hubieran alcanzado los requisitos para acceder a la financiación pública deberán presentar ante el Tribunal de Cuentas la correspondiente contabilidad, que deberá sujetarse en los principios generales del Plan General de Contabilidad. ${ }^{531}$ Se trata de una innovación importante para la eficiencia de la función de fiscalización, a la vez que facilita y uniformiza las informaciones que serán manejadas por el Tribunal de Cuentas. De hecho, lo más correcto sería que dicha disposición estuviera directamente en la LOREG, condicionando al resto de las Comunidades Autónomas a adoptar este parámetro de presentación de datos, y fomentando concretamente la función fiscalizadora ejercida por el Tribunal. Por fin, en el mismo sentido que la legislación de Castilla y León, existe la posibilidad de solicitar el anticipo de

\footnotetext{
${ }^{527}$ Cfr. art. 49.3.

${ }^{528}$ Cfr. Ley 2/87, de 16 de Marzo.

${ }^{529}$ Cfr. art. 48 y 51.1.

${ }^{530}$ Cfr. 52. La cantidad por cada escaño obtenido es de 1.000 .000 pesetas, y de 40 pesetas por voto en candidaturas que hayan obtenido al menos a un escaño. Esto corresponde a 6.010,12 y 0,24 euros respectivamente.

${ }^{531} \mathrm{Cfr}$. art. 55.
} 
$45 \%$ del total de la subvención debida considerando los resultados recientes de las elecciones, en el plazo de 30 días desde la entrega de la documentación requerida. ${ }^{532}$

En la Comunidad de Madrid $^{53}$ se producen algunas diferencias que llaman la atención por su originalidad. ${ }^{534}$ Es necesario, lógicamente, un administrador electoral, y la obligatoria apertura de cuenta para la gestión de los recursos utilizados en la campaña. ${ }^{535}$ Con relación a la financiación pública, continua prevaleciendo el doble criterio escaños/votos, con la previsión de la subvención a título de envío de sobres, papeletas, propaganda y publicidad directamente a los electores para las organizaciones que obtengan por lo menos un $3 \%$ de los votos sobre las candidaturas presentadas, lo que significa que no hay obligatoriedad de lograr un escaño. Además, caben destacarse dos aspectos concretos: el primero se refiere a la excepción contenida en el art. 22.2 de la Ley autonómica, de que la subvención para el envío de sobres y demás documentos se producirá cuando las elecciones para la Asamblea de Madrid no concurran con ningún otro tipo de proceso electoral. De este modo, por la redacción contenida en el texto de la ley, se entiende que en el caso de acumulación de procesos electorales - como para la Asamblea de Madrid y para las Cortes Generales - solamente se abonaría la subvención prevista en la LOREG, lo que cabe entender como una medida positiva, considerando que se trata de una subvención de carácter finalista, y habiendo esta prohibición, evita que los partidos y las demás organizaciones utilicen las cantidades otorgadas por la Comunidad Autónoma con fines distintos, además de ser una medida de control de flujo de recursos públicos hacia dichas entidades.

El segundo punto a destacar es el art. 22.4, que determina que la subvención o la suma de las subvenciones debidas en elecciones coincidentes a los partidos, federaciones, coaliciones y agrupaciones de electores no deben sobrepasar la cifra de gastos electorales declarados justificado por el Tribunal de Cuentas. La redacción de la ley no resulta clara, lo que puede dejar el

\footnotetext{
${ }^{532}$ Cfr. art. 56.5 .

${ }^{533}$ Cfr. Ley $11 / 86$, de 16 de Diciembre.

${ }^{534}$ Punto curioso es la remisión expresa al límite de gastos contenido en la LOREG (arts. 55 y

58) en su art. 21.4. No se ha considerado la supletoriedad, pero sí se ha asegurado su aplicación directa, aunque sin necesidad.

${ }^{535}$ Cfr. art. 19.
} 
camino abierto a muchas opciones, "vaciando" una norma que podría ser útil para el sistema. ${ }^{536}$ La interpretación más correcta parece ser la de que las cantidades concedidas a título de subvenciones no deben ser mayores que el valor de los gastos. Sin embargo, se puede entender que las subvenciones acabarán costeando todos los gastos de las organizaciones, incluso debido a la imprecisión de la propia LOREG en la determinación de lo que sería un gasto electoral, dejándolos a cargo del Estado y haciendo que los partidos, una vez más, se sientan libres de la obligación de buscar el apoyo social para la financiación de su campaña. Es una alternativa muy peligrosa que, nuevamente, puede poner en jaque el sistema elegido. Además de dichas disposiciones, existe la posibilidad de solicitud un anticipo con el máximo 30\% de la cantidad debida en las elecciones anteriores. También está presente en la ley la posibilidad de solicitar el anticipo de las subvenciones debidas por un importe máximo de $80 \%$ del total calculado con base en los resultados de las últimas elecciones celebradas. ${ }^{537}$

En la Comunidad Autónoma de Aragón ${ }^{538}$ la legislación se adecua en mayor medida a los rasgos comunes presentes en mayor parte del resto de las leyes autonómicas. Es necesario un administrador electoral y de un provincial, junto con la apertura de una cuenta bancaria para los recursos utilizados con fines electorales. El doble criterio de escaños/votos también es utilizado en la financiación pública ${ }^{539}$, como también la previsión de subvención para el envío de sobres, papeletas, propaganda y publicidad directa para los electores. ${ }^{540} \mathrm{~A}$ diferencia con otras leyes anteriormente expuestas dicha subvención finalista solamente se concede si los partidos han obtenido un número suficiente de diputados para formar un grupo parlamentario. Se trata de la adopción del criterio contenido en la LOREG, y que no es nada favorable respecto a la igualdad de trato entre las fuerzas políticas a nivel autonómico. Cabe reiterar

\footnotetext{
${ }^{536}$ El texto de dicha norma legal es: "4. En ningún caso la subvención, o la suma de las subvenciones percibidas en el supuesto de elecciones coincidentes, correspondiente a cada partido, federación, coalición o agrupación podrá sobrepasar la cifra de gastos electorales declarados justificados por el Tribunal de Cuentas en el ejercicio de su función fiscalizadora".

${ }^{537}$ Cfr. arts. 23, 24 y 25.

${ }^{538}$ Cfr. Ley 2/87, de 16 de Febrero.

${ }^{539}$ Cfr. art. 39.1. Los valores en euros serían $6.010,12$ por escaño y 0,36 por voto en la candidatura que haya obtenido al menos a un escaño.

${ }^{540}$ Cfr. art. 39.2.
} 
que dicho gasto no está incluido en el cómputo del límite global de gastos impuesto a cada entidad política. La posibilidad del anticipo también está presente en la normativa, y no podrá ser superior al $30 \%$ de la cantidad debida a título de subvención en las elecciones anteriores. La rendición de cuentas sigue el plazo de 100 a 125 días posteriores al proceso para la entrega de la contabilidad y de la documentación debida, y que en los 30 días posteriores a las elecciones es posible solicitar el importe del $90 \%$ de la subvención a que se tiene derecho considerando los resultados recientes. Para esta solicitud, el partido, federación, coalición o agrupación de electores deberán presentar un aval del $10 \%$ sobre la cantidad total de la subvención debida. ${ }^{541}$ Aquí la dificultad se centra en el cálculo del límite de gastos de los partidos, considerando que las elecciones autonómicas suelen coincidir con las locales y al Parlamento Europeo, y dado que el legislador autonómico no ha fijado criterios armonizadores de la simultaneidad de procesos electorales, se acaba por aplicar la sistemática de la LOREG. Junto a esto, la cuestión quizás más problemática es la referida al control de las cuentas de los partidos, ya que el Tribunal de Cuentas constantemente apunta a las deficiencias de las informaciones apartadas, que acaban por frustrar la transparencia exigida en dichas operaciones. ${ }^{542}$

La legislación vuelve a tener diferencias significativas en la Comunidad Foral de Navarra. ${ }^{543}$ Los rasgos comunes de obligación de un administrador electoral y de la apertura de una cuenta bancaria para la gestión de fondos continúan, como también la previsión de la posibilidad de obtención de un anticipo de las subvenciones, en el máximo de $30 \%$ sobre el valor total debido en las elecciones anteriores. ${ }^{544}$ Sin embargo, la ley incorpora una disposición inédita en su artículo 42 , en lo cual la normativa define qué será considerado como un gasto electoral. Aunque utilice términos muy semejantes a los

\footnotetext{
${ }^{541}$ Cfr. art. 41.

${ }^{542}$ Cfr. CHUECA, R. "La Financiación Electoral". In: CHUECA, R.; RAMÓN MONTERO, J. (eds.): Elecciones Autonómicas en Aragón. Tecnos, Madrid, 1995. Pp. 99 y ss.; CHUECA RODRIGUEZ, R. "Elecciones a Cortes de Aragón: Régimen Jurídico y Sistema Electoral". In: Derecho Público Aragonés. Dykinson, Madrid, 2000. Pp. 24-26; y CHUECA RODRIGUEZ, R. "Régimen Electoral de la Comunidad Autónoma de Aragón". In: Derecho Público Aragonés. Dykinson, Madrid, 2005. Pp. 145 y ss.

${ }_{544}$ Cfr. Ley 16/86, de 17 de Noviembre.

${ }^{544}$ Cfr. art. 38,41 y 45.
} 
utilizados en la LOREG, existe una diferencia que es relevante para su interpretación: la LOREG considera un gasto electoral aquél que es realizado por un partido, federación, coalición o agrupación de electores, desde el día de la convocatoria hasta la proclamación de los electos. Con todo, en el art. 42 este período es limitado desde la convocatoria de las elecciones hasta el día de la votación, siendo un tiempo menor que el previsto en el régimen general. Respecto a la financiación pública, el doble criterio de escaños/votos se mantiene, como también la previsión de subvenciones para el envío directo de sobres, papeletas, propaganda y publicidad, siendo que este gasto no será contabilizado en el límite global de gastos, como es comúnmente adoptado por las legislaciones autonómicas. ${ }^{545}$ Una de las diferencias significativas aparece si se compara la redacción del art. 44.4 de esta ley con el art. 22.4 de la ley electoral de la Comunidad de Madrid. Como ya se expuso anteriormente, la redacción de la legislación madrileña no favorece una buena interpretación sobre cuál sería realmente la intención del legislador, lo que no ocurre en la legislación de Navarra, que deja claro que no se concederán subvenciones que superen la cifra de gastos electorales efectivamente realizados. ${ }^{546}$

Otra diferencia digna de elogio aparece respecto al control de las cuentas que deben presentarse a la Cámara de Comptos, que no se limita a prever la entrega de una contabilidad detallada acompañada de la documentación correspondiente, sino que también enumera los documentos que deberán ser obligatoriamente presentados, constituyendo un listado bastante completo, que engloba libro de registro de ingresos y gastos, relación de deudores, estado-resumen de ingresos por conceptos, estado-resumen de gastos por los conceptos individualizados a que se refiere el artículo 130 de la LOREG, arqueo de fondos, documentos justificativos, relación de cuentas electorales, extractos de movimientos bancarios y declaración de que la documentación presentada comprende la totalidad de los ingresos y gastos electorales. Por otra parte, la ley impone plazos más reducidos para la entrega

\footnotetext{
${ }^{545}$ Cfr. arts. 43.4 y 44 . El valor de la financiación pública es de 750.000 pesetas por escaño y 60 pesetas por votos obtenidos por candidaturas que dieron origen por lo menos a un escaño, traducidos en $4.507,59$ y 0,36 euros, respectivamente.

${ }^{546}$ La disposición que se menciona es: "4. En ningún caso se concederán subvenciones que superen la cifra de gastos electorales efectivamente realizados.”.
} 
de dicha documentación, de solamente dos meses desde la votación, siendo que en los 30 días posteriores a la presentación de este dosier se puede solicitar un anticipo de las subvenciones en el importe máximo de $45 \%$ del total a que se tiene derecho. Es decir, considerando la especificidad de lo que debe ser entregado, junto con la posibilidad de anticipo de subvenciones solamente después de la entrega de la documentación, se fomenta que los partidos cumplan el plazo de dos meses, permitiendo que la fiscalización de las cuentas se agilice, sin que ello comprometa su calidad, ya que la rapidez del procedimiento no depende de la Cámara de Comptos, sino sí de los propios partidos.

Otra disposición que no se contempla en las demás leyes autonómicas es la del art. $47.2^{547}$, que prevé la posibilidad de que, en caso de irregularidades o violación de los limites antes establecidos, la Cámara de Comptos pueda proponer la denegación o la reducción del valor de las subvenciones correspondientes a una organización, como también permite comunicar al Ministerio Fiscal cualquier violación que de origen a un delito. Aunque no sea una medida que traduzca fielmente la potestad de imponer una sanción real a quien no observe la norma, se trata, sin duda ninguna, de una facultad que por lo menos posibilita al ente fiscalizador tomar algún tipo de actitud ante la inobservancia de alguna de las normas legales impuestas.

En la ley electoral de La Rioja ${ }^{548}$ se verifican características comunes, como la necesidad de administrador electoral, y la apertura de cuenta bancaria para la gestión de recursos. También aparece el doble criterio de escaños/votos para la financiación pública ${ }^{549}$, así como la existencia de subvenciones para el envío directo de sobres y demás documentos directamente para los electores sin que esto sea contabilizado en el límite global de gastos, siempre que dicho envío esté justificado, en caso contrario, será incluido en el límite de gastos. Existe, como en las legislaciones de la

\footnotetext{
${ }^{547}$ El texto del artículo que se menciona es: "2. En el supuesto de que la Cámara de Comptos apreciase irregularidades contables o violación de los límites establecidos en materia de ingresos y gastos electorales, podrá proponer la denegación o la reducción de la subvención correspondiente al partido político, federación, coalición o agrupación de electores de que se trate. Si advirtiese, además, indicios de conductas constitutivas de delito, lo comunicará al Ministerio Fiscal.".

${ }_{548}$ Cfr. Ley 3/91, de 21 de Marzo.

${ }^{549}$ Los valores en euros, serían, respectivamente, $5.709,61$ y 0,45.
} 
Comunidad de Madrid y Navarra, y en el art. 47.1, la permisión de que no es posible que el valor de las subvenciones sea superior al valor de los gastos electorales, pero su redacción tampoco favorece un entendimiento univoco y, por otra parte, en este caso en vez de considerar como destinarios de la subvención a los partidos, federaciones, coaliciones y agrupaciones de electores - como es lo más común - la ley alude al "grupo político", no especificando exactamente quien está englobado en dicha categoría. ${ }^{550} \mathrm{Se}$ trata claramente de un empleo inadecuado del término que puede perjudicar bastante la aplicación de dicha disposición en la práctica. Otra diferencia que en relación con la mayoría de las leyes autonómicas sobre el tema es en la subvención por envío directo de sobres, papeletas, propaganda y publicidad a los electores, es que solamente podrán acceder a dicho beneficio las candidaturas que hubieran obtenido por lo menos dos escaños. ${ }^{551}$

La posibilidad de solicitar un anticipo de como máximo el 30\% sobre la cantidad debida a titulo de subvenciones en las elecciones anteriores está presente en la norma, y por último en relación al control de cuentas, lo único que merece destacarse es el art. 51.3, que obliga a las entidades financieras que hubieran concedido créditos al envío de los elementos de la transacción al Tribunal de Cuentas, como también la obligatoriedad de las empresas que hayan facturado con los partidos, federaciones, coaliciones y agrupaciones de electores superiores al millón de pesetas (6.010,12 euros) de informar al Tribunal de Cuentas de los datos que puedan ser necesarios para la fiscalización. ${ }^{552}$ Por su parte, el plazo para la presentación de dosier sigue siendo de 100 a 125 días posteriores a las elecciones, siendo posible solicitar el anticipo de las subvenciones debidas en el plazo de 30 días desde la presentación de la documentación. ${ }^{553}$

\footnotetext{
${ }^{550}$ El texto que se comenta es: "En ningún caso, la subvención correspondiente a cada grupo político podrá sobrepasar la cifra de gastos electorales declarados, justificados por el Tribunal de Cuentas en el ejercicio de su función fiscalizadora.".

${ }_{551}$ Cfr. art. 47.2.

552 El texto del artículo mencionado es: "3. Las entidades financieras de cualquier tipo que hubieran concedido crédito a aquellos partidos, federaciones, coaliciones o agrupaciones de electores enviarán noticia detallada de los mismos al Tribunal de Cuentas, dentro del plazo referido en el apartado 1 de este artículo. 4. En los mismos términos deberán informar al Tribunal de Cuentas las empresas que hubiesen facturado con aquellos partidos, federaciones, coaliciones o agrupación de electores, por gastos superiores al millón de pesetas." ${ }^{553}$ Cfr. art. 51.
} 
En Galicia ${ }^{554}$ también existe la obligación de designar a un administrador electoral y uno general, en el caso de más de una candidatura, como también la necesidad de la apertura de una cuenta bancaria para registrar el flujo de recursos económicos destinados a la campaña. ${ }^{555}$ El doble criterio escaños/votos es adoptado también para la financiación pública ${ }^{556}$, así como la previsión de la subvención destinada al envío de sobres, papeletas, propaganda y publicidad directamente a los electores. ${ }^{557}$ La posibilidad de solicitar un anticipo de hasta el $30 \%$ de las subvenciones debidas en las elecciones anteriores se mantiene y, con relación al control de cuentas, el plazo es de cuatro meses para la entrega de la contabilidad y documentación por parte de las organizaciones permanece. La diferencia está que la contabilidad deberá ser entregada y evaluada por el Consejo de Cuentas, con un plazo de un mes desde la entrega de la contabilidad para que se soliciten las informaciones y datos necesarios para el análisis de los dossiers. La resolución sobre la contabilidad debe producirse en siete meses, y el Consejo de Cuentas podrá sugerir la reducción de las subvenciones en caso de inobservancia de alguna de las normas. ${ }^{558}$ No hay ninguna disposición sobre un posible anticipo de las subvenciones antes del término del análisis de la documentación correspondiente.

En el caso del Principado de Asturias ${ }^{559}$, nos encontraremos ante las disposiciones más breves sobre la materia, previendo solamente la necesidad de un administrador electoral y el doble criterio escaños/votos para la financiación pública ${ }^{560}$, sin ninguna otra subvención. El control de cuentas es competencia del Tribunal de Cuentas ${ }^{561}$, sin posibilidad de anticipo de las

\footnotetext{
${ }^{554}$ Cfr. Ley 8/85, de 13 de Agosto.

${ }^{555}$ Cfr. arts. 39, 40 y 43.

${ }^{556}$ Los valores son 2.000 .000 de pesetas para cada escaño y 75 pesetas por cada voto en candidaturas que dieron origen al menos a un escaño. Esto corresponde a 12.020,24 y 0,45 euros, respectivamente.

${ }^{557}$ Cfr. art. 44.2.

${ }^{558558}$ Cfr. art. 47.

${ }^{559}$ Cfr. Ley $14 / 86$, de 26 de Diciembre.

${ }^{560}$ La cantidad asignada por escaño es de 1.000 .000 de pesetas, y del voto en las candidaturas que originaron al menos un escaño es de 50 pesetas, representando 6.010,12 y 0,30 respectivamente.

561 Sin embargo, en la ley del Principado de Asturias consta como función de la Sindicatura de Cuentas autonómica dicha función, que, sin embargo, no está presente en la ley electoral. Además, aunque la ley determine que el resultado de la fiscalización se remita a la Comisión de Reglamento de la Junta General, en la práctica no llega a ella, ya que solamente se traslada
} 
subvenciones debidas. Sorprende, sin embargo, que el artículo 37.2 se refiera a un posible anticipo considerando las subvenciones debidas en las elecciones anteriores, sin que se haga referencia a un máximo sobre el total que los partidos, federaciones, coaliciones y agrupaciones de electores puedan solicitar. Siendo así, debe interpretarse conforme a las disposiciones de la LOREG, que fijan un máximo del $30 \%$ sobre el valor total de la subvención percibida anteriormente, seguido en esto de gran parte de la legislación autonómica sobre el tema.

En Cantabria ${ }^{562}$, resulta llamativa la ausencia de disposiciones sobre la necesidad de un administrador electoral y de una cuenta bancaria para la gestión de recursos, una necesidad que debe entenderse implícita bajo los dictámenes de la LOREG. Se recoge el doble criterio de escaños/votos para la financiación pública ${ }^{563}$, así como la posibilidad de un anticipo de un máximo del $30 \%$ sobre el valor total de las subvenciones debidas en las elecciones anteriores. ${ }^{564}$ Sin embargo, lo que llama la atención son las similitudes con la legislación de la Comunidad Foral de Navarra y de La Rioja. Como en Navarra, la ley de gastos electorales también establece una definición legal de gasto electoral, y el periodo estipulado para realizar un gasto electoral no es hasta la proclamación de los electos, como en el Régimen Electoral General, sino hasta el día de la votación. ${ }^{565}$ Cabe pues reproducir las críticas realizadas a la legislación de Navarra. En línea con la legislación de La Rioja, el art. 39.3 dispone que las subvenciones correspondientes a cada "grupo político" no podrán sobrepasar la cifra de gastos electorales declarados justificados por el Tribunal de Cuentas. No queda claro tampoco aquí si se refiere a los partidos, federaciones, coaliciones o agrupaciones de electores, o si se refiere a los grupos político del Parlamento Autonómico y la subvención que estos reciben y que acaban ingresando una parte para los partidos. En relación al control de

a los grupos parlamentarios. Por último, pese a lo dispuesto en el art. 41.2, que determina la presentación de un proyecto de ley estableciendo el crédito extraordinario por las subvenciones a adjudicar no hubo ningún proyecto de ley de esta naturaleza. (In: ARCE JAÑARIZ, Alberto. El Régimen Electoral del Principado de Asturias. In: Cuadernos de Derecho Público. № 22-23. may/dic. Madrid, 2004. Pp. 371).

${ }^{562}$ Cfr. Ley 5/87, de 27 de Marzo.

${ }^{563}$ Son 750.000 pesetas por escaño y 70 pesetas por cada voto en las candidaturas que dieron origen al menos a un escaño. Esto son $4.507,59$ y 0,42 euros, respectivamente.

${ }^{564}$ Cfr. art. 40.

${ }^{565}$ Cfr. art. 37. 
las cuentas, prácticamente se remite a la aplicación directa de la LOREG, existiendo también la posibilidad, en el plazo de 30 días desde la presentación de la contabilidad y documentación referente, de solicitar un anticipo de las subvenciones debidas, en el máximo de $60 \%$ del total. ${ }^{566}$

En las Islas Canarias ${ }^{567}$ se verifica que, por la menor antigüedad de la norma, algunos criterios comunes en las demás legislaciones son traspasados con modificaciones a la misma. La necesidad del administrador electoral y de la apertura de una cuenta bancaria para el flujo de recursos permanece. ${ }^{568} \mathrm{Sin}$ embargo, se establece que la contabilidad que deben aportar las organizaciones políticas deberá seguir el Plan General de Contabilidad vigente, ayudando en la función fiscalizadora que será realizada posteriormente. ${ }^{569}$ Respecto a la financiación pública, se observa un incremento significativo en el valor de las subvenciones, siendo segunda norma más generosa de todas las Comunidades Autónomas, arbitrando el valor de 17.484 euros por cada escaño obtenido, y 0,65 euros por cada voto en candidaturas que hayan obtenido al menos un escaño. ${ }^{570}$ Otro punto a destacar gira en torno a la subvención para el envío directo de sobres, papeletas, propaganda y publicidad para los electores. La sistemática adoptada tanto para determinar el valor es diferente de la de otras disposiciones, pues de fijar valores también generosos por voto obtenido, los criterios de acceso no son comunes. ${ }^{571}$ Para tener acceso a dicha subvención existen dos vías: los partidos, federaciones, coaliciones y agrupaciones de electores tendrán que haber alcanzado el $5 \%$ del total de votos válidos emitidos en la Comunidad Autónoma, o el 20\% de los votos válidos emitidos en la respectiva circunscripción electoral. Dependiendo de la vía por la que se obtenga el derecho a la subvención, los valores cambian, aumentando conforme su clasificación: 0.08 euros por cada elector de la respectiva circunscripción electoral, cuando la organización haya obtenido de $5 \%$ a $10 \%$ de los votos válidos emitidos en la Comunidad Autónoma; 0,11 euros por elector cuando se supera estos $10 \%$, hasta $15 \%$; 0,14 euros cuando

\footnotetext{
${ }^{566}$ Cfr. art. 41.2.

${ }^{567}$ Cfr. Ley $7 / 2003$, de 20 de Marzo.

${ }^{568}$ Cfr. art. 28.1 y 29.

${ }^{569}$ Cfr. art. 28.2.

${ }^{570}$ Debido al año de aprobación de la ley, los valores ya están previstos en euros. Cfr. art. 31.2.

${ }^{571}$ Cfr. art. 31.2.
} 
el resultado supere el $15 \%$ hasta $20 \%$; y 0,16 euros cuando se supera el $20 \%$ de los votos válidos emitidos en la Comunidad Autónoma. Así, tanto el criterio de acceso como la determinación del valor debido considerando solamente los votos priorizan la representatividad de la organización política, siendo bastante más democrático que el doble criterio empleado para la subvención electoral propiamente dicha.

En relación a la posibilidad de obtener anticipos, también se produce una diferencia con respecto de las otras legislaciones ya analizadas. La posibilidad de solicitar dicho beneficio también depende de dos vías: para las organizaciones que hayan participado en las elecciones anteriores y hayan logrado al menos un representante, o los que no habiendo concurrido, acrediten ante la Junta Electoral de Canarias que cuentan con diputados en la última composición del Parlamento disuelto o cuyo mandato expirará. ${ }^{572}$ Aunque tampoco abra espacio para nuevas organizaciones, hay que reconocer la amplitud del criterio, posibilitando que otras fuerzas políticas también accedan a este beneficio, lo que fomenta el equilibrio de condiciones entre los competidores. Con todo, el máximo que se puede solicitar sigue siendo de $30 \%$ sobre el valor total de las subvenciones debidas anteriormente, pero aún en este punto hay una innovación: la posibilidad de la Junta Electoral de tomar en consideración otro valor para nuevas situaciones que no están previstas en la Ley. Nuevamente cabe destacar la apertura de la norma. Con relación a las demás reglas sobre el control de cuentas, se sigue la tendencia de las otras Comunidades Autónomas, o sea, de 100 a 125 días desde el fin del período electoral para la presentación de la contabilidad detallada y documentada ante la Audiencia de Cuentas de Canarias, como también la presencia de la posibilidad de, en los 30 días posteriores a la entrega del dossier, solicitar el anticipo de las subvenciones debidas, con un máximo del $45 \%$ de la cantidad total. ${ }^{573}$

La más clara diferencia con la legislación autonómica sobre el tema se produce en la ley del País Vasco y Territorios Históricos. ${ }^{574}$ Se trata de la ley más detallada sobre financiación electoral, siguiendo parámetros establecidos

\footnotetext{
${ }^{572}$ Cfr. art. 32.1.

${ }^{573}$ Cfr. art. 33.3.

${ }^{574}$ Cfr. Ley 5/90, de 15 de Junio.
} 
en la LOREG, pero ampliándolos. ${ }^{575}$ Como se trata de una normativa exhaustiva en comparación con las demás ${ }^{576}$, únicamente se resaltarán aquí los elementos más relevantes sobre nuestro objeto de estudio. ${ }^{577}$

Se amplía la obligatoriedad del administrador electoral es ampliada, porque no solamente es necesario uno, sino que también debe ser designado un suplente, y en caso de candidaturas en diversos territorios históricos, en cada uno de ellos deberá haber otro administrador electoral y un suplente. ${ }^{578}$ La regulación sobre las cuentas electorales también es detallada, disponiendo que la contabilidad deberá atender al Plan General Contable vigente, además de establecer los elementos básicos que deberá contener. ${ }^{579} \mathrm{Al}$ tratar de los ingresos y otras fuentes, la norma contempla un listado bastante completo de cómo dichas informaciones deberán aparecer en los informes, aunque sin mencionar directamente la cuestión de identificación del donante. Al tratar de las cuentas abiertas para el manejo de recursos, la ley muchas veces remite a los términos utilizados en la LOREG, como en la determinación de que las reclamaciones por gastos electorales que no sean notificados a los administradores electorales en el plazo de los 60 días siguientes a la votación serán considerados como nulas y no abonables ${ }^{580}$, como ocurre con el art. 125.4 de la LOREG, y los adelantos podrán concederse antes de la campaña, en un máximo del $30 \%$ del valor total de las subvenciones debidas en las elecciones anteriores, o como el anticipo de hasta $90 \%$ del total de las subvenciones debidas basadas en los resultados recién conseguidos,

\footnotetext{
${ }^{575}$ FERNÁNDEZ VIVAS afirma que se trata de una excepción al sistema establecido por la LOREG. Sin embargo, más bien parece que nos encontramos ante particularidades que ante una verdadera excepción. Cfr. FERNÁNDEZ VIVAS, Y.: Op. Cit. Pp. 339.

576 La diferencia entre las disposiciones legales fue reconocida por el gobierno vasco tanto en la ley electoral anterior (28/1983 de 25 de noviembre) como en la ley $5 / 1990$, actualmente vigente. El recelo a una eventual inseguridad jurídica es abordado en la exposición de motivos de ambas leyes debido no solo a la fragmentación legislativa, sino también a un conflicto de comportamiento por parte de los electores, acostumbrados a otro sistema. Sin embargo, en la primera ley la justificación es por la ausencia de innovación en el momento de la elaboración de la norma, lo que no ocurre en la segunda ley.

577 La legislación electoral vasca es la más extensa de las normativas autonómicas, pero a costa de reproducir muchas de las reglas de la LOREG. Sin embargo, es la comunidad autónoma que más ha aprovechado sus espacios de decisión. En este sentido, cfr. PAJARES MONTOLIO, E. "La Financiación y la..." Pp. 242 y PRESNO LINERA, M. Á. "Nuevos Estatutos..." Pp. 135.

${ }^{578}$ Cfr. art. 138. 2.

${ }^{579}$ Cfr. art. 140.1.

${ }^{580}$ Cfr. art. 142.4.
} 
manteniendo la tradicional obligatoriedad del aval bancario del $10 \%$ en el caso del segundo adelanto. ${ }^{581}$ La ley también dispone sobre fuentes ${ }^{582}$, y sobre el control de cuentas, la función fiscalizadora pertenece al Tribunal Vasco de Cuentas Públicas, existiendo también disposiciones bastante detalladas sobre el tema, como también ocurre con la LOREG. ${ }^{583}$

Sin embargo, lo que más es destacable de la norma son las cantidades concedidas a titulo de subvención por financiación pública. Se trata de la legislación más beneficiosa para los partidos a nivel autonómico, previendo para cada escaño obtenido en el Parlamento Vasco una cantidad de 24.935,90 euros; 0,84 euros por voto obtenido en las candidaturas, siempre que al menos uno de sus miembros haya obtenido escaño en la circunscripción correspondiente; 41.559,81 euros por circunscripción electoral a quienes obtengan al menos un escaño en ellas, siendo este último un criterio innovador dentro de la legislación sobre el tema. ${ }^{584}$ Además, existe la subvención por envío directo de sobres, papeletas, propaganda y publicidad a los electores, y dicho gasto no será contabilizado para el límite global de gastos electorales, y es concedido a las candidaturas que hayan presentado lista y hubieran obtenido un escaño en una o más circunscripciones. ${ }^{585}$ La critica hecha en la legislación de La Rioja, Castilla la Mancha y Cantabria sobre el hecho de que el importe de las subvenciones a los grupos políticos no puede ser mayor que la cifra de gastos electorales declarados también puede ser repetida en la legislación vasca. ${ }^{586}$

También destaca su capítulo VII, que versa sobre posibles sanciones por incumplimiento de las normas, que pueden ir desde la reducción del valor de las subvenciones, hasta la pérdida total de esta. ${ }^{587}$

Los casos particulares se restringen a Cataluña, Ceuta y Melilla. Ninguna de las tres dispone de una ley electoral específica como ocurre con las

\footnotetext{
${ }^{581}$ Cfr. arts. 144.1 y 144.8 .

${ }^{582}$ Como ejemplo se puede citar la prohibición de donaciones realizadas por aquellos que tienen domicilio fuera del País Vasco, lo que no es común en las legislaciones sobre el tema. Así, cfr. 145.2.

${ }^{583}$ Cfr. arts. 148 a 150.

${ }^{584}$ Cfr. art. 151.

${ }^{585}$ Cfr. art. 151.2.

${ }^{586}$ Cfr. art. 151.4 .

${ }^{587}$ Cfr. art. 152.
} 
demás Comunidades Autónomas. De este modo, las normas referentes a la financiación electoral son aprobadas a cada proceso electoral. ${ }^{588}$ Ello impide fijar parámetros estables como ocurrió con las demás legislaciones autonómicas, y por tanto, se analizará las últimas disposiciones sobre el tema.

El caso de Cataluña ${ }^{589}$ es muy particular debido a la ausencia de ley electoral, lo que equivale a decir que la LOREG es directamente aplicable. Por ello, en cada convocatoria se aprueba un Decreto de la Presidencia de la Generalitat. ${ }^{590}$ En todos los decretos aprobados, se nota una similitud latente con las restantes disposiciones autonómicas sobre financiación, incluso con los contenidos disponibles de la LOREG, junto con una cierta irregularidad por parte del ejecutivo, que no debería regular la materia de manera infralegal a cada proceso electoral, ya que en algunos supuestos parecería que se puede entrar en colisión con el Estatut ${ }^{591}$ o dar lugar a un conflicto de competencia entre el Tribunal de Cuentas y el Sindicatura de Comptes. ${ }^{592}$

Para las elecciones realizadas en 2010, el Decret 134/2010 de 5 de Octubre ${ }^{593}$ determina que las subvenciones para fines de financiación electoral atenderán al doble criterio escaños/votos, siendo valores que se pueden entender como generosos, o sea, 20.127 euros por cada escaño y 0,76 euros por cada voto en las candidaturas que dieron origen a escaños. Sobre la subvención de envío directo de sobres, papeletas, propaganda y publicidad para los electores, el valor será de 0,21 euros por elector, siempre que haya obtenido al menos un escaño en su circunscripción y que logre formar un grupo

\footnotetext{
${ }^{588}$ En Cataluña las últimas elecciones se celebraron en el 2010, y en Ceuta y Melilla se celebraron en 2011.

${ }^{589}$ Una de las principales razones por las que Cataluña no posee una ley electoral fue la falta de acuerdo en el momento de establecer los criterios para determinar la circunscripción electoral. En este sentido, véase: TORRES DEL MORAL, A. "Sistemas Electorales y Sistemas de Partidos en las Comunidades Autónomas". In: GÁLVEZ MUÑOZ, L. A. (Dir.): El Derecho Electoral de las Comunidades Autónomas. Revisión y Mejora. Cuadernos y Debates, Centro de Estudios Constitucionales, Madrid, 2009. Pp. 227.

${ }^{590}$ Los decretos aprobados hasta hoy fueron: Decret 80/1988 de 12 de abril; 3/1992, de 20 de enero; 254/1995, de 28 de septiembre; 232/1999, de 24 de agosto; 213/2003, de 23 de septiembre.

${ }_{591}$ En este sentido, cfr. PAJARES MONTOLIO, E. "La Financiación y la..." Pp. 254.

592 Dicho punto es abordado en la moción aprobada por el Tribunal de Cuentas para la modificación de la legislación sobre financiación y fiscalización de los partidos, en 30 de octubre de 2001, siendo también objeto de la resolución aprobada en 11 de junio de 2001. 593 Dicho documento puede ser encontrado en <<http://www.parlament2010.cat/almacen/normativa/EPC10_DOGC_20101006_D1342010_DSE.pdf $>>$.
} 
parlamentario. El anticipo del máximo del $30 \%$ sobre la cantidad total debida a titulo de subvención en las elecciones de 2006 también está contenido en el decreto, como también el anticipo del 90 de la cantidad total debida considerando los nuevos resultados, en el plazo de 30 días desde la entrega de la contabilidad y la documentación para fiscalización. Es obligatoria la presentación de un aval bancario de $10 \%$ sobre los $90 \%$ de las subvenciones, como determina la LOREG. La fiscalización queda a cargo de la Sindicatura de Comptes y sigue los parámetros del Régimen Electoral General.

Por fin, en el caso de Ceuta y Melilla ${ }^{594}$, el Real Decreto 424/2011 de 28 de marzo ha regulado las elecciones de 2011 para sus Asambleas, no habiendo novedades en su previsión, ya que determinó la aplicación directa del régimen electoral general, esto es, de la LOREG.

La primera conclusión que se pueden obtener del examen de dichas leyes autonómicas es que la característica de la homogeneidad enfatizada por GAVARA DE CARA se presenta en alto grado. ${ }^{595}$ Sin embargo, no creo que ello conlleve necesariamente una valoración negativa. Otras experiencias han demostrado que la diferencia entre las legislaciones estatal y regional ocasiona no raras veces un conflicto de normas difícil de manejar en el caso concreto. Por más que las potestades normativas de las autonomías hubieran podido utilizarse para perfeccionar los defectos existentes en la LOREG, esto no ha ocurrido. Sin embargo, también es un hecho de que, cuando se trata de una cuestión tan problemática como la financiación electoral, la diferencia entre las disposiciones legales y el conflicto de fuentes normativas acaban por frustrar los principios básicos que amparan el sistema, como la transparencia de las cuentas de los partidos. La actuación del legislador autonómico puede así considerarse indirectamente una contribución al mantenimiento de una cierta regularidad del sistema de financiación, una armonización necesaria en el proceso electoral.

Como critica general puede subrayarse que el valor de las subvenciones está por encima de las subvenciones para las elecciones a las Cortes

\footnotetext{
${ }^{594}$ Por la formulación de sus sistemas electorales, se puede entender que ambas poseen sistemas mayoritarios, y no proporcionales, como las demás Comunidades Autónomas.

${ }^{595}$ Cfr. GAVARA DE CARA, J. C.: La Homogeneidad de los Regímenes Electorales Autonómicos. CEPC, Madrid, 2007. Pp. 285 y ss.
} 
Generales, sin que exista un motivo claro para ello, y lo mismo puede decirse respecto a las subvenciones para el envío de sobres y papeletas a los electores. De esta manera, hay quizás un uso desmesurado de recursos públicos, que colaboran tanto a la dependencia de los partidos, como al encarecimiento de sus campañas. ${ }^{596}$ Otro punto a destacar es una cierta laxitud de las leyes en relación a la rendición de cuentas de los partidos. Por más que algunas normativas contengan disposiciones sobre el asunto, es perceptible la ausencia de una verdadera regulación. De hecho, esta insuficiente regulación añade a las lagunas ya existentes en la ley estatal. ${ }^{597}$

\section{8) La financiación de las actividades ordinarias de los partidos políticos}

Como es obvio, la labor de los partidos políticos no se limita al momento electoral, en cuanto los partidos son organizaciones permanentes ${ }^{598}$, e independiente de las críticas que se haga sobre cuáles podrían ser las actividades no electorales que serian necesarias para mantener la actividad de una formación política, la financiación de este tipo de actividad denominada de "ordinaria" es la que tiene más peso dentro de las finanzas de todas las organizaciones políticas, y siendo así, acaba por tener gran influencia sobre el nivel de discriminación y desigualdades que puedan existir en un sistema partidista.

La financiación de las actividades ordinarias, al contrario de la electoral o de las actividades extraordinarias - tiene periodicidad anual, y también cuenta con medidas de transferencia directa de recursos, y otras de incidencia indirecta, no transfiriendo a los partidos cantidades en metálico, pero sí a través de la adquisición de determinados bienes o servicios. Cabe resaltar que, conforme se apuntó al analizar la evolución legislativa, el rasgo más significativo de la financiación de las actividades ordinarias sigue siendo la necesidad de que el partido logre por lo menos un escaño en el Congreso de

\footnotetext{
${ }^{596}$ Cfr. PAJARES MONTOLIO, E. “La Financiación y la...” Pp. 262.

${ }^{597}$ En este sentido, cfr. CHUECA, Ricardo. La Financiación Electoral. In: CHUECA, Ricardo; RAMÓN MONTERO, José (eds.): Elecciones Autonómicas en Aragón. Tecnos, Madrid, 1995. Pp. 94 y ss.$$
{ }^{598} \text { Cfr. HOLGADO GONZÁLEZ, M.: La Financiación de los... Pp. } 132 .
$$ 
los Diputados para acceder a los recursos provenientes de los presupuestos generales del Estado.

Con el beneficio de la financiación pública para gastos ordinarios, los partidos que reciben dichos recursos del Estado (que suponen la mayoría de la financiación ordinaria, ya que las donaciones realizadas con dicho fin siguen estando muy limitadas por la ley, aunque con límites superiores que las existentes para las donaciones con fines electorales), los partidos mantienen su presencia pública, y hay que resaltar que, en cierto modo, la competencia entre los partidos en este tipo de actividades es aún más difícil que la competición en campañas electorales, ya que la implantación social de los partidos subvencionados también desempeña un papel importante en la formación de una cierta y hoy escasa identidad partidaria de nuevas generaciones, a partir de lo que se entiende por lealtad partidaria. ${ }^{599}$

Sin embargo, no se puede ignorar que la presencia de este tipo de financiación, con el peso que le fue atribuido en sus orígenes ${ }^{600}$, acaba por producir efectos no deseables para el sistema como un todo. Como ya se ha apuntado en el análisis de la Ley Orgánica 8/2007 el alto valor de las subvenciones, sumado a la combinación de criterios para su acceso permite que las formaciones políticas se mantienen sin un efectivo enraizamiento en la sociedad. Lamentablemente la Ley Orgánica 8/2007 no puede revertir todos los defectos generados por la legislación anterior, aunque da pasos, por insuficientes que sean, para subsanar algunas de las deficiencias del sistema de financiación vigente. Elementos como la limitación del aumento del valor de la parte de los presupuestos generales del estado destinados a los partidos una novedad de la nueva legislación - no tienen el poder de congelar dichos valores o disminuirlos, sino simplemente de controlar su crecimiento. En todo

\footnotetext{
${ }^{599}$ GARCÍA VIÑUELA, E. "Financiación Pública de los..." Pp. 80. Los autores entienden que, con ello, el descenso de la volatilidad electoral en a finales de los 80 puede ser considerado como una consecuencia de la consolidación de un pequeño número de partidos con representación parlamentaria, que acompañó el crecimiento de las subvenciones para las actividades ordinarias de los mismos, posibilitando el aumento de la presencia de dichas organizaciones en la sociedad, a través de aperturas de sedes y de la contratación de personal permanente. Con todo, los autores no rechazan la hipótesis de corresponder un comportamiento típico de voto útil, aliado con el sistema electoral vigente.

600 VAN BIEZEN entiende que el alto nivel de los gastos de este tipo en España puede ser parcialmente explicado por la extensa y costosa estructura extra-parlamentaria de los partidos, con sedes locales con profesionales contratados por todo el país. (In: VAN BIEZEN, I.: Political Parties in New... Pp. 198).
} 
caso, otros efectos político-sociales, como el fenómeno de la cierta "cartelización" del sistema de partidos, evento este que creemos que está concretizándose, no sólo en España, sino en parte de las democracias occidentales modernas, continuará sin duda desarrollándose. ${ }^{601}$

\section{9) La financiación de los grupos parlamentarios}

A fin de complementar el estudio de las fuentes de financiación existentes, realizaremos aquí un breve análisis de la financiación de los grupos parlamentarios, necesario también dada la polémica que genera dentro del sistema de financiación. No se abordará en este punto en profundidad la permanente discusión sobre la naturaleza jurídica de los mencionados grupos, sino tan solo un mínimo apunte necesario para la exposición de los argumentos.

Esta fuente de financiación pública ${ }^{602}$ está presente en España desde hace mucho tiempo ${ }^{603}$, tanto que puede considerarse que su primera aparición se produce ya en las cuentas del PSOE de segundo semestre de 1931 y 1932. Como en aquella época no había regulación sobre este tipo de contribución en la legislación republicana, esta fue considerada como una aportación privada por parte de cada uno de los diputados integrantes del grupo, como si voluntariamente hubieran concedido parte de su sueldo al partido, aunque este no fuera reconocido formalmente en la época. ${ }^{604}$ Después del período franquista, la financiación de los grupos parlamentarios ha resurgido en 1977, con el objetivo de apoyar a estos para que pudieran desarrollar su labor legislativa en mejores condiciones, haciendo frente a gastos administrativos como los del personal administrativo, la asesoría jurídica, el apoyo técnico o

\footnotetext{
${ }^{601}$ El análisis completo sobre dicha afirmación está contenido en el capítulo II.

602 Este tipo de financiación de partidos es uno de los más antiguos existentes y, como se verá, aunque posea una reglamentación distinta del resto de las demás, en la práctica es muy difícil separarla de la financiación de los partidos. Cfr. PIERRE, J.; et al. "State Subsidies to Political Parties: Confronting Rhetoric with Reality". In: West European Politics. vol. 23. no 3, jul, Frank Cass Press, London, 2000. Pp. 7.

${ }^{603}$ Para un buen resumen sobre la evolución histórica de los grupos parlamentarios, cfr. SAIZ ARNAIZ, A.: Los Grupos Parlamentarios. ed. Congreso de los Diputados, Madrid, 1989. Pp. 17 y ss; y DE HIJAS MERINO, M. M. "Los Grupos Parlamentarios desde una Perspectiva Histórica". In: Asamblea: Revista Parlamentaria de la Asamblea de Madrid. no extraordinario, Madrid, 2007. Pp. 3-18.

${ }^{604}$ CORTÉS BURETA, P.: Recursos Públicos y Partidos Políticos... Pp. 55-56.
} 
parlamentario, etc. ${ }^{605}$ Es de resaltar que esta financiación se justifica en parte en la obligada igualdad de oportunidades entre todos los representantes en el ejercicio de sus funciones institucionales, y sirve pues, en último término, para facilitar la participación de todos los parlamentares en un mismo grado ${ }^{606}$

La norma que reguló esta subvención estaba contenida en el reglamento provisorio del Congreso de los diputados, en el art. 21 y aunque no se trataba de una subvención directa para los partidos, preveía una cantidad fija para todos los grupos y otra variable, según su número de miembros. En el Senado, todavía prevalecía el silencio. Es innegable el hecho de que los partidos se beneficiaron (y siguen beneficiándose) de estos recursos, que acabaron por perpetuarse en prácticamente en los mismos términos en el reglamento definitivo del Congreso de los Diputados, y también ya del Senado. ${ }^{607}$

Las disposiciones contenidas en dichos reglamentos son bastante sencillas, aun cuando el Congreso de los Diputados se preocupó en detallar más los beneficios que serían conferidos a los grupos. Se traduce en materiales y medios suficientes para el ejercicio de sus funciones, además de una subvención fija idéntica para todos, y otra variable en función del número de diputados que componen dicho grupo. Las cuantías son fijadas por la Mesa de la Cámara, observando los límites contenidos en el presupuesto. Además, establece la obligación de los grupos de mantener una contabilidad específica sobre esta subvención, que deberá estar siempre a la disposición de la Mesa del Congreso. ${ }^{608}$ La normativa sobre el tema en el reglamento en el Senado se resume a un artículo, en donde se prevé una subvención fija e igual para todos, y otra variable conforme el número de integrantes de dicho grupo. No hay

\footnotetext{
${ }^{605}$ DÍAZ-SANTANA CASTAÑOS, H. Op. Cit. Pp. 182

${ }^{606}$ HOLGADO GONZÁLEZ, M.: La Financiación de los... Pp. 202-203.

607 DÍAZ-SANTANA CASTAÑOS, H. Op. Cit. Pp. 182; y CORTÉS BURETA, P.: Recursos Públicos y Partidos Políticos... Pp. 75 y ss.

${ }^{608}$ El Artículo 28 del mencionado reglamento dice, así: "1. El Congreso pondrá a disposición de los Grupos Parlamentarios, locales y medios materiales suficientes y les asignará, con cargo a su Presupuesto, una subvención fija idéntica para todos y otra variable en función del número de Diputados de cada uno de ellos. Las cuantías se fijarán por la Mesa de la Cámara dentro de los límites de la correspondiente consignación presupuestaria. 2. Los Grupos Parlamentarios deberán llevar una contabilidad específica de la subvención a que se refiere el apartado anterior, que pondrán a disposición de la Mesa del Congreso siempre que ésta lo pida."
} 
disposiciones sobre contabilidad $u$ otros posibles beneficios. ${ }^{609}$ Es de destacar que la única excepción a dicha regla es en el caso de que exista un grupo que no tenga escaños suficientes para tener una formación propia (constituyendo así el grupo mixto), será transferida la parte debida a cada candidato a dicho grupo. ${ }^{610}$

A partir de ello se puede observar que no hay una fórmula de cálculo descrita en las normas en cuestión, y como los informes sobre dicha financiación se consideran confidenciales, no existe forma de acceder a los datos, y como no compone expresamente los presupuestos generales del Estado, acaba por ser considerado dentro del concepto de dicho presupuesto referente a "familias e instituciones sin fines de lucro" ${ }^{611}$

Uno de los puntos doctrinales conflictivos en torno a esta subvención es su propia clasificación. Parte de la doctrina defiende que se trata de una financiación pública ${ }^{612}$, aunque dicha cuestión depende mucho más de la conclusión que se tiene sobre la naturaleza jurídica de dichos grupos. ${ }^{613}$

Es sabido que todos los grupos parlamentarios tanto de las cámaras a nivel estatal como a nivel autonómico reciben dichas subvenciones, y aunque tengan una naturaleza jurídica distinta de la de los partidos, en la práctica quien acaba por usar estos recursos son los partidos. ${ }^{614}$ Con todo, hay que considerar también que en muchos casos los parlamentarios también están obligados por los estatutos del partido a entregar al mismo una parte de sus

\footnotetext{
${ }^{609}$ Vid. "Artículo 34. El Senado facilitará a los Grupos Parlamentarios una subvención cuya cuantía se fijará en función del número de sus componentes y, además, un complemento fijo igual para todos."

${ }^{610}$ HOLGADO GONZÁLEZ, M.: La Financiación de los... Pp. 206-207.

${ }^{611}$ DÍAZ-SANTANA CASTAÑOS, H. Op. Cit. Pp. 183, nota de píe no 32. ARIÑO ORTIZ afirma que dicha financiación puede llegar al $15 \%$ de la subvención ordinaria, que no aparecen en el BOE y tampoco tienen un concepto específico. (In: ARIÑO ORTIZ, G.: Op. Cit. Pp. 47).

${ }^{612}$ Cfr. por todos, FERNÁNDEZ VIVAS, Y.: Op. Cit. Pp. 328.

${ }^{613}$ En opinión de CASAS-ZAMORA, los subsidios públicos están separados de los recursos procedentes de organizaciones relacionadas o controladas por los partidos, por los parlamentarios o instituciones de investigación, porque, desde su punto de vista, dichos subsidios están fuera del control de la cúpula del partido o órganos locales, y son concedidos por el Estado a entidades que no forman parte legalmente de los mismos, y tampoco está claro que, en el caso de los parlamentarios, por ejemplo, que estos ayuden mucho más a los partidos que a su propia actividad de parlamentario. Debido a ello, el autor sólo considera subvenciones públicos los concedidos directamente a los partidos políticos. (In: CASASZAMORA, K.: Op. Cit. Pp. 28).

${ }^{614}$ Cfr. FERNÁNDEZ VIVAS, Y.: Op. Cit. Pp. 321.
} 
ingresos. ${ }^{615} \mathrm{El}$ hecho es que dicha subvención se considera por una línea doctrinal como una fuente de financiación de los partidos porque los grupos parlamentarios, en cierto modo, no son más que la expresión de los partidos en las Cámaras. En todo caso, los grupos parlamentarios no son propiamente los partidos en el Parlamento, son grupos que son estables y con disciplina constante, pero que podría eventualmente no estar de acuerdo con la voluntad del partido. Justamente por esta distinción, otra línea doctrinal defiende que esta fuente de financiación debería ser excluida de la ley de financiación ordinaria. ${ }^{616}$ Una razón más para la exclusión de dicha subvención en el cómputo de la financiación de los partidos es que, por ser personas distintas y recursos con finalidades distintas, el desvío de la finalidad de la subvención puede afectar la libertad de actuación de los parlamentarios del grupo que recibe la subvención, lo que en hipótesis resultaría prohibido. ${ }^{617}$

Sin embargo, la naturaleza jurídica de los grupos parlamentarios también es debatida en este contexto, porque dicha respuesta tiene influencia sobre la utilización la subvención por parte de los partidos. Todo dependerá si se considera a los grupos parlamentarios como parte integrante de los partidos, permitiendo, de esta manera, que los valores sean incluidos en sus presupuestos para hacer frente a los gastos generados por la vida política, o si son órganos de las Cámaras, dado que su reglamentación está conferida a estas. $^{618}$

\footnotetext{
${ }^{615}$ SANTAOLALLA, F. "Regulación de Campañas..." Pp. 164.

616 En este sentido, cfr. MARTíNEZ SOSPEDRA, M. "La Financiación..." Pp. 38-39; GONZÁleZ-AURIOLES, J. A. Op. Cit. Pp. 217; PRESNO LINERA, M. Á.: Los Partidos y las Distorsiones... Pp. 96 y; HOLGADO GONZÁLEZ, M.: La Financiación de los... Pp. 196-198, en el que la autora afirma que los principios de la prohibición del mandato imperativo y el derecho individual de ciudadanos de participar en asuntos públicos, no de los partidos, es justamente donde se basa el principio representativo, y por ello, y por la falta de mención en la Constitución Española y por la doctrina del Tribunal de Cuentas en excluir esta fuente de financiación, es por lo que la autora mantiene esta posición, que sigue al ordenamiento alemán, que considera como jurídicamente improcedente la utilización por parte de los partidos de los recursos concedidos a los grupos parlamentarios. Así, véase: SCHOLZ, R. "Los Partidos Políticos en el Sistema Constitucional de la República Federal de Alemania. Fundamentos Jurídico-Constitucionales y Realidad Constitucional". In: AA.VV.: Anuario de Derecho Constitucional Latinoamericano, tomo I, ed. Konhad Adenauer Stiftung. Uruguay, 2006. Pp.175. 617 Vid. BASTIDA FREIJEDO, en AA.VV.: "Encuesta Sobre la Regulación..." Pp. 37.

${ }^{618}$ Como ya dicho, no es posible en el presente trabajo tratar el tema con la profundidad necesaria. Vid. CID VILLAGRASA, B. "La Naturaleza Jurídica de los Grupos Parlamentarios: EI Grupo Parlamentario como Titular de Derechos y Obligaciones". In: Asamblea: Revista Parlamentaria de la Asamblea de Madrid. oe extraordinario, Madrid, 2007. Pp. 179-204.
} 
Es evidente que la relación existente entre los partidos y los grupos parlamentarios es acentuada en sistemas parlamentarios con un régimen electoral que fomenta los gobiernos mayoritarios unipartidistas. La propia regulación reglamentaria da cuenta de ello. ${ }^{619}$ En todo caso, las posiciones doctrinales sobre la naturaleza jurídica de los grupos parlamentarios son diversas, y se mueven, como es sabido, entre considerarlos como órganos de los partidos; órganos de las Cámaras; órganos tanto de los partidos como de las Cámaras; y, siendo órgano de las Cámaras, también órganos del Estado; con naturaleza asociativa con o sin personalidad jurídica; 0 , finalmente, personas jurídicas de derecho público o constitucional. ${ }^{620}$

La teoría de que los grupos parlamentarios son órganos del partido está bastante presente en la doctrina italiana ${ }^{621}$ y se justifica por la indudable conexión que los grupos tienen con los partidos. Existiría una relación de dependencia o "casi" dependencia de los grupos en relación con los partidos, no sólo en sus actividades, sino también en el elemento subjetivo de dicha relación, que son los propios parlamentarios. Los diputados y senadores no serían electos si no fuera por la actuación de los partidos, y a la vez no produciría la formación del grupo parlamentario si el partido no lograra los escaños suficientes para formarlo. La "cooperación" entre los dos tampoco para aquí, considerando que generalmente la posición adoptada por el grupo parlamentario en el día a día del parlamento se corresponde - en la gran mayoría de veces - a la posición defendida por el partido sobre una cuestión. Llevado al extremo, hay una alteración de la teoría de representación, dónde el pueblo elige a sus representantes, pero que decidido en las Cámaras pasará

\footnotetext{
${ }^{619}$ Además, es un hecho que el partido ejerce un control bastante fuerte de sus parlamentarios a través del grupo parlamentario. Cfr. BALAGUER CALLEJÓN, M. L. "La Relación entre los Grupos Parlamentarios y los Partidos Políticos en el Ordenamiento Jurídico-Constitucional Español”. In: Corts - Anuario de Derecho Parlamentario. no 10, Valencia, 2001. Pp. 43. También, cfr. SERRANO JÁUREGUI, N. P.: Los Grupos Parlamentarios. ed. Tecnos, Madrid, 1989. Pp. 63-68.

${ }^{620}$ Y aquí cabe la observación hecha por SAIZ ARNAIZ, que se comparte plenamente: en muchos de los casos, la doctrina que trata sobre el tema no opta entre una u otra opción de manera clara, y algunas veces acaba por mezclar dos corrientes de pensamiento, a partir de los criterios que sugiere en sus respectivos trabajos. (Cfr. SAIZ ARNAIZ, A.: Op. Cit. Pp. 292).

${ }^{621}$ Dicha postura domina principalmente en la doctrina italiana clásica. En este sentido, por todos, cfr. PETTA, P. "Gruppi Parlamentari e Partiti Polítici". In: Rivista Italiana per le Scienze Giuridiche. $\mathrm{n}^{\circ}$ 14, fasc. 24, ed. Università di Roma, Roma, 1970. Pp. 230 y ss; y CIAURRO, G. F. "Gli Organi della Camera". In: II Regolamento della Camera dei Deputati. Segretariato Generale della Camera, Roma, 1968. Pp. 240.
} 
inevitablemente por el partido político, y será transmitido por su respectivo grupo parlamentario. ${ }^{622}$ Otro dato que los aproxima es el hecho de que en los estatutos de los partidos, muchas veces los grupos parlamentarios aparecen como parte integrante de la estructura partidista. Aunque no haya remisión directa sobre el tema, suele haber una cobertura estatutaria significativamente grande para los grupos de cada partido, incluso algunos con la condición de que el parlamentario que salga del partido, sale también del grupo. ${ }^{623} \mathrm{Sin}$ embargo, en contra de dicha posición hay diversos argumentos, desde los que parten de la teoría del órgano, para los cuáles la forma del grupo sería más amplia al punto de permitir imputar al partido todos los actos realizados a través de dicho órgano; como también la existencia de grupos mixtos ${ }^{624}$, o la existencia de grupos que se conectan con dos o más partidos. ${ }^{625}$ Sin embargo, limitándonos sólo a un argumento, lo cierto es que no hay mención en los Reglamentos de las Cámaras, o en las leyes electorales o en la propia ley de partidos de que los grupos compongan las estructuras partidistas, como tampoco hay indicios en el derecho positivo de que el grupo sea fielmente el porta voz de las voluntades del partido en el parlamento. ${ }^{626}$ Teniendo eso en mente, surge la posición neutra de que un grupo parlamentario no es ni órgano del partido, ni tampoco de las Cámaras, sino grupos con una matiz autónoma de ambos. ${ }^{627}$

No es defendible que los grupos parlamentarios sean órganos de los partidos $^{628}$, porque dichos grupos no pueden ser considerados como asociaciones privadas (por su voluntad de creación, expresión del derecho de asociación, pero con funciones públicas). No existe el derecho de asociarse o

622 Cfr. SANZ PÉREZ, Á. L. "La Naturaleza Jurídica de los Grupos Parlamentarios. Una Aproximación al Proceso de Juridificación de los Grupos Parlamentarios". In: Corts - Anuario de Derecho Parlamentario. № 10, Valencia, 2001. Pp. 340-341.

${ }_{623}$ Se puede citar como ejemplo el estatuto del PSOE (arts. 74 y ss.); PP (art. 53 y apartados) e IU (art. 56).

624 Cfr. SERRANO JÁUREGUI, N. P.: Op. Cit. Pp. 144-145.

${ }^{625}$ Cfr. BISCARETTI DI RUFFIA, P.: Derecho Constitucional. 3 o ed., Ed. Tecnos, Madrid, 1987. Pp. 723 y ss; y SAIZ ARNAIZ, A.: Op. Cit. Pp. 330-331.

${ }^{626}$ Cfr. SAIZ ARNAIZ, A.: Op. Cit. Pp. 332-333.

${ }^{627}$ En este sentido, cfr. UGO RESCIGNO, G. "Gruppi Parlamentari”. In: AA.VV.: Enciclopedia del Diritto. vol. XIX, ed. Giuffrè, Milano, 1970. Pp. 793 y ss.

${ }^{628}$ Según SAIZ ARNAIZ, en España ningún autor ha defendido exclusivamente dicha posición. (Cfr. SAIZ ARNAIZ, A.: Op. Cit. Pp. 332). Como ejemplo más actual, véase PRESNO LINERA, M. Á. "La Reforma del Sistema de Financiación de los Partidos Políticos". In: Revista Española de Derecho Constitucional. año 19, no 57, sep/dic, 1999. Pp. 215-216; 
no a un grupo, es una obligación de todos los parlamentarios pertenecer a un grupo, aunque sea al grupo mixto, e incluso la existencia de este grupo mixto convierte imposible la figura del parlamentario en nuestro Derecho Parlamentario sin grupo. ${ }^{629}$ Además de ello, está claro que las subvenciones se transfieren a los grupos parlamentarios no para sostener al partido, sino para mantener al propio grupo, dotándole de medios para la participación de sus miembros en la dinámica parlamentaria. ${ }^{630} \mathrm{Si}$ el grupo fuera considerado un órgano del partido, no estaría el grupo obligado al traspaso de recursos al partido, sino al contrario. Está claro que componiendo la estructura de organización del partido, el grupo parlamentario debería ser financiado por este, y no de manera separada, con fondos de origen público, teniendo incluso patrimonios separados, como deudas y obligaciones. Dado pues que ninguna de las primeras explicaciones para la cuestión parezca satisfactoria, parece evidente que dicha subvención no debería, en ningún caso formar parte de las finanzas de las formaciones políticas.

Con relación a la teoría de que los grupos parlamentarios son órganos de las Cámaras, el debate se vuelve en otra dirección. Se fundamenta en múltiples razones, como puede ser el hecho de que el proceso de reconocimiento y regulación de los grupos parlamentarios esté vinculado a la evolución de la institución parlamentaria, y que también tengan derecho a una subvención por parte de las Cámaras, que desarrollen sus actividades en el seno del parlamento, incluyendo que su régimen jurídico sea el dispuesto exclusivamente en el marco de los Reglamentos Parlamentarios o que estén compuestos exclusivamente de diputados o senadores. Junto a ello, el grupo mixto también es usado como argumento, ya que es obligatorio que los parlamentarios estén en uno de los grupos de la casa legislativa. Esto

629 Aquí se está de acuerdo con CORTÉs BURETA, P.: Recursos Públicos y Partidos Políticos... Pp. 166-172. La autora también expone las diferencias entre los grupos parlamentarios y los partidos, concluyendo que entre estos solamente hay una relación política. Sin embargo, la autora recuerda la corriente que entiende que los grupos son órganos de los partidos porque este elabora la lista con el nombre de los parlamentarios que integrarán el grupo, imponen disciplina en el voto, y que tiene en su estatuto la obligatoriedad de formar parte de un grupo. Con todo, aunque entienda que no hay disposición alguna que diga que el grupo expresa la voluntad del partido, o que sus actos sean imputables a los partidos, o que las decisiones de los partidos puedan ser impuestas a los grupos, esto está limitado por el acuerdo existente entre los miembros. Sigue la autora García Guerrero in: GARCíA GUERRERO, J. L.: Escritos sobre... Pp. 211.

${ }^{630}$ En este sentido, véase STC 214/90 de 20 de diciembre, y STC 15/92, de 10 de febrero. 
comprobaría el carácter interno y organizativo de dichos grupos. No importa el grado de conexión que tengan con los partidos políticos, ya que su actuación se produciría en el seno del parlamento, permitiendo que dicha institución disponga de una organización mínima necesaria para su funcionamiento. ${ }^{631} \mathrm{De}$ esta manera, forma parte directamente de la institución parlamentaria. ${ }^{632}$ Con todo, no parece que las funciones ejercidas por los grupos parlamentarios sean potestades públicas. ${ }^{633}$ Los grupos, por su parte, gozan de una autonomía no sólo en relación a sus actividades, sino también patrimonial y laboral. Tanto es así que las subvenciones concedidas a dichos grupos son utilizados para sus necesidades sin que sea necesaria la aprobación del parlamento para el gasto de dichos recursos. Sin ir más lejos, la propia utilización de los recursos por parte de los partidos demostraría este hecho. ${ }^{634}$

Una de las posturas más comunes en la doctrina es la de que el grupo parlamentario es tanto órgano del Parlamento, como también del Estado. Se basa en el hecho de que, en cuanto órganos de los partidos, los grupos recibirían las directrices para su actuación en el Parlamento, y en cuanto órganos estatales, harían dichas políticas en pro del Estado-comunidad. ${ }^{635}$ Hay una bipolaridad que caracteriza esta posición, ya que, como asociación privada, el grupo se centra no solamente en su actuación en el parlamento,

${ }^{631}$ Cfr. SANZ PÉREZ, Á. L. Op. Cit. Pp. 337.

${ }^{632}$ En este sentido, cfr. PETTA, P. Op. Cit. Pp. 242-243. Sin embargo, esta también es una tesis muy defendida por la doctrina italiana, y también en una ocasión el Tribunal Constitucional alemán ha considerado a los grupos parlamentarios como órganos de Bundestag, en 1960. Cfr. SERRANO JÁUREGUI, N. P.: Op. Cit. Pp. 149-150. Aquí también cabe citar el dictamen de los servicios jurídicos del Congreso de los Diputados sobre la posibilidad de embargar las asignaciones económicas de los diputados y las subvenciones de los grupos parlamentarios, publicado en el no 1 de la Revista de las Cortes Generales, que dice que "es un hecho que nadie les atribuye personalidad jurídica "ad extra" ni competencias en el tráfico jurídico externo", para concluir que se trata de "entes u órganos si se acepta esta calificación que integran la estructura interna de cada una de las Cámaras de las Cortes Generales".

${ }_{633}$ Cfr. UGO RESCIGNO, G. "Gruppi Parlamentari..." Pp. 795.

${ }^{634}$ Cfr. MORALES ARROYO, J. M.: Los Grupos Parlamentarios en las Cortes Generales. ed. Centro de Estudios Constitucionales, Madrid, 1990. Pp. 330 y ss.

${ }^{635}$ En este sentido, cfr. LEONI, F. "Partidos Políticos y Grupos Parlamentarios en Italia". In: Revista de Estudios Políticos, no 186, nov/dic, ed. Centro de Estudios Constitucionales, 1972. Pp. 244; y CIANCIO, A.: I Gruppi Parlamentari. Studi Intorno a una Manifestazione del Pluralismo Politico. ed. Giuffrè, Milano, 2008. Pp. 33 y ss. Para finalizar, MUSUMECI entiende que los grupos parlamentarios son órganos tanto del partido como del Parlamento, sometiéndose ambos a estatutos y reglamentos, ya que interactúa en ambas esferas, confundiéndose muchas veces en cuestiones como es la financiación de la política. Cfr. MUSUMECI, T. S.: /l Costo della Politica ed il Finanziamento ai Partiti. ed. CEDAM, Padova, 1999. Pp. 26-27. 
sino también en los riesgos de un desgaste del gobierno, o la promoción de dicho desgaste. El grupo como un órgano interno de la Cámara, sería un colaborador de toda la institución, una parte indisoluble de esta, contribuyendo con su parte a los fines parlamentarios institucionales. ${ }^{636}$ Entre tanto, siendo una asociación de derecho privado con funciones públicas, el grupo también debería estar dotado de la libertad de asociación, en este caso, en su perfil negativo, razón que por sí sola excluye la posibilidad de atribuir a los grupos una clasificación de asociación privada. ${ }^{637}$ Además, es notorio que los autores que apoyan dicha posición también se inclinan a considerar a los partidos como órganos estatales, así que se puede suscitar aquí las mismas críticas que se hacen para dicha corriente doctrinal. ${ }^{638}$

Sin embargo, cabe destacar que se trata de una discusión todavía no agotada, que excede el objeto del presente trabajo. De todos modos, a los fines que nos ocupan, aunque no sea posible optar únicamente por una de las posiciones doctrinarias, lo cierto es que no cabe concluir que grupos y partidos compongan la misma persona jurídica. Disponen ciertamente de una intima conexión, lo que no permite su análisis aisladamente, pero tampoco autoriza a la utilización indisciplinada por los partidos de los recursos del grupo parlamentario concedidos por las Cámaras. Dado que son personas jurídicas distintas, los partidos no pueden comprometer de esta forma el funcionamiento de dichos grupos, dado que estos también tienen funciones institucionales que cumplir. Con todo, no parece realista esperar que este tipo de comportamiento vaya a desaparecer en breve tiempo. ${ }^{639}$

\footnotetext{
${ }^{636}$ Cfr. BALAGUER CALLEJÓN, M. L. Op. Cit. Pp. 43.

${ }^{637}$ Cfr. SAIZ ARNAIZ, A.: Op. Cit. Pp. 321.

${ }^{638}$ Cfr. MORAles ARROYO, J. M.: Op. Cit. Pp. 331 y ss. Un análisis completo de las subvenciones a los grupos parlamentarios, en SERRANO RUIZ, E. "Régimen Jurídico de la Financiación de los Grupos Parlamentarios. Las Subvenciones, la Cesión de Locales y de Medios Materiales". In: Asamblea: Revista Parlamentaria de la Asamblea de Madrid. oㅡ extraordinario, Madrid, 2007. Pp. 360 y ss, donde la autora expone los conflictos existente.

${ }^{639}$ Así defiende MORALES ARROYO, J. M.: Op. Cit. Pp. 358-359 y MIRÓN ORTEGA, Manuel Antonio. Subvenciones y Contabilidad de los Grupos Parlamentarios. In: Corts - Anuario de Derecho Parlamentario. no 10, Valencia, 2001. Pp. 194. Por otra parte, considerando la subvención destinada a los grupos parlamentarios a nivel autonómico, se verifica que hay grande similitud entre las disposiciones, aunque se debe reconocer las Asambleas Autonómicas han dedicado más atención a la regulación de dicha subvención. (Cfr MIRÓN ORTEGA, M. A. "Subvenciones y Contabilidad de los Grupos Parlamentarios". In: Corts Anuario de Derecho Parlamentario. oㅜ 10, Valencia, 2001. Pp. 191). Sin embargo, se producen algunas diferencias, como en relación a los beneficios destinados a los grupos parlamentarios
} 


\section{0) Breves notas sobre la financiación de partidos políticos y de las elecciones en el ámbito de la Unión Europea}

El tema de los partidos políticos europeos todavía es abordado por la doctrina con notable dosis de incertidumbre ${ }^{640}$, ya que el fenómeno de la supranacionalidad partidista está lejos de constituir un fenómeno consolidado. Tampoco en el presente tópico se pretende agotar el tema o profundizarlo, por trascender el objeto de la presente investigación. Lo que se expondrá serán algunos puntos básicos sobre el sistema de financiación de partidos a nivel europeo.

Es conocido que el mayor reto para los partidos políticos, para la sociedad y para sus instituciones es el arraigo del pluralismo político en un país. ${ }^{641}$ Ocurre que con los partidos y las instituciones europeas, la supranacionalidad vuelve todo ello aún más difícil, justamente porque el sentimiento de sociedad europea no está presente en todos los países que lo componen, y aun más porque los partidos europeos son vistos no como partidos fijos y permanentes, sino como organizaciones interpartidistas lejanas de la realidad europea o nacional.

Sin embargo, es interesante analizar, aunque sea superficialmente, un sistema quizás basado en los mismos principios democráticos de igualdad de condiciones y pluripartidismo, y que acaba en determinadas situaciones siendo

\footnotetext{
- que no se limitan a las subvenciones - así como también locales y material considerados necesarios. La fórmula de cálculo de las subvenciones también puede sufrir algunas variaciones, aunque en general se constituya en dos partes (una fija y otra variable dependiendo del número de parlamentarios que componen el grupo). Por otro lado, es cierto que no son todas las comunidades autónomas determinan que los grupos parlamentarios mantengan una contabilidad detallada de sus finanzas, aunque la mayoría fije esta regla. Las disposiciones sobre el tema a nivel autonómico se encuentran en los respectivos reglamentos de las Asambleas Autónomas: País Vasco: art. 27; Cataluña: art. 25; Galicia: art. 27; Andalucía: art. 25; Asturias: art. 34; Cantabria: art. 27; La Rioja: art. 25; Murcia: art. 38; Comunidad Valenciana: art. 28 y 29; Castilla La-Mancha: art. 29; Islas Canarias: art. 25; Navarra: art. 35; Extremadura: art. 39; Islas Baleares: art. 27; Comunidad Autónoma de Madrid: art. 46; Castilla y León: art. 24; Cortes de Aragón: art. 26; Ceuta: art. 46; Melilla: art. 22.

640 Sobre la materia, vid. LADRECH, R. "Europeanization and Political Parties: Towards a Framework for Analysis". In: Party Politics. v. 8. no 4. Sage, London, 2002. Pp. 389-403, trabajo que el autor trata de los partidos a nivel europeo en su faceta orgánica, concluyendo que hasta aquél momento - el de la elaboración del artículo - estos estaban limitadamente organizados, ya que dependían de sus bases nacionales para su estructuración.

641 MORAL MORAL, María Carmen. "El Control de la Financiación de los Partidos Políticos". In: Revista Española de Control Externo. v. 1. oㅜ 3, Madrid, 1999. Pp. 149.
} 
más justo que el sistema aplicado dentro de los países miembros, como puede ser el caso de España.

La legislación referente a la materia no es vasta, pero tiene los detalles necesarios para alcanzar una cierta efectividad. El propio Consejo de Europa, por medio de la Asamblea Parlamentaria, ha emitido algunas recomendaciones en materia de financiación de partidos, que no dejan de ser recomendaciones que no poseen fuerza vinculante.

La primera recomendación sobre financiación de partidos fue la Recommendation 1516 de 2001, de 22 de mayo. El documento expresa la preocupación por la igualdad de oportunidades entre los partidos, la importancia del combate a la corrupción - incluso considerando los diversos escándalos políticos generados por ello - y también de que los partidos tengan condiciones suficientes para ejercer sus funciones políticas de la manera debida. La recomendación opta por un equilibrio entre la financiación pública y la privada, con reglas estrictas para las donaciones privadas, límites de gastos electorales, transparencia en las cuentas de los partidos, a partir de una autoridad independiente para realizar la fiscalización, y la adopción de sanciones en caso de violación de normas.

Así, sobre las fuentes de financiación, la recomendación sugiere que los Estados miembros incentiven la participación ciudadana en las actividades de los partidos políticos, incluyendo su financiación, ya que las cuotas de los afiliados resultan ya a todas luces insuficientes. Junto a ello, los Estados deben proveer de recursos económicos a los partidos, previniendo intereses oscuros articulados a través de donaciones privadas, así como también la posible dependencia de las organizaciones de dicha fuente de financiación. La financiación pública debería corresponderse con el número de votos recibidos por cada partido o con el número de escaños, conciliando dicho criterio con la posibilidad de que nuevos partidos puedan competir de manera justa con los partidos más estabilizados. La recomendación también sugiere que la financiación pública no llegue al punto de debilitar las conexiones existentes entre las organizaciones y la sociedad.

Además de la financiación pública directa, los Estados miembros también pueden adoptar medidas de financiación indirecta, como tarifas 
postales especiales, regulación de los espacios publicitarios, o fomentando fundaciones y asociaciones conectadas a los partidos, y también a través de las desgravaciones fiscales. Todas estas medidas no pueden ser aplicadas sin canales de financiación privada, que debe ser regulada para combatir una posible corrupción, a partir de límites en las donaciones permitidas y prohibiendo la donación por parte de personas jurídicas e instituciones religiosas. Tanto la financiación pública como la privada no pueden interferir en la independencia de los partidos.

Sobre los gastos durante las campañas electorales y su transparencia, se sugiere arbitrar un límite a los partidos, existiendo uno global y otros específicos para los conocidos como "disparadores de gastos", motivando a los partidos para que racionalicen el gasto. La transparencia debe ser total, exponiendo gastos e ingresos, y siendo sometidos estos a un control por lo menos una vez al año, declarando la identidad de los donantes que superen un determinado valor. El control debe ser realizado por una autoridad independiente del Estado, con suficientes poderes para supervisar las cuentas de los partidos y con potestades sancionatorias, como pérdidas de subvenciones total o parcial, y en casos de responsabilidades individuales, una posible anulación del mandato electivo o un periodo de inelegibilidad.

Al final, la recomendación sugiere que los Estados miembros adopten reglas comunes contra la corrupción, como también que todos los miembros posean una legislación referente al tema de la financiación de los partidos.

Posteriormente fue aprobada la Recommendation 2003/4, ahora por medio del Comité de Ministros del Consejo de Europa, enfocada hacia el problema de la corrupción en la financiación de los partidos políticos. ${ }^{642}$ Debido a esto, se hicieron algunas modificaciones en las sugerencias anteriores, como es el caso de las donaciones anónimas. En este documento, el Consejo

\footnotetext{
${ }^{642}$ Cabe destacar la preocupación constante del Consejo de Europa respecto a la corrupción en la financiación de los partidos, como también el crimen organizado. Dicho órgano ha organizado diversas conferencias sobre el tema, siempre aportando sugerencias en pro de una mejora en la regulación de la materia. En este sentido, cfr. AA.VV.: Trading in Influence and the Illegal Financing of Political Parties. Programme of Action Against Corruption - Third European Conference of Specialised Services in the Fight Against Corruption. Council of Europe Press. Germany, 2000, solamente como un ejemplo de los variados trabajos elaborados a partir de este enfoque. Los documentos que fueron redactados como resultado de los debates realizados sirvieron de base para la elaboración de la Recommendation 2003/4.
} 
sugiere que se evite cualquier donación con carácter secreto; que se adopten medidas en el combate a la violación de las normas como las que limitan las donaciones; la limitación de valores en la desgravación fiscal; en caso de donaciones por empresas, que todo el procedimiento esté documentado en libros contables, con la debida información a los socios; que la desgravación fiscal también fuera aplicada para donaciones privadas a instituciones conectadas con los partidos, posibilitando también su control; la limitación o la total prohibición de donaciones extranjeras; y que el servicio de control y fiscalización de los partidos, tanto de sus cuentas anuales como las cuentas de las campañas electorales fuera realizado por personal especializado, no siendo suficiente que sea una autoridad independiente del Estado.

Ya en la esfera de la Unión Europea, el surgimiento de la legislación sobre los partidos políticos y su financiación a escala europea se dio más concretamente en el Tratado de Maastricht, con la inserción del art. $138 \mathrm{a}^{643}$ que se refiere por la primera vez a los partidos a nivel europeo, aunque fue considerado insuficiente para permitir que se tuviera una normativa real sobre la materia. Solamente con el Tratado de Niza fue posible iniciar las negociaciones para una legislación específica ${ }^{644}$, y como consecuencia de ello fue la aprobación de la recommendation 2004/2003 de 4 de noviembre de 2003, y que entró en vigor en febrero de $2004^{645}$, siendo esta la primera normativa más detallada tanto sobre partidos políticos a nivel europeo, como

643 El texto original es: "Article 138a: Political parties at European level are important as a factor for integration within the Union. They contribute to forming a European awareness and to expressing the political will of the citizens of the Union". Dicho artículo fue considerado como la primera manifestación de "constitucionalización" e institucionalización de los partidos a nivel europeo. (In: FUSACCHIA, A. "The Party Must Go On!": II Finanziamento Pubblico dei Partito Politici Europei”. In: Rivista Italiana di Scienza Política. no 1, anno XXXVI, aprile, II Mulino, Bologna, 2006. Pp. 94). Cabe subrayar que dicho artículo es el art. 191 del Tratado de Niza, y el actual .art. 10.4 del Tratado de Lisboa, o el Tratado de la Unión Europea.

${ }^{644}$ Los estatutos normativos que permitieron el desarrollo de la materia son: "19. In Article 191, the following second paragraph shall be added: The Council, acting in accordance with the procedure referred to in Article 251, shall lay down the regulations governing political parties at European level and in particular the rules regarding their funding. 11. Declaration on Article 191 of the Treaty establishing the European Community: The Conference recalls that the provisions of Article 191 do not imply any transfer of powers to the European Community and do not affect the application of the relevant national constitutional rules. The funding for political parties at European level provided out of the budget of the European Communities may not be used to fund, either directly or indirectly, political parties at national level. The provisions on the funding for political parties shall apply, on the same basis, to all the political forces represented in the European Parliament".

645 El documento versión en español puede ser accedido en: <<http://eurlex.europa.eu/LexUriServ/LexUriServ.do?uri=OJ:L:2003:297:0001:0004:ES:PDF>> 
también sobre su financiación. ${ }^{646}$ Esta recommendation fue modificada en 2007 (a través del reglamento 1524/2007, de 18 de diciembre ${ }^{647}$ ), para afilar algunas de sus disposiciones, basándose en la primera experiencia. En ambas, estaba evidenciada la idea de codecisión de la Unión con los Estados miembros, subrayando desde el inicio que las subvenciones recibidas por los partidos europeos no podrían ser utilizados a favor de los partidos nacionales o regionales, sea directamente o indirectamente. Para una mejor comprensión de la evolución de la normativa, en primer lugar se expondrán las reglas contenidas en la Recomendación 2004/2003, para enseguida tratar de las modificaciones introducidas por la Recomendación 1524/2007.

Teniendo en consideración que las normas se referían a los partidos políticos a escala europea, era necesario definir lo que sería un partido político a nivel europeo, algo que la normativa no estableció objetivamente. De hecho, la Recomendación 2004/2003 únicamente trajo en sí una definición primaria, remitiendo el concepto al cumplimiento de ciertos requisitos. No existe, por lo tanto, una conceptualización completa de lo que es un partido político a escala europea, y esta ausencia de un término exacto aporta algunas consecuencias no muy favorables para la consolidación de un Derecho de Partidos en el marco jurídico europeo.

De todos modos, lo que se trató en el inicio fue establecer algunos requisitos capaces de identificarlos y de clasificarlos como partidos a nivel europeo, diferenciándoles de la clásica idea de partidos políticos en la esfera nacional. La intención era crear un mecanismo que no sólo pudiera identificar a

646 Sin embargo, considerando toda la negociación habida antes de la edición de dicha recomendación, FUSACCHIA la considera bastante insatisfactoria, considerando las pretensiones de la Comisión. (FUSACCHIA, A. Op. Cit. Pp. 99).

647 Vid. documento en: $\quad<$ http://eurlex.europa.eu/LexUriServ/LexUriServ.do?uri=OJ:L:2007:343:0005:01:EN:HTML>> Acceso en 28/06/2011. Cabe subrayar que dicho reglamento fue aprobado por una amplia mayoría, obteniendo 538 votos a favor, 74 en contra, y 10 abstenciones, lo que demuestra la preocupación por la integración ciudadana en las políticas desarrolladas por el Parlamento Europeo, y que incluso la promoción de las fundaciones de los partidos europeos se fundamenta en la promoción de la democracia a nivel supranacional que carece de efectividad. La normativa también es bastante clara en el sentido de que el déficit democrático arraigado en la esfera europea debe ser combatido justo por dichas fundaciones dentro de cada país miembro, como un requisito para participar del reparto de las subvenciones. Vid. SEATZU, F. "La Nuova Disciplina Giuridica sul Finanziamento dei "Partiti Politici a Livello Europeo". In: Studi sull'Integrazione Europea. oㅜ 3. anno III, ed. Cacucci, Bari, 2008. Pp. 575-595, donde el autor analiza la nueva normativa, en una comparación con el art. 191 del tratado de la constitución europea y con las definiciones de las normas sobre financiación de partidos a nivel europeo. 
los partidos políticos a escala europea como tales, sino también garantizar un perfil supranacional de dichas organizaciones, traduciendo los objetivos de integración que tiene la Unión Europea. Así, para que el partido político tenga el status de un partido político europeo (lo que la literatura también define como europartido), y por consiguiente tenga el derecho a las subvenciones del presupuesto europeo, ellos deberán cumplir con los cuatro requisitos dispuestos en el art. $3^{\circ}$ de la Recomendación, a ser comprobados anualmente:

- Que tengan personalidad jurídica debidamente legal en el país Estado miembro en que tengan su sede. ${ }^{648}$

- El partido debe estar representado en al menos $1 / 4$ de los Estados miembros, por miembros del Parlamento Europeo; o estar representado en al menos $1 / 4$ en los Parlamentos nacionales 0 regionales, 0 en las Asambleas Regionales; o bien haber obtenido en por lo menos 1/4 de los Estados miembros, al menos el $3 \%$ de los votos en cada uno de dichos Estados en las últimas elecciones europeas.

- Observar y agregar en sus actividades y programas los principios en los que se basa la Unión Europea, es decir, libertad, democracia, respeto a los derechos humanos y a las libertades fundamentales, como también el Estado de Derecho.

- Haber participado en las elecciones europeas, o haber expresado la intención de participar.

A partir de aquí cabe subrayar que la normativa muestra en sí misma la naturaleza dual del partido europeo, como también su posición destinada a la cooperación transnacional, y a una forma soberana de integración política. ${ }^{649}$ Lamentablemente la combinación de los criterios genera la ya citada discriminación contra los partidos minoritarios, ya que la solicitud de los

\footnotetext{
${ }^{648}$ El problema apuntado por MARTINELLI es que, aunque se pueda clasificar como un avanzo significativo el formal reconocimiento de los partidos en la esfera europea, no ha sido considerado en la elaboración de este criterio que dentro de la Europa existen realidades mucho diversas, como es el caso de Italia, que no tiene en su ordenamiento la configuración de los partidos como una persona jurídica, pero sí de asociación no reconocida. En este caso, no hay todavía una directriz interpretativa, lo que podrá ser algo futuramente. (In: MARTINELLI, C. "Il Finanziamento Pubblico dei Partiti Europei". In: Quaderni Costituzionali. Anno XXVX. № 2, Giugno. Ed. II Mulino, Bologna, 2004. Pp.416-418). Es de resaltar que Italia es el único caso europeo a no tener reglamentada la cuestión de los partidos, no siendo esto resuelto aunque la legislación electoral fue reformada a menos de 5 años.

${ }^{649}$ FUSACCHIA, A. Op. Cit. Pp. 99.
} 
recursos posiblemente solo podía realizarse por los partidos que ya existen desde hace muchos años y que acompañaron la propia evolución de la Unión Europea. ${ }^{650}$ Por otro lado, también es cierto que a partir de dicho mecanismo, la norma trató de separar los partidos nacionales de los partidos europeos, ya que, para ser considerada una organización partidista a escala europea, esta debe ser representativa a nivel transnacional. ${ }^{651}$

La solicitud a las subvenciones deberá seguir el procedimiento descrito en el art. 4 y que busca, básicamente, verificar el cumplimiento de las condiciones previstas en el art. 3, a y b. El Parlamento Europeo es el responsable en verificar periódicamente el cumplimiento de los requisitos descritos en el art. 3 y, en todo caso, en el art. 5 está prevista la posibilidad de que los partidos realicen un control horizontal del status de partido político a escala europea, a partir de la petición de una cuarta parte de los eurodiputados que representen al menos a tres grupos políticos en el Parlamento Europeo. Realizada la petición, el Parlamento Europeo pedirá a un Comité de personas independientes una opinión sobre el asunto, antes mismo de proceder con la verificación. En dicho Comité estarán involucrados también el Consejo y la Comisión. Si el Parlamento Europeo considera que alguno de los requisitos ya no se cumplen, el partido político en cuestión será excluido de la financiación. Aquí lo que cabe subrayar es la adopción por parte de la normativa de medidas de democracia militante, principalmente si consideramos el control externo de la verificación del cumplimiento del art. 3.c, que se refiere directamente al contenido de los programas y de las actividades de las organizaciones partidistas a escala europea. Dicho punto - muy polémico entre los Estados miembros - fue ampliamente abordado durante el debate para la aprobación de la Recomendación 2004/2003, y todavía no ha encontrado un consenso.

\footnotetext{
650 BOZÓKI, A. "Political Parties and the Prospects for Democracy". In: <<http://www.unc.edu/depts/europe/conferences/parties/papers/bozoki_cosntitution2.pdf>>. Acceso en 22/11/2009. Pp. 18.

${ }^{651}$ FUSACCHIA, A. Op. Cit. Pp. 100. Cabe subrayar que en los debates también fue tenido en consideración la posibilidad de la exclusión de fuerzas políticas nuevas o extraparlamentarias, lo que fue mitigado en parte por el requisito cuarto del artículo 3. En este sentido, vid. GAGATEK, W. "Political Financing Regulation at the EU Level: The Conflict of National Traditions and Interests". In: Papers: Party Law - The Legal Regulation of Political Parties in Post-war Europe. no 14, Nov., Centre for Europe, [s.I.], 2011. Pp. 12 y ss.
} 
El derecho a las subvenciones de la Unión Europea también impone a los partidos una serie de obligaciones. Así, dichas organizaciones no podrán aceptar donaciones anónimas; donaciones procedentes de los grupos políticos del Parlamento Europeo; donaciones de cualquier empresa que el poder público pueda ejercer directa o indirectamente cualquier tipo de influencia; donaciones que sobrepasen los 12.000 euros al año tanto de personas físicas o también de personas jurídicas; y donaciones de cualquier autoridad pública de un tercer país, o de empresas de fuera de la Unión Europea, que puedan tener cualquier tipo de influencia directa o indirecta.

Existen también obligaciones que se relacionan a la transparencia de sus ingresos y gastos, a partir de una rendición anual de cuentas y la declaración de las fuentes de las donaciones privadas que sean superiores a 500 euros. La verificación de los registros deberá ser realizada por medio de una auditoría externa e independiente, dentro de los seis meses siguientes al cierre del ejercicio a ser verificado. Los partidos tienen el deber de colaborar en caso de solicitud de documentos e informaciones referentes a sus cuentas, y si fueran detectados fondos recibidos indebidamente por los partidos, estos deberán reintegrarlos al presupuesto general de la Unión Europea.

La principal prohibición impuesta por la normativa es la que las subvenciones de los fondos europeos o recursos económicos de cualquier otra fuente de recursos económicos que componga la financiación de los partidos a escala europea no podrán ser utilizados a favor de los partidos nacionales $u$ otros. Con dichos recursos únicamente podrán costear los gastos relacionados con los programas directos de los europartidos, incluyendo los gastos administrativos, de apoyo técnico, investigación, publicaciones, etc. ${ }^{652}$

El control será realizado por una auditoria exterior e independiente, con periodicidad anual, a partir de las disposiciones del Reglamento financiero europeo, comunicándose el resultado al Parlamento Europeo en los seis meses siguientes al cierre del ejercicio auditado. En caso de violación de las reglas de

652 CORTÉS BURETA afirma que dichos valores solo podrán ser utilizados para el mantenimiento de los partidos, estando prohibido usarlos en gastos de campañas electorales. Dicha interpretación está de acuerdo con la normativa, dado que la LOREG dispone que las subvenciones deben ser utilizadas en las elecciones europeas, no siendo conflictivas una y otra. (In: CORTES BURETA, P. "La Financiación de los Partidos..." Pp. 2892). 
financiación, el partido deberá restituir las cantidades al presupuesto europeo en su totalidad. Toda la documentación debe ser sometida a una auditoría externa e independiente, con las informaciones sobre los gastos efectuados por los partidos a escala europea con los partidos nacionales, de manera conjunta.

El reparto de las subvenciones implica la distribución del 15\% del valor total de los recursos destinados a los partidos en partes iguales, siendo los $85 \%$ restantes divididos entre los partidos que tengan escaños en el Parlamento Europeo, en proporción al número de diputados. Teniendo en cuenta esta regla, un parlamentario no podrá ser miembro de más de un partido a escala europea. La financiación de los partidos a nivel europeo a cargo del presupuesto europeo no puede sobrepasar el 75 por 100 de las finanzas partidistas.

La pronta aprobación de la recommendation 1524/2007 refleta la necesidad de ampliar la regulación tanto de los partidos políticos a escala europea, como de su financiación, tomándose en cuenta la experiencia habida a partir de la aplicación de la Recomendación 2004/2003. De esta manera, la nueva normativa permitió un perfeccionamiento de las reglas, y sus resultados continúan siendo verificados hasta el día de hoy.

El nuevo reglamento aporta un nuevo concepto referente a las fundaciones de los partidos políticos, representando uno de los puntos centrales de la nueva Recomendación. Las fundaciones vinculadas a los partidos europeos tienen como objetivo promover la participación ciudadana en las políticas ejercidas por el Parlamento Europeo, fomentando paralelamente la función de información y de formación política que tienen los partidos políticos europeos. En primer lugar, la Recomendación trata de definir qué debe considerarse como una fundación a nivel europeo, posibilitando su financiación por medio de los presupuestos generales de la Unión Europea. Dichas fundaciones deben cumplir algunos requisitos de la misma manera que ocurre con los partidos políticos a nivel europeo, estando también sometidas al respeto de los principios que fundamentan la Unión Europea, aunque no se limita a esto, ya que tampoco deben tener objetivos de lucro, y también estar distribuidas de forma equilibrada geográficamente. Las subvenciones deben ser obtenidas únicamente a través del partido a escala europea al que están 
afiliadas, estando prohibida la utilización de dichos recursos para la financiación de campañas electorales o referendos. Dichas reglas tienen como propósito el de diferenciar las funciones de las fundaciones de las funciones de los partidos, y es un claro intento de evitar que dichas fundaciones se conviertan en un nuevo e informal canal de propaganda.

Para que puedan recibir las subvenciones, las fundaciones también están sometidas a un control externo del cumplimiento de los elementos descritos en el art. 3, es decir, el mismo control al que los partidos están sujetos tanto por parte del Parlamento Europeo, como por la petición de otros miembros de la misma institución, también es aplicado a las fundaciones. Además, si el partido a nivel europeo con el que la fundación está vinculada pierde el status de partido y, por lo tanto, pierde el derecho a la financiación, hace que la fundación también pierda dicho derecho.

Todas las obligaciones impuestas a los partidos políticos a nivel europeo referentes a transparencia, donaciones y prohibiciones son extendidas a las fundaciones. Por otro lado, la nueva normativa amplia el régimen de límites y prohibiciones de donaciones también para los partidos. Así, los partidos nacionales, como también sus miembros podrán realizar donaciones a favor del partido a escala europea el cual se vincula, en su límite del 40 por 100 del presupuesto anual del partido a nivel europeo. Lo mismo es aplicable para las fundaciones a nivel europeo. Sin embargo, sigue no siendo permitido el camino contrario, es decir, los partidos y las fundaciones a escala europea no podrán financiar a los partidos o fundaciones nacionales directa o indirectamente.

Cabe subrayar el cambio que se produjo en la normativa en relación a los gastos de los partidos y de las fundaciones a nivel europeo. A partir de las nuevas reglas, los partidos a escala europea podrán utilizar los recursos recibidos con cargo al presupuesto general de la Unión Europea para financiar campañas para las elecciones al Parlamento Europeo, estando excluido de esta autorización sufragar directa o indirectamente los gastos de los partidos nacionales con sus candidatos o los gastos de campaña para referendos y elecciones que no sean las europeas. El régimen de la financiación de las elecciones al Parlamento Europeo sigue siendo de competencia normativa de cada Estado miembro. 
Otros cambios significativos producidos fueron en relación a la no sumisión de los partidos políticos a escala europea al art. 133 del Reglamento financiero del Consejo, que establece que las subvenciones no pueden financiar a todos los gastos del organismo perceptor. Dicha excepción a favor de los partidos demuestra su importancia en la tarea de buscar el interés general europeo, y es una solución a la falta de fuentes de financiación que los partidos a nivel europeo tienen si comparados con los partidos nacionales. Por otro lado, la nueva normativa tampoco ha permitido que las subvenciones puedan financiar a la totalidad de los gastos de los partidos o de las fundaciones a escala europea, aunque haya aumentado su límite al $85 \%$ del total de los gastos realizados.

Las reglas sobre el control de las cuentas también fueron ampliadas, siendo asimismo aplicable a las fundaciones. Así, la publicidad de los informes es una de las nuevas obligaciones introducidas, y el Parlamento Europeo debe publicar en su sitio web dichos informes anuales de los partidos políticos y fundaciones que han recibido subvenciones, indicando las cantidades concedidas y sus respectivos ejercicios. Dicha publicación también alcanza a los informes emitidos por las auditorías externas realizadas en las cuentas de dichas organizaciones.

El reglamento europeo que trata de la financiación de las actividades ordinarias, de aplicación directa y obligatoria por parte de los Estados miembros. ${ }^{653}$ Sin embargo, y como ya fue mencionado, las elecciones europeas son sometidas a la legislación de cada país miembro, y así siendo, España dispone de reglas especificas para la subvención de gastos electorales en las campañas electorales para el Parlamento Electoral, y dichas disposiciones están contenidas en la LOREG, a partir de los arts. 226.

La sistemática dictada por la LOREG es muy similar a las que son aplicadas para la financiación para las elecciones generales y autonómicas y sufrió una actualización en la última reforma de la ley. La obligatoriedad de un administrador general rige aquí también para los partidos, federaciones y coaliciones, que deberán observar lo dispuesto en el art. 174.1 para su

\footnotetext{
${ }^{653}$ En la Ley Orgánica 3/1987 había mención sobre la financiación ordinaria de los partidos a escala europea (art. 6.2), que fue excluida en la Ley Orgánica 8/2007 por ya existir los reglamentos arriba analizados.
} 
designación. Los administradores de las candidaturas en cada provincia también deberán proceder como en el art. 174.2, siendo ambos designados antes del $21^{\circ}$ día posterior a la convocatoria de elecciones. El Estado concederá subvenciones a los gastos generados de la misma forma que ocurre en los demás niveles, es decir, 32.508,74 euros ${ }^{654}$ por cada escaño obtenido, y 1,08 euros $^{655}$ para cada uno de los votos obtenidos por cada candidatura que haya obtenido al menos un escaño. Aunque corresponda a la misma estructura de acceso y distribución de las ayudas públicas, se puede considerar que dicha financiación representa una excepción en relación al resto del sistema, porque como hay solamente una circunscripción electoral, la diferencia entre partidos mayoritarios y minoritarios disminuye, aunque no se elimina por completo por la aplicación de la regla D'Hondt. ${ }^{656}$

El mailing sigue presente ${ }^{657}$ y posee una escala de cantidades a reembolsar por los gastos de envío directo y personal a los electores en por lo menos una comunidad autónoma. Dicha ayuda será accesible a los partidos, federaciones y coaliciones cuya candidatura haya obtenido por lo menos un diputado, no importante el porcentaje, y la escala de valores corresponde a 0,16 euros por elector cuando hay como mínimo un 15 por 100 de los votos válidos emitidos; el valor de 0,11 euros por elector si se alcanza el mínimo de 6 por 100 de los votos validos; el valor de 0,03 euros por elector si se alcanza el mínimo de 3 por 100 de los votos válidos; y el valor de 0,02 euros por elector si se alcanza el mínimo de 1 por 100 de los votos válidos. ${ }^{658}$ Cabe resaltar que dicho gasto no se incluye en el límite global de gastos, siguiendo lo dispuesto para los demás niveles, como también la cantidad está en euros constantes ${ }^{659}$, actualizables por el Ministerio de Economía y Hacienda, en los cinco días subsiguientes a la convocatoria de las elecciones. La extinción del derecho a

\footnotetext{
${ }^{654}$ Antes de la reforma, eran tres millones de pesetas, que correspondía a 18.030,363 euros.

${ }^{655}$ Anteriormente, eran 100 pesetas, que correspondía a 0,60 euros.

${ }^{656}$ HOLGADO GONZÁLEZ, M.: La Financiación de los... Pp. 66-69. Aquí, nuevamente la autora reafirma su sugerencia de aplicar solamente el criterio de los votos, con el establecimiento de un umbral para acceder a la financiación pública.

${ }^{657}$ Cfr. art. 227.3, LOREG.

${ }^{658}$ Corresponde a, respectivamente, 0,09 euros; 0,07 euros; 0,01 euros y 0,006 euros.

${ }^{659}$ Aunque en el texto todavía conste como "pesetas constantes", por un olvido del legislador de la nueva ley que reformó la LOREG.
} 
las subvenciones también sigue en casos de ilegalización de partidos, federaciones y coaliciones, conforme dicta el art. 127, apartados 2, 3 y 4 .

Ante ello, se percibe que las diferencias existentes entre las normativas se centran más en las disposiciones aprobadas por el Parlamento Europeo, aunque el problema de la financiación de los partidos europeos está lejos de ser resuelto por la escasez de los recursos, por la falta de transparencia y por su regulación, así como también, por la insuficiencia de su fiscalización. ${ }^{660}$

${ }^{660}$ BOZÓKI, A. Op. Cit. Pp. 16. 


\section{CAPÍTULO IV}

\section{EL CONTROL DE LA FINANCIACIÓN DE LOS PARTIDOS POLÍTICOS Y SUS DISFUNCIONALIDADES}

Uno de los puntos centrales de la financiación de los partidos políticos es, sin lugar a dudas, la cuestión de la fiscalización y el control externo de sus finanzas ${ }^{1}$, englobando, lógicamente aquí, la transparencia que se espera de esta función. Se puede entender que existe un "cuadrado mágico" - en las palabras de NASSMACHER - para los regímenes de financiación de la política, debiendo estos poseer mecanismos de transparencia hacia la ciudadanía, con una rendición de cuentas que debe ser realizada tanto interna como externamente. Junto a ello, también deben existir mecanismos institucionales para concretar esta función fiscalizadora, con la posibilidad real de sanciones. ${ }^{2}$

El tema resulta hoy de la máxima actualidad porque la evolución de la financiación de los partidos, junto con la creciente aparición de escándalos en este ámbito suscitaron en la sociedad civil una fuerte demanda frente a los órganos del Estado, que junto con los propios partidos y la sociedad civil son quienes ejercen la función fiscalizadora última de las organizaciones partidarias, con mayor apertura en pro de la salud de la propia política. ${ }^{3}$ Con todo, es obvio que no resulta fácil encontrar soluciones eficientes, dada la peculiar "aporía" del Derecho de partidos, sus resistencias, muy acusadas en

\footnotetext{
${ }^{1}$ El control de los partidos puede ser interno o externo, y en el interno puede afectar el deber de las formaciones políticas de democracia interna, ya que los afiliados tienen el derecho de saber la situación actualizada de las finanzas del partido. Junto a ello, es importante dicho control para que no existan "economías paralelas", y también puede ser un intento de controlar el endeudamiento de la organización. Como ya se ha visto en el capítulo I, y también será analizado en este punto, el control interno en España posee grandes deficiencias. El control externo está actualmente en manos de las juntas electorales y del Tribunal de Cuentas. (cfr. ÁLVAREZ CONDE, E. "Algunas Propuestas sobre la Financiación de los Partidos Políticos". In: AA. VV.: La Financiación de los Partidos Políticos. Cuadernos y Debates, no 47, Centro de Estudios Constitucionales, Madrid, 1994. Pp. 26-27).

${ }^{2}$ NASSMACHER, K-H. "Monitoring, Control and Enforcement of Political Finance Regulation". In: AUSTIN, R.; TJERNSTRÖM, M. (eds.): Funding of Political Parties and Election Campaigns. International IDEA, Stockholm, 2003. Pp. 139. El autor mantiene que este punto fue el último paso en la regulación de la financiación de la política, ya porque se ignorase su necesidad, ya porque se pensase que la política por si sola solucionaría estos problemas.

${ }^{3}$ ALBERTO CORDERO, L. "La Fiscalización del Financiamiento de los Partidos Políticos: un Asunto de Conciencia Crítica". In: AA.VV.: Administración y Financiamiento de las Elecciones en el Umbral del Siglo XXI - Memoria del III Congreso Internacional de Derecho Electoral. Tomo II, Instituto de Investigaciones Jurídicas, DF, México, 1999. Pp. 401.
} 
este campo a la "juridificación". No se puede olvidar el escaso éxito de las medidas de prohibición/penalización en este campo. Por ello, la doctrina parece girar hacia sistemas menos prohibitivos, pero más transparentes, en dónde el problema de la financiación ilegal e irregular pueda ser al menos jurídicamente "controlado". 4 Por otra parte, parecería que en España a partir de la existencia de un sistema de partidos consolidado, con organizaciones estables, es más fácil de realizar esta fiscalización ${ }^{5}$ aun cuando desgraciadamente, la práctica esté demostrando lo discutible de semejante conclusión.

En el ámbito de la financiación partidista, resulta pues imprescindible analizar de manera detallada el régimen de fiscalización existente dentro de un sistema normativo, teniendo evidentemente muy presente la capacidad efectiva de la regulación normativa para encauzar dicha financiación.

\section{1) Consideraciones sobre la función de fiscalización de los partidos políticos}

Los mecanismos de control de ingresos y gastos de las formaciones políticas se componen de tres elementos clásicos: cómo se realiza este control; quién es su responsable ${ }^{6}$; y cuál es el sistema de sanciones por su incumplimiento. ${ }^{7}$ Adquieren también centralidad los elementos de publicidad y transparencia, pues afectan al derecho a la información del electorado, mejorando consecuentemente la calidad de la democracia. ${ }^{8}$

\footnotetext{
${ }^{4}$ Debido a ello GARCÍA VIÑUELA comenta que lo que más llama la atención en este panorama es que los partidos terminan por incumplir una legislación que ellos mismos aprobaron priorizando sus propios intereses sin la posibilidad de intromisiones externas. (In: GARCíA VIÑUELA, E.: Un Tigre de Papel - ¿Deben prohibirse la donaciones anónimas a los partidos políticos?. El País, 18 de diciembre de 2005).

NAVAS, X. "La Financiación Electoral: Subvenciones y Gastos". In: NOHLEN, D.; PICADO, S.; ZOVATTO, D. (comp.): Tratado de Derecho Electoral Comparado de América Latina. Ed. Fondo de Cultura Económica, DF, México, 1998. Pp. 477.

${ }^{6}$ Caben múltiples modelos. En el Reino Unido existe una Administración electoral, como también en Brasil, que posee una Justicia especializada en asuntos electorales, incluyendo el control externo de los partidos. En los EE.UU. existe la FEC - Federal Electoral Commission, que no se integra el Ejecutivo. Existen otras opciones, por ejemplo, tener un órgano parlamentario como responsable de este control, como es el caso de Alemania e Italia.

CASTILLO VERA, P. del: La Financiación de Partidos y Candidatos en las Democracias Occidentales. CIS Siglo XXI, Madrid, 1985. Pp. 126.

${ }^{8}$ Según DEL CASTILLO, la publicidad en los mecanismos de control de los partidos hace que mejore la democracia porque obliga a los partidos a diversificar sus fuentes de financiación, para que no parezcan depender de determinadas fuentes. Entiende esto como sostenimiento del partido, ya que hará que el partido busque en el seno de la sociedad dicha diversificación de fuentes, fomentando a la vez la participación ciudadana en la política. También hace que los
} 
Por otra parte, cabe recordar que, en España, los partidos están excluidos de la Ley Orgánica General de Subvenciones 38/2003 de 17 de noviembre, lo que les exonera de estar obligados a una serie de deberes que otros beneficiarios de subvenciones públicas tienen que cumplir, conforme disposición del art. 4.

En este apartado del trabajo, se analizará en primer lugar la forma en que se realiza este control, en segundo término la competencia del Tribunal de Cuentas sobre el tema, y, por último, se realizará un estudio de los datos procedentes de los informes de fiscalización de las formaciones políticas emitidos por el propio Tribunal, a fin de poder alcanzar una valoración más ajustada a la realidad del funcionamiento del sistema.

\subsection{Aspectos generales de la fiscalización - la "accountability"}

En la estructura de los mecanismos de control en los sistemas de financiación de los partidos políticos los dos aspectos más relevantes son, indudablemente, la transparencia que todo el procedimiento tiene que tener, así como también la eventual publicidad de los datos obtenidos en este ámbito.

La transparencia debe ser la base del sistema, y esta, aliada a un correcto y equilibrado sistema de sanciones determinará que los mecanismos de control previstos sean eficaces. ${ }^{9}$ Si no fuera así, cualquier intervención legislativa en el tema no tendría efecto alguno. La transparencia por otra parte tiene un coste, en primer lugar económico, tanto para las organizaciones políticas como para los organismos públicos que realizan el control. También

grandes donantes que ejercen favores y presión sobre los partidos sean más cautelosos, pudiendo hacer que disminuya esta práctica. Además, existe el temor ante el escándalo político y el miedo a que el mercado lo vea como un simpatizante tanto del partido como de las políticas que este aplica. A la vez también ayuda a fortalecer la confianza de los ciudadanos en el sistema democrático haciendo este proceso mucho más transparente. (In: CASTILLO VERA, P. del: La Financiación de Partidos y Candidatos... Pp. 127-129). Acompaña la autora en este pensamiento DÍAZ-SANTANA CASTAÑOS (cfr. DÍAZ-SANTANA CASTAÑOS, H. "Experiencia con el Financiamiento de los Partidos Políticos en España". In: www.cepchile.cl/dms/archivo_3516.../refor1_05_diaz_santana.pdf. <<Acceso en 25/11/2009>> Pp. 203), y NASSMACHER, que entiende que el objetivo principal de la "accountability" de los partidos sea animarlos a levantar y gastar sus recursos de manera que no provoque polémica entre el electorado. La apertura de nombres de donantes, por ejemplo, auxiliaría en esta tarea seguramente. (In: NASSMACHER, K-H. "The Funding of Political Parties in the Anglo-Saxon Orbit”. In: AUSTIN, R.; TJERNSTRÖM, M. (eds.): Funding of Political Parties and Election Campaigns. International IDEA, Stockholm, 2003. Pp. 42).

9 BALMELLI, T.: Le financement des Partis Politiques et des Campagnes Électorales: Entre Exigences Démocratiques et Corruption. Universitaires Fribourg, Suisse, 2001. Pp. 382-385. 
puede tener un coste político, en cuanto puede ser que afecte a la confianza que la sociedad deposita en las formaciones políticas, eliminando poco a poco el interés de entes privados en general en hacer donaciones. $Y$, en todo caso, nunca se puede garantizar, sino más bien lo contrario, que la transparencia sea capaz de evitar los escándalos políticos en torno a las finanzas de los partidos. ${ }^{10}$ Pero en pro de un bien mucho mayor, la defensa de la legitimidad democrática del sistema, y de la propia igualdad de condiciones" en la competición partidista, se debe buscar incesantemente una "accountability" satisfactoria $^{11}$, que permita al ciudadano un conocimiento suficiente, y a los poderes públicos la sanción de las infracciones. Sin embargo, no basta solo con tener transparencia.

La transparencia por sí sola no puede hacer que partidos o políticos individualmente considerados sean sancionados de la manera más eficaz - es decir - con sanciones electorales-democráticas. Debido a ello en la doctrina aparece muy clara la necesidad de publicidad de los datos que componen la "accountability". Como ya se ha subrayado, existe el temor de que el volumen de contribuciones privadas a favor de los partidos disminuya si la publicidad se vuelve obligatoria, y también se ha llegado a argumentar que la publicidad en este sentido violaría en cierta forma el carácter secreto de voto. ${ }^{12}$

\footnotetext{
${ }^{10}$ FISHER, J.; EISENSTADT, T. A. "Introduction Comparative Party Finance. What is to be Done?" In: Party Politics. v. 10. no 6. Sage, London, 2004. Pp. 621.

${ }_{11}$ El fenómeno conocido como "accountability", como es sabido, está bastante presente en diversas manifestaciones de la vida estatal, a fin de garantizar a la sociedad gobiernos dignos su naturaleza democrática. Las prácticas de buen gobierno son, incluso, recibidas por muchas empresas privadas.

${ }^{12}$ CORTÉS BURETA, P.: Recursos Públicos y Partidos Políticos: Balances y Perspectivas de Reforma. Centro de Estudios Políticos y Constitucionales, Madrid, 2003. Pp. 42-44. Debido a ello, la autora incluso cita una doctrina más liberal, para la que bastaría con la obligación de los partidos de publicar solamente un informe periódico en lugar de establecer normas de dudoso cumplimiento. Sin embargo, en su opinión, no basta solamente con esto, e incluso no sería exagerado si hubiera un control del presupuesto del partido como un todo. Como ejemplo de un autor liberal, se puede citar NASSMACHER. Cfr. NASSMACHER, K-H. "Party Funding in Continental Western Europe". In: AUSTIN, R.; TJERNSTRÖM, M. (eds.): Funding of Political Parties and Election Campaigns. International IDEA, Stockholm, 2003. Pp. 134. También es un hecho que hay un incumplimiento bastante acentuado de la obligación de rendir cuentas por parte de los partidos que participan en elecciones municipales que, aunque reciban subvenciones públicas y que tengan la obligación formal de presentar sus datos, se debe tener en mente que en muchos casos se referían a candidaturas sólo a nivel municipal, con un número pequeño de votos y de concejales, lo que les permitía recibir subvenciones muy reducidas, que, considerando el coste del envío de las cuentas al Tribunal, al final no compensaba. (In: PAJARES MONTOLIO, E. "El Tribunal de Cuentas y los Límites del Control de la Financiación de los Partidos Políticos". In: AA.VV.: Derecho Constitucional para el Siglo $X X I$ - Actas del VIII Congreso Iberoamericano de Derecho Constitucional, Tomo II. Ed. Thompson - Aranzadi, Sevilla, 2006. Pp. 2737).
} 
La cuestión sobre la publicidad de los datos y la eventual violación del secreto de voto, con la consecuente disminución del volumen de donaciones ha sido muy debatida por la doctrina, incluso por la posibilidad de afectar en distinta forma a los partidos según su tamaño y organización. ${ }^{13}$ Esta discusión ganó forma en el Derecho Comparado cuando se llevó a cabo la declaración de constitucionalidad de la Supreme Court en los EE.UU. en 1975 sobre la FECA, determinando que la publicidad de los gastos e ingresos de los partidos no afectaba a la First Amendment, y que el derecho de información de los votantes debería prevalecer sobre una hipotética afectación al secreto del voto. ${ }^{14}$

Pero no se puede entender que la existencia de publicidad de los datos por sí sola, consiga los objetivos que se pretenden, se debe tratar ante todo de que la divulgación de datos este a disposición de los ciudadanos, a través de una exposición simple, comprensible y puntual, para que los datos puedan ser utilizados como criterio de valoración y crítica política. ${ }^{15}$ Por otra parte, los informes publicados tienen que ser fiables y efectivos, o sea, deben ser resultado de auditorías independientes. Por último, la infracción de este tipo de transparencia y publicidad debe sancionarse jurídicamente. ${ }^{16}$

Centrándonos en el ordenamiento español, y respecto a los aspectos generales del mecanismo de control existente, las dificultades que acompañan a la labor del Tribunal de Cuentas son claramente originadas por las lagunas 0 ambigüedades de la regulación jurídica existente. ${ }^{17}$ Más allá de los obstáculos procedimentales que el propio órgano fiscalizador sufre - como la casi imposibilidad de cumplimiento de los plazos establecidos tanto en la LOREG como en la LOFPP, aunque estos hayan sido ampliados en la Ley Orgánica 8/2007 - las disposiciones legales no terminan de precisar con la suficiente seguridad jurídica criterios claros para la fiscalización. En cuanto a los plazos

\footnotetext{
${ }_{13}^{13}$ CASTILLO VERA, P. del: La Financiación de Partidos y Candidatos... Pp. 129-130.

${ }^{14}$ Sobre el debate, se remite al punto 4.1 del Capítulo II.

${ }^{15}$ NASSMACHER, K-H. "The Funding of..." Pp. 45.

${ }^{16}$ KATZ, R. S. "Party Organizations and Finance". In: LE DUC, L.; G. NIEMI, R.; NORRIS, P. (ed.): Comparing Democracies: Elections and Voting in Global Perspective. Ed. Sage, London, 1996. Pp. 128-129.

17 Se puede citar aquí la situación en que la formación política participa en dos o más campañas electorales convocadas en concurrencia, ya que no hay criterios claros de cómo efectuar esta fiscalización. (cfr. CUÑADO AUSIN, G. "La Fiscalización de los Partidos Políticos: Una Síntesis de las Actuaciones Practicadas por el Tribunal de Cuentas". In: Revista Española de Control Externo, vol. 3, o 9, 2001. Pp. 154). También exponiendo críticas sobre la fiscalización del Tribunal, véase opinión de PRADERA, J.: Balances Tramposos. El País. 12 de octubre de 2003.
} 
de la misma, se entiende que estos están contenidos en la ley debido a la inmediatez de la fiscalización ${ }^{18}$, al menos de la fiscalización electoral, por los motivos ya citados. Sin embargo, se da el hecho de que los partidos no suelen respetar el plazo de 30 días para entregar las cuentas, y en muchas ocasiones lo hacen sólo para poder recibir el adelanto correspondiente al $90 \%$ del montante total debido a cada formación política y, para poder saldar sus deudas que según el art. 133.4 de la LOREG no es necesario que haya terminado la función fiscalizadora del Tribunal de Cuentas para que el Estado libere dichos recursos. Lo que está claro es que mientras todas las organizaciones entregan sus rendiciones de cuentas, además de que se obtengan las informaciones solicitadas por el Tribunal de Cuentas a terceros y a los propios partidos (30 días según el art. 134), y contando con los 200 días para realizar la auditoría en las cuentas, muchas veces el plazo de fiscalización, que debería ser de entre 260 y 300 días, acaba por ser al final de más de año, como se verifica constantemente en los propios informes emitidos por el Tribunal.

Lo que sucede con la fiscalización de las cuentas ordinarias es aún más grave, ya que la diferencia entre la entrega de cuentas de un ejercicio y la realización del informe puede llegar a más de tres años ${ }^{19}$, para que finalmente sea analizado por las propias Cortes Generales. ${ }^{20}$ Aunque en la Ley Orgánica 8/2007 se mencione que la aprobación por las Cortes será requerida únicamente cuando "proceda", ya que el Tribunal tiene exclusividad de la actividad de control, no se sabe todavía como se articulará concretamente el sistema, lo que genera la sospecha de que no se producirán cambios significativos.

Tampoco se puede olvidar el volumen de trabajo que resulta de la fiscalización de los partidos, dado el número de formaciones políticas que deben someter sus cuentas al Tribunal, aun descontando las formaciones que no tienen derecho a subvenciones y, consecuentemente no son fiscalizadas -

${ }^{18}$ TORRES FERNANDEZ, J. J. "El Control de las Subvenciones a los Partidos Políticos". In: XV Jornadas de Estudio: El Sistema Económico en la Constitución Española - Vol. II. Secretaria General Técnica - Centro de Publicaciones, Ministerio de Justicia, Madrid, 1994. Pp. 1868.

${ }^{19}$ Esta es la diferencia actualmente. El último informe ordinario es de 2006, entregado en 2010.

${ }^{20}$ Lo que, en la opinión de ARIÑO ORTIZ, hace que aparezca una extraña figura unificada de fiscal y fiscalizado. Cfr. ARIÑO ORTIZ, G.: La Financiación de los Partidos Políticos. Documentos del Foro de la Sociedad Civil. no 1. Ed. Foro de la Sociedad Civil, Madrid, 2009. Pp. 56. 
siendo este un fallo significativo de la normativa - así como también las deficiencias que cada rendición de cuentas presenta sin excepción, lo cierto es que al Tribunal le resulta casi imposible realizar su labor de efectuar una fiscalización de alta calidad. En mi opinión, de hecho, el Tribunal ya trabaja por encima de su capacidad, como se subraya continuamente en el envío de mociones y notas informativas al Parlamento con el fin de mejorar la legislación y el resultado de todo este procedimiento por el propio Tribunal, sin que hasta hoy hayan mostrado los partidos una especial receptividad hacia las mismas.

Otro elemento que acentúa las dificultades con que se enfrenta el Tribunal de Cuentas en el momento de fiscalizar la financiación de los partidos tiene que ver con la diferencia entre las leyes electoral y ordinaria, originando problemas en aspectos como el límite de gastos de uno y de otro. Es sabido que la LOREG es mucho más rígida que la LOFPP, y ya se ha diagnosticado un aumento bastante significativo en los gastos ordinarios, que no se someten a ninguna limitación - incluso por su naturaleza - lo que permite deducir que la transferencia de gastos electorales hacia las cuentas ordinarias es frecuente, y que la ley presenta múltiples deficiencias en su objetivo de controlar este fenómeno. La situación se complica si se analizan procesos electorales concurrentes, ya que los partidos deciden informalmente aplicar el mayor de todos los límites para las elecciones, y aún más si el partido participa en alguna coalición electoral, sin que existan reglas claras en la LOREG, ni tampoco directrices de interpretación para este tipo de situación. ${ }^{21}$

Con todo, conviene recordar, que como subraya el profesor CASCAJO CASTRO, no caben tampoco aquí falsos moralismos en la cuestión de control de los partidos, y que ciertos elementos de corrupción política o administrativa inevitablemente sobrevivirán a cualquier regulación normativa, por lo que no cabe depositar en las normas legales todas las esperanzas de una solución satisfactoria. $^{22}$ En todo caso, lo cierto es que tampoco cabe renunciar a la mejora de la regulación existente. ${ }^{23}$

\footnotetext{
${ }^{21}$ CUÑADO AUSIN, G. Op. Cit. Pp. 164-167.

22 CASCAJO CASTRO, J. L. "Controles sobre los Partidos Políticos". In: GONZÁLEZ ENCINAR, J. J. (coord.): Derecho de Partidos. Espasa-Calpe, Madrid, 1992. Pp. 178-180.

${ }^{23}$ Aunque no ofrezca soluciones perfectas, se puede acceder a algunos datos de medidas tomadas en países de América Latina, véase ZOVATTO, D.: Dinero y Política en América Latina: Una Visión Comparada. International IDEA, Lima, 2003. Pp. 59-63.
} 
En este sentido, cabe recordar que la solución no es tanto importar modelos del Derecho Comparado, sino mejorar el existente, partiendo de las particularidades de cada sistema político y electoral. Debido a esto, no podemos hablar de un modelo perfecto o que maximice resultados, pero sí se puede afirmar que, mientras España no se enfrente normativamente a este problema de forma más adecuada, no existirá solución a corto o medio plazo para las serias disfunciones del sistema. ${ }^{24}$

\subsection{La discusión sobre la competencia del Tribunal de Cuentas y su comparación con la ley orgánica 8/2007}

Antes de la aprobación de la Ley Orgánica 8/2007 se discutía en la doctrina la propia legitimidad del Tribunal de Cuentas para ejercer su función fiscalizadora sobre las formaciones políticas. Aunque estuviera expresamente prevista dicha competencia en la anterior Ley Orgánica 3/1987, lo que suscitaba la cuestión era la comparación de esta disposición con otros artículos tanto de la Constitución como de la Ley Orgánica 2/1982, del Tribunal de Cuentas (en adelante LOTCu) y la Ley $7 / 1988$, del funcionamiento del Tribunal de Cuentas (en adelante LFTCu).

Cabe subrayar que cuando se aprobó la LOREG, parecía clara la decisión de fiscalizar en este aspecto a los partidos, y que por la sistemática existente, dicha competencia debería ser de las Juntas Electorales y del Tribunal de Cuentas, debiendo este pronunciarse sobre la rendición de cuentas de los partidos dentro del plazo previsto en el art. 133.4. Este entendimiento del sistema pasó a la Ley Orgánica 3/1987, y en dicho momento no hubo ningún cuestionamiento de la competencia del Tribunal de Cuentas en el ejercicio de dicha función. ${ }^{25}$ Dado que dicho Tribunal es el legitimado para efectuar la fiscalización de todo el sector público ${ }^{26}$, aparte del Estado (art. 136 de la

\footnotetext{
${ }^{24}$ Aquí cabe una mención al trabajo de NASSMACHER, que considera que la filosofía básica de los informes sobre ingresos y gastos de los partidos consiste en hacer que las cuentas partidistas sean sujeto de debate público. (In: NASSMACHER, K-H. "Monitoring, Control..." Pp. 148).

${ }^{25}$ TORRES FERNANDEZ, J. J. Op. Cit. Pp. 1868.

${ }^{26}$ Según NASSMACHER, cuando se atribuye a una agencia del Gobierno o departamento el poder de fiscalización de los partidos, además de dotarle de competencia, también se deben definir procedimientos de elección de sus miembros, garantizando la independencia de dicho órgano, definir potestades específicas, interpretaciones de leyes relevantes y verificación y
} 
Constitución $)^{27}$ a él también competía en control sobre las personas físicas y jurídicas que recibieran subvenciones, créditos, avales $u$ otras ayudas del Estado, no importando si estas eran privadas o públicas, según lo dispuesto en el art. 4.2 de la LOTCu ${ }^{28}$, reflejado en el art. 1.b de la LFTCu. ${ }^{29}$ La decisión sobre la naturaleza jurídica de los que se someten a la fiscalización del Tribunal está clara en estas disposiciones y, a priori, no debería despertar discusiones a este respeto. Sin embargo, aunque existe un gran número de autores que consideran que el Tribunal de Cuentas está perfectamente legitimado para ejecutar la tarea de fiscalización ${ }^{30}$, todavía subsiste una cierta corriente minoritaria dentro de la doctrina que cuestiona esta competencia.

Los argumentos a favor son bastante similares, y se basan obviamente en las normativas que otorgan dicha competencia al Tribunal prevalece, aunque no se restrinja a los recursos públicos que reciban los partidos políticos, lo que no anula dicha competencia. ${ }^{31}$ Por lo demás, a partir del momento en que los partidos, considerados como entes privados, reciben

publicación de informaciones que indiquen una supuesta violación de la legislación, especificar las actividades de la agencia como informador y aplicador de sanciones, tipificar las infracciones y definir el sistema de recursos contra los pronunciamientos de la agencia. (In: NASSMACHER, K-H. "Monitoring, Control..." Pp. 144). Bajo dicho punto de vista, aunque haya fallos legislativos en algunos puntos citados por el autor, se entiende que en España con el procedimiento de elección de los miembros, se asegura una cierta independencia del Tribunal. Aún, reforzando la importancia de la independencia del órgano fiscalizador, cfr. VALLÉS VIVES, F. "Control Externo del Gasto Público y Estado Constitucional". Tesis Doctoral presentada en la UAB, Bellaterra, septiembre de 2001. In: <<www.tdx.cbuc.es/TESISa_UAB/AVAILABLE/TDX-1118102-184233//fvv1de3.pdf>> Acceso en 20.09.09. Pp. 314-366.

${ }^{27}$ Lo dispuesto en el artículo es: "Artículo 136. 1. El Tribunal de Cuentas es el supremo órgano fiscalizador de las cuentas y de la gestión económica del Estado, así como del sector público".

28 "Art. 4.2. Al Tribunal de Cuentas corresponde la fiscalización de las subvenciones, créditos, avales u otras ayudas del sector público percibidas por personas físicas o jurídicas".

29 "Artículo 1. De acuerdo con lo preceptuado en la Ley 2/1982, Orgánica del Tribunal de Cuentas, la presente Ley tiene como objeto: (...) b. La regulación de los procedimientos, mediante los cuales el Tribunal de Cuentas lleva a cabo la función de fiscalización externa de la actividad económico-financiera del sector público, así como de las subvenciones, créditos, avales y otras ayudas que, procedentes del mismo, sean concedidas a personas físicas 0 jurídicas, públicas o privadas".

${ }_{30}$ Como ejemplo de dicha doctrina, cfr. MARIN ARIAS, M. "Arts. 121 al 134". In: CAZORLA PRIETO, L. M. (dir.): Comentarios a la Ley Orgánica del Régimen Electoral General. Ed. Civitas, Madrid, 1986. Pp. 1090; GARCIA GUERRERO, J. L. "Algunas Cuestiones sobre la Constitucionalización de los Partidos Políticos". In: Revista de Estudios Políticos (nueva época), no 70, oct/dic, 1990. Pp. 183; ALVAREZ CONDE en AA.VV. "Debates". In: La Financiación de los Partidos Políticos. Cuadernos y Debates, no 47, Centro de Estudios Constitucionales, Madrid, 1994. Pp. 104-105, TORRES FERNANDEZ, J. J. Op. Cit. Pp. 1870; y MARTíNEZ CUEVAS, M. D.: El Régimen Jurídico de los Partidos Políticos. ed. Marcial Pons, Madrid, 2006. Pp. 140.

${ }^{31}$ CORTÉS BURETA, P. "Los Recursos Económicos de los Partidos Políticos: Una Perspectiva Histórica de su Regulación". In: Revista Aragonesa de Administración Pública. no 22, junio, 2003. Pp. 231. 
subvenciones públicas, también adquieren la obligación de someterse a la fiscalización ante el Tribunal de Cuentas. ${ }^{32}$ Junto a ello se subraya lo dispuesto en el art. 136 de la Constitución Española, que vuelve obligatoria la fiscalización por referido Tribunal del sector público. Acaba por volver a la situación anterior, por más que los partidos sean entes privados, ejercen funciones públicas contando con subvenciones del erario para cumplirlas. Dentro de esta sistemática, en el caso de financiación privada de los partidos, la obligatoriedad constitucional de fiscalización por el Tribunal de Cuentas no existiría, lo que no significaría que el legislador no pudiera establecerla a través de ley. De todos modos, no se encontraría obstáculos constitucionales. ${ }^{33}$

Desde una postura crítica, GÓMEZ SÁNCHEZ entiende que no es común que se otorgue a órganos como el Tribunal de Cuentas la función fiscalizadora, y que este debería intervenir solamente en caso de conflicto, o antes de las elecciones, o facultativamente para otros asuntos económicos de los partidos. Fuera de estas hipótesis, la fiscalización debería ser realizada por una auditoría externa con una entidad privada. Junto a ello, la atribución de la competencia al Tribunal es técnicamente deficiente, porque no debería haberse producido a través de la Ley Orgánica 3/1987. ${ }^{34}$ Por su parte, GONZÁLEZVARAS entiende que el Tribunal de Cuentas no ofrece las garantías necesarias para realizar esta función fiscalizadora de los partidos políticos, a la vez que sólo le compete la fiscalización de fondos públicos, y como los partidos políticos son jurídicamente considerados entes privados, a partir del momento de la transferencia de la subvención estatal, dicho recurso deja de tener naturaleza pública. ${ }^{35}$

En todo caso, lo cierto es que, con la aprobación de la Ley Orgánica 8/2007 no quedan dudas sobre la configuración del Tribunal de Cuentas como

\footnotetext{
32 HOLGAdo GONZÁleZ, M.: La Financiación de los Partidos Políticos en España. Tirant lo Blanch, Valencia, 2003.224-226. Esta posición es contraria a la de GARCÍA CRESPO, que entiende que los partidos políticos no son entes públicos, y que no deberían someterse a esta fiscalización. (In: AA. VV.: "Debates". In: La Financiación... Pp. 96-97.

33 En este sentido, cfr. AZPITARTE SÁNCHEZ, M. "La Dimensión Constitucional del Procedimiento Electoral”. In: Teoría y Realidad Constitucional. № 11-12, 1ำ semestre. UNED, Madrid, 2002-2003. Pp. 438.

${ }^{34}$ GÓMEZ SANCHEZ, Y.: El Tribunal de Cuentas: El Control Económico - Financiero Externo en el Ordenamiento Constitucional Español. Universidad Nacional de Educación a Distancia. Ed. Marcial Pons, Madrid, 2001, Pp. 226-228.

${ }^{35}$ GONZÁleZ-VARAS, S.: La Financiación de los Partidos Políticos. Dykinson, Madrid, 1995. Pp. 137-138.
} 
el órgano fiscalizador de las finanzas de las formaciones políticas, pues aunque este sugiriera indirectamente en la moción de su autoría enviada a las Cortes Generales para la reforma de la LOFPP que podría continuar realizando la tarea, pero sin que le fuera atribuida la responsabilidad de sancionar a las organizaciones que no observaran las disposiciones legales, la competencia se mantuvo, siendo ampliada justamente para la aplicación de sanciones. Lo que sí es cierto es que se pueden interpretar extensivamente los arts.4.2 de la LOTCu y 1.b de la LFTCu, pero lo ideal sería que se alteraran dichas normas, en consonancia con la Ley Orgánica 8/2007, algo que debería haberse realizado al aprobar esta.

Es de resaltar que, por lo dispuesto en el art. 16 de la Ley Orgánica 8/2007, no hay ninguna incompatibilidad entre la competencia atribuida al Tribunal de Cuentas y la de los órganos fiscalizadores de las Comunidades Autónomas, prevista en los Estatutos de Autonomía.

\subsection{Análisis de los datos constantes en los informes emitidos por el Tribunal de Cuentas}

Uno de los elementos con que se pueda confirmar la falta de efectividad de la normativa sobre financiación de las formaciones políticas - no importando si esta es electoral u ordinaria - son los informes emitidos por el Tribunal de Cuentas, fruto de su labor fiscalizadora sobre estas organizaciones. ${ }^{36}$

Debido a sus diferentes regulaciones, la fiscalización electoral tiene un recorrido histórico más largo que la ordinaria, lo que no la hizo mejor que esta última, considerando que los primeros informes sobre la fiscalización electoral de los partidos reflejan una labor incompleta, carente en muchos aspectos de transparencia y publicidad. Tampoco añadirán mucha más credibilidad los

\footnotetext{
${ }^{36}$ MORAL MORAL entiende que hay dos tipos de actuaciones fiscalizadoras del Tribunal de Cuentas, una que sería el control externo de la actividad económico-financiera anual de los partidos políticos, en que el Tribunal debe pronunciarse sobre la regularidad de esta actividad en el plazo legal; y la otra que fiscaliza la actividad económico-financiera derivada de procesos electorales, que requiere del Tribunal no solamente su pronunciamiento sobre la regularidad de la misma, sino que también le concede la facultad de proponer la no adjudicación o reducción de la subvención pública destinada a la organización afectada en caso de irregularidades en la contabilidad o el incumplimiento de reglas vinculadas al ingreso y gasto electoral. (In: MORAL MORAL, M. C. "El Control de la Financiación de los Partidos Políticos". In: Revista Española de Control Externo. v. 1, № 3, Madrid, 1999. Pp. 144).
} 
primeros informes de fiscalización de las cuentas ordinarias, ya que fueron innumerables las dificultades con que tuvo que enfrentar el Tribunal de Cuentas, estando ambas fiscalizaciones sometidas a un proceso normativo de constante perfeccionamiento hasta el día de hoy.

Antes de exponer el análisis de los informes, es conveniente fijar determinados conceptos utilizados en la exposición. Según la LOREG, en el art. 121 está dispuesto que la contabilidad de los partidos políticos deberá ajustarse a los principios generales del Plan General de Contabilidad, y en la Ley Orgánica $3 / 1987$, art. 10 , se precisa que se deberán seguir los principios de contabilidad general aceptados. A partir de ello, el Tribunal de Cuentas aplicaba el Plan General de Contabilidad, con sus conceptos y principios. Aunque en la Ley Orgánica 8/2007 se haga mención a un plan especifico de contabilidad para los partidos, que deberá ser aprobado en un futuro tanto por el Tribunal de Cuentas como por la Comisión mixta del Congreso-Senado para las relaciones con el Tribunal, no parece probable que se produzca una modificación significativa de los criterios contables hasta ahora utilizados, y más aún estando vigente el Plan General de Contabilidad 2007, elaborado conforme el Plan Internacional de Contabilidad. Por ello los elementos contenidos en el Plan General de Contabilidad probablemente pueden ser adoptados tanto para el análisis de los informes ya existentes, como también para los futuros.

El Tribunal de Cuentas siempre requiere de las formaciones políticas un balance completo de su situación económico-financiera. Este se puede considerar como un estado contable donde queda reflejada la situación patrimonial de su titular, que corresponde a un determinado período, sintetizando las informaciones económico-financieras de los partidos. ${ }^{37} \mathrm{El}$ patrimonio neto de los partidos está compuesto por sus fondos propios, las subvenciones y las donaciones y legados recibidos. Las subvenciones, donaciones y legados deberán ser entendidos como el conjunto de recursos financieros y otros bienes transferidos a los partidos, que fueron obtenidos por

\footnotetext{
${ }^{37}$ Este concepto se toma de la definición dada por RODRÍGUEZ LÓPEZ, considerando ya el PGC de 2007, adaptado al PGC internacional, regulado por el RC 1514/07, y que entró en vigencia en 01/01/08. (cfr. RODRIGUEZ LOPEZ, Á. "Subvenciones, Donaciones y Legados a los Partidos Políticos desde la Perspectiva del PGC 2007". In: Partida Doble. no 221, mayo, Madrid, 2010. Pp. 31). Se entiende que este Plan General todavía no haya sido aplicado por el Tribunal, considerando que su último informe es del ejercicio de 2006.
} 
otros entes externos, sean estos públicos o privados, personas físicas o jurídicas. $^{38}$

\subsubsection{Informes sobre la financiación electoral}

En un primer momento, la fiscalización prevista sobre las cuentas electorales preveía un control externo realizado por las Juntas Electorales, en virtud del art. 45 del Decreto-Ley 20/1977, y siempre en el supuesto de las elecciones generales. Aunque hubiera una obligación de publicidad de esta contabilidad, dado el art. 48.3, la Junta Electoral Central solamente publicó los informes referentes a las elecciones de 1977. La fiscalización de las elecciones de 1979 y 1982 no fueron objeto de publicación debido a la resolución de la JEC de 13/07/78, que determinaba la publicación solamente del montante concedido por el Estado a las formaciones políticas, lo recaudado por cada partido y la proporción que había sido destinada a la presentación de candidatos y a la propaganda electoral. ${ }^{39}$ Ya en 1985 se produjo la aprobación de la LOREG, que acabó por transferir al Tribunal de Cuentas la función de fiscalizar la financiación de los partidos, lo que no evitó que la tarea haya sido cumplida con bastantes deficiencias. De hecho, puede constatarse que en algunos casos en el periodo de 1977 a 1982, la información disponible se limitó a los presupuestos electorales declarados por los propios partidos a los medios, ya que ni siquiera se puede afirmar si la labor fiscalizadora realizada por la Junta Electoral Central fue correcta por la falta de medios técnicos disponibles, y tampoco se puede excluir la hipótesis de una falta de voluntad "política" en realizar esta fiscalización. ${ }^{40}$

En el presente trabajo se ha realizado el análisis de los 3 últimos informes sobre las cuentas electorales, o sea, la fiscalización de las elecciones

\footnotetext{
38 Concepto basado en las definiciones dispuestas en RODRIGUEZ LOPEZ, Á. "Subvenciones..." Pp. 33.

${ }^{39}$ CASTILLO, P. del. "La Financiación de los Partidos Políticos en España". In: CASTILLO, P. del; ZOVATTO G., D. (eds.): La Financiación de la Política en Iberoamérica. $1^{\circ}$ ed. IIDH/CAPEL, San José, $1998 . \quad$ Disponible en: <<http://www.iidh.ed.cr/comunidades/redelectoral/docs/red_publinea/indice-financiacion.htm>> Acceso en 17 de junio de 2009. Pp. 38.

${ }^{40}$ GARCIA VIÑUELA, E.; ARTÉS CASELLES, J. "La Financiación de las Elecciones Generales en España, 1977-2000". In: Documentos - Universidad Complutense de Madrid. Instituto de Estudios Fiscales, no 24, Madrid, 2004. Pp. 6.
} 
de 2000, 2004 y $2008 .{ }^{41}$ Las cuentas referentes a las elecciones realizadas en el 20 de noviembre de 2011 todavía no han sido analizadas, ya que el plazo que las organizaciones están obligadas a rendir cuentas (entre 100 y 125 días posteriores a la celebración del pleito) se agota en el período comprendido entre 28 de febrero a 24 de marzo de $2012 .^{42}$

Cabe considerar que aunque se trate de los tres últimos informes, existen deficiencias que ya podrían haber sido superadas, pero que chocan con una reglamentación insuficiente que se alía con la insistencia en no cumplir con parámetros básicos de contabilidad por parte de los partidos, lo que obviamente afecta sustancialmente la actividad del Tribunal de Cuentas. Si es posible subrayar que el Tribunal intenta verdaderamente llevar a cabo una fiscalización completa, intentando suplir deficiencias normativas o directamente las lagunas, sin afectar a la separación de poderes existente.

El primer dato que cabe subrayar es el relativo al cumplimiento del plazo de entrega de las cuentas por parte de los partidos políticos (aquellos que hayan alcanzado los requisitos para acceder a la subvención pública o que hayan solicitado el adelanto de $30 \%$ antes de las elecciones) cuando se trata de las cuentas electorales. Considerando que las formaciones políticas tienen entre 100 a 125 días para entregar la rendición de cuentas, además de ser un plazo razonable, el motivo principal para cumplir dicho plazo es la regla de la liberación del $90 \%$ del montante debido al partido a titulo de subvención pública, como está dispuesto en el art. 133 de la LOREG. Sin embargo, cabe recordar que la observancia del término concedido por la ley no significa en absoluto un cierto nivel de calidad en las cuentas presentadas. Por su parte, el plazo de 200 días posteriores a las elecciones ${ }^{43}$ para que el Tribunal se pronuncie sobre las cuentas no funciona en la práctica, ya que el órgano no tiene una estructura que le permita cumplirlo, y dado también que las cuentas

\footnotetext{
${ }^{41}$ Por dificultades técnicas, no fue posible acceder a los demás informes emitidos por el Tribunal.

${ }^{42}$ Las condiciones generales de la fiscalización de las mencionadas cuentas constan expresamente en el Acuerdo del Pleno del Tribunal de Cuentas para la fiscalización de la contabilidad de las elecciones a las Cortes Generales de 2011, aprobado en 27/10/2011.

${ }^{43}$ Conforme art. 134.2 de la LOREG. Hay que considerar que las formaciones políticas tienen entre 100 y 125 días posteriores a las elecciones para entregar al Tribunal su rendición de cuentas, o sea, quedarían únicamente 75 días de plazo en la mayoría de los supuestos para el pronunciamiento del Tribunal sobre estas mismas cuentas, y aun considerando que estas estuvieran perfectamente elaboradas, un órgano con tantas competencias como es el Tribunal de Cuentas jamás podría ejercer sus funciones en un plazo tan exiguo.
} 
muchas veces poseen significativas deficiencias, obligando al ente fiscalizador a solicitar informaciones a terceros - que raramente las conceden - y también a dirigirse a las sedes de los partidos en búsqueda de aclaraciones. Sin embargo, como también se verá en los informes sobre las cuentas anuales de las formaciones políticas, el Tribunal de Cuentas no cuenta con facultades de investigación, lo que además de imposibilitar la comprobación de la veracidad de algunos datos aportados por las organizaciones, acaba también por dilatar este plazo descrito en la LOREG, ya de por sí solo de casi imposible cumplimiento.

\section{a) Elecciones de 2000}

El informe referente a las cuentas electorales de $2000^{44}$ - realizadas el 12 de marzo - con el informe por el Tribunal de Cuentas de 30 de noviembre del mismo año, fue aprobado por la Comisión mixta del Congreso-Senado en 19 de junio de 2001. En este informe, fueron fiscalizadas 19 formaciones políticas $^{45}$, siendo que la Unió Valenciana también entregó sus cuentas, aunque no estuviera obligada a hacerlo.

El Tribunal destacó que hubo una correcta presentación de documentos en general, con cuantías comprobadas por la documentación justificativa aportada. También se realizó la identificación del origen de los recursos, de los donantes y del cumplimiento del límite máximo de cuantías y aportaciones.

\footnotetext{
${ }^{44}$ GARCÍA VIÑUELA y ARTÉS CASELLES afirman que en el informe de estas elecciones quedó claro que el proceso electoral ya no es un problema para los grandes partidos, que fueron los mayores privilegiados de la reforma del sistema de financiación realizada en los años 90 . Pero junto a ello también se pueden incluir a los partidos regionales pequeños que coinciden ideológicamente con gran partido de nivel nacional, pues la coalición acaba siendo la fórmula para presentarse a las elecciones. Los autores también destacan una caída en el gasto electoral en términos reales, reflejo de las limitaciones introducidas en la ley electoral en 1994. Otro hecho que llamó la atención de los autores es el volumen de las subvenciones públicas, que llegó alrededor del 95\% de los gastos electorales, lo que significa que se sanearon las finanzas de los partidos, transfiriendo estos gastos a los presupuestos públicos. (In: GARCIA VIÑUELA, E.; ARTÉS CASELLES, J. "La Financiación de las Elecciones..." Pp. 19-22).

${ }^{45}$ Fueron fiscalizados: PP - Partido Popular, PSOE - Partido Socialista Obrero Español, IU Izquierda Unida, PSC - Partit dels Socialistes de Catalunya, CiU - Convergencia i Unió, PNV Partido Nacional Vasco, BNG - Bloque Nacionalista Galego, CC - Coalición Canaria, PA Partido Andalucista, ERC -Esquerra Republicana de Catalunya, UNP-PP: Unión del Pueblo Navarro en coalición con el Partido Popular, IC - Iniciativa per Catalunya - Verds, EA - Eusko Alkartasuna, CA - Chunta Aragonesista, Partido Popular en coalición con Unión del Pueblo Melillense, Entesa Catalana del Progrés, Partido Independiente de Lanzarote, Coalición Electoral Coalición Canaria - Agrupación Herreña de Independientes y Partido Aragonés.
} 
Sobre los recursos propios de los partidos, el Tribunal menciona que, debido a la falta de regulación en la LOREG y la falta de armonización con la LOFPP (1987) sobre los límites máximos, la fiscalización es incompleta, basándose tan solo en las normas de la LOREG. Sobre las prohibiciones de determinadas aportaciones, los partidos acabaron por respetarlas, pero la mayoría de las entidades y empresas que facturaron valores superiores a 1.000 .000 de pesetas a cada partido no contestaron a las solicitudes de informaciones complementarias.

Para algunas formaciones políticas se sugirió la reducción de las subvenciones debidas por la verificación de gastos en emisoras de radiodifusión terrestres no permitidas en la LOREG. Hubo casos en que se sobrepasó el límite de gastos, pero que en ninguno el montante alcanzó el 1\% del límite establecido.

Ya considerando cada organización política, se constata que el Partido Popular declaró recursos de 2.688.933.738 pesetas (16.160.817,24 euros). Debido a las imprecisiones en los datos sobre gastos ordinarios y cálculo de intereses en que no fueron aplicados los criterios del Tribunal, se sugirió la reducción de la subvención en 88.000 pesetas (528,89 euros). Lo que se destaca aquí es el montante de gastos que no fueron justificados por los respectivos proveedores, sumando 30.906 .941 de pesetas (185.754,46 euros). Se trata de una cuantía significativa si se considera que corresponden a gastos electorales. ${ }^{46}$

Izquierda Unida declaró unos recursos de 1.012.748.073 pesetas (6.086.738,50 euros), pero por la confusión entre gastos electorales y ordinarios, algo que se repetía en cuentas anteriores, no fue posible realizar una fiscalización fiable. Hubo también aportaciones privadas parcialmente identificadas, y pago de gastos electorales con fondos ordinarios, lo que está prohibido por el art. 125, LOREG. ${ }^{47}$ Debido a ello, se sugirió la reducción de la subvención pública al partido en 35.000 pesetas (210,35 euros).

El Partit dels Socialistes de Catalunya declaró recursos de 425.478.975 pesetas (2.557.180,14 euros), existiendo pagos de gastos electorales con fondos ordinarios y flujo de recursos fuera de las cuentas electorales. Sin

\footnotetext{
${ }^{46}$ Cfr. Pp. 86 del suplemento del BOE de 27 de junio de 2001.

${ }^{47}$ Dichos gastos fueron en el valor de 2.295 .593 pesetas (13.796,79 euros).
} 
embargo, no hubo sugerencia de reducción. Convergencia i Unió declaró recursos de 449.723 .316 pesetas (2.702.891,56 euros), y fue detectado un exceso en el límite de gastos causado por errores en el cálculo de intereses de un préstamo realizado. Pero esto no motivó una sugerencia de reducción de subvenciones por parte del Tribunal. El Partido Nacionalista Vasco hizo públicos unos recursos de 184.014 .058 pesetas (1.105.946,76 euros), existiendo pagos efectuados fuera del plazo, lo que contraría el art. 125.3 de la LOREG. No obstante, no hubo sugerencia de reducción de subvenciones.

El Bloque Nacionalista Galego declaró unos recursos de 126.963.312 pesetas (763.064,87 euros), existiendo también un exceso en el límite de gastos calculado por la organización. Esto derivaba de no haber conseguido formar un grupo parlamentario, lo que hizo que los envíos de sobres y papeletas fueran considerados como gastos ordinarios. Debido a ello, no hubo sugerencia de reducción de subvenciones. Aquí vemos un ejemplo de cómo una mejor regulación de los gastos de este tipo de envío podría colaborar incluso para una posible racionalización en los costes de las campañas. Además, con la disparidad entre la legislación sobre financiación electoral y ordinaria, situaciones de esta naturaleza se repiten constantemente, sin que haya mayores consecuencias.

Unión del Pueblo Navarro en coalición con el PP declaró unos recursos de 73.409 .077 pesetas (411.197,43 euros) con un exceso considerado irrelevante por el Tribunal en gastos de prensa y radio, pero que terminó por motivar una sugerencia de reducción de las subvenciones, lo que demuestra una diferencia entre esta situación y la descrita en el caso del BNG, si bien el exceso verificado en las cuentas de este último fue en virtud de la clasificación del envío de papeletas y sobres como gasto ordinario, fruto de la no formación de grupo parlamentario propio. ${ }^{48}$ En el caso de Iniciativa per Catalunya - Verds, los datos eran incorrectos, produciéndose también fallos en la identificación de los donantes personas físicas. Sin embargo, no fue suficiente para motivar una sugerencia de reducción de los valores de subvención.

El Partido Independiente de Lanzarote fue uno de los partidos que no respetó el plazo de entrega de la rendición de cuentas. Declaró unos recursos

\footnotetext{
${ }^{48}$ Cfr. Pp. 95 del suplemento del BOE de 27 de junio de 2001.
} 
de 3.500 .000 pesetas (21.035,42 euros), y no observó la obligatoriedad de la apertura de una cuenta bancaria específica para los gastos electorales, contrariando el art. 124 de la LOREG. También fueron detectadas adquisiciones de espacios de publicidad electoral en emisoras de televisión local por ondas terrestres, algo que está totalmente prohibido por la legislación en vigor. Así, se produjo una sugerencia de reducción de la subvención a la que tenía derecho de 20.000 pesetas (120,20 euros). ${ }^{49}$

Otro partido que no observó el plazo de entrega de las cuentas al Tribunal de Cuentas fue el Partido Aragonés, que declaró unos recursos de 44.133.621 pesetas (265.248,40 euros). En las cuentas, fueron apuntadas deficiencias como gastos mal justificados y, como no lograron escaños en aquellas elecciones, se previó la devolución del adelanto que le se había concedido de 5.549 .947 pesetas (33.355,85 euros).

A la vez, El Partido Socialista Obrero Español (con unos recursos de 2.240.886.136 pesetas - 13.467.996,92 euros), Coalición Canaria (con unos recursos de 107.942 .059 pesetas - $648.744,84$ euros), Partido Andalucista (con recursos de 8.861.139 pesetas - 53.256,51 euros), Esquerra Republicana de Catalunya (con recursos de 69.205 .516 pesetas $-415.933,52$ euros), Eusko Alkartasuna (total recursos de 92.440 .464 pesetas - 555.578,37 euros), Chunta Aragonesista (recursos de 27.251.008 pesetas - 163.781,85 euros), Partido Popular en coalición con Unión del Pueblo Melillense (recursos de 2.972.985 pesetas - 17.868,00 euros), Entesa Catalana de Progrés (recursos de 335.545.637 pesetas - 2.016.669, 89 euros) y Coalición Electoral Coalición Canaria - Agrupación Herreña de Independientes (recursos de 360.913 pesetas - 2.169,13 euros) presentaron cuentas que no culminaron en la denuncia de irregularidades por parte del Tribunal, lo que no significa en absoluto que las cuentas no contaran con fallos en el cumplimiento de la legislación vigente, como es el caso del PSOE, que en sus cuentas tenía cuatro proveedores por prestación de servicios o adquisición de bienes, con una facturación total de 6.097 .365 pesetas $(36.645,90$ euros), y que no han informado al Tribunal, incumpliendo lo dispuesto en el art. 133 de la LOREG. ${ }^{50}$ Sin embargo, esto no ha motivado ninguna propuesta por parte del Tribunal

\footnotetext{
${ }^{49}$ Informaciones constantes en la pp. 105 del suplemento del BOE de 27 de junio de 2001.

${ }^{50}$ Cfr. Pp. 88 del suplemento del BOE de 27 de junio de 2001.
} 
que pudiera afectar al valor de las subvenciones públicas debidas a dicho partido, y la razón es sencilla: no había previsión legal que autorizara cualquier propuesta en este sentido.

Es digno de mención la no inclusión de los datos contables de Unió Valenciana, que con buena voluntad entregó sus cuentas al Tribunal de Cuentas. No por el hecho de que el partido no tuviera la obligación de hacerlo el Tribunal estaba impedido de incluir dichas informaciones en el resultado de la fiscalización. Si toda la doctrina - e incluso el propio Tribunal - reivindica la ampliación de la obligación de rendir cuentas a todas las formaciones políticas, no parece razonable eludir oportunidades como esta, por excepcionales que sean.

\section{b) Elecciones de 2004}

El siguiente informe es el correspondiente a las elecciones de 2004, el cual se realizó el 14 de marzo de 2004, con su aprobación por el Pleno del Tribunal el 26 de mayo de 2005, y por la Comisión Mixta del Congreso-Senado el 28 de junio del mismo año. Hubo una reducción en el número de partidos fiscalizados, que fueron $16 .{ }^{51}$ Además de eso, el Tribunal destaca la celebración de las elecciones autonómicas en Andalucía en 2000, y que en aquel año la competencia para fiscalizar a los partidos andaluces todavía era del Tribunal de Cuentas. Sin embargo, ya en el 2004, la competencia para fiscalizar las cuentas estaba transferida a la Cámara de Cuentas de Andalucía.

De un modo general, el Tribunal destaca el cumplimiento del límite global de gastos y que no todas las entidades y empresas enviaron las informaciones solicitadas por este. Las sugerencias de reducción de las subvenciones fueron motivadas principalmente por excesos de gastos en

\footnotetext{
${ }^{51}$ Los partidos fiscalizados fueron: PSOE - Partido Socialista Obrero Español, PP - Partido Popular, PSC - Partit dels Socialistes de Catalunya, CiU - Convergencia i Unió, ERC Esquerra Republicana de Catalunya, IU - Izquierda Unida, Eusko Alderdi Jetzalea - PNV, BNG - Bloque Nacionalista Galego, CC - Coalición Canaria, UNP-PP: Unión del Pueblo Navarro en coalición con el Partido Popular, IC - Iniciativa per Catalunya - Verds - Esquerra Unida i Alternativa, Esquerra Unida País Valenciá y I. Republicana: Entesa, CA - Chunta Aragonesista, Eusko Alkartasuna, Nafarroa Bai y Entesa Catalana del Progrés.
} 
prensa y radio, y el Tribunal aplicó una tabla progresiva de coeficientes para determinar el porcentual de reducción sugerido. ${ }^{52}$

El Partido Socialista Obrero Español (con unos recursos de 15.670.489,53 euros), Partido Popular (recursos de 18.457.802,20 euros), Convergencia i Unió (recursos de 3.144.214,42), Esquerra Republicana de Catalunya (recursos de 1.201.314,49 euros), EAJ-PNV (recursos de 969.767,42 euros), Coalición Canaria (recursos de 683.344,38 euros), Bloque Nacionalista Galego (recursos de 829.314,42 euros), Esquerra Unida País Valenciá (recursos de 93.163,51 euros) y Chunta Aragonesista (recursos de $271.428,06$ euros) presentaron cuentas sin irregularidades.

A la vez, el Partit dels Socialistes de Catalunya declaró unos recursos de 2.727.395,81 euros, y sus cuentas carecían de informaciones como la identificación de las donaciones de personas físicas, además de existir confusión entre las contabilidades electorales y ordinarias, como se detectó en las donaciones. Hubo también pagos fuera de la cuenta electoral obligatoria por el art. 125 de la LOREG, y pagos fuera del plazo establecido por la ley. ${ }^{53}$ Con todo, no hubo sugerencia de reducción de subvenciones por parte del Tribunal.

En las cuentas de Izquierda Unida - que declaró unos recursos de 6.729.257,48 euros - había problemas en la identificación de donaciones de personas físicas, como también gastos electorales pagados con recursos ordinarios. ${ }^{54}$ Esto mismo se detectó a Iniciativa per Catalunya - Verds y Esquerra Unida i Alternativa (recursos de 1.344.474,49 euros). Sin embargo, en ninguno de los dos casos se produjo una sugerencia para la reducción de subvenciones, muy probablemente debido a la falta de previsión legal para hacerlo.

\footnotetext{
${ }^{52}$ El Tribunal resalta que la aplicación de la tabla progresiva de coeficientes de penalización se realiza según el porcentaje que representa el exceso sobre cada uno de los límites de gastos autorizados en cada caso, siempre que el exceso haya alcanzado, al menos, el uno por ciento del límite establecido. (Cfr. Pp. 28802 del BOE no 197 de 18 de agosto de 2005).

${ }^{53}$ Por un valor de 323.109,25 euros, no siendo este un valor irrisorio. (Cfr. Pp. 28805 del BOE № 197 de 18 de agosto de 2005).

${ }^{54}$ Aquí el Tribunal destaca que había una insuficiencia de saldo de tesorería electoral, y a pesar de las deudas electorales pendientes, previo al cierre de la contabilidad electoral, han sido detectados diversos traspasos de fondos de la actividad electoral a las cuentas de contabilidad ordinaria, totalizando 341.974,63 euros los comprobados. (Cfr. Pp. 28807 del BOE no 197 de 18 de agosto de 2005). Esto verifica empíricamente que la separación entre actividad electoral y ordinaria es una ficción, y mucho más aun la separación de su régimen legal, que no contribuye en nada a facilitar el procedimiento de fiscalización.
} 
Unión del Pueblo Navarro en coalición con Partido Popular declaró unos recursos de 266.625,58 euros, y había superado el límite de gastos. De esta forma, se recomendó la reducción de la subvención a que tenía derecho en 2.200 euros.

Eusko Alkartasuna hizo públicos unos recursos de 667.044, 18 euros y poseía pagos fuera del plazo de la LOREG, aunque esto no motivó una sugerencia de reducción de subvenciones. Ya respecto a Nafarroa Bai (recursos de 176.382,42 euros), además de existir pagos fuera del plazo, había facturas sin justificación suficiente y una cantidad de 1.382 euros sin la indicación de su procedencia. Y con Entesa Catalana del Progrés (recursos de 2.844.999,00 euros), del mismo modo había pagos fuera del plazo, como también pagos de gastos electorales con recursos ordinarios. Con todo, en ninguno de los casos se produjo una sugerencia de reducción de subvenciones.

A partir de estos datos, puede constatarse en el informe una cantidad significativa de fallos por parte de los partidos, pero que no culminan en ningún tipo de propuesta por parte del Tribunal dirigida a las Cortes Generales, por la propia inexistencia de previsión legal. Además, se nota que muchos de dichos fallos son bastante evidentes ${ }^{55}$, y si fueron realizados por organizaciones partidistas complejas, no parece fruto de un desconocimiento de la legalidad vigente.

\section{c) Elecciones de 2008}

El último informe emitido por el Tribunal se refiere a las elecciones del 2008, realizadas el 9 de marzo. El informe fue aprobado por el Pleno del Tribunal el 26 de marzo de 2009, y por la Comisión mixta del Congreso-Senado el 27 de abril de 2010. Por las fechas, cabe destacar en primer lugar el tiempo que fue necesario para hacer públicas las informaciones referentes a este proceso electoral, lo que significa que los plazos previstos en los arts. $133 \mathrm{y}$ 134 de la LOREG no fueron observados.

\footnotetext{
${ }^{55}$ Como es el supuesto del no ingreso de valores concedidos a título de adelanto para cuentas bancarias específicas para gastos electorales hecha por el PSC. (Cfr. Pp. 28805 del BOE oㅡ 197 de 18 de agosto de 2005).
} 
En estas elecciones, el número de formaciones políticas fiscalizadas fue de 17, entre partidos fiscalizados para las elecciones al Congreso y otros para el Senado. ${ }^{56}$ Este dato es relevante si se considera que, aunque haya un sistema electoral en cierto modo favorece la llegada de formaciones regionalistas, su número es escaso, más aun si consideramos que 4 de estos 17 partidos han logrado escaño solamente en el Senado, no teniendo derecho a recibir subvenciones ordinarias por estos escaños.

Se destaca en el Informe la coincidencia de las elecciones generales con las de Andalucía y el cumplimiento por parte de todos los fiscalizados del plazo para la entrega de la rendición de cuentas.

El Bloque Nacionalista Galego (recursos de 852.447,84 euros), Coalición Canaria (recursos de 4.000,00 euros para elecciones al Senado), Convergencia i Unió (recursos de 3.516.607,90 euros), Esquerra Republicana de Catalunya (recursos de 1.614.676,18 euros), Partido Socialista Obrero Español (recursos de 19.007.264,78 euros), EAJ-PNV (recursos de 1.163.738,03 euros), Iniciativa per Catalunya - Verds (recursos de 1.626.225,32) y Unión del Pueblo Navarro en coalición con Partido Popular (recursos de 323.039,54 euros) presentaron cuentas sin irregularidades.

A la vez, Coalición Canaria - Partido Nacionalista Canario declararon recursos de 345.009,44 euros, y tuvieron problemas de facturación de terceros, lo que bajo las directrices del Tribunal, no motiva una sugerencia de reducción de subvenciones.

Eivissa i Formentera al Senat (recursos de $34.060,00$ euros) y Entesa Catalana de Progrés (recursos de 3.023.920,38 euros) tenían cuentas que identificaban pagos fuera del plazo que consta en la LOREG, y la última poseía pagos de gastos electorales pagados con recursos ingresados en cuentas ordinarias. ${ }^{57}$ Sin embargo, no hubo sugerencia de reducción de subvenciones.

\footnotetext{
${ }^{56}$ Los partidos fiscalizados en las elecciones al Congreso fueron: Bloque Nacionalista Galego, Coalición Canaria - Partido Nacionalista Canario, Convergencia i Unió, Esquerra Unida de Catalunya, Eusko Alderdi Jetzalea - Partido Nacionalista Vasco, Iniciativa per Catalunya Verds - Esquerra Unida i Alternativa, Izquierda Unida, Nafarroa Bai, Partido Popular, Partido Socialista Obrero Español, Partit dels Socialistes de Catalunya, Unión Progreso y Democracia y Unión del Pueblo Navarro en coalición con Partido Popular. Los partidos fiscalizados por las elecciones al Senado fueron: Coalición Canaria, Eivissa i Formentera al Senat, Entesa Catalana de Progrés y PSOE-EU-PSM-Verds.

57 Aunque el valor de $1.873,40$ euros pueda ser considerado pequeño, también se debe considerar el tamaño de dicha fuerza política, aun más si se compara con el valor total declarado por ella al Tribunal. (Cfr. Pp. 47791 del BOE o 134 de 2 de junio de 2010).
} 
Izquierda Unida declaró unos recursos de 6.771.633,12 euros, y sus cuentas presentaban problemas en la identificación de donaciones de personas físicas, incluso de los que se adhirieron a la campaña de recaudación de fondos entre afiliados y simpatizantes. ${ }^{58}$ Tampoco se produjo el pago integral de los gastos electorales por falta de recursos en tesorería, originando una deuda de 553.878,58 euros. Con todo, no hubo sugerencia de reducción de subvenciones. La existencia de esta deuda refleja la disminución en el número de escaños fruto del resultado de estas elecciones, acompañado de un proceso de decrecimiento de rendimiento electoral de esta organización con el pasar de los años, y la consecuencia más evidente de esto es la falta de recursos provocada por la disminución en el volumen de subvenciones recibidas. Se trata de una muestra más de la dependencia de los partidos de los recursos estatales, y de la impotencia de algunos de ellos frente a todo este sistema que tiende a mantener el status quo.

Nafarroa Bai declaró recursos de 319.243,11 euros, y se detectó el incumplimiento del límite de gastos en 94.292,67 euros. De esta manera, el Tribunal sugirió una reducción en el valor de su subvención, de 13.450,00 euros. La inobservancia del límite de gastos también se produjo en el Partido Popular (con unos recursos de 22.550.896,85 euros), que lo sobrepasó en 15.866,19 euros, pero que al sistema de tablas del Tribunal, no motivó ninguna sugerencia de reducción de subvenciones.

Partit dels Socialistes de Catalunya declaró unos recursos de 3.658.607,05 euros, produciéndose pagos de gastos electorales a través de la cuenta de recursos ordinarios. Algunos de ellos también estaban fuera del plazo. Dichas razones no fueron suficientes para motivar una reducción en las subvenciones.

La coalición PSOE-EU-PSM-VERDS declaró unos recursos de 22.502,05 euros, con cuentas indicando pagos de gastos electorales a través de la cuenta ordinaria, y también fuera del plazo por falta de recursos en

\footnotetext{
${ }^{58}$ No se puede afirmar que dicha fuerza política no haya presentado ninguna irregularidad en sus cuentas porque consta el valor de 5.049 euros que representan aportaciones de personas físicas, que están identificados únicamente con el nombre del donante, careciendo de las demás informaciones, como domicilio y número de $\mathrm{DNI}$, datos obligatorios por disposición del art. 126.1 de la LOREG. Sin embargo, el Tribunal no formuló ninguna propuesta de sanción. Aunque se trate de un valor relativamente pequeño en comparación tanto con el tamaño de la coalición, como con el valor total declarado, es patente la falta de voluntad para combatir este tipo de infracción. (Cfr. Pp. 47797, del BOE no 134 de 2 de junio de 2010).
} 
tesorería, lo que no fundamenta sugerencias de reducción de subvenciones por parte del Tribunal.

Finalmente, Unión Progreso y Democracia declaró recursos de $675.415,47$ euros, reflejados en cuentas que apuntaban problemas en la identificación de las donaciones de personas físicas, existiendo muchas donaciones de bajo valor, pero donde solamente se indicaba el nombre del donante. ${ }^{59}$ Existía también cierta confusión entre las cuentas electorales y ordinarias ya que, si bien el partido había abierto una cuenta específica para sus cuentas electorales, todos los recursos han sido canalizados, en un principio, a través de una cuenta ordinaria. ${ }^{60}$ Con todo, no hubo sugerencia de reducción de subvenciones.

Chunta Aragonesista (recursos de 313.161,24 euros) y Eusko Alkartasuna (recursos de 791.235,50 euros) no alcanzaron escaño, condición esta que les obliga a devolver el adelanto recibido anteriormente.

\section{d) Conclusiones del Tribunal de Cuentas}

En sus conclusiones, el Tribunal termina avalando algunas de las críticas de la doctrina, repitiendo muchas veces lo que ya había sugerido en informes anteriores. La impresión que se tiene es que, aun considerando la creciente mejora de la calidad de las cuentas presentadas con el paso de los años, las formaciones políticas acaban por reiterar errores ya apuntados por el Tribunal. Como no se produjeron cambios legislativos que eliminaran los problemas identificados en el procedimiento de fiscalización, tampoco se produjo un cambio en la actitud de los propios partidos o una señal de ello.

De hecho, en el último informe analizado, el Tribunal hace expresa mención a su Informe relativo a la modificación de la normativa sobre financiación y fiscalización de los partidos, que había remitido a las Cortes Generales. $^{61}$ Se trataba de las posibles modificaciones que dicho órgano fiscalizador había juzgado como necesarias para la mejora del resultado de la rendición de cuentas de los partidos en general.

\footnotetext{
${ }^{59}$ Se trata del mismo caso detectado en el mismo informe con Izquierda Unida.

${ }^{60}$ Cfr. Pp. 47803, del BOE no 134 de 2 de junio de 2010.

${ }^{61}$ Dichas sugerencias componen parte de la nota relativa a las propuestas de modificación de la financiación electoral, aprobada por el Pleno del Tribunal de Cuentas el 24 de junio de 2010.
} 
Una de estas propuestas consistía básicamente en la armonización de la normativa sobre financiación electoral general con la autonómica, que se justifica porque, según el Tribunal, hay diferencias que no están suficientemente explicadas en función de los rasgos específicos que posee cada proceso electoral. Dicha recomendación choca con algunas de las críticas doctrinales recogidas aquí en este trabajo, considerando que no se produjo una utilización fructífera de las potestades transferidas desde el gobierno central a las Comunidades Autónomas. ${ }^{62}$ En este caso, quizás lo más adecuado fuera mantener la legislación autonómica con sus diferencias, pero transferir la tarea fiscalizadora de este nivel a los órganos de control también de cada Comunidad Autónoma. Así seguramente habría menos situaciones de conflicto entre las competencias otorgadas y los intereses de cada ente.

El Tribunal también apunta la necesidad de uniformizar tanto la financiación electoral como la ordinaria, ante todo en cuestiones como el límite de las donaciones privadas, o el límite de gastos. Ya se ha subrayado que las diferencias entre las disposiciones de la LOREG y la LOFPP perjudican en gran medida la labor fiscalizadora del Tribunal. La ley electoral posee reglas más rígidas, y basta que el partido clasifique determinados gastos y donaciones como ordinarias para que el objetivo del límite - fijado justamente para asegurar la igualdad de oportunidades entre los competidores - sea eludido. De hecho, así queda claro en el análisis de los mencionados informes, pues en los tres se detecta la presencia de pagos de gastos electorales realizados con recursos ordinarios, o de algunos gastos que fueron clasificados como ordinarios, para así no sobrepasar el límite determinado.

Sobre la rendición de cuentas propiamente dicha, el Tribunal subraya importantes lagunas que afectan a la transparencia de la financiación. Así, lo que sugiere es que "se debería contemplar la potestad de solicitar, en función de criterios objetivos, las cuentas de las formaciones políticas que, no estando obligadas a presentarlas al no haber obtenido representación, han participado en la campaña electoral a fin de poder comprobar el cumplimiento de los requisitos y limitaciones previstos legalmente". ${ }^{63}$ Sobre estos aspectos, poco

\footnotetext{
${ }^{62}$ Sobre las críticas, véase punto 7.1 del cap. III de este trabajo.

${ }^{63} \mathrm{Cfr}$. nota aprobada en 24 de junio de 2010.
} 
cabe añadir, dado que han sido señalados constantemente por la doctrina, aun cuando tampoco hayan sido subsanados en la reciente reforma de la LOREG.

El Tribunal también señaló el problema que supone la posibilidad de que las fundaciones privadas, asociaciones y otras entidades reciban subvenciones de las Administraciones Públicas y terminen asumiendo gastos de campaña de los partidos. Es más, ha solicitado su total prohibición, en sentido contrario a lo dispuesto en la Ley Orgánica 8/2007, incluso pidiendo la previsión de sanciones en estos supuestos. Como ya apuntamos, no parece lo más adecuado para la transparencia permitir esta posibilidad, como ha ocurrido en la legislación para la financiación ordinaria. En todo caso, por razones obvias, se trata de un aspecto que ofrece fuertes resistencias a su modificación normativa.

Otra reivindicación del Tribunal de Cuentas es la de una mayor regulación tanto de los gastos de precampaña, como también de los gastos electorales, conceptuándolos de manera más precisa, junto con los gastos realizados para la campaña pero asumidos por terceros ajenos al proceso electoral. Además, también se subraya la necesidad de una mayor regulación de la subvención para el envío personal de sobres y papeletas, permitiendo que las formaciones políticas puedan calcular los valores subvencionables y que no tengan que incurrir en gastos que al final no serán reembolsados por el Estado y que acaban siendo considerados como gastos ordinarios. También se sugiere que los partidos adecuen este tipo de gasto al límite de gastos para propaganda, considerando su conveniencia frente a las técnicas de propaganda actualmente utilizadas en las campañas electorales.

Dadas las razones expuestas por el Tribunal, creo que es posible reconsiderar la conveniencia de la existencia misma de dicha subvención, o por lo menos de sus requisitos, que van en contra de todos los principios en los que se basa el sistema. Como ya se ha subrayado, la mayoría de la doctrina ${ }^{64}$ no es favorable a esta subvención, además de evidenciarse en los informes que es frecuente que, por falta de una regulación más detallada, existan cuantías significativas empleadas por los partidos para el envío de sobres y propaganda que al final no son subvencionables, precisamente por la

\footnotetext{
${ }^{64}$ Como ejemplo se puede citar, por todos, AA. VV.: "Debates". In: La Financiación... Pp. 106107, que reúne la opinión de expertos en el tema.
} 
imposibilidad para el partido de saber si logrará grupo parlamentario. Esto contribuye al gasto innecesario de recursos en un medio de propaganda de dudoso efecto electoral.

Finalmente, el Tribunal solicita el desarrollo de un régimen de sanciones adecuado para ser aplicado a las formaciones políticas que incurrieran en alguna conducta prohibida por la ley, ya que, como se ha expuesto, la única providencia que el órgano fiscalizador está autorizado a tomar es sugerir a las Cortes Generales la reducción del montante total de la subvención a que el partido tiene derecho, siendo que no en todos los casos, por múltiples razones, resulta adecuada tal medida desde criterios de proporcionalidad. $Y$ el problema no se limita aquí, ya que el Tribunal, utilizando su discrecionalidad, elaboró un sistema de tabla de valores que es empleado para determinar la reducción en el montante de las subvenciones que será sugerida a las Cortes Generales. Dicha tabla refleja la ausencia de una regulación adecuada, y en mi opinión también una cuestionable flexibilización del mandato legal. El valor a reducir de las subvenciones debería corresponderse con el que haya sido detectado como exceso al límite de gastos, para que el partido sea más cauteloso antes de sobrepasarlo en la campaña. Si el fundamento de la medida legal es justamente controlar el poder económico de las grandes organizaciones en pro de las menores y, de esta manera, equilibrar la competición, la proporción utilizada por el Tribunal en el citado sistema de tabla de valores resulta inútil para dicha finalidad, ya que el partido acaba por sufrir una penalización insignificante si la comparamos con el supuesto beneficio que haya obtenido con el gasto adicional realizado. Basta con verificar el resultado de los informes para darse cuenta de este hecho.

Como complemento, el Tribunal no debería limitarse a sugerir la reducción de subvenciones solamente en el caso de exceso en el límite de gastos o en el límite de donaciones, que debería ser penalizada con el doble del valor recibido, aunque es de difícil comprobación. El órgano fiscalizador debería recurrir a esta sugerencia siempre que hubiera algún incumplimiento sustancial de la ley, dando fuerza a la norma. Sin embargo, con la postura flexible del Tribunal, unida a su incompetencia jurídica para sancionar a los partidos, la transparencia de la financiación electoral queda comprometida. 


\subsubsection{Informes de la Financiación Ordinaria}

Tras el análisis de informes de financiación electoral, es posible comparar las diferencias existentes entre estos y los informes de la financiación ordinaria. Mucho más amplios - considerando toda la gama de actividades económicas que pueden ser realizadas por las formaciones políticas en su actividad ordinaria - dichos informes comportan aún más dificultades, no sólo por la debilidad de la Ley Orgánica 3/1987, sino también por la propia postura de los partidos que, una vez más, no colaboran eficientemente con la labor fiscalizadora del Tribunal. Cabe recordar que durante la vigencia de la Ley Orgánica 54/1978, el control fue prácticamente inexistente, comenzando de manera rigurosa solamente tras la aprobación de la Ley Orgánica 3/1987. ${ }^{65}$

Ha sido analizados los informes contables de los ejercicios de 1987, 1988, 1990, 1991, 1992, 1993 y de 2000 hasta 2006, último informe sometido a las reglas de la Ley Orgánica 3/1987. Ya en el informe de 2007 el Tribunal aplicó las nuevas reglas dispuestas en la Ley Orgánica 8/2007, lo que posibilitó no solamente la comparación entre las normativas, sino también entre los propios resultados de los análisis realizados.

Se debe resaltar el hecho de que el informe referente al ejercicio de 2007 fue presentado bastante fuera de plazo, lo que conlleva el retraso de los demás informes que ya deberían haber sido aprobados tanto por el Tribunal de Cuentas como por las Cortes Generales. ${ }^{66}$

\footnotetext{
${ }^{65}$ CASTILLO, P. del. "La Financiación de los Partidos Políticos en España...” Pp. 39.

${ }^{66}$ Existen especulaciones periodísticas de que los últimos informes de fiscalización de la financiación ordinaria de los partidos todavía no han sido concluidos, no por causa de la aplicación de la nueva legislación, sino porque se refieren al periodo de 2007 hasta 2011, cuando saltó a la luz el caso Gürtel, involucrando al Partido Popular. Por otra parte, un importante grupo de los actuales consejeros del Tribunal de Cuentas fue nombrado durante el gobierno de José María Aznar, que contaba con mayoría absoluta en el Parlamento. En todo caso, según la Ley Orgánica 2/1982, art. 30, los consejeros del Tribunal de Cuentas son designados por las Cortes Generales, por votación de mayoría de $3 / 5$ de los miembros de cada una de las Cámaras. En su labor, el Tribunal de Cuentas demuestra a través de los informes que aprueba para la fiscalización de los partidos, que el nivel de neutralidad en su función de fiscalización es significativamente alto. Sin embargo, también es un hecho de que, al designar un órgano fiscalizador para esta función, también es importante establecer un procedimiento de elección de sus componentes. La independencia en la tarea de fiscalización es bastante importante para que el resultado alcance los objetivos pretendidos, incluso por el peligro constante de que haya una politización de esta estructura interna, conduciendo al órgano a un lento proceso de división de sus miembros. Considerando que el Tribunal de Cuentas ha realizado su labor de fiscalización de partidos durante gobiernos diferentes, muchas de las sospechas apuntadas no resultan avaladas por la doctrina. Sobre el tema, cfr. por todos: LOZANO MIRALLES, J.: Configuración e Independencia de los Órganos de Control Externo:
} 
De hecho, este es el primer aspecto que merece subrayarse: el considerable retraso en la entrega de este tipo de informe. Hay un largo intervalo de tiempo entre la entrega de la documentación por parte de los partidos y el resultado del informe, llegando ser de seis años, y no siendo nunca menor de tres. Considerando que el art. 12 de la Ley Orgánica 3/1987 prescribe a los partidos el plazo de seis meses desde el cierre del ejercicio para la entrega de sus estados económico-financieros, y que a partir de ello el Tribunal tiene otros ocho meses para pronunciarse sobre la regularidad de las cuentas, los plazos, en la práctica, exceden con mucho de la previsión legal, y como se verá, muchas veces la principal responsabilidad corresponde a los propios partidos.

Otro dato bastante significativo es que en ninguno de sus Informes el Tribunal recomendó la aplicación de sanciones por alguna de las irregularidades existentes en las cuentas de los partidos, ni siquiera "envió" una señal de ello, y la razón parece ser que, como la Ley Orgánica 3/1987 disponía en su art. 8 que la única sanción posible quedaba restringida a casos en los cuales las organizaciones recibieran donaciones contraviniendo las prohibiciones de los arts. 4 y 5 - sanción que consistiría en una multa en el doble del valor recibido irregularmente - y que no se indicaba en la norma el responsable para arbitrar y aplicar dicha sanción, el Tribunal consideró que la facultad de sancionar a los partidos no era suya. Además, debido a las dificultades para comprobar la recepción de donaciones que contravinieran la ley, ni siquiera hubo recomendaciones de sanción, por la imposibilidad de verificar el supuesto de hecho.

\section{a) Del 1987 al 1993}

Como era de esperar, en la primera aplicación de la Ley Orgánica 3/1987 existieron muchas dificultades, tanto de carácter técnico como procedimental. Hay que considerar que las cuentas presentadas por los partidos y coaliciones fueron de baja calidad, con datos incorrectos y en

Un Análisis Comparado. ed. Civitas, Madrid, 1996. Pp. 60 y ss.; JIMENEZ RIUS, P.: EI Control de los Fondos Públicos: Propuestas de Mejora. Thompson-Civitas, Madrid, 2007. Pp. 577-579; y FERNÁNDEZ AJENJO, J. A.: El Control de las Administraciones Públicas y la Lucha contra la Corrupción. ed. Thompson-Civitas, Madrid, 2011. Pp. 336 y ss. 
algunos casos comprometiendo la verificación de la regularidad de las mismas. Esta situación fue debidamente reconocida por la Comisión mixta para las relaciones con el Tribunal de Cuentas del Congreso-Senado, que acabó por ratificar ipsis literis el contenido del informe. Las dificultades también se concentran en la transición entre la Ley Orgánica 54/1978 y 3/1987, originando que en el primer semestre de 1987 fuera aplicada la ley anterior, con criterios distintos en el acceso a las subvenciones, ya que en la Ley Orgánica 54/78 se tenían en cuenta tanto los escaños del Congreso de los Diputados como del Senado. El problema no pudo evitarse aunque en la Ley Orgánica 3/1987 se preveía una aplicación retroactiva a 1 de Enero, pues hubo partidos que presentaron las cuentas de todo el ejercicio, y otros que las limitaron al periodo de vigencia de la Ley Orgánica 3/1987.

Por otra parte, en 1987 se celebraron elecciones europeas, locales y autónomas, lo que contribuyó a perjudicar la calidad de la fiscalización. La falta de determinación de los criterios de análisis, como por ejemplo, la estructura de los documentos, o la ausencia de estos, y principalmente la entrega de la rendición de cuentas fuera de plazo por parte de las formaciones políticas, unidos a su lentitud en contestar los requerimientos del Tribunal, terminaron por perjudicar seriamente la fiscalización. ${ }^{67}$

El listado de las formaciones políticas fiscalizadas incluye partidos y coaliciones que lograron escaños, en total veinte. ${ }^{68}$ Sin embargo, el Partido Comunista de los Pueblos de España y el Partit Socialista Unificat de Catalunya no presentaron sus cuentas, aunque fueran requeridos diversas

\footnotetext{
${ }^{67}$ Todos estos puntos están contenidos en las conclusiones del Tribunal en el informe de 1987. Dicho órgano destaca la gran disparidad entre los formatos de cuentas presentados, la no inclusión en las operaciones de los diversos niveles de los partidos, la inadecuada periodificación de los recursos financieros procedentes tanto de la financiación pública como de la privada, y muchos otros fallos que evidencian no solo la falta de práctica por parte de los partidos en rendir cuentas, sino más bien las lagunas legales existentes desde el comienzo de la aplicación de la entonces recién aprobada ley. Es de suponer que este comienzo del control influyera en el agravamiento de la situación que se ha arrastrado por tantos años, ya que desde el inicio los partidos han percibido que no habría significativas consecuencias en caso de no observancia de la normativa en cuestión. Así, cfr. Pp. 29597, del BOE oㅡ 242 de 9 de octubre de 1990.

${ }^{68}$ Los Partidos fueron: Partido Socialista Obrero Español, Partit del Socialistes de Catalunya, Centro Democrático y Social, Partido Nacionalista Vasco, Euskadiko Ezkerra, Coalición Galera, Partido Aragonés Regionalista y Unión Valenciana. Ya las coaliciones fueron: Federación de Partidos de Alianza Popular, Partido Demócrata Popular, Partido Liberal Centrista de Galicia, Unión del Pueblo Navarro, Convergencia Democrática de Catalunya, Unió Democrática de Catalunya, Partido Comunista de España, Partido de Acción Socialista, Federación Progresista, Agrupación Tinerfeña de Independientes.
} 
veces para hacerlo. Además, la Federación Progresista no rindió cuentas por haber presentado un recurso contencioso administrativo contra la decisión de transferir la subvención a que supuestamente tenía derecho a Izquierda Unida. Para favorecer la comprensión de las dificultades de la primera fiscalización hecha por el Tribunal de Cuentas, se expondrá el análisis de cuentas partido por partido.

El Partido Socialista Obrero Español presentó cuentas ${ }^{69}$ englobando las subvenciones que había recibido. ${ }^{70}$ Lo que merece destacarse aquí es que desde el primer informe el partido incluye en sus subvenciones los valores concedidos a los grupos parlamentarios autonómicos, que aunque citados en el art. 2.b de la Ley Orgánica 3/1987, se remitían a ley autonómica, que no existía en la época. A la vez, el Partit dels Socialistes de Catalunya ${ }^{71}$ y la Agrupación Tinerfeña de Independientes ${ }^{72}$ fueron los únicos que no han merecido comentarios significativos por parte del Tribunal, tras constatar únicamente la insuficiencia de datos en la rendición de cuentas y los errores en la clasificación de los gastos en el procedimiento contable. Además, es de resaltar que los errores técnicos serán una constante en todas las cuentas presentadas en 1987, ya que hubo diversas interpretaciones de cómo elaborarlas. En el caso del Partido Aragonés Regionalista ${ }^{73}$ había deficiencias en el registro del fondo acreedor, con la afirmación de que el partido solamente tuvo pérdidas durante el ejercicio ${ }^{74}$ y diferencias entre los valores declarados y los enviados por el Ministerio del Interior.

69 Total de ingresos: 5.538 .116 .085 pesetas $(33.284 .748,02$ euros). Total de gastos: 4.493.661.416 pesetas (27.007.449,04 euros).

${ }^{70}$ Las subvenciones fueron concedidas al partido, a los grupos parlamentarios en el Congreso y en el Senado, subvenciones a las elecciones autonómicas, los grupos parlamentarios de las Asambleas Legislativas, como la subvención del Ministerio de Cultura y del Instituto de la Mujer. Se ha entendido que esta subvención no es incompatible con la subvención principal para la financiación del partido porque fue concedida en 01/07/87, 1 día antes de la vigencia de la Ley Orgánica 3/87.

${ }^{71}$ Total de ingresos: 697.850 .586 pesetas (41.941.662,67 euros). Total de gastos: 429.433 .791 pesetas (2.580.949,06 euros).

72 Total de ingresos: 41.222 .380 pesetas (247.751,49 euros). Total de gastos: 37.556 .583 pesetas (225.719,61 euros).

73 Total de ingresos: 117.794 .569 pesetas $(707.959,61$ euros). Total de gastos: 57.444 .231 pesetas (345.246,78 euros)

${ }^{74}$ Información esta que no coincidía con las demás informaciones, que indicaba un saldo positivo. 
Errores más sencillos se encontraron en las cuentas de Unión Valenciana $^{75}$, en torno a la clasificación de ingresos y gastos, y en el procedimiento contable. La Federación de Partidos de Alianza Popular ${ }^{76}$, cuyos datos englobaban solamente el $2^{\circ}$ semestre de 1987 y las elecciones de 1986 , los presentó incompletos, y el Partido de Acción Socialista ${ }^{77}$ poseía errores en el procedimiento contable, aunque quepa aquí destacar el alto valor referente a las cuotas de afiliados y a las donaciones privadas, considerando el valor total de ingresos. ${ }^{78}$ Siguiendo la tendencia de estos tipos de equívocos, las cuentas del Partido Demócrata Popular ${ }^{79}$ implicaban diferencias entre valores, errores en el procedimiento contable, al igual que las cuentas del Partido Liberal ${ }^{80}$, Centristas de Galicia ${ }^{81}$ y Unión del Pueblo Navarro. ${ }^{82}$ Otra de las interpretaciones interesantes se dio en torno a las de Convergencia Democrática de Catalunya ${ }^{83}$, Unió Democrática de Catalunya ${ }^{84}$ y Partido Comunista de España ${ }^{85}$, que presentaron cuentas sin contabilizar las subvenciones de los grupos parlamentarios, o incluso la principal como fue el caso del PCE, afirmando que utilizaron todos los recursos para el pago de las deudas, no restando remanente. Afirmaban también que consideraban los grupos parlamentarios como elementos autónomos de los partidos, y que por ello no los incluían en su contabilidad.

\footnotetext{
${ }^{75}$ Total de ingresos: 52.191 .416 pesetas (313.676,72 euros). Total de gastos: 81.272 .484 pesetas (488.457,46 euros).

${ }^{76}$ Total de ingresos: 871.841 .619 pesetas (5.239.873,66 euros). Total de gastos: 512.043 .119 pesetas (3.077.441,12 euros).

77 Total de ingresos: 14.389 .063 pesetas $(86.480,01$ euros). Total de gastos: 13.211 .340 pesetas $(79.401,75$ euros).

78 Juntos sumaban 9.802 .593 pesetas $(58.914,77$ euros).

${ }^{79}$ Total de ingresos: 219.335 .311 pesetas (1.318.231,76 euros). Total de gastos: 172.980 .798 pesetas (1.039.635,53 euros).

${ }^{80}$ Total de ingresos: 181.649 .000 pesetas (1.091.732,47 euros). Total de gastos: 248.292 .000 pesetas (1.492.264,97 euros).

81 Total de ingresos: 19.765 .375 pesetas (118.792.29 euros). Total de gastos: 3.333 .936 pesetas $(20.037,35$ euros).

82 Total de ingresos: 29.699 .477 pesetas (178.497,45 euros). Total de gastos: 21.631 .018 pesetas (130.005,03 euros).

${ }^{83}$ Total de ingresos: 236.567 .188 pesetas (1.421.797,43 euros). Total de gastos: 129.050 .272 pesetas (775.607,75 euros).

84 Total de ingresos: 61.027 .744 pesetas (366.784,30 euros). Total de gastos: 23.897 .936 pesetas $(143.629,48$ euros).

85 Total de ingresos: 113.233 .343 pesetas (680.546,09 euros). Total de gastos: 337.834 .089 pesetas $(2.030 .423,76$ euros).
} 
Deficiencias más significativas involucraron a otros partidos, como el Centro Democrático y Social ${ }^{86}$ que presentó cuentas conteniendo divergencias entre los datos, causadas por su interpretación de que la organización de los partidos no tiene fines lucrativos, y por ello algunos recursos no deberían ser incluidos ${ }^{87}$, como también la inclusión de datos de periodos equivocados, en lugar de incluir datos de 1987. En las cuentas del Partido Nacionalista Vasco había errores formales de valores y errores en la clasificación de gastos, destacándose el punto sobre tributos pagados y las actividades mercantiles realizadas por el partido. Euskadiko Ezkerra ${ }^{88}$ incurrió en los mismos fallos, en especial sobre los gastos a titulo de precampaña, considerados estos como ordinarios. Resulta evidente que en la práctica la separación temporal entre campaña y precampaña hecha por la LOREG no tiene efectividad en la financiación de partidos, y seguramente dichos gastos fueron utilizados para este fin.

Con todo, el caso más destacable es el de Coalición Galega, que entregó su rendición de cuentas totalmente fuera del plazo y de manera parcial, esto es, la primera parte de sus cuentas fue entregada en 25/10/88, y la restante solamente en $07 / 12 / 88$. Debido a las deficiencias contenidas en la rendición ${ }^{89}$, el Tribunal acabó por solicitar un nuevo estado económicofinanciero, que sólo fue presentado por la coalición el 25 de Abril de 1989, casi un año después del fin del plazo legal. Las cuentas contenían un largo abanico de problemas, ya que en los dos estados presentados, los datos no coincidían, siendo muy deficientes y distintos. La formación política atribuyó la función de depurar y englobar valores del estado al Tribunal, cuando en realidad ésta labor era de la coalición. Hubo muchas subvenciones que no fueron incluidas en las cuentas, como es del grupo parlamentario, y también confusión en el periodo que fue considerado para las cuentas, dándose datos referentes a las elecciones de 1986, no al ejercicio de 1987, motivo este que llevó al Tribunal a pronunciarse sobre su regularidad.

\footnotetext{
86 Total de ingresos: 2.014.496.925 pesetas (12.107.370,36 euros). Total de gastos: 1.723.394.451 pesetas ( $10.357 .809,25$ euros).

${ }^{87}$ Se resalta que el Tribunal negó esta interpretación hecha por el partido.

${ }^{88}$ Total de ingresos: 254.553 .000 pesetas (1.529.894,34 euros). Total de gastos: 246.142 .000 pesetas (1.479.343,21 euros).

${ }^{89}$ No fue posible identificar valores con seguridad.
} 
Como conclusiones de este primero informe, el Tribunal subraya que las actividades incluidas en las rendiciones de cuentas no se corresponden con la totalidad de actividades ejercidas por los partidos, lo que termina provocando fallos técnicos, como la utilización de diferentes criterios para la elaboración de las cuentas, la no inclusión de la totalidad de las subvenciones recibidas (considerando incluso subvenciones de las elecciones del ejercicio realizadas en 1987), la inadecuada periodicidad entre la financiación pública y privada, la mala aplicación de los principios contables como el de devengo, la falta de registro de las subvenciones públicas, aunque fueran utilizadas en su totalidad para pagar deudas, como también la falta de contabilidad de los intereses de los préstamos realizados.

A partir de ello, se puede verificar que en la totalidad de los informes el Tribunal será constante testigo de la continuidad de prácticamente todos los defectos constatados en el ejercicio de 1987. Los comentarios realizados pasarán directamente a los siguientes informes, dada la falta de definiciones legales en la estructura, ámbito y contenido de las cuentas ${ }^{90}$, como también por la propia postura de los partidos, que, como se verá, mantendrán metodologías de contabilidad equivocadas, y cometerán las mismas equivocaciones apuntadas, aun alertados previamente por el Tribunal.

Sin embargo, aunque la fiscalización del ejercicio de 1987 se pueda clasificar como deficiente, la de 1988 demuestra que no había ánimo - o preparación - por parte de las formaciones políticas en pro de la mejora de esta labor. ${ }^{91}$ En realidad, además de haber un significativo aumento en el tiempo en que tardó en finalizarse dicho informe ${ }^{92}$, se verifica también un descenso en la calidad de la fiscalización, fruto de muchos factores ajenos al Tribunal. Un ejemplo de ello se apunta en el comienzo del informe, en el que el órgano denuncia el grado de incumplimiento de la obligación de rendir cuentas por parte de los partidos o la inobservancia de los plazos determinados para la entrega de documentos y eventuales alegaciones. De las 21 organizaciones

\footnotetext{
${ }^{90}$ Incluso se nota que no hay muchas coincidencias entre la nomenclatura empleada por los partidos en la clasificación de ingresos y gastos, demostrando que cada uno ha procedido de la forma que pensó ser correcta, o más adecuada.

${ }_{91}$ Esto ha ocurrido aunque el grupo parlamentario socialista del Congreso solicitaba a la Comisión Mixta del Congreso-Senado que se ampliara la fiscalización, considerándola beneficiosa par el funcionamiento del sistema democrático.

${ }_{92}$ La resolución del Tribunal de Cuentas tiene fecha de 03/02/1993, y su aprobación por la Comisión mixta del Congreso-Senado de 28/12/1993.
} 
políticas fiscalizadas ${ }^{93}$, nueve incumplieron de alguna manera el deber de presentar sus estados económicos-financieros al Tribunal, siendo las razones más frecuentes para ello la entrega muy tardía de documentos esenciales para la fiscalización, o simplemente su no entrega. ${ }^{94}$ Además, las cuentas presentadas carecían de parámetros básicos para su análisis, comprometiendo directamente el resultado de la fiscalización de este ejercicio, como se verá partido por partido. Los casos que merecen destacarse van mucho más allá de lo que resultaría oportuno desarrollar en el presente trabajo, lo que no impide que se seleccionen algunas situaciones típicas de las críticas aquí expuestas.

El Centro Democrático y Social presentó cuentas ${ }^{95}$ con muchas deficiencias técnicas y contables, con diferencia entre cantidades y datos declarados en general. Dejó de incluir las sedes locales, las subvenciones electorales recibidas en 1988 (pero contabilizando las de 1987), e imposibilitó al Tribunal verificar documentos internos, por la inexistencia de un control interno, con diferencias incluso entre datos registrados internamente entre las sedes del partido. Dichas deficiencias se repetirían en las cuentas del Partit dels Socialistes de Catalunya ${ }^{96}$ (que presentaba muchas irregularidades, elaborando un estado económico-financiero sin la mínima base contable

\footnotetext{
${ }^{93}$ Las formaciones políticas fiscalizadas fueron: Partido Socialista Obrero Español, Centro Democrático y Social, Partit dels Socialistes de Catalunya, Partido Nacionalista Vasco, Euskadiko Ezkerra, Coalición Galega, Partido Aragonés Regionalista, Unión Valenciana, Federación de Partidos de Alianza Popular - Partido Popular, Partido Liberal, Centristas de Galicia, Unión del Pueblo Navarro, Convergencia Democrática de Catalunya, Unió Democrática de Catalunya, Partido Comunista de España, Partido Comunista de los Pueblos de España, Partido de Acción Socialista, Federación Progresista, Partit dels Socialistes de Catalunya, Agrupación Tinerfeña de Independientes. Cabe destacar que el PSOE presentó rendición de cuentas por separado de los ejercicios de 1988 y 1989, siendo aprobadas por el Tribunal en sesión de 25/06/1992.

94 El Centro Democrático y Social presentó documentación incompleta, incumpliendo el plazo de 20 días para ello. Solamente entregó una pequeña parte de los documentos solicitados después de 150 días. Euskadiko Ezkerra no atendió a las solicitudes del Tribunal para presentar documentos esenciales. Coalición Galega presentó cuentas fuera del plazo, excediéndolo en un año. Acabó por entregar la documentación adicional solicitada solamente después de 120 días, alegando un robo en la sede de Orense. El Partido Aragonés Regionalista presentó cuentas fuera del plazo, complementándola solamente después de tres requerimientos del Tribunal. El Partido Liberal solicitó al Tribunal que acudiera a la sede del partido para realizar el análisis de la documentación El partido, finalmente, entregó la documentación 120 días después de un nuevo requerimiento, en la fecha de 21/03/90. Los Centristas de Galicia entregaron solamente parte de la documentación y después de tres requerimientos del Tribunal. La Federación Progresista alegó la existencia de una serie de recursos contra Izquierda Unida por las subvenciones, como en 1987. El Partit Socialista Unificat de Catalunya entregó su rendición de cuentas fuera del plazo, después de tres requerimientos, y el Tribunal recibió la documentación de la sede central en 1989.

${ }_{95}$ Total de ingresos y gastos informados: 1.495 .968 .064 pesetas (8.990.946,14 euros).

${ }^{96}$ Total de ingresos y gastos informados: 705.322 .618 pesetas $(4.239 .074,30$ euros).
} 
necesaria ${ }^{97}$ ), Coalición Galega ${ }^{98}$, Partido Aragonés Regionalista ${ }^{99}$, Centristas de Galicia ${ }^{100}$, Unión del Pueblo Navarro ${ }^{101}$, Convergencia Democrática de Catalunya $^{102}$, Unió Democrática de Catalunya ${ }^{103}$, Partido Comunista de España $^{104}$ y Agrupación Tinerfeña de Independientes. En los casos de Unión Valenciana ${ }^{105}$, Partido de Acción Socialista ${ }^{106}$, Partit Socialista Unificat de Catalunya $^{107}$ y Euskadiko Ezkerra ${ }^{108}$, además de las deficiencias antes apuntadas en las demás cuentas, contrariaba directamente el art. 7 de la Ley Orgánica 3/1987 no teniendo una cuenta específica para las donaciones privadas, lo que es síntoma del incumplimiento sistemático de la ley por dichos partidos. $^{109}$

Sin embargo, hubo casos aún más relevantes. En las cuentas del Partido Nacionalista Vasco ${ }^{110}$, además de contar con un control interno fallo, se incluyeron - por la primera vez - las subvenciones concedidas por el gobierno autonómico vasco, fuente esta que no estaba prevista en la Ley Orgánica 3/1987, como tampoco se abrió una cuenta específica para el flujo de donaciones privadas, violando el dispuesto en el art. 7 de la misma ley. Cabe resaltar que a partir de este informe, esta formación política siempre declarará la existencia de la subvención autonómica, motivando que el Tribunal de Cuentas sugiera el cambio de la Ley Orgánica 3/1987 a fin de regularizar dicha fuente de financiación. La reivindicación solamente fue atendida con la aprobación de Ley Orgánica 8/2007, veinte años después, y con la intención

\footnotetext{
${ }^{97}$ Como ejemplo se menciona el inventario presentado, carente del inmovilizado, operaciones de crédito no incluidas, diferencias de valores declarados por el partido y por el grupo parlamentario, deficiencia en los valores referentes a las elecciones de Catalunya realizadas en 1988 y confusión con valores de 1987 y problemas con procedimientos contables en general.

${ }_{98}^{98}$ Total de ingresos y gastos informados: 66.980 .354 pesetas (402.560,03 euros).

${ }^{99}$ Total de ingresos y gastos informados: 53.520 .145 pesetas $(321.662,55$ euros).

100 Total de ingresos y gastos informados: 27.341 .087 pesetas (164.323,24 euros).

101 Total de ingresos y gastos informados: 51.707 .318 pesetas $(310.767,24$ euros).

102 Total de ingresos y gastos informados: 436.587 .925 pesetas (2.623.946,27 euros).

${ }^{103}$ Total de ingresos y gastos informados: 118.294 .364 pesetas $(710.963,45$ euros).

104 Total de ingresos y gastos informados: 301.513 .187 pesetas ( $1.812 .130,75$ euros).

${ }^{105}$ Total de ingresos y gastos informados: 70.643 .543 pesetas (424.576,24 euros).

${ }^{106}$ Total de ingresos y gastos informados: 16.011 .038 pesetas $(96.228,27$ euros).

${ }^{107}$ Total de ingresos y gastos informados: 193.234 .193 pesetas $(1.161 .360,89$ euros).

${ }^{108}$ Total de ingresos y gastos informados: 305.374 .000 pesetas (1.835.334 euros).

${ }^{109}$ En este caso fue todavía peor, pues debido a las irregularidades identificadas, el Tribunal no fue capaz de pronunciarse sobre la veracidad de los datos presentados, llegando a realizar la siguiente afirmación: "Las tantas veces denunciada falta de libros de contabilidad así como la dispersión y heterogeneidad en las rubricas de ingresos y gastos no permiten determinar la veracidad de los importes recogidos en los estados rendidos y la naturaleza de los mismos". (Pp. 14 del referido informe).

${ }^{110}$ Total de ingresos y gastos informados: 249.118 .049 pesetas (1.497.229,62 euros).
} 
precisamente de ampliar las posibilidades de recibir subvenciones, en contrapartida a la prohibición de las donaciones anónimas. ${ }^{111}$

En los casos de la Federación de Partidos de Alianza Popular - Partido Popular $^{112}$, Partido Demócrata Popular ${ }^{113}$, y Partido Liberal ${ }^{114}$ fueron objeto de análisis después de su extinción formal como organizaciones políticas, y como sus cuentas tenían significativas deficiencias, no fue posible verificar su ajuste a la ley.

Las conclusiones del Tribunal sellaban la existencia de un ciclo que se prolonga en el tiempo, ya que ninguna de las formaciones políticas había presentado estados contables consolidados en su totalidad, con un alto nivel de irregularidades y con una notable falta de directrices en su elaboración. ${ }^{115}$ Las recomendaciones del primer informe serían repetidas y ampliadas, y se nota que el propio Tribunal no se ha detenido en igual medida en las conclusiones que siguieron al Informe de 1988. En dicho informe, el órgano fiscalizador realiza un pequeño compendio sobre los fallos identificados, incorporando un texto explicativo sobre cada uno de los temas tratados y aportando recomendaciones para el perfeccionamiento de la ley. Sin embargo, a partir del informe de 1990, el Tribunal se limita a exponer sus conclusiones resultado del análisis de las rendiciones de cuentas, agregando nuevos aspectos problemáticos, pero no formula recomendaciones de reforma legal. La palabra "reiterar" comienza a aparecer frecuentemente en las conclusiones del Tribunal, y no sin razón.

Las sugerencias se centran en que los partidos tuviesen un representante externo responsable de la rendición de cuentas; en que la elaboración de estas se basara en el Plan General de Contabilidad acompañada de un adecuado control interno englobando todos los niveles de la organización; en que se establecieran claramente derechos y obligaciones entre los partidos integrados en las coaliciones; en la definición de conceptos y

\footnotetext{
111 Estas constataciones se detallan en el apartado sobre la Ley Orgánica 8/2007, en este capítulo.

${ }_{112}$ Total de ingresos y gastos informados: 1.860 .523 .513 pesetas ( $11.181 .971,51$ euros).

${ }_{114}^{113}$ Total de ingresos y gastos informados: 441.154 .043 pesetas $(2.651 .389,19$ euros).

114 Total de ingresos y gastos informados: 265.516 .000 pesetas $(1.595 .783,29$ euros).

115 El Tribunal acabó por detectar errores en la retención del Impuesto de Renta, comunicándolo al Ministerio de la Hacienda y Economía para eventuales providencias. Cabe recordar que los partidos, en esta época, no tenían un régimen tributario propio como el existente en la actualidad en la Ley Orgánica 8/2007.
} 
la verificación de eventuales irregularidades en la retención del impuesto de renta. Sin embargo, el énfasis del Tribunal se dirige hacia la necesidad de desarrollar las disposiciones de la Ley Orgánica 3/1987, estableciendo un régimen de sanciones y responsabilidades, concretando las fuentes de financiación en general, ampliando las facultades del Tribunal para la fiscalización de las coaliciones y de sus estados patrimoniales cuando reciban subvenciones y reforzando el deber de colaboración de las empresas y entidades financieras cuando sean requeridas por el Tribunal para aportar determinadas informaciones. ${ }^{116}$

A partir de este punto es posible deducir de la evolución de los informes que los partidos reiteran sus errores en la presentación de sus cuentas, presentándolas de forma inadecuada y con los mismos defectos apuntados por el Tribunal en ocasiones anteriores, evidenciando que el resultado de la labor de fiscalización no cumple una labor prescriptiva, así como también que las recomendaciones hechas por el órgano fiscalizador tampoco son tenidas en cuenta por las Cortes Generales. Además, la elaboración de una buena contabilidad también se relaciona con la capacidad de afrontar sus costes, es decir, los partidos mayores tienen mucho más capacidad para presentar sus cuentas conforme a las disposiciones del Tribunal - en detrimento de los menores - y que así, sus cuentas no son totalmente fiables según los parámetros de dicho órgano.

En la década de los 90, el tiempo necesario para completar la fiscalización ordinaria de los partidos aumentó significativamente, llegando a ser de seis años. ${ }^{117}$ Las subvenciones públicas ordinarias también han

\footnotetext{
${ }^{116}$ Se sugiere en dicho informe que el partido realice un control interno a través de un órgano que ostente su representación externa; sumisión al Plan General de Contabilidad; que las cuentas sean presentadas ya consolidadas a partir de las cuentas de toda la organización del partido, tanto territorial como la derivada de su representación en instituciones públicas; que partidos organizados en coaliciones deberían fijar objetivamente los criterios de reparto de derechos y obligaciones asumidas, reflejando dicha condición en sus respectivos estados contables; que, a los fines de verificación de los arts. 4, 5 y 6 de la Ley Orgánica 3/1987, los partidos deberían distinguir los registros de los ingresos de valores a título de cuotas y aportaciones de los afiliados de otras aportaciones voluntarias; que las cuentas deberían englobar las de la actividad electoral; y apunta también a las deficiencias en las previsiones sobre las irregularidades relativas al impuesto de renta de persona física. Estos elementos serían repetidos sistemáticamente por todos los demás informes. Cfr. Pp. 38, del suplemento del BOE ํㅜ 35, de 10 de febrero de 1994.

${ }_{117}$ Los informes de 1990, 1991 y 1992 fueron aprobados por el Tribunal en 28/03/1996, y por la Comisión Mixta del Congreso-Senado en 27/12/1996, siendo publicados en el BOE en 16/04/1997. Sin embargo, el único caso de entrega de rendición de cuentas fuera del plazo
} 
aumentado gradualmente ${ }^{118}$, como también el endeudamiento de los partidos $^{119}$, lo que motivó la ampliación del ámbito de fiscalización del Tribunal hasta el nivel de las corporaciones locales, aunque no estuviera regulado en la ley de subvenciones procedentes de este nivel estatal. Cabe resaltar que esta decisión de ampliación de la fiscalización fue tomada por el Tribunal de manera discrecional.

El número de formaciones políticas fiscalizadas se mantuvo estable, variando entre 21 y $22^{120}$, como también las deficiencias e irregularidades en las cuentas. Los errores técnicos contables, de procedimiento y la inobservancia de los principios generales de contabilidad, principalmente del Plan General de Contabilidad estuvieron presentes en prácticamente la totalidad de las rendiciones de cuentas presentadas, incluso considerando todo el período analizado entre 1990 y 1993. Estos se traducen en la mala clasificación de ingresos y gastos, la falta de inventario del inmovilizado, las diferencias entre valores declarados y documentados, la falta de parámetros de procedimientos de registro, la confusión entre donaciones privadas y cuotas de afiliados, la no aplicación de principios contables en los cálculos, como el de devengo, y tantos otros, lo que también acaba por comprobar la debilidad - o la inexistencia en muchos casos - de un control interno en la organización política que se prolonga en el tiempo, ya que, aunque compelidos por el Tribunal a instituir procedimientos internos capaces de controlar las actividades

legal fue el de Coalición Canaria en el ejercicio de 1993. Ante ello, se supone que el retraso fue causado tanto por la dificultad en analizar cuentas considerablemente deficientes, como por el tiempo utilizado para solicitar informaciones a entidades financieras o a los propios partidos, muchas veces sin el resultados satisfactorios.

${ }^{118}$ En 1990 las subvenciones públicas totalizaban 13.726.056.179 pesetas (82.495.259,09 euros); en 1991, 15.013.376.586 pesetas (90.232.210,55 euros); en 1992, 16.457.770.495 pesetas (98.913.192,78 euros); y en 1993, 17.027.931.379 pesetas (102.339.928,71 euros).

${ }_{119}$ Organizaciones como Unión Democrática de Catalunya, Convergencia i Unió, Convergencia Democrática de Catalunya, Iniciativa per Catalunya, Izquierda Unida, Eusko Alkartasuna, Partido Comunista de España y Partido Nacionalista Vasco tuvieron un aumento considerable de sus deudas, pero el caso más destacable es de Partido Socialista Obrero Español, que en 1991 declaró un aumento de $25 \%$ en el valor de sus deudas.

${ }^{120} 17$ de ellos fueron fiscalizados en los 4 ejercicios indicados: Agrupación Independiente de Canarias, Agrupación Tinerfeña Independiente, Centro Democrático y Social, Convergencia i Unió, Euskadiko Ezkerra, Partido Nacionalista Vasco , Eusko Alkartasuna, Iniciativa per Calatunya , Partido Comunista Español, Partido de la Acción Socialista, Partido Andalucista, Partido Aragonés, Partido Popular, Partido Socialista Obrero Español, Partit dels Socialistes de Catalunya, Unión del Pueblo Navarro y Unión Valenciana. La variación fue de los Centristas de Galicia y Convergencia Democrática de Catalunya, no fiscalizados en 1993 y Coalición Canaria, fiscalizada únicamente en 1993. Por su parte, Herri Batasuna, aunque tuviera derecho, no recibió las subvenciones públicas de los ejercicios de 1990 y 1991. 
económico-financieras de la formación, estas no toman ninguna medida para ajustarse a las recomendaciones anteriormente mencionadas. En una nítida postura de violación a los arts. 10 y 11 de la ley, se nota que los partidos cometen siempre los mismos equívocos, año tras año, en una actitud de conformidad con la situación. Queda implícita la idea de que, cuando no hay sanciones, no hay preocupación.

Además de ello, ninguna de las rendiciones de cuentas presentadas en estos cuatro ejercicios estaban consolidadas y completas englobando toda la organización, más bien al contrario, dado que muchos partidos entregaban cuentas solamente de la sede central y aun así muy deficientes. Hubo casos, como el de Partido Socialista Obrero Español, que casi abarcó a la totalidad de la formación política, lo que no evitó la gran cantidad de incorrecciones técnicas contenidas en los estados presentados. Se verificaron algunos casos extremos de cuentas defectuosas, como es el de los Centristas de Galicia, que en los ejercicios de 1990 y 1991 no presentaron una rendición de cuentas como tal, sino solamente un mero registro auxiliar de tesorería con muchas deficiencias. Ya en 1992, aun presentando una rendición de cuentas formal, la misma formación incurrió en más irregularidades que en el documento antes citado. Por otra vez, las deficiencias continuas en las cuentas llevaron nuevamente a impedir la declaración del Tribunal sobre su regularidad, considerando los casos del Centro Democrático y Social y Euskadiko Ezkerra, que entregaron cuentas imposibles de analizar en tres ejercicios consecutivos - 1990, 1991 y 1992. ${ }^{121}$ En el caso de la Agrupación de Independientes de Canarias, ante la entrega solamente de las cuentas del grupo parlamentario en las Cortes Generales en el ejercicio de 1993, tampoco fue posible su análisis.

Por otra parte, además de las dificultades antes identificadas, se fueron detectando nuevas irregularidades o supuestos en que simplemente no existía una regulación en la Ley Orgánica 3/1987. Un ejemplo importante es la constatación de recibir subvenciones públicas de origen local por parte de algunas formaciones políticas durante los cuatro ejercicios analizados, es decir, además de algunos gobiernos autonómicos, las diputaciones y ayuntamientos también estaban concediendo subvenciones públicas a los partidos, aunque

\footnotetext{
${ }^{121}$ Lo que llama la atención en las cuentas de Euskadiko Ezkerra es el alto valor de recursos declarado, en comparación con las demás organizaciones.
} 
ello no estuviera previsto como fuente de financiación pública en el art. 2 de la ley. A nivel autonómico, el Gobierno Vasco concedió subvenciones al Partido Nacionalista Vasco, Partido Popular, Eusko Alkartasuna e incluso a Herri Batasuna. En el nivel local, obtuvieron subvenciones la Agrupación Tinerfeña de Independientes, Centristas de Galicia, Convergencia i Unió, Iniciativa per Catalunya, Izquierda Unida, Partido Comunista de España, Convergencia Democrática de Catalunya, Partido Andalucista, Partit dels Socialistes de Catalunya, Partido Socialista Obrero Español, Unión del Pueblo Navarro, Unión Valenciana y Unión Democrática de Catalunya. Cabe destacar que en 1990 fueron pocas las organizaciones que declararon recibir subvenciones de estas fuentes, aunque en 1991 el número aumentó considerablemente, repitiéndose esta mención en los ejercicios subsiguientes. Se puede suponer que la razón de este aumento fue realmente la consolidación de una tendencia, pero también se puede pensar que, en realidad, no se produjo un aumento real de valores transferidos, sino la incorporación a los informes de la existencia de estas subvenciones presentes en las cuentas de los partidos. Ante ello, el Tribunal recomendó que se regulara este tipo de fuente de financiación pública, lo que solamente se produjo, como apuntamos en la Ley Orgánica 8/2007.

Otro supuesto que no es regulado por la ley era la posibilidad de que la formación política ejerciera algún tipo de actividades mercantil. En el ejercicio de 1990, Convergencia Democrática de Catalunya declaró la compra de acciones de una empresa, y en 1992 su participación en la sociedad "Jurídico Manresana", manteniéndola en los ejercicios siguientes. Eusko Alkartasuna declaró en el ejercicio de 1991 su participación en la sociedad "Gure Etxea", en una emisora de radio llamada "E. Irratia" y también la tenencia de acciones en un periódico. A su vez, el Partido Socialista Obrero Español también ha declarado su participación en la sociedad "Prensa Sur" a partir de 1992, como también el Partido Nacionalista Vasco en diversas empresas en el ejercicio de 1993, aunque sin documentos justificantes. Caso interesante es de Euskal Ezkerra, que fue fundado en 1993, y que en su primer estado económicofinanciero declaró participaciones, a través de activos, en fondos de inversiones inmobiliarios, como también compra y venta de activos. Como no existía ninguna regulación sobre este aspecto en la Ley Orgánica 3/1987, el Tribunal 
no se manifestó contrario a ello, aunque pudiera entenderse que el fin de las formaciones políticas no era la actividad mercantil.

Junto con estas situaciones no previstas en la ley, en los informes analizados se verificó la existencia de posibles condonaciones por parte de las entidades financieras de las deudas de los partidos, o de los intereses originados por estas deudas. Del simple indicio de la existencia de dichos acuerdos extra contractuales sobre deudas existentes - como fue el caso del Partido Comunista de España en 1990 y el Partido Popular en 1991 - se pasó a la seguridad de su existencia, alcanzando nuevamente al PCE en 1992 y 1993, al Partido Popular en 1993 y al Partido Socialista Obrero Español en 1992. Se trata de una práctica utilizada por entes privados, pero cuando involucra partidos políticos, el enfoque cambia debido al principio de la igualdad de oportunidades electorales que debe regir entre las organizaciones partidistas en un sistema democrático. Como ya se indicó anteriormente, aun actualmente no se sabe cuáles son los criterios utilizados en el momento de la renegociación. Junto a esto, el "perdón" de parte de la deuda debería ser considerado como una donación de origen privado, sometida a los limites determinados por la ley. Sin embargo, como la Ley Orgánica 3/1987 guardaba silencio a este respeto, y las recomendaciones del Tribunal sobre la necesidad de regular esta posibilidad tampoco fueron atendidas, no se produjo ninguna sanción, ni ninguna "sugerencia" de sanción. Cabe recordar que la nueva Ley Orgánica 8/2007 ha tratado de autorizar la renegociación de deudas, sin profundizar en su reglamentación, lo que significa que el problema seguirá presente en el momento de fiscalizar a los partidos.

Se verificaron también otras irregularidades identificadas en las cuentas del Partido de Acción Social de 1990, Partido Andalucista de 1991 y del Partido Aragonés de 1990 y 1992, dada la vulneración del límite del 25\% de los ingresos de la organización procedentes de la financiación pública para el pago de anualidades de amortización de operaciones de crédito, dispuesto en el art. 9 de la Ley Orgánica 3/1987. Esto demuestra no tanto la inobservancia de la norma, sino el alto nivel de endeudamiento de estas formaciones políticas, que se ven "obligadas" a violar la ley para hacer frente a sus deudas. En definitiva, el control de las deudas contraídas por los partidos ha sido siempre un "punto oscuro" dentro de la actividad de fiscalización. 
Por último, un dato que llama la atención se dio en el ejercicio de 1993 en las cuentas de Centro Democrático y Social que, por no haber logrado escaños en las elecciones, fue obligado a despedir a todo su personal administrativo, lo que le impidió rendir cuentas de manera adecuada alegando falta de infraestructura. ${ }^{122}$ Se trata de una señal de que, desde la década de los noventa (cuando la concesión de las subvenciones públicas a título ordinario era aun reciente), los partidos ya presentaban síntomas de dependencia de estos recursos, sin que existiera una alternativa legal a estos. Actualmente, después de casi 20 años desde esta señal, el nivel de esta dependencia resulta decisivo.

En las conclusiones presentadas sobre estos cuatro ejercicios fiscalizados, el Tribunal de Cuentas reiteró muchas de las consideraciones ya antes apuntadas, añadiendo algunas recomendaciones sobre los nuevos aspectos polémicos identificados. Así, resaltó que la fiscalización debe englobar a toda la organización, incluso el de la participación de sus miembros en instituciones como los grupos parlamentarios, los grupos de cargos electos en corporaciones locales, y otros. Apuntó también que las cuentas deberían tener un formato general común, con la obligatoriedad de llevar libros contables e inventarios del inmovilizado, señalando la necesidad de un desarrollo legal para uniformizar procedimientos y directrices para el control interno, formalizándolas. Además, las cuentas deberían contener todas las actividades propias de las organizaciones, presentándose de manera consolidada. EI Tribunal también recomienda - en tono de reivindicación - la regulación normativa de las subvenciones a nivel autonómico y local y de las condonaciones de deudas, así como reforzar el deber de colaboración de las entidades financieras ante el órgano fiscalizador, volviéndolo más efectivo. Es decir, tras siete años de vigencia de la Ley Orgánica 3/1987, no se habían atendido los problemas más importantes en la fiscalización, y, más bien, se originaron nuevas cuestiones, fueron fruto de la clamorosa inactividad del Poder Legislativo en esta materia. Nuevamente se percibe que hay un ambiente político propicio para que los partidos se sientan seguros a la hora de

${ }^{122}$ Cfr. Pp. 30, del suplemento del BOE no 88, de 13 de abril de 1999. 
dar cuenta de sus recursos de la manera que estimen más conveniente, aunque ello signifique caminar al margen de la normativa entonces vigente.

\section{b) Del 2000 al 2006}

A pesar del trascurso del tiempo, en la década del 2000 la situación apenas se modificó. En los informes analizados sobre las actividades entre el 2000 y el 2006, se constata la consolidación de los problemas antes denunciados por el Tribunal. Sin embargo, ante la falta de acciones reales por parte del parlamento, el Tribunal de Cuentas acabó por elaborar y aprobar un informe especial dirigido a las Cortes Generales, sobre los puntos críticos en la fiscalización de los partidos en sus actividades ordinarias, de fecha 30 de octubre de 2001, que fue enviada a la Comisión Mixta para las Relaciones con el Tribunal de Cuentas del Congreso-Senado, intentando sin duda llamar la atención de los partidos y la opinión pública sobre los problemas existentes. ${ }^{123}$

El primer aspecto clave tratado en la moción fue la gran dificultad para aplicar el procedimiento de fiscalización de los partidos, dado que la Ley Orgánica 3/1987 guardada silencio sobre aspectos muy relevantes de la misma. La ley no desarrollaba suficientemente la función de fiscalización a realizar, en aspectos como la delimitación de la actuación fiscalizadora, la posibilidad de los partidos de participar de actividades mercantiles, la regulación sobre subvenciones concedidas por gobiernos autonómicos y corporaciones locales, e incluso sobre la cuestión de las fundaciones y asociaciones y su vínculo con los partidos. El Tribunal tenía (quizás se podría decir que todavía tiene) dificultades en proceder en estas situaciones debido a la total ausencia de previsión legal. De esa manera, en ese tema, el Tribunal de Cuentas sugirió no eximir ningún nivel de actividad de los partidos políticos de su fiscalización, englobando a las organizaciones locales, a los grupos de representación política en los diversos parlamentos, y también en las corporaciones locales, adecuando la normativa para evitar conflictos entre normas. Por otra parte, el Tribunal también proponía regular normativamente la cuestión de la participación de las fundaciones partidistas en sociedades

\footnotetext{
${ }^{123}$ La aprobación de dicha moción por la Comisión Mixta fue de 11 de junio de 2002, siendo publicada en el BOE de 21 de agosto del mismo año.
} 
mercantiles, especificando cuáles son las actividades que dichas fundaciones podrían realizar, y sus correspondientes mecanismos de control. Según el órgano fiscalizador, era necesaria una modificación en la ley ya que no se considera prudente permitir que organizaciones con dicha naturaleza especial participen en mercados con características volátiles, como son los mercados especulativos.

Específicamente acerca de la financiación pública ordinaria, el Tribunal de Cuentas destacó la restricción que implicaba la obligación de rendir cuentas solamente a los partidos políticos con representación en el Congreso de los Diputados, estando exentas de ello las organizaciones que tienen representación sólo en el Senado o en alguna de las Asambleas Legislativas de las Comunidades Autonómicas. El Tribunal de Cuentas ha sugerido que la fiscalización alcance a todas las formaciones políticas que posean representación, considerando todos los órganos representativos. Entiende también conveniente que se debería establecer en la ley de financiación ordinaria algún criterio para fijar el crédito presupuestario correspondiente a las subvenciones, como también prever algún criterio de incremento anual de esa cuantía, ya que la Ley Orgánica 3/1987 carecía de ello. Además de ello, el Tribunal aprovechó la oportunidad para solicitar la regulación legal de nuevas situaciones que se han vuelto comunes durante los ejercicios contables, como es la sugerencia de que se evite la utilización de las subvenciones de grupos parlamentarios en la financiación de los partidos, utilizando cada recurso para el fin que haya sido destinado y a la vez posibilitando que se pueda mensurar el coste de cada actividad, reforzando el control.

En relación a la financiación privada, el Tribunal de Cuentas resaltó la evidencia de fraudes con relación al límite de donaciones privadas debido a la diferencia de criterios entre la LOREG y la Ley Orgánica 3/1987. La rigidez en el límite de las donaciones privadas en la LOREG y la prohibición de aportaciones anónimas son fácilmente eludibles por la permisividad de la LOFPP, que poseía un límite para las mismas donaciones muy superior, y permitía además donaciones anónimas. Ante esto, como se constataba en los informes, en la práctica las restricciones eran meramente formales. Por lo tanto, el Tribunal sugería la coordinación de criterios entre las dos normas, algo que favorecería el control de la financiación privada. Dentro del mismo tema, el 
Tribunal de Cuentas había sugerido hacer alguna diferenciación entre donaciones privadas y cuotas de afiliados (algo que no existía en la Ley Orgánica 3/1987), y también que fuera objeto de regulación la financiación indirecta privada a favor de los partidos, a través de sus fundaciones, ya que no existían normas referentes al asunto. También se subrayaba la frecuencia en las condonaciones de deudas, solicitándose una regulación de este fenómeno, dada la frecuente presencia de renegociaciones en los estados contables de los partidos.

En lo que se refiere a las obligaciones contables originadas por la actividad económica-financiera de los partidos políticos, el Tribunal de Cuentas sugirió una pormenorizada reforma, que comienza con la ampliación de la obligación de rendición de cuentas a las formaciones políticas con representación en cualquier nivel, incluso fundaciones y asociaciones pertenecientes a los partidos. ${ }^{124}$ Además, el Tribunal destacó que no era suficiente que los partidos políticos articularan las cuentas anuales a partir de una contabilidad detallada. Era necesario también que se facilitara todo un conjunto de documentos contables, como el Balance de Pérdidas y Ganancias y una Memoria que contenga detalladamente todo el patrimonio del partido, como también sus cuentas, flujos económicos, etc. Así, también se resaltó la importancia de la obligación de disponer de un libro contable y de otro de inventarios de cada partido, y que dicha documentación atienda a un solo sistema contable, sin discrepancias de criterios en la presentación de las cuentas, algo que ha comprometido la fiscalización por parte del órgano responsable. Otro punto también abordado por el Tribunal de Cuentas era la ausencia de normas sancionadoras para las entidades que realizan operaciones financieras o económicas con los partidos políticos y que no remitan las informaciones solicitadas por dicho Tribunal, incumpliendo su deber de colaboración.

El último aspecto tratado por el Tribunal de Cuentas fue la ausencia de un régimen sancionador por el incumplimiento de las normas de la Ley

\footnotetext{
${ }^{124}$ Rodríguez López expone la manera en que entiende que, bajo el PGC 2007, se deben incluir las condonaciones de deudas, intereses y demás datos en el balance de la situación. Cfr. RODRIGUEZ LOPEZ, Á. "Subvenciones..." Pp. 30-38. Sobre la metodología que el autor sugiere para el análisis de las finanzas de los partidos, cfr. RODRIGUEZ LÓPEZ, A.: Contabilidad y Financiación de los Partidos Políticos. ed. CISS, Madrid, 2011. Pp. 167 y ss.
} 
Orgánica 3/1987, así como de un procedimiento para exigir la responsabilidad por dichos hechos. El Tribunal proponía la inclusión - tanto en la LOREG como en la LOFPP - de un régimen sancionador completo para el incumplimiento de dichas normas, y también un procedimiento de ejecución de las sanciones. Sin embargo, el Tribunal de Cuentas resaltó que no tiene la pretensión de ser el responsable de la aplicación de dichas sanciones, por entender que esto afectaría negativamente a la actividad fiscalizadora del Tribunal.

Así, la moción fue útil a los fines de sistematizar las reivindicaciones del Tribunal en aras de una mejora en la fiscalización, y algunas de sus sugerencias fueron consideradas en el momento de elaboración de la Ley Orgánica 8/2007. A partir de la aprobación de la moción, el Tribunal se sirvió de sus informes subsiguientes para demostrar en la práctica la evidente necesidad de realizar cambios en la ley. Dado que la aprobación del informe de fiscalización del ejercicio de 2000 se dio en el 2003, los argumentos contenidos en la moción sirvieron de base para las conclusiones sobre la labor de fiscalización realizada.

Del análisis de los informes del período entre 2000 y 2006 (éste último fue aprobado en el 2010), destacan algunas características significativas si se considera su continuidad todos estos años. En general, el tiempo que al Tribunal lleva analizar la rendición de cuentas de las formaciones políticas no ha variado mucho, con una media de tres años ${ }^{125}$, superior en todo caso al plazo contenido en la Ley Orgánica 3/1987. Los partidos, obviamente, continúan cometiendo faltas en la entrega de la documentación, con incumplimientos del plazo legal, retrasos en la entrega de informaciones adicionales, así como también se acentúa la propia dificultad en este análisis por la falta de criterios contables y las innumerables deficiencias que poseen los dossiers presentados. El número de partidos fiscalizados también se mantuvo estable, entre 17 y 18 en total. Ello demuestra que el sistema de partidos, en estos siete años, no ha sufrido modificaciones significativas, lo que ayuda a evidenciar la tendencia a la cristalización del mismo, circunstancia esta subrayada siempre por la doctrina, y fueron prácticamente los mismos partidos

${ }^{125}$ Las fechas de aprobación de los informes por el Tribunal fueron: ejercicio de 2000: 26/02/2003; ejercicio de 2001: 30/09/2003; ejercicio de 2002: 27/10/2005; ejercicio de 2003: 01/06/2006; ejercicio de 2004: 27/06/2007; ejercicio de 2005: 24/04/2008; ejercicio de 2006: 25/02/2010. 
los que fueron fiscalizados en este período, aunque dentro de este tiempo haya habido varios procesos electorales generales. Con todo, un cambio significativo fue la ampliación de la fiscalización a las formaciones políticas con representación en las Asambleas Autonómicas a partir de 2004. Además de los 17-18 partidos fiscalizados por su representación en el Congreso de los Diputados $^{126}$, se incluyeron entre 13 a 14 formaciones políticas a nivel autonómico $^{127}$, siendo la variación entre estos partidos menores que entre el anterior grupo de organizaciones fiscalizadas. Dicha constatación refuerza aún más los argumentos sobre una eventual cristalización del sistema de partidos, que no alcanza solo al nivel nacional, como también el autonómico. ${ }^{128}$

Un dato interesante es el aumento real del valor de las subvenciones $\sin$ que se siguiera ningún criterio, ya que la Ley Orgánica 3/1987 no preveía ningún índice para la actualización de sus valores. En el 2000 los recursos públicos transferidos a los partidos solamente a título de financiación ordinaria alcanzaron 142.444.010,84 euros, y en 2006 ya eran de 193.191.103,40 euros. Considerando que la Ley Orgánica 8/2007 determinó el IPC (índice de precios del consumidor) como criterio de corrección de valores, si fuera aplicado al período analizado, se constata que entre 2000 y 2006 se produjo un aumento claramente superior. En términos nominales, las subvenciones a título ordinario sufrieron un aumento de 35,6\%, siendo que el IPC entre 01/01/2000 a $31 / 12 / 2006$ ha variado $24,8 \% .{ }^{129}$ La diferencia del $10,8 \%$ entre un porcentaje y otro demuestra que las subvenciones han aumentado más que el IPC en términos reales, lo que significa decir que por año el aumento era superior en un $1,54 \%$ a lo previsto. Quizás se pueda argumentar que los partidos no

\footnotetext{
${ }^{126}$ Los partidos eran: Bloque Nacionalista Galego, Chunta Aragonesista, Coalición Canaria, Centro Democrático de Catalunya, Convergencia i Unió, Esquerra Republicana de Catalunya, Eusko Alkartasuna, Iniciativa per Catalunya - Verds, Izquierda Unida, Partido Andalucista, Partido Comunista de España, Partido Nacionalista Vasco, Partido Popular, Partido Socialista Obrero Español, Unió Democrática de Catalunya y Unión del Pueblo Navarro. La variación fue con Unió Valenciana, Nafarroa Bai, Partido Aragonés y Partit dels Socialistes de Catalunya.

${ }^{127}$ Las formaciones políticas a este nivel fiscalizadas fueron: Aralar, Bloque per Asturies, Convergencia de Demócratas de Navarra, Els Verds de Mallorca, Partido Aragonés, Partido Andalucista, Partido Comunista de las Tierras Vascas, Partido de Independientes de Lanzarote, Partido Regionalista de Cantabria, Partido Riojano, Partit Socialsta de Menorca - Entesa Nacionalista, PSM-Entesa Nacionalista de Mallorca, Unió Mallorquina, Unión del Pueblo Leonés. La variación ocurrió con Els Verds del País Valencia y Ciutadans - Partido para la Ciudadanía.

${ }^{128}$ La ampliación del objeto de fiscalización se produjo por un acuerdo firmado entre el Tribunal de Cuentas y las Cortes Generales.

${ }^{129}$ Fuente: Instituto Nacional de Estadística.
} 
abusaron de la "reflexibilidad" del Derecho de Partidos para aumentar dichos valores $^{130}$, pero no se puede olvidar que se está disponiendo de fondos públicos regulados por ley. ${ }^{131}$ Otra cuestión importante es que en este cálculo no se contabilizaron las subvenciones electorales y a los grupos parlamentarios. Cabe también recordar que a partir del 2003 las ayudas públicas fueron ampliadas para costear los gastos de seguridad, aunque en la Ley Orgánica no se preveían estos supuestos. De hecho, no existía regulación alguna, obligando al Tribunal a acordar algunos parámetros para posibilitar el control de la regularidad de estos recursos, al tratarse de una subvención finalista.

La última consideración general que cabe en este período es que ninguna formación política presentó las cuentas conforme a las orientaciones del Tribunal. Es decir, en los siete años analizados, todos los partidos cometieron fallos tanto en la elaboración y presentación de la rendición de cuentas, como en la documentación, o por la falta de esta. En una nueva demostración de "desatención" hacia las recomendaciones del Tribunal de Cuentas, las organizaciones políticas siguieron sin rectificar sus comportamientos, amparadas también por la total ausencia de sanciones. Se dieron casos de fallos consecutivos y significativos, como fue el caso de Eusko Alkartasuna, que incumplió el plazo para entregar la rendición de cuentas durante cinco años consecutivos, superando en mucho el plazo legal. ${ }^{132}$ Cabe destacar, por otra parte, que sus cuentas tampoco atendían a los parámetros indicados por el órgano fiscalizador, y tampoco contenían toda la documentación requerida. Ya en el ejercicio de 2006, el Tribunal resaltó que el Partido Riojano había cometido los mismos fallos que los ya indicados pormenorizadamente en el ejercicio de 2005.

\footnotetext{
${ }^{130}$ En este sentido, cfr. CASTILLO, P. del. "Financing of Spanish Political Parties". In: ALEXANDER, H. E. (ed): Comparative Political Finance in the 1980's. Cambridge University Press, UK, 1989. Pp. 185 y; HOLGADO GONZÁLEZ, M.: La Financiación de los... Pp. 156-157. ${ }^{131}$ Se podría igual argumentar que el incremento fue causado por los gastos de seguridad subvencionados a partir de 2003, pero de la evolución de los valores no se deduce esta conclusión.

${ }^{132}$ En los ejercicios de 2000 a 2004, en el mismo fallo incurren Partido Aragonés (2000), Partido Andalucista (2000), Partido Aragonés (2000), Coalición Canaria (2002 y 2004, también por mucho tiempo), Esquerra Republicana de Catalunya (2003), Izquierda Unida (con parte de sus cuentas entregadas fuera del plazo en el ejercicio de 2006) y Unión del Pueblo Leonés (en 2006, con casi 2 años de retraso).
} 
Por su parte, las cuentas de las formaciones políticas a nivel autonómico presentaban múltiples deficiencias, en muchos casos comprometiendo la realización de la fiscalización por el Tribunal. ${ }^{133}$

Junto a ello, también se constata una presencia mucho mayor de donaciones anónimas en muchas de las cuentas de los partidos de este periodo, llegando a valores considerablemente altos, principalmente por parte de los partidos nacionalistas o regionalistas, como es el caso del Partido Nacionalista Vasco, que en el ejercicio de 2000, 2003 y 2006 declaraba un alto valor bajo este concepto, alcanzando 1.072.073,37 euros en 2000. Nuevamente llama la atención la imposibilidad de control de este tipo de recursos, ya que no es posible verificar si han cumplido con los límites legales, aunque el Tribunal haya identificado algunos valores donados anónimamente e ingresados fuera de la cuenta específica para este fin, lo que viola el art. 7 de la Ley Orgánica 3/1987. En estos casos, el Tribunal acabó por indicar la sanción descrita en el art. 8, pero no se puede afirmar que dichas multas fueran efectivamente abonadas por las respectivas formaciones políticas. ${ }^{134}$

Hubo también aspectos que se consolidaron especialmente en este período, como es el caso de la participación de las formaciones políticas en sociedades de actividad mercantil e incluso en el mercado especulativo. El Centro Democrático de Catalunya declaró su participación en la sociedad Manresana S/A, desde 2001 hasta 2006. El Partido Socialista Obrero Español también declaró participación en la sociedad, "El Socialista S/A" en los ejercicios de 2000 y 2001, seguido del Eusko Alkartasuna en la empresa "Fundación Elkartu S/A" desde 2000 y con propiedad en acciones. Sin embargo, el caso más relevante es nuevamente el del Partido Nacionalista Vasco, que durante el período analizado fue quien más diversificó sus actividades mercantiles. En el 2000 declaró participación en las sociedades "Garapen S/A", "Campbell S/A", y "Fibro Cementos Aurrera S/A", además de poseer inversiones de carácter especulativo. Excluyendo la primera, la participación en las demás sociedades continuó hasta el 2006, y el partido

\footnotetext{
${ }^{133}$ Como fue el caso de la Unión del Pueblo Leonés en el ejercicio de 2004.

${ }^{134}$ Se puede citar el caso del Partido Andalucista (ejercicios de 2000 y 2005-2006 en el nivel autonómico), Unió Democrática de Catalunya (ejercicio de 2006, con multa de 271.797,58 euros), Partido Nacionalista Vasco (ejercicio de 2001), Partido de Independientes de Lanzarote (ejercicio de 2006) y Partido Comunista de España (ejercicio de 2005 y 2006, con multa de $18.000,00$ euros).
} 
amplió el listado de empresas, incluyendo otras seis ${ }^{135}$ en el ejercicio de 2006, y también pasó a invertir en fondos de inversión, como warrants, en 2005 y 2006. Los fondos de inversión también constaba en las cuentas de otras organizaciones políticas, como Iniciativa per Catalunya - Verds (2005), Izquierda Unida (2005) y Partit dels Socialistes de Catalunya (2006).

Las subvenciones a nivel autonómico también reforzaron la economía de los partidos, principalmente de los nacionalistas. El caso vasco y catalán merecen destacarse, por su "generosidad". ${ }^{136}$ En el caso del País Vasco, hubo traspaso de recursos hacia el Partido Popular en 2004 a 2006, a Eusko Alkartasuna en 2000, Partido Socialista Obrero Español en 2000 y 2006 e Izquierda Unida y Partido Comunista de las Tierras Vascas en 2005. Ya el caso catalán sorprende por ser atípico y no tener base legal, indicando que en los ejercicios de 2003 y 2004 la Generalitat ha otorgado subvenciones a Iniciativa per Catalunya - Verds, Esquerra Republicana de Catalunya, Convergencia i Unió y Partido Popular con un valor mayor de las aprobadas para dicho fin, y sin una justificación clara. De hecho, no parece existir fundamento para esta aportación de la Generalitat en la vigente legislación autonómica.

Las condonaciones de deudas también fueron frecuentes y constantes en los años analizados. Así, el caso del Partido Socialista Obrero Español en los años 2004 a 2006, de Izquierda Unida, que realizó operaciones de esta naturaleza en 2001 y 2003, de Eusko Alkartasuna en 2000 y de Esquerra Republicana y el Partit dels Socialistes de Catalunya en 2004. Como ya se ha indicado anteriormente, parecía claro que la periodicidad de estas renegociaciones aumentaba, y más considerando la ausencia de regulación legal. De igual forma que los préstamos se realizan sin parámetros normativos, las condonaciones de deudas pueden ser la señal de transferencia de valores de origen irregular, ya que no tienen control alguno, además de traducirse en la práctica en un tipo de donaciones ajenas a la ley.

Otro evento bastante identificado en las cuentas pero carente de normación es la vinculación de diversos partidos con fundaciones, existiendo

\footnotetext{
${ }^{135}$ Las empresas son: Batzokia S/L, Lurukas S/L, Iguzkia S/L, Larrabide S/L, Arabako Batzokick y Cia y Landaburu Etxea S/L.

${ }^{336}$ También merece mención la aportación de recursos por parte de la Junta de Andalucía al Partido Popular, en el ejercicio de 2004 y para el Partido Andalucista a nivel autonómico, en 2005 y 2006.
} 
también transferencia de recursos entre los mismos. El hecho se constata en las cuentas de Esquerra Republicana de Catalunya de 2001, Izquierda Unida en 2002, Unió Democrática de Catalunya en 2004, Iniciativa per Catalunya Verds en 2005 y 2006, y Chunta Aragonesista, Partido Comunista de España y Aralar en 2006. Aunque existan ya en la Ley Orgánica 8/2007 disposiciones sobre el tema, existe la posibilidad de que las nuevas reglas, junto a no solucionar todas las posibles cuestiones, incrementen su "conflictividad", dado el alto valor del límite de donaciones que pueden recibir las fundaciones y asociaciones, la ausencia de una regulación más detallada, y que ya presenta evidentes lagunas, que incluso pueden permitir que dichos entes asuman costes de los partidos sin que estos sean contabilizados en los límites contenidos en la ley. $\mathrm{Y}$ todo ello, dada la ausencia de previsión legal, sin ninguna sanción. ${ }^{137}$

Finalmente, la violación más común cometida por las formaciones políticas se refiere a las donaciones privadas realizadas por personas jurídicas, que no vienen acompañadas del acuerdo firmado por el órgano social competente, obligación constante en el art. 5.2 de la Ley Orgánica 3/1987. ${ }^{138}$ Llama la atención lo frecuente de este fallo, pues en los siete ejercicios analizados, hubo siete supuestos exactos, involucrando muchas veces al mismo partido en ejercicios consecutivos, como es el caso del Centro Democrático de Catalunya en 2002 a 2004. Claro está que el partido ignoró sencillamente las conclusiones del Tribunal de Cuentas. El Partido Popular incumplió este aspecto de la ley en 2003 y 2004, y Coalición Canaria en 2000 y Ciutadans - Partido para la Ciudadanía en 2006. Lamentablemente, el Tribunal no pudo aplicar o sugerir cualquier sanción a estos partidos, por falta de previsión en la Ley Orgánica 3/1987, mucho menos a las empresas donantes, que tampoco cumplieron con el deber de colaboración previsto en el art. 12.2. La situación tiende a perpetuarse, dado que la Ley Orgánica 8/2007 no reforzó

\footnotetext{
${ }^{137}$ Las nuevas disposiciones están contenidas en la disposición adicional séptima de la Ley Orgánica 8/07 a ser aplicada en el ejercicio de 2007.

${ }^{138}$ Como subrayó Murillo de la Cueva, se trata de la única norma cuya violación es sancionada, quedando las demás sin cualquier providencia de penalización. (In: MURILLO DE LA CUEVA, P. L. "La Financiación de los Partidos Políticos: Materiales para un Debate". In: AA.VV.: Anuario de Derecho Constitucional y Parlamentario. ํㅜ 5. Asamblea Regional de Murcia - Universidad de Murcia, Murcia, 1993. Pp. 128). Cabe subrayar que, conforme a lo ya expuesto en el punto 3.2.2.3, la Ley Orgánica 8/2007 tampoco ha fijado de manera extensiva un catálogo de sanciones, aunque pudiera solucionar algunos de los problemas aquí apuntados.
} 
la obligatoriedad del cumplimiento del deber de colaboración, como tampoco incluyó en su listado de posibles sanciones esta hipótesis, ni muchas otras. ${ }^{139}$

\section{c) El informe de 2007}

El informe de 2007 refleja el inicio de la aplicación de los cambios producidos en la fiscalización a partir de la aprobación de la Ley Orgánica 8/2007. Como es sabido, dicha ley no solamente amplió el ámbito de la fiscalización, sino también ha introducido una regulación más exhaustiva sobre los procedimientos según los cuales el Tribunal de Cuentas debe desarrollar su labor.

Como en cualquier período de transición entre diversas normativas, existieron dificultades en el momento de aplicar la nueva legislación, que culminaron con un retraso de más de cuatro años entre el período fiscalizado y la aprobación del correspondiente informe, que todavía carece de la aprobación de las Cortes Generales. ${ }^{140}$ De igual forma que ocurrió con la aplicación de la Ley Orgánica 3/1987, el Tribunal de Cuentas decidió que el alcance de las nuevas reglas solo afectaría a las operaciones realizadas después de su entrada en vigor en el 5 de julio de 2007. Las operaciones anteriores seguirían siendo revisadas a la luz de las prescripciones de la ley anterior. Por otra parte, no solo los partidos con representación en el Congreso de los Diputados y en las Asambleas Autonómicas fueron sometidos a la verificación de cuentas, sino también las fundaciones y asociaciones vinculadas a ellos, como determinaba la disposición adicional séptima. En total, fueron fiscalizados 17 partidos con representación en el Congreso de los Diputados ${ }^{141} ; 15$ con representación en

\footnotetext{
${ }^{139}$ Sin embargo, el Tribunal no deja de mencionar en dicho informe que sería necesario que se normativizara mejor la subvención para gastos de seguridad, a fin de facilitar su fiscalización, delimitando sus extremos, la naturaleza de dichos gastos y el periodo de devengo y justificación del cumplimiento de esta finalidad. (Cfr. Pp. 82629, del BOE № 235, de 28 de septiembre de 2010).

${ }_{140}$ El informe fue aprobado por el Pleno del Tribunal de Cuentas el 12 de marzo de 2012.

141 Los partidos fiscalizados fueron: Bloque Nacionalista Gallego; Chunta Aragonesista; Coalición Canaria; Convergéncia Democrática de Catalunya; Convergéncia i Unió; Esquerra Republicana de Catalunya; Eusko Alkartasuna; Iniciativa per Catalunya - Verds; Izquierda Unida; Nafarroa Bai; Partido Comunista de España; Partido Nacionalista Vasco; Partido Popular; Partido Socialista Obrero Español; Partit dels Socialistes de Catalunya; Unió Democrática de Catalunya; y Unión del Pueblo Navarro.
} 
las Asambleas Autonómicas ${ }^{142}$; y 26 fundaciones vinculadas a los partidos, que analizaremos por separado.

De manera general, existen un grupo de partidos que siguen incurriendo en los errores ya identificados en otros informes. Muchos de los partidos entregaron la rendición de cuentas en el plazo legal, aunque Izquierda Unida haya entregado solamente parte de su dossier, haciendo que el análisis de sus cuentas resultaba parcial, y que la parte omitida deba ser incluida en el informe de 2008. El Bloc Nacionalista Valenciá no ha presentado ni las cuentas anuales, ni la documentación contable, aunque haya sido requerida a hacerlo en más de una ocasión. A su vez, la Unión del Pueblo Leonés entregó sus cuentas anuales con un retraso de veinte y ocho meses, y cuando lo ha hecho, entregó cuentas bastante deficientes, sin la memoria descriptiva (art. 14.5) o la documentación que amparara el contenido de sus cuentas. Los demás partidos han entregado las cuentas dentro del plazo.

Sin embargo, la falta de memoria y documentos necesarios para la verificación de cuentas ha afectado otros partidos. Con relación a los estados consolidados, Coalición Canaria e Izquierda Unida no han cumplido con la norma; y con relación a los documentos que integran las cuentas anuales, Bloque por Asturies entregó solamente una relación de partidas de ingresos y gastos, sin balance o memoria. Convergencia de Demócratas de Navarra, Partido Comunista de España y Unió Mallorquina tampoco han entregado documentación alguna. Junto a esto, Iniciativa per Catalunya - Verds, Convergencia i Unió, Nafarroa Bai, Unión del Pueblo Navarro y Partido Regionalista de Cantabria no han rendido cuentas de toda su organización, principalmente la local, lo que impide verificar datos sobre la cuota de afiliados en municipios con un número significativo de habitantes y la adquisición de inmuebles para sedes y su financiación, elementos que en el ámbito local adquieren una importancia considerable.

Con carácter general, la memoria que consta en el art. 14.5 de la Ley Orgánica 8/2007, aunque entregada por la mayoría de las organizaciones

\footnotetext{
142 Los partidos fiscalizados fueron: Aralar; Bloc Nacionalista Valenciá; Bloque por Asturies; Ciutadans - Partido de la Ciudadanía; Convergencia de Demócratas de Navarra; Els Verds de Mallorca; Partido Andalucista; Partido Aragonés; Partido de Independientes de Lanzarote; Partido Regionalista de Cantabria; Partido Riojano; Partit Socialista de Menorca - Entesa Nacionalista; PSM - Entesa Nacionalista de Mallorca; Unió Mallorquina; y Unión del Pueblo Leonés.
} 
partidistas, sufre de múltiples deficiencias, bien porque simplemente no contempla las informaciones requeridas por la ley, o bien porque los datos constantes están incompletos, llegando a extremos como la ausencia de datos sobre subvenciones, donaciones privadas y deudas con entidades de crédito, como ocurrió en los casos de Coalición Canaria, Unió Democrática de Catalunya, Ciutadans- Partido de la Ciudadanía y Partido Andalucista.

Otra obligación incumplida por todos los partidos fue la prevista en el art. 15 de la Ley Orgánica 8/2007, que determina la revisión del sistema de control interno existente en la organización. Como ningún partido ha rendido dichas informaciones al Tribunal de Cuentas, no es posible ni siquiera evaluar el grado de cumplimiento y adecuación del sistema de control interno implantado. Aun dentro del ámbito formal de presentación de las cuentas, en el caso del Partido Andalucista y de Izquierda Unida no fue posible valorar adecuadamente sus resultados, dada la falta de documentación acreditativa de los créditos bancarios y la inexistencia de registros contables. En un sentido similar, los casos del Bloque por Asturies, Bloc Nacionalista Valenciá, Convergencia de Demócratas de Navarra, Unió Mallorquina y Unión del Pueblo Leonés, no solo reflejan la falta de cumplimiento del deber de colaboración establecido en el art. 19.1 de la ley en vigor, sino también el menoscabo de la transparencia, principal objeto de la fiscalización de los partidos políticos.

Adentrándonos en el contenido material del informe, uno de los datos verificados en diversas organizaciones partidistas fue el ingreso de recursos privados (tanto cuota de afiliados y simpatizantes, como también donaciones propiamente dichas) en una cuenta bancaria no exclusivamente destinada a dicho fin, como determina el art. 4.2, "d", especialmente en los casos del Partido Comunista de España, Unió Democrática de Catalunya, Partido de Independientes de Lanzarote o del Partido Aragonesista.

Un aspecto que llama la atención es el relativo a las donaciones anónimas. El Tribunal de Cuentas subrayó los periodos en que dichas donaciones habían sido realizadas, ya que de los 7,1 millones de euros del total de donaciones anónimas, 424.902,06 constan con fechas posteriores a la entrada en vigor de la Ley Orgánica 8/2007, lo que viola directamente el dispuesto en el art. 5 de dicha ley. Los partidos presentaron diversas razones para justificar la existencia de dichos recursos sin la completa identificación del 
donante, que van desde la alegación de aplicación del plazo de adaptación de un año dispuesto en la disposición transitoria primera de la ley (en el caso del Partido Popular y Partido Socialista Obrero Español), hasta el caso del Partido Aragonesista, que afirmó no haber identificado sus donantes porque no era su obligación hacerlo, sino de la entidad bancaria.

Sobre las donaciones de personas jurídicas, en el caso de Convergencia Democrática de Catalunya y Unió Mallorquina no consta el acuerdo del órgano social competente, violando el art. 5.2 de la Ley Orgánica 8/2007.

Otro dato también importante es el relativo a las deudas de los partidos políticos con entidades de crédito, que suma 214,6 millones de euros. En algunos casos (como en el de Unión del Pueblo Leonés) el nivel de endeudamiento puede comprometer el futuro de la organización, como subraya el Tribunal de Cuentas. Las condonaciones de deudas siguen realizándose, y algunas de dichas operaciones continúan no siendo aclaradas al Tribunal por el partido, como es el caso de la Unió Democrática de Catalunya, que realizó tres operaciones, sin que fueran facilitados los detalles al Tribunal de Cuentas de ninguna de ellas.

Aunque en la Ley Orgánica 8/2007 ya se prohíba la realización de actividades mercantiles por parte de los partidos, todavía se dan algunos casos, como el de Convergencia Democrática de Catalunya, Eusko Alkartasuna, y el Partido Nacionalista Vasco, que mantienen participaciones en diversas sociedades mercantiles, donde figuran prácticamente como socios mayoritarios. En el caso de Convergencia Democrática de Catalunya, el partido informó que procedió a la disolución de la sociedad en 2008. Ya en los casos de Eusko Alkartasuna y Partido Nacionalista Vasco, ambos alegan que no se trata de actividades mercantiles, sino de la titularidad de activos de dichas empresas, lo que, en su opinión, no violaría la ley. El Tribunal de Cuentas no está de acuerdo con dicha interpretación, y llega a la conclusión de que ambos partidos están incumpliendo el mencionado artículo y que deberán regularizar dicha situación en los próximos ejercicios. 


\section{c.1) Las fundaciones vinculadas a los partidos fiscalizadas por el} Tribunal de Cuentas

El informe de 2007 también destaca por su mayor amplitud en la fiscalización realizada. Dado el temor de la disposición adicional séptima de la Ley Orgánica 8/2007, las fundaciones y asociaciones vinculadas a los partidos también deben someterse al control de sus cuentas, aunque no en su totalidad. La ley les somete solamente a los títulos V y VI de la norma en vigor, que se refieren a su fiscalización y control y al régimen sancionador. Al no someterlas al título IV de la Ley Orgánica 8/2007, las fundaciones y asociaciones no están obligadas a rendir cuentas de igual manera que los partidos, limitándose tan solo a la fiscalización de las donaciones hechas a dichos entes organizativos. En este punto, el Tribunal de Cuentas alerta que en muchas de las cuentas presentadas por los partidos existen dotaciones fundacionales, es decir, existen concesiones de préstamos, adquisición de inmuebles por parte de las fundaciones, y posterior cesión del uso al partido, como también aportaciones realizadas por cargos públicos y prestaciones del aval por parte del partido en operaciones de deuda contraídas por las fundaciones. Además, existen entregas directas de fondos entre las organizaciones partidistas y las fundaciones $^{143}$, poniendo de manifiesto que tales finanzas acaban por mezclarse en la práctica. Por lo tanto, limitar la fiscalización y control de las cuentas de las fundaciones y asociaciones vinculadas a los partidos únicamente a la verificación de las donaciones privadas recibidas es, también, de hecho, menoscabar la eficacia de la labor del Tribunal de Cuentas, debilitando el principio de transparencia.

Los problemas para el control de las fundaciones y asociaciones vinculadas a los partidos tampoco son de sencilla solución. El Tribunal de Cuentas destaca que, como no hay regulación para determinar qué fundaciones y asociaciones deben someterse a su fiscalización, es decir, como la ley no estableció criterios de distinción e identificación del vínculo entre dichos entes y los partidos, el 28 de mayo de 2009 el propio Tribunal tuvo que

\footnotetext{
${ }^{143}$ Como ejemplo se pueden mencionarse al Bloque Nacionalista Galego, Iniciativa per Catalunya - Verds, Esquerra Republicana de Catalunya, Chunta Aragonesista e Izquierda Unida. En total, los fondos entregados suman $857.243,00$ euros.
} 
aprobar algunas directrices técnicas al respecto. Para que una fundación o asociación fuera considerada como vinculada a algún partido, debe estar constituida con una aportación mayoritaria, directa o indirecta, del partido; su patrimonio fundacional, y con carácter permanente, debe proceder en al menos, 50 por 100 de bienes y derechos cedidos o aportados por el partido; y debe controlarse su patrimonio en términos similares a los que se regula para las sociedades mercantiles, vía art. 42 del Código de Comercio. A partir de estos tres criterios, se ha determinado qué fundaciones y asociaciones deberían someterse a la fiscalización, sumando veintiséis, aunque el Tribunal no haya podido verificar con exactitud la vinculación de otras fundaciones y asociaciones con los partidos. ${ }^{144}$

Otro punto que merece destacarse es que el Tribunal de Cuentas, al identificar fundaciones y asociaciones vinculadas a los partidos, lo hizo basándose en toda la estructura organizativa de los partidos, lo que generó cierta dificultad en identificar realmente qué entes tenían conexión con las organizaciones partidistas. Ante dichas dificultades y la imposibilidad de confrontar las afirmaciones hechas por los partidos y sus deficientes registros en este sentido, quizás en dicho informe no haya sido posible englobar todas las fundaciones y asociaciones que deberían ser fiscalizadas, aunque el

\footnotetext{
${ }^{144}$ Las fundaciones y asociaciones fiscalizadas fueron: Fundación Galiza Sempre (Bloque Nacionalista Galego); Fundación Canaria 7 Islas (Coalición Canaria); Fundació Privada Catalanista i Demócrata Trias Fargas (Convergencia Democrática de Catalunya); Fundación Gaspar Torrente para la Investigación y el Desarrollo de Aragonesismo y Fundación Aragonesista Veintinueve de Junio (Chunta Aragonesista); Fundació Josep Irla (Esquerra Republicana de Catalunya); Fundación Alkartasuna Fundazioa (Eusko Alkartasuna); Fundació Privada Nous Horitzons (Iniciativa per Catalunya - Verds); Fundación por la Europa de los Ciudadanos (Izquierda Unida); Fundació L'Alternativa (Ezquerra Unida i Alternativa); Fundación de Estudios Municipales y Territoriales (Izquierda Unida de la Comunidad de Madrid); Fundación Catorce de Abril (Federación Izquierda Unida de Aragón); Fundación Zabaldiak (Nafarroako Ezker Batua); Fundación Idi Ezquerra (Ezker Bauta Berdeak); Fundación de Investigaciones Marxistas, Fundación Rey del Corral de Investigaciones Marxistas, Fundación Domingo Malagón, Fundación Horacio Fernández Iguanzo (Partido Comunista de España); Fundación para el Análisis y Estudios Sociales (Partido Popular); Fundación Progreso Global, Fundación Jaime Vera, Fundación Pablo Iglesias (Partido Socialista Obrero Español); Fundació Rafael Campalans (Partit dels Socialistes de Catalunya); Institut D'Estudis Humanistics Miquel Coll I Alentorn (Unió Democrática de Catalunya) y Fundación de Estudios Sociales de Navarra (Unión del Pueblo Navarro). En el caso de Convergencia i Unió, Nafarroa Bai y Partido Nacionalista Vasco, aunque haya sido identificadas por el Tribunal fundaciones que cumplían con los requisitos establecidos, dichos partidos comunicaron que no tenían vinculación con fundaciones o asociaciones que concurrieran con los criterios fijados. Por la imposibilidad de comprobar las alegaciones realizadas, el Tribunal ha decidido no incluir dichas fundaciones 0 asociaciones en su fiscalización, algo que en los informes futuros intentará regularizar.
} 
Tribunal ha afirmado que en un futuro regularizará la situación y emitirá informes retrospectivamente.

De igual forma que ocurrió con los partidos políticos, la fiscalización de las fundaciones y asociaciones se ha limitado temporalmente a la fecha de entrada en vigencia de la Ley Orgánica 8/2007, es decir, el 5 de julio de 2007. A partir de esta fecha, las donaciones realizadas fueron controladas, conforme a los datos enviados al Tribunal de Cuentas.

Como resultado de la fiscalización realizada, aunque Convergencia Democrática de Catalunya haya manifestado que la Fundació Privada Fórum de Barcelona tenía vínculos con el partido, posteriormente el presidente de dicha fundación afirmó que no existía dicha vinculación según los criterios fijados por el Tribunal de Cuentas, conforme fue verificado en la escritura de constitución facilitada. A su vez, la Fundació Horacio Fernández Iguanzo no ha entregado ninguna documentación, aunque haya sido requerida a hacerlo en múltiples ocasiones, lo que incumple directamente el deber de colaboración constante en el art. 19.1 de la Ley Orgánica 8/2007. Por otro lado, la Fundación Canarias 7 Islas y la Fundación Zabaldiak declararon que no habían elaborado sus cuentas anuales, y que tampoco recibieron donaciones durante el 2007, dada a su falta de actividad, lo que ha imposibilitado la verificación de los datos.

En general, el Tribunal de Cuentas subraya la existencia de donaciones no ingresadas en la cuenta específica en la mayoría de las fundaciones, lo que viola lo dispuesto en el art. 4.2 "d" de la Ley vigente. Además, existen donaciones realizadas por personas jurídicas sin el respectivo acuerdo del órgano social, incumpliendo lo dispuesto en el art. 4.2 "b", como en los casos de la Fundación Galiza Sempre, Fundación Jaime Vera, Fundación Privada Catalanista y Demócrata Tras Fargas y la Fundación Institut D'Estudis Humanistics Miquel Coll y Alentorn Fundació Privada. Dichas fundaciones afirmaron no considerar tales ingresos como donaciones, aunque el Tribunal no esté de acuerdo con dicha alegación, por reunir las características de una donación. En conjunto, las donaciones analizadas por el Tribunal en el ejercicio de 2007 ascienden a 3.205.247,00 euros. 


\section{d) Conclusiones sobre el informe de 2007}

El informe analizado ha motivado diversas recomendaciones por parte del Tribunal de Cuentas, que nuevamente vuelven a indicar las debilidades del sistema de fiscalización y control de la financiación de los partidos políticos.

Una vez más, el Tribunal menciona la omisión en la tipificación de las infracciones susceptibles de sanción, sí como de la prescripción de dichas infracciones y sanciones. La ausencia de esta reglamentación produce inseguridad jurídica en relación a la incoación de los procedimientos sancionadores previstos, así como respecto al propio desarrollo de su tramitación, que deberá aplicarse ya desde el informe de 2007. Por otra parte, no solo la tipificación es importante, sino también los plazos relacionados con la graduación de la gravedad de las infracciones, y las causas de interrupción de dicha prescripción. El Tribunal sugiere que una de dichas causas sea el inicio del procedimiento fiscalizador de las cuentas rendidas, medida que parece lógica en el sistema.

En relación con los recursos previstos en el art. 18.6 de la Ley Orgánica $8 / 2007$, el Tribunal señala la necesidad de precisar tanto el tipo de recurso que procede y ante qué órgano, como cuándo se da la específica práctica probatoria. Apunta también la importancia de asegurar el cumplimiento de las sanciones a través de la disminución de las otras subvenciones debidas.

En lo que se refiere a las fundaciones y asociaciones vinculadas a los partidos, las dificultades aumentan, dada la escueta y deficiente reglamentación legislativa. Respecto a la metodología de la fiscalización, el Tribunal menciona lagunas importantes, como la falta de criterios para establecer el vinculo entre fundación y partido (lo que genera incertidumbre en el momento de determinar qué entes organizativos deben someterse a la fiscalización), y el Tribunal incluso sugiere la integración de dichas fundaciones y asociaciones en el propio registro de partido. Además, la fiscalización de dichas fundaciones y asociaciones también debería comprender el título IV de la Ley Orgánica 8/2007, a partir de una rendición de cuentas detallada, de igual forma que los partidos, y en dicha fiscalización también se debería incluir no solo a las fundaciones y asociaciones vinculadas a los partidos con representación en las Cortes Generales, sino también aquellas vinculadas a los 
partidos con representación en las Asambleas Legislativas de las Comunidades Autónomas.

Ya sobre el objeto de la fiscalización, el Tribunal nuevamente destaca la necesidad de control de toda la actividad de la fundación, y no solamente las donaciones realizadas en su favor, como también la de someterlas a las mismas limitaciones en las donaciones que los partidos, prohibiendo que reciban aportaciones de empresas privadas que tengan contrato vigente o que presten servicios a la Administración Pública, o de empresas con capital mayoritariamente público. Es de resaltar que el nuevo proyecto de ley de financiación ordinaria de partidos avanza poco en estos puntos, lo que nuevamente frustra las expectativas del Tribunal de Cuentas de mejorar el nivel de transparencia en su labor de control de las cuentas partidistas.

Otro punto mencionado en las conclusiones del Tribunal fueron las dificultades que conlleva la aplicación de sanciones a las fundaciones y asociaciones vinculadas a los partidos. Dicha dificultad tiene un origen claro en la falta de regulación de la prescripción ya mencionada para el caso de los partidos, y también en la ausencia de reglamentación de la restricción legal que supone obtener los recursos de las entidades sujetas al pago o cumplimiento de tales sanciones. Tampoco existe un desarrollo del régimen sancionador que permita adaptarlo a las fundaciones y asociaciones vinculadas a los partidos, dado que es un aspecto sometido a reserva de ley, que no puede ser regulado por el propio Tribunal, y como es sabido, sin un sistema eficaz de sanciones, la fiscalización resulta, en último término, inútil.

\subsection{Conclusiones generales sobre el análisis de los informes del Tribunal de Cuentas - ¿la constatación de un control fallido?}

Basándose en el análisis presentado, parece difícil no concluir que el Tribunal de Cuentas intenta de la mejor manera posible ejercer su tarea de fiscalización, aún a pesar de sus propias limitaciones normativas. Es evidente que dicho órgano carece de instrumentos - no solo estructurales, sino ante todo legales - para realizar correctamente esta función. Y también parece claro que no existe una significativa voluntad por parte de los partidos para cambiar este panorama, por razones obvias. Los estados contables presentados por 
dichas organizaciones no reflejan su realidad, careciendo las cuentas de la relevancia y la fiabilidad necesarias para una verdadera evaluación de su rendición de cuentas. Existe, a mi juicio, una clara necesidad de desarrollar e implantar un modelo contable específico que colabore con la tarea de homogeneizar las informaciones financieras aportadas por los partidos. Sin esto, no será posible alcanzar la transparencia requerida para que el sistema de financiación de partidos obtenga credibilidad, afectando obviamente a la legitimidad de los propios partidos en el sistema democrático. ${ }^{145}$

La legislación anterior tenía tales deficiencias que terminaban comprometiendo la necesaria "accountabilty" que la cuestión de la financiación requiere. Junto a ello, las disparidades de reglas entre la financiación electoral y ordinaria no colaboran en nada al propósito de lograr una fiscalización más amplia. En todo caso, y aunque se pueda constatar que con el tiempo los procedimientos de fiscalización han mejorado, parece claro que queda mucho por hacer.

Los informes existentes demuestran que los cambios en la legislación (considerando aquí tanto la Ley Orgánica 8/2007 como el nuevo proyecto de reforma de dicha norma, o la reforma de la LOREG de 2011) son nítidamente inferiores a las necesidades reales que el principio de transparencia implica, aun cuando significan avances que de alguna manera contribuyen a la evolución en este punto del ordenamiento español. Y prueba de ello es el retraso que ya sufren los informes que todavía tienen que ser elaborados por el Tribunal de Cuentas y aprobados por las Cortes Generales. No es solo el eventual problema del nombramiento de sus consejeros el que el Tribunal tiene que afrontar en este momento, sino que también debe adaptarse a los nuevos procedimientos legales impuestos, y manejarlos juntamente con las cuestiones anteriormente existentes, como la falta de mecanismos para hacer cumplir el deber de colaboración, por ejemplo, y la fiscalización de fundaciones y asociaciones vinculadas a los partidos, tema que se vislumbra como conflictivo.

El peligro de la judicialización en la fiscalización de los partidos también es constante. Con las nuevas reglas, el Tribunal podrá contar con un arsenal de sanciones que antes no poseía, y siempre que hay sanciones, también

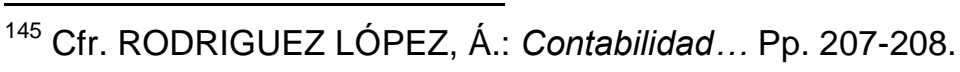


existe el peligro de aumentar la judicialización del conflicto. En este punto, las reformas también afectan indirectamente al ejercicio del propio Poder Judicial, responsable de legitimar de manera resolutiva la solución dada a una cierta inobservancia a la ley. Las nuevas normas tienen una carga que sugiere más la presencia del Poder Judicial en la resolución de problemas, y ello genera una cuestión más en la ya enredada financiación de los partidos.

Las expectativas de mejora del sistema de fiscalización existentes antes de la aprobación del informe de 2007 se vieron frustradas en cierta forma por las múltiples lagunas legales del nuevo régimen legal. No obstante, algunos cambios redundarán seguramente en beneficio de la transparencia, principalmente los relacionados con la fiscalización de la financiación ordinaria, y cabe destacarse aquí la ampliación del procedimiento de rendición de cuentas y la prohibición de donaciones anónimas. Con todo, ello contrasta significativamente con el recelo que otros aspectos de la reforma pueden suscitar, bien por la falta de una cobertura legal más detallada, en algunos aspectos, o bien por la legitimación indirecta de determinadas conductas de los partidos, como es el caso de la condonación de deudas. Ahora el riesgo se encuentra en una autorización carente de una regulación detallada.

\section{2) Las consecuencias para el sistema democrático de la aplicación del actual modelo de financiación de partidos: desafección, apatía y deslegitimación}

La existencia de una eventual crisis en el modelo actual de partidos políticos cobra vigor como hipótesis doctrinal desde hace ya bastantes años. No se trata de una crisis en la posición que dichas organizaciones ostentan en el sistema. Esta hegemonía sigue siendo incuestionable, y no solo se subraya la importancia de su papel, sino también que no alcanza a cuestionar la legitimidad del propio sistema democrático. Se trata más bien de una crisis en el ejercicio de las funciones que competen a los partidos, no siendo este un proceso, como es sabido, exclusivo de España. Esta crisis se refleja en múltiples aspectos, como, por ejemplo, la disminución de la identificación partidista; el incremento de la abstención electoral o el aumento de la participación política por medios no convencionales con la correspondiente 
caída de la tasa de afiliación de los ciudadanos. Todo ello representa quizás el mayor reto de los partidos en los tiempos contemporáneos: el de cómo actuar ante esta desafección y el descontento político de la sociedad. ${ }^{146}$

El protagonismo concedido a los partidos en nuestro ordenamiento constitucional refleja tanto el "momento constitucional" europeo, como el deseo que se tenía en la transición política de fortalecerlos ante la democracia que se instauraba. $Y$ lo cierto es que hoy parece en cambio necesaria una nueva interpretación de las funciones confiadas a los partidos, como también de su relación con el Estado.

Uno de los elementos utilizados para el fortalecimiento de dichas organizaciones fue el sistema de financiación, que constituye un "nudo" que tiene el mismo potencial en la solución de los problemas, que para su generación o agravamiento. Los moldes adoptados para el modelo español, aunque se puedan explicar, son de difícil justificación en los tiempos actuales, ante los múltiples cambios en las demandas de participación de la ciudadanía. No basta ya una presencia fuerte y estable de los partidos en todos los niveles de la organización política, se percibe hoy que el llamado "Estado de partidos" ha terminado monopolizando, y en cierta forma empobreciendo la realidad de la representación política. ${ }^{147}$ Junto a ello, el sistema de financiación no ha sido eficaz en algunas de sus finalidades últimas, dado que no ha evitado el aumento del gasto de la política, no ha incentivado la participación ciudadana en el proceso democrático; no ha evitado a los partidos posibles dificultades financieras, y mucho menos ha combatido la corrupción como se esperaba.

Las condiciones extraordinariamente favorables para una financiación estable de los partidos se perciben ya desde el Decreto Ley 20/1977, hasta la actualidad. En el caso de la LOREG, esta ha tratado directamente de concretizar un modelo de "constitucionalización" de los partidos más que un modelo de su "legalización", aportando al sistema un desequilibrio importante a través del sistema electoral elegido. Y esta misma disparidad de armas también

${ }_{146}$ En este sentido, cfr. HOPKIN, J. "The Problem with Party Finance - Theoretical Perspectives on the Funding of Party Politics". In: Party Politics. v. 10. no 6. Sage, London, 2004. Pp. 628; ALCÁNTARA SÁEZ, M. "Las Tipologías y Funciones de los Partidos Políticos". In: VV.AA.: Curso de Partidos Políticos. Ed. Akal, Madrid, 2003 (¿). Pp. 48-50 y VERGE MESTRE, T. "¿Crisis de los Partidos en España? Una Revisión Crítica”. In: Revista de Investigaciones Políticas y Sociológicas. no 1. v. 5, Madrid, 2006. Pp. 105-107.

${ }_{147}$ BLANCO VALDÉS, R. L.: Las Conexiones Políticas: Partidos, Estado, Sociedad. Alianza Editorial, Madrid, 2001. Pp. 189-208. 
fue transferida al sistema de financiación ${ }^{148}$, y si las medidas de financiación contribuían a sostener a los partidos dentro de un marco democrático, lo cierto es que el diseño no se ha "afinado" con el tiempo, para permitir resolver los problemas diagnosticados en este período. ${ }^{149}$

Es cierto que una de las medidas más corrientes a la hora de intentar una cierta reforma del sistema de partidos suele ser la de modificar los términos de la financiación pública. En todo caso, las modificaciones en estas materias no suelen conseguir fácilmente los objetivos pretendidos, insertas en una "cultura política" y enfrentadas al peculiar carácter y eficacia del "Derecho de partidos". En pocas materias como en estas, hay que ser consciente del carácter "autopoiético" del sistema jurídico. ${ }^{150}$

En la época de la transición política, las normas sobre financiación cumplieron su función al establecer un camino en la consolidación de un sistema de partidos estable. Sin embargo, el derecho tiene un límite en su pretensión de normativizar la realidad. El mundo del "deber ser" es difícil de concretizarse y de prever. Si la Constitución establece un sistema representativo y democrático, en lo cual el pueblo interviene en la formación de la voluntad popular, sea de manera directa o indirecta (con representantes elegidos), consecuentemente el principio democrático estará insertado en esta idea, siendo directamente dependiente del derecho de partidos para su realización. Esto hace que el intérprete del derecho de partidos no pueda ignorar que dichas organizaciones tienen una tendencia a utilizar la estructura estatal en su beneficio, una realidad bien estudiada no solo por la ciencia del

\footnotetext{
${ }^{148}$ RODRIGUEZ-VERGARA DÍAZ, Á. "El Estado de Partidos y Algunas Cuestiones de Derecho Electoral". In: La Evolución del Derecho en los Diez Últimos Años. Ed. Tecnos, Madrid, 1992. Pp. 420 y ss.

${ }^{149}$ BLANCO VALDÉS entiende que el factor histórico puede no tener tanta influencia en el comportamiento político porque los partidos concentran una gran parte de su militancia en grupos de personas de edad media o avanzada, y en ellas la memoria histórica debería actuar más, mientras que hay una escasa militancia de los jóvenes, sobre los cuales la historia no pesa tanto. De esta forma, el autor cree que la memoria histórica puede no ser tan explicativa para la crisis de los partidos. (In: AA. VV.: "Debates". In: Régimen Jurídico de los Partidos Políticos y Constitución. Cuadernos y Debates, ํㅡ 51, Centro de Estudios Constitucionales, Madrid, 1994. Pp. 86).

150 ALEXANDER, H. E. "Introduction". In: ALEXANDER, H. E.; SHIRATORI, R. (eds.): Comparative Political Finance Among the Democracies. Westview Press, USA, 1994. Pp. 2-3.
} 
Derecho, sino por la ciencia política, la sociología, y otras áreas que forzosamente deben ser tenidas en cuenta por el intérprete. ${ }^{151}$

Teniendo esto en mente, lo que puede constatarse es que, en relación con la financiación de partidos, el hilo de las reformas legales poco a poco ha conferido a los partidos cada vez más recursos, para cada vez menos beneficiados, prescindiendo en gran parte tanto de la opinión pública como de la crítica doctrinal al curso de la legislación, lo que a su vez ha generado un coste político en su legitimación significativamente mayor que los beneficios conseguidos con el ingreso de más recursos, en una demostración de cierta indiferencia ante el fenómeno. ${ }^{152}$

Aunque sus pilares pudieran estar justificados en la época de su construcción, el modelo actual de financiación de partidos que sigue siendo aplicado en España, con todas sus características, ya no parece que pueda seguir cumpliendo adecuadamente sus funciones constitucionales. ${ }^{153}$ Es claro que, lamentablemente, dicho sistema no fue capaz de eliminar la financiación irregular, no ha logrado disminuir las diferencias presentes entre los partidos (más bien ha provocado el efecto contrario, produciendo más desigualdades), y no ha fomentado una equitativa competición electoral. Con el tiempo, el escenario actual muestra las secuelas del sistema, no solo en el sentido de permitir una considerable cristalización del sistema de partidos o de generar barreras aún más significativas para nuevas fuerzas políticas ${ }^{154}$, sino también en cuanto no ha servido para fomentar en último término la participación

151 GONZÁLEZ ENCINAR, J. J. "Democracia de Partidos "versus" Estado de Partidos". In: GONZÁLEZ ENCINAR, J. J. (coord.): Derecho de Partidos. Espasa-Calpe, Madrid, 1992. Pp. 34-39.

152 SCARROW, Susan E. "Explaining Political Finance Reforms: Competition and Context". In: Party Politics. v. 10. oㅡ 6. Sage, London, 2004. Pp. 656-657. Aunque lógicamente no es una regla, porque todo depende de cómo está la situación actual de los partidos para intentar prever su postura ante la cuestión.

${ }_{153}$ GIL CASTELLANO, J. "La Financiación de los Partidos Políticos: El Estado de la Cuestión". In: Cuadernos Constitucionales de la Cátedra Fadrique Furió Ceriol, № 36/37, Valencia, 2001. Pp. 256.

${ }^{154}$ Ya que, como bien ha dicho BASTIDA, una democracia sin pluralismo no puede ser considerada como una democracia, y no hay cómo haber pluralismo en un sistema cerrado. (In: BASTIDA, F. J. "La Soberanía Borrosa: La Democracia". In: www.uniovi.es/constitucional/fundamentos/primero/bastida.pdf. <<Acceso en 30.10.2009 > Pp. 27-29). 
política. $^{155}$ Junto a esto, no se puede ignorar el impacto de la actual crisis económica sobre el modelo vigente de financiación. ${ }^{156}$

Los recursos públicos que son conferidos a los partidos les posibilitan tener una base sólida que les permite no sólo subsistir como organización, sino también mantener los espacios de poder que les fueron gradualmente concedidos. Y aquí la argumentación crítica sobre un posible comportamiento de cartel parece fundamentada, aunque carezca de una comprobación empírica absoluta.

En último término, la financiación pública ha fomentado una excesiva autonomía de los partidos respecto de la propia sociedad, además de aproximarles mucho más del Estado de lo que se podría entender como adecuado. La financiación de los partidos no debería contribuir a separar a los partidos de sus bases sociales, sino al contrario. Tanto las medidas de financiación pública como la financiación privada tienen un papel básico en el entramado de la democracia, pues de esta manera el Estado garantiza las condiciones para una competición democrática justa y limpia, mientras que las organizaciones divulgan sus ideas, promueven el debate público, y presentan su agenda política a los electores, recaudando a la vez recursos para ello. La posibilidad de la inserción de nuevas fuerzas políticas, a la vez, es fundamental para la renovación del espectro político y la representación de las nuevas demandas por parte de la sociedad. En un medio social con constantes cambios la política institucional debe acompañar a este proceso. ${ }^{157}$

\footnotetext{
${ }^{155}$ Porque es innegable que hay una cierta crisis de representatividad. Cfr. BLANCO VALDÉS, R. L. "Crisis en los Partido, Partidos en la Crisis: La Democracia en los Partidos en la Frontera del Fin de Siglo". In: ASENSI SABATER, J. (coord.): Ciudadanos e Instituciones en el Constitucionalismo Actual. ed. Tirant Lo Blanch, Valencia, 1997. Pp. 117 y ss.; HERRERO R. DE MIÑON, M. "Los Partidos como Estamentos Privilegiados: Ideas para su Reforma". In: La Democracia Constitucional. Estudios en Homenaje al Prof. Francisco Rubio Llorente. ed. CEPC, Madrid, 2003. Pp. 204; TORCAL, M.; et al. "Ciudadanos y Partidos en el Sur de Europa: Los Sentimientos Antipartidistas". In: Revista Española de Investigaciones Sociológicas - REIS, no 101, ene/mar, CIS, Madrid, 2003. Pp. 26 También en este sentido, cfr. CARRERAS SERRA, F. de. "Los Partidos en Nuestra Democracia de Partidos". In: Revista Española de Derecho Constitucional, año 24, no 70, ene/abr, 2004. Pp. 110; y ARIÑO ORTIZ, G.: Op. Cit. Pp. 4. Sin embargo, cabe la observación de que dichos efectos no son producidos exclusivamente por una mala modelación del sistema de financiación de partidos, aunque se debe reconocer su significativo impacto en el origen de dichos eventos.

${ }^{156}$ Al sugerir dicha medida, el autor enfatiza que la transición del actual sistema hacia un sistema de autofinanciación sería gradual. (In: GARCÍA-MONCÓ, A. "La Financiación Electoral. Los Avales de los Partidos". Conferencia proferida en 24 de marzo de 2011 en el Seminario Internacional sobre la Reforma de la Ley Orgánica del Régimen Electoral General. Universidad Rey Juan Carlos, Madrid, 2011. Pp. 2).

${ }^{157}$ ARIÑO ORTIZ, G.: Op. Cit. Pp. 60-63.
} 
En los procesos electorales en España se está iniciando una preocupante tendencia hacia el alza en los índices de abstención. ${ }^{158}$ En la presente situación se está presenciando el comportamiento de un sistema de partidos donde estos se sienten confortablemente instalados en el sistema, y faltos de estímulos políticos para reaccionar ante comportamientos internos más propios de una verdadera "cultura de la corrupción". ${ }^{159}$

Las actividades corruptas representan solamente la señal de la existencia de un problema mucho más profundo, que es la tendencia a sustituir el ideal de un comportamiento democrático por la imposición de condiciones que contradicen totalmente el ideal antes adoptado. ${ }^{160}$

La principal razón de existir de los partidos - aunque suene utópica en la posmodernidad - todavía es atender a las demandas originadas en el medio social, y ya está comprobado que la ausencia de controles no colabora a la concreción de dicho objetivo. Lo que el momento actual requiere es la institución de controles más rígidos sobre las organizaciones políticas, permitiendo controlar no solo los recursos públicos que son destinados a los partidos, sino también que estos obedezcan a los fines destinados, una limpia competición política a partir de un sistema razonablemente abierto. ${ }^{161}$

Aun a costa de "perfilar" sus esferas de autonomía, los partidos deben de ser conscientes de la necesidad de dotarse de un marco jurídico que efectivamente implique la reducción de los recursos públicos que les son destinados, el control serio de sus cuentas, la vigilancia de sus miembros y la

\footnotetext{
158 Incluso se extrae de los estudios del CIS que, entre los $15 \%$ a $20 \%$ del total de electores que no votaron en las elecciones de 2011 , alrededor de $42 \%$ ya había decidido abstenerse antes del inicio mismo de la campaña electoral, alegando como principales razones la insuficiencia de alternativas para votar; que están hartos de la política como un todo; y que les parece que da lo mismo votar o no votar. Dicha situación requiere atención por sus relevantes

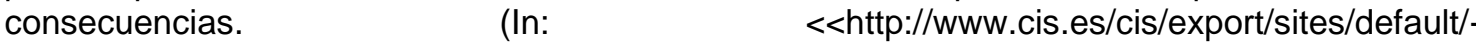
Archivos/Marginales/2920_2939/2920/Es2920.pdf>> Acceso en 11/07/2012). También, cfr. UGO RESCIGNO, G. "Democracia e Principio Maggioritario". In: Quaderni Costituzionali. Anno XIV. no 2, Agosto. Ed. II Mulino, Bologna, 1994. Pp. 224. Debiendo el pluralismo ser mayor que el valor-dinero, porque la sociedad no puede ser basada en parámetros económicos. (Cfr. ZAGREBELSKY, G.: El Derecho Dúctil - Ley, Derechos, Justicia. $7^{\circ}$ ed. ed. Trotta. 2007. Pp. 126). En el mismo sentido, cfr. SARTORI, G.; SANI, G. "Polarization, Fragmentation and Competition in Western Democracies". In: DAALDER, H.; MAIR, P.: West European Party Systems. ed. Sage, Beverly Hills, 1983. Pp. 307 y ss.

${ }^{159}$ Cfr. MALEM SEÑA, J. F.: La Corrupción. Aspectos Éticos, Económicos, Políticos y Jurídicos. Ed. Gedisa, Barcelona, 2002. Pp. 127.

${ }^{160}$ Cfr. GARZÓN VALDÉS, E. "Acerca del Concepto de Corrupción". In: J. LAPORTA, F.; ÁLVAREZ, S. (eds.): La Corrupción Política. ed. Alianza, Madrid, 1997. Pp. 59-70. También, cfr. VILLORIA MENDIETA, M.: La Corrupción Política. Ed. Síntesis, Madrid, 2006. Pp. 245-246.

${ }^{161}$ BALMELLI, T.: Op. Cit. Pp. 348.
} 
prevalencia absoluta de la transparencia, con la correspondiente sanción a aquellos que no observen estrictamente la ley. ${ }^{162}$

Junto a esto, probablemente habría que reducir las barreras de entrada en el sistema de partidos, ampliando las opciones para los electores y reforzando, a la vez, la legitimidad democrática. El poder de gobernar no se legitima solamente por los votos obtenidos, sino por haberlos conquistado a través de un proceso electoral competitivo, basado por los principios constitucionales. ${ }^{163}$

Está claro que el sistema español de partidos está consolidado y la democracia es estable, pero por ello mismo es posible actualmente abordar ciertas reformas en profundidad del sistema de financiación y de la representación partidista. ${ }^{164} \mathrm{Y}$ en este momento, son más que necesarias.

\footnotetext{
${ }^{162}$ En este sentido, GONZÁLEZ VARAS entiende que es algo un tanto perverso permitir que la financiación estatal sea instituida por los partidos que están instalados en el poder, para a través de esto poder lograr su perduración en el parlamento. (In: GONZÁLEZ-VARAS, S.: La Financiación de los... Pp. 92).

163 GARCíA VIÑUELA, E. "La Regulación del Dinero Público". In: Revista Española de Investigaciones Sociológicas - REIS, no 118, abr/jun, CIS, Madrid, 2007. Pp. 90.

${ }^{164}$ MORODO, R.; MURILLO DE LA CUEVA, P. L.: El Ordenamiento Constitucional de los Partidos Políticos. 1을 ed. UNAM - Instituto de Investigaciones Jurídicas, Derechos Fundamentales, 2001. Pp. 183.
} 


\section{CAPITULO V}

\section{EL NUEVO PROYECTO DE LEY SOBRE LA FINANCIACIÓN ORDINARIA DE PARTIDOS POLÍTICOS}

En la fase de conclusión de este trabajo, el actual Gobierno presentó un proyecto de ley para reformar la Ley Orgánica 8/2007 ante el Congreso de los Diputados. Con ello, se inició el procedimiento para su aprobación, restando actualmente su aprobación por el Senado.

El primer proyecto de ley presentado por el Gobierno en $2012^{1}$ tenía como único objetivo reducir el valor de las subvenciones destinadas a los partidos en ese mismo año. Desde la aprobación de la Ley Orgánica 08/2007, la disposición transitoria tercera establecía los valores tanto de la financiación ordinaria general como de los gastos de seguridad en 78.100,00 miles de euros y 4.010,00 miles de euros, respectivamente. El Gobierno ha estimado que entre el 2008 y el 2011 dichos valores han sido actualizados en un importe de $20 \%$, lo que considerando la actual coyuntura económica de España, motivaría la reducción de las subvenciones en la misma proporción. ${ }^{2}$ Además, el proyecto de ley también prevé que la actualización por el IPC debería constituir el límite para el aumento del valor de las subvenciones, no su mínimo, como estaba previsto en la Ley Orgánica 08/2007.

Siguiendo el trámite legislativo, fue abierto el plazo para presentación de enmiendas al proyecto por parte de los grupos parlamentarios. En total, fueron presentadas cuarenta y seis enmiendas ${ }^{3}$, que no solo versaba sobre la reducción de las cantidades destinadas a los partidos, sino más bien se encaminaban en gran parte hacia el incremento en el nivel de publicidad y transparencia de la rendición de cuentas. Lo cierto es que las enmiendas tienen perfiles muy variados, pero en general demuestran un aparente incremento de

\footnotetext{
${ }^{1}$ Publicado en el BOCG ํㅡ A-1-1, de 13/01/2012.

2 Los valores fijados en el proyecto de ley serían de $65.883 .000,58$ euros como asignación anual, y 3.382.000,75 como gastos de seguridad.

${ }^{3}$ BOCG $n^{\circ}$ A-1-9, de 17/04/2012. Las enmiendas fueron: 15 del Grupo Mixto; 15 del Grupo Unión, Progreso y Democracia (UPyD); 7 del Grupo La Izquierda Plural (IU, ICV-EUiA, CHA); 2 del Grupo Vasco (EAJ-PNV); 2 del Grupo Socialista; y 2 del Grupo Popular.
} 
la preocupación por la transparencia de la contabilidad de los partidos, algo que no estuvo tan presente durante la aprobación de la Ley Orgánica 08/2007.

De las cuarenta y seis enmiendas, fueron aceptadas veinte y cuatro, versando estas casi en exclusiva sobre el régimen de rendición de cuentas.

\section{1) Las enmiendas presentadas - La negociación previa}

Debido a la cantidad de enmiendas presentadas y por la similitud de contenido de algunas de ellas, se ha entendido conveniente exponer solamente los rasgos generales propuestos por los grupos parlamentarios, subrayando los elementos más destacados de cada una de las propuestas. ${ }^{4}$

Por otro lado, muchas de las enmiendas se centraron no solo en la reducción del montante destinado anualmente a los partidos, sino también sobre los criterios de distribución de las subvenciones, el deber de rendición de cuentas, la publicación de los datos enviados al Tribunal de Cuentas, y principalmente, sobre el régimen de financiación de las asociaciones y fundaciones vinculadas a los partidos, algo que con la vigencia de la Ley Orgánica 08/2007 se ha demostrado como una laguna muy importante de la norma.

Sobre los criterios de distribución de las subvenciones, el Grupo Unión, Progreso y Democracia y el Grupo Mixto sugirieron excluir el criterio de escaños, y considerar únicamente el número de votos obtenidos por los

\footnotetext{
${ }^{4}$ Existieron, sin embargo, enmiendas que por su singularidad merecen ser subrayadas. Las sugerencias van en el sentido de establecer que la financiación privada debería al menos cubrir el funcionamiento básico de los partidos ( $\mathrm{n}$ - 1 del Grupo Mixto); la reducción del límite para donaciones de personas físicas y jurídicas a cincuenta mil euros (no 2 del Grupo Mixto); la fiscalización por el partido de sus cargos electos, principalmente con relación a la labor económica (enmienda 9 del Grupo Mixto); la supresión total del mailing (no 14 del Grupo Unión, Progreso y Democracia); la ampliación de la obligación de presentar cuentas anuales de los partidos en los ámbitos europeo, estatal, autonómico, comarcal, provincial y local, y también de los grupos parlamentarios, los grupos políticos en el Parlamento Europeo y en las Corporaciones Locales, extendiendo dicha obligación también para las fundaciones y sociedades mercantiles donde el partido sea el socio mayoritario (no 19, del Grupo Unión, Progreso y Democracia); la previsión del delito de financiación ilegal también en la financiación ordinaria, como ocurrió con la LOREG en 2011, con la imposición de la pena de prisión de uno a cuatro años y multa de doce a veinte y cuatro meses, progresivamente a la gravedad del caso (no 26, del Grupo Unión, Progreso y Democracia); y la determinación de que el Gobierno establezca un límite máximo en las cantidades asignadas a los partidos a nivel autonómico y local ( $n \div 28$, del Grupo Unión, Progreso y Democracia). Ninguna de estas fueron aceptadas en el Congreso.
} 
partidos, sin arbitrar un umbral. Ambas enmiendas no fueron aceptadas por la mayoría parlamentaria. ${ }^{5}$

En relación a la disminución del valor de las subvenciones (principal objeto del proyecto de ley), los grupos parlamentarios estuvieron en gran parte de acuerdo en reducirlos, aunque existía el recelo por parte de los partidos de que el Gobierno, a través del grupo mayoritario, disminuyera aún más las cantidades propuestas en el proyecto. Entre las enmiendas presentadas, dos de ellos propusieron una reducción de solo un diez por ciento (enmienda 38 y 39 del Grupo Vasco), y una que divide la reducción de veinte por ciento prevista en el proyecto de ley en dos periodos, aplicándose en el 2012 una reducción del diez por ciento, y en el 2013 otra del mismo importe (enmienda 11 del Grupo Mixto). Por otro lado, la enmienda 33 del Grupo La Izquierda Plural propuso un interesante criterio para la reducción de valores, sugiriendo un sistema progresivo donde los partidos que reciben una mayor subvención tendrían una mayor reducción, calculada de manera proporcional. Solamente el Grupo Socialista ha propuesto la no aplicación de la reducción de valores (enmienda 44).

El régimen de donaciones también fue abordado en las enmiendas bajo diferentes parámetros. No solo la reducción del límite máximo permitido para las donaciones (como es el caso de la limitación en cien mil euros para donaciones de bienes inmuebles y condonaciones de deudas, sometiéndolos al régimen de donaciones privadas - enmienda 17 del Grupo Unión, Progreso y Democracia), sino que también se propuso la ampliación del listado de entes que tengan prohibido donar, como las fundaciones privadas, asociaciones y entidades que reciban subvenciones de la Administración Pública, o que tenga un presupuesto integrado total o parcialmente con aportaciones del Estado, tanto de manera directa como indirecta (enmienda 8 del Grupo Mixto). Otra interesante propuesta fue la de la enmienda 16 del grupo Unión, Progreso y Democracia, determinando que las personas jurídicas que donen a los partidos no puedan concurrir a licitaciones públicas durante los cuatro años posteriores a la donación, aplicándose la misma prohibición para empresas del mismo grupo económico. En esta misma línea, dicho grupo también ha sugerido que

\footnotetext{
${ }^{5}$ Enmiendas no 32 y 42.
} 
las donaciones superiores a cincuenta mil euros fueran objeto de notificación inmediata al Tribunal de Cuentas (enmienda 18).

Ya sobre la posibilidad de condonación de deudas, tema que también recibió una amplia atención, las propuestas se centraron en limitar a un cierto valor porcentual del presupuesto anual de los partidos el valor susceptible de negociación (como en la enmienda 6 del Grupo Mixto, que establece el cincuenta por ciento como máximo, debiendo tanto el Tribunal de Cuentas como el Banco de España tener conocimiento de los términos del acuerdo pactado entre el partido y la entidad financiera). Además, también se ha sugerido establecer la obligación de presentar un informe previo del Tribunal de Cuentas o del órgano de control de cuentas autonómico y del Banco de España (enmienda 36 del Grupo La Izquierda Plural). La sugerencia de supresión total de la posibilidad de renegociación de deudas fue incorporada en la enmienda 29 del Grupo Unión, Progreso y Democracia, sometiendo dichas negociaciones a los límites para las donaciones privadas.

Uno de los puntos más recurrentes en las enmiendas fue el régimen de donaciones a las fundaciones y asociaciones vinculadas a los partidos políticos. Algunos partidos parecen coincidir en la postura de someterlas al mismo régimen de donaciones privadas existente en la ley, como también a los mismos mecanismos de control y fiscalización por parte del Tribunal de Cuentas (enmienda 5 del Grupo Mixto y 34 del Grupo La Izquierda Plural). Una postura distinta provenía por parte del Grupo Popular, que pretendía la reducción de las subvenciones para dichas fundaciones y asociaciones en el mismo importe que el aplicado para los partidos, es decir, reducir en veinte por ciento el montante. Además, se excluye de la limitación impuesta a las donaciones privadas las aportaciones concedidas a un proyecto específico o de interés común que se relacione con el objeto fijado en el estatuto. Sus cuentas también deberán ser auditadas anualmente, siendo publicadas dichas informaciones a través del sitio web de la organización. Junto a esto, se propuso establecer la obligación de informar anualmente al Ministerio de la Hacienda y a la Administración Pública de las donaciones y aportaciones recibidas (enmiendas 45 y 46 ). 
Por otro lado, el régimen de fiscalización de los partidos también fue una preocupación constante en las enmiendas presentadas. La enmienda $31 \mathrm{del}$ Grupo Unión, Progreso y Democracia concedía al Tribunal de Cuentas la prerrogativa de acceder a las informaciones del Banco de España en el momento del análisis de cuentas, y que constaban en la central de información de riesgos, principalmente créditos y préstamos. Además, las cuentas deberían contener todas las informaciones, tales como valores y bienes inmuebles, descripción de las condiciones contractuales para créditos y préstamos o de las condonaciones de deudas habidas (enmienda 20 del mismo grupo). Existe también la obligación de una auditoria previa de las cuentas anuales de los partidos que reciban subvenciones, siendo los auditores nombrados por los partidos. Posteriormente, con las cuentas consolidadas y auditadas, se establecería la obligación de publicarlas en el sitio web del partido y del Tribunal de Cuentas (enmiendas 22 y 23 del mismo grupo).

Ya en relación a la labor fiscalizadora del Tribunal de Cuentas y el régimen sancionador, la enmienda 35 del Grupo La Izquierda Plural sugiere que dicho Tribunal tenga la potestad de aplicar sanciones directamente, consistentes en multas por el doble del valor de la aportación ilegalmente recibida; la suspensión de las subvenciones en caso de no entrega de la rendición de cuentas o de que sus deficiencias impidan su verificación; y la deducción directamente de la subvención del valor excedente en caso de violación del límite de gastos electorales. Las enmiendas 3 y 4 del Grupo Mixto solamente intentaban que el Tribunal pueda proponer la imposición de multa de dos a cinco veces del valor recibido ilegalmente, deducidos directamente de la subvención destinada al partido, permitiendo que, tras identificar la existencia de una aportación ilegal, el Tribunal de Cuentas de cuentas a la fiscalía para depurar responsabilidades penales tanto del donante como del donatario.

Todo ello denota un cierto cambio de actitud por parte de los partidos en lo que se refiere a su financiación ordinaria, y, de hecho, algunas de las enmiendas mencionadas pasarían a integrar el texto definitivo que saldrá del Congreso. 


\section{2) El proyecto de ley tras su aprobación por el Congreso de los Diputados}

El proyecto de ley fue sometido al Pleno del Congreso de los Diputados en julio de 2012, incorporando algunas innovaciones que, de mantenerse al final del procedimiento legislativo, seguramente contribuirán en parte a la mejora del sistema de financiación ordinaria de los partidos en España. ${ }^{6}$

Aunque con avances significativos, la Ley Orgánica 8/2007 siguió en gran medida la línea establecida en la Ley Orgánica 3/1987, no dando respuesta a muchas de las demandas ya señaladas en esta época por la literatura jurídica sobre el tema, en el actual momento de crisis económica, los partidos también deben hacer un esfuerzo para ayudar a reducir las cuentas públicas. La reducción en el veinte por ciento del montante destinado anualmente al mantenimiento de los partidos y a sus gastos de seguridad, así como la reducción de las cantidades destinadas a las fundaciones y asociaciones vinculadas a las organizaciones partidistas en veinte por ciento, será sin duda bien recibida por la opinión pública.

En todo caso, debe valorarse el hecho de que los partidos hayan aprovechado dicha oportunidad de reforma para introducir cambios o mecanismos de mejora del actual sistema. En el nuevo proyecto de ley, se acepta la ampliación del número de sujetos que no pueden realizar donaciones, como aquellos entes que reciban aportaciones directa o indirectamente de la Administración Pública, y también aquellas empresas que pertenezcan al mismo grupo económico o a sus fundaciones. Dicha limitación también alcanza a las fundaciones y asociaciones privadas que reciban subvenciones públicas 0 que tengan total o parcialmente su presupuesto integrado por recursos públicos, constituyendo en un importante paso en la mejora de las necesidades de transparencia y control. Junto a ello, también se incorpora la obligación de que todas las donaciones superiores a cincuenta mil euros 0 en bienes inmuebles sean objeto de notificación al Tribunal de Cuentas, en el plazo de tres meses. En este punto, cabe lamentar quizás la no inclusión en el límite de cien mil euros de donaciones también para los bienes inmuebles, como se había propuesto en alguna enmienda.

\footnotetext{
${ }^{6}$ Cfr. BOCG, Senado, serie I, no 81-634, de 06/07/2012.
} 
En el nuevo proyecto de ley también está previsto un nuevo artículo 4 sobre la condonación de deudas. Ninguna entidad de crédito podrá condonar a un partido político más de cien mil euros al año de deuda, cantidad que se calcula a partir del montante principal y de los intereses pactados en dicho acuerdo. Por otro lado, respetando la autonomía de la voluntad que rige el derecho de contratos, se mantiene la posibilidad de que los partidos puedan llegar a acuerdos en relación con las condiciones de la deuda que pudieran mantener con entidades de crédito de conformidad con el ordenamiento jurídico, y siempre que se ponga en conocimiento del Tribunal de Cuentas y del Banco de España. Sin embargo, pensamos que sería bastante más adecuado no permitir tanta discrecionalidad para la negociación de dichas deudas, porque dada la prevalencia de la autonomía de la voluntad, el Tribunal de Cuentas tampoco podrá interferir en las condiciones del negocio, y si este tiene el límite de cien mil euros, dentro de dicho margen, nada impide que las condiciones establecidas entre las partes no sean perjudiciales respecto al equilibrio del sistema de financiación. Junto a ello, tampoco está claro si el límite lo es respecto a cada una de las deudas contraídas por el partido con entidades financieras, o si se consideran a estos efectos todas las deudas existentes. Si son todas las deudas, el límite es bastante adecuado, lo que no ocurre si el límite es aplicado a cada una de los débitos existentes, ya que es sabido que los partidos contraen deudas con diversas entidades financieras a la vez.

En lo que se refiere al régimen sancionador, el nuevo proyecto de ley confiere al Tribunal de Cuentas la potestad para acordar la imposición de sanciones por infracciones muy graves identificadas en la rendición de cuentas, tanto por el incumplimiento de las obligaciones previstas en la ley de financiación ordinaria, como en la LOREG en lo que respecta a los gastos electorales. El artículo 17 de la actual Ley Orgánica 08/2007 es ampliado para englobar las infracciones de aceptación de donaciones que violen los límites y requisitos legales, para el caso de no presentación de la rendición de cuentas, y también para el incumplimiento del límite de gastos electorales, siguiendo una línea constante en las reformas de la LOREG. Las sanciones previstas en estos supuestos van desde la imposición de multas por el doble del valor 
recibido irregularmente o excedido (en lo que respecta los gastos electorales), a la suspensión en la entrega de las subvenciones.

En este punto el nuevo proyecto de ley también contempla un plazo de prescripción de dichas infracciones de cuatro años, a partir del momento de la comisión de la infracción. Aunque sin negar el papel de la prescripción en el ordenamiento jurídico, en la financiación de partidos probablemente presente características especiales, y aun más si se realiza el cómputo desde el momento de la comisión de la infracción. Es sabido que el Tribunal de Cuentas lleva un retraso importante en el análisis de las cuentas de los partidos, y este plazo prescriptivo podría neutralizar la potestad punitiva de dicho Tribunal concedida por la ley. No parece adecuado pues que se prevea sanciones para "de facto" volver extremadamente difícil su aplicación.

El procedimiento sancionador administrativo se mantiene en sus líneas generales, confiriendo solamente el efecto suspensivo a los recursos interpuestos frente a la resolución emitida por el Tribunal de Cuentas determinando la imposición de cualquier de las sanciones anteriormente previstas. Se trata, en parte, nuevamente de "neutralizar" la potestad punitiva del Tribunal de Cuentas.

Respecto a la fiscalización de cuentas por parte del Tribunal de Cuentas, las fundaciones y asociaciones vinculadas a los partidos también deberán estar sometidas al mismo régimen aplicado a los partidos, no solo respecto a las donaciones recibidas, sino también respecto a cualquier aportación, ampliando así el ámbito fiscalizable de su actuación.

Ya directamente en el campo de las fundaciones y asociaciones vinculadas a los partidos con representación parlamentaria, se producen significativas modificaciones. Las donaciones realizadas a dichos entes deben someterse al régimen de donaciones privadas aplicado a los partidos, aunque existan excepciones importantes. Desgraciadamente las fundaciones y asociaciones vinculadas a los partidos no están sometidas al límite de cien mil euros establecido para los partidos, y tampoco a la prohibición de recibir donaciones de empresas privadas que tienen contratos vigentes con la Administración Pública, que presten servicios o que realicen obras para el Estado, organismos públicos o empresas de capital mayoritariamente público, 
como también las empresas pertenecientes al mismo grupo que aquellas y sus fundaciones. Dichas excepciones abren vías de agua en la efectividad de esta sumisión de las fundaciones y asociaciones vinculadas a los partidos al régimen de donaciones privadas, porque quedan excluidos de su régimen justamente dos elementos clave del sistema de limitación y prohibición de donaciones. Lamentablemente pues nos encontramos aquí ante un avance muy débil frente a un importante problema de la financiación ordinaria de los partidos.

Por otro lado, algunas de las otras excepciones previstas en el nuevo artículo 18 parecen poner en evidencia la tímida intención de los partidos de regular la materia, como la disposición de que no serán consideradas donaciones las cantidades aportadas tanto por personas físicas como jurídicas a dichos entes para una actividad o proyecto en concreto, que se realice como consecuencia de un interés común derivado de las actividades propias del objeto societario o estatutario de ambas entidades. El aspecto más positivo, a nuestro juicio, del nuevo artículo 18 son las disposiciones que amplían los mecanismos de fiscalización de dichas entidades. Está prevista la obligación de aprobar sus cuentas y de realizar una auditoría, y una vez emitido el informe del Tribunal de Cuentas, dichas cuentas deberán hacerse públicas, preferentemente a través de su sitio web para un más fácil acceso. Además, dichas entidades estarán obligadas a informar anualmente al Ministerio de Hacienda y Administraciones Públicas de todas las donaciones y aportaciones recibidas, así como también todas las donaciones procedentes de personas jurídicas deberán ser objeto de notificación al Tribunal de Cuentas en el plazo de tres meses. Junto a esto, las donaciones superiores a ciento veinte mil euros deberán verse precedidas de la aprobación del órgano o representante competente a través de documento público.

Finalmente, las medidas contenidas en el nuevo proyecto de ley que hacen referencia al principio de publicidad y transparencia también vienen parecen oportunas. Se trata de medidas de publicidad activa que obliga a los partidos políticos, no solamente a notificar al Tribunal de Cuentas las donaciones superiores a cincuenta mil euros, y en todo caso, en bienes inmuebles, o las condonaciones de deudas negociadas, sino que también 
obligan a los partidos a la publicación de sus balances y sus cuentas, preferentemente a través de su sitio web, una vez que el Tribunal de Cuentas haya emitido el informe referente a la fiscalización de un determinado ejercicio. La norma establece también que deberán constar en las informaciones los créditos, las entidades financieras que han contratado con el partido, y también las condiciones fijadas entre las partes en caso de condonación de deudas. Además, el texto subraya que dichas informaciones deben ser de fácil acceso y gratuitas a los ciudadanos.

En el momento de cierre de este trabajo de investigación, el proyecto de ley ya había sido aprobado por el Senado, sin alteraciones en el texto enviado por el Congreso de los Diputados, siendo ahora la Ley Orgánica 5/2012, de 22 de octubre. 


\section{CONCLUSIONES}

A lo largo de este trabajo, se ha intentado subrayar que la regulación de la financiación de los partidos políticos es comúnmente abordada en los ordenamientos a partir de soluciones normativas casuísticas, que impiden dar a la sociedad respuestas eficaces para los problemas identificados. Analizamos, pues, un espacio jurídico en donde los agentes políticos, directamente afectados, priman en general por sus intereses partidistas, por encima de una cierta racionalidad jurídica, lo que inevitablemente se plasma en las sucesivas reformas aprobadas.

Iniciamos nuestra exposición con un análisis general del derecho de partidos en España desde la constitucionalización de los mismos en el ordenamiento español. La forma en que se produjo dicha constitucionalización ha influido lógicamente en el entendimiento de su naturaleza jurídica, y ha tenido reflejos en la regulación de sus funciones e, indirectamente, de su financiación.

Ante esto, se han abordado algunos de los posibles problemas que las disposiciones contenidas en el art. 6ำ de la Constitución Española ha encontrado en la democracia actual, comenzando por la idea del pluralismo político y su expresión a través de dichos partidos. No consagrándose un monopolio por parte de los partidos de dicha función, se constató una cierta obstaculización a la "apertura representativa" a partir de mecanismos como el sistema electoral combinado con la financiación de estas organizaciones.

Constatada esta dificultad de "acceso al sistema", se cuestionó si este hecho no influiría en la correspondiente función de los partidos de ser el principal canal de manifestación de las demandas populares. Partiendo de las inevitables insuficiencias representativas de las Cámaras en una sociedad moderna y compleja, el análisis se centró en una eventual distorsión de la función de representación por parte de los partidos, a partir de un determinado entendimiento de la idea del Estado de partidos. Es probable que en los sistemas europeos actuales (y también como resultado de la aplicación de dicho modelo por largo tiempo), los partidos estén ocupando un espacio mayor que el democráticamente recomendable dentro del Estado, lo que a la vez abre 
espacio a una cierta "partitocracia", que provoca efectos antagónicos en los ciudadanos en relación a los partidos, como la idea de que dichas organizaciones no representan a la sociedad y que tampoco buscan solucionar 0 atender a las demandas de los ciudadanos, a pesar de estar subvencionados con recursos públicos para el cumplimiento de dichas funciones. Por lo tanto, se observa una cierta crisis de representatividad.

Ambas conclusiones condujeron al análisis de la última función atribuida a los partidos, que se relaciona con la participación política (íntimamente conectada con el pluralismo político). Se trata de un elemento armonizador del sistema democrático que se encuentra muy determinado por el sistema electoral. Así, se cuestionó si el actual sistema electoral permite que se cumpla correctamente dicha función por las organizaciones partidistas. En la esfera del derecho de sufragio activo, se trató del principio de la igualdad de oportunidades, una de las razones por la cual se adoptó el actual modelo de financiación pública de partidos. Sin embargo, además de constatar que las reglas de financiación pública vigentes no colaboran en grado optimo al fomento de dicho principio entre los competidores electorales, el importante sesgo que imprime el sistema electoral vigente puede ser uno de los principales elementos distorsionantes de esta estructura. No es un hecho nuevo que el sistema electoral no atiende prioritariamente a las exigencias del principio de igualdad de oportunidades, teniendo además efectos directos sobre el acceso y distribución de las subvenciones públicas a los partidos. La imagen que se transmite a la sociedad es que las elecciones se han convertido tan solo en un procedimiento de legitimación de élites en el poder, y que dichas elites no se sienten amenazadas justamente porque el ordenamiento desincentiva cualquier alteración del status quo que pueda alterar esta dinámica.

En un segundo momento, el trabajo se centra en el análisis de los modelos de financiación existentes, y en los elementos en que se ha producido una mayor polémica doctrinal. La primera controversia analizada gira en torno a ciertos elementos privados de financiación, sobre los que existe en la actualidad a un cierto cuestionamiento. Muchas de las fuentes previstas en las normas de financiación ya no son aplicables a la estructura de los actuales 
partidos y deberían adecuarse a nuestro tiempo, como las publicaciones partidistas, casi inexistentes, el patrimonio propio del partido o su actividad mercantil, fuente esta que fue recientemente prohibida por no relacionarse con la verdadera función de un partido político. Junto a esto, la cuota de afiliados refleja directamente la actual debilidad de la militancia política, y afecta sobremanera a las cuentas partidistas, colaborando poco la actual legislación a fomentarla. Se suma a ello la falta de interés prioritario de los propios partidos en su incremento, tanto por cuestiones internas, como, ante todo, por la propia seguridad que les otorgan las subvenciones públicas.

Actualmente se puede considerar como fuentes importantes de recaudación, las donaciones particulares (tanto de personas físicas como jurídicas), las aportaciones de los candidatos y de los cargos electos del partido, y los préstamos y créditos, muy presentes en tiempos de campaña electoral. Las donaciones privadas en algunos países son consideradas como vitales para la realización de las campañas electorales o el mantenimiento de las organizaciones partidistas, y esto abre un amplio espacio para la dependencia de los partidos de dichos recursos privados, y también para la corrupción, tan difícil de combatir jurídicamente de manera efectiva. Dejando al margen la polémica sobre la prohibición o no de las donaciones anónimas - y en el trabajo se comparte su actual prohibición en la legislación sobre financiación de partidos por su carácter poco transparente y muy peligroso está claro que las normas vigentes penalizan mucho más de lo recomendable a las donaciones privadas. Resulta evidentemente ingenuo pensar que estas desaparecerán debido tan sólo a su prohibición legal, si el propio sistema no cuenta con un sistema de fiscalización adecuado para impedir su efectiva influencia en el proceso electoral. Se mantiene en el trabajo que no sería perjudicial para el sistema una cierta apertura de esta fuente de financiación. Con ajustes normativos acertados, es posible alcanzar buenos resultados a partir de estas donaciones privadas, al mismo tiempo que disminuiría la presión sobre los presupuestos públicos de la financiación de los partidos.

Un ejemplo de la ineficacia del actual régimen aplicado a las donaciones privadas son los préstamos y créditos (entendidos también como fuentes de financiación), que no raras veces se corresponden con donaciones privadas 
"disfrazadas". Un fenómeno que tiende a agravarse con la nueva legislación española, que ha autorizado la realización de condonaciones de deudas, sin establecer unos claros criterios jurídicos para ello. Aquí el tema se conecta con la imposibilidad de ignorar la existencia de ingresos atípicos en la contabilidad de los partidos, porque aunque no haya datos fiables sobre la real presencia de recursos económicos originados a través de lo que entendemos por corrupción, a favor de los partidos, es un hecho que existen y que su volumen no autoriza a obviarlos en cualquier análisis jurídico del sistema de financiación.

Sobre la financiación pública, los problemas giran en torno a la necesaria garantía de la igualdad de oportunidades en la competición política. Es un hecho que la financiación pública fue pensada para combatir la corrupción creciente en torno a la financiación privada, y para liberar a los partidos de la dependencia de dichos recursos. Con fundamentos muy claros, la financiación pública desempeña un importante papel en los sistemas de financiación europeos, al tratarse de una intervención estatal que no solo posibilita el cumplimiento de las funciones constitucionalmente asignadas a los partidos, sino que también garantiza unas ciertas condiciones de desarrollo del sistema a partir de la igualdad, del pluralismo y del combate a la corrupción. Las subvenciones públicas son distribuidas entre las diversas opciones políticas como forma de equilibrar su poder en la competición electoral, abriendo camino para el pluralismo. Sin embargo, en la práctica los resultados obtenidos han sido muy diversos, dadas las diferencias entre los modelos jurídicos adoptados por los diferentes países europeos. No se ha verificado un sistema que encuentre un equilibrio ideal en la igualdad de oportunidades, lo que consecuentemente afecta al pluralismo político. Además, se ha alcanzado muy imperfectamente el objetivo de combatir o disminuir la corrupción pues en muchos casos el encarecimiento de las campañas electorales provocó que los partidos recurrieran al dinero "ilegal" como manera de hacer frente a sus deudas y de realizar una campaña competitiva. Las críticas en contra de este sistema de financiación apuntan en el sentido de una excesiva dependencia del Estado de las organizaciones partidistas. Junto a ello, la financiación pública ha permitido a los partidos una cierta "condición confortable", desincentivando que estos busquen reforzar sus lazos con la sociedad, y provocando un cierto 
alejamiento respecto a esta. Existe pues un control de la entrada y salida de fuerzas políticas del sistema de partidos (traducido en una petrificación de dicho sistema), que ahora de una cierta manera forman parte del Estado y que no se sienten obligadas a establecer conexiones con sus bases sociales.

En un momento posterior del trabajo se analizaron algunos aspectos de la financiación pública que tienen impacto directo sobre el sistema democrático. Existe un importante debate doctrinal del nivel al que debe llegar la financiación estatal, ya a las organizaciones centrales, ya a las regionales de los partidos. Se teme que, de la misma manera que la democracia interna constitucionalmente requerida no ha sido objeto de la debida atención por parte del legislador, el grado de autonomía concedido a través de la financiación pública a los niveles regionales de los partidos provoque otros problemas innecesarios, fundamentando la opción española por la entrega centralizada de la subvenciones, aunque esto conlleve un aumento de la oligarquización de las estructuras partidistas. Otro punto que se debate igualmente en la financiación pública es si las subvenciones deben ser entregadas a título de reembolso de gastos electorales, o como contribución a estos. Es sabido que la entrega a posteriori de dichos recursos perjudica fuertemente a los partidos de reciente creación, con menores recursos económicos y capacidad crediticia. Sin embargo, también tiene efectos positivos sobre el control de los gastos de los partidos, aunque dicho control sea discreto o discutible actualmente.

Otro criterio que despierta debate es si la financiación debe alcanzar a los partidos o a los candidatos. Dicho debate viene muy determinado por el sistema general aplicado en cada país (principalmente en torno al eje EE.UU. Europa). No hay una decisión fija en este punto, ya que cada legislación deberá ser moldeada conforme a su realidad social. Otro elemento importante a considerar es si la financiación pública alcanzará solo a las actividades electorales de los partidos, o también a las ordinarias, esto es, a las cotidianas. Creo que dicha discusión carece de sentido actualmente, considerando que no es posible diferenciar en la práctica las actividades partidistas en estos dos ámbitos.

Por todas estas causas, los sistemas mixtos de financiación son, como es sabido, los más comunes en el ámbito europeo, diferenciándose por su 
mayor o menor tendencia hacia fuentes de financiación privadas o públicas. En vez de abordar los sistemas mixtos en abstracto, se optó en este trabajo por analizar tres modelos paradigmáticos, y así nos hemos centrado en el estudio de los ordenamientos de Estados Unidos, Alemania e Italia. La diferencia entre países con influencia anglosajona y el resto es evidente, toda vez que el modelo de Estados Unidos se inclina significativamente por la financiación privada (aunque contemple la financiación pública) y por el papel central de los candidatos, mientras en Europa el modelo es predominantemente de financiación pública centrada en los partidos.

En los Estados Unidos, la fuerza de las donaciones privadas y de los lobbies ha terminado siendo más poderosa que las iniciales regulaciones jurídicas sobre el tema. Con constantes intervenciones de la Supreme Court, lentamente las rígidas reglas de limitación de donaciones han ido siendo flexibilizadas en pro de la libertad de expresión, como reflejo directo pues de la First Amendment. Es cierto que hay una marcada preferencia en el sistema por la garantía de la transparencia en el flujo de recursos económicos frente a las medidas de prohibición, pero también es cierto que, confrontando la última reforma de la ley (Bipartisan Campaign Reform Act) con las más inmediatas decisiones de la Supreme Court sobre el tema, la libertad de expresión se configura como eje que determina cualquier posible medida del control del aumento de los costes de las campañas o de incentivación de la igualdad de oportunidades en la competición electoral. Lamentablemente la buena estructura aportada por la última reforma de la legislación, que logró combatir la fuerza de los PAC's, fue casi que totalmente desmantelada por la Supreme Court, basándose en dicha libertad de expresión. Se suma a esto el hecho de que la nueva legislación no ha fomentado la financiación pública como medio de control del gasto de los partidos o como medida para equilibrar las fuerzas políticas, lo que colabora sobremanera al aumento del empleo de dinero privado en las campañas y en su coste. En el país donde el lobbying es permitido y donde en las últimas elecciones presidenciales se ha movilizado una cuantía nunca vista de recursos económicos, el dinero tiene mucho poder en campañas conducidas a través de los medios de comunicación, aun 
resultando admirable el grado de exigencia de transparencia en dichos recursos en comparación con algunos ordenamientos europeos.

En el caso alemán, también caben destacarse las constantes intervenciones del Tribunal Constitucional en la legislación sobre el tema, pero con otro enfoque: el de preservar la apertura del sistema y la igualdad de oportunidades entre los competidores electorales. Desde la adopción de medidas de financiación pública, poco a poco el Tribunal Constitucional ha ido colaborando en la mejora de la legislación, permitiendo una apertura ejemplar del modelo en el sentido de no permitir la cristalización del sistema de partidos y de no dejarlos desamparados económicamente, preservando sus lazos con la sociedad. El actual sistema que determina el valor de subvenciones públicas debido a cada partido a partir de los valores recaudados por ellos mismos de la sociedad es, a nuestro juicio, un modelo eficiente de tutela de los derechos de los ciudadanos, atendiendo a los parámetros democráticos necesarios para la salud política del país.

Desgraciadamente no fue este el caso italiano, el cual, habiendo partido casi del mismo punto que Alemania, y debido a algunas características propias de su sistema político, ha venido determinado por la decisión popular de eliminación de la financiación pública de los partidos en sus actividades cotidianas u ordinarias, expresada a través de referéndum. La presencia de la corrupción en este ámbito en aquél país siempre fue significativa y en ella no influyó la financiación pública ya antes existente. Con la retirada de las medidas de financiación pública, los partidos italianos han sufrido las consecuencias de una crisis de legitimidad y de representación importantes, acentuada posteriormente por los diversos intentos por parte de los partidos de volver a introducir mecanismos de otorgamiento de subvenciones públicas para el sostenimiento de sus actividades ordinarias. Actualmente, Italia cuenta solamente con la financiación pública para las campañas electorales. No obstante toda la sociedad sabe que se trata únicamente de una "nomenclatura" jurídica, y que los recursos son utilizados indistintamente para todo tipo de actividades partidistas, lo que aumenta aún más la apatía y desafección política existente en aquél país. 
En Europa el sistema mixto de financiación de partidos es el más común, también es bastante usual que en dichos sistemas se produzcan desequilibrios entre las medidas de financiación privada y pública, lo que favorece determinadas dinámicas que bordean o infringen la legalidad. Ante al desequilibrio provocado por la mayor presencia de medidas de financiación privadas, o la insuficiencia de la pública, existe el problema endémico de la corrupción. En un breve análisis, se ha buscado conceptuar qué sea en este campo corrupción política, que se relaciona en el trabajo con otros términos, como el de accountability y transparencia, que pueden clarificar conceptualmente el sentido de este tipo de corrupción. Es evidente que la corrupción en torno a la financiación de los partidos es una manifestación de corrupción política porque los sujetos pueden ser tanto partidos, como entes privados; el bien dañado es el interés público; y lo determinante es tanto el producirse en el seno de los partidos, como el ser también un medio de influencia en la agenda política. Seguidamente se han analizados algunos de los incentivos que los partidos encuentran para recurrir a la práctica de la financiación ilegal, concluyendo que el fenómeno no trae causa únicamente de que vivan en una constante y cada vez más cara campaña electoral, acompañada de la insuficiencia de recursos económicos propios. El verdadero incentivo para continuar en dicha práctica es la mayor parte de las veces la clamorosa ineficacia de los mecanismos de control de las finanzas partidistas, además de carecer de herramientas para concretizar lo que dicta la accountability, y se trata claramente de un problema que no sólo afecta al sistema español.

En los sistemas con un claro desequilibrio a favor de las medidas de financiación pública, se abre espacio a la teoría de la "cartelización" de los partidos políticos, que sostiene que estos, una vez presentes en el espacio público estatal, acaban por comportarse como un cartel, como forma de mantener sus propios beneficios, y también perpetuar su posición dominante frente a la posible intervención de otras fuerzas políticas externas, generando una barrera casi imposible de traspasar para los partidos extraparlamentarios. Se trata de una tendencia verificada en las democracias occidentales y que empieza a ser considerablemente visible en el sistema español. 
En el Capítulo tercero del trabajo se ubica el análisis del sistema de financiación de partidos español, que no puede ser comprendido sin el análisis de su origen histórico, bastante particular considerando otros sistemas. Debido a su prohibición durante la dictadura, en la transición política se hizo necesario establecer un sistema de financiación mixto, privilegiando las medidas de financiación pública justamente para proveer a los partidos recién constitucionalizados del soporte económico necesario para su actuación. Además, se configuró una estructura constitucional y legislativa centrada en los mismos como garantes de la efectividad y la estabilidad de la dinámica política, como se comprueba en la regulación de las elecciones, las campañas, etc. Las particularidades y consecuencias de este sistema son en la actualidad evidentes, y merecen atención.

La primera norma que aborda la materia de los partidos políticos de manera global fue el Decreto-Ley 20/1977, que intentó regular muy brevemente los puntos vitales para el funcionamiento de dichas organizaciones. La intención de la norma era clara, limitándose a instrumentalizar los elementos básicos para la realización de las primeras elecciones democráticas después de la dictadura. Fue aquí sin embargo donde se adoptaron decisiones básicas del actual sistema electoral que, como es sabido, perdurarán en el tiempo, como la de la fórmula electoral D'Hondt para la conversión de los votos en escaños, de las circunscripciones de baja magnitud, todo ello dirigido a estabilizar el sistema democrático recién instaurado. Poco después, se aprobó la Ley Orgánica 54/1978, como norma responsable de regular los partidos recién constitucionalizados y posibilitar la participación de estos en las elecciones que estaban por venir. Al tratar de la financiación para las campañas electorales, el Decreto-Ley 20/1977 estableció uno de los rasgos más determinantes del actual modelo de financiación, que es el doble criterio de acceso a las subvenciones públicas. Los partidos sólo participarían en el reparto de las subvenciones si lograban obtener por lo menos un escaño, y para el cálculo de las cantidades solamente serían considerados los votos en aquellas circunscripciones donde hubieran obtenido escaños. La Ley Orgánica 54/1978 por su parte, reguló, en línea con el art. 60 de la nueva Constitución, otros elementos como el registro de partidos, la democracia interna, y la 
financiación pública de sus actividades ordinarias,. De la misma manera que el Decreto-Ley 20/1977, la Ley Orgánica 54/1978 también fijó el doble criterio para el acceso al reparto de las subvenciones electorales, considerando únicamente los votos obtenidos en las circunscripciones en donde se lograron escaños.

Sin embargo, aunque fueran normas de carácter provisionales, ambas estuvieron vigentes mucho más tiempo de lo previsto, lo que provocó su gradual insuficiencia para regular a largo plazo los elementos centrales del Derecho de Partidos. Por otra parte, y debido a sus múltiples lagunas, existían cuestiones carentes de solución normativa, no siendo la financiación de partidos una excepción. Solamente debido a la presión de estos problemas y al descubrimiento público de casos notorios de corrupción relacionados con la financiación de los partidos (a través del caso Flick), se inició la elaboración de una nueva legislación tanto electoral como de la financiación de los partidos (Ley Orgánica 5/1985 - LOREG - y Ley Orgánica 3/1987, respectivamente). Aunque el tratamiento de la materia se amplió manifiestamente, la sistemática para el acceso y distribución de las subvenciones públicas no fue alterada, aumentándose, eso sí, los beneficios procedentes del Estado, con más subvenciones bajo otros conceptos, y asegurando a los partidos parlamentarios una cierta "comodidad" en cuanto a su supervivencia financiera. En el análisis realizado en el trabajo, se apuntan los "nudos gordianos" existentes en la Ley Orgánica 3/1987, que han colaborado sobremanera al agravamiento del sistema de financiación ordinaria, a partir de la autorización de las donaciones anónimas; su nítida ventaja ante el régimen de la financiación electoral; el no cómputo de los escaños del Senado para el cálculo de las subvenciones, y otros tantos elementos que contribuyeron a que el sistema se volviera aún más problemático. En esta época ya era posible observar que la combinación entre el sistema electoral y el sistema de financiación pública de los partidos ocasionaba distorsiones significativas en la dinámica política, contribuyendo a la inmovilidad del sistema de partidos. Por otra parte, el protagonismo de dichas fuerzas ha aumentado considerablemente si se analizan las reformas legales producidas con posterioridad y que tienen a estos partidos como los grandes beneficiarios de sus propias medidas. 
Algunas décadas después, con el agravamiento de problemas antes diagnosticados, se produjo una cierta presión de la opinión pública para que el tema de la financiación de partidos volviera a la agenda política, lo que culminó con la aprobación de la actual ley de financiación ordinaria de partidos (Ley Orgánica 8/2007), y la reforma recién aprobada de la LOREG. Es importante reconocer que existió una cierta evolución en algunos temas antes problemáticos (como es el caso del control de la contabilidad partidista), pero lamentablemente no se puede afirmar que haya mejorado sustancialmente la normativa en su conjunto, porque más allá de que aun no ha tenido una importante aplicación en la práctica, también es cierto que, basándose solo en la letra de la ley, no se verifican cambios importantes en pro de la apertura del sistema de partidos. Lo que se verifica es la pervivencia, e incluso la aplicación, de ciertas lagunas jurídicas que dificultan el carácter transparente del sistema de financiación, y valga como ejemplo la nueva autorización para la condonación de deudas entre los partidos y las entidades financieras y la posibilidad de que las asociaciones y fundaciones vinculadas a los partidos también reciban subvenciones y cuenten con un régimen de donaciones privadas significativamente más ventajoso que las propias organizaciones partidistas. Son temas tradicionalmente "críticos" en los sistemas de financiación, en los que el legislador se ha mostrado nuevamente negligente en su tratamiento jurídico, y que prometen ser los "nuevos" problemas dentro de la financiación de partidos.

Analizadas las líneas generales del sistema de financiación, se ha expuesto en la investigación la tan común discusión sobre la posibilidad o no de la separación de la financiación de las actividades extraordinarias y ordinarias de los partidos, considerando la incompatibilidad entre una normativa y otra. Como era de esperar, se concluye manteniendo la imposibilidad de dicha separación. Por otra parte se analizan los concretos aspectos de la financiación pública y su impacto sobre la constitucionalmente exigida democracia interna de los partidos. En el trabajo se sostiene que la financiación pública existente tal y como se configura actualmente en el ordenamiento jurídico español, fomenta la concentración interna de poder en los partidos, afectando a la relación entre dirigentes y afiliados y la propia insuficiencia de la 
regulación legal cuestiona los derechos constitucionales de los afiliados y, en cierta manera, compromete también el pluralismo político existente internamente en los partidos.

Se analiza también en el trabajo el sistema de financiación indirecta de partidos existente en España, que va desde el acceso a los medios (lo que seguramente supone un ahorro significativo en las cuentas de los partidos) a partir de criterios más plurales y equitativos que los del acceso a las subvenciones, las medidas de desgravación fiscal (principalmente con la Ley Orgánica 8/2007), y otros beneficios que ciertamente causan un impacto en los gastos en la campaña electoral. Aquí las críticas se centran en una posible reformulación de la utilización de los medios de comunicación, principalmente de la televisión, ya que existe un déficit de regulación de medios más modernos de hacer campaña, como los debates entre candidatos y el internet. Se concluye que los criterios para la distribución del tiempo en las cadenas de televisión públicas son más plurales que para las subvenciones públicas, aunque se podría mejorar mucho su eficacia. Quizás sería el momento de repensar la conveniencia de la prohibición de la utilización de canales de televisión privadas en las campañas, considerando que estas obviamente participan indirectamente en las mismas, sin una excesiva regulación legal. Al tratarse de una concesión de servicio público, se ha sugerido la posibilidad de instaurar la obligatoriedad de cesión de tiempo en su programación de forma gratuita a los partidos, estando este tiempo dividido de acuerdo a los criterios vigentes en la televisión pública. Ello podría conllevar indirectamente una mejora en la igualdad de trato entre los competidores y también aumentar la eficacia de las campañas, involucrando a la sociedad en los debates de las propuestas. Se destaca que este es el sistema vigente en otros países como Brasil y que produce buenos resultados.

Una vez analizada pormenorizadamente la estructura de financiación de los partidos, se centró la atención en el debate de los puntos considerados conflictivos en la financiación electoral y en el modelo actual de campañas electorales. El primero de ellos fue el problema del mailing, considerado por muchos como el más desigual de los beneficios concedidos por el Estado a los partidos. Además de contener criterios propios de concesión que dificultan su 
acceso, acaba por aumentar las desigualdades en la financiación de los partidos e incrementa sus gastos en las campañas, al no ser contabilizado en el límite de gastos electorales de dichas organizaciones. La única conclusión que se puede obtener de la regulación actual del mailing es que esta tan solo aumenta la estatalización de los partidos, y por ello creemos que, por más que se haya en cierta manera consolidado dentro del comportamiento político del elector, se podría pensar en su reformulación legal o quizás su exclusión.

El segundo tópico tratado fue la cuestión de la precampaña y campaña electoral, conceptos determinados por la LOREG. Después de un análisis actualizado con la nueva reforma de la norma, se mantiene en el texto que los cambios no resultan suficientes para resolver los problemas centrales de la financiación electoral de los partidos. Si los gastos electorales son solo aquellos hechos durante la campaña electoral, y solamente estos gastos son contabilizados en el límite de gastos prescrito en la LOREG, las probabilidades de que continúe existiendo una campaña electoral indirecta en época de precampaña son las mismas que antes de la reforma. El mismo problema se produce respecto a la propaganda política y la propaganda electoral. La propaganda política es un tipo de publicidad continua, que no pide el voto, sino que atiende a fines generales partidarios. La propaganda electoral, además de ser la responsable de un gasto importante en las campañas, se somete en cambio a los estrictos límites de la LOREG. La efectividad del control por parte del Tribunal de Cuentas de dichos gastos electorales queda comprometida a partir del momento en que resulta casi imposible distinguir entre propaganda política o propaganda electoral disfrazada de política como medio de defraudar los límites de la LOREG. La cuestión se vuelve aún más difusa si se tiene en cuenta la autorización de la nueva Ley Orgánica 8/2007 para que asociaciones y fundaciones sean también financiadas por el Estado, seguida del silencio legal sobre eventual propaganda que estas realicen a favor de un determinado partido.

Como último punto específico, se expuso en el trabajo el debate actual sobre la eficacia del vigente modelo de campañas electorales. Parece claro que, dado que el Estado costea indirectamente la campaña, por lo menos esta debe cumplir su finalidad en el sistema democrático, lo que no parece ocurrir 
actualmente debido ante todo al formato anticuado de campaña electoral previsto en la LOREG. La reforma recién aprobada no ha abordado los nuevos canales de campaña, como el internet, y tampoco ha regulado aspectos como la obligatoriedad de los debates electorales en los medios televisivos, lo que permite afirmar que la actual legislación continua teniendo un considerable grado de desfase con la realidad política. Junto a ello, el tiempo muy reducido en que se enmarca legalmente la campaña contribuye a que ésta también pierda su eficacia, ya que los electores forman su opinión durante los movimientos a largo plazo, y no durante este periodo.

También se juzgó necesario analizar el sistema de financiación electoral, exponiendo cómo funciona a nivel autonómico, ya que cada comunidad autónoma tiene competencia para aprobar sus propias normas a respeto. Debido a lo que algún autor denomina de la homogeneidad de la legislación electoral a nivel autonómico, no hay importantes diferencias entre ésta y el régimen general, y las diferencias más significativas como las de la legislación del País Vasco, no adquieren gran relieve. Sin embargo, entendemos que el fenómeno no es negativo dentro del ordenamiento, ya que evita en gran parte el riesgo de conflictos normativos, como ocurre en otros tantos ordenamientos, como EE.UU.

Teniendo en cuenta su peso en las finanzas de los partidos, entendimos necesario abordar también sumariamente la financiación de los grupos parlamentarios, que acaba por ser también un medio de financiación de las organizaciones partidistas. El debate sobre la legitimidad del uso de dichos recursos por los partidos todavía no ha cerrado con consenso, y nuestra posición se alinea con quienes no consideran correcto desde el punto de vista legal dicho uso.

Finalmente, se apuntaron algunos sobre la financiación de partidos a nivel europeo, destacando los criterios de acceso a las subvenciones públicas del Parlamento Europeo. Después de un análisis de las normas al respecto que privilegian la transparencia y el control de las cuentas de los partidos - se concluyó que dichos criterios de acceso también generan una fuerte discriminación entre partidos mayoritarios y minoritarios, provocando un desequilibrio entre las organizaciones, y mucho más si se piensa en las fuerzas 
políticas extraparlamentarias. Lo que se destaca en este nivel es la naturaleza dual de las organizaciones partidistas, que deben renovar su "titulo" de partidos europeos periódicamente, para que puedan consecuentemente ser considerados como tal y participar en el reparto de las subvenciones.

El cuarto Capítulo de este trabajo se centra en el análisis de la fiscalización de la financiación de los partidos. Esta se constituye un tema de extrema relevancia por ser la utilización masiva de dinero público y, por lo tanto, debiendo ser fiscalizado. Tanto electoral como ordinariamente, la financiación pública ejerce un papel prácticamente único en este proceso. La transparencia en el flujo de recursos y en la utilización de los mismos genera una importante preocupación en las democracias modernas. En España, el responsable de la fiscalización de ambas financiaciones es, como es sabido, el Tribunal de Cuentas, encargado de esta tarea desde la aprobación de la Ley Orgánica 3/1987. Con anterioridad, lo cierto es que la ineficacia casi completa de las disposiciones sobre el tema, hizo que los partidos se sintieran libres del cumplimiento de cualquier norma sobre el control de sus finanzas.

Tras abordar la corrección desde el punto de vista funcionalconstitucional de encomendar dicho control al Tribunal este, fueron analizados los informes del Tribunal de Cuentas relativos a las elecciones de 2000, 2004 y 2008 (donde este no aplica aún las nuevas reglas establecidas por la reciente reforma de la LOREG, ya que el informe sobre las elecciones celebradas en 2011 todavía se encuentra en fase de aprobación); y de los ejercicios ordinarios de 1987, 1988, 1990, 1991, 1992, 1993 y de 2000 hasta 2006, y 2007 (ya aplicando el nuevo régimen de la Ley Orgánica 08/2007) último informe presentado hasta la fecha.

El resultado fue el esperado: en todos los informes se constatan deficiencias importantes por parte de todos los partidos, desde el incumplimiento del plazo legal para la presentación de las cuentas o la completa ausencia de criterios técnicos en la elaboración de las mismas, hasta la clara violación de las normas de financiación, con muy pocas sugerencias de sanciones, dado que el Tribunal de Cuentas no tiene dicha potestad. Son errores e incumplimientos reiterados que en cada ejercicio el Tribunal no hace nada más que subrayar en sus sugerencias y conclusiones, además de 
aprobar mociones dirigidas al Congreso de los Diputados - como ha ocurrido en 2010 - pidiendo nuevamente el perfeccionamiento de las normas de financiación de los partidos, lo que refleja la falta de interés de los partidos en solucionar estas cuestiones pendientes desde hace mucho tiempo. Este análisis pone en evidencia la parcial ineficacia de la legislación sobre el tema, y permite un cierto escepticismo ante los últimos cambios normativos. El actual modelo es pues insuficiente, y vuelve ineficaz la función fiscalizadora.

El contexto en lo cual la normativa sobre financiación de partidos fue aprobada eran otros, que no son los mismos de ahora. El derecho debe acompañar la evolución de la sociedad y, si los partidos en España ya se encuentran consolidados conjuntamente con el sistema democrático, es el momento de garantizar la propia democracia a los ciudadanos, a partir de un cambio de paradigma.

Ante esto, hay una significativa probabilidad de que los partidos actualmente sean dependientes de las subvenciones públicas, ya que con una financiación pública tan generosa, estos dependen sobremanera del Estado. Además, hay una cierta crisis de legitimidad de dichas organizaciones, que tienen un espacio mayor de lo recomendable en las estructuras de poder sin que esto signifique representatividad, debido a su alejamiento de la sociedad. La idea clásica del Estado de Partidos ha sido distorsionada por la dinámica de los propios partidos en el Estado y puede ser que actualmente su comportamiento pueda caracterizarse como tendiente al de un "cartel". El problema central no es sólo la cristalización del sistema de partidos, sino ante todo la imagen que se tiene de ellos en la sociedad.

Un poco antes de la conclusión de este trabajo, el gobierno ha presentado un nuevo proyecto de ley para la reforma de la Ley Orgánica 8/2007, sobre la financiación ordinaria de los partidos políticos, lo que motivó la inclusión del quinto y último Capítulo. Aunque se pueda percibir el aumento de la preocupación con la transparencia y con la publicidad en la fiscalización de los partidos políticos, es claro el tímido progreso en una mejora del sistema. El proyecto se centra principalmente en el aumento de la fiscalización de las fundaciones y asociaciones vinculadas a los partidos, y avanza únicamente en el sentido de reducir las subvenciones públicas destinadas tanto a las 
organizaciones partidistas, como a dichas fundaciones, no debido a su alto valor, sino más bien por la fuerte crisis económica que afecta directamente al presupuesto del Estado, que tiene metas de déficit a cumplir.

En realidad, la ya aprobada Ley Orgánica 5/2012 describe una nueva regla, ya aportando enseguida una excepción a ella, lo que neutraliza la potencial fuerza de la nueva normativa. Lamentablemente, otra vez más cabe subrayar la no actuación del Estado ante los problemas referentes a esta rama del Derecho de Partidos. 


\section{CONCLUSÃO}

Ao longo deste trabalho, foi possível demonstrar que o tema do financiamento de partidos políticos é normalmente tratado a partir de regras casuísticas, que impedem dar à sociedade respostas eficazes para os problemas identificados. Como se trata de um espaço onde os atores envolvidos costumam não se comportar com racionalidade, isto também se reflete nas reformas das normas referentes ao financiamento, aprovadas recentemente.

Assim, a exposição sobre o tema central do presente trabalho iniciou-se a partir da análise global do direito de partidos na Espanha, partindo desde a constitucionalização dos partidos políticos em âmbito mundial, à constitucionalização no próprio ordenamento espanhol. A maneira como ocorreu tal processo na Espanha influenciou diretamente a natureza jurídica atribuída às agremiações partidárias, existindo reflexos também na própria regulação dos partidos e de suas funções.

Frente a isto, foram tratados alguns possíveis problemas que as disposições contidas no art. 6ำ da Constituição Espanhola encontraram na atual democracia, começando pela noção de pluralismo político e de sua expressão através dos partidos políticos. Como no modelo espanhol não há o monopólio partidário para a apresentação de candidaturas, constatou-se a existência de um bloqueio das forças políticas - com possível apoio social - a partir de mecanismos, como o sistema eleitoral combinado com 0 financiamento de tais organizações.

Seguindo tal constatação, questionou-se se tal evidencia não influenciaria na segunda função dos partidos, de ser o canal principal de manifestação das demandas populares. Considerando a impossibilidade das casas legislativas constituírem o "espelho" perfeito de uma sociedade moderna e complexa, a análise volta-se mais para uma eventual distorção da função de representação exercida pelos partidos, com base na ideia do Estado de partidos. É possível que, nos moldes atuais (e também como um resultado da aplicação de tal modelo por tantos anos), as agremiações partidárias estejam ocupando um espaço maior que o recomendável dentro do Estado, 
confundindo a vontade popular com a sua, e por sua vez, abrindo caminho à "partidocracia", responsável por provocar efeitos antagônicos nos cidadãos com relação aos partidos em si. Um destes efeitos pode ser a ideia de que tais organizações partidárias não representam a sociedade e que tampouco buscam soluções ou que atendam às demandas sociais, sendo que são subvencionados com recursos públicos para o cumprimento de estas funções. Portanto, observam-se sinais de uma crise de representatividade.

Ambas as conclusões levam à análise da última função atribuída aos partidos, que se relaciona com a participação política (que por sua vez está intimamente conectada com o pluralismo político). Trata-se de um elemento harmonizador do sistema democrático e está muito determinado pelo sistema eleitoral. Assim sendo, o que se questionou foi se o atual sistema eleitoral permite que seja cumprida esta tarefa por parte das agremiações partidárias. $\mathrm{Na}$ esfera do direito de sufrágio ativo, tratou-se do princípio da igualdade de oportunidades, uma das razões pela qual também se adotou o presente modelo de financiamento público de partidos. Contudo, além de constatar que as regras de financiamento público aplicadas presentemente não colaboram para o fomento de tal princípio entre os competidores eleitorais, verificou-se que o grande impacto no resultado das urnas causado pelo sistema eleitoral em vigor pode ser um dos elementos principais que distorcem toda esta estrutura. Não é uma novidade de que o sistema eleitoral não atende de modo nenhum às exigências do princípio da igualdade de oportunidades, já que além das conhecidas resultantes provocadas pela fórmula D'Hondt sobre circunscrições de pequena magnitude (como é no caso espanhol), isto impede que todos os partidos tenham reais condições de exercer suas funções constitucionais, como também produz reflexos diretos sobre o acesso e distribuição das subvenções públicas aos partidos. Ao atrelar os resultados eleitorais ao financiamento dos partidos, as distorções ocasionadas pelo sistema eleitoral sobre a distribuição das cadeiras é um fator importantíssimo para determinar, paralelamente, quais partidos receberão mais recursos econômicos por parte do Estado.

Tendo este cenário em mente, a imagem que se transmite à sociedade é a de que as eleições se tornaram apenas um procedimento de legitimação de 
elites no poder (conforme as lições de SCHUMPETER), e que tais elites não se sentem ameaçadas justamente porque não há qualquer opção/opções políticas capaz de alterar esta dinâmica desde dentro. Conjuntamente, o comportamento denominado de voto útil passou a ser adotado com certa regularidade pelos eleitores espanhóis, algo que é bastante significativo e não coaduna exatamente com os ideais democráticos. Esta conduta evidentemente favorece aos partidos majoritários e nacionalistas e, ao mesmo tempo, dificulta 0 cumprimento das funções constantes no art. 6ำ da CE pelos demais partidos. Tal fato tão corriqueiro na prática e de evidente visualização geram casos em que há partidos que recebem menos votos, mas que têm direito a um maior número de cadeiras, e, por conseguinte, têm direito a um maior montante de recursos públicos, como pôde ser observado a partir dos dados referente às eleições de 2011.

Já ao longo do Capítulo 2, o trabalho se centra nos modelos de financiamento de partidos já existentes, destacando algumas polêmicas que surgem em cada tópico. A primeira controvérsia levantada foi sobre o modelo privado de financiamento de partidos, no qual os recursos econômicos se originam diretamente da sociedade, de fontes sem vinculação com o Estado, mas que não estão isentas de problemas. Muitas destas fontes previstas nas normas de financiamento já não são mais aplicáveis à atual estrutura dos partidos e deveriam ser adequadas aos novos tempos, como é o caso das publicações partidárias, já quase inexistentes, do próprio patrimônio dos partidos ou da sua atividade mercantil ou empresarial, fonte esta que foi recentemente proibida por não se tratar da verdadeira função de um partido. Junto disto, a quota de afiliados reproduz diretamente a hodierna fragilidade da militância, que afeta principalmente as contas partidárias, sendo que a legislação em vigor pouco colabora para o seu fomento. Alia-se a isto a falta de interesse por parte dos próprios partidos no aumento do número de afiliados, tanto por razões de democracia interna (já que, quanto mais membros, mais haverá demandas internas), e a própria segurança que as formações políticas têm com a concessão das subvenções públicas.

Atualmente, podem ser admitidas como fontes importantes de arrecadação de recursos as doações particulares (tanto de pessoas físicas 
como jurídicas), contribuições de candidatos e de cargos eletivos pelo partido e empréstimos e créditos de valores, muito presentes durante o período de campanha eleitoral. Em alguns países, as doações privadas são tidas como vitais para a realização das campanhas eleitorais ou a manutenção das organizações partidárias, e isto abre um grande espaço para a dependência dos partidos com relação a estes recursos. Da mesma forma ocorre com a corrupção, tão difícil de ser combatida. À margem da polêmica sobre a permissão ou não das doações anônimas - que felizmente foram expurgadas da legislação devido ao seu caráter pouco transparente e bastante nocivo está explícito que as normas em vigor penalizam as doações privadas muito mais do recomendável. É muita ingenuidade pensar que tais doações não serão realizadas apenas devido às proibições legais, se a própria legislação não conta com um sistema de fiscalização adequado para coibir a sua influencia sobre o processo eleitoral. Acredito que seria muito saudável à democracia como um todo uma abertura - ainda que pequena - desta fonte de financiamento, porque não se trata somente da utilização de mais recursos na política, mas também na própria participação cidadã neste processo, de maneira mais ativa e apoiando à opção que lhe pareça mais adequada, o que, por sua vez, provoca uma mobilização popular muito mais significativa na dinâmica tanto eleitoral como na partidária. Com acertados ajustes, é possível alcançar resultados favoráveis a partir destas doações privadas, beneficiando a toda sociedade, ao mesmo tempo em que diminui a pressão sobre as arcas publicas da pesada responsabilidade do financiamento dos partidos.

Um exemplo da ineficácia do atual regime aplicado às doações privadas são os empréstimos e os créditos (arrolados também como fontes de financiamento), que não raras vezes correspondem às doações privadas ocultas ou disfarçadas. Isto tende a agravar-se com a nova legislação que autoriza a realização de acordos para o perdão de dívidas, sem que se tenha estabelecido qualquer critério para isto. Aqui o tema se conecta diretamente com a impossibilidade de negar a existência de "ingressos atípicos" na contabilidade dos partidos, porque por mais que não seja possível obterem-se dados confiáveis sobre a real presença de tais recursos econômicos resultante 
de práticas corruptas por parte das organizações partidárias, é axiomático que eles existem e que seu volume não admite que se o desestime desta análise.

Com relação ao financiamento publico, o problema gira em torno à obrigatória garantia da igualdade de oportunidades na competição política. É cediço que o financiamento público foi idealizado como forma de combater a crescente corrupção com o financiamento privado, e também como uma maneira de livrar aos partidos desta dependência econômica. Com uma fundamentação muito clara, o financiamento público desempenha um importante papel porque se trata de uma intervenção estatal tanto para possibilitar o cumprimento das funções que foram atribuídas aos partidos, como também para garantir as devidas condições de desenvolvimento da democracia a partir da igualdade, do pluralismo, e do combate à corrupção. Os subsídios públicos seriam distribuídos entre as diversas opções políticas como uma maneira de equilibrar seu poder na competição eleitoral, abrindo caminho para o pluralismo e fazendo com que os partidos perdessem seus incentivos para participar tanto ativamente como passivamente de atos de corrupção. Apesar disto, na prática foram alcançados resultados diferentes, considerando a variedade de modelos que introduziram o financiamento público pelo mundo. Não se verificou um equilíbrio ideal da igualdade de oportunidades, o que consequentemente afetou o pluralismo político. Outrossim, falhou no combate ou na diminuição da corrupção, já que, em muitos casos, o encarecimento das campanhas eleitorais fez com que os partidos recorressem ao dinheiro "negro", como forma de honrar com suas dívidas e de realizar uma campanha competitiva. As criticas em torno ao sistema público de financiamento de partidos apontam no sentido de que eles agora estão muito mais dependentes do Estado do que antes (sendo inclusive "absolvidos" por este), ao invés de depender dos recursos privados. Aliado a isto, o financiamento público concedeu uma confortável situação aos partidos para o pagamento de suas despesas, não existindo mais motivação para que tais organizações mantenham laços com a sociedade, o que provoca, por sua vez, o seu afastamento da sociedade, o que é totalmente contrario ao que seria adequado em uma democracia. 
Há um controle da entrada e saída de forças políticas do sistema de partidos (o que pode ser traduzido como uma petrificação do mesmo), fazendo com que eles, de uma certa forma, componham a estrutura do Estado e que não se sintam obrigados a estabelecer conexões com as suas bases sociais.

Em sequência, foram expostas algumas aplicações do financiamento público que têm impacto direto sobre a democracia. Existem discussões sobre qual o nível dos partidos que devem ser financiados pelo Estado, referindo-se às suas sedes nacionais ou regionais. Teme-se que, da mesma maneira que a democracia interna não teve a devida atenção do legislador, o grau de autonomia concedido por meio do financiamento público aos níveis regionais dos partidos provoque outros infortúnios desnecessários. A causa disto, a opção feita pela Espanha foi a da entrega centralizada dos recursos, ainda que isto leve a um aumento na oligarquização das estruturas partidárias.

Outro item que se debate no financiamento público é se as subvenções devem ser entregues a título de reembolso de gastos eleitorais, ou como contribuição a estes. É cediço que a entrega a posteriori de tais recursos desfavorece aos partidos recém-criados, com condição econômica e capacidade de crédito inferior. Contudo, também têm efeitos positivos sobre 0 controle dos gastos dos partidos, ainda que tal controle seja discreto ou discutível.

Já outro critério que gera debate é se o financiamento deve alcançar aos partidos ou aos candidatos. Esta decisão está muito influenciada pelo sistema aplicado em cada país (principalmente no eixo EUA - Europa), e determina o herdeiro do protagonismo político frente ao outro que não será subvencionado. Não existe uma decisão exata neste ponto, já que cada legislação deverá ser moldada conforma a sua própria realidade social. Por outro lado, é importante considerar se o financiamento público alcançará somente as atividades eleitorais dos partidos, ou se também englobará as ordinárias, ou seja, as quotidianas. Penso que esta discussão hoje em dia carece de sentido, tendo em vista que não é possível classificar as atividades partidárias nestes dois grupos, sendo tal fato facilmente comprovável na prática.

Devido a isto, os modelos mistos de financiamento são os mais comuns, distinguindo-se pela sua tendência ao modelo privado ou modelo público. 
Como tratar do tema dos sistemas mistos pode ser algo muito abstrato, neste trabalho optou-se por ilustrar três modelos paradigmáticos, sendo escolhidos para isto países como Estados Unidos, Alemanha e Itália. A diferença entre países anglo-saxônicos com os europeus é evidente, uma vez que os Estados Unidos se inclinam significativamente para o financiamento privado (ainda que tenham disposições legais sobre financiamento público) e de possuir um maior enfoque sobre os candidatos, e na Europa o mais comum é que se tenda ao financiamento público, mais centrado nos partidos.

Nos Estados Unidos, a força das doações privadas e dos lobbies foram mais fortes que as legislações que versavam sobre o tema. Com constantes interferências da Supreme Court, pouco a pouco as rígidas regras de limitação de doações foram abrandadas em prol da liberdade de expressão, um direito expresso na First Amendment. É certo que há uma preferência pela transparência do fluxo de recursos econômicos do que pela sua proibição, mas também é certo que, analisando a última reforma da ley (Bipartisan Campaign Reform Act) com as últimas decisões da Supreme Court sobre o tema, a liberdade de expressão é um direito que está em frente do controle do aumento do custo das campanhas ou da igualdade de oportunidades entre os partidos. Infelizmente, a boa estrutura trazida pela última reforma da legislação que conseguiu combater a força dos PAC's foi quase que totalmente desfeita pela Supreme Court, embasando-se nesta noção de liberdade de expressão, o que, ao mesmo tempo, desvirtua os princípios democráticos. A isto se alia o fato de que a nova legislação não fomentou o financiamento público como um meio de controle de gastos dos partidos, ou inclusive como uma medida para equilibrar as forças políticas, o que colabora importantemente ao aumento do uso do dinheiro privado nas campanhas e o seu custo. No país onde o lobbying é permitido e que nas últimas eleições para presidente se tenha levantado uma quantia quase que inimaginável de recursos, o dinheiro tem muito poder nas campanhas, que são conduzidas pelos meios de comunicação. Ainda assim, é admirável o peso da transparência da movimentação de tais recursos, em comparação com outros ordenamentos jurídicos.

Por outro lado, no caso alemão também se destacam as constantes intervenções do Tribunal Constitucional na legislação referente ao tema, mas 
com outro enfoque: o de preservar a abertura do sistema de partidos e a igualdade de oportunidades entre os competidores eleitorais. Desde a adoção de medidas de financiamento público, pouco a pouco o Tribunal Constitucional foi auxiliando na melhora da legislação, permitindo uma abertura ideal do modelo e impedindo a cristalização do sistema de partidos, sem que os mesmos estivessem desamparados economicamente, mantendo e preservando seus laços com a sociedade. $\mathrm{O}$ atual sistema determina que $\mathrm{O}$ valor das subvenções públicas devidas a cada partido seja calculado a partir dos valores arrecadados por eles mesmos da sociedade, formando desta maneira um modelo eficiente de tutela de direitos dos cidadãos, como também atendendo aos parâmetros democráticos necessários para a saúde política do país.

Lamentavelmente não foi o que ocorreu com o caso italiano, que ainda que tenha partido quase do mesmo ponto que a Alemanha, em consequência de algumas de suas próprias características de seu sistema político, há sucumbido à decisão popular da eliminação do financiamento público ordinário dos partidos, resultante de um referendum. A presença da corrupção naquele país sempre foi expressiva e não acreditamos que tenha sido pressionada pelo financiamento público antes existente. Com a revogação das medidas de financiamento público, os partidos italianos sofreram uma importante crise de legitimidade e de representação, ainda mais após as várias tentativas de voltar a introduzir os mecanismos de outorga de subvenções públicas para o sustento das suas atividades ordinárias. Atualmente, Itália conta somente com 0 financiamento público para as campanhas eleitorais. Não obstante, toda a sociedade italiana tem conhecimento de que isto se trata unicamente de uma nomenclatura, e que os recursos são também utilizados indistintamente para as atividades partidárias em geral, o que aumenta ainda mais a apatia e a desafetação política existente naquele país.

Da mesma maneira que um sistema misto de financiamento de partidos é o mais comum, também é bastante usual que, em tais sistemas, existam desequilíbrios entre as medidas de financiamento privado e público, o que, por sua vez, também não favorecem a uma dinâmica saudável. Frente ao desequilíbrio provocado pela maior presença de medidas de financiamento 
privado, existe o endêmico problema da corrupção. Para esta breve análise, buscou-se conceituar exatamente o que se entende por corrupção política, que se relaciona também com outros termos, como o de accountability e o da transparência, que presentemente regem a noção deste tipo de corrupção. É evidente apontar que a corrupção no financiamento dos partidos se trata de corrupção política porque os sujeitos podem ser tanto partidos, como também entes privados; o bem afetado é o interesse público; e a sua classificação se da por ocorrer tanto no seio dos partidos, como também por ser um meio de influencia na agenda política. Em seguida, foram expostos alguns dos incentivos que os partidos têm para a prática de atos corruptos no seu financiamento, o que permitiu concluir que não é somente o fato de que eles vivem em uma campanha eleitoral constante e cada vez mais cara, acompanhada da insuficiência de recursos econômicos próprios para este fim. O verdadeiro incentivo que permanece para tal ocorrência é, na maior parte das vezes, a ineficácia dos mecanismos de controle das finanças partidárias, além de carecer de ferramentas para concretizar o que dita o conceito de accountability. Está claro que este não é um problema somente do sistema espanhol, mas sim é um problema que atinge a grande parte dos países do mundo.

Já com o desequilíbrio das medidas de financiamento público, se abre espaço à teoria da cartelização de partidos, que significa que eles, uma vez dentro das estruturas do Estado, acabam por comportar-se como um cartel, como uma maneira de manter seus próprios benefícios, e também de manter aos beneficiados seguros frente a uma possível intervenção de forças políticas alheias externas, gerando, desta maneira, uma barreira quase impossível de transpassar por parte dos partidos extraparlamentares. Trata-se de uma tendência verificada nas democracias ocidentais e que começa a ser consideravelmente visível no sistema espanhol.

No Capitulo 3 encontra-se a análise do sistema de financiamento de partidos espanhol, que não pode ser compreendido sem a análise de sua origem histórica, bastante particular se consideramos outros sistemas. A causa da ausência de uma base adequada de desenvolvimento dos partidos no período pós-ditatorial, fez-se necessário formular um sistema de financiamento 
misto, privilegiando medidas de financiamento público justamente para fornecer aos partidos recém-constitucionalizados o suporte econômico necessário para a sua atuação. Além disto, elaborou-se uma estrutura legislativa voltada a eles e capaz de dar-Ihes efetividade na dinâmica política, como pode ser as eleições, as campanhas, e outros eventos, sempre lhes protegendo e thes privilegiando frente ao sistema. As particularidades aplicadas na Espanha são bastante evidentes atualmente e merecem muita atenção.

Como início do seu histórico legislativo, a primeira norma sobre o tema dos partidos políticos em geral foi o Decreto-lei 20/1077, que tratou de maneira muito breve os pontos vitais para o funcionamento de tais organizações. A intenção desta norma era patente, limitando-se a instrumentalizar os elementos básicos para a realização das primeiras eleições democráticas. Foi aqui que o sistema eleitoral ainda em vigor foi adotado, perdurando-se no tempo por meio da fórmula eleitoral D'Hondt para a conversão dos votos em cadeiras, a partir de circunscrições de baixa magnitude (modelo indicado para estabilizar sistemas recém-democratizados). Pouco depois, aprovou-se a Lei Ordinaria 54/1978 como norma responsável por regular os partidos recémconstitucionalizados e, também, por possibilitar sua participação nas eleições que estavam por vir.

Ao abordar o financiamento das campanhas eleitorais, o Decreto-lei 20/1977 estabeleceu uma das características mais determinantes do modelo em vigor de financiamento, que é o duplo critério de acesso às subvenções públicas. Os partidos tão só participariam do reparto das subvenções se conseguissem obter pelo menos uma cadeira, sendo que para o cálculo dos valores, seriam considerados unicamente os votos nas circunscrições onde conquistassem estas cadeiras. Acompanhando tal norma, a Lei Ordinaria 54/1978 regulou o art. 6o da Constituição Espanhola (recém-aprovada na ocasião), versando sobre outros elementos, como o registro de partidos, a democracia interna, e o financiamento público das suas atividades ordinárias. Da mesma maneira que o Decreto-lei 20/1977, a Lei Ordinaria 54/1978 também fixou o critério duplo para o acesso à divisão das subvenções eleitorais, como também considerava somente os votos nas circunscrições onde se conseguiram cadeiras, para fins de cálculo de tais valores. 
Entretanto, ainda que fossem normas de perfil transitório, ambas estiveram em vigor por muito mais tempo que o previsto, o que provocou a sua gradual insuficiência para regular a longo prazo todos os temas que envolviam os partidos. Além disto, devido às lacunas contidas em tais leis, havia tópicos sem uma solução jurídica, não sendo o financiamento de partidos uma exceção disto.

Somente com a pressão dos problemas e do descobrimento de casos de corrupção envolvendo o financiamento dos partidos (como o caso Flick), iniciou-se a elaboração de uma nova legislação, tanto eleitoral como do financiamento ordinário das organizações partidárias (Lei Ordinaria 5/1985 LOREG - e Lei Ordinaria 3/1987, respectivamente). Ainda que o tratamento da matéria tenha sido notoriamente ampliado, a sistemática para o acesso e a distribuição das subvenções publicas não foi alterada, diferenciando-se tão somente com a ampliação dos benefícios oriundos do Estado, com mais subvenções concedidas por outros conceitos, o que assegurou aos partidos parlamentares mais comodidade na sua situação.

Como parte da exposição, indicou-se alguns pontos problemáticos existentes antes da Lei Ordinaria 3/1987, que colaboraram, sobretudo, para o agravamento do sistema de financiamento ordinário, como a permissão para a realização de doações anônimas; sua nítida vantagem frente ao regime de financiamento eleitoral; a desconsideração das cadeiras obtidas no Senado para o cômputo dos valores devidos a cada partido, e outros tantos itens que certamente contribuíram diretamente para que o sistema se voltasse ainda mais intrincado. Nesta época já era possível observar que a combinação do sistema eleitoral com as medidas de financiamento público de partidos causava difíceis obstáculos na dinâmica política de Espanha, auxiliando na falta de mobilidade de forças políticas no sistema de partidos. Além disto, seu protagonismo aumentou de maneira importante se forem analisadas as reformas legislativas havidas nestes temas, fazendo com que os partidos fossem os grandes beneficiários de suas próprias medidas.

Após algumas décadas, com o agravamento dos problemas antes diagnosticados, houve uma pressão para que o tema do financiamento de partidos voltasse à agenda política, o que culminou na aprovação da Lei 
Ordinaria atualmente em vigor sobre o financiamento ordinário dos partidos (Lei Ordinaria 8/2007), e a reforma recém-aprovada da LOREG. É importante reconhecer que existiu uma certa evolução em alguns dos temas antes tido como graves (como é o caso do controle da contabilidade partidária), mas infelizmente não se pode afirmar que houve uma melhora na norma sobre o sistema, porque além de não ter sido ainda aplicada na prática (já que, por mais que esteja em vigor desde 2007, os informes de fiscalização das contas dos partidos referentes a este período ainda não foram elaborados, com exceção ao de 2007), é muito prematuro confirmar a eficácia e as intenções pelas quais tais regras foram aprovadas, como também é certo que, fundamentando-se só no texto da lei, não se observam importantes modificações em prol da abertura do sistema de partidos. O que se nota é a ampliação do espaço ou das lacunas que permitirão a ocorrência de fatos pouco condizentes com um sistema de financiamento transparente e limpo, como é a nova autorização para a renegociação ou perdão de dívidas entre os partidos e as entidades financeiras, e a possibilidade de que as associações e fundações vinculadas aos partidos também possam receber subvenções, que também dispõem de um regime de doações muito mais benéfico que 0 aplicado para os partidos. São temas bastante conflituosos que o legislador mostrou-se negligente no seu tratamento legal e que prometem ser os "novos" problemas dentro do financiamento de partidos.

Posteriormente à analise legislativa, passou-se à exposição da discussão tão comum sobre a possibilidade ou não da separação do financiamento dos partidos em eleitoral e ordinário, considerando a incompatibilidade entre uma normativa e outra. Como era de se esperar, concluiu-se que não é possível fazer tal classificação.

Também foram analisados o financiamento público em vigor e seu impacto sobre a democracia interna dos partidos e os efeitos econômicos da dissolução dos partidos, enfocando o caso paradigmático de Herri Batasuna. Assim, fundamentando-se no formato atual da normativa que se aplica neste caso, comprovou-se que o financiamento público existente fomenta a concentração interna de poder nos partidos, afetando a relação entre dirigentes e afiliados. Portanto, está evidenciada uma insuficiência de normas legais 
sobre o tema, pondo em risco os direitos constitucionais dos afiliados e, em certa maneira, comprometendo também o pluralismo político existente dentro das organizações partidárias. Já com relação às consequências econômicas da dissolução dos partidos, abstivemo-nos de tratar sobre a ilegalização dos partidos, por ultrapassar o objeto de análise. Contudo, a partir do caso paradigmático exposto, pudemos observar que as regras em vigor novamente não são suficientes, havendo uma incompatibilidade entre o procedimento ditado pela norma e a sua posta em prática. Ressalte-se que o caso de Herri Batasuna - como é o único existente - quiçá não seja o mais adequado para verificar as hipóteses trazidas neste trabalho, já que a sua dissolução foi muito mais para desarticular um grupo terrorista de que propriamente para privar-lhe de seu direito às subvenções públicas.

A análise prossegue com o sistema de financiamento indireto de partidos na Espanha, que vai desde o acesso aos meios de comunicação (o que seguramente supõe uma economia importante nas contas dos partidos) a partir de critérios mais plurais e mais equânimes que os aplicados ao acesso às subvenções diretas; medidas de dedução fiscal (principalmente a partir da Lei Ordinaria 8/2007), e outros benefícios que certamente causam impacto nos gastos de campanha eleitoral. Aqui as criticas se centram mais na possível reformulação da utilização dos meios de comunicação, principalmente a televisão, já que existe um déficit na regulação dos canais mais modernos utilizados nas campanhas, como os debates entre os candidatos e a internet. Conclui-se que os critérios para a distribuição do tempo nos canais de televisão públicos são mais plurais que os aplicados para as subvenções públicas, ainda que pudessem ser melhorados ou aperfeiçoados, favorecendo a sua eficácia. Talvez fosse o momento de pensar sobre a conveniência da proibição da utilização dos canais de televisão privados nas campanhas, considerando que tais canais participam de maneira ativa destes eventos, e quase que sem controle. Como se trata de uma concessão de serviço público, o que se sugere é que talvez fosse possível determinar-lhes a ceder tempo na sua programação, de forma gratuita aos partidos, sendo este tempo dividido conforme os parâmetros já aplicados para a televisão pública. Isto poderia assegurar um maior controle sobre a igualdade de tratamento entre os 
competidores e também de aumentar a eficácia das campanhas, envolvendo a sociedade no debate das propostas. Destaca-se que este sistema já existe em outros países, como é o caso do Brasil, e obtém bons resultados.

Tendo a estrutura do financiamento de partidos tratada detalhadamente, passou-se ao debate de pontos considerados como chaves no financiamento eleitoral e no presente modelo de campanhas eleitorais. O primeiro deles foi 0 problema do mailing, considerado por muitos como o mais desigual dos benefícios concedidos pelo Estado aos partidos. Além de conter critérios próprios para a sua outorga que dificultam expressivamente o seu acesso, acaba por aumentar as desigualdades no financiamento dos partidos, e colabora para aumentar seus gastos nas campanhas, por não ser contabilizado no limite máximo de gastos determinado a cada um dos partidos. A única conclusão que se pode ter com relação ao mailing é que somente aumenta a estatalização das agremiações partidárias e, portanto, por mais que haja um certo impacto sobre o atual comportamento político dos votantes espanhóis, poderia cogitar-se a sua reformulação, ou mesmo a sua revogação.

O segundo tópico tratado foi a questão da pré-campanha e da campanha eleitoral, conceitos fixados pela LOREG. Após uma análise atualizada com a última reforma normativa, conclui-se que as modificações não terão a possibilidade de resolver os problemas do financiamento eleitoral dos partidos. Se os gastos eleitorais são aqueles realizados durante a campanha eleitoral, e somente tais gastos serão contabilizados no limite de gastos descrito na LOREG, a probabilidade de que continue existindo campanha eleitoral indireta na época da pré-campanha são as mesmas que anteriormente à reforma. $\mathrm{O}$ mesmo problema ocorre com o terceiro tópico, que se refere à propaganda política e à propaganda eleitoral. A propaganda política é um tipo de publicidade contínua, que não faz petição expressa pelo voto, mas que atende a fins institucionais. Já a propaganda eleitoral, além de ser a responsável por um importante gasto nas campanhas, submete-se aos limites estritos da LOREG. O controle por parte do Tribunal de Contas destes gastos eleitorais é comprometido a partir do momento que não há como distinguir se as propagandas políticas - um direito dos partidos de difundir seus ideais e seus programas, como também das instituições - são tão só propagandas 
políticas ou são propagandas eleitorais mascaradas de políticas, como meio de fraudar os limites da LOREG. A questão torna-se ainda mais nebulosa se consideramos a autorização da nova Lei Ordinaria 8/2007 que alcança às associações e fundações vinculadas aos partidos de também ser financiadas pelo Estado, seguido por um silêncio sobre eventuais propagandas que tais entes realizem a favor de um determinado partido.

Como último tópico específico, argumentou-se sobre a eficácia do atual modelo de campanha eleitoral. É evidente que, se o Estado custeia a campanha, pelo menos que seja feita uma campanha efetiva e que cumpra com seus objetivos, o que não ocorre atualmente devido ao formato antiquado previsto na LOREG. A reforma recém-aprovada não tratou sobre os novos canais de campanha, como a internet, e tampouco regulou a possibilidade de debates entre os partidos na televisão, o que permite afirmar que a presente legislação continua tendo um considerável grau de incompatibilidade com a realidade. Junto com isto, o tempo muito reduzido aplicado às campanhas eleitorais faz com que estas percam a sua eficácia, já que os eleitores tomam a sua decisão sobre o voto durante os movimentos a longo prazo, e não durante este curto período.

Também julgou-se necessário analisar o sistema de financiamento eleitoral em nível autonômico, já que cada comunidade autônoma tem competência para legislar sobre o tema. Devido ao que muitos autores chamam de "homogeneidade" da legislação eleitoral em nível autonômico, não existem importantes diferenças entre os regimes autonômicos e o regime geral, e as diferenças mais significativas vêm das leis de territórios com tendências separatistas, como pode ser o País Vasco, ainda que existam outras exceções de alguma relevância. Porém, neste trabalho tal característica é vista como algo positivo dentro do ordenamento, já que há um risco de conflito de fontes de direito que podem gerar infortúnios desnecessários na regulação das campanhas e de outros pontos, como ocorre em tantos outros ordenamentos, como nos EUA.

Tendo em vista o peso das finanças dos partidos, foi necessário tratar também sobre o financiamento dos grupos parlamentares, que acaba por ser também um meio de financiamento das organizações partidárias. $O$ debate 
sobre a legitimidade do uso de tais recursos pelos partidos é algo que ainda não encontrou um consenso, e inclusive neste trabalho, a posição que se adotou foi pela ilegitimidade do uso de tais recursos por parte dos partidos, porque o grupo parlamentar pertence à Casa Legislativa respectiva, ou seja, não integra o partido, ainda que este conquiste um número de cadeiras necessárias para formar um próprio.

Finalmente, tratou-se sobre o financiamento de partidos em nível europeu, ainda que brevemente, destacam-se os critérios de acesso às subvenções públicas do parlamento europeu. Após uma analise das normas a respeito - as quais privilegiam a transparência e o controle das contas dos partidos - concluiu-se que tais requisitos de acesso também geram discriminação entre partidos majoritários e minoritários, provocando um desequilíbrio entre as organizações, e muito mais se for pensar nos partidos extraparlamentares. O que se ressalta neste nível é a natureza dual das organizações partidárias, que devem "renovar" seu título de partidos a nível europeus periodicamente, para que possam ser considerados como tal e participar do reparto das subvenções.

No $4^{\circ}$ Capítulo deste trabalho, analisou-se a fiscalização do financiamento de partidos. Representa um tema de extrema relevância por tratar-se da utilização massiva de dinheiro público e, portanto, devendo ser fiscalizada. Tanto eleitoralmente como também ordinariamente, o financiamento público exerce um papel praticamente único neste processo. A transparência do fluxo de recursos e na utilização dos mesmos gera uma importante preocupação, principalmente nas democracias modernas nas quais se acredita que os cidadãos têm o direito de saber quem está amparando a sua opção política, além de que tal informação possa igualmente auxiliar o eleitor a escolher melhor o seu candidato. Assim, tratando-se de uma tendência mundial, Espanha não estaria fora disto. Aqui, o responsável pela fiscalização de ambos os financiamentos é o Tribunal de Contas, encarregado desta tarefa desde a aprovação da Lei Ordinaria 3/1987. Anteriormente à esta lei, observase que houve uma ineficácia evidente e quase que completa das disposições sobre o tema, o que fez com que os partidos se sentissem livres do cumprimento de qualquer norma sobre o controle de suas finanças. 
Logo, tratou-se sobre o debate da legitimidade do Tribunal de Contas em realizar este trabalho de fiscalização. Considerando que se trata de recursos públicos e pela legitimidade desta função através da aprovação da Lei Ordinaria 8/2007, comprovou-se que o Tribunal é perfeitamente habilitado e competente para exercer esta função.

Como não poderia ser de outra maneira, foram analisados os informes do Tribunal de Contas, relativos às eleições de 2000, 2004 e 2008 (não sendo ainda aplicadas as novas regras estabelecidas pela reforma recém-aprovada da LOREG, já que o informe sobre as eleições de 2011 ainda está sendo elaborado), e dos exercícios de 1987; 1988; 1990; 1991; 1992; 1993, e de 2000 até 2006; e 2007 (sendo neste último caso já aplicada a nova Lei Ordinaria 8/2007), último informe apresentado na atualidade. É importante ressaltar que, referente aos informes de 2008 até 2010 existem algumas especulações sobre o seu atraso, como é o atual problema de nomeação dos membros do Tribunal, ou também por referir-se a uns períodos em que houve importantes casos de corrupção envolvendo o Partido Popular, atualmente com maioria absoluta no Parlamento. Contudo, não se pode afirmar em absoluto que estas sejam as causas reais para tal atraso.

O resultado foi o já esperado: em todos os informes analisados existem deficiências muito significativas por parte de todos os partidos, havendo faltas desde o cumprimento do prazo legal para a apresentação das contas e da completa ausência técnica em sua elaboração, até a nítida violação de normas de financiamento, com muito poucas sugestões de sanções, tendo em vista que o Tribunal de Contas não tem competência para arbitrar sanções diretamente. São reiterados erros e descumprimentos que, a cada exercício, o Tribunal simplesmente repete sugestões já feitas anteriormente, bem como suas conclusões, além de aprovar moções dirigidas ao Congreso de los Diputados - como ocorreu em 2010 - solicitando novamente o aperfeiçoamento das normas de financiamento dos partidos, o que reflete a falta de interesse dos partidos em solucionar estas questões pendentes deste muito antes. Esta análise evidencia a frágil condição da legislação sobre o tema, e que não existem falsas ilusões com as ultimas modificações legislativas, já que inclusive no informe de 2007 estão atestadas as deficiências 
das novas regras. $O$ atual modelo é insuficiente, e torna incapaz a função fiscalizadora. As perspectivas não são de todo convincentes para alterar esta descrença nas novas medidas a ser aplicadas.

Como conclusões finais, primeiramente devemos resaltar que está claro que as intenções do legislador no momento de elaborar tanto as leis eleitorais, como as de financiamento não foram alcançadas na prática, e que também colaborou para introduzir na sociedade espanhola um sentimento de apatia política, podendo evoluir para um quadro de desafetação política, com uma eventual ruptura do sistema democrático como um todo. O contexto no qual a normativa sobre financiamento de partidos foi aprovada era outro, que não é o mesmo de agora. O direito deve acompanhar a evolução da sociedade e, se os partidos na Espanha já se encontram consolidados, como também ocorre com o sistema democrático em si, chegou o momento de garantir a própria democracia aos cidadãos, a partir de uma mudança de paradigma.

Frente a isto, existe uma significativa probabilidade de que os partidos sejam atualmente dependentes das subvenções públicas, já que, com um financiamento público tão generoso, eles dependam sobretudo do Estado. Além disto, existe uma certa crise de legitimidade de tais organizações, que possuem um espaço maior que o recomendável nas estruturas de poder, sem que isto signifique representatividade, devido ao seu afastamento da sociedade. A ideia anterior de Estado de partidos foi distorcida pela dinâmica dos próprios partidos frente o Estado, e pode ser que o seu presente comportamento possa ser caracterizado como um tendente ao de um cartel, sem que atenda aos ditames democráticos. Não se trata somente da cristalização do sistema de partidos, mas também da imagem que se tem deles na sociedade. Junto com isto, o financiamento público não será de todo aceito pela sociedade se os partidos seguem tendo esta reputação que vai paralela à corrupção, porque não se justifica que o Estado se encarregue de fornecer tantos recursos econômicos a eles - fruto de impostos e que poderiam ser aplicados em outras necessidades melhor vistas pelos cidadãos - sendo que tais organizações não retribuem este aporte. Ou seja, seria como questionar a necessidade de remitir tantas subvenções a um ente que não faz da sociedade 
sua prioridade, e tal questionamento é especialmente perigoso em um sistema democrático.

O que seria aconselhável era diminuir ou eliminar alguns dos obstáculos para a entrada de novas forças políticas que contêm apoio social para isto, como também redistribuir as subvenções de uma maneira mais equânime entre eles, abandonando a tendência de concentração de recursos econômicos em tão poucos atores políticos. Adstrito a isto, investir na melhora do controle das organizações partidárias e privilegiar a transparência também é uma formula indispensável para a solução dos problemas aqui apontados. Tais providências colaborariam a dar uma nova legitimidade ao atual sistema, por meio de um processo eleitoral realmente competitivo e dentro do marco constitucional. Com a maturidade da democracia em Espanha, é possível que se conte com uma estrutura capaz de suportar fortes modificações no sistema de financiamento de partidos.

Um pouco antes da conclusão deste trabalho, o governo composto pelo Partido Popular apresentou um novo projeto de lei para a reforma da Lei Ordinaria 8/2007, sobre o financiamento ordinário dos partidos, o que motivou a inclusão do Capítulo 5‥ Ainda que se possa verificar a preocupação com o aumento da garantia da publicidade e da transparência na fiscalização dos partidos, é um fato que o projeto, já contendo as sugestões aportadas pelos grupos parlamentares por meio das diferentes emendas apresentadas, pouco avança na direção da melhora do sistema. Ainda que se centre principalmente no aumento da fiscalização das fundações e das associações vinculadas aos partidos, a realidade é que a lei traz uma regra, já prevendo uma exceção a ela quase que em seguida, neutralizando a força das novas disposições. O novo projeto de lei avança somente no sentido de reduzir as subvenções públicas destinadas tanto às organizações partidárias, como também às fundações e associações vinculadas a elas, não propriamente devido ao seu alto valor, mas bem a causa da forte crise econômica que afeta diretamente ao orçamento do Estado, que tem metas de déficit a cumprir.

Infelizmente, outra vez mais, observa-se a omissão do Estado frente aos assuntos que prejudicam significativamente a democracia como um todo. 